\title{
Avaliação da degradação ambiental por meio de testes de toxicidade com sedimento e de análises histopatológicas em peixes
}

\section{Paulo Cesar Meletti}

Tese apresentada à Escola de Engenharia de São Carlos, da Universidade de São Paulo, como parte dos requisitos para obtenção do título de Doutor em Ciências da Engenharia Ambiental

ORIENTADORA: Profa. Dra. Odete Rocha

São Carlos

2003 
A meu pai, Nelson (in memorian) e à minha mãe, Doroti, por acreditarem que a Educação é a maior herança que se pode deixar;

à minha esposa, Sílvia, pelo amor e pelo apoio irrestrito sem os quais a realização desse trabalho não teria sido possível;

às minhas filhas, Laura e Ana, que nasceram no meio desse trabalho intenso que muitas vezes privou-as da atenção merecida. 


\section{AGRADECIMENTOS}

À Prof ${ }^{a}$. Dr ${ }^{\text {a }}$. Odete Rocha, pela orientação, amizade e confiança. Obrigado, ainda, pelo incentivo e apoio no enfrentamento das dificuldades e desafios surgidos.

À Prof ${ }^{a}$. Dr ${ }^{a}$. Cláudia Bueno dos Reis Martinez, do Departamento de Ciências Fisiológicas da Universidade Estadual de Londrina (UEL), pela amizade, apoio, confiança e acolhida em seu laboratório, sem os quais meu projeto de vida profissional e familiar em Londrina não teria sido possível.

Ao Programa de Pós-Graduação em Ciências da Engenharia Ambiental da Universidade de São Paulo.

Aos membros da banca de qualificação, professores Maria Beatriz C. Bohrer-Morel e Evaldo L. Gaeta Espíndola pelas preciosas sugestões.

À Fundação de Amparo à Pesquisa no Estado de São Paulo, FAPESP, pelo auxílio financeiro.

Aos técnicos do Departamento de Ecologia e Biologia Evolutiva da UFSCar, Airton Santo Soares, pela amizade, disposição e extrema competência nos trabalhos de campo, José Valdecir de Lucca e Maria Luíza pela amizade e prestatividade no apoio à realização das análises de laboratório.

Ao amigo Marlon Rodríguez Peláez pela acolhida nas minhas idas a São Carlos e pela ajuda e companhia nas primeiras coletas no rio Mogi Guaçu.

Aos amigos estagiários do laboratório de Ecofisiologia Animal da Universidade Estadual de Londrina, em especial à Andressa das Graças Silva, pelo compartilhamento das dúvidas e das descobertas durante as análises histológicas, à Juliana Schietti de Almeida, pelo apoio e companhia durante as coletas no rio Tibagi e à Henrique Chaikoski Galindo pelo apoio nas coletas de peixes e nas determinações de amônia durante os experimentos.

À Prof ${ }^{a}$ Nelsy Fenerich Verani e aos técnicos e amigos do Laboratório de Histologia do Departamento de Hidrobiologia da UFSCar pela atenção durante os trabalhos de microtomia realizados em São Carlos. 
Às diretorias das empresas de água das cidades de Sumaré, Campinas, Americana e Limeira, por permitirem as coletas de sedimento e a realização dos testes in situ nas dependências das estações de captação.

Aos técnicos das estações de captação de água das cidades de Telêmaco Borba, Sumaré, Americana, Limeira e Campinas e aos pescadores e ribeirinhos pela atenção e informações valiosas durante os trabalhos de campo.

Aos colegas professores, secretários, técnicos e estagiários do Departamento de Ciências Fisiológicas da UEL, pela carinhosa receptividade e incentivo.

À amiga Marta Marques de Souza pelo carinho e incentivo constantes.

Aos amigos William M. da Silva, Cláudia A. Stefane, Corina Sidagis Galli, Carlos A. Bon e a todos os colegas do curso de Pós-Graduação pelo agradável convívio em todas as minhas idas à São Carlos.

Aos amigos Nelson Salim Abbud e Maria Luíza Macedo Abbud pelo carinho com que acolheram a mim e à minha família em Londrina e pelo apoio constante.

Aos meus pais, irmãos e sobrinhos pelo carinho e compreensão pelas ausências.

À minha esposa Sílvia pelo incentivo nos bons e maus momentos e às minhas filhas, Laura e Ana, por tudo que não tem explicação e que só os pais sabem.

A todos que direta ou indiretamente contribuíram para a realização deste trabalho. 


\section{SUMÁRIO}

LISTA DE FIGURAS..................................................................................

LISTA DE TABELAS..............................................................................

RESUMO

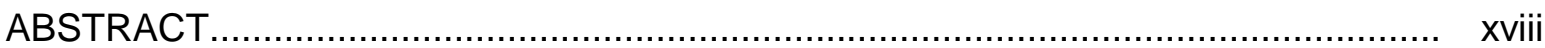

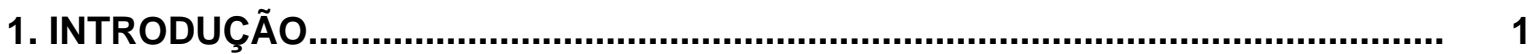

1.1. Breve histórico da Ecotoxicologia e a importância dessa Ciência para o estudo dos problemas ambientais.

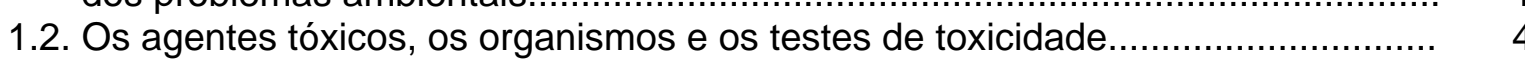

1.3. O estudo histopatológico como ferramenta para a avaliação de agentes tóxicos.. 7

1.4. Aspectos da morfofisiologia das brânquias, rim e fígado de teleósteos dulcícolas 9

1.5. A Ecotoxicologia no Brasil e os testes de toxicidade com sedimentos e peixes.... 12

1.6. Efeitos tóxicos dos metais presentes na água e no sedimento sobre os peixes.... 14

1.7. Fatores que influenciam a toxicidade dos metais............................................. 17

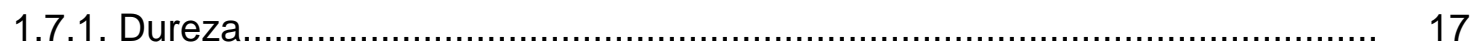

1.7.2. Concentração de oxigênio dissolvido na água......................................... 20

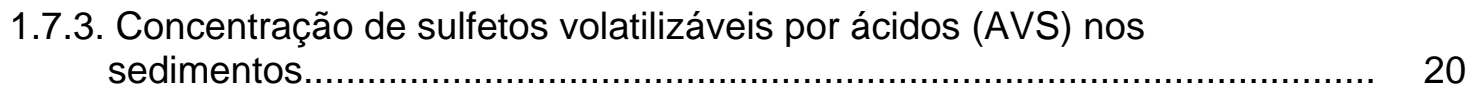

1.7.4. Concentração de matéria orgânica na água e nos sedimentos.................... 21

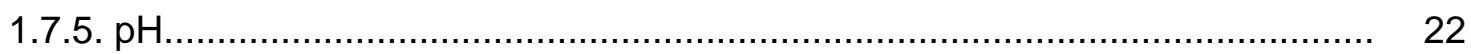

1.8. A poluição pelo efluente de indústria de papel e celulose .................................. 23

2. OBJETIVOS.

3. MATERIAIS E MÉTODOS............................................................................. 30

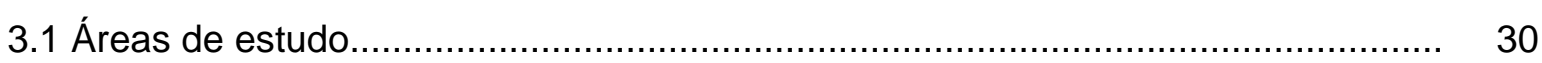

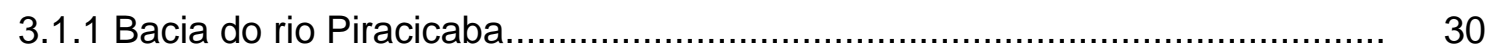

3.1.2 Bacia do rio Mogi Guaçu............................................................. 33

3.1.3 Bacia do rio Tibagi.............................................................................. $\quad 37$

3.2 Locais de amostragem, procedimentos de coleta, manutenção e análise das amostras de água, sedimento e efluentes industriais........................................ 42

3.3 Organismos utilizados nos testes de toxicidade em laboratório e in situ.................... 44

3.4 Testes de toxicidade aguda com substâncias de referência $\left(\mathrm{K}_{2} \mathrm{Cr}_{2} \mathrm{O}_{7}\right) \ldots \ldots \ldots \ldots \ldots \ldots . . . \ldots . . . .47$

3.5. Teste de toxicidade aguda do efluente de indústria de papel e celulose a Serrapinnus notomelas............................................................................. 48

3.6. Testes de toxicidade aguda com sedimento................................................ 49

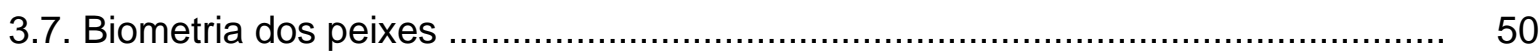

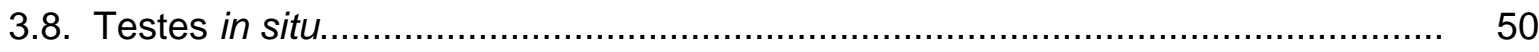

3.9. Estabelecimento do protocolo para a histologia de peixes inteiros e preparação e análise histológica dos peixes submetidos aos testes de toxicidade com sedimentos e efluente de papel e celulose.

3.9.1. Seleção dos peixes para o estabelecimento do protocolo de preparação histológica. 
3.9.2. Preparo do material..................................................................... 53

3.9.3. Métodos de análise do material preparado............................................... 56

3.9.4. Análise estatística.................................................................... 60

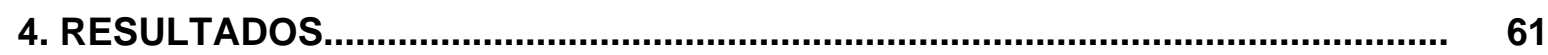

4.1. Testes de toxicidade aguda do dicromato de potássio a Serrapinnus notomelas e Danio rerio.

4.1.1. Monitoramento das variáveis físicas e químicas durante os testes de toxicidade com dicromato de potássio.

4.2. Relação peso-comprimento para Serrapinnus notomelas e Danio rerio.

4.3. Descrição da morfologia interna normal de Serrapinnus notomelas e de Danio rerio.

4.4. Testes de toxicidade aguda sedimento das várias localidades amostradas a $S$. notomelas e a $D$. rerio.

4.4.1. Variáveis físicas e químicas monitoradas ao longo dos testes de toxicidade do sedimento.

4.4.2. Alterações histológicas mais freqüentes observadas nos peixes expostos às amostras de sedimento dos locais de estudo....

4.5. Testes de toxicidade in situ com Serrapinnus notomelas.

4.6. Análises físicas e químicas da água e do sedimento de diferentes localidades nas bacias dos rios Piracicaba, Mogi-Guaçu e Tibagi.....

4.7. Teste de toxicidade aguda ( $96 \mathrm{~h}$ ) do efluente de indústria de papel e celulose a Serrapinnus notomelas.

4.7.1. Monitoramento das variáveis físicas e químicas durante o teste de toxicidade do efluente.

4.7.2. Alterações histológicas observadas nos peixes expostos ao efluente de indústria de papel e celulose.

5. DISCUSSÃO

5.1. Sensibilidade de Serrapinnus notomelas comparada à de outras espécies de peixe utilizadas como organismos-teste.

5.2. Amplitude de variações de fatores em testes ecotoxicológicos de laboratório e no campo.

5.3. Concentração de nutrientes na água e de metais na água e no sedimento das diferentes localidades estudadas....

5.4. Alterações histopatológicas observadas nos peixes expostos às amostras de sedimento dos locais de estudo.

5.4.1. Alterações no tecido branquial.

5.4.2. Alterações no tecido renal.

5.4.3. Alterações no tecido hepático.

5.5. Toxicidade do efluente de indústria de papel e celulose a Serrapinnus notomelas. 


\section{LISTA DE FIGURAS}

FIGURA 01 Caminhos das perturbações físicas e químicas. Os caminhos e os componentes dentro da caixa maior representam os efeitos das perturbações naturais severas e os vários tipos de perturbações químicas nos organismos e os caminhos pelos quais esses efeitos alcançam o nível ecossistema (WEINSTEIN \& BIRK, 1989).

FIGURA 02 Locais de coleta de água e de sedimento, unidades hidrográficas, limites e localização da bacia do rio Piracicaba. 1) S $22^{\circ} 39^{\prime} 38,0^{\prime \prime}$ / W $47^{\circ} 16^{\prime} 35,7^{\prime \prime}$; 2) S $22^{\circ} 39^{\prime \prime} 44,8^{\prime \prime}$ / W $47^{\circ} 16^{\prime} 40,3^{\prime \prime}$; 3) S $22^{\circ} 54^{\prime} 11,6^{\prime \prime}$ / W $46^{\circ} 58^{\prime} 25,7^{\prime \prime} ; \quad$ 4) S $22^{\circ} 45^{\prime} 43,0^{\prime \prime}$ / W $47^{\circ} 10^{\prime} 32,4^{\prime \prime}$; 5) S $22^{\circ} 42^{\prime} 38,9^{\prime \prime}$ I W $47^{\circ} 19^{\prime} 23,3^{\prime \prime}$ 6) S $22^{\circ} 42^{\prime} 44,5^{\prime \prime}$ / W $47^{\circ} 38^{\prime} 59,6^{\prime \prime}$. (Programa de Investimentos para Recuperação e Proteção das bacias dos rios Piracicaba e Capivari, 1992 - modificado).

FIGURA 03 Panoramas dos locais de coleta de água e de sedimento na bacia do rio Piracicaba, SP: 1) Ribeirão do Pinhal, em Limeira, próximo ao deságue no rio Jaguari; 2) Estação de captação de água para a cidade de Limeira, no rio Jaguari; 3) Estação de captação de água para a cidade de Campinas, no rio Atibaia, próximo à Valinhos; 4) Estação de captação de água para a cidade de Sumaré, no rio Atibaia, próximo à Paulínia; 5) Estação de captação de água para a cidade de Americana, no rio Piracicaba (a indústria na margem oposta e à jusante, é a Ripasa, indústria de papel e celulose); 6) Estação de captação de água (atualmente desativada) para a cidade de Piracicaba, no rio Piracicaba........

FIGURA 04 Locais de coleta de água e de sedimento, unidades hidrográficas, limites e localização da bacia do rio Mogi-Guaçu. 1) S $22^{\circ} 00^{\prime} 11,1^{\prime \prime}$ / W $46^{\circ} 47^{\prime} 35,5^{\prime \prime}$; 2) S $22^{\circ} 21^{\prime \prime} 52,6^{\prime \prime}$ /

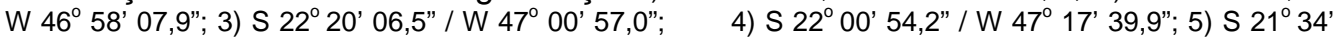
$42,0^{\prime \prime}$ / W $47^{\circ} 56^{\prime} 15,7^{\prime \prime}$ 6) $521^{\circ} 34^{\prime} 22,4^{\prime \prime}$ / W $47^{\circ} 55^{\prime} 25,1^{\prime \prime}$. (GODOY, 1975; www.fcav.unesp.br/ cbhmogi, 2000 - modificados).

FIGURA 05 Panoramas dos locais de coleta de água e de sedimento na bacia do rio Mogi Guaçu, SP: 1) Rio Jaguari Mirim, em São João da Boa Vista, próximo à estação de captação de água da cidade; 2) Rio Mogi Guaçu, em Mogi Guaçu, à montante da International Paper; 3) Rio Mogi Guaçu, em Mogi Guaçu, à jusante da International Paper; 4) Rio Mogi Guaçu, em Pirassununga à montante do deságue do rio Jaguari-Mirim; 5) Rio Mogi Guaçu, em Luiz Antônio, à montante da VCP (Votorantim Celulose e Papel); 6) Rio Mogi Guaçu, em Luiz Antônio, à jusante da VCP.

FIGURA 06 Locais de coleta de água e de sedimento, unidades hidrográficas, limites e localização da bacia do rio Tibagi. 1) S $24^{\circ} 20^{\prime} 17,6^{\prime \prime}$ / W $50^{\circ} 35^{\prime} 56,1^{\prime \prime}$; 2) S $24^{\circ} 18^{\prime \prime} 38,9^{\prime \prime} /$ W $50^{\circ}$ $\left.36^{\prime} 57,0^{\prime \prime} ; 3\right)$ S $23^{\circ} 21^{\prime} 05,8^{\prime \prime}$ / W $51^{\circ} 00^{\prime} 24,5^{\prime \prime}$. (INSTITUTO BRASILEIRO DE GEOGRAFIA E ESTATÍSTICA, IBGE, 1980; www.copati.org.br, 2000 - modificados).

FIGURA 07 Panoramas dos locais de coleta de água e de sedimento na bacia do rio Tibagi, PR: 1) Rio Tibagi, em Telêmaco Borba, próximo à estação de captação de água da cidade (à montante da Klabin Papel e Celulose); $\quad$ 2) Rio Tibagi, em Telêmaco Borba, à jusante da Klabin Papel e Celulose; 3) Rio Tibagi, em Londrina, próximo ao local de captação de água na região rural do Limoeiro (à jusante do deságue dos principais rios e ribeirões que atravessam a zona urbana de Londrina).

FIGURA 08 Espécies utilizadas nos testes de toxicidade com substâncias de referência, efluentes de indústrias de papel e celulose e amostras de sedimento de rios das bacias hidrográficas estudadas: a) Serrapinnus notomelas (Characiformes, Characidae); b) Danio rerio (Cypriniformes, Cyprinidae)......

FIGURA 09 Sistema para manutenção de pequenos peixes em laboratório. Os 12 aquários, de 20 litros cada, comunicam-se a um aquário-filtro que contém a bomba e os termostatos/aquecedores (vide esquema de montagem na firgura 77 - anexos)............

FIGURA 10 Câmaras desenvolvidas para os testes in situ (MELETTI \& ROCHA, 2002). a-alça para suspensão da câmara; b-base da câmara; al-abertura lateral; ab-abertura da base; b-base; cc-corpo da câmara. Como referência das dimensões, a base possui 25 $\mathrm{cm}$ de lado e o corpo, $20 \mathrm{~cm}$ de altura..... 
FIGURA 11 Monitoramento para verificação do estado dos organismos e remoção dos mortos.......

FIGURA 12 Esquema de montagem de um teste in situ com peixes de pequeno porte.

FIGURA 13 Organograma do ajuste do protocolo de diafanização e inclusão de Serrapinnus notomelas adultos inteiros. Os números entre parênteses correspondem ao número de peixes utilizados em cada etapa; $\left({ }^{*}\right)$ - meio de inclusão testado posteriormente, o qual foi utilizado na maior parte das preparações histológicas do trabalho.

FIGURA 14 Etapas do processo de preparação histológica de Serrapinnus notomelas. A) Peixe fixado (Bouin) e descalcificado; B) Peixe seccionado longitudinalmente, sem nadadeiras e sem cauda (opcional); C) Metade incluída em parafina, pronta para microtomia; D) Lâmina com cortes corados (HE), pronta para a observação em microscópio óptico.

FIGURA 15 Concentrações letais médias $\left(\mathrm{CL}_{50}\right)$ de dicromato de potássio para Serrapinnus notomelas, em 24, 48, 72 e 96 horas, em quatro testes de toxicidade, comparadas à $\mathrm{CL}_{50}$ obtida em um teste similar, realizado com Danio rerio.

FIGURA 16 Relações peso-comprimento para Serrapinnus notomelas e Danio rerio. Os gráficos da direita contêm as relações peso-comprimento total; os da esquerda, pesocomprimento padrão.

FIGURA 17 Morfologia interna de Serrapinnus notomelas e Danio rerio. a) corte longitudinal de S. notomelas; b) desenho esquemático de "a", com indicações dos principais órgãos; c) corte longitudinal de $D$. rerio; d) desenho esquemático de "c", com indicações dos principais órgãos. (Bouin, HE, $8 \mu \mathrm{m}(\mathrm{a}), 5 \mu \mathrm{m}(\mathrm{c}), \mathrm{X} 4,6)$...

FIGURA 18 Cortes transversais de Serrapinnus notomelas. a - átrio; br - brânquias; ce - cerebelo; co - coração; e - estômago; eo - epitélio olfatório; f - fígado; fa - faringe; h - hipófise; i intestino; lo - lobo olfatório; lop - lobo óptico; $\mathrm{m}$ - medula; $\mathrm{n}$ - base da nadadeira peitoral; o - olho; op - opérculo; ra - rim anterior; re - reto; rm - rim médio; rp - rim posterior; $\mathrm{t}$ - testículos; te - telencéfalo; $\mathrm{v}$ - ventrículo. (Bouin, $\mathrm{HE}, 6 \mu \mathrm{m}, \mathrm{x} 5,5)$......

FIGURA 19 Filamento branquial de S. notomelas em corte longitudinal - controle (Ribeirão do Pinhal). cm-canal marginal; cp-célula pilar; EF-epitélio estratificado do filamento; ELSepitélio pavimentoso das lamelas secundárias; LS - lamela secundária; h-hemácia no lúmen de um capilar lamelar; SVC-seio venoso central. A seta indica uma célula mucosa. Notar os capilares lamelares separados pelas células pilares $(\mathrm{HE}, 5 \mu \mathrm{m}) \ldots \ldots .$.

FIGURA 20 Filamento branquial de D. rerio em corte longitudinal - controle (Ribeirão do Pinhal). cm-canal marginal; cp-célula pilar; ef-epitélio estratificado do filamento; els-epitélio pavimentoso das lamelas secundárias; LS - lamela secundária, SVC-seio venoso central. A seta indica uma célula mucosa. (HE, $7 \mu \mathrm{m})$...

FIGURA 21 Rim anterior de S. notomelas - controle (Ribeirão do Pinhal). Notar a predominância de tecido linfóide (TL) e a intensa rede de vasos sangüíneos. A seta o lúmen de um grande vaso, o qual é rodeado por células interrenais. (HE, $5 \mu \mathrm{m})$.

Rim anterior de D. rerio - controle (Ribeirão do Pinhal). Notar a presença, além do tecido linfóide (TL), de túbulos e glomérulo (seta). TP-túbulo contorcido proximal

FIGURA 22 (notar lúmen mais opaco, devido à borda em escova do epitélio); TD-túbulo contorcido distal (notar lúmen mais claro). A seta menor aponta hemácias em um vaso. (HE, $5 \mu \mathrm{m})$. 
FIGURA 23 Rim médio de $D$. rerio - controle (água de manutenção). Notar a presença de dois glomérulos (G). O asterisco em um deles mostra o espaço intercapsular. No outro, o corte atingiu uma porção mais superficial, o que evidenciou a camada fibrosa externa. Observar o tecido linfóide (TL), o túbulo contorcido distal (TD), o túbulo contorcido proximal (TP). As setas indicam túbulos em regeneração. (HE, $5 \mu \mathrm{m})$

FIGURA 24 Rim médio de S. notomelas - controle (Ribeirão do Pinhal). Notar no glomérulo o espaço intercapsular (asterisco). os capilares glomerulares (seta maior), as células mesangiais (seta menor) e o pólo vascular (PV). O pólo urinário situa-se do lado oposto. Notar um outro glomérulo, menor (G). (PAS-hematoxilina, $5 \mu \mathrm{m}$ ).

FIGURA 25 Fígado de S. notomelas (controle - Rib. do Pinhal). Observar o arranjo dos cordões hepáticos, delimitados pelos sinusóides (s) que confluem em direção a um vaso de maior calibre. Notar as hemácias (he) no vaso e nos sinusóides. Notar o formato poliédrico dos hepatócitos (h) e os seus núcleos grandes e arredondados (seta). (PAS-hematoxilina, $5 \mu \mathrm{m}$ ).

FIGURA 26 Fígado de S. notomelas (controle- Rib. do Pinhal). Neste corte o formato típico dos hepatócitos está mais evidenciado. Observar a presença de vacúolos (setas menores) no citoplasma dos hepatócitos. Notar a presença de hepatopâncreas (seta maior). (HE, $5 \mu \mathrm{m})$

FIGURA 27 Fígado de D. rerio (controle- Rib. do Pinhal). Notar a vacuolização citoplasmática (áreas mais claras no citoplasma), o formato típico dos hepatócitos (h) e a rede de sinusóides (s), como o observado no fígado de S. notomelas. (HE, $5 \mu \mathrm{m}$ ).

FIGURA 28 Valores do IAH e do VMA calculados a partir das alterações observadas nas brânquias de $S$. notomelas e de $D$. rerio expostos às amostras de sedimento coletadas nas diferentes localidades das bacias dos rios Piracicaba, Mogi-Guaçu e Tibagi. Os asteriscos indicam diferença significativa entre a localidade controle de uma bacia e as demais localidades da mesma bacia.

FIGURA 29 Valores do IAH e do VMA calculados a partir das alterações observadas no rim de S. notomelas e de $D$. rerio expostos às amostras de sedimento coletadas nas diferentes localidades das bacias dos rios Piracicaba, Mogi-Guaçu e Tibagi. Os asteriscos indicam diferença significativa entre a localidade controle de uma bacia e as demais localidades da mesma bacia.

FIGURA 30 Valores do IAH e do VMA calculados a partir das alterações observadas no fígado de $S$. notomelas e de $D$. rerio expostos às amostras de sedimento coletadas nas diferentes localidades das bacias dos rios Piracicaba, Mogi-Guaçu e Tibagi. Os asteriscos indicam diferença significativa entre a localidade controle de uma bacia e as demais localidades da mesma bacia.....

FIGURA 31 Corte longitudinal de um filamento branquial de S. notomelas exposto ao sedimento da localidade de Campinas. Notar a desorganização dos capilares das lamelas secundárias (DeC). Observar as extensas elevações epiteliais (EELS) e a congestão vascular nessas lamelas (CV). LS= lamelas secundárias; SVC=seio venoso central. As setas indicam células mucosas (HE, $5 \mu \mathrm{m})$......

FIGURA 32 Corte longitudinal de um filamento branquial de $S$. notomelas exposto ao sedimento da localidade de Piracicaba. Notar a proliferação de células epiteliais com a conseqüente fusão de lamelas secundárias (FLS). LS=lamelas secundárias; $\mathrm{SVC}=$ seio venoso central. As setas indicam células mucosas. (PAS-hematoxilina, $5 \mu \mathrm{m})$ 
FIGURA 33 Corte longitudinal de um filamento branquial de S. notomelas exposto ao sedimento da localidade de Campinas. Notar a presença de células mucosas (setas) e de muco (corado em lilás) entre as lamelas secundárias. Observar também a proliferação de células epiteliais, ocasionando a fusão parcial de algumas lamelas secundárias (PAShematoxilina, $5 \mu \mathrm{m})$.

FIGURA 34 Corte longitudinal de um filamento branquial de $D$. rerio, exposto ao sedimento da localidade de Mogi Guaçu 2. Notar o aneurisma lamelar (An) e intensa proliferação de células epiteliais que levou à fusão completa de várias lamelas secundárias (FCLS). (PAS-hematoxilina, $5 \mu \mathrm{m})$...

FIGURA 35 Corte longitudinal de um filamento branquial de $S$. notomelas, exposto ao sedimento da localidade de Pirassununga. Notar a presença de células mucosas (setas) e a intensa secreção de muco entre as lamelas secundárias. A seta menor indica uma elevação epitelial (PAS-hematoxilina, $5 \mu \mathrm{m}$ ).

FIGURA 36 Corte longitudinal de um filamento branquial de $D$. rerio exposto ao sedimento da localidade Telêmaco Borba 2. Observar um aglomerado de hemácias (Hem) entre as lamelas. A seta aponta um local de ruptura do epitélio de uma lamela secundária (HE, $5 \mu \mathrm{m})$

FIGURA 37 Aneurisma (An) em uma lamela secundária em brânquia de $D$. rerio exposto ao sedimento da localidade de Piracicaba. Notar as hemácias no interior do aneurisma. $(\mathrm{HE}, 5 \mu \mathrm{m})$

FIGURA 38 Aneurismas (setas) em lamelas secundárias em brânquia de S. notomelas exposto ao sedimento da localidade de Sumaré. Notar a congestão vascular (CV) e desorganização dos capilares nas outras lamelas secundárias. EELS=elevação do epitélio da lamela secundária (HE, $5 \mu \mathrm{m})$.....

FIGURA 39 Diminuição do espaço da cápsula de Bowman (seta) em rim de $D$. rerio exposto ao sedimento da localidade Mogi Guaçu 2. DCG=dilatação dos capilares glomerulares; $\mathrm{TL}=$ tecido linfóide intersticial. (PAS-hematoxilina, $5 \mu \mathrm{m})$.....

FIGURA 40 Rim de S. notomelas exposto ao sedimento da localidade de Americana. Notar a degeneração de um glomérulo, cujos capilares estão dilatados (seta). Observar o aumento do espaço da cápsula de Bowman (asterisco) e também o processo avançado de degeneração hialina (DH) em um túbulo renal.

FIGURA 41 Rim de S. notomelas exposto ao sedimento da localidade de Americana. Notar o grande número túbulos renais em degeneração por grânulos (amarelos) infiltrados no citoplasma das células epiteliais. A seta aponta um glomérulo em degeneração. Notar o aumento do espaço da cápsula de Bowman. (HE, $6 \mu \mathrm{m})$.

FIGURA 42 Rim de D. rerio exposto ao sedimento da localidade de Limeira. Notar o avançado processo de degeneração hialina em túbulos renais (DHS). Há, ainda, outros túbulos em degeneração, mas aparentemente não dessa natureza (DT). Observar também, em um glomérulo, a diminuição do espaço da cápsula de Bowman (seta) e também a dilatação de vasos sãngüíneos renais (seta maior). (HE, $5 \mu \mathrm{m}$ ).

FIGURA 43 Rim de $D$. rerio exposto ao sedimento da localidade de Piracicaba. Notar a hiperemia, e a degeneração hialina dos túbulos rnais (setas). (HE, $5 \mu \mathrm{m}$ ). 
FIGURA 44 Necrose em rim de S. notomelas exposto ao sedimento de Luiz Antônio 1. Observar a área central necrosada $(\mathrm{N})$, com a completa desorganização dos túbulos. Notar também a presença de substância PAS-positiva (em lilás) no interior das células epiteliais tubulares. (PAS-hematoxilina, $5 \mu \mathrm{m}$ )

FIGURA 45 Novos néfrons (setas) no rim de S. notomelas exposto ao sedimento da localidade de Americana. Notar as estruturas em forma de "C". Notar em B a presença de uma substância de coloração amarela no lúmen de um túbulo degenerado (HE, $5 \mu \mathrm{m})$. Em C é possível observar um novo néfron em formação (estágio inicial) no rim de $S$. notomelas exposto ao sedimento da localidade de Pirassununga; $\mathrm{G}=$ glomérulo. Em $\mathrm{D}$, um novo néfron em estado mais adiantado de formação no rim de $S$. notomelas exposto ao sedimento da localidade de São João. Neste novo néfron já é possível identificar o glomérulo (G) e os túbulos (T) (PAS-hematoxilina, $5 \mu \mathrm{m}$ )

FIGURA 46 Fígado de $D$. rerio exposto ao sedimento da localidade de Sumaré. Notar a intensa vacuolização citoplasmática (setas maiores), o grande número de núcleos com contorno atípico, o rompimento celular (cabeças de setas)e a descaracterização dos cordões hepáticos. (HE, $5 \mu \mathrm{m})$.

FIGURA 47 Estagnação biliar no fígado de S. notomelas exposto ao sedimento da localidade de Americana. Notar a aglomeração de grânulos amarelados no citoplasma dos hepatócitos (colestase). Observar também que os hepatócitos não apresentam contorno e forma bem definidos. (HE, $6 \mu \mathrm{m}$ ).

FIGURA 48 Fígado de S. notomelas exposto ao sedimento da localidade Luiz Antônio 1. Notar a quantidade relativamente alta de grânulos de glicogênio nos hepatócitos. (PAShematoxilina, $5 \mu \mathrm{m}$ ).

FIGURA 49 Fígado de S. notomelas exposto ao sedimento da localidade Luiz Antônio 2. Observar a quantidade reduzida de glicogênio nos hepatócitos. (PAS-hematoxilina, $5 \mu \mathrm{m}$ ). Notar a alta ocorrência de degeneração nuclear (setas). (PAS-hematoxilina, $5 \mu \mathrm{m}$ )......

FIGURA 50 Fígado de $S$. notomelas exposto ao sedimento da localidade S. João. A e B correspondem ao mesmo animal. Porém, em A a coloração utilizada foi HE e em B, PAS contra-corado com hematoxilina. Comprova-se, assim, que os grânulos (setas) não correspondem a glicogênio, mas provavelmente à estagnação de bile nos hepatócitos, pois não apareceram corados fortemente em B. Observar em B os sinusóides (s) em secção transversal e os vacúolos no citoplasma dos hepatócitos (áreas mais claras).

FIGURA 51 Necrose do tecido hepático de D. rerio exposto ao sedimento da localidade de Mogi Guaçu 2. Notar, na área central, a desorganização do tecido, cujas células não têm contorno definido e muitos núcleos aparecem atrofiados. Observar nas áreas adjacentes os grandes vacúolos no citoplasma dos hepatócitos e a ausência de reservas de glicogênio. (PAS-hematoxilina, $5 \mu \mathrm{m}$ ).

FIGURA 52 Concentrações de nitrogênio total (em $\mu \mathrm{g} \cdot \mathrm{L}^{-1}$ ) em diferentes localidades das bacias dos rios Piracicaba, Mogi Guaçu e Tibagi, em duas coletas. Notar a inversão dos períodos chuvoso e seco para a bacia do rio Tibagi. Pin. = Rib. Pinhal; Lim. = Limeira; Camp. = Campinas; Sum. = Sumaré; Amer. = Americana; Pira. = Piracicaba; S.J. = S.João da Boa Vista; M.G.1 = Mogi Guaçu à montante da Int. Paper; M.G.2 = Mogi Guaçu à jusante da Int. Paper; Psng. = Pirassununga; L.A.1 = Rio Mogi-Guaçu em Luiz Antônio à montante da VCP; L.A.2 = Rio Mogi-Guaçu em Luiz Antônio à jusante da VCP; T.B.1 = Rio Tibagi em Telêmaco Borba à montante da Klabin; T.B.2 = Rio Tibagi em Telêmaco Borba à jusante da Klabin; Lon = Rio Tibagi em Londrina. 
FIGURA 53 Concentrações de amônio, amônia não ionizada, nitrito e nitrato (em $\mu \mathrm{g} \cdot \mathrm{L}^{-1}$ ) em diferentes localidades das bacias dos rios Piracicaba, Mogi Guaçu e Tibagi, em duas coletas. Notar a inversão dos períodos chuvoso e seco para a bacia do rio Tibagi. Pin. = Rib. Pinhal; Lim. = Limeira; Camp. = Campinas; Sum. = Sumaré; Amer. = Americana; Pira. = Piracicaba; S.J. = S.João da Boa Vista; M.G.1 = Mogi Guaçu à montante da Int. Paper; M.G.2 = Mogi Guaçu à jusante da Int. Paper; Psng. = Pirassununga; L.A.1 = Rio Mogi-Guaçu em Luiz Antônio à montante da VCP; L.A.2 = Rio Mogi-Guaçu em Luiz Antônio à jusante da VCP; T.B.1 = Rio Tibagi em Telêmaco Borba à montante da Klabin; T.B.2 = Rio Tibagi em Telêmaco Borba à jusante da Klabin; Lon = Rio Tibagi em Londrina.

FIGURA 54 Concentrações de fosfato total, fosfato inorgânico, fosfato orgânico e fósforo total (em $\mu \mathrm{g} . \mathrm{L}^{-1}$ ) em diferentes localidades das bacias dos rios Piracicaba, Mogi Guaçu e Tibagi, em duas coletas. Notar a inversão dos períodos chuvoso e seco para a bacia do rio Tibagi. $\quad$ Pin. = Rib. Pinhal; Lim. = Limeira; Camp. = Campinas; Sum. = Sumaré; Amer. = Americana; Pira. = Piracicaba; S.J. = S.João da Boa Vista; M.G.1 = Mogi Guaçu à montante da Int. Paper; M.G.2 = Mogi Guaçu à jusante da Int. Paper; Psng. = Pirassununga; L.A.1 = Rio Mogi-Guaçu em Luiz Antônio à montante da VCP; L.A.2 = Rio Mogi-Guaçu em Luiz Antônio à jusante da VCP; T.B.1 = Rio Tibagi em Telêmaco Borba à montante da Klabin; T.B.2 = Rio Tibagi em Telêmaco Borba à jusante da Klabin; Lon = Rio Tibagi em Londrina.

FIGURA 55 Concentrações $\left(\mathrm{mg} \cdot \mathrm{L}^{-1}\right)$ dos metais zinco, chumbo, cádmio e níquel nos períodos chuvoso e seco, na água dos locais de estudo das bacias dos rios Piracicaba, Mogi Guaçu e Tibagi. As letras A e B correspondem, respectivamente ao período chuvoso e seco, para as bacias dos rios Piracicaba e Mogi Guaçu e o inverso para a bacia do rio Tibagi. $\quad$ Pin. = Rib. Pinhal; Lim. = Limeira; Camp. = Campinas; Sum. = Sumaré; Amer. = Americana; Pira. $=$ Piracicaba; S.J. = S.João da Boa Vista; M.G.1 = Mogi Guaçu à montante da Int. Paper; M.G.2 = Mogi Guaçu à jusante da Int. Paper; Psng. = Pirassununga; L.A.1 = Rio Mogi-Guaçu em Luiz Antônio à montante da VCP; L.A.2 = Rio Mogi-Guaçu em Luiz Antônio à jusante da VCP; T.B.1 = Rio Tibagi em Telêmaco Borba à montante da Klabin; T.B.2 = Rio Tibagi em Telêmaco Borba à jusante da Klabin; Lon = Rio Tibagi em Londrina.

FIGURA 56 Concentrações (mg. $\mathrm{L}^{-1}$ ) dos metais ferro, manganês, cobre e cromo nos períodos chuvoso e seco, na água dos locais de estudo das bacias dos rios Piracicaba, Mogi Guaçu e Tibagi. As letras A e B correspondem, respectivamente, ao período chuvoso e seco, para as bacias dos rios Piracicaba e Mogi Guaçu e o inverso para a bacia do rio Tibagi. Pin. = Rib. Pinhal; Lim. = Limeira; Camp. = Campinas; Sum. = Sumaré; Amer. = Americana; Pira. = Piracicaba; S.J. = S.João da Boa Vista; M.G.1 = Mogi Guaçu à montante da Int. Paper; M.G.2 = Mogi Guaçu à jusante da Int. Paper; Psng. = Pirassununga; $\quad$ L.A.1 = Rio Mogi-Guaçu em Luiz Antônio à montante da VCP; L.A.2 = Rio Mogi-Guaçu em Luiz Antônio à jusante da VCP; T.B.1 = Rio Tibagi em Telêmaco Borba à montante da Klabin; T.B.2 = Rio Tibagi em Telêmaco Borba à jusante da Klabin; Lon = Rio Tibagi em Londrina.

FIGURA 57 Concentrações $\left(\mathrm{mg}^{\mathrm{L}} \mathrm{L}^{-1}\right.$ ) dos metais zinco, chumbo e níquel nos períodos chuvoso e seco, no sedimento dos locais de estudo das bacias dos rios Piracicaba, Mogi Guaçu e Tibagi. As letras A e B correspondem, respectivamente ao período chuvoso e seco, para as bacias dos rios Piracicaba e Mogi Guaçu e o inverso para a bacia do rio Tibagi. $\quad$ Pin. = Rib. Pinhal; Lim. = Limeira; Camp. = Campinas; Sum. = Sumaré; Amer. = Americana; Pira. = Piracicaba; S.J. = S.João da Boa Vista; M.G.1 = Mogi Guaçu à montante da Int. Paper; M.G.2 = Mogi Guaçu à jusante da Int. Paper; Psng. = Pirassununga; L.A.1 = Rio Mogi-Guaçu em Luiz Antônio à montante da VCP; L.A.2 = Rio Mogi-Guaçu em Luiz Antônio à jusante da VCP; T.B.1 = Rio Tibagi em Telêmaco Borba à montante da Klabin; T.B.2 = Rio Tibagi em Telêmaco Borba à jusante da Klabin; Lon = Rio Tibagi em Londrina. 
FIGURA 58 Concentrações $\left(\mathrm{mg} \cdot \mathrm{L}^{-1}\right.$ ) dos metais cobre, ferro, manganês e cromo nos períodos chuvoso e seco, no sedimento dos locais de estudo das bacias dos rios Piracicaba, Mogi Guaçu e Tibagi. As letras A e B correspondem, respectivamente, ao período chuvoso e seco, para as bacias dos rios Piracicaba e Mogi Guaçu e o inverso para a bacia do rio Tibagi. Pin. = Rib. Pinhal; Lim. = Limeira; Camp. = Campinas; Sum. = Sumaré; Amer. = Americana; $\quad$ Pira. = Piracicaba; S.J. = S.João da Boa Vista; M.G.1 = Mogi Guaçu à montante da Int. Paper; M.G.2 = Mogi Guaçu à jusante da Int. Paper; Psng. = Pirassununga; $\quad$ L.A.1 = Rio Mogi-Guaçu em Luiz Antônio à montante da VCP; L.A.2 = Rio Mogi-Guaçu em Luiz Antônio à jusante da VCP; T.B.1 = Rio Tibagi em Telêmaco Borba à montante da Klabin; T.B.2 = Rio Tibagi em Telêmaco Borba à jusante da Klabin; Lon = Rio Tibagi em Londrina......

FIGURA 59 Porcentagens de argila, silte, areia, argila e matéria orgânica nas amostras de sedimento coletadas nas diferentes localidades nas bacias dos rios Piracicaba, Mogi Guaçu e Tibagi. As letras A e B correspondem, respectivamente, ao período chuvoso e seco, para as bacias dos rios Piracicaba e Mogi Guaçu e o inverso para a bacia do rio Tibagi.

FIGURA 60 Concentrações de material em suspensão, matéria orgânica e matéria inorgânica nas amostras de água coletadas nas diferentes localidades nas bacias dos rios Piracicaba, Mogi Guaçu e Tibagi. A primeira e a segunda coletas correspondem, respectivamente, ao período chuvoso e seco, para as bacias dos rios Piracicaba e Mogi Guaçu e o inverso para a bacia do rio Tibagi.....

FIGURA 61 Valores de $\mathrm{pH}$, condutividade $\left(\mu \mathrm{S} . \mathrm{cm}^{-1}\right.$ ), concentração de oxigênio dissolvido (mg $\mathrm{O}_{2} \cdot \mathrm{L}^{-1}$ ) e temperatura $\left({ }^{\circ} \mathrm{C}\right)$ no momento das coletas das amostras de água e de sedimento nas diferentes localidades das bacias dos rios Piracicaba, Mogi Guaçu e Tibagi. Notar a inversão dos períodos chuvoso e seco para a bacia do rio Tibagi. Pin. = Rib. Pinhal; Lim. = Limeira; Cam. = Campinas; Sum. = Sumaré; Ame. = Americana; $\quad$ Pira. = Piracicaba; S.João. = S.João da Boa Vista; Mogi 1 = Mogi Guaçu à montante da Int. Paper; Mogi 2 = Mogi Guaçu à jusante da Int. Paper; Psng. = Pirassununga; L.Aant. 1 = Rio Mogi-Guaçu em Luiz Antônio à montante da VCP; L.Aant. 2 = Rio Mogi-Guaçu em Luiz Antônio à jusante da VCP; T.B.1 = Rio Tibagi em Telêmaco Borba à montante da Klabin; T.B.2 = Rio Tibagi em Telêmaco Borba à jusante da Klabin; Londr = Rio Tibagi em Londrina.

FIGURA 62 Índices de Alterações Histológicas e Valores Médios de Alterações calculados a partir das alterações observadas nas brânquias, rim e fígado de Serrapinnus notomelas expostos a diferentes concentrações do efluente final de indústria de papel e celulose. Os asteriscos indicam diferença estatisticamente significativa com relação ao grupo controle.

FIGURA 63 Detalhes de filamentos branquiais de Serrapinnus notomelas exposto a efluente final de indústria de papel e celulose a 5\% (96h), em cortes longitudinais. A) EE-elevações epiteliais nas lamelas secundárias; hiperplasia do epitélio estratificado do filamento branquial e a conseqüente fusão de lamelas secundárias (seta); Bouin, HE, x 640. B) EE-elevações epiteliais; Bouin, HE, x 500.

FIGURA 64 Filamentos branquiais de Serrapinnus notomelas exposto a efluente final de indústria de papel e celulose a 100\% (96h), em cortes longitudinais. Aneurismas nas lamelas secundárias (asteriscos); elevações epiteliais (setas menores); proliferação das células do epitélio estratificado do filamento (seta maior); C - cartilagem do filamento; Bouin, HE, x 320 . 
FIGURA 65 Rim posterior de Serrapinnus notomelas exposto a efluente final de indústria de papel e celulose a 20\% (96h). DG-degeneração glomerular; DT-início de degeneração tubular. Espaço intercapsular (seta) praticamente inexistente, devido à dilatação dos capilares glomerulares; TP - túbulo contorcido proximal; TD - túbulo contorcido distal; TL-tecido linfóide; Notar a grande quantidade de eritrócitos (E) entre os túbulos. Bouin, HE, x 500 .

FIGURA 66 Rim posterior de Serrapinnus notomelas exposto a efluente final de indústria de papel e celulose a $60 \%$ (96h). A) G-glomérulos com capilares dilatados e a conseqüente redução do espaço da cápsula de Bowman (asteriscos); DT-degeneração tubular. B) DT-degeneração tubular, caracterizando a necrose desta porção do tecido renal. A e B, Bouin, HE, x 640 .

FIGURA 67 Fígado de Serrapinnus notomelas exposto a efluente final de indústria de papel e celulose a 5\%. Observar a degeneração vacuolar do núcleo dos hepatócitos (setas) e a hipertrofia de alguns hepatócitos, acompanhada da degeneração do núcleo. (asteriscos). Bouin, HE, x 1000.

FIGURA 68 Fígado de Serrapinnus notomelas exposto a efluente final de indústria de papel e celulose a 60\%: Observar a desorganização dos cordões hepáticos, com a degeneração de hepatócitos e a perda de definição do epitélio dos sinusóides (S). Notar a presença de hepatócitos com núcleos hipertrofiados (setas) e núcleos com degeneração vacuolar (DV). V-vacúolos no citoplasma de hepatócitos; E-eritrócitos em um sinusóide dilatado. Bouin, HE, x 800 .

FIGURA 69 Fígado de Serrapinnus notomelas exposto a efluente final de indústria de papel e celulose a 100\% (96h). Nesta situação extrema, notar a área necrosada (N) do tecido hepático, o completo desarranjo dos cordões, o rompimento do epitélio dos sinusóides (S) e a hipertrofia de núcleos (n) e nucléolos (nu), além da presença de numerosos e volumosos vacúolos no citoplasma dos hepatócitos. Bouin, HE, x 1000...

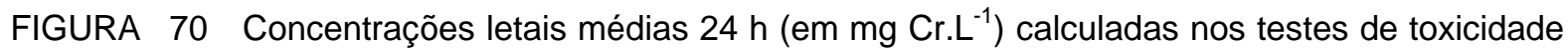
com dicromato de potássio, para Serrapinnus notomelas, comparadas à calculada para Danio rerio e àquelas observadas por MELETTI (1997) em testes com Serrapinnus stenodon, Hyphessobrycon eques e Poecilia reticulata.

FIGURA 71 Encéfalo de S. notomelas. LO = lobo óptico; C= cerebelo. $(\mathrm{HE}, 5 \mu \mathrm{m})$ (anexos)

FIGURA 72 Pseudobrânquia de D. rerio. (PAS - hematoxilina; $5 \mu \mathrm{m}$ ). 202 (anexos)

FIGURA 73 Rim anterior de S. notomelas. Notar a disposição do tecido inter-renal e das células (anexos) cromafins (asterisco) ao redor do vaso sangüineo (VS); TL = tecido linfóide. No aumento, a seta indica células cromafins e as cabeças de setas indicam partes do tecido inter-renal. (HE, $5 \mu \mathrm{m})$.

FIGURA 74 Duto biliar no fígado de $D$. rerio. $\mathrm{L}=$ lúmen do duto; $\mathrm{H}=$ hepatócitos; $\mathrm{HP}=$ (anexos) hepatopâncreas; TC = tecido conjuntivo. O asterisco indica a parede do duto, formada por células colunares. (HE, $5 \mu \mathrm{m}$ ).

FIGURA 75 Corte de $D$. rerio mostrando o coração (C), porções do estômago (E), da faringe (Fa), (anexos) do fígado $(\mathrm{Fi})$ e do tegumento $(\mathrm{T})$, na qual é possível observar as escamas. 
FIGURA 76 A - Corte do olho de $D$. rerio. A seta indica a fóvea. B - camadas da retina de $D$. (anexos) rerio. 1 - fibras nervosas; 2 - camada de células ganglionares; 3 - camada plexiforme interna; 4 - camada nuclear interna; 5 - camada plexiforme externa; 6 - camada nuclear externa; 7 - cones e bastonetes; 8 - camada de pigmento. A seta indica 0 sentido de incidência da luz. (HE, $5 \mu \mathrm{m}$ )

FIGURA 77 Esquema de montagem do sistema de manutenção de peixes de pequeno porte. (anexos)

FIGURA 78 Esquema de montagem do descalcificador. Este aparelho foi montado com base em (anexos) um pré-existente no laboratório de Histologia da UEL, e cujo projeto é de autoria desconhecida.

FIGURA 79 Descalcificador. c = cuba onde são colocados os peixes em metades e a solução de (anexos) EDTA; e = eletrodos de carvão; $g$ = garras para preensão dos eletrodos; $i$ = botão interruptor; $\mathrm{ma}=$ microamperímetro; $\mathrm{p}$ = botão do potenciômetro.

FIGURA 80 Girador para materiais em preparação histológica. $b=$ base de madeira; $c$ = caixa (anexos) plástica para montagem do motor; $i=$ interruptor; $p=$ prato giratório para suporte dos frascos contendo o material; $\mathrm{pa}=$ parafuso de ajuste do ângulo......

FIGURA 81 Partes e seqüência para montagem de uma câmara para teste de toxicidade in situ (anexos) com peixes de pequeno porte (MELETTI \& ROCHA, 2002). a=anel de preensão da tela da abertura do fundo; al=alça de corda de nylon; $b=$ base de ferro; cc=corpo da

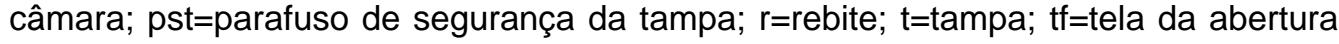
do fundo; $\mathrm{tl}=$ tela das aberturas laterais 


\section{LISTA DE TABELAS}

TABELA 1 Precipitações médias $(\mathrm{mm})$ em localidades próximas aos pontos estudados nas bacias dos rios Piracicaba e Mogi-Guaçu. Os valores referem-se às médias e aos desvios médios calculados a partir das precipitações mensais do período de 1988 a 2000 nas bacias dos rios Piracicaba e Mogi Guaçu (http://www.sigrh.sp.gov.br/sigrh/basecon/bancodedados/) e à precipitação mensal média registrada no ano de 2002 em Telêmaco Borba e Londrina (http://www.pr.gov.br/iapar).

TABELA 2 Vazões médias mensais $\left(\mathrm{m}^{3} . \mathrm{s}^{-1}\right)$ dos rios Jaguari, Atibaia, Piracicaba e Mogi-Guaçu em localidades próximas aos pontos estudados. Os valores referem-se às médias e aos desvios médios calculados a partir das vazões $\left(\mathrm{m}^{3} . \mathrm{s}^{-1}\right)$ mensais registradas nos seguintes períodos: 1990 a 1999 em Limeira, Piracicaba e Luiz Antônio; 1991 a 1999 em Sumaré; 1978 a 1987 em Mogi Guaçu e 1984 a 1994 em Pirassununga. (http://www.sigrh.sp.gov.br/sigrh/basecon/bancodedados/).

TABELA 3 Vazões médias $\left(\mathrm{m}^{3} \cdot \mathrm{s}^{-1}\right)$ do rio Tibagi em localidades próximas aos pontos estudados, calculadas* a partir dos valores médios das vazões diárias registradas de 1974 a 1993 (http://www.hidricos.mg.gov.br/ufparana/relprin3/tab31.htm).

TABELA 4 Lotes de peixes utilizados em cada teste de toxicidade aguda com dicromato de potássio e com sedimento das localidades estudadas.

TABELA 5 Alterações histológicas consideradas na análise das brânquiais de Serrapinnus notomelas e de Danio rerio expostos às amostras de sedimento e ao efluente de indústria de papel e celulose. O estágio considerado para cada alteração está indicado na segunda coluna. Baseado em POLEKSIC \& MITROVIC-TUTUNDZIC (1994)......

TABELA 6 Alterações histológicas consideradas na análise do rim de Serrapinnus notomelas e de Danio rerio expostos às amostras de sedimento e ao efluente de indústria de papel e celulose. O estágio considerado para cada alteração está indicado na segunda coluna. Baseado em RIGOLIN-SÁ (1998) e em alterações descritas por TAKASHIMA \& HIBIYA (1995).

TABELA 7 Alterações histológicas consideradas na análise do fígado de Serrapinnus notomelas e de Danio rerio expostos às amostras de sedimento e ao efluente de indústria de papel e celulose. O estágio considerado para cada alteração está indicado na segunda coluna. Baseado em RIGOLIN-SÁ (1998).

TABELA 8 Características físicas e químicas das soluções teste, monitoradas durante o teste $n^{\circ} 1$ de sensibilidade de Serrapinnus notomelas ao dicromato de potássio.

TABELA 9 Características físicas e químicas das soluções teste monitoradas durante o teste $\mathrm{n}^{0} 2$ de sensibilidade de Serrapinnus notomelas ao dicromato de potássio.....

TABELA 10 Características físicas e químicas das soluções-teste monitoradas durante o teste nำ 3 de sensibilidade de Serrapinnus notomelas ao dicromato de potássio.....

TABELA 11 Características físicas e químicas das soluções-teste monitoradas durante o teste n⿳0 4 de sensibilidade de Serrapinnus notomelas ao dicromato de potássio.

TABELA 12 Características físicas e químicas das soluções-teste monitoradas durante o teste $\mathrm{n}^{0} 1$ de sensibilidade de Danio rerio ao dicromato de potássio. 
TABELA 13 Variações dos valores de pH da água ao longo dos testes de toxicidade com amostras de sedimento coletadas nos períodos seco e chuvoso em diferentes localidades nas bacias dos rios Piracicaba, Mogi Guaçu e Tibagi. Pin = Rib. Pinhal; Lim = Limeira; Cam = Campinas; Sum = Sumaré; Ame = Americana; Pira = Piracicaba; S.João = São João da Boa Vista; Mogi $1=$ Mogi Guaçu 1; Mogi 2 = Mogi Guaçu 2; Psng = Pirassununga; L.Ant.1 = Luiz Antônio 1; L.Ant.2 = Luiz Antônio 2; T.Borba 1 = Telêmaco Borba 1; T.Borba 2 = Telêmaco Borba 2; Londr = Londrina.

TABELA 14 Variações dos valores de Condutividade da água $\left(\mu \mathrm{S} . \mathrm{cm}^{-1}\right)$ ao longo dos testes de toxicidade com amostras de sedimento coletadas nos períodos seco e chuvoso em diferentes localidades nas bacias dos rios Piracicaba, Mogi Guaçu e Tibagi. Pin = Rib. Pinhal; Lim = Limeira; Cam = Campinas; Sum = Sumaré; Ame = Americana; Pira = Piracicaba; S.João = São João da Boa Vista; Mogi 1 = Mogi Guaçu 1; Mogi 2 = Mogi Guaçu 2; Psng = Pirassununga; L.Ant.1 = Luiz Antônio 1; L.Ant.2 = Luiz Antônio 2; T.Borba 1 = Telêmaco Borba 1; T.Borba 2 = Telêmaco Borba 2; Londr = Londrina.....

TABELA 15 Variações das concentrações de oxigênio dissolvido na água ( $\mathrm{mg} \mathrm{O}_{2} \cdot \mathrm{L}^{-1}$ ) ao longo dos testes de toxicidade com amostras de sedimento coletadas nos períodos seco e chuvoso em diferentes localidades nas bacias dos rios Piracicaba, Mogi Guaçu e Tibagi. Pin = Rib. Pinhal; Lim = Limeira; Cam = Campinas; Sum = Sumaré; Ame = Americana; Pira = Piracicaba; S.João = São João da Boa Vista; Mogi 1 = Mogi Guaçu 1; Mogi 2 = Mogi Guaçu 2; Psng = Pirassununga; L.Ant.1 = Luiz Antônio 1; L.Ant.2 = Luiz Antônio 2; T.Borba 1 = Telêmaco Borba 1; T.Borba $2=$ Telêmaco Borba 2; Londr = Londrina.

TABELA 16 Variações da temperatura da água $\left({ }^{\circ} \mathrm{C}\right)$ ao longo dos testes de toxicidade com amostras de sedimento coletadas nos períodos seco e chuvoso em diferentes localidades nas bacias dos rios Piracicaba, Mogi Guaçu e Tibagi. Pin = Rib. Pinhal; Lim = Limeira; Cam = Campinas; Sum = Sumaré; Ame = Americana; Pira = Piracicaba; S.João = São João da Boa Vista; Mogi 1 = Mogi Guaçu 1; Mogi 2 = Mogi Guaçu 2; Psng = Pirassununga; L.Ant.1 = Luiz Antônio 1; L.Ant.2 = Luiz Antônio 2; T.Borba 1 = Telêmaco Borba 1; T.Borba 2 = Telêmaco Borba 2; Londr = Londrina....

TABELA 17 Variações dos valores da dureza da água ( $\mathrm{mg} \mathrm{CaCO}_{3} \cdot \mathrm{L}^{-1}$ ) no início (0h) e ao final (96h) dos testes de toxicidade com amostras de sedimento coletadas nos períodos seco e chuvoso em diferentes localidades nas bacias dos rios Piracicaba, Mogi Guaçu e Tibagi. Pin = Rib. Pinhal; Lim = Limeira; Cam = Campinas; Sum = Sumaré; Ame = Americana; Pira = Piracicaba; S.João = São João da Boa Vista; Mogi 1 = Mogi Guaçu 1; Mogi 2 = Mogi Guaçu 2; Psng = Pirassununga; L.Ant.1 = Luiz Antônio 1; L.Ant.2 = Luiz Antônio 2; T.Borba 1 = Telêmaco Borba 1; T.Borba 2 = Telêmaco Borba 2; Londr = Londrina.

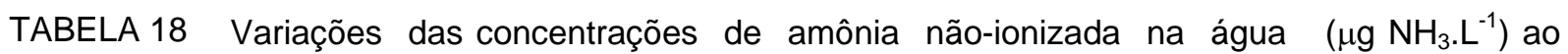
longo dos testes de toxicidade com amostras de sedimento coletadas nos períodos seco e chuvoso em diferentes localidades nas bacias dos rios Piracicaba, Mogi Guaçu e Tibagi. Pin = Rib. Pinhal; Lim = Limeira; Cam = Campinas; Sum = Sumaré; Ame = Americana; Pira $=$ Piracicaba; S.João = São João da Boa Vista; Mogi 1 = Mogi Guaçu 1; Mogi 2 = Mogi Guaçu 2; Psng = Pirassununga; L.Ant.1 = Luiz Antônio 1; L.Ant.2 = Luiz Antônio 2; T.Borba 1 = Telêmaco Borba 1; T.Borba 2 = Telêmaco Borba 2; Londr = Londrina.

TABELA 19 Ocorrência das alterações branquiais nos grupos de peixes das duas espécies expostos às amostras de sedimento das diferentes localidades de cada bacia. Os números representam, em porcentagens, o número de peixes que apresentaram o dano, do total de peixes analisados para cada localidade $(\mathrm{N}=5)$. HTCE=hipertrofia das células epiteliais; AdE=adelgamento do epitélio; ELS=elevação do epitélio da lamela scundária (LS); HPBLS: hiperplasia na base das LS.; HPLS=hiperplasia ao longo das LS.; LeuELS= presença de leucócitos; HP/HTCM=hiperplasia/trofia das céls. mucosas; HP/HTCC= hiperplasia/trofia das céls. cloreto; $C C L S=c e ́ l s$ cloreto nas LS; MuLS=presença de muco entre as LS; DiC=dilatação de capilares; DeC=desorganização de capilares; $\mathrm{CV}=$ congestão vascular; $\mathrm{Par}=$ presença de parasitas; FCalgLS=fusão completa de algumas LS; FCtodLS=fusão completa de toas as LS; DC=degeneração celular: RE=ruptura epitelial; Hem=hemorragia; An=aneurisma; Fib=fibrose; $N=$ necrose... 
TABELA 20 Ocorrência das alterações renais nos grupos de peixes das duas espécies expostos às amostras de sedimento das diferentes localidades de cada bacia. Os números representam, em porcentagens, o número de peixes que apresentaram o dano, do total de peixes analisados para cada localidade $(N=5)$. $P C T L=$ perda do contorno ou contorno atípico das células do tecido linfóide; $\mathrm{DHL}=$ degeneração hialina leve; HTCT=hipertrofia das células tubulares;

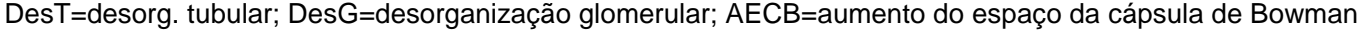
(CB); DECB=diminuição do espaço da cápsula de Bowman; DCG=dilatação dos capilares glomerulares; TR/NN=ocorrência de túbulos em regeneração ou de novos néfrons; PAST=presença de material PASpositivo nas céls tubulares; DFreqG=diminuição da freq. relativa de glomérulos; DilVS=dilatação de vasos sangüíneos; ALumTub=aumento do diâm. do lúmen tubular; ObsTub=obstrução tubular; DHS=degeneração hialina severa; DT=degeneração tubular; DegG=degeneração glomerular; DCTub=deg.citoplasmática das células tubulares; DNTub=deg. nuclear das céls tubulares; TLCB=tecido linfóide na $\mathrm{CB} ; \mathrm{HH}=$ hiperemia; RVS=ruptura de vasos sangüíneos; Nec=necrose.

TABELA 21 Ocorrência das alterações hepáticas nos grupos de peixes das duas espécies expostos às amostras de sedimento das diferentes localidades de cada bacia. Os números representam, em porcentagens, o número de peixes que apresentaram o dano, do total de peixes analisados para cada localidade $(\mathrm{N}=5)$. Des $\mathrm{CH}=$ desorganização/descaracterização dos cordões hepáticos; PContCel=perda ou atipia do contorno dos hepatócitos; PCont Nuc=perda ou atipia do contorno do núcleo dos hepatócitos; AVolCel=aumento do volume celular; AVolNuc= aumento do volume nuclear; VacCit=vacuolização citoplasmática; DFreqNuc=diminuição da freqüência relativa de núcleos; AFreqVas=aumento da freqüência relativa de vasos; AVolVasos=aumento do volume de vasos; DimGlic=diminuição do glicogênio; EstBil=estagnação biliar; HHem=hiperemia; RupVas=ruptura de vasos; DegCanBil=degeneração de canalículos biliares; VacNuc=vacuolização nuclear; DegCit= degeneração citoplasmática; DegNuc=degeneração nuclear; AtrofNuc= atrofia nuclear; RompCel=rompimento celular........

TABELA 22 Tabela-resumo da intensidade das alterações em cada órgão (em valores absolutos), segundo o Índice de Alteração Histológica (IAH) e o Valor Médio de Alterações (VMA), nas duas espécies de peixes, após a exposição por 96 horas às amostras de sedimento coletadas nos locais de estudo nas bacias dos rios Piracicaba, Mogi-Guaçu e Tibagi.

TABELAS Número de organismos mortos, variáveis físicas e químicas monitoradas e $23 \mathrm{~A}$ a $23 \mathrm{O}$ observações realizadas ao longo dos testes in situ nos locais de estudo nas bacias dos rios Tibagi, Piracicaba e Mogi Guaçu.

Obs.: * nível da água em $0 \mathrm{~h}$ classificado como baixo, médio ou alto (de acordo com observações em outras épocas e informações de pescadores e ribeirinhos); nos demais dias, variações relativas ao dia anterior $(0 \mathrm{~h}$ $=0 \mathrm{~cm}$ ); ${ }^{* *}$ clima: parc.nublado.=parcialmente nublado.

TABELA 24 Características físicas e químicas monitoradas durante o teste de toxicidade do efluente final de indústria de papel e celulose a Serrapinnus notomelas.

TABELA 25 Porcentagem de ocorrência das alterações histológicas no grupo de peixes (Serrapinnus notomelas) ( $\mathrm{N}$ ) exposto a cada concentração do efluente final de indústria de papel e celulose e ao controle (0\%)

TABELA 26 Composição da ração em flocos Alcon Basic ${ }^{\circledR}$ para peixes tropicais, de acordo com as informações contidas no rótulo da embalagem.

TABELA 27 Valores das concentrações letais médias $\left(\mathrm{CL}_{50}\right)$ de dicromato de potássio calculados (de acordo com HAMILTON et al., 1977) nos testes de toxicidade com Serrapinnus notomelas e Danio rerio em 24, 48, 72 e 96 horas de exposição. 
TABELAS Alterações branquiais observadas nos peixes Serrapinnus notomelas e Danio rerio $28 \mathrm{~A}$ a expostos às localidades Ribeirão do Pinhal, Jaguari, Campinas, Sumaré, Americana, 280 (anexos) Piracicaba, São João da Boa Vista, Mogi Guaçu 1, Mogi Guaçu 2, Pirassununga, Luiz Antônio 1, Luiz Antônio 2, Telêmaco Borba 1, Telêmaco Borba 2 e Londrina. Os sinais de + indicam a freqüência de ocorrência das alterações, sendo + = baixa freqüência, ++ $=$ média freqüência $\mathrm{e}+++=$ alta freqüência de ocorrência da alteração. Os traços $(-)$ indicam a não observação do órgão nos cortes. As abreviações significam: HTCE=hipertrofia das células epiteliais; AdE=adelgamento do epitélio; ELS=elevação do epitélio da lamela scundária (LS); HPBLS: hiperplasia na base das LS.; HPLS=hiperplasia ao longo das LS.; LeuELS= presença de leucócitos; HP/HTCM=hiperplasia/trofia das céls. mucosas; HP/HTCC= hiperplasia/trofia das céls. cloreto; CCLS=céls cloreto nas LS; MuLS=presença de muco entre as LS; DiC=dilatação de capilares; DeC=desorganização de capilares; CV=congestão vascular; Par=presença de parasitas; FCalgLS=fusão completa de algumas LS; FCtodLS=fusão completa de toas as LS; DC=degeneração celular: RE=ruptura epitelial; Hem=hemorragia; An=aneurisma; Fib=fibrose; $\mathrm{N}=$ necrose.

TABELAS $29 \mathrm{~A} \mathrm{a}$ 290 (anexos)

TABELAS $30 \mathrm{~A} \mathrm{a}$ 300 (anexos)

TABELA 31 (anexos)
Alterações renais observadas nos peixes Serrapinnus notomelas e Danio rerio expostos às localidades Ribeirão do Pinhal, Jaguari, Campinas, Sumaré, Americana, Piracicaba, São João da Boa Vista, Mogi Guaçu 1, Mogi Guaçu 2, Pirassununga, Luiz Antônio 1, Luiz Antônio 2, Telêmaco Borba 1, Telêmaco Borba 2 e Londrina. Os sinais de + indicam a freqüência de ocorrência das alterações, sendo $+=$ baixa freqüência, ++ $=$ média freqüência e $+++=$ alta freqüência de ocorrência da alteração. Os traços $(-)$ indicam a não observação do órgão nos cortes. As abreviações significam: PCTL= perda do contorno ou contorno atípico das células do tecido linfóide; DHL= degeneração hialina leve; HTCT=hipertrofia das células tubulares; DesT=desorg. tubular; DesG=desorganização glomerular; $\mathrm{AECB}=$ aumento do espaço da cápsula de Bowman (CB); DECB=diminuição do espaço da cápsula de Bowman; DCG=dilatação dos capilares glomerulares; TR/NN=ocorrência de túbulos em regeneração ou de novos néfrons; PAST=presença de material PAS-positivo nas céls tubulares; DFreqG=diminuição da freq. relativa de glomérulos; DilVS=dilatação de vasos sangüíneos; ALumTub=aumento do diâm. do lúmen tubular; ObsTub=obstrução tubular; DHS=degeneração hialina severa; DegT=degeneração tubular; DegG=degeneração glomerular; DCTub=deg.citoplasmática das células tubulares; DNTub=deg. nuclear das céls tubulares; TLCB=tecido linfóide na $\mathrm{CB}$; $\mathrm{HH}=$ hiperemia; $\quad \mathrm{RVS}=$ ruptura de vasos sangüíneos; $\mathrm{Nec}=$ necros

Alterações hepáticas observadas nos peixes Serrapinnus notomelas e Danio rerio expostos às localidades Ribeirão do Pinhal, Jaguari, Campinas, Sumaré, Americana, Piracicaba, São João da Boa Vista, Mogi Guaçu 1, Mogi Guaçu 2, Pirassununga, Luiz Antônio 1, Luiz Antônio 2, Telêmaco Borba 1, Telêmaco Borba 2 e Londrina. Os sinais de + indicam a freqüência de ocorrência das alterações, sendo + = baixa freqüência, ++ $=$ média freqüência e $+++=$ alta freqüência de ocorrência da alteração. Os traços $(-)$ indicam a não observação do órgão nos cortes. As abreviações significam: DesCH=desorganização/descaracterização dos cordões hepáticos; PContCel=perda ou atipia do contorno dos hepatócitos; PCont Nuc=perda ou atipia do contorno do núcleo dos hepatócitos; AVolCel=aumento do volume celular; AVolNuc= aumento do volume nuclear; VacCit=vacuolização citoplasmática; DFreqNuc=diminuição da freqüência relativa de núcleos; AFreqVas=aumento da freqüência relativa de vasos; AVolVasos=aumento do volume de vasos; DimGlic=diminuição do glicogênio; EstBil=estagnação biliar; HHem=hiperemia; RupVas=ruptura de vasos; DegCanBil=degeneração de canalículos biliares; VacNuc=vacuolização nuclear; DegCit= degeneração citoplasmática; DegNuc=degeneração nuclear; AtrofNuc= atrofia nuclear; RompCel=rompimento celular.

Alterações branquiais observadas no peixe Serrapinnus notomelas exposto às concentrações $0 \%$ (controle), 5\%, 20\%, 60\% e 100\% do efluente final de indústria de papel e celulose. Os sinais de + indicam a freqüência de ocorrência das alterações, sendo $+=$ baixa freqüência, $++=$ média freqüência $\mathrm{e}+++=$ alta freqüência de ocorrência da alteração. As abreviações significam: HTCE=hipertrofia das células epiteliais; AdE=adelgamento do epitélio; ELS=elevação do epitélio da lamela scundária (LS); HPBLS: hiperplasia na base das LS.; HPLS=hiperplasia ao longo das LS.; LeuELS= presença de leucócitos; HP/HTCM=hiperplasia/trofia das céls. mucosas; HP/HTCC= hiperplasia/trofia das céls. cloreto; $C C L S=c e ́ l s$ cloreto nas LS; MuLS=presença de muco entre as LS; DiC=dilatação de capilares; $\mathrm{DeC}=$ desorganização de capilares; $\mathrm{CV}=$ =congestão vascular; $\mathrm{Par}=$ presença de parasitas; FCalgLS=fusão completa de algumas LS; FCtodLS=fusão completa de toas as LS; DC=degeneração celular: RE=ruptura epitelial; Hem=hemorragia; An=aneurisma; Fib=fibrose; $\mathrm{N}=$ necrose. 
TABELA 32 Alterações renais observadas no peixe Serrapinnus notomelas exposto às (anexos) concentrações 0\% (controle), 5\%, 20\%, 60\% e 100\% do efluente final de indústria de papel e celulose. Os sinais de + indicam a freqüência de ocorrência das alterações, sendo $+=$ baixa freqüência, $++=$ média freqüência $\mathrm{e}+++=$ alta freqüência de ocorrência da alteração. As abreviações significam: PCTL= perda do contorno ou contorno atípico das células do tecido linfóide; $\mathrm{DHL}=$ degeneração hialina leve; HTCT=hipertrofia das células tubulares;

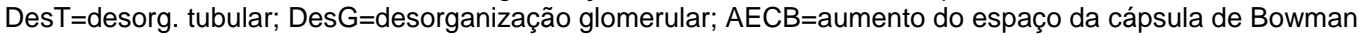
(CB); $D E C B=$ diminuição do espaço da cápsula de Bowman; $D C G=$ dilatação dos capilares glomerulares; TR/NN=ocorrência de túbulos em regeneração ou de novos néfrons; PAST=presença de material PASpositivo nas céls tubulares; DFreqG=diminuição da freq. relativa de glomérulos; DilVS=dilatação de vasos sangüíneos; ALumTub=aumento do diâm. do lúmen tubular; ObsTub=obstrução tubular; DHS=degeneração hialina severa; DegT=degeneração tubular; DegG=degeneração glomerular; DCTub=deg.citoplasmática das células tubulares; DNTub=deg. nuclear das céls tubulares; TLCB=tecido linfóide na CB; HH=hiperemia; RVS=ruptura de vasos sangüíneos; Nec=necrose.....

TABELA 33 Alterações hepáticas observadas no peixe Serrapinnus notomelas exposto às (anexos) concentrações 0\% (controle), 5\%, 20\%, 60\% e 100\% do efluente final de indústria de papel e celulose. Os sinais de + indicam a freqüência de ocorrência das alterações, sendo $+=$ baixa freqüência, $++=$ média freqüência $\mathrm{e}+++=$ alta freqüência de ocorrência da alteração. As abreviações significam: DesCH=desorganização/descaracterização dos cordões hepáticos; PContCel=perda ou atipia do contorno dos hepatócitos; PCont Nuc=perda ou atipia do contorno do núcleo dos hepatócitos; AVolCel=aumento do volume celular; AVolNuc= aumento do volume nuclear; VacCit=vacuolização citoplasmática; DFreqNuc=diminuição da freqüência relativa de núcleos; AFreqVas=aumento da freqüência relativa de vasos; AVolVasos=aumento do volume de vasos; DimGlic=diminuição do glicogênio; EstBil=estagnação biliar; HHem=hiperemia; RupVas=ruptura de vasos; DegCanBil=degeneração de canalículos biliares; VacNuc=vacuolização nuclear; DegCit= degeneração citoplasmática; DegNuc=degeneração nuclear; AtrofNuc= atrofia nuclear; RompCel=rompimento celular. 


\section{RESUMO}

As cidades e as atividades industriais e agrícolas geram uma infinidade de substâncias, muitas vezes desconhecidas, que quando lançadas nos corpos de água receptores podem por em risco a biota local e até mesmo a saúde humana. O presente trabalho avaliou o estado de degradação ambiental nas bacias dos rios Piracicaba, Mogi Guaçu (ambas no estado de São Paulo) e Tibagi (estado do Paraná), tendo como ferramentas os testes de toxicidade de sedimentos com peixes, em laboratório e in situ, análises histopatológicas dos animais expostos e análises físicas e químicas da água e do sedimento. Foram realizadas, ainda, análises das alterações histológicas em peixes expostos ao efluente final de indústria de papel e celulose, atividade presente nas três bacias estudadas. Os organismos-teste selecionados foram a espécie nativa Serrapinnus notomelas (Characiformes, Characidae) e a espécie padronizada Danio rerio (Cypriniformes, Cyprinidae). As preparações histológicas foram realizadas com os peixes inteiros, o que possibilitou a análise dos órgãos-alvo brânquias, rim e fígado, em um mesmo corte. Nenhum organismo morreu após 96 horas de exposição às amostras de sedimento. No entanto, as análises histológicas revelaram alterações importantes, as quais foram sistematizadas para o cálculo do Índice de Alterações Histológicas (IAH) e do Valor Médio de Alterações (VMA), por órgão e por espécie, para cada localidade estudada. Os sedimentos provenientes das localidades de Sumaré (rio Atibaia) e de Piracicaba (rio Piracicaba) foram os mais tóxicos a ambas as espécies, de acordo com os índices calculados, seguidos pelos sedimentos de Campinas (rio Atibaia), Limeira (rio Jaguari) e Americana (rio Piracicaba). Os sedimentos da bacia do rio Mogi Guaçu foram menos tóxicos, mas aqueles provenientes de Mogi Guaçu e Luiz Antônio (ambos em localidades a jusante de indústrias de papel e celulose) provocaram alterações renais e hepáticas significativas em $D$. rerio. Apesar de terem sido observadas alterações importantes nos peixes de ambas as espécies, expostas aos sedimentos da bacia do rio Tibagi, estas não foram tão intensas e freqüentes como aquelas observadas nos peixes expostos aos sedimentos das localidades das outras bacias hidrográficas. As análises físicas e químicas comprovaram a crítica situação de degradação do ambiente aquático na bacia do rio Piracicaba e alertam para os cuidados que deverão ser tomados com relação a esta e às bacias dos rios Mogi-Guaçu e Tibagi, cujos recursos estão sendo cada dia mais explorados. As graves alterações observadas nas brânquias, rim e fígado dos peixes expostos ao efluente de indústria de papel e celulose indicaram que o monitoramento da toxicidade desse tipo de efluente aos peixes deve ser realizado por ferramentas mais sensíveis, tais como as análises histopatológicas. 


\section{ABSTRACT}

Urban and industrial activities generate a large number of substances, frequently unknown that if discharged into water body receptors can put at risk the aquatic biota as well as the human health. The present work evaluated the state of environmental degradation in the basins of Rivers Piracicaba, Mogi Guaçu (both in São Paulo State) and Tibagi (Paraná State), using as tools the toxicity tests with sediments and fishes as test-organisms, for both laboratory and in situ, together with histopathological analyses of exposed animals and chemical and physical analysis of sediments and water. Also, histological alterations in fishes exposed to the final pulp-mill effluent were analyzed. The species selected as test-organisms were the native species Serrapinnus notomelas (Characiformes, Characidae) and the standard species Danio rerio (Cypriniformes, Cyprinidae). Hystological preparations were performed with whole fish specimens, what allowed the analysis of the target-organs: gills, kidney and liver in the same section. No fish mortality was found after 96 hours exposition to the sediment samples. Nevertheless histological analyses revealed important alterations, which were used to calculate the Histological Alteration Index (IAH) and the Mean Value of Alterations (VMA), for each organ and species, for each locality evaluated. Sediments coming from Sumaré (Atibaia River) and Piracicaba (Piracicaba River) were the most toxic to both species, according to the calculated index, followed by the sediments from Campinas (Atibaia River), Limeira (Jaguari River) and Americana (Piracicaba River). The sediments of Mogi Guaçu River basin had a lower toxicity, but those coming from Mogi Guaçu and Luiz Antônio (both localities placed downstream pulp-mill plants) have caused significant alterations in kidney and liver for $D$. rerio. Although important alterations were found for both species of fish exposed to the sediments from Tibagi River basin, these were not so intense and frequent as those observed in the fishes exposed to the sediment from the other localities studied. Physical and chemical analysis corroborated the critical environmental degradation degree of water systems in the Piracicaba River basin and function as an early warning for the measures that must be taken in relation to this and Mogi-Guaçu and Tibagi basins, where resources are increasingly being overexploited. The severe damage found in the gills, kidney and liver of fishes exposed to the pulpmill effluent suggest that monitoring this type of effluent to fishes must include a high sensibility tool such as the histopatological analyses. 


\section{INTRODUÇÃO}

\subsection{Breve histórico da Ecotoxicologia e a importância dessa ciência para o estudo dos problemas ambientais.}

Embora as observações sobre a natureza remontem de longa data, como aquelas feitas por Aristóteles (384-322 a.C.) sobre as águas continentais, o termo Ecologia foi cunhado por Haeckel (1834-1919) há menos de 140 anos apenas. Datam da mesma época os primeiros testes de toxicidade aquática que focalizaram os agentes tóxicos presentes em efluentes industriais (HOFFMAN et al., 1995). Observações interessantes também foram realizadas por MARSH (1908) a respeito do efeito, nos peixes, de metais e de outras substâncias dissolvidas na água. Já naquela época o autor observou que a toxicidade de metais variava de acordo com a composição química da água, demonstrando, mesmo sem uma explicação clara, que componentes, tais como os carbonatos, influenciavam na toxicidade dos metais. Outros trabalhos em "toxicologia aquática" foram realizados por químicos, limnólogos e outros pesquisadores, mas nenhum deles, ainda, seguia procedimentos padronizados. De acordo com HOFFMAN et al. (1995), o primeiro método padronizado para testes de toxicidade aquática foi publicado por Hart et al. em 1945 e subsequentemente adotado pela ASTM (American Society for Testing and Materials). Na mesma época, DOUDOROFF et al. (1951) utilizaram testes de toxicidade com peixes para avaliar a toxicidade de efluentes e para dar suporte ao desenvolvimento de novos métodos padronizados. Ao uso de organismos aquáticos na análise de efluentes foi dada a denominação de "bioensaios aquáticos". A publicação de Doudoroff de 1951 levou aos procedimentos padronizados que foram incluídos no "Standard Methods for Examination of Water and Wastewater", uma publicação da APHA (American Public Health Association).

Embora os testes de toxicidade aquática então já existissem, o termo Ecotoxicologia foi proposto somente em 1969, por Truhaut, como sendo uma extensão da toxicologia, a ciência dos efeitos dos agentes tóxicos nos organismos individuais. Esse conceito foi então ampliado para "a ciência dos efeitos ecológicos dos poluentes" (HOFFMAN et al., 1995). Definições mais amplas surgiram, como "a ciência que se baseia no estudo das modificações que sofrem os ecossistemas a curto ou a longo prazo, utilizando-se de conceitos gerais bem estabelecidos de Ecologia, 
para entender os processos envolvidos, compreender os efeitos no ambiente e prever os prováveis riscos em caso de contaminação" (BOUDOU \& RIBEYRE, 1989).

Essa nova ciência e, em especial o ramo que trata dos ambientes aquáticos - a Ecotoxicologia Aquática -, tem se desenvolvido muito nas últimas décadas em virtude da grande velocidade de degradação dos recursos hídricos. Embora os lagos e rios contenham uma porção muito pequena da água doce do planeta $(0,33$ e 0,004\%, respectivamente) eles desempenharam um importante papel no desenvolvimento das civilizações e serão sempre primordiais ao desenvolvimento das nações. O crescimento populacional e o desenvolvimento tecnológico, porém, tem provocado profundas alterações na paisagem, como o desmatamento para a construção de cidades e para a expansão das fronteiras agrícolas. Além disso, a drenagem de áreas alagadas, a canalização de rios, a construção de barragens e as quantidades crescentes de água desviadas para o abastecimento das cidades, indústrias e para a irrigação de terras acarretam mudanças na natureza física dos rios (CORSON, 1990; LLOYD, 1992; PETTS \& CALOW, 1996), e o desaparecimento de espécies da fauna e da flora (PETTS \& CALOW, 1996). No entanto, os piores impactos provocados pelo homem nos ambientes aquáticos talvez sejam aqueles advindos do despejo de agentes tóxicos nos corpos d'água. Tais despejos podem ser oriundos de uma grande variedade de fontes, algumas delas óbvias, outras nem tanto. Estes despejos podem ser tão variáveis, tanto quantitativamente, quanto qualitativamente, que as concentrações e a espécie das substâncias lançadas na água raramente são constantes, fazendo com que sempre haja novos problemas a serem resolvidos (LLOYD, 1992). Como um agravante desse quadro existe o incessante desenvolvimento da indústria química, de forma que o número de contaminantes que podem causar efeitos preocupantes cresce anualmente, e o conhecimento a respeito dos destinos e efeitos desses novos compostos no ambiente torna-se cada vez mais defasado (JøRGENSEN, 1990).

No intuito de fornecer informações a respeito dos impactos causados pela poluição e da eficiência das medidas mitigadoras, devem ser realizados programas de monitoramento ambiental que, assim, auxiliem o gerenciamento dos recursos hídricos (CHAPMAN, 1989). Segundo ABEL (1989), o monitoramento permite detectar e descrever as alterações ocorrendo em um ambiente e entender as relações qualitativas e quantitativas entre a poluição e suas conseqüências biológicas. No entanto, para que o monitoramento ambiental tenha caráter preditivo, deve sempre contemplar o estudo dos contaminantes aquáticos não só nos ambientes degradados, mas também naqueles ambientes recuperados cujas fontes poluidoras já foram identificadas e presumivelmente controladas, pois, conforme destacam EYSINK \& 
MORAES (1988), mesmo após a melhoria da qualidade da água, os agentes tóxicos contidos no sedimento podem ser disponibilizados por processos físicos, químicos e biológicos.

De acordo com PETTS \& CALOW (1996), a presença de poluentes nos ambientes aquáticos pode ser detectada de duas formas: diretamente, por análises químicas, e indiretamente pelos efeitos que causam nos organismos presentes no próprio corpo d'água e no ambiente que o cerca. As análises químicas constituem o método mais direto de estudar a poluição e podem ser utilizadas para detectar desde substâncias simples, como os metais, sais e gases dissolvidos, até compostos orgânicos complexos. Variáveis tais como temperatura, turbidez, cor, pH, entre outras, também podem ser utilizadas na avaliação de efluentes.

Entretanto, quando se trata de efluentes muito complexos e de amostras de água ou de sedimento de locais poluídos, é inviável ou até mesmo impossível detectar a presença de todas as substâncias presentes. No entanto, podem ser observados os efeitos destas nos sistemas biológicos, através de estudos ecotoxicológicos (SOARES 1990; PETTS \& CALOW,1996).

SOARES (1990) apresenta considerações importantes em relação aos agentes tóxicos:

(1) alguns agentes químicos produzem efeitos biológicos adversos em concentrações bastante inferiores às detectadas pelos atuais métodos analíticos;

(2) nos sistemas aquáticos as substâncias químicas não são encontradas, normalmente, em concentrações constantes, podendo ocorrer picos ocasionais de concentrações elevadas, que terão obviamente um significado biológico muito maior do que os níveis "normais";

(3) as águas residuárias contêm misturas complexas de substâncias químicas cuja toxicidade não pode ser atribuída a um ou vários componentes isolados, de forma que, devido aos efeitos antagonísticos e sinergísticos, a toxicidade pode ser maior, menor, ou igualar a soma da toxicidade dos seus constituintes;

(4) os efeitos biológicos de um agente químico são função da sua concentração e das características do sistema em que atua.

Os testes de toxicidade são instrumentos úteis na avaliação dos danos causados pelos contaminantes ambientais. VISWANATHAN et al. (1988) ressaltam que os estudos ecotoxicológicos em ambientes afetados pela poluição dão subsídios para o manejo de ambientes menos degradados, e a comparação entre eles ajuda a identificar espécies vulneráveis e espécies indicadoras da qualidade ambiental.

Assim, o conhecimento biológico é primordial para o controle da poluição e para a compreensão das conseqüências desta para a saúde pública e para a biota aquática, 
pois oferece subsídios para especialistas de outras áreas, tais como químicos, engenheiros, administradores e legisladores, que dividem a responsabilidade do manejo dos recursos hídricos (ABEL, 1989).

\subsection{Os agentes tóxicos, os organismos e os testes de toxicidade}

WEINSTEIN \& BIRK (1989) elaboraram um diagrama (figura 1) que indica os caminhos das perturbações físicas e químicas que podem levar a alterações no ecossistema.

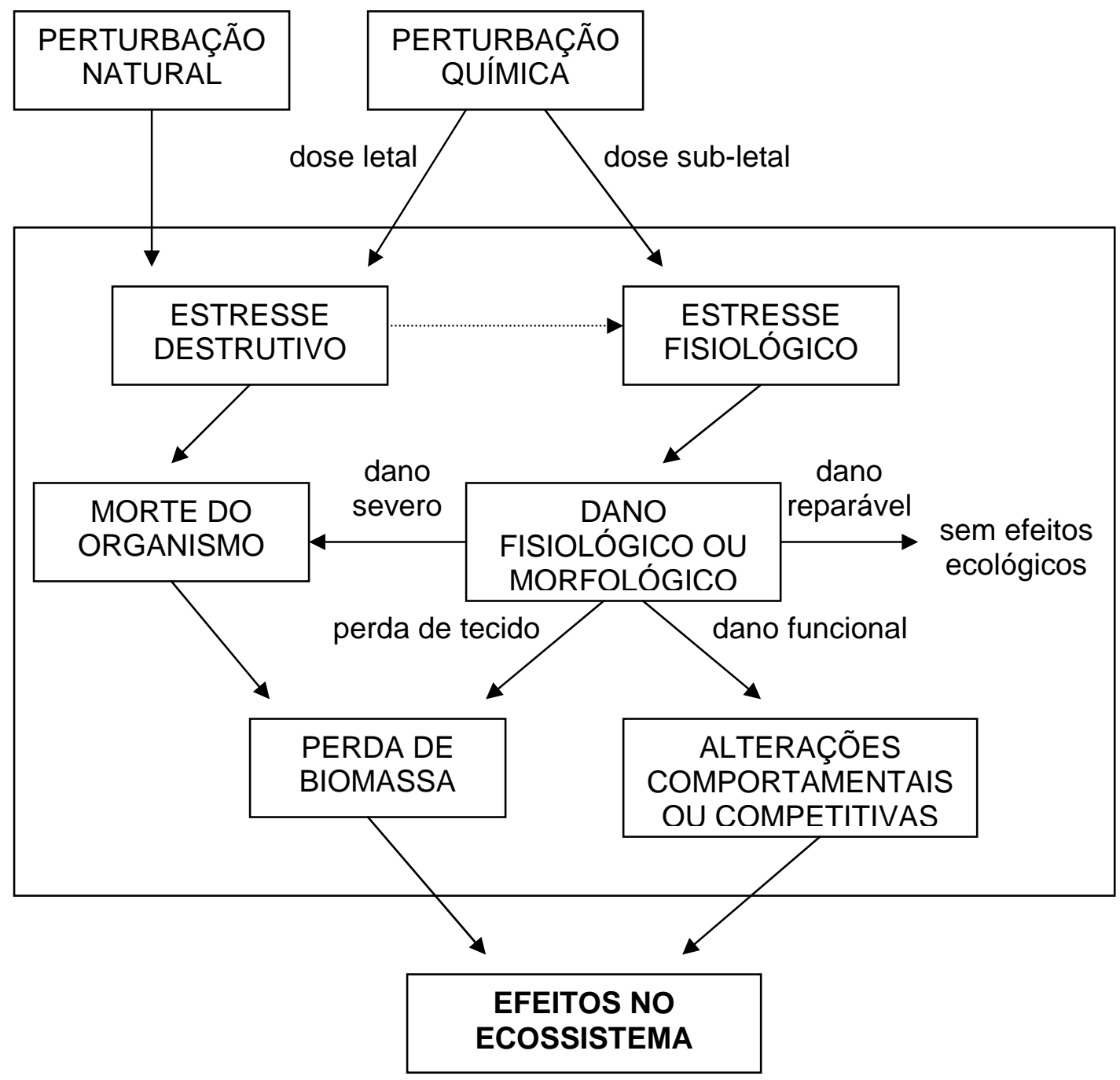

FIGURA 1. Caminhos das perturbações físicas e químicas. Os caminhos e os componentes dentro da caixa maior representam os efeitos das perturbações naturais severas e os vários tipos de perturbações químicas nos organismos e os caminhos pelos quais esses efeitos alcançam o nível ecossistema (WEINSTEIN \& BIRK, 1989).

Embora os autores façam referência aos ecossistemas terrestres, o diagrama pode ser considerado para outros ambientes. Segundo os autores, as alterações 
observadas na estrutura do ecossistema normalmente têm início em perturbações no indivíduo, traduzidas pela perda de biomassa devido à destruição física ou, se menos graves, pelo estresse fisiológico que poderá resultar em danos metabólicos ou perda de alguma função necessária ao crescimento e/ou manutenção do organismo.

Assim, embora o estresse fisiológico tenha início no indivíduo, as manifestações no ecossistema como um todo resultam da interação entre os indivíduos e entre esses e o ambiente físico-químico (LEVIN \& KIMBALL, 1984 apud WEINSTEIN \& BIRK, 1989).

Para avaliar os efeitos adversos de um agente tóxico nos organismos vivos sob condições padronizadas, de maneira a permitir comparações com outras substâncias e espécies testadas, são realizados os testes de toxicidade. Toxicidade é uma propriedade relativa de uma substância química que se refere ao seu potencial de causar danos aos organismos vivos e é uma função da concentração da substância química e da duração da exposição (RAND \& PETROCELLI, 1985).

Nos testes de toxicidade podem ser observados efeitos agudos e efeitos crônicos, sendo os primeiros aqueles que ocorrem rapidamente como um resultado da exposição ao agente tóxico por um curto período de tempo (para peixes, horas, dias ou semanas). De acordo com a CETESB (1990), o efeito agudo trata-se de uma resposta severa e rápida dos organismos a um estímulo, que se manifesta, em geral, num intervalo de 0 a 96 horas. Normalmente o efeito é a letalidade (ou para alguns organismos, como os microcrustáceos, pode ser a imobilidade). Para a avaliação do efeito agudo são consideradas a $\mathrm{CL}_{50}$ e a $C E_{50}$, sendo a primeira a concentração letal média, ou a concentração do agente tóxico que causa mortalidade a $50 \%$ dos organismos expostos num intervalo de 24 a 96 horas, e a última, a concentração efetiva média, ou a concentração do agente tóxico que causa imobilidade a 50\% dos organismos expostos no mesmo intervalo de tempo. De acordo com WEINSTEIN \& BIRK (1989), o estresse agudo é caracterizado por danos morfológicos severos, alterações significativas no metabolismo, colapso celular e perda de tecido. Se essa perda for muito grande ou se algum processo fisiológico vital for permanentemente comprometido, o organismo irá morrer. Isso caracteriza a toxicidade letal aguda que resulta de um rápido bloqueio do metabolismo. No ambiente, tais doses geralmente estão associadas com acidentes localizados envolvendo o derramamento de alguma substância tóxica como por exemplo um efluente não tratado.

Quanto aos efeitos crônicos, estes podem ocorrer quando o agente tóxico produz efeitos deletérios como resultado de exposições repetidas ou exposições por longos períodos de tempo. Os efeitos crônicos podem ser letais ou subletais. Um efeito letal típico para uma população é a incapacidade dos organismos expostos em 
produzir proles viáveis. Os efeitos subletais mais comuns são as mudanças comportamentais (na natação, na atração-repulsão, nas relações predador-presa), fisiológicas (crescimento, reprodução, desenvolvimento), bioquímicas (enzimas, equilíbrio iônico) e histológicas (RAND \& PETROCELLI, 1985). O efeito crônico é definido como uma resposta a um estímulo duradouro e que normalmente é subletal e afeta funções biológicas como reprodução, desenvolvimento dos ovos, crescimento e maturação, entre outras (CETESB, 1990). Neste caso, o que se determina é o CENO concentração de efeito não observado, que corresponde à maior concentração do agente tóxico que não causa efeito deletério na sobrevivência e reprodução dos organismos, em um período de tempo correspondente a parte ou a todo o ciclo de vida dos organismos expostos.

Há ainda, de acordo com CAIRNS et al. (1973), efeitos fisiológicos subletais quase imediatos, ou seja, que ocorrem em curtos espaços de tempo, como as alterações nos ritmos respiratório e cardíaco dos animais expostos. Uma vez estabelecido um padrão para estes parâmetros para uma dada espécie, em uma determinada condição ambiental, qualquer alteração em um, em outro, ou em ambos, pode significar uma mudança nas características físicas e químicas do meio. Da mesma forma, alterações em padrões comportamentais podem ser estudadas e relacionadas com a exposição a certos níveis de poluição (CHAPMAN, 1989).

Várias técnicas têm sido desenvolvidas para avaliar os efeitos imediatos e a longo prazo dos agentes tóxicos no ambiente. Estas técnicas não são as mesmas para todas as classes de substâncias e, quando se tratam de misturas, a avaliação torna-se ainda mais difícil. Os xenobióticos agem nos organismos vivos de diversas maneiras e em diferentes níveis. Assim, são importantes os estudos dos efeitos genotóxicos, bioquímicos, histológicos, fisiológicos e comportamentais, assim como são imprescindíveis os estudos em bioacumulação, biotransformação e biodegradação, além daqueles que consideram a dinâmica das populações e comunidades (LANDIS \& YU, 1995).

Os indicadores fisiológicos e comportamentais são freqüentemente utilizados na avaliação dos impactos causados pelos agentes tóxicos nas populações. Uma grande variedade de danos causados pelos agentes tóxicos pode ser observada nos peixes. Entre estes danos podem ser citadas as alterações histológicas e morfológicas na estrutura óssea, no fígado, nos rins e em outros órgãos, como as brânquias. Estas, por possuírem tecidos sensíveis, freqüentemente indicam a presença de materiais irritantes na água. O estudo de lesões e necroses em tecidos têm sido o fundamento de muitas pesquisas. Tumores, por exemplo, têm sido amplamente estudados como 
indicadores de materiais oncogênicos presentes em sedimentos marinhos. (LANDIS \& YU, 1995).

Segundo OVERSTREET (1987), o interesse a respeito dos efeitos dos poluentes sobre os peixes e outros organismos aquáticos tem crescido nas últimas décadas porque os poluentes podem causar doenças que, além de aumentar a mortalidade de espécies comercialmente importantes, também podem ser utilizados no monitoramento dos efeitos da poluição.

De acordo com WESTER \& ROGHAIR (1994), o estudo dos efeitos dos agentes tóxicos sobre as populações muitas vezes é um processo complicado e difícil. No estudo de efeitos agudos, os parâmetros sobrevivência/mortalidade são apropriados e evidentes, ao passo que para o estudo de efeitos crônicos, causados por concentrações subletais, os parâmetros relevantes são difíceis de serem averiguados. Como os efeitos subletais são, em geral, mais sutis e qualitativos, é difícil monitorá-los em populações ou em comunidades naturais, devido à complexidade de um ecossistema e à especificidade do efeito induzido. Assim, os estudos dos organismos em laboratório são indispensáveis para a identificação dos efeitos causados por baixas concentrações de um dado agente tóxico em algum órgão ou tecido. Ainda segundo WESTER \& ROGHAIR (1994), o estudo histopatológico pode revelar efeitos tóxicos estruturais específicos em vários órgãos de pequenos peixes utilizados experimentalmente em laboratório. Este tipo de estudo constitui uma ferramenta útil na avaliação de risco dos agentes tóxicos nos ambientes aquáticos.

\subsection{0 estudo histopatológico como ferramenta para a avaliação de agentes tóxicos.}

SCHWAIGER et al. (1997) utilizaram "valores médios de avaliação" (VMA), calculados a partir de uma análise semiquantitativa baseada em uma escala de severidade das lesões. Esta escala foi utilizada para estabelecer uma avaliação geral das lesões histopatológicas para cada órgão de cada peixe exposto à água de dois rios (Körsch e Krähenbach, na Alemanha). Neste estudo os peixes foram mantidos em um sistema de fluxo contínuo "semi in situ" , no qual a água dos rios foi bombeada diretamente para os tanques que continham os peixes (Salmo trutta $f$. fario (truta) e Barbatula barbatula (perca)). Foi encontrada uma grande variedade de alterações histopatológicas nos órgãos examinados das trutas e percas. A severidade e freqüência das lesões nos órgãos foi maior nas trutas expostas à água do rio Körsch que naquelas expostas às águas do rio Krähenbach e do controle. Estes resultados corroboraram as análises químicas, pois no rio Körsch foram detectados, tanto na água quanto no sedimento, altos níveis de pesticidas, metais pesados (em teores mais 
elevados no sedimento) e PAHs (hidrocarbonetos policíclicos aromáticos). A situação no rio Krähenbach foi menos dramática.

Além disso, os estudos histopatológicos revelaram diferenças sazonais nos tipos e severidade das lesões nos órgãos dos peixes expostos. Também puderam ser discriminadas as alterações induzidas pelos agentes tóxicos daquelas lesões resultantes de estressores naturais (fatores físicos e químicos) e dos efeitos de estressores secundários relacionados à poluição (doenças).

OVERSTREET (1987), pesquisando o efeito da poluição aquática sobre as populações animais da costa sudeste dos EUA, observou lesões e infecções parasíticas em várias espécies de crustáceos, mariscos e peixes. Foram observados peixes com linfocistos, úlceras, inflamações avermelhadas, nadadeiras rasgadas e granulomas e crustáceos com lesões nas carapaças. Outros indicadores incluíram parasitas microbianos e metazoários. Segundo o autor, devido à falta de estudos detalhados sobre causa e efeito, as condições histopatológicas que ocorreram nas espécies estuarinas e marinhas da região estudada não puderam ser associadas a agentes tóxicos individuais ou em mistura.

WESTER \& CANTON (1991) avaliaram a utilidade do estudo histopatológico na identificação dos efeitos tóxicos de contaminantes ambientais em peixes. Para isso, utilizaram populações de guaru (Poecilia reticulata) e de medaka (Oryzias latipes) em estágio juvenil, as quais foram expostas aos seguintes tóxicos: $\beta$-hexaclorociclohexano $(\beta-\mathrm{HCH})$, bis(tri-n-butilestanho)óxido (TBTO), di-n-butilestanhodicloreto (DBTC), brometo de metila, brometo de sódio e cloreto de metilmercúrio por períodos de 1 e 3 meses. Foram observadas alterações nos níveis estrogênicos, causadas pelo $\beta-\mathrm{HCH}$, necrose espermática, causada pelo cloreto de metilmercúrio, degeneração e paralisia muscular, causada pelo brometo, atrofia do timo e lesões oculares provocadas pelo TBTO e DBTC. Surpreendentemente, segundo os autores, não foram observadas alterações branquiais, freqüentemente observadas nos casos de exposição aguda. Quanto ao enquadramento dos organismos nos objetivos do teste e aos períodos de exposição determinados, os autores concluíram que os guarus foram mais adequados qualitativa e quantitativamente que os medakas, e que não houve nenhuma vantagem especial da exposição por 3 meses sobre a exposição por 1 mês, pois todas as alterações já haviam ocorrido, significativamente, ao final do menor período de exposição. Concluíram, ainda, que as técnicas histopatológicas são úteis na identificação dos órgãos-alvo e dos mecanismos de ação, e que o conhecimento dos processos patológicos e toxicológicos fundamentais são importantes tanto para o controle dos poluentes aquáticos, como para os pesquisadores envolvidos nos estudos de campo. De acordo com WESTER \& ROGHAIR (1994), do ponto de vista 
qualitativo, alguns efeitos observados nos organismos podem alterar toda a dinâmica da população, particularmente aqueles que afetam o metabolismo energético, o crescimento e a reprodução. Estes efeitos podem não ser revelados pelos estudos toxicológicos clássicos, nos quais somente são monitorados a mortalidade, o crescimento e a condição geral dos indivíduos.

Segundo FOURNIE et al. (1996), há vários métodos padronizados para a preparação histológica de órgãos e tecidos específicos de interesse particular para os estudos toxicológicos. Estes estudos utilizam como organismos-teste salmonídeos e outros peixes de grande porte. No entanto, a utilização crescente de espécies de pequeno porte em testes de toxicidade aquática tornou necessário o desenvolvimento de protocolos específicos para a avaliação histopatológica para estas espécies. Uma das vantagens da utilização de espécies de pequeno porte em estudos toxicológicos é que o processamento e a avaliação histológica são facilitados pelo fato dos organismos serem utilizados inteiros, ao invés de terem os tecidos dissecados. Os mesmos autores propuseram, assim, um protocolo relativamente simples para a preparação de pequenos peixes inteiros para avaliação histológica. Este procedimento permite visualizar, muitas vezes em uma secção apenas, órgãos como o fígado, o rim, o cérebro, os filamentos branquiais e o intestino.

Assim, a avaliação histopatológica de pequenos peixes preparados inteiros pode ser um importante parâmetro para os testes toxicológicos. No entanto, FOURNIE et al. (1996) recomendam que, para o sucesso da avaliação, deve-se (1) planejar cuidadosamente o seccionamento do peixe inteiro a fim de que seja possível observar todas as lesões que se deseja e (2) manter o padrão das secções de um peixe para outro.

\subsection{Aspectos da morfofisiologia das brânquias, rim e fígado de teleósteos dulcícolas.}

A maioria dos teleósteos possui, em cada lado da faringe, 4 arcos branquiais, sendo cada arco constituído por duas fileiras de filamentos branquiais (hemibrânquias anterior e posterior). De ambos os lados de cada filamento se projetam as lamelas secundárias, que constituem o epitélio respiratório.

Os filamentos branquiais, ou lamelas primárias, possuem um suporte cartilaginoso, um sistema vascular e um epitélio multiestratificado. Já as lamelas secundárias possuem apenas duas camadas de células epiteliais assentadas sobre uma membrana basal e sustentadas por células pilares que separam os capilares lamelares. O sistema vascular branquial possui um circuito artério-arterial e um circuito artério-venoso. O primeiro é formado, ao longo dos filamentos, por artérias aferentes e 
eferentes que se ramificam em arteríolas (também aferentes e eferentes). Entre essas últimas encontra-se, nas lamelas secundárias, uma rede de capilares anastomosados e é na passagem do sangue por esses capilares que ocorre a troca gasosa. A eficiente difusão dos gases é proporcionada pela estreita barreira água-sangue e pelo fato do fluxo sangüíneo na lamela ter direção oposta ao fluxo de água (mecanismo de contracorrente), de forma que o sangue que abandona as lamelas está em íntimo contato com a água que apresenta máxima tensão de $\mathrm{O}_{2}$ e mínima tensão de $\mathrm{CO}_{2}$. A partir dos capilares, o sangue oxigenado segue, então, pelas arteríolas e artérias branquiais eferentes para a aorta dorsal. Já o circuito artério-venoso possui um seio venoso central ao longo de cada lamela secundária e, paralelos a este, vasos aferentes e eferentes que correm juntos às artérias aferentes e eferentes. Este circuito drena o sangue que irriga os filamentos e as lamelas secundárias, transportando-o de volta ao coração. Todas essas características são comuns à grande maioria dos teleósteos (GEORGE et al., 1998; LEAKE, 1975; TAKASHIMA \& HIBIYA, 1995).

O epitélio dos filamentos branquiais possui, ainda, células mucosas e de cloreto, sendo essas últimas mais freqüentes nas espécies marinhas (TAKASHIMA \& HIBYIA, 1995).

A principal função dos rins dos teleósteos de água doce é excretar o excesso de água que penetra no organismo, que é hipertônico em relação ao meio. Assim, os rins desses peixes são capazes de produzir grande quantidade de urina diluída. De acordo com TAKASHIMA \& HIBIYA (1995), a forma do rim dos peixes varia entre as espécies e, nos teleósteos, podem ser reconhecidas pelo menos duas porções: o rim anterior e o rim posterior. O rim anterior, segundo os autores, é constituído por tecido linfóide e no rim posterior são encontrados muitos néfrons e tecido linfóide intersticial. O tecido linfóide renal (principalmente o da porção anterior) é o tecido hemocitopoético dos teleósteos, e é composto por células reticulares e muitos capilares.

O néfron é a unidade funcional do rim e é constituído, basicamente, pelo corpúsculo renal, onde ocorre o processo de filtração e pelos túbulos renais (contorcido proximal, porção intermediária e contorcido distal), onde ocorrem os processos de reabsorção e de secreção. Há diferenças entre os néfrons de peixes marinhos e dulcícolas. Apenas estes últimos apresentam túbulos contorcidos distais e seus corpúsculos renais são maiores e mais numerosos (TAKASHIMA \& HIBIYA 1995).

O corpúsculo renal é composto pela cápsula de Bowman e pelo glomérulo. A cápsula possui uma camada fibrosa externa e, internamente um epitélio pavimentoso simples, o qual, no pólo urinário, é contínuo com o epitélio tubular proximal. O glomérulo consiste em um tufo de capilares fenestrados enovelados, que são 
ramificações da arteríola aferente; esses capilares novamente se reúnem em um único vaso, formando a arteríola eferente. O ponto em que as duas arteríolas (aferente e eferente) penetram e deixam a cápsula de Bowman é denominado pólo vascular e opõe-se ao pólo urinário. Dentro da cápsula, os espaços entre as voltas dos capilares glomerulares são preenchidos pelas células mesangiais. Junto à parede das arteríolas aferentes encontram-se as células justaglomerulares. O epitélio do túbulo contorcido proximal é constituído por células cubóides, cuja superfície apical possui muitos microvilos, o que confere à borda um aspecto de escova. O núcleo, localizado na porção central ou basal dessas células, é grande e arredondado. A porção distal do túbulo renal é formada por células epiteliais semelhantes às do túbulo proximal, porém com menos microvilos, o que dá à borda do lúmen um aspecto mais liso. Além disso, o citoplasma destas células é corado mais fracamente pela eosina (TAKASHIMA \& HIBIYA 1995).

O fígado dos peixes é muito semelhante estruturalmente ao dos demais vertebrados (LEAKE, 1975), sendo formado por um parênquima de grandes células poliédricas, os hepatócitos, dispostos em placas constituídas por uma única camada de células, formando "cordões" que freqüentemente se anastomosam; tais cordões são delimitados por numerosos capilares, os sinusóides, cujo fluxo sangüíneo vem dos ramos terminais da veia porta e artéria hepática, que trazem, respectivamente, sangue rico em nutrientes do trato gastrintestinal e sangue rico em oxigênio. A estrutura lobular caracterizada por uma veia central para onde convergem radialmente os sinusóides e os cordões hepáticos, característica dos vertebrados superiores, é muito variável nos peixes (TAKASHIMA \& HIBIYA, 1995; YOUNG \& HEATH, 2000). No contato de um hepatócito com a superfície de outra célula vizinha existe um espaço tubular limitado apenas pela membrana das duas células, denominado canalículo biliar, que drena a bile até o duto hepático pelo qual é conduzida, em alguns peixes, até o duodeno e, em outros, até a vesícula biliar, onde é armazenada (LEAKE, 1975; GEORGE, 1998). As células hepáticas têm muitas funções vitais além da secreção de bile; elas também participam do metabolismo das proteínas, gorduras e carboidratos, estão envolvidas em processos de desentoxicação, de hematopoiese e produção de anticorpos (este último durante a fase larval) e ainda servem como locais de armazenamento de glicogênio e lipídios (TAKASHIMA \& HIBIYA, 1995).

O núcleo dos hepatócitos é redondo, contém cromatina perifericamente dispersa e nucléolo proeminente. O tamanho dos núcleos pode variar muito, o que faz do hepatócito um tipo celular incomum; células binucleadas também são comuns no fígado normal. O citoplasma possui uma aparência variável, dependendo do estado nutricional do indivíduo. Quando bem nutridos, os hepatócitos estocam quantidades 
significativas de glicogênio e processam grandes quantidades de lipídeos (YOUNG \& HEATH, 2000). No indivíduo desnutrido, quando há esgotamento dos estoques de glicogênio e lipídeos, o citoplasma é corado uniformemente pela eosina. Em geral há poucas gotículas lipídicas nos hepatócitos que, contudo, aumentam muito após a ingestão de certas substâncias tóxicas (ROSS \& ROWRELL,1998).

Ambos os metabólitos são parcialmente removidos durante a preparação histológica de rotina, deixando áreas irregulares não coradas dentro do citoplasma (ROSS \& ROWRELL,1998; YOUNG \& HEATH, 2000). Segundo TAKASHIMA \& HIBIYA (1995), essas áreas aparecem como estruturas vacuolares quando se utiliza, por exemplo, hematoxilina-eosina, que não cora lipídios. O formato dessas áreas não coradas pode indicar, de modo grosseiro e impreciso a presença de uma ou outra substância, pela forma do vacúolo que elas formam. Assim, partículas lipídicas que se agrupam em glóbulos únicos e arredondados, tendem a formar vacúolos de mesma forma, ao contrário dos grânulos de glicogênio que têm formato irregular e por isso tendem a formar vacúolos também irregulares. No entanto, a presença de grânulos de glicogênio pode ser constatada em material corado com PAS. Nesse caso, o glicogênio, sendo um polissacarídeo, é PAS-positivo e aparece magenta; o núcleo, quando o material é contra-corado com hematoxilina, aparece roxo-azulado.

\subsection{A Ecotoxicologia no Brasil e os testes de toxicidade com sedimentos e peixes.}

A Ecotoxicologia no Brasil cresce a cada ano, já contando com alguns encontros científicos importantes realizados periodicamente. Hoje, os testes de toxicidade aquática são desenvolvidos por várias instituições de pesquisa e por órgãos de monitoramento ambiental brasileiros. São realizados experimentos com metais, defensivos agrícolas, efluentes industriais, amostras ambientais de água e sedimentos, e várias outras substâncias. Como organismos-teste são utilizados algas e bactérias, invertebrados aquáticos planctônicos e bentônicos e os peixes, entre outros. Nesses estudos são considerados desde os parâmetros dos testes de toxicidade padronizados, como sobrevivência ou mortalidade, crescimento e taxa de fecundidade, até parâmetros bioquímicos, fisiológicos, histológicos, comportamentais, entre outros.

Nos últimos anos, os testes de toxicidade com sedimento têm se destacado, dada a especial importância do bentos para o ambiente aquático. Os sedimentos são considerados fonte e sumidouro de inúmeros contaminantes aquáticos, ou seja, tanto podem minimizar um problema existente, quanto serem a causa dele em um ambiente aparentemente recuperado. Assim, já estão se tornando de uso corrente os testes de 
toxicidade que utilizam invertebrados bentônicos como organismos-teste na avaliação de sedimentos.

O presente trabalho, no entanto, utiliza peixes em estado adulto como organismos-teste para a avaliação da toxicidade de sedimentos. Vários trabalhos indicaram os efeitos de contaminantes presentes nos sedimentos nos peixes. A mortalidade, porém, raramente é observada em organismos adultos, a não ser em amostras altamente contaminadas (MELETTI, 1997). Assim, em testes de toxicidade aguda (96 h) são geralmente utilizados peixes em estágio larval. Em peixes adultos, os efeitos observados são as alterações genéticas, histológicas, bioquímicas, fisiológicas e comportamentais.

Os peixes, em sua maioria, não vivem em íntimo contato com o sedimento e, por isso não teriam, em princípio, a mesma significância que têm invertebrados como os anfípodos, as larvas de quironomídeos e os poliquetos na avaliação da toxicidade de sedimentos. No entanto, muitos contaminantes presentes nos sedimentos podem passar para a coluna d'água pela constante atividade dos organismos bentônicos e também após eventos como chuvas e ventos intensos, dragagem e turbulência provocada por embarcações. BORDAS \& BOURG (2001), estudando a remobilização do cobre, chumbo, cádmio e zinco de sedimentos de rios poluídos, concluíram que a dependência da solubilização de metais na água da concentração do sedimento em suspensão pode ter conseqüências importantes do ponto de vista ambiental. Segundo os autores, quando sedimentos contaminados são ressuspensos, há um decréscimo da razão sólido/líquido e o equilíbrio da adsorção de metais pelo sedimento pode caminhar em direção à solubilização do metal. Percebendo que os contaminantes associados aos sedimentos ressuspensos podem causar efeitos adversos aos peixes, já foram propostos, com sucesso, sistemas específicos para testes de toxicidade com peixes nessa condição (COPE et al., 1996). No caso de metais imobilizados no sedimento, peixes iliófagos podem, ainda, ingerir partículas cujos contaminantes poderão ser disponibilizados pelo ambiente ácido do trato digestivo, e os peixes que não são necessariamente de fundo podem predar organismos contaminados que transitam entre o bentos e o nécton.

Os peixes ocupam, entre os organismos essencialmente aquáticos, níveis tróficos elevados na cadeia alimentar e são passíveis de acumular altos teores de substâncias por biomagnificação. Considerando que muitos animais, como répteis, aves e mamíferos, alimentam-se de peixes e que estes também são fonte de alimento importante para todos os povos, a contaminação desses animais pode por em risco uma série de outros organismos, além da saúde humana. 
A importância da utilização de peixes nos programas de monitoramento também se dá pelo fato de que os sistemas orgânicos dos peixes são muito mais próximos histológica e fisiologicamente dos sistemas humanos (e dos outros vertebrados) que o são os dos invertebrados, possibilitando extrapolações mais confiáveis.

\subsection{Efeitos tóxicos dos metais presentes na água e no sedimento sobre os peixes.}

A maioria dos metais absorvidos pelos tecidos dos peixes encontra-se na forma iônica e a entrada destes através das brânquias se dá, predominantemente, por simples difusão. Outras vias de tomada de metais são a alimentação e a ingestão de água, sendo que esta última é mais importante nos peixes marinhos, que necessitam ingerir quantidades maiores de água que os de água doce. Uma vez no sangue, os metais são transportados ligados a proteínas e, nos tecidos, poderão ser acumulados e/ou metabolizados e excretados. Embora os locais de acúmulo nos peixes variem conforme a espécie e o metal, muitos trabalhos indicam que os epitélios, o fígado, os rins, as brânquias, a musculatura esquelética, o baço e o intestino constituem os órgãos-alvo principais, além do tecido gorduroso, o cérebro, os ossos e até as nadadeiras. Os mecanismos de excreção de metais nos peixes ainda não foram completamente elucidados e assim como acontece na acumulação, os mecanismos podem variar com a espécie e o metal. Assim como nos mamíferos, o fígado parece ter uma função importante, já que metais como o cromo, o arsênio, o estanho e o cobre já foram encontrados em teores elevados na bile de peixes. No entanto, essa via não garante que o metal será completamente excretado, devido à absorção intestinal. Da mesma forma, embora alguns metais possam ser encontrados na urina, outros podem ficar retidos nos rins, como o chumbo e o cádmio. Esses mesmos metais já foram encontrados no muco, indicando a possível excreção pelas brânquias e pela pele (HEATH, 1987).

Metais como cobre, zinco, manganês, cobalto, selênio e cromo são necessários, em concentrações traço, à manutenção das funções fisiológicas de mamíferos, sendo que alguns destes, senão todos, também são essenciais aos peixes. No entanto, em concentrações mais elevadas, estes e outros metais podem ser altamente prejudiciais aos organismos. De acordo com ABEL (1989) e HEATH (1987), os metais mais importantes no que diz respeito aos efeitos da poluição na fisiologia dos peixes são o mercúrio, o cádmio, o chumbo, o cobre, o arsênio, o zinco, o estanho (forma metilada, principalmente), o cromo, o níquel, e o alumínio, não necessariamente nessa ordem de toxicidade. Até mesmo o ferro, elemento 
considerado pouco tóxico, pode provocar efeitos danosos aos peixes em sua forma solúvel $\left(\mathrm{Fe}^{2+}\right.$ ou $\mathrm{Fe}^{3+}$ ), como demonstraram GEERTZ-HANSEN \& RASMUSSEN (in MÜLLER \& LLOYD, 1994). Segundo os autores, o ferro solúvel em concentrações superiores a $0,5 \mathrm{mg} \cdot \mathrm{L}^{-1}$ provocou uma diminuição significativa na sobrevivência de larvas de truta (Salmo trutta).

O cádmio, utilizado principalmente como componente de baterias $\mathrm{Ni}-\mathrm{Cd}$, revestimento contra corrosão, pigmentos de tintas e na indústria eletrônica, está incluído na lista dos agentes tóxicos principais da USEPA (United States Environmental Protection Agency) e da Comunidade Européia e a possui embriotoxicidade e teratogenicidade conhecidas. Em humanos, causa a doença de Itai-Itai e é suspeito de causar danos ao desenvolvimento, osteoporose e disfunções renais. Em pintos, ratos e camundongos, a exposição ao cádmio causa a redução do tamanho do embrião, microftalmia e retardo no crescimento. Também são relatados problemas de deformidade óssea em peixes expostos a concentrações subletais. Com uma meia-vida de 20 a 30 anos no corpo humano, o cádmio se acumula principalmente nos rins, no fígado e nos ossos (CHENG et al. 2000).

Com relação à acumulação de cádmio nos tecidos dos peixes, HOLLIS et al. (2000), expuseram exemplares juvenis de truta arco-íris (Oncorhynchus mykiss) a 2 $\mu \mathrm{gCd} / \mathrm{L}$ em águas de diferentes durezas e observaram que o rim foi o órgão que mais acumulou o metal, seguidos pelas brânquias e fígado.

CHENG et al. (2000), trabalhando com embriões de paulistinha, Danio rerio, expostos ao cádmio, estudaram as alterações no formato e morfologia dos olhos, cordão espinhal, cérebro e somitos em desenvolvimento. Após exposições a diferentes concentrações (1, 10, 50, 100, 500 e $1000 \mu \mathrm{M}$, e um controle) por um período de 5 a 28 horas após a fertilização, os autores observaram seis tipos principais de deformidades: hipoplasia na cabeça e nos olhos, hipopigmentação, edema cardíaco, anormalidades no saco vitelínico, curvatura axial alterada e malformações na cauda. A freqüência dessas malformações aumentou com a concentração de cádmio. Os autores ressaltaram, ainda, que essa espécie serve como um excelente modelo para estudos em biologia do desenvolvimento, pois a transparência dos embriões facilita a identificação de deformidades craniofaciais, cardíacas e esqueléticas. Além disso, o estudo do desenvolvimento embrionário de Danio rerio tem sido amplamente empregado na avaliação de efeitos teratogênicos de várias substâncias, tais como aminas, tetraclorodibenzo- $p$-dioxina e bifenilas policloradas (PCBs).

Uma das respostas mais sensíveis dos peixes aos metais é a aversão comportamental. Trabalhos indicam que os peixes evitam metais como o cobre, o zinco, o níquel e o mercúrio em concentrações muito inferiores à CL50. No entanto, 
HANSEN et al. (1999a) observaram em experimentos que o salmão (Oncorhynchus tshawytscha) e a truta (Oncorhynchus mykiss) evitam locais com concentrações de cobre de $0,7 \mu \mathrm{g} / \mathrm{L}$ e 1,6 $\mu \mathrm{g} / \mathrm{L}$ e deixam de evitar aqueles com concentrações de 44 $\mu \mathrm{g} / \mathrm{L}$ e $180 \mu \mathrm{g} / \mathrm{L}$, respectivamente. Os autores explicam que a falha em evitar altas concentrações de metais por ambas as espécies sugere que os mecanismos sensoriais responsáveis pelas respostas de aversão foram bloqueados. Assim, exposições a altas concentrações de cobre que não provocam aversão podem resultar em letalidade após períodos prolongados ou em um bloqueio dos comportamentos sensorial-dependentes que são essenciais à sobrevivência e à reprodução.

HANSEN et al. (1999b), estudando a estrutura do epitélio olfatório e as respostas neurofisiológicas do bulbo olfatório no salmão e na truta expostos às concentrações de cobre de 25 a $300 \mu \mathrm{g} / \mathrm{L}$, constataram que o número de receptores olfatórios foi significativamente reduzido nos salmões expostos a concentrações maiores ou iguais a $50 \mu \mathrm{gCu} / \mathrm{L}$ e nas trutas expostas a concentrações maiores ou iguais a $200 \mu \mathrm{gCu} / \mathrm{L}$ por 1 hora. O número de receptores foi significativamente reduzido em ambas as espécies após exposição a $25 \mu \mathrm{gCu} / \mathrm{L}$ por 4 horas. A observação do epitélio olfatório por microscopia eletrônica de transmissão indicou que a perda de receptores foi devida à necrose celular. Além disso, a realização de eletroencefalograma (EEG) indicou que as respostas à L-serina injetada na água foram inicialmente reduzidas (em ambas as espécies, em todas as concentrações de cobre) e até eliminadas em 1 hora de exposição a concentrações superiores a $50 \mu \mathrm{gCu} / \mathrm{L}$ para o salmão e $200 \mu \mathrm{gCu} / \mathrm{L}$ para a truta.

Alterações no epitélio olfatório também foram observadas por OLIVEIRARIBEIRO et al. (1994) no peixe Trichomycterus brasiliensis exposto ao mercúrio. Os autores concluíram que o mercúrio inorgânico dissolvido na água, em baixas concentrações $(0,05$ e $0,1 \mathrm{mg} \mathrm{HgCl} / \mathrm{L})$, é um potente agente tóxico para essa espécie e que o dano causado à superfície epitelial dos órgãos olfatórios compromete funções tais como a procura por alimento, reconhecimento de presas, comunicação e orientação. Trabalhando com a mesma espécie, OLIVEIRA-RIBEIRO et al. (1996) observaram que o mercúrio inorgânico é letal acima de $0,1 \mathrm{mg} \cdot \mathrm{L}^{-1} \mathrm{em} 24$ horas e que em períodos de exposição mais curtos ocorreram alterações histológicas nas brânquias, fígado, rins e nervos. 


\subsection{Fatores que influenciam a toxicidade dos metais}

\subsubsection{Dureza}

Diversos trabalhos já demonstraram que a toxicidade de alguns metais pesados aos peixes de água doce é reduzida em águas duras (PASCOE et al., 1986). GÓMEZ et al. (1998) constataram que a toxicidade do zinco ao peixe Cnesterodon decemmaculatus, comparando diferentes águas (naturais, reconstituída, de torneira e destilada), foi menor naquelas cujas concentrações dos íons cálcio, magnésio e bicarbonato era maior. Investigando a toxicidade do cobre a diferentes organismos, NADDY et al. (2002) observaram que os principais íons que contribuem para a dureza da água (cálcio e magnésio) interferem diferentemente na toxicidade desse metal. Os autores avaliaram a toxicidade do cobre em cinco diferentes espécies aquáticas: os peixes truta arco-íris (Oncorhynchus mykiss) e "fathead minnow" (Pimephales promelas), os microcrustáceos Ceriodaphnia dúbia e Daphnia magna, e o anfípoda Gammarus sp expostos em diferentes razões Ca:Mg (4:0, 3:1, 1:1, 1:3 e 1:4) em uma dureza de $180 \mathrm{mg} / \mathrm{L} \mathrm{CaCO}_{3}$ e alcalinidade de $120 \mathrm{mg} / \mathrm{L} \mathrm{CaCO}_{3}$. Para a truta o cobre foi mais tóxico em razões Ca:Mg menores (menos $\mathrm{Ca}$ ); para Daphnia magna, o cobre foi mais tóxico em razões Ca:Mg maiores (menos $\mathrm{Mg}$ ); o fathead minnow (com menos de 24 horas de vida) foi mais sensível ao cobre na água com proporções iguais dos dois elementos, ou seja, razão Ca:Mg de 1:1. Para o anfípoda, para C. dubia e para os "minnows" com menos de 28 dias de vida a toxicidade do cobre não variou sob as diferentes razões $\mathrm{Ca}: \mathrm{Mg}$.

CARROLL et al. (1979, apud PASCOE et al., 1986), em estudos realizados com a truta Salvelinus fontinalis, também demonstraram que o íon cálcio foi o mais efetivo componente da "água dura" na proteção desses peixes contra outro metal, o cádmio. Segundo os autores, vários mecanismos podem ser considerados para explicar a menor toxicidade dos metais em águas duras:

a) mecanismos químicos tais como a redução na disponibilidade do metal devido à diferenças na especiação química em águas de dureza aumentada.

b) mecanismos fisiológicos tais como: 1) redução na tomada do metal, devido, por exemplo, à diminuição da permeabilidade da membrana branquial em águas duras, 2) aumento da excreção do metal por várias maneiras, como a proliferação de células de cloreto em águas duras, 3) atividade compensatória de alguns componentes da água dura que contrabalança o efeito tóxico do metal, como por exemplo, a correção das alterações no balanço iônico causado pelo cádmio 4) inativação do metal absorvido pelo seqüestro deste em grânulos ou pela ligação em proteínas, tais como a proteína cádmio-ligante (CdBP). 
De acordo com PASCOE et al. (1986), testes de toxicidade com truta arco-íris confirmaram que o cádmio é menos tóxico em águas duras ( $C L 50$ 96h = 2,6 mg Cd/L) que em águas moles (CL50 96h = 1,3 mgCd/L). Segundo os autores, estudos em qualidade de água indicam que isto não é devido a uma redução química do cádmio disponível na água dura (contradizendo o item "a" acima) e não foram detectadas diferenças significativas na tomada de cádmio entre os peixes expostos aos dois níveis de dureza (contradizendo o item "b1" acima). Nesse trabalho, os peixes foram mantidos em tanques com água mole (70 mg CaCO3/L) por 14 dias antes dos testes. Para os testes, foram separados dois grupos de 40 peixes cada. Um grupo foi aclimatado em água mole por 10 dias (mesma concentração dos tanques) e exposto, em sub-grupos de 10 peixes, às concentrações de 10,0, 1,0, 0,1 e $0 \mathrm{mg} \mathrm{Cd/L}$. O outro grupo foi aclimatado em água dura (280 mg CaCO3/L) por 10 dias e testado, nessa dureza, da mesma maneira que o primeiro grupo. Nas concentrações mais altas

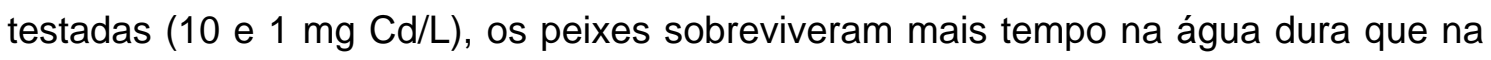
água mole e a CL50 (96h) foi menor na água mole que na dura, indicando maior toxicidade na primeira. A concentração de cádmio nos tecidos dos peixes aumentou com a concentração de exposição. Porém, não houve diferenças significativas entre durezas no referente à acumulação. Os autores concluem que uma possível explicação para a menor toxicidade dos metais na água dura é que os peixes, nessa condição, tomam menos e/ou excretam mais do metal que na água mole.

HOLLIS et al. (2000), expuseram exemplares juvenis de truta arco-íris (Oncorhynchus mykiss) a $2 \mu \mathrm{gCd} / \mathrm{L}$ em concentrações de 260 ("residual"), 470 (baixa), 770 (média) e 1200 (alta) $\mu \mathrm{M}$ de cálcio, por 30 dias. Foram utilizados grupos controle para cada concentração de cálcio. A maior mortalidade (80\%) foi observada na menor dureza ("residual"), para o grupo exposto ao cádmio. Na dureza baixa foi observada mortalidade de $40 \%$. Nos outros tratamentos a mortalidade foi de $10 \%$ ou menos. Não foram observadas alterações no crescimento. A acumulação de cádmio nos rins, brânquias e fígado foi gradativamente menor com o aumento da concentração de cálcio. A performance natatória foi prejudicada nos tratamentos com baixa concentração de cálcio. Pela medida da tomada de cádmio pelas brânquias foi constatado que a afinidade e o número de sítios de ligação para esse metal diminuíram conforme a concentração de cálcio na água aumentou.

MILLER \& MACKAY (1980), pesquisando o efeito do $\mathrm{pH}$, da alcalinidade e da dureza na toxicidade do cobre à truta, relatam que vários outros trabalhos já demonstraram os efeitos tóxicos dos metais e do $\mathrm{pH}$ nos peixes. Sabe-se que, tanto esse metal, quanto o pH ácido podem levar à alterações no balanço iônico e podem provocar a produção excessiva de muco pelo epitélio branquial, entre outros efeitos. 
Os mesmos autores relataram que, embora seja comum relacionar a toxicidade do cobre mais à alcalinidade que à dureza, as observações indicaram o contrário, ou seja, que a dureza (cálcio) protegeu os peixes dos efeitos tóxicos do cobre muito mais do que somente os íons carbonato e bicarbonato.

TAYLOR et al. (2000) investigaram os efeitos da exposição crônica ao cobre em águas moles e duras na truta arco-íris (Oncorhynchus mykiss) em um conjunto de indicadores: toxicidade aguda, aclimatação, crescimento, performance de natação, eletrólitos totais, resíduos teciduais e ligação cobre-brânquias. Embora também tenha ficado claro que a dureza afeta a toxicidade desse metal aos peixes, os autores fazem algumas ressalvas, conforme descrito nos itens adiante. Nesse trabalho foram expostos indivíduos juvenis de truta arco-íris, por 30 dias, a concentrações de cobre de 20 a $60 \mu \mathrm{g} / \mathrm{L}$ em água dura (dureza de $120 \mathrm{mgCaCO}_{3} / \mathrm{L}$ e $\mathrm{pH}=8,0$ ) e de 1 e $2 \mu \mathrm{g} / \mathrm{L}$ em água mole (dureza de $20 \mathrm{mgCaCO}_{3} / \mathrm{L} \mathrm{e} \mathrm{pH} \mathrm{=} \mathrm{7,2).}$

O estudo levou a quatro conclusões que são relevantes para a avaliação de risco da exposição de populações naturais de peixes ao cobre:

1. A carga de cobre nas brânquias é um indicador confiável da exposição crônica ao cobre (melhor até que a carga hepática), mas outros indicadores fisiológicos, tais como o crescimento, a perda iônica e a performance de natação, podem ser menos confiáveis devido ao importante efeito quantitativo (e possivelmente qualitativo) na sua expressão.

2. A resistência aumentada ao cobre observada em populações naturais pode ser também um indicador confiável da exposição crônica, mas somente em ambientes com água dura. Em águas moles, o efeito combinado do aumento da toxicidade do cobre e o estresse adicional associado com a exposição em águas desse tipo parece favorecer a letalidade.

3. O período de aclimatação em água mole sugere que os estudos em laboratório sobre os efeitos da dureza da água na toxicidade do cobre devem ser reavaliados. O trabalho mostrou que a toxicidade do cobre foi 20 vezes maior em água mole. No entanto, essa toxicidade foi apenas 6 vezes maior quando os peixes foram previamente aclimatados em água mole por 10 dias. É possível, assim, que as relações com a dureza sejam diferentes se forem testados peixes nativos de ambientes de água mole, comparando-os a peixes nativos de águas duras. Assim, os efeitos do aumento da dureza podem ser diferentes dos efeitos da diminuição da dureza.

4. Embora os efeitos na ligação cobre-brânquias tenham constituído o indicador mais confiável na avaliação dos efeitos crônicos do cobre, ainda não está clara a 
relação entre a constituição química da água, a ligação do cobre às brânquias e a toxicidade.

Dessa forma, segundo os autores, são necessários estudos mais detalhados e cuidadosos para elucidar estes achados aparentemente contraditórios e para estabelecer um conjunto de constantes que melhor representem a acumulação de metais pelas brânquias e a toxicidade resultante sob um amplo espectro de diferentes constituições da água.

\subsubsection{Concentração de oxigênio dissolvido na água.}

A concentração de oxigênio dissolvido na água pode variar muito e é o principal determinante ventilatório em todos os animais de respiração aquática. Águas com baixas pressões parciais de oxigênio $\left(\mathrm{PO}_{2}\right)$ estimulam fortemente a atividade respiratória comparadas àquelas com concentrações normais de oxigênio. TRAN et al. (2001) estudaram a influência da atividade ventilatória na taxa de bioacumulação de Cd no bivalve asiático de água doce Corbicula fluminea em pressões parciais de oxigênio que variaram de 2 a $0,5 \mu \mathrm{g} / \mathrm{L}$ em condições de campo e laboratório. A concentração de $\mathrm{Cd}$ na água expirada foi medida para a determinação do coeficiente de extração. Os resultados mostraram que baixas $\mathrm{PO}_{2}$ incrementaram fortemente a taxa de bioacumulação de cádmio nos tecidos moles totais do corpo.

\subsubsection{Concentração de sulfetos volatilizáveis por ácidos (AVS) nos} sedimentos.

As medidas dos sulfetos volatilizáveis por ácido (AVS) estão sendo cada vez mais utilizadas nos estudos sobre qualidade dos sedimentos para estimar a toxicidade dos metais cádmio, cobre, níquel, chumbo e zinco, tanto em ambientes de água doce quanto em ambientes marinhos. Os metais reagem com o sulfeto ferroso, que é o maior componente do AVS para formar sulfetos de metal, (MeS), como se segue:

$$
\mathrm{Me}^{2+}+\mathrm{FeS} \leftrightharpoons \mathrm{MeS}+\mathrm{Fe}^{2+}
$$

Assim, enquanto houver uma certa reserva de FeS no sedimento, não serão observadas concentrações significativas de $\mathrm{Cd}, \mathrm{Cu}, \mathrm{Ni}, \mathrm{Pb}$ e $\mathrm{Zn}$ na água intersticial. Como esses sulfetos de metal possuem solubilidade muito baixa, os sedimentos com excesso de AVS terão concentrações de metais dissolvidos muito baixas e não deverão ser tóxicos à biota. Por outro lado, em sedimentos nos quais a soma das concentrações dos metais citados for maior que os AVS, e na ausência de outras formas ligantes, as concentrações de metais na água intersticial poderão ser altas e até mesmo tóxicas (SIMPSON, 2001). 
Por outro lado, ANKLEY et al. (1993) relatam que, embora os AVS sejam considerados determinantes na biodisponibilidade de metais catiônicos nos sedimentos, os resultados de seus experimentos indicaram que somente os AVS não são suficientes para prever a biodisponibilidade do cobre em sedimentos de água doce. Os referidos autores avaliaram o papel dos AVS na toxicidade do cobre em sedimentos de dois locais altamente contaminados com cobre: Steilacoom Lake, Washington, e Keweenaw Watershed, Michigan. Os sedimentos dos dois locais foram testados em experimentos de 10 dias com o anfípodo Hyalella azteca, e os resultados de toxicidade foram comparados à previsão de toxicidade baseada nas concentrações de cobre e AVS nos sedimentos-teste, bem como nas concentrações de cobre medidas na água intersticial. Os resultados indicaram não haver toxicidade destes sedimentos quando a razão concentração de cobre/AVS foi menor que 1, nem quando esta razão foi significativamente maior que 1 . Contrastando com esses achados, as medidas de cobre na água intersticial e subseqüentes comparações destas concentrações com a toxicidade da água somente com cobre à Hyalella azteca resultaram em previsões precisas da presença e do grau da toxicidade do cobre nos sedimentos-teste. Ou seja, as concentrações de cobre nas águas dos locais estudados seriam tóxicas à Hyalella azteca, o que não foi observado mesmo em baixos teores de AVS, o que indica que outros fatores devem ser considerados, como por exemplo o conteúdo de matéria orgânica.

\subsubsection{Concentração de matéria orgânica na água e nos sedimentos.}

RICHARDS et al. (2001) demonstraram o efeito da matéria orgânica natural (autóctone e alóctone) na redução da toxicidade de uma mistura de metais. Para isso, foram expostas trutas em estágio juvenil $(3 \mathrm{~g})$ por $74 \mathrm{~h}$ a uma solução de diferentes metais $(0,2 \mu \mathrm{M} \mathrm{Pb}, 0,1 \mu \mathrm{M} \mathrm{Hg}, 0,1 \mu \mathrm{M} \mathrm{Cd}, 1,3 \mu \mathrm{M} \mathrm{Cu}, 0,05 \mu \mathrm{M}$ Ag e 3,5 $\mu \mathrm{M}$ Co), em água mole e na presença de 4, 6 e $10 \mathrm{mg} C / L$ de matéria orgânica natural (MON). A matéria orgânica natural foi isolada de águas superficiais de três diferentes localidades, cada uma com concentração diferente de MON. Os autores observaram que a solução destes seis metais misturados, sem a adição de matéria orgânica adicionada, apresentaram alta toxicidade aos peixes (100\% de mortalidade em $26 \mathrm{~h}$ ) e que a sobrevivência destes foi progressivamente maior com o aumento do teor de matéria orgânica. Foi constatado, ainda, que as soluções que apresentavam matéria orgânica com mais propriedades alóctones aumentaram mais a sobrevivência dos peixes que aquelas com matéria orgânica com mais propriedades autóctones. O mesmo padrão foi observado no grau de acumulação de $\mathrm{Pb}$ e $\mathrm{Cu}$ nas brânquias, ou seja, a MON alóctone levou a uma menor acumulação desses metais nas brânquias 
do que a MON autóctone. Foi considerada MON alóctone aquela com maiores razões proteína/carboidrato, menores concentrações de nitrogênio e fósforo e maior grau de aromaticidade, indicado por características ópticas (coeficiente de absorção específica do carbono a $350 \mathrm{~nm}$, entre outras).

A matéria orgânica influencia a toxicidade e a acumulação não só de metais, mas de outros xenobióticos, como alguns inseticidas. MAUND et al. (2002), verificaram que a concentração do inseticida piretróide Cypermethrin em Daphnia magna e Chironomus tentans como uma proporção da concentração no sedimento, diminuiu com o aumento do conteúdo de carbono orgânico. No entanto, alertam para o fato de que, embora os piretróides sejam rapidamente adsorvidos aos sedimentos, os quais reduzem em muito a biodisponibilidade deste agente tóxico aos organismos que habitam a coluna d'água, há o risco potencial para organismos bentônicos que, obviamente, estão em contato e ingerem partículas de sedimento. Na verdade, mesmo organismos da coluna d'água podem não estar livres dos efeitos dessas substâncias, como os peixes de fundo ou os iliófagos.

O mesmo pode ser aplicado para a biodisponibilidade dos metais, conforme observaram HOSS et al. (2001), os quais consideraram importante o fator ingestão ao constatarem que, quando as concentrações de cádmio excediam a capacidade de ligação a sulfetos, a toxicidade deste metal a nemátodos era maior com o aumento do conteúdo de matéria orgânica, tanto no sedimento total, quanto na água intersticial. Este fenômeno, completamente contrário ao que normalmente se constata em experimentos que relacionam toxicidade de metais e matéria orgânica, foi explicado pelo fato de que as bactérias, que servem de alimento para os nemátodos, devem funcionar como "vetores" para o cádmio por se ligarem aos complexos cádmio-matéria orgânica dissolvida e também particulada. Assim, o cádmio entraria no sistema digestório dos nemátodos onde seria solubilizado pelas enzimas digestivas e assimilado pelo organismo. Nesse caso, a matéria orgânica desempenharia um papel ambíguo na biodisponibilidade dos metais nos ambientes aquáticos.

\subsection{5. $\mathrm{pH}$}

$\mathrm{O} \mathrm{pH}$ ácido (normalmente abaixo de 5,5) ou básico (normalmente acima de $9,0)$, por si só, quase sempre causa danos à saúde dos peixes, e freqüentemente está relacionado a eventos de mortalidade em massa desses organismos. Alterações na regulação iônica, osmorregulação, equilíbrio ácido-básico, excreção, respiração e taxa de crescimento nos peixes, além da diminuição (ou ausência) da taxa de eclosão de ovos já foram atribuídas aos pHs ácidos (MASON, 1996; ALABASTER \& LLOYD, 1982). Além disso, o pH pode influenciar a toxicidade de várias substâncias, como a 
amônia e os metais, Uma observação comum em muitos trabalhos, segundo HEATH (1987) é a de que muitos metais são mais tóxicos em pHs mais baixos. O alumínio, por exemplo, é mais tóxico em águas ácidas. Dentro de uma faixa de pH de 5,5 a 7,0, este elemento praticamente não acarreta toxicidade. No entanto, abaixo desta faixa de pH o alumínio pode se solubilizar, tornando-se muito tóxico aos peixes (ABEL, 1989; MASON, 1996).

\subsection{A poluição pelo efluente de indústrias de papel e celulose.}

A poluição causada pelas descargas líquidas das indústrias de papel e celulose representam um grande problema, já que poucas outras indústrias necessitam de tão grande quantidade de água para os seus processos de manufatura. Em média, o volume de descarga de efluentes é de 80 a $150 \mathrm{~m}^{3}$ por tonelada de produto final. Estes efluentes, se não forem tratados adequadamente, podem causar sérios danos ao ambiente, devido à sua toxicidade (GALVÃO et al., 1987). Os efluentes destas indústrias são bastante complexos, sendo inúmeras as substâncias responsáveis por sua toxicidade. Entre estas substâncias estão resinas, ácidos graxos e compostos fenólicos clorados (GALVÃO et al., 1987; MASON, 1996). Um estudo a respeito dos efeitos mutagênicos destas substâncias pode ser encontrado em ROSA (1997). A maior parte das substâncias orgânicas contidas nos efluentes das indústrias de papel e celulose causa efeitos deletérios aos organismos presentes nas águas receptoras, sendo os principais, os seguintes:

- depleção de oxigênio devido à oxidação biológica dessas substâncias;

- produção de maus odores devido à redução biológica na ausência de oxigênio;

- efeitos nocivos à vida aquática devido à toxicidade de algumas substâncias ou ausência de oxigênio;

- produção de espumas e cor e

- crescimento excessivo de algas.

GALVÃO et al. (1987) realizaram testes de toxicidade com o efluente final da indústria Ripasa S/A Papel e Celulose e não observaram efeitos tóxicos agudos a Daphnia similis (Crustacea, Cladocera) e a Cheirodon notomelas (Serrapinnus notomelas) (Pisces, Characidae), em testes de 24 horas de duração. Porém, observaram efeitos crônicos sobre Ceriodaphnia dubia (também Cladocera). No entanto, não foram realizadas análises histopatológicas, as quais poderiam revelar alterações nos tecidos dos peixes expostos, além de que efeitos crônicos (alterações no crescimento, reprodução, entre outros) poderiam aparecer após as 24 horas de exposição. 
Além disso, importantes efeitos fisiológicos podem ser observados em peixes expostos a estes efluentes e diversos trabalhos já os demonstraram. HEATH (1987) no primeiro capítulo do livro "Water Pollution and Fish Physiology", ao listar as principais substâncias tóxicas que alcançam os corpos d'água, coloca os efluentes de indústria de papel e celulose ao lado dos metais, cloretos, cianetos, amônia, PCBs (bifenilas policloradas), pesticidas e hidrocarbonetos de petróleo. O autor cita trabalhos (McLEAY, 1973; McLEAY \& BROWN, 1975) nos quais o salmão (Oncorhynchus kisutch) foi exposto ao efluente de papel e celulose, em uma concentração de $80 \%$ do valor da $\mathrm{CL}_{50} 96 \mathrm{~h}$. Os efeitos observados foram uma hiperglicemia imediata (acréscimo de 80\% na glicose sangüínea) e após 48 horas de exposição contínua, a glicose no sangue chegou a níveis quase quatro vezes superiores aos observados no controle. Ao mesmo tempo, os níveis de glicogênio no fígado chegaram a quase zero. Nos testes de toxicidade crônica (90 dias), utilizando concentrações que variaram de 10 a $50 \%$ da $C L_{50} 96 \mathrm{~h}$, foram observados os mesmos efeitos produzidos no teste de toxicidade aguda, embora em menor grau. Em 25 dias de exposição ao efluente foi observada anemia nos indivíduos dessa mesma espécie.

PACHECO \& SANTOS (2002), trabalhando com a enguia européia, Anguilla anguilla, exposta por 30 dias a $12,5 \%$ do efluente de papel e celulose, observaram importantes alterações histológicas na pele, rim, brânquias, baço e fígado. Neste último foi constatado um estado de necrose acentuada, com núcleos picnóticos, além da perda de células do parênquima, causando a desintegração da estrutura hepática. Diversos trabalhos relatam os efeitos de componentes dos efluentes de indústria de papel e celulose no sistema reprodutor dos peixes. Uma ampla variedade de agentes tóxicos naturais e antropogênicos, como fitoestrógenos e certos micoestrógenos, vários pesticidas, herbicidas, PCBs, PAHs, dibenzodioxinas policloradas e compostos alquilfenólicos, têm sido relatados como sendo capazes de perturbar os sistemas endócrinos dos animais. Os alquilfenóis etoxilados, por exemplo, são surfactantes nãoiônicos que têm sido utilizados por mais de 40 anos, principalmente na manufatura de plásticos, elastômeros, defensivos agrícolas, fabricação de celulose e de detergentes. De acordo com KWAK et al. (2001), a maioria desses agentes tóxicos levam a essas perturbações endócrinas por ligarem-se aos receptores hormonais e podem não somente interagir com receptores androgênicos e estrogênicos, como também com receptores de vários outros hormônios. Além disso, há muitos outros caminhos não mediados por receptores através dos quais essas substâncias podem exercer seus efeitos. Esses xenobióticos têm sido relacionados com efeitos adversos na saúde, reprodução e desenvolvimento em humanos e na vida animal, tais como o aumento da incidência de tumores hormônio-dependentes, comprometimento do desempenho 
reprodutor e função reprodutiva anormal. Os mesmos autores, trabalhando com o peixe espada Xiphophorus helleri, exposto a compostos fenólicos, observaram necrose de células nos túbulos seminíferos e espermatogênese altamente suprimida, entre outros efeitos.

De acordo com DUBÉ \& MACLATCHY (2000), inicialmente pensava-se que as perturbações endócrinas eram causadas, nos peixes, por componentes do efluente de celulose advindos do processo de branqueamento, ou seja, por compostos orgânicos clorados, como a dioxina e o furano. Porém, mesmo após as indústrias adotarem processos "chlorine-free" e instalarem sistemas de tratamento secundário, os efeitos sobre o sistema endócrino-reprodutivo continuaram a ser observados, tanto em peixes nativos, quanto em experimentos em laboratório. Tais efeitos incluíam redução do tamanho gonadal, diminuição da fecundidade, expressão alterada das características sexuais secundárias, retardo da idade de maturação gonadal e redução plasmática de hormônios esteróides, principalmente de testosterona, que é o hormônio androgênico predominante nos peixes e é o precursor de outros hormônios sexuais, como a 11ketosterona nos machos e o $17 \beta$-estradiol nas fêmeas.

KARELS et al. (1999), tomando como índices reprodutivos o tamanho gonadal, a fecundidade, o tamanho dos ovos, os níveis de esteróides sexuais estradiol e testosterona, vitelogenina no sangue e a atividade da EROD (7-ethoxyresorufin Odeethylase) em populações naturais de perca e "roach" e em peixes expostos experimentalmente ("whitefish") em um lago que recebe efluente de indústria de papel e celulose na Finlândia, demonstraram que a introdução do processo chlorine-free (ECF) e de um tratamento secundário (lodo ativado) reduziu a exposição dos peixes a organoclorados. No entanto, a atividade da EROD hepática tanto nos peixes nativos quanto nos confinados próximos ao lançamento foi bem maior que nos peixes dos locais controle, assim como os níveis de estradiol plasmático e testosterona no período de desenvolvimento gonadal, que indicaram perturbação endócrina. Assim, esse trabalho reforça a tese de que outras substâncias, e não somente os organoclorados, devem estar envolvidas nos processos de disfunção endócrina em peixes. Os efluentes de indústrias de papel e celulose contêm também alguns tipos de PAHs como o reteno (7-isopropil-1-metilfenantreno) que, conforme demonstraram LEPP \& OIKARI (1999), podem induzir alterações bioquímicas (em citocromos, especialmente) em peixes. O trabalho analisou as resinas ácidas e os retenos nos sedimentos de sete localidades que recebem efluentes de 4 indústrias de papel e celulose (todas com tratamento dos efluentes por lodo ativado) e em dois pontos controle. Foram encontradas, próximo aos lançamentos, altas concentrações tanto de reteno quanto de resinas ácidas, sendo que ainda a $12 \mathrm{~km}$ de distância dos 
lançamentos foram encontradas concentrações no sedimento (camada de 5 a $10 \mathrm{~cm}$ da superfície) de cerca de 1/100 das concentrações de reteno do sedimento próximo ao lançamento e de 1/10 das concentrações de resinas ácidas. Segundo os autores, são claras as diferenças na concentração e na taxa de sedimentação destas substâncias antes e depois da instalação do tratamento por lodo ativado. Estas melhorias foram demonstradas também por PARROT et al., (1999), durante estudos de monitoramento ambiental, nos quais peixes nativos foram coletados a jusante de uma fábrica canadense de papel e celulose, e foi observada a diminuição do tamanho das gônadas e da fecundidade. A fim de comprovar o efeito dos efluentes sobre a produção de esteróides sexuais, foram expostos peixes ("goldfish", Carassius auratus) por 16 a 21 dias ao efluente final a 100\% e foi observada uma redução na produção de testosterona e 11-ketosterona pelos testículos, sendo a produção de esteróides de $1 / 10$ da dos peixes controle. No entanto, no ano seguinte, após a implementação de melhorias na qualidade dos efluentes, não foram observados efeitos destes na produção de esteróides nestes peixes. Porém, o trabalho de LEPP \& OIKARI (1999) alerta para o fato de que, mesmo com as melhorias nos tratamentos dos efluentes dessas indústrias, alguns efeitos nocivos ainda persistiram, como mostraram os estudos sobre a biodisponibilidade do reteno. O autores analisaram a concentração de reteno na bile de peixes engaiolados em um trecho de 1 a $2 \mathrm{~km}$ abaixo dos lançamentos e concluíram que o composto pode estar disponível aos peixes que se alimentam de animais bentônicos.

Segundo DUBÉ \& MACLATCHY (2001), não está claro onde está a fonte desses efeitos dentro do efluente, ou seja, quais são os compostos responsáveis, ou que alterações no processo produtivo são efetivas para removê-los. De acordo com os autores, o efluente final proveniente de uma fábrica de celulose é uma mistura complexa contendo efluentes originários de diferentes estágios no processo de fabricação da polpa. O efluente é abundantemente produzido nos processos de digestão e no processo de branqueamento. Após a digestão das fibras, a celulose é lavada e separada do líquor preto, contendo as fibras orgânicas de descarte (lignina e extratos vegetais) e substâncias químicas inorgânicas. A celulose é, então, dirigida para o processo de branqueamento, onde é lavada e clareada por substâncias tais como o dióxido de cloro e o peróxido de hidrogênio, no processo denominado "Elementary Chlorine Free" (ECF), menos nocivo ao ambiente que o processo que utiliza o cloro elementar e o dióxido de cloro. Os extratos vegetais incluem taninos e fitoesteróides que são encontrados no líquor preto e têm sido identificados nos efluentes finais. Alguns taninos são compostos naturais vegetais biologicamente ativos que formam o mecanismo de defesa das plantas contra a infestação de insetos. Além 
disso, os fitoesteróides são similares estruturalmente aos hormônios esteróides animais naturais e têm o potencial de mimetizar o efeito destes hormônios, afetando a função e a produção de esteróides reprodutivos. Há indícios de que o efluente produzido na fase de digestão tenha, de fato, efeitos na reprodução dos peixes.

Ainda segundo DUBÉ \& MACLATCHY (2001), há trabalhos que sugerem que a fonte desses efeitos é independente do processo de branqueamento e do sistema de tratamento de efluentes, já que as perturbações reprodutivas têm sido observadas tanto em peixes expostos aos efluentes de fábricas que utilizam modernos processos de clareamento (ECF), quanto naqueles expostos a efluentes de fábricas com tratamento secundário. Um estudo anterior dos mesmos autores (DUBÉ \& MACLATCHY, 2000) indicou que o efluente final despejado de uma fábrica de celulose em Saint John, Canadá, deprimiu os níveis de testosterona em um peixe estuarino, o "mummichog" (Fundulus heteroclitus). Após iniciado o tratamento do efluente advindo do processo de digestão (por osmose reversa do condensado), as concentrações de testosterona no "mummichog" não foram afetadas após exposição a uma concentração ambientalmente relevante do efluente (1\%). Os resultados sugeriram, então, que o tratamento do condensado por osmose reversa removeu esta fonte. Ainda segundo DUBÉ \& MACLATCHY (2000), em 1997, antes da instalação do tratamento por osmose reversa, a exposição de machos e fêmeas de mummichog a uma concentração de $1 \%$ do efluente final de indústria de celulose por 30 dias resultou em 88 a 92\% de redução dos níveis da testosterona plasmática, comparado ao grupo controle. Em 1998, após a instalação deste sistema, a concentração da testosterona no plasma em machos e fêmeas expostos à mesma concentração, pelo mesmo período de tempo, não diferiu significativamente do grupo controle.

A osmose reversa é, basicamente, o mesmo processo utilizado na dessalinização da água do mar, no qual uma membrana semi-permeável permite a passagem das moléculas de água mas retém determinados íons e sólidos dissolvidos. Para isso, porém, é aplicada uma pressão (logicamente, maior que a pressão osmótica) no lado da solução mais concentrada, ou mais salina, suficiente para provocar uma inversão no fluxo natural. Assim, a água da solução salina irá passar para o lado de menor concentração de sais, ficando os íons e sólidos dissolvidos retidos na membrana que separa as duas soluções. A água que passa através da superfície da membrana é coletada, enquanto os resíduos são levados da superfície da membrana para fora, através de drenos.

Além dos efeitos tóxicos causados pelas substâncias que compõem o efluente de papel e celulose, já foi observado que as fibras (especialmente as de pinheiros) contidas nestes efluentes podem causar efeitos mecânicos prejudiciais no processo 
respiratório de peixes. Conforme observaram McLEOD \& SMITH (1966), estas fibras tendem a obstruir as lamelas branquiais dos peixes, interferindo no fluxo normal de água através destas e reduzindo, provavelmente, a tomada de oxigênio. Em um experimento com o "minnow" Pimephales promelas, a presença das fibras causou uma diminuição da velocidade natatória, o que na prática pode influenciar a capacidade de fuga (de predadores), a captura de alimentos e a migração, interferindo diretamente na sobrevivência dos indivíduos e na existência da espécie. 


\section{OBJETIVOS}

\subsection{Objetivos principais}

- Avaliação da degradação ambiental nas bacias dos rios Piracicaba, Mogi Guaçu e Tibagi, baseada em testes de toxicidade de sedimentos in situ e em laboratório, análises histopatológicas em peixes, e em análises físicas e químicas da água e do sedimento.

- Avaliação da toxicidade e análise das anomalias histopatológicas em peixes causadas por efluente de indústria de papel e celulose, atividade industrial presente nas três bacias estudadas.

\subsection{Objetivos complementares}

- Adaptação da técnica existente de preparação e análise histológica de pequenos peixes para as espécies selecionadas (Serrapinnus notomelas e Danio rerio) para utilização na avaliação dos efeitos dos efluentes e sedimentos estudados.

- Realização de testes com substância de referência (dicromato de potássio $\mathrm{K}_{2} \mathrm{Cr}_{2} \mathrm{O}_{7}$ ) com o peixe nativo Serrapinnus notomelas, a fim de comparar a sensibilidade desta espécie com a de outras espécies-teste.

- Aperfeiçoamento da técnica para execução de testes in situ com peixes. 


\section{MATERIAIS E MÉTODOS}

\section{1. Áreas de estudo e locais de amostragem}

\subsubsection{Bacia do rio Piracicaba}

A bacia do rio Piracicaba possui superfície de $12.746 \mathrm{~km}^{2}$ e sentido geral de escoamento leste-oeste e noroeste (Programa de Investimentos para Recuperação e Proteção das bacias (P.I.R.B.) dos rios Piracicaba e Capivari, 1992) (figura 2); tem suas nascentes nos estados de Minas Gerais, nas cabeceiras do rio Jaguari, em Camanducaia, e de São Paulo, onde os rios Atibainha e Cachoeira dão origem ao rio Atibaia. O Atibainha nasce nas proximidades de Nazaré Paulista e o Cachoeira, na região de Piracicaba. O rio Piracicaba, com $115 \mathrm{~km}$ de extensão, nasce na cidade de Americana, no encontro das águas do rio Atibaia com as do rio Jaguari, e tem sua foz no Reservatório de Barra Bonita. Outros afluentes importantes do rio Piracicaba são: Corumbataí (que nasce em Analândia), Quilombo (que nasce em Campinas), Toledo (que nasce na região de Santa Bárbara D'Oeste), ribeirão Anhumas (que nasce em Campinas), ribeirão Piracicamirim (que nasce na região de Piracicaba), ribeirão Pinheiros (que nasce em Vinhedo), entre outros (SEMAE - Serviço Municipal de Água e Esgoto de Piracicaba).

A cobertura florestal cobre aproximadamente $7 \%$ da região de Piracicaba e corresponde a fragmentos isolados, assim constituídos: matas de planalto (matas mesófilas semidecíduas) em grande parte da área; matas ciliares nas margens dos rios e afluentes; matas de brejo em locais de solos hidromórficos; matas secas (matas mesófilas decíduas) em alguns trechos de litossolos; e cerrados e cerradões em alguns pontos da paisagem.

Fazem parte da bacia 57 municípios que juntos representam uma população de 3,8 milhões de habitantes. De acordo com a CETESB (1995), a bacia abastece 42 municípios, sendo que, até 1995, 33 deles utilizavam águas superficiais, 4 de mananciais subterrâneos e 3 de sistema misto. Além disso, na década de 60, foi criado o Sistema Cantareira que abastece cerca de 55\% da população da Região Metropolitana de São Paulo e é composto por três grandes reservatórios na Bacia do rio Piracicaba: Jaguari, Cachoeira e Atibainha. Esses reservatórios, interligados por túneis, permitem a transferência para São Paulo de $31 \mathrm{~m}^{3} / \mathrm{s}$. Essa transferência tornou-se um agravante para a qualidade da água na bacia, principalmente nos meses de estiagem. (SEMAE; R.I.O.B. - Rede Internacional dos Organismos de Bacia; Organização não governamental Piracicaba 2010 - sites na Internet). 


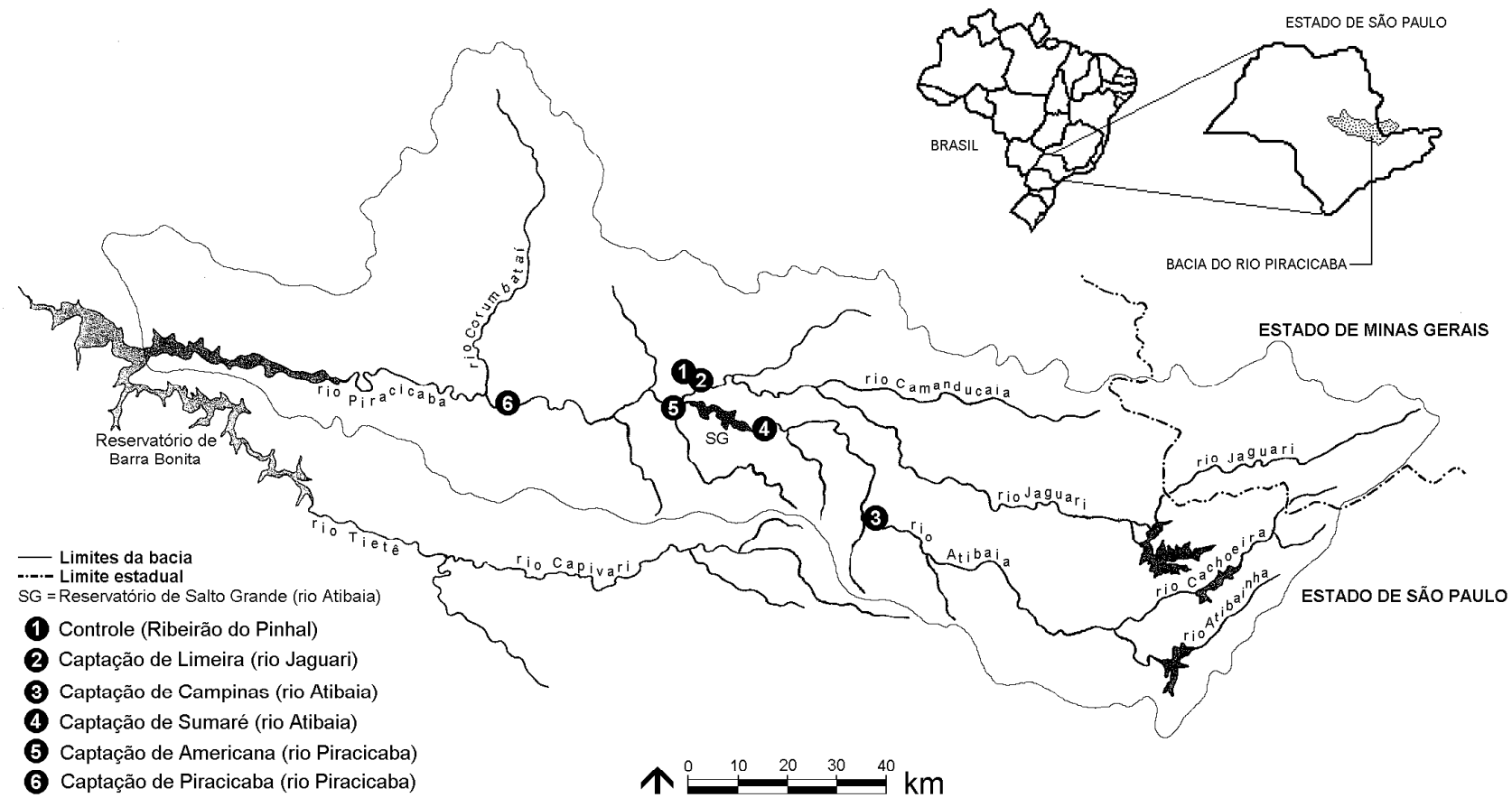

FIGURA 2: Locais de coleta de água e de sedimento, unidades hidrográficas, limites e localização da bacia do rio Piracicaba. 1) S $22^{\circ} 39^{\prime} 38,0^{\prime \prime}$ / W $47^{\circ} 16^{\prime} 35,7^{\prime \prime}$; 2) S $22^{\circ} 39^{\prime \prime}$ $44,8^{\prime \prime}$ / W $47^{\circ} 16^{\prime} 40,3^{\prime \prime}$; 3) S $22^{\circ} 54^{\prime} 11,6^{\prime \prime}$ / W $46^{\circ} 58^{\prime} 25,7^{\prime \prime} ; \quad$ 4) S $22^{\circ} 45^{\prime} 43,0^{\prime \prime}$ / W $47^{\circ}$ 10' 32,4"; 5) S $22^{\circ} 42^{\prime} 38,9^{\prime \prime}$ / W $47^{\circ} 19^{\prime} 23,3^{\prime \prime}$; $\quad$ 6) S $22^{\circ} 42^{\prime} 44,5^{\prime \prime}$ / W $47^{\circ} 38^{\prime} 59,6^{\prime \prime}$. (Programa de Investimentos para Recuperação e Proteção das bacias dos rios Piracicaba e Capivari, 1992 - modificado).

A região de Campinas, na área central da bacia, possui a maior concentração industrial e populacional e é responsável por aproximadamente $50 \%$ da carga poluidora e do consumo dos recursos hídricos. Na bacia do rio Piracicaba estão instaladas grandes indústrias petroquímicas e químicas, têxteis, de papel e celulose, usinas de açúcar e álcool, metalúrgicas, alimentícias e curtumes. A área rural é ocupada por pastagens que cobrem 57\% da área da bacia e por culturas agrícolas, principalmente de cana-de-açúcar, de citros, de milho, de hortaliças e frutas (P.I.R.B. dos rios Piracicaba e Capivari, 1992; CETESB, 2002; ONG Piracicaba 2010 - site na Internet). As precipitações médias na bacia do rio Piracicaba podem podem ser observadas na tabela 1 e as vazões dos rios em localidades próximas aos pontos de coleta estão representadas na tabela 2. A figura 3 mostra um panorama dos locais de coleta nessa bacia. Estes pontos (que podem ser observados no mapa da figura 2) foram escolhidos por corresponderem a locais de captação de água (exceto o local referência, Ribeirão do Pinhal e a captação de Piracicaba, desativada há 3 anos), por terem sido locais de estudo em trabalhos anteriores (GRANDE et al., 2003; FONSECA, 1997; MELETTI, 1997;) e por possuírem acesso fácil. 

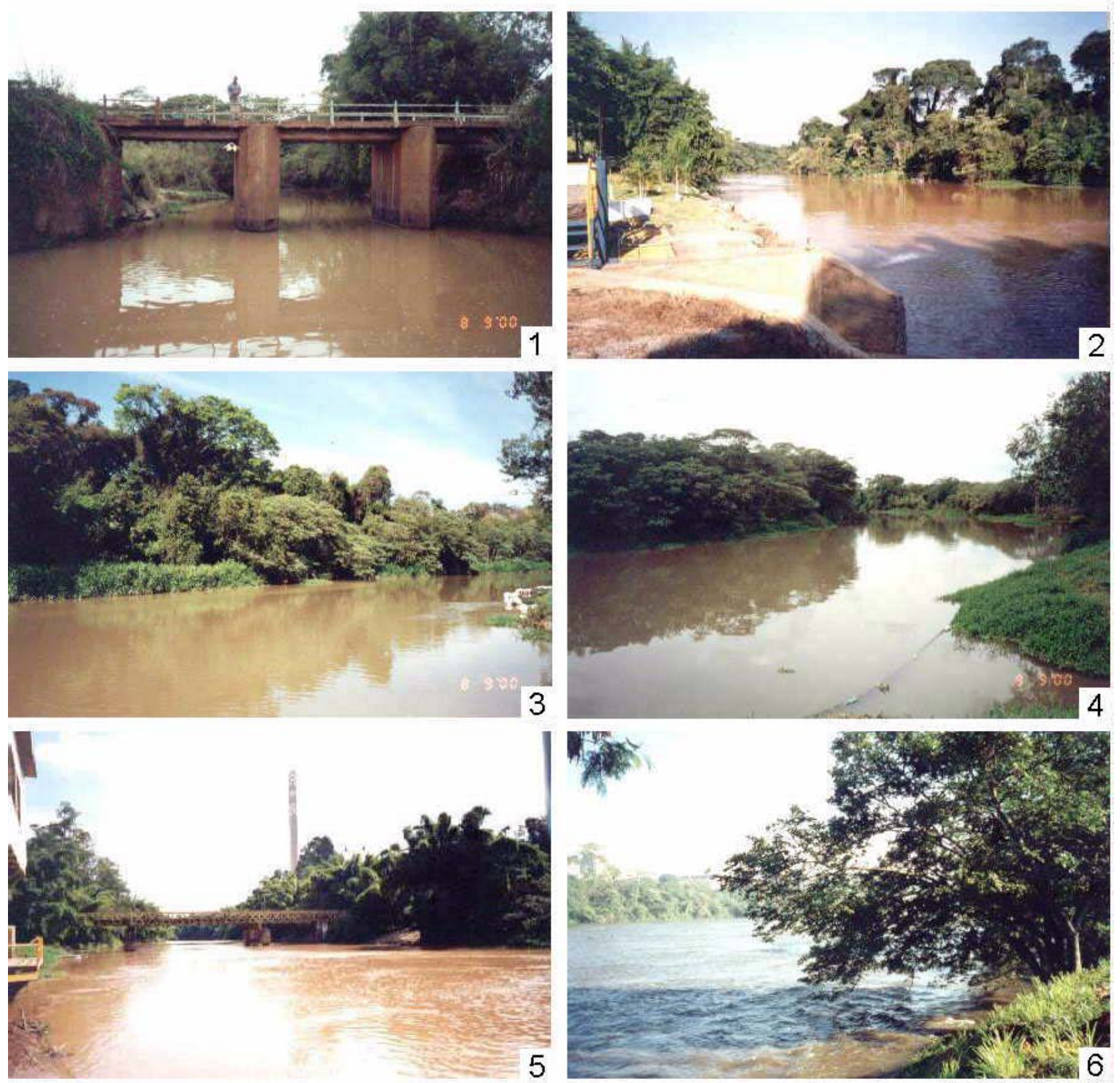

FIGURA 3: Panoramas dos locais de coleta de água e de sedimento na bacia do rio Piracicaba, SP: 1) Ribeirão do Pinhal, em Limeira, próximo ao deságue no rio Jaguari; 2) Estação de captação de água para a cidade de Limeira, no rio Jaguari; 3) Estação de captação de água para a cidade de Campinas, no rio Atibaia, próximo à Valinhos; 4) Estação de captação de água para a cidade de Sumaré, no rio Atibaia, próximo à Paulínia; 5) Estação de captação de água para a cidade de Americana, no rio Piracicaba (a indústria na margem oposta e à jusante, é a Ripasa, indústria de papel e celulose); 6) Estação de captação de água (atualmente desativada) para a cidade de Piracicaba, no rio Piracicaba.

O Relatório de Qualidade das Águas Interiores do Estado de São Paulo de 2001 elaborado pela CETESB (2002), classificou como boa ou ótima as águas de 7 dos 15 pontos monitorados na bacia. Os outros 8 pontos obtiveram índice aceitável (5 pontos) ou 
ruim (3 pontos, sendo 2 no rio Piracicaba e 1 no rio Jaguari). De acordo com o mesmo relatório, todos os pontos monitorados pela CETESB na bacia apresentaram vários parâmetros fora dos padrões de qualidade estabelecidos pelo CONAMA (1986). Parâmetros referentes às concentrações de oxigênio dissolvido, amônia, alumínio, manganês, fenóis e coliformes foram observados acima dos limites em pelo menos 12 dos 15 pontos e na maioria dos meses monitorados.

Devido à queda da qualidade da água do rio Piracicaba, a própria cidade de Piracicaba já não capta mais água deste rio para o abastecimento público. Já em 1980, $33 \%$ da água captada eram provenientes do rio Corumbataí, de onde vem, hoje, a totalidade da água consumida na cidade de Piracicaba.

\subsubsection{Bacia do rio Mogi Guaçu}

A bacia do rio Mogi Guaçu possui uma área de $17.460 \mathrm{~km}^{2}$ e tem suas nascentes no Estado de Minas Gerais, na divisa entre os municípios de Bom Repouso e Cambuí, a 1.650 metros de altitude, onde nasce o rio que dá nome à bacia (figura 4).

O Rio Mogi Guaçu percorre 95,5 km em terras mineiras, atravessa a Serra da Mantiqueira em uma garganta a uma altitude de 825 metros e no Estado de São Paulo percorre mais $377,5 \mathrm{~km}$, completando uma extensão total de $473 \mathrm{~km}$ (GODOY, 1975), até a foz no Rio Pardo em uma altitude de 490 metros, no lugar conhecido como Bico do Pontal, no município de Pontal (Comitê da Bacia Hidrográfica do rio Mogi Guaçu - site na Internet).

Neste percurso recebe vários afluentes, sendo os principais: ribeirões dos Araújos e da Água Espraiada, na região de Bom Repouso e Inconfidentes, em Minas Gerais, e os rios Jaguari-Mirim, Itupeva, Bonito, ribeirão das Onças, Eleutério, Cachoeirinha, do Peixe, Araras, do Pântano, do Quilombo, Anhumas, Capetinga, entre outros, no estado de São Paulo. Devido ao grande desnível (cerca de $1160 \mathrm{~m}$ ) entre a nascente e a foz, o rio possui muitas cachoeiras e corredeiras, dentre as quais destacam-se as do Salto do Pinhal, Cachoeira de Cima, Cachoeira de Baixo na região de Mogi-Guaçu/Mogi-Mirim, Cachoeira de Pádua-Sales, em Conchal, Cachoeira de Emas, em Pirassununga, as corredeiras de Santa Helena, Boa Vista, dos Patos, Itapecerica, em Porto Ferreira, dos Patos, dos Gaviões em Descalvado e Santa Rita do Passa Quatro, e das Escaramuças, em Luiz Antonio e São Carlos. Com relação à cobertura florestal, há reservas estaduais como a reserva florestal de Capetinga em Mogi-Guaçu, o Parque Estadual de Porto Ferreira, a Estação Ecológica de Jataí, em Luiz Antônio, e o Parque Estadual de Vassununga (sites na Internet da Prefeitura Municipal de Leme e dos Canoeiros de Porto Ferreira).

Predominam nesta bacia as atividades agrícolas, com culturas de milho, feijão, batata, algodão, citros, café e extensas plantações de cana. São importantes também as atividades pecuária e granjeira. 


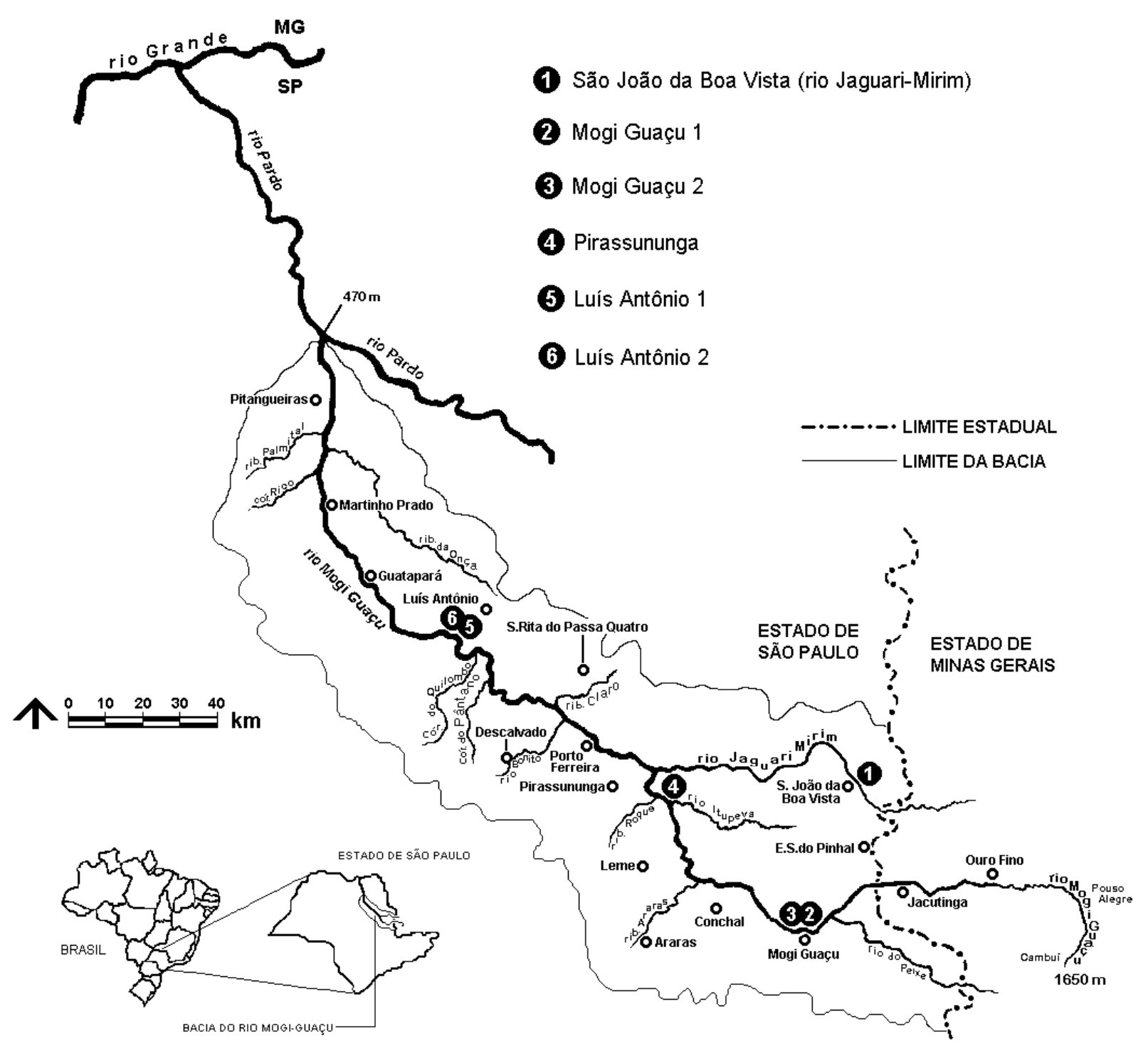

FIGURA 4: Locais de coleta de água e de sedimento, unidades hidrográficas, limites e localização da bacia do rio Mogi-Guaçu. 1) S $22^{\circ} 00^{\prime} 11,1^{\prime \prime}$ / W $46^{\circ} 47^{\prime} 35,5^{\prime \prime}$; 2) S $22^{\circ} 21^{\prime \prime}$

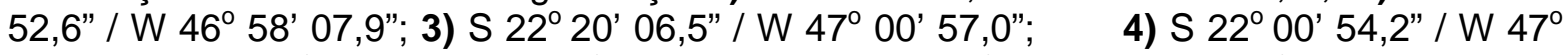
$17^{\prime} 39,9^{\prime \prime} ;$ 5) S $21^{\circ} 34^{\prime} 42,0^{\prime \prime} / \mathrm{W} 47^{\circ} 56^{\prime} 15,7^{\prime \prime}$; $\quad$ 6) S $21^{\circ} 34^{\prime} 22,4^{\prime \prime} / \mathrm{W} 47^{\circ} 55^{\prime} 25,1^{\prime \prime}$. (GODOY, 1975; www.fcav.unesp.br/cbhmogi, 2000 - modificados).

As principais indústrias são as alimentícias (fecularias, laticínios, frigoríficos e matadouros), as de papel e celulose (ex.: International Paper, antiga Champion, em Mogi Guaçu e VCP - Votorantin Celulose e Papel, em Luiz Antônio), as metalúrgicas, as usinas de álcool e açúcar (ex.: Usina São Martinho, em Pradópolis), os engenhos e destilarias e os curtumes. Há, ainda, muitas indústrias cerâmicas na região de Porto Ferreira e mineradoras (portos) de areia principalmente no médio/baixo Mogi-Guaçu e ao longo do rio Jaguari-Mirim.

A figura 5 mostra um panorama dos locais de coleta nessa bacia. Os pontos (que podem ser observados no mapa da figura 4) foram escolhidos pela localização na bacia: alto-médio (locais 2 e 3), médio (local 4) e médio-baixo Mogi-Guaçu (locais 5 e 6). Além disso, os pontos $2 / 5$ e 3/6 correspondem a localidades, respectivamente, à montante e à jusante de indústrias de papel e celulose. A localidade 1 (referência) corresponde ao rio 
Jaguari Mirim, um dos maiores afluentes do rio Mogi-Guaçu, e é o local de captação de água para a cidade de São João da Boa Vista.
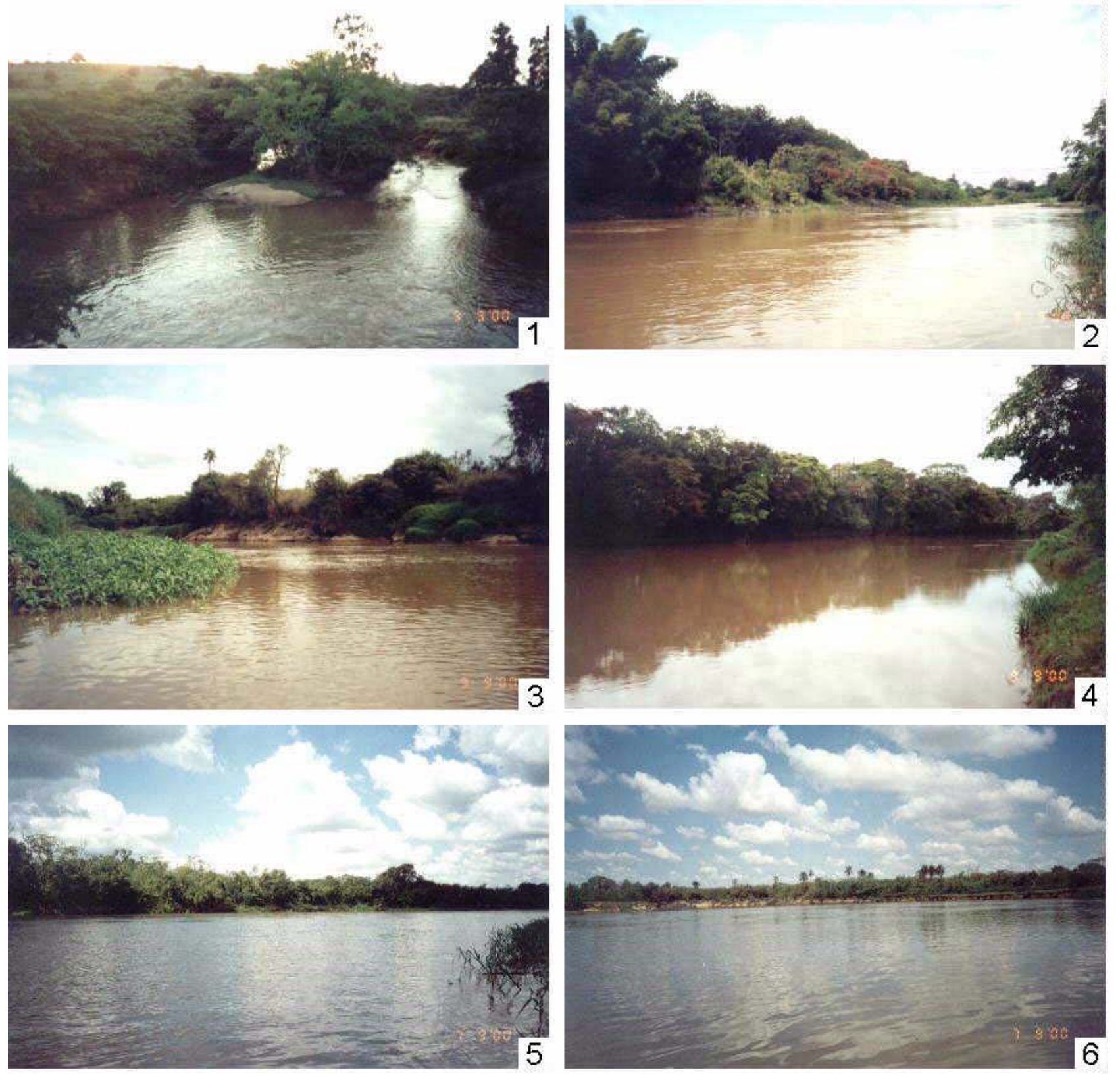

FIGURA 5: Panoramas dos locais de coleta de água e de sedimento na bacia do rio Mogi Guaçu, SP: 1) Rio Jaguari Mirim, em São João da Boa Vista, próximo à estação de captação de água da cidade; 2) Rio Mogi Guaçu, em Mogi Guaçu, à montante da International Paper; 3) Rio Mogi Guaçu, em Mogi Guaçu, à jusante da International Paper; 4) Rio Mogi Guaçu, em Pirassununga à montante do deságue do rio Jaguari-Mirim; 5) Rio Mogi Guaçu, em Luiz Antônio, à montante da VCP (Votorantim Celulose e Papel); 6) Rio Mogi Guaçu, em Luiz Antônio, à jusante da VCP.

Situam-se na bacia do rio Mogi Guaçu 47 municípios, sendo que destes, 38 estão em território Paulista, com uma população estimada em mais de um milhão de habitantes e a maioria destes municípios despeja seus esgotos domésticos "in natura" (site da Câmara 
Municipal de Mogi Guaçu). Os municípios mais populosos do trecho inicial do rio Mogi Guaçu são Mogi Guaçu e Mogi Mirim e os lançamentos de seus esgotos domésticos constituem uma importante fonte de poluição, além da carga oriunda do escoamento superficial agrícola (CETESB, 2002).

De acordo com o Relatório de Qualidade das Águas Superficiais do Estado de São Paulo do ano de 2001 (CETESB, 2002), as águas provenientes do Estado de Minas Gerais encontram-se comprometidas apenas por coliformes fecais, porém após a entrada do rio Mogi Guaçu no Estado de São Paulo ocorre um prejuízo maior quanto à qualidade das águas, nas quais os níveis de coliformes fecais, condutividade, fósforo total e nitrogênio amoniacal são maiores, indicando que o tratamento dos esgotos domésticos nesta bacia é ainda bastante deficiente. No mesmo relatório é feita a observação de que o trecho final do rio Mogi Guaçu evidencia sinais de recuperação, devido à autodepuração de suas águas, apesar de o arraste de solo das áreas de pastagem, nos períodos de chuva, consistir em uma fonte expressiva de poluentes. O menor valor de IQA entre as 4 localidades monitoradas pela CETESB na bacia foi obtido, de fato, no ponto próximo à região de Mogi Guaçu/Mogi Mirim. Porém, em todos os pontos a qualidade da água foi considerada boa.

Embora na bacia do rio Mogi Guaçu ainda não sejam detectados problemas de poluição no mesmo grau em que estes ocorrem na bacia do rio Piracicaba, já ocorreram eventos preocupantes, sendo o derrame de lixívia negra pela indústria de papel e celulose Champion (atual International Paper), em 1976, o mais conhecido. Segundo a CETESB (1977, apud EYSINK \& MORAES, 1988), a lixívia negra continha mercúrio em sua composição, além de que, dos 20 mil metros cúbicos de lixívia derramados, 6 mil toneladas correspondiam a hidróxido de sódio, o que causou a morte de 2,2 milhões de quilos de peixe ou $65 \%$ do estoque pesqueiro do rio. Ainda segundo os autores, trabalhos posteriores (VARGAS-BOLDRINI et al., 1983 apud EYSINK \& MORAES, 1988) constataram que os rios Mogi Guaçu e Pardo continuavam contaminados com mercúrio após 3 ou 4 anos, pois os peixes apresentavam teores do metal bem acima do limite máximo permitido para o consumo humano. Cerca de 10 anos depois o mercúrio ainda era detectado na musculatura de peixes desses rios, porém em teores bem mais baixos, indicando uma recuperação da qualidade da água (EYSINK \& MORAES, 1988). No entanto, o relatório de qualidade de águas da CETESB de 2001 (CETESB, 2002) indicou que as concentrações médias de mercúrio na água no trecho do Rio Mogi Guaçu situado em Pirassununga não estiveram dentro dos limites determinados para a classe 2. Ainda segundo o relatório, "a análise das médias anuais do mercúrio demonstrou que nos últimos anos têm se notado valores médios superiores ao padrão de qualidade, justificando uma ação de controle com vistas a identificar eventuais fontes do metal". Existe a possibilidade de que haja novas fontes desse metal, como também não se pode descartar a hipótese de 
que o mercúrio oriundo do referido derramamento esteja sendo liberado do sedimento, principalmente pela ação da atividade de mineração de areia.

O rio Mogi Guaçu continua tendo grande importância no desenvolvimento econômico e social da baixa Mogiana. Infelizmente, por falta de conhecimento e também pela omissão por parte de todos aqueles que, direta ou indiretamente, dele usufruem, hoje a qualidade da água do rio encontra-se degradada e a fauna ictiológica ameaçada por riscos de extinção (site da Câmara Municipal de Mogi Guaçu).

As precipitações médias na bacia do rio Mogi-Guaçu podem ser observadas na tabela 1 e as vazões dos rios em localidades próximas aos pontos de coleta estão representadas na tabela 2.

\subsubsection{Bacia do rio Tibagi}

Com uma área de drenagem de $24.530 \mathrm{~km}^{2}$, a bacia do rio Tibagi é a terceira maior bacia hidrográfica do estado do Paraná. O rio Tibagi nasce na Serra das Almas, entre os municípios de Palmeira e Ponta Grossa (PR), a 1150 metros de altitude, percorre cerca de $550 \mathrm{~km}$ na direção principal noroeste, desembocando, a 334 metros de altitude, no Reservatório da Usina Hidrelétrica de Capivara, no rio Paranapanema, na divisa dos estados de São Paulo e Paraná (figura 6). Devido ao grande desnível (aproximadamente $800 \mathrm{~m}$ ), o rio Tibagi possui fortes corredeiras em alguns trechos, como em Telêmaco Borba, Sapopema e Londrina.

Aproximadamente 65 tributários diretos e 1200 pequenos riachos compõem a rede hidrográfica do rio Tibagi. As principais sub-bacias, na margem direita, no sentido das nascentes até à foz, são as do rio Pitangui, rio lapó, ribeirão das Antas e rio Congonhas. Na margem esquerda, no mesmo sentido, são as sub-bacias do rio Imbituba, rio Capivari, rio Imbaú, rio Barra Grande, rio Apucarana, rio Apucaraninha, rio Taquara, ribeirão dos Apertados e ribeirão Três Bocas.

A vegetação ao longo do percurso deste rio varia muito de local para local, de acordo com a ocupação do solo, com a altitude e com o clima bastante diverso. Em Ipiranga (alto Tibagi), a mata ciliar é composta por um bosque natural de árvores e arbustos e é inundável nos períodos chuvosos. No planalto predomina a vegetação campestre, sendo que nas depressões úmidas, bordas de platôs e margens de rios ocorrem ilhas de Floresta Ombrófila Densa (Floresta de Araucária). Em Telêmaco Borba (médio Tibagi), apenas a margem direita apresenta vegetação nativa. Em Sapopema a vegetação encontra-se mais fragmentada, em Londrina (baixo Tibagi) é ainda mais escassa e em Sertanópolis, já próximo ao reservatório, não há vegetação ciliar (BENNEMANN et al., 1995; WORKSHOP DO PROJETO "ASPECTOS DA FAUNA E FLORA DA BACIA DO RIO TIBAGI", 2000; COPATI - Consórcio da Bacia Hidrográfica do rio Tibagi - site na Internet). Ao longo de 
sua extensão predominam as atividades de reflorestamento (destinada à produção de papel e celulose, em Telêmaco Borba) e, principalmente, as de agricultura e pecuária.

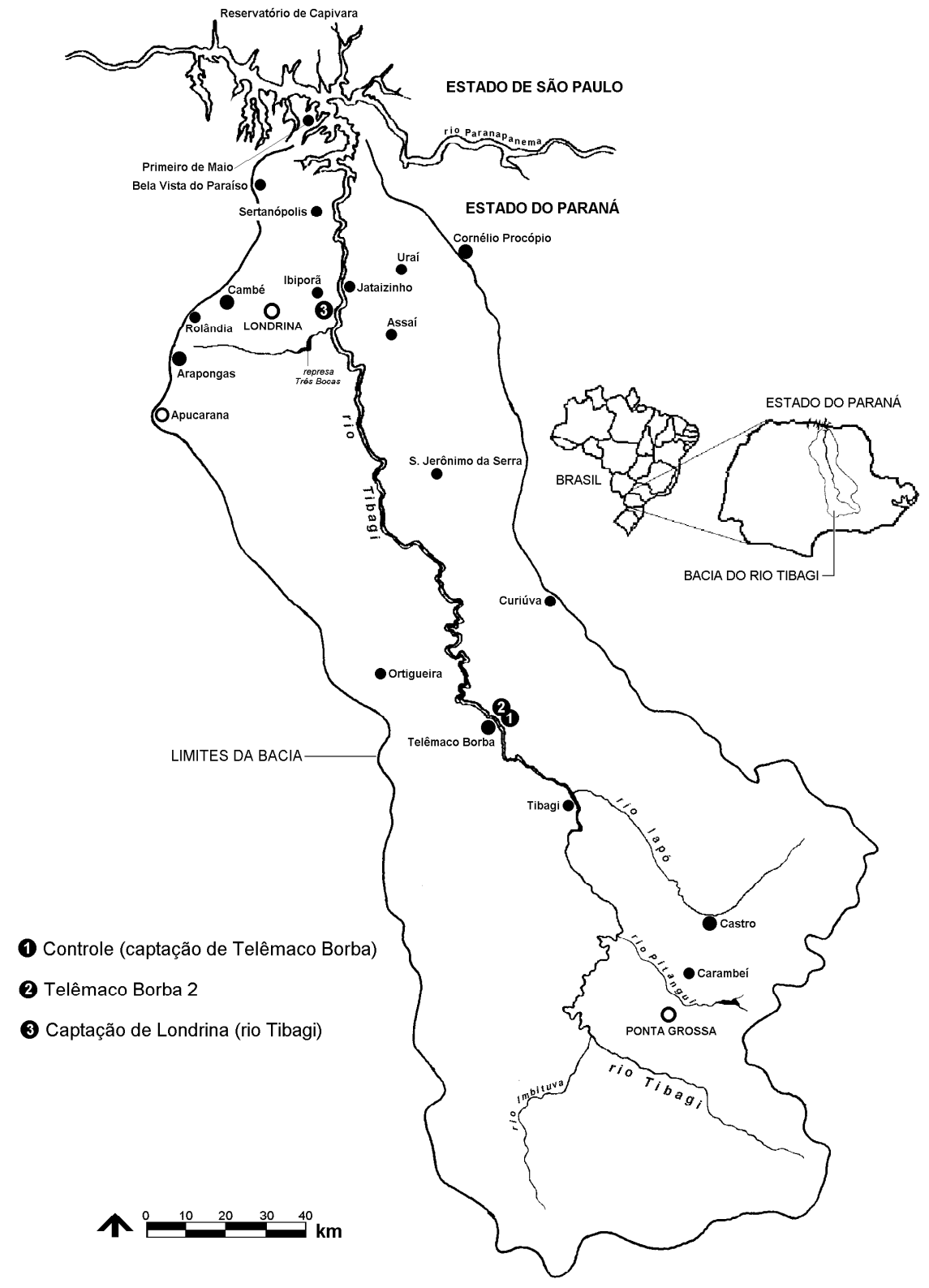

FIGURA 6: Locais de coleta de água e de sedimento, unidades hidrográficas, limites e localização da bacia do rio Tibagi. 1) S $24^{\circ} 20^{\prime} 17,6^{\prime \prime}$ / W $50^{\circ} 35^{\prime} 56,1^{\prime \prime}$; 2) S $24^{\circ} 18^{\prime \prime} 38,9^{\prime \prime}$ /

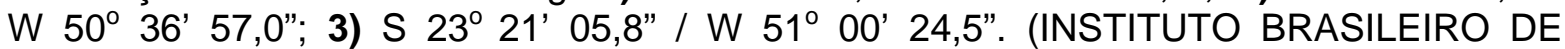
GEOGRAFIA E ESTATÍSTICA, IBGE, 1980; www.copati.org.br, 2000 - modificados).

De acordo com o COPATI (site na Internet), a bacia hidrográfica do rio Tibagi não é muito industrializada, situando-se os principais pólos em Londrina e Ponta Grossa, os quais também possuem as maiores demandas de água para o abastecimento doméstico. A maioria das indústrias está ligada à agropecuária, mas há também indústrias de outros 
setores, como o têxtil, o de bebidas e o de papel. Uma das maiores indústrias de papel e celulose do país, a Klabin, situa-se em Telêmaco Borba, às margens do rio Tibagi. Os locais de estudo 1 e 2 foram escolhidos por se situarem, respectivamente, à montante e à jusante dessa indústria, da qual o efluente foi avaliado nesse trabalho. As maiores cargas poluidoras (em termos de DBO) contidas nos esgotos domésticos e efluentes industriais são provenientes dos municípios de Londrina (daí, a escolha do ponto 3), Ponta Grossa e Telêmaco Borba. Londrina também possui, juntamente com os municípios de Tibagi e Castro, as maiores demandas de água para a criação de animais. A figura 7 mostra panoramas dos locais de coleta.

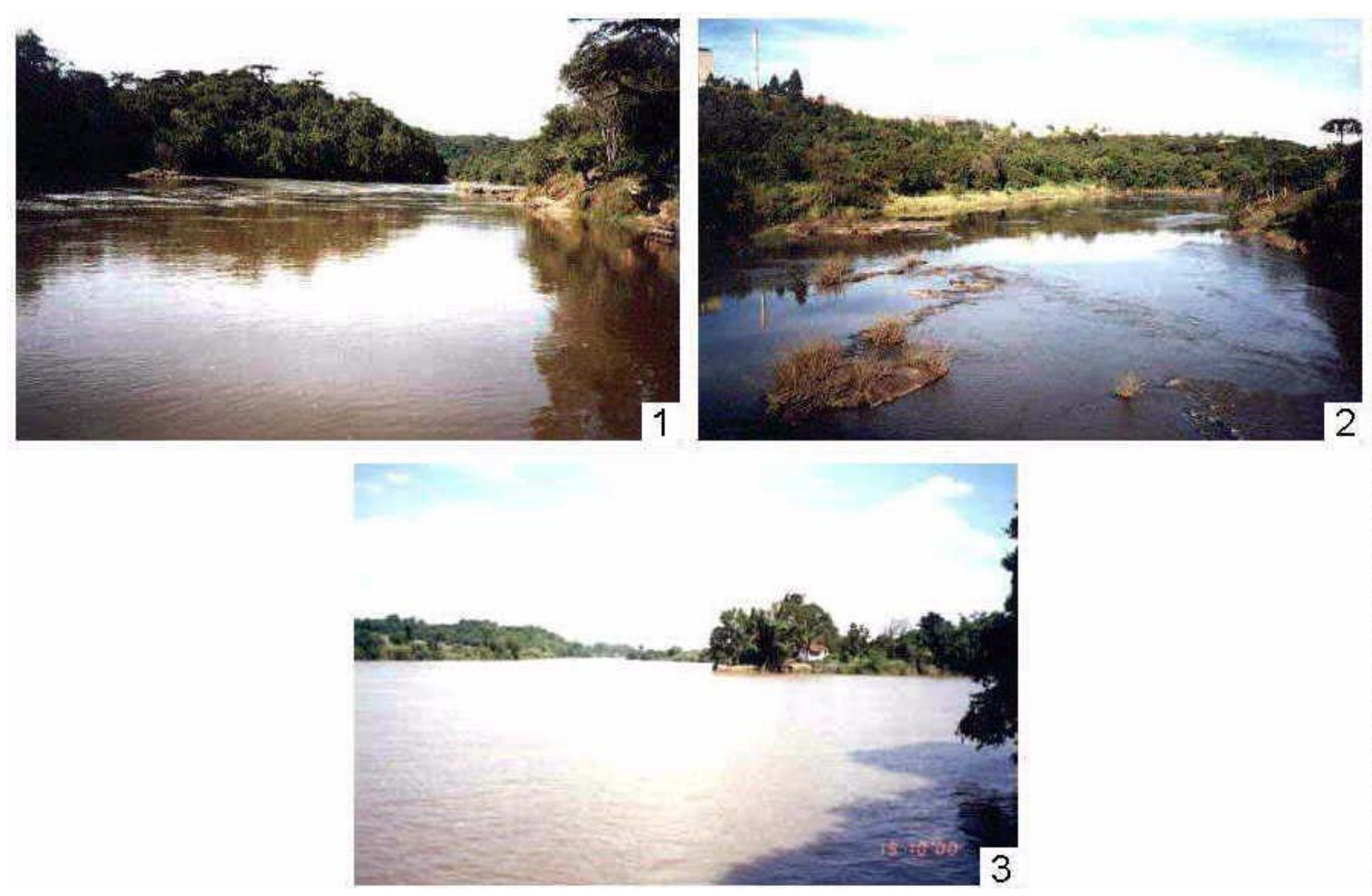

FIGURA 7: Panoramas dos locais de coleta de água e de sedimento na bacia do rio Tibagi, PR: 1) Rio Tibagi, em Telêmaco Borba, próximo à estação de captação de água da cidade (à montante da Klabin Papel e Celulose); $\quad$ 2) Rio Tibagi, em Telêmaco Borba, à jusante da Klabin Papel e Celulose; 3) Rio Tibagi, em Londrina, próximo ao local de captação de água na região rural do Limoeiro (à jusante do deságue dos principais rios e ribeirões que atravessam a zona urbana de Londrina).

As precipitações médias em Telêmaco Borba e Londrina podem ser visualizadas na tabela 1 e as vazões dos rios em localidades próximas aos pontos de coleta estão representadas na tabela 3 . 
TABELA 1: Precipitações médias ( $\mathrm{mm}$ ) em localidades próximas aos pontos estudados nas bacias dos rios Piracicaba e Mogi-Guaçu. Os valores referem-se às médias e aos desvios médios calculados a partir das precipitações mensais do período de 1988 a 2000 nas bacias dos rios Piracicaba e Mogi Guaçu (http://www.sigrh.sp.gov.br/sigrh/basecon/bancodedados/) e à precipitação mensal média registrada no ano de 2002 em Telêmaco Borba e Londrina (http://www.pr.gov.br/iapar).

\begin{tabular}{|c|c|c|c|c|c|c|c|c|c|c|c|c|c|}
\hline Localidade & Coord. & jan & fev & mar & $a b r$ & mai & jun & jul & ago & set & out & nov & dez \\
\hline Pin./Limeira & $\begin{array}{l}22^{\circ} 40^{\prime} \mathrm{S} \\
47^{\circ} 13^{\prime} \mathrm{W}\end{array}$ & $275 \pm 86$ & $219 \pm 37$ & $201 \pm 67$ & $76 \pm 26$ & $65 \pm 27$ & $42 \pm 29$ & $36 \pm 25$ & $20 \pm 17$ & $76 \pm 35$ & $129 \pm 48$ & $139 \pm 52$ & $202 \pm 48$ \\
\hline Camp./Sum. & $\begin{array}{l}42^{\circ} 56^{\prime} \mathrm{S} \\
46^{\circ} 54^{\prime} \mathrm{W}\end{array}$ & $283 \pm 66$ & $207 \pm 62$ & $205 \pm 84$ & $76 \pm 33$ & $66 \pm 33$ & $45 \pm 22$ & $48 \pm 42$ & $17 \pm 13$ & $88 \pm 39$ & $133 \pm 54$ & $151 \pm 55$ & $244 \pm 56$ \\
\hline Americana & $\begin{array}{l}22^{\circ} 42^{\prime} \mathrm{S} \\
47^{\circ} 17^{\prime} \mathrm{W}\end{array}$ & $274 \pm 79$ & 208 & 185 & $68 \pm 29$ & 66 & 26 & 3 & 2 & 38 & 51 & 1 & \pm 39 \\
\hline Piracicaba & $\begin{array}{l}22^{\circ} 43^{\prime} \mathrm{S} \\
47^{\circ} 39^{\prime} \mathrm{W}\end{array}$ & $223 \pm 73$ & $223 \pm 97$ & $200 \pm 75$ & $78 \pm 43$ & $54 \pm 22$ & $38 \pm 24$ & $26 \pm 21$ & $16 \pm 14$ & $61 \pm 35$ & $130 \pm 59$ & $122 \pm 61$ & $181 \pm 47$ \\
\hline São João & $\begin{array}{l}21^{\circ} 57^{\prime} \mathrm{S} \\
46^{\circ} 48^{\prime} \mathrm{W}\end{array}$ & $262 \pm 65$ & $247 \pm 80$ & $200 \pm 57$ & $77 \pm 26$ & $62 \pm 22$ & $31 \pm 24$ & $26 \pm 17$ & $18 \pm 17$ & $73 \pm 41$ & $155 \pm 55$ & $154 \pm 52$ & $230 \pm 59$ \\
\hline Mogi-Guaçu & $\begin{array}{l}22^{\circ} 10^{\prime} \mathrm{S} \\
47^{\circ} 08^{\prime} \mathrm{W}\end{array}$ & $239 \pm 66$ & $235 \pm 98$ & $178 \pm 57$ & $70 \pm 29$ & $71 \pm 30$ & $38 \pm 27$ & $24 \pm 17$ & $14 \pm 13$ & $66 \pm 43$ & $137 \pm 54$ & $129 \pm 35$ & $180 \pm 33$ \\
\hline Pirassununga & $\begin{array}{l}22^{\circ} 02^{\prime} \mathrm{S} \\
47^{\circ} 25^{\prime} \mathrm{W}\end{array}$ & $254 \pm 39$ & $261 \pm 75$ & $199 \pm 72$ & $86 \pm 45$ & $59 \pm 26$ & $31 \pm 27$ & $26 \pm 18$ & $12 \pm 11$ & $68 \pm 40$ & $129 \pm 41$ & $131 \pm 51$ & $218 \pm 31$ \\
\hline Luiz Antônio & $\begin{array}{l}21^{\circ} 35^{\prime} \mathrm{S} \\
47^{\circ} 42^{\prime} \mathrm{W}\end{array}$ & $251 \pm 53$ & $256 \pm 87$ & $159 \pm 53$ & $68 \pm 30$ & $53 \pm 21$ & $33 \pm 28$ & $18 \pm 15$ & $15 \pm 14$ & $60 \pm 42$ & $132 \pm 37$ & $177 \pm 83$ & $218 \pm 51$ \\
\hline Tel. Borba & $\begin{array}{l}24^{\circ} 19^{\prime} \mathrm{S} \\
50^{\circ} 37^{\prime} \mathrm{W}\end{array}$ & $220-$ & $100-$ & $100-$ & $50-$ & $210-$ & $10-$ & $60-$ & $70-$ & $200-$ & $100-$ & $200-$ & $130-$ \\
\hline Londrina & $\begin{array}{l}23^{\circ} 21^{\prime} \mathrm{S} \\
51^{\circ} 00^{\prime} \mathrm{W}\end{array}$ & $240-$ & $100-$ & $100-$ & $25-$ & $290-$ & $20-$ & $70-$ & $85-$ & $90-$ & $50-$ & $250-$ & $90-$ \\
\hline
\end{tabular}


TABELA 2 : Vazões médias mensais $\left(\mathrm{m}^{3} . \mathrm{s}^{-1}\right)$ dos rios Jaguari, Atibaia, Piracicaba e Mogi-Guaçu em localidades próximas aos pontos estudados. Os valores referem-se às médias e aos desvios médios calculados a partir das vazões $\left(\mathrm{m}^{3} . \mathrm{s}^{-1}\right)$ mensais registradas nos seguintes períodos: 1990 a 1999 em Limeira, Piracicaba e Luiz Antônio; 1991 a 1999 em Sumaré; 1978 a 1987 em Mogi Guaçu e 1984 a 1994 em Pirassununga. (http://www.sigrh.sp.gov.br/sigrh/basecon/bancodedados/).

\begin{tabular}{|c|c|c|c|c|c|c|c|c|c|c|c|c|c|}
\hline Rio/Loc.próx. & Coord. & jan & fev & mar & abr & mai & jun & jul & ago & set & out & nov & dez \\
\hline $\begin{array}{c}\text { Jaguari / } \\
\text { Limeira } \\
\end{array}$ & $\begin{array}{l}22^{\circ} 39^{\prime} \mathrm{S} \\
47^{\circ} 13^{\prime} \mathrm{W}\end{array}$ & $161 \pm 101$ & $122 \pm 49$ & $141 \pm 81$ & $90 \pm 57$ & $55 \pm 16$ & $42 \pm 19$ & $32 \pm 8$ & $24 \pm 8$ & $40 \pm 19$ & $67 \pm 27$ & $52 \pm 24$ & $96 \pm 39$ \\
\hline $\begin{array}{l}\text { Atibaia / } \\
\text { Sumaré }\end{array}$ & $\begin{array}{l}22^{\circ} 44^{\prime} \mathrm{S} \\
47^{\circ} 08^{\prime} \mathrm{W}\end{array}$ & $120 \pm 51$ & $125 \pm 48$ & $95 \pm 41$ & $73 \pm 39$ & $49 \pm 10$ & $40 \pm 12$ & $32 \pm 11$ & $28 \pm 9$ & $58 \pm 23$ & $72 \pm 24$ & $59 \pm 22$ & $94 \pm 26$ \\
\hline $\begin{array}{l}\text { Piracicaba / } \\
\text { Piracicaba }\end{array}$ & $\begin{array}{l}22^{\circ} 41^{\prime} \mathrm{S} \\
47^{\circ} 46^{\prime} \mathrm{W}\end{array}$ & $212 \pm 88$ & $244 \pm 84$ & $199 \pm 59$ & $145 \pm 59$ & $109 \pm 24$ & $94 \pm 24$ & $74 \pm 14$ & $56 \pm 9$ & $68 \pm 18$ & $94 \pm 25$ & $96 \pm 36$ & $126 \pm 25$ \\
\hline $\begin{array}{c}\text { Mogi Guaçu / } \\
\text { M.Guaçu }\end{array}$ & $\begin{array}{l}22^{\circ} 22^{\prime} \mathrm{S} \\
46^{\circ} 56^{\prime} \mathrm{W}\end{array}$ & $139 \pm 50$ & $131 \pm 44$ & $121 \pm 48$ & $89 \pm 28$ & $70 \pm 21$ & $71 \pm 36$ & $49 \pm 17$ & $40 \pm 10$ & $46 \pm 21$ & $48 \pm 22$ & $55 \pm 19$ & $121 \pm 56$ \\
\hline $\begin{array}{l}\text { Mogi Guaçu / } \\
\text { Pirassununga }\end{array}$ & $\begin{array}{l}21^{\circ} 55^{\prime} \mathrm{S} \\
47^{\circ} 24^{\prime} \mathrm{W}\end{array}$ & $215 \pm 71$ & $224 \pm 48$ & $229 \pm 52$ & $178 \pm 46$ & $135 \pm 23$ & $98 \pm 23$ & $75 \pm 13$ & $69 \pm 11$ & $64 \pm 17$ & $70 \pm 24$ & $85 \pm 29$ & $149 \pm 54$ \\
\hline $\begin{array}{c}\text { Mogi Guaçu / } \\
\text { L. Antônio }\end{array}$ & $\begin{array}{l}21^{\circ} 42^{\prime} \mathrm{S} \\
47^{\circ} 50^{\prime} \mathrm{W}\end{array}$ & $250 \pm 89$ & $302 \pm 120$ & $277 \pm 60$ & $232 \pm 75$ & $173 \pm 37$ & $139 \pm 33$ & $111 \pm 16$ & $85 \pm 8$ & $86 \pm 17$ & $111 \pm 29$ & $130 \pm 47$ & $178 \pm 51$ \\
\hline
\end{tabular}

TABELA 3: Vazões médias $\left(\mathrm{m}^{3} \cdot \mathrm{s}^{-1}\right)$ do rio Tibagi em localidades próximas aos pontos estudados, calculadas* a partir dos valores médios das vazões diárias registradas de 1974 a 1993 (http://www.hidricos.mg.gov.br/ufparana/relprin3/tab31.htm).

\begin{tabular}{|l|c|c|c|c|}
\hline Rio / Localidade & vazão de cheia** & vazão normal** & vazão mínima** & vazão de seca** \\
\hline $\begin{array}{l}\text { Tibagi / } \\
\text { Tibagi (a montante de T. Borba) }\end{array}$ & 229 & 133 & 87 & 52 \\
\hline $\begin{array}{l}\text { Tibagi / } \\
\text { Jataizinho (a jusante de Londrina) }\end{array}$ & 502 & 312 & 212 & 129 \\
\hline
\end{tabular}

* Dados calculados pelo autor; ** Denominações dadas pelo autor. 


\subsection{Locais de amostragem, procedimentos de coleta, manutenção e análise das amostras de água, sedimento e efluentes industriais.}

A primeira coleta de amostras de água e de sedimento utilizadas nos testes de toxicidade foi realizada no período de 23 a 28 de março de 2000 (final do período chuvoso) nas bacias dos rios Piracicaba e Mogi-Guaçu e em 23, 24 e 25 de junho do mesmo ano na bacia do rio Tibagi (já no período seco). A segunda coleta foi realizada no período de 07 a 09 de setembro de 2000 nas bacias dos rios Piracicaba e Mogi Guaçu (período seco) e nos dias 23 de setembro (Telêmaco Borba) e 19 de outubro de 2000 (Londrina), já no início das chuvas (que ocorreram antes naquela região). As amostras foram coletadas na bacia do rio Piracicaba em seis locais, correspondentes às captações de água para o abastecimento público das cidades de Piracicaba, Americana (ambas no rio Piracicaba), Sumaré, Campinas (ambas no rio Atibaia) e Limeira (rio Jaguari), além de um local referência, situado no ribeirão do Pinhal, junto à captação de Limeira). A escolha do local de referência foi baseada em estudos anteriores (FONSECA, 1997; MELETTI, 1997), que indicaram a localidade "Ribeirão do Pinhal" como a menos impactada e cujas amostras de água e de sedimento não foram tóxicas a microcrustáceos, quironomídeos e peixes. Na bacia do rio Mogi Guaçu as amostras foram coletadas nos municípios de Mogi Guaçu (a montante e a jusante da indústria International Paper), Pirassununga, Luiz Antônio (a montante e a jusante da indústria Votorantin Celulose e Papel), todas no rio Mogi Guaçu e em São João da Boa Vista, junto à captação no rio Jaguari-Mirim (local referência). Este rio, a montante da cidade de São João da Boa Vista, passa por uma região predominantemente agrícola. As maiores cargas poluidoras são lançadas à jusante da referida cidade. O local escolhido como referência não está livre de impactos, mas é, supostamente, mais adequado para servir de referência do que todos os outros locais de fácil acesso para coleta e que podem ser monitorados sistematicamente nos testes in situ (quando todos os pontos devem ser visitados em um curto espaço de tempo). Na bacia do rio Tibagi as amostras foram coletadas em 3 locais: em Telêmaco Borba (alto Tibagi) (a montante e a jusante da Indústria Klabin de Papel e Celulose) e em Londrina, no baixo Tibagi (em local próximo à captação dessa cidade). Os locais descritos anteriormente estão assinalados nos mapas das figuras 2, 4 e 6 .

As amostras de água foram coletadas superficialmente com um balde, armazenadas em frascos plásticos e congeladas até o momento das análises, com exceção daquelas destinadas à análise de metais, que foram fixadas com ácido clorídrico e resfriadas. As determinações das concentrações de nitrogênio amoniacal (KOROLEF, 1976, apud GOLTERMAN et al, 1978), nitrato, fósforo total (MACKERETH \& TALLING, 1978), nitrito, fosfato inorgânico (GOLTERMAN et al, 1978), fosfato total, nitrogênio total (VALDERRAMA, 1981), silicato reativo (STRICKLAND e PARSONS, 1965), e material em suspensão (técnica gravimétrica - TEIXEIRA et al., 1965) foram realizadas no Laboratório 
de Análises Químicas do Departamento de Ecologia e Biologia Evolutiva (DEBE) da Universidade Federal de São Carlos (UFSCar). Os metais analisados foram: zinco, chumbo, cádmio, níquel, ferro, manganês, cobre e cromo, de acordo com as metodologias contidas no Standard Methods for Examination of Water and Wastewater, $17^{\underline{a}}$ edição (AMERICAN PUBLIC HEALTH ASSOCIATION - APHA, 1989). As determinações das concentrações destes metais foram realizadas no Laboratório de Análises Químicas do Centro de Recursos Hídricos e Ecologia Aplicada (CRHEA) da EESC/USP. As características físicas e químicas como $\mathrm{pH}$, temperatura, oxigênio dissolvido e condutividade, foram realizadas no local da coleta, com o auxílio de um condutivímetro Corning CD-55, um medidor de pH Corning pH-30 e de um oxímetro Cole-Parmer DO-100.

As amostras de sedimento foram coletadas com uma draga de Van Veen e armazenadas em um refrigerador a $4^{\circ} \mathrm{C}$ por períodos não superiores a uma semana até $\mathrm{o}$ seu uso nos testes de toxicidade (ASTM, 1994; BURTON, 1991; BURTON \& MacPHERSON, 1995). Também foram coletadas amostras de sedimento para as análises de metais pesados e granulométricas. Os metais pesados no sedimento foram analisados na forma de metais potencialmente biodisponíveis (fracamente ligados), que é a forma mais importante no contexto toxicológico. Para estas análises, pesaram-se cerca de 1,0 g de sedimento seco $\left(120^{\circ} \mathrm{C}\right.$, por 12 horas) que foi, então, pulverizado no interior de um erlenmeyer, no qual foram adicionados, em seguida, $25 \mathrm{ml}$ de ácido clorídrico $(\mathrm{HCl})$ 0,1 M. Esta mistura foi mantida sob agitação em um agitador horizontal por 2 horas. A seguir, a suspensão foi filtrada e a absorbância do filtrado determinada por meio de espectrofotometria de absorção atômica por chama (MOZETO, 1999). As análises granulométricas e dos teores de matéria orgânica no sedimento seguiram a metodologia descrita por SUGUIO (1973).

Com relação às coletas do efluente de indústria de papel e celulose, a intenção inicial era a de realizá-las diretamente no local de despejo, o que não foi possível devido ao fato dos tubos de descarga estarem em locais inacessíveis ou situados muito abaixo da superfície da água (lançamento submerso). A coleta feita dessa maneira poderia averiguar as suspeitas de ribeirinhos que residem próximos às indústrias de que a qualidade do efluente lançado parece variar muito. Segundo os relatos, em alguns dias, ao por do sol e à noite, o efluente é mais "sujo" do que aquele lançado à luz do dia.

Para a obtenção de amostras de efluente final, produzido no processo de produção de papel, o mesmo foi solicitado às seguintes indústrias de papel e celulose, em cada uma das bacias:

Bacia do rio Mogi-Guaçu: VCP - Votorantim Celulose e Papel, em Luís Antônio, SP. Champion S/A (atual International Paper), em Mogi-Guaçu, SP.

Bacia do rio Piracicaba: Ripasa S/A Celulose e Papel, em Americana, SP (município de Limeira). 
Bacia do rio Tibagi: Indústrias Klabin de Papel e Celulose S/A, unidade de Telêmaco Borba, PR.

Todas as indústrias, com exceção da International Paper, se dispuseram a fornecer amostras de seus efluentes finais para os testes de toxicidade. Como o objetivo não foi o de comparar a qualidade dos efluentes de diferentes indústrias, mas sim o efeito desse tipo de efluente em peixes com relação a alterações histopatológicas, foi utilizado apenas o efluente da Klabin pelo fato da indústria estar situada mais próxima do local de realização dos testes de toxicidade, o que possibilitou o início do teste poucas horas após a coleta. Além disso, mesmo considerando que a qualidade do efluente pode variar de indústria para indústria, conforme o tipo de matéria-prima, o processo de produção e o tratamento utilizado, foi priorizada a utilização dos peixes para o objetivo principal do trabalho, que foi a realização dos testes com sedimento.

O teste de toxicidade com o efluente teve início 6 horas após a coleta. As amostras foram transportadas em galões plásticos, em caixas de isopor com gelo até o Laboratório de Bioensaios do Departamento de Ciências Fisiológicas da Universidade Estadual de Londrina, onde foram realizados os experimentos.

\subsection{Organismos utilizados nos testes de toxicidade em laboratório e in situ.}

Os principais critérios considerados para a seleção dos organismos-teste, de acordo com RAND \& PETROCELLI (1985), são a disponibilidade e abundância, a facilidade de cultivo em laboratório e o conhecimento sobre a biologia da espécie. É recomendada, ainda, a utilização de espécies autóctones, mais representativas do ecossistema impactado, ou sob investigação.

Assim, a espécie nativa escolhida como organismo-teste foi o peixe de pequeno porte Serrapinnus notomelas (Characiformes, Characidae) (figura 8a), utilizado em estágio de adulto jovem. A subfamília Cheirodontinae possui numerosos gêneros, que são muito semelhantes entre si. As espécies desta subfamília são conhecidos popularmente como "pequiras" e são comuns em todo o Brasil, em ambientes lóticos e lênticos (BRITSKY, 1972).

O gênero Serrapinnus (até há pouco tempo denominado Cheirodon), possui dentes multicúspides com 5 ou mais pontas e corpo com linha lateral incompleta. No estado de São Paulo ocorrem duas espécies: S. stenodon, que possui corpo mais afilado, uma mancha reduzida na base da nadadeira caudal e dentes de topo estreito e $S$. notomelas que, por sua vez, possui uma mancha negra posterior envolvendo todo o pedúnculo caudal, nadadeira dorsal com base escura, corpo relativamente alto e dentes de topo largo (BRITSKY, 1972).

A espécie Serrapinnus notomelas é recomendada para o uso em testes de toxicidade aquática pela Associação Brasileira de Normas Técnicas (ABNT, 1993), pelo 
Instituto Brasileiro do Meio Ambiente e dos Recursos Naturais Renováveis (IBAMA, 1990) e pela Companhia de Tecnologia de Saneamento Ambiental (CETESB, 1990), que também a utiliza nos testes por ela realizados.

Serrapinnus notomelas é ovulípara e não apresenta reprodução contínua, o que dificulta sua criação em laboratório (como ocorre com os poecilídeos que são vivíparos e que se reproduzem várias vezes durante o ano) para a utilização em ensaios biológicos. No entanto, é possível coletar os organismos, de modo controlado, em ambientes naturais e não impactados onde ocorram em abundância, e aclimatá-los em laboratório. Outra opção seria criá-los em tanques de piscicultura, onde também é comum encontrá-los em abundância.

S. notomelas foi facilmente encontrado na Represa Três Bocas, formada pelo ribeirão de mesmo nome (afluente do rio Tibagi), situada no município de Londrina, estado do Paraná. Os peixes dos dois primeiros lotes (tabela 4) foram coletados nessa represa. As coletas dos peixes foram realizadas utilizando-se uma peneira circular formada por um aro de ferro de 1,3 $\mathrm{m}$ de diâmetro e tela de náilon de malha de $2 \mathrm{~mm}$. Os organismos foram acondicionados em sacos plásticos e transportados em caixa de isopor até o laboratório, onde passaram por um processo de aclimatação. Porém, em virtude da referida represa ter sido transformada em um parque, a captura dos peixes neste local teve de ser suspensa, apesar da não existência de riscos de extinção para a população de peixes (devido às coletas esporádicas e ao número inexpressivo de indivíduos coletados). Houve, além disso, a ocorrência da elevada mortalidade de peixes, supostamente devido ao um aporte de agrotóxicos carreados pela chuva. Tal fato trouxe desconfianças quanto à qualidade dos organismos-teste, que passaram, então, a ser adquiridos de criadores comerciais.

Para a adaptação dos peixes em laboratório foi desenvolvido um sistema de aquários que permite manter um grande número de peixes em um pequeno espaço físico. Para isso, foram utilizados 12 aquários de vidro de $20 \mathrm{~L}$ cada, ligados a um filtro biológico (figura 5). Este sistema possui várias vantagens sobre o armazenamento em grandes aquários, pois:

1. permite manter maiores quantidades de peixes em uma menor área, pois embora a relação massa dos organismos/volume de água seja a mesma para os dois sistemas, neste é possível "empilhar" os aquários;

2. dispensa a utilização de vários aeradores, pois há só um aerador, no filtro e o fluxo de água nos aquários é contínuo;

3. é possível manter a mesma temperatura em todos os aquários, pois só há aquecedores no aquário-filtro;

4. a água é constantemente filtrada;

5. os peixes podem ser facilmente selecionados por espécie, classes de tamanho, sexo (se houver dimorfismo aparente e caso seja necessário) e idade dos lotes; 
6. no caso de doenças ou parasitismos, os aquários podem ser facilmente isolados, bastando fechar as entradas e saídas de água.

A temperatura foi controlada em aproximadamente $24{ }^{\circ} \mathrm{C}$ por termostatos/ aquecedores (depois substituídos por um ar-condicionado automático, com resfriamento/aquecimento) e o fotoperíodo de 12/12 horas. A alimentação foi administrada uma vez ao dia, consistindo de ração em flocos para peixes ornamentais Alcon Basic ${ }^{\circledR}$ (composição na tabela 26 anexos).

A fim de se estabelecer comparações com uma espécie internacionalmente padronizada, também foram realizados testes com a espécie exótica Danio rerio (Cypriniformes, Cyprinidae) (figura 8b). D. rerio, conhecido popularmente como paulistinha ou "zebra-fish", é uma espécie de pequeno porte muito apreciada pelos aquariofilistas e amplamente utilizada em testes de toxicidade por ter reprodução contínua ao longo do ano e ser de fácil adaptação às condições experimentais. Esta espécie foi adquirida de criadores comerciais e adaptada em laboratório (por um período mínimo de 15 dias antes dos testes) sob as mesmas condições anteriormente descritas para Serrapinnus notomelas. No período de aclimatação dos peixes (de ambas as espécies), estes foram triados a fim de formar lotes homogêneos com relação ao tamanho dos animais.

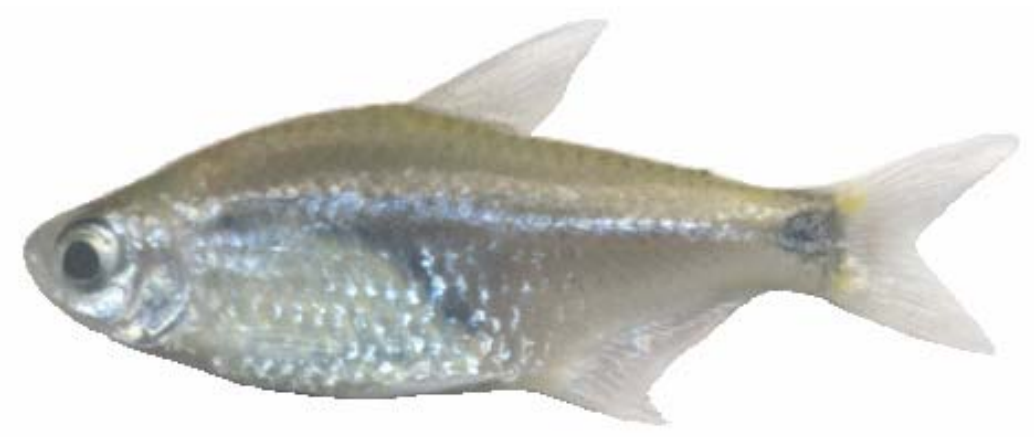

a

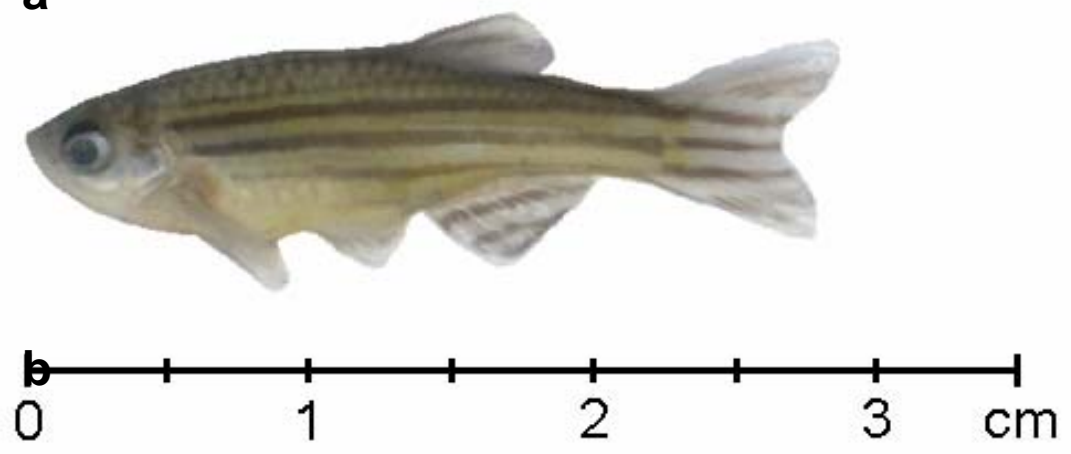

FIGURA 8: Espécies utilizadas nos testes de toxicidade com substâncias de referência, efluentes de indústrias de papel e celulose e amostras de sedimento de rios das bacias hidrográficas estudadas: a) Serrapinnus notomelas (Characiformes, Characidae); b) Danio rerio (Cypriniformes, Cyprinidae). 


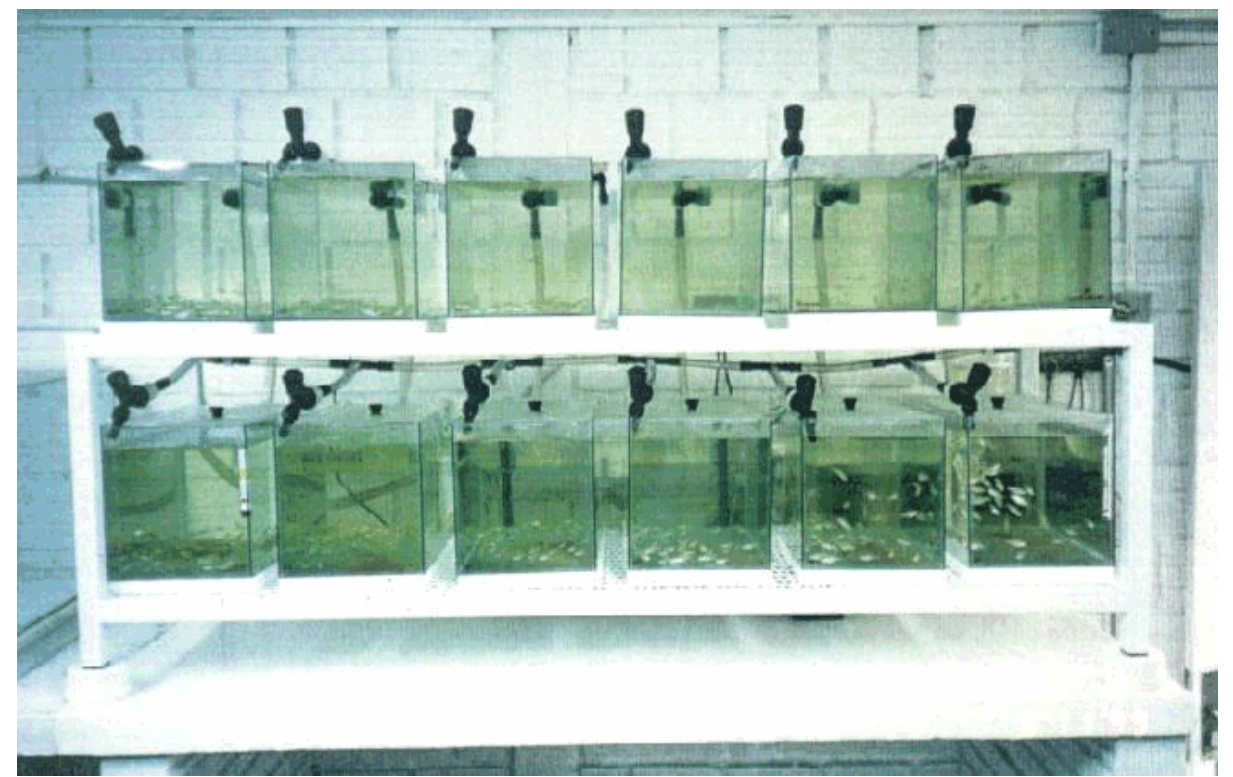

FIGURA 9: Sistema para manutenção de pequenos peixes em laboratório. Os 12 aquários, de 20 litros cada, comunicam-se com um aquário-filtro que contém a bomba e os termostatos/aquecedores (vide esquema de montagem na figura77 -anexos).

No total, seis lotes de peixes foram aclimatados para a realização dos testes, sendo 4 de Serrapinnus notomelas e 2 de Danio rerio, assim utilizados conforme descrito na tabela 4.

TABELA 4: Lotes de peixes utilizados em cada teste de toxicidade aguda com dicromato de potássio e com sedimento das localidades estudadas.

\begin{tabular}{|c|c|c|}
\hline Lote de peixes & $\begin{array}{c}\text { Número do teste de } \\
\text { sensibilidade ao } \mathrm{K}_{2} \mathrm{Cr}_{2} \mathrm{O}_{7}\end{array}$ & $\begin{array}{l}\text { Teste com amostras de sedimento } \\
\text { da(s) bacia(s) dos rios }\end{array}$ \\
\hline 1 - S. notomelas* & 1 & - \\
\hline 2 - S. notomelas & 2 & Piracicaba e Mogi Guaçu ( $1^{\text {a }}$ coleta - chuvoso) \\
\hline 3 - S. notomelas & 3 & Tibagi ( $1^{\underline{a}}$ coleta - chuvoso) \\
\hline 4 - S. notomelas & 4 & Piracicaba, Mogi Guaçu e Tibagi ( $2^{2}$ coleta - seco) \\
\hline $1-D$. rerio & - & Piracicaba, Mogi Guaçu e Tibagi (1 ${ }^{\underline{a}}$ coleta - chuvoso) \\
\hline $2-$ D. rerio & 1 & Piracicaba, Mogi Guaçu e Tibagi ( $2^{2}$ coleta - seco) \\
\hline
\end{tabular}

* Também utilizados no teste com efluente de indústria de papel e celulose

\subsection{Testes de toxicidade aguda com substância de referência $\left(\mathrm{K}_{2} \mathrm{Cr}_{2} \mathrm{O}_{7}\right)$}

Foram realizados testes de toxicidade com dicromato de potássio $\left(\mathrm{K}_{2} \mathrm{Cr}_{2} \mathrm{O}_{7}\right)$ com duração de 96 horas, em uma grande amplitude de concentrações, o que possibilitou a determinação da $\mathrm{CL}_{50}$ em 24, 48, 72 e 96 horas. Foram realizados 4 testes com Serrapinnus notomelas e 1 teste com Danio rerio para fins comparativos.

As diferentes concentrações foram obtidas a partir de uma solução-estoque de dicromato de potássio $\left(\mathrm{K}_{2} \mathrm{Cr}_{2} \mathrm{O}_{7}\right)$ de $5,634 \mathrm{~g} \cdot \mathrm{L}^{-1}\left(2,0 \mathrm{~g} \mathrm{Cr} \cdot \mathrm{L}^{-1}\right)$, utilizando como água de diluição a água de cultivo (originária, principalmente, de poço artesiano), com as seguintes características:

- $\mathrm{pH}: 7,45 \pm 0,24$

- condutividade: $168 \pm 16,15 \mathrm{mS} . \mathrm{cm}^{-1}$

- oxigênio dissolvido: $6,5 \pm 1,05 \mathrm{mg} \mathrm{O} \cdot \mathrm{L}^{-1}$

- dureza: $68 \pm 16,17 \mathrm{mg} \mathrm{CaCO}{ }_{3} \cdot \mathrm{L}^{-1}$
Obs.: variáveis medidas a $23 \pm 1{ }^{\circ} \mathrm{C}$; concentração de oxigênio dissolvido controlada por aeração; variações na dureza e na condutividade devidas a misturas da água do poço artesiano com a água da rede pública de abastecimento (misturas realizadas pela Universidade). Antes de todos os testes a água foi armazenada em uma tina com forte aeração durante 3 dias. 
Foram preparadas, então, as seguintes concentrações (em mg Cr.L-1 (os números entre parênteses referem-se às concentrações em mg. $\mathrm{L}^{-1}$ de dicromato de potássio - $\mathrm{mg}$ $\mathrm{K}_{2} \mathrm{Cr}_{2} \mathrm{O}_{7} \cdot \mathrm{L}^{-1}$ - forma como os resultados estão apresentados)):

Teste 1 - S. notomelas: 0 (controle); 5,6 (15,8); $10(28,2) ; \quad 18(50,7) ; \quad 32(90,1) ; \quad 56(157,8) ; \quad 100(281,7) ;$

Teste 2 - S. notomelas: 0 (controle); $18(50,7) ; \quad 32(90,1) ; \quad 56(157,8) ; \quad 80(225,4) ; \quad 130(366,2)$;

Teste 3 - S. notomelas: 0 (controle); $20(56,3) ; \quad 35(98,6) ; \quad 50(140,9) ; \quad 80(225,4) ; 120(338,0)$;

Teste 4 - S. notomelas: 0 (controle); $20(56,3) ; \quad 40(112,7) ; \quad 60(169,0) ; \quad 80(225,4) ; 100(281,7) ; 120(338,0) ; 140(394,4)$

Teste 1 - D. rerio: $\quad 0$ (controle); $20(56,3) ; \quad 40(112,7) ; \quad 60(169,0) ; \quad 80(225,4) ; 100(281,7) ; 120(338,0) ; \quad 140(394,4)$

Foram utilizados como recipientes-teste potes de vidro com volume total de 3265 $\mathrm{mL}$. As tampas dos potes foram perfuradas e utilizadas para evitar que os peixes saltassem para fora. Os recipientes-teste foram revestidos com sacos plásticos descartáveis a fim de evitar contaminação. Este procedimento, adotado por FONSECA (1991) e por MELETTI (1997), é bastante prático, barato e confiável.

Durante os primeiros testes, quando ainda não havia controle automático de temperatura no laboratório, os recipientes foram mantidos em banho-maria a $23 \pm 1,5{ }^{\circ} \mathrm{C}$ e sem aeração. A fim de evitar hipoxia, a água de diluição foi aerada até a saturação. $O$ fotoperíodo utilizado foi de 12:12 horas claro/escuro.

Os testes foram realizados com 2 repetições $(2$ recipientes-teste por concentração), com seis organismos e $2000 \mathrm{~mL}$ de solução em cada recipiente-teste, de modo a respeitar a proporção de $1 \mathrm{~g}$ de organismo por litro de solução (ABNT, 1993; IBAMA, 1990). A alimentação foi interrompida 24 horas antes do início dos testes. A distribuição dos organismos nos recipientes-teste foi aleatória, transferindo-os um a um e de forma alternada, até completar o número de seis organismos em cada repetição.

As características físicas e químicas da solução-teste $(\mathrm{pH}$, condutividade, dureza, concentração de oxigênio dissolvido e temperatura) foram monitoradas no início e a cada 24 horas até o término dos testes, com o auxílio de um medidor de $\mathrm{pH}$ "Corning pH-30", um condutivímetro "Corning CD-55" e um oxímetro/termômetro "Cole-Parmer DO 100". A dureza foi determinada por titulação com EDTA, de acordo com a metodologia contida na 17ํㅡㄹ edição do "Standard Methods for Examination of Water and Wastewater" (APHA, 1989).

\subsection{Teste de toxicidade aguda do efluente de indústria de papel e celulose a Serrapinnus notomelas.}

O teste de toxicidade com efluente final (após tratamento secundário) oriundo da fabricação de papel e celulose foi realizado com uma amostra fornecida pela indústria localizada no Paraná. O teste foi realizado com as seguintes diluições do efluente: 5\%, 20\%, 40\%, 60\%, 80\% e 100\% (sem diluição), além de um controle. Os parâmetros pH, 
condutividade, concentração de oxigênio dissolvido e temperatura foram medidos diariamente; a dureza foi medida no início e ao final do teste. Assim como nos testes com dicromato de potássio, neste teste foram utilizados 6 organismos por repetição. No entanto, o teste foi realizado em triplicata. As condições do teste foram as mesmas já descritas para aqueles com dicromato de potássio.

\subsection{Testes de toxicidade aguda com sedimento}

Os testes com sedimento seguiram a metodologia descrita por BURTON (1991;1994) e BURTON \& MacPHERSON (1995) para o "fathead minnow", Pimephales promelas. Esta metodologia sugere a realização de testes de toxicidade aguda (ou subletais de 7 dias, nos quais são avaliados os parâmetros sobrevivência e crescimento) de elutriatos, água intersticial ou de sedimentos totais com organismos em estágio larval ou juvenil.

O volume mínimo do recipiente-teste deve respeitar a proporção de, no máximo, $1 \mathrm{~g}$ de organismo por litro de solução. Ainda segundo BURTON (1994), elutriatos ou água intersticial devem ser testados em uma única concentração (normalmente 100\%) ou em uma série de concentrações a fim de determinar o valor da $\mathrm{CL}_{50}$. Neste trabalho foram realizados somente testes com sedimento total, para os quais foi utilizada a proporção de 1:4 de sedimento/água, sendo que a água teve de ser adicionada cuidadosamente a fim de não revolver o sedimento. A preparação dos recipientes-teste foi realizada 24 horas antes do início dos testes a fim de que o excesso de partículas em suspensão decantasse. O controle foi feito com a água dos aquários onde os peixes eram mantidos, convencionalmente chamada de água de manutenção ou de cultivo. Para cada tratamento houveram duas repetições, com seis peixes em cada, distribuídos aleatoriamente. A duração dos testes foi de 96 horas. As condições de temperatura e fotoperíodo foram as mesmas já descritas para os testes com substância de referência. A concentração de oxigênio dissolvido, o pH, a condutividade e a temperatura foram monitorados diariamente, enquanto que a dureza e a concentração de amônia foram monitoradas no início e ao final dos testes.

Para a determinação da concentração de amônia nos testes com sedimento foi utilizado o método proposto por REARDON et al. (1966). Por este método, utiliza-se apenas $1 \mathrm{~mL}$ de amostra (em triplicatas, $3 \mathrm{~mL}$ ) o que praticamente não altera o volume de água nos recipientes-teste. Este método é amplamente utilizado por fisiologistas na determinação de amônia em amostras de água (doce e salgada), de sangue (peixes e outros vertebrados) ou de hemolinfa (crustáceos).

Os organismos sobreviventes ao final dos testes foram fixados em fixador de Bouin para posterior análise histopatológica. 
Os testes de toxicidade e as preparações e análises histológicas foram realizados nos Laboratórios de Bioensaios e de Histologia do Departamento de Ciências Fisiológicas da Universidade Estadual de Londrina, com o apoio da Profa. Dra. Cláudia Bueno dos Reis Martinez.

\subsection{Biometria dos peixes}

A biometria (peso e comprimento total e padrão) foi realizada em 25 peixes capturados aleatoriamente em cada lote, antes de realizada a triagem, na chegada dos animais ao laboratório. Este método é mais adequado do que tomar as medidas dos peixes imediatamente antes dos testes, pois evita o estresse que pode comprometer o resultado dos experimentos; também não é apropriado realizar a biometria dos peixes sobreviventes ao final dos testes se eles forem utilizados em análises histológicas, pois, devido à fragilidade dos animais, o manuseio destes pode causar coágulos e/ou alterações ao material de análise histológica (a não ser que seja realizada fixação prévia (nos primeiros testes de toxicidade foi adotado esse método).

\subsection{Testes in situ}

Os testes de toxicidade aguda (96h) in situ possuem um procedimento simples e os animais são expostos aos agentes tóxicos sob condições reais. Neste tipo de experimento os peixes ficam contidos em recipientes-teste (nesse caso denominados câmaras) mergulhados no corpo d'água a ser avaliado, por um período de 96 horas (BOUDOU \& RIBEYRE ,1989; BURTON, 1992) (figura 12).

Os testes in situ foram realizados com o organismo-teste $S$. notomelas nas mesmas localidades de coleta das amostras de sedimento para os testes de toxicidade realizados em laboratório, as quais estão assinaladas nos mapas das figuras 1, 3 e 5 . Estes experimentos foram realizados na bacia do rio Tibagi, de 16 a 20/11/2001; na bacia do rio Piracicaba, de 07 a 11/12/2001 e na bacia do rio Mogi-Guaçu, de 13 a 17/12/2001. De modo a sanar deficiências de um aparato utilizado anteriormente (MELETTI, 1997), foram desenvolvidas câmaras especialmente para este trabalho (MELETTI \& ROCHA, 2002). Os testes foram realizados com repetições, com um número de dez organismos em cada uma das duas câmaras. Este aparato substituiu, com vantagens, as câmaras utilizadas anteriormente e que, a princípio, seriam utilizadas no presente trabalho. Naquele modelo, as câmaras, com 6 organismos por repetição, eram instaladas em gaiolas que, além de servirem de suporte para a fixação, protegiam contra materiais levados pela correnteza. As gaiolas eram fixadas em contato com o sedimento por meio de estacas de ferro (para que não fossem arrastadas pela correnteza da água sob condições adversas, ou danificadas), a uma profundidade máxima de 1,5 metro. No entanto, a gaiola e a estaca dificultavam o manuseio e o pequeno volume da câmara limitava o número de organismos utilizados em 
cada repetição. Assim, a nova câmara, além de possuir volume maior, é mais resistente e possui um lastro, o que eliminou a gaiola e a estaca. O monitoramento foi diário, pela colocação das câmaras em bandejas previamente cheias com água do próprio local; os organismos foram contados e os mortos removidos. $\mathrm{O}$ pH, a concentração de oxigênio dissolvido, a temperatura, a condutividade e a dureza foram monitoradas diariamente.

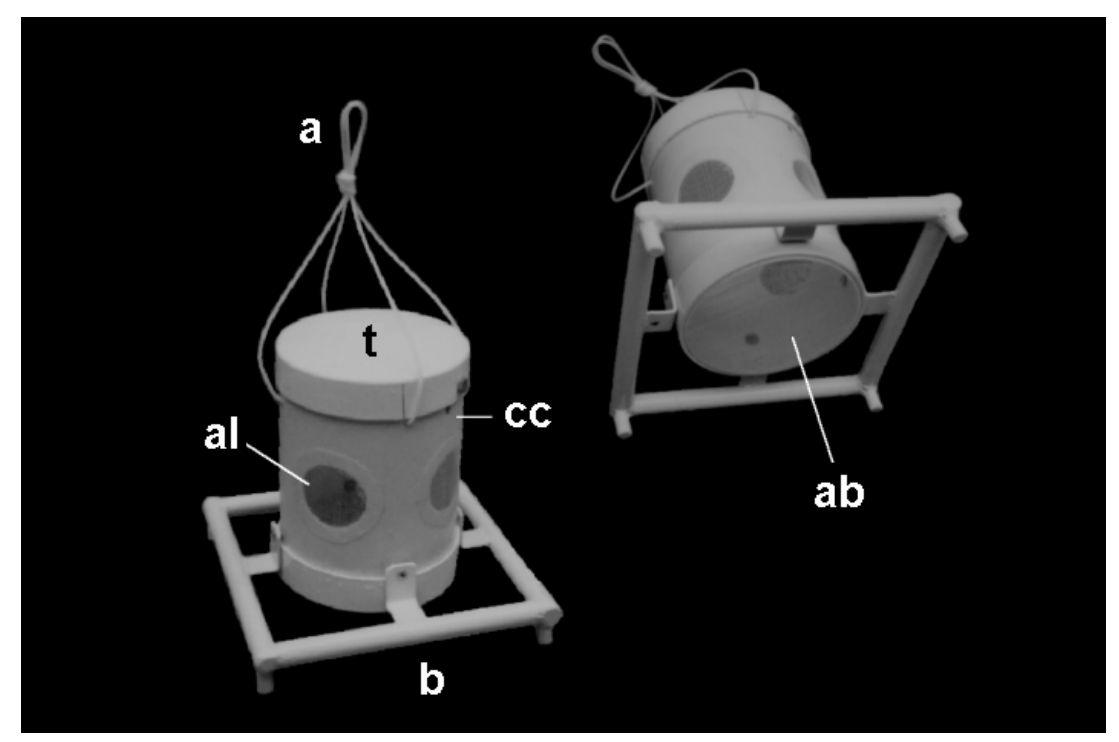

FIGURA 10: Câmaras desenvolvidas para os testes in situ (MELETTI \& ROCHA, 2002). aalça para suspensão da câmara; b-base da câmara; al-abertura lateral; ab-abertura da base; b-base; cc-corpo da câmara. Como referência das dimensões, a base possui $25 \mathrm{~cm}$ de lado e o corpo, $20 \mathrm{~cm}$ de altura.

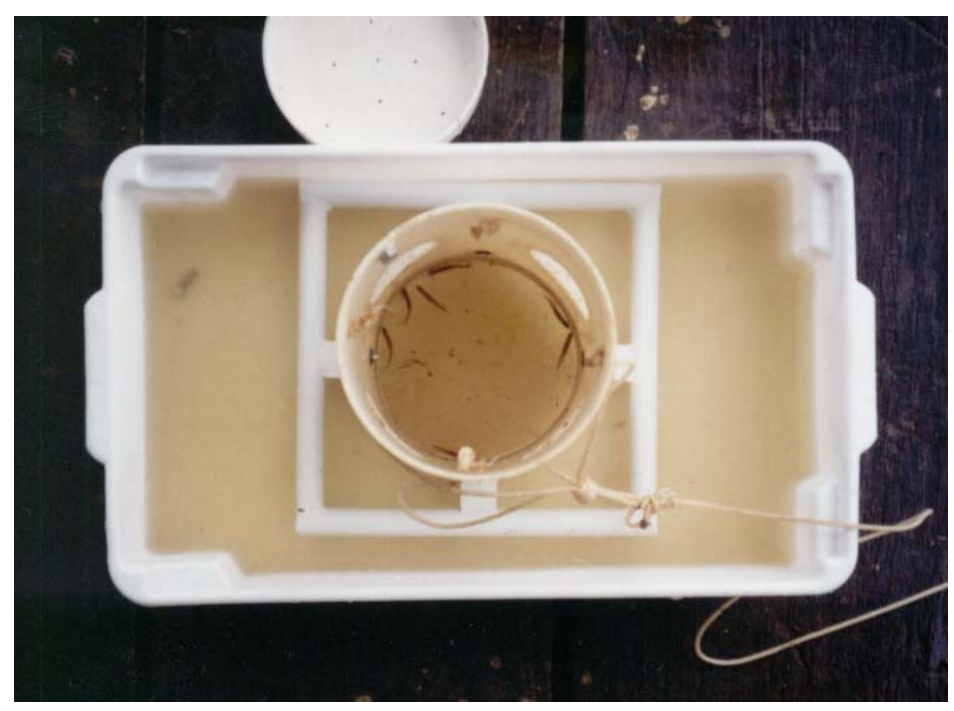

FIGURA 11: Monitoramento para verificação do estado dos organismos e remoção dos mortos. 


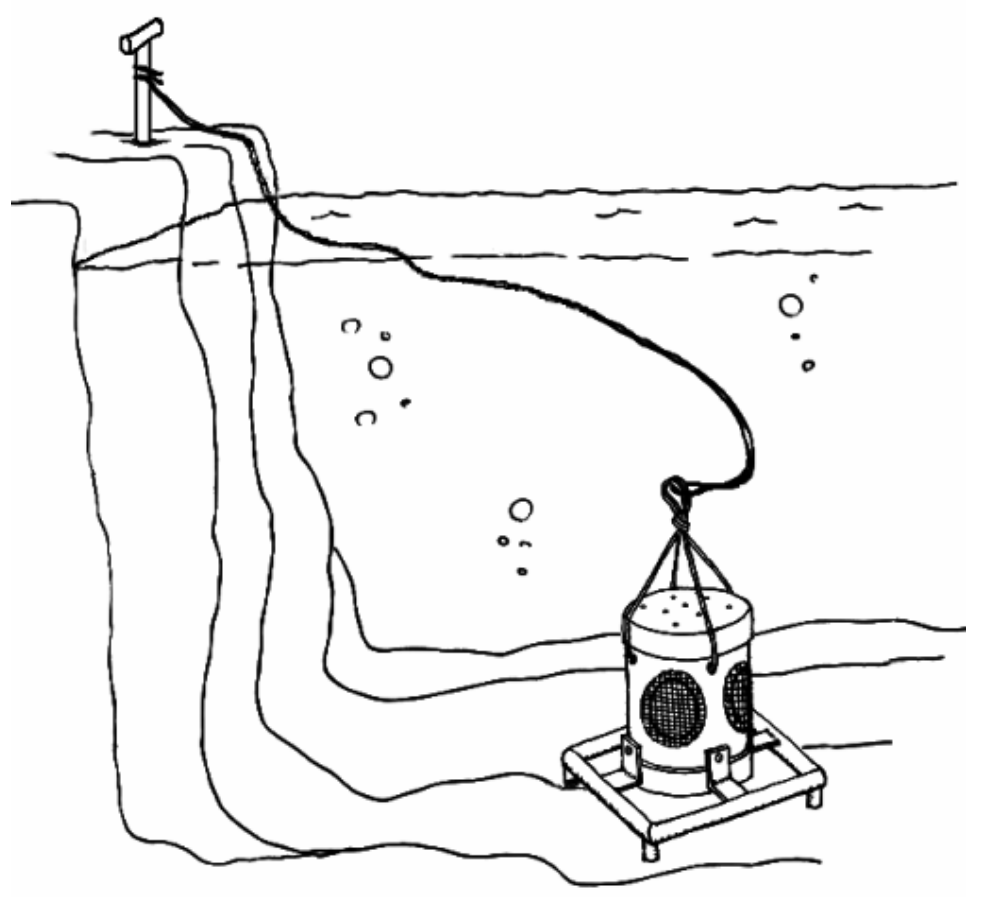

FIGURA 12: Esquema de montagem de um teste in situ com peixes de pequeno porte

Para o transporte dos organismos aos locais dos testes in situ foi utilizada uma caixa térmica de isopor, na qual foram acomodados sacos plásticos contendo os peixes (20 em cada saco). Para garantir o número de peixes necessário à realização dos experimentos (caso houvesse perdas durante o transporte e para eventuais substituições) foi transportada uma quantidade $40 \%$ maior que a necessária. Os peixes não utilizados na montagem dos testes ficaram acondicionados em um aquário de vidro, na cidade-base dos testes em cada bacia. Estas cidades foram: Piracicaba (testes na bacia do rio Piracicaba), São Carlos (testes na bacia do rio Mogi-Guaçu) e Telêmaco Borba e Londrina (testes na bacia do rio Tibagi).

Os organismos sobreviventes ao término dos experimentos foram fixados e armazenados da mesma maneira que aqueles dos testes realizados em laboratório.

\subsection{Estabelecimento do protocolo para a histologia de peixes inteiros e preparação e} análise histológica dos peixes submetidos aos testes de toxicidade com sedimentos em laboratório e com o efluente de papel e celulose.

Como a proposta do presente estudo foi a de trabalhar com uma espécie nativa, $S$. notomelas, decidiu-se utilizar outros indicadores ("end-points") que não o crescimento e a reprodução (pela dificuldade em conseguir um grande número de peixes em estágio larval). Desta forma, pensou-se em analisar, através de cortes histológicos, tecidos que podem 
apresentar alterações após um período menor que todo o ciclo de vida do organismo. Como S. notomelas é uma espécie de pequeno porte, exemplares desta espécie foram preparados inteiros, o que permitiu observar órgãos como o fígado, os rins, as brânquias, o cérebro, o intestino, entre outros.

Embora tenham sido realizados testes de toxicidade com sedimentos coletados nas estações seca e chuvosa, apenas os peixes expostos ao sedimento da estação seca foram analisados pois, dada à quase ausência de precipitação pluviométrica nessa estação, há uma grande redução da vazão de água e, portanto, um aumento na capacidade de diluição de agentes tóxicos, ocasionando concentrações mais elevadas destes na água e no sedimento.

\subsubsection{Seleção dos peixes para o estabelecimento do protocolo de preparação} histológica.

Inicialmente foram utilizados peixes controle, ou seja, que não foram submetidos a quaisquer substâncias, já que o objetivo foi apenas o de testar a metodologia de preparo para os cortes histológicos e não o de observar alterações decorrentes da exposição a tóxicos.

Foram selecionados exemplares de Serrapinnus notomelas com comprimento total entre 2,5 e $3,5 \mathrm{~cm}$ porque esta foi a faixa de tamanho mais utilizada nos testes e corresponde a adultos jovens. Os peixes selecionados foram privados de alimento por 48 horas antes de serem sacrificados a fim de que houvesse o mínimo de alimento em seus tubos digestivos. Até o acerto do protocolo final, várias opções de diafanização e inclusão foram testadas, de acordo o organograma da figura 13.

No total, foram utilizados 25 peixes (dos quais foram produzidas 47 lâminas e aproximadamente 300 cortes) para a determinação da metodologia a ser utilizada. O protocolo foi inicialmente estabelecido para Serrapinnus notomelas e posteriormente adaptado para Danio rerio.

\subsubsection{Preparo do material}

Nas preparações iniciais os organismos foram fixados em fixador de Bouin por 8 horas, seccionados longitudinalmente do abdômen ao dorso em metades, com uma lâmina de barbear (para a retirada da bexiga natatória), voltando novamente ao fixador por mais 4 horas. Este procedimento foi adotado como precaução à não fixação dos órgãos internos, o que foi descartado posteriormente, quando os peixes passaram a ser fixados inteiros por 24 h e não foi constatada perda de qualidade na preparação do material, exceto quando seccionados em metades antes da fixação (que causava o "enrigecimento" do material).

Os peixes fixados tiveram as nadadeiras removidas e a cauda seccionada na linha que vai do ânus até a porção posterior da nadadeira dorsal. Esta porção corresponde 
apenas a músculos, e este procedimento reduz o tamanho dos blocos, o que facilita a microtomia.

Além dos 25 peixes preparados para os cortes longitudinais, foram preparados 4 peixes, de acordo com o protocolo final, para a realização de cortes transversais. Para isso, porém, os peixes não foram seccionados longitudinalmente e a bexiga natatória foi retirada com uma pinça através de um orifício aberto no abdome. Os cortes transversais não foram realizados nos peixes destinados às análises histopatológicas, mas auxiliaram na localização dos órgãos, otimizando a microtomia.

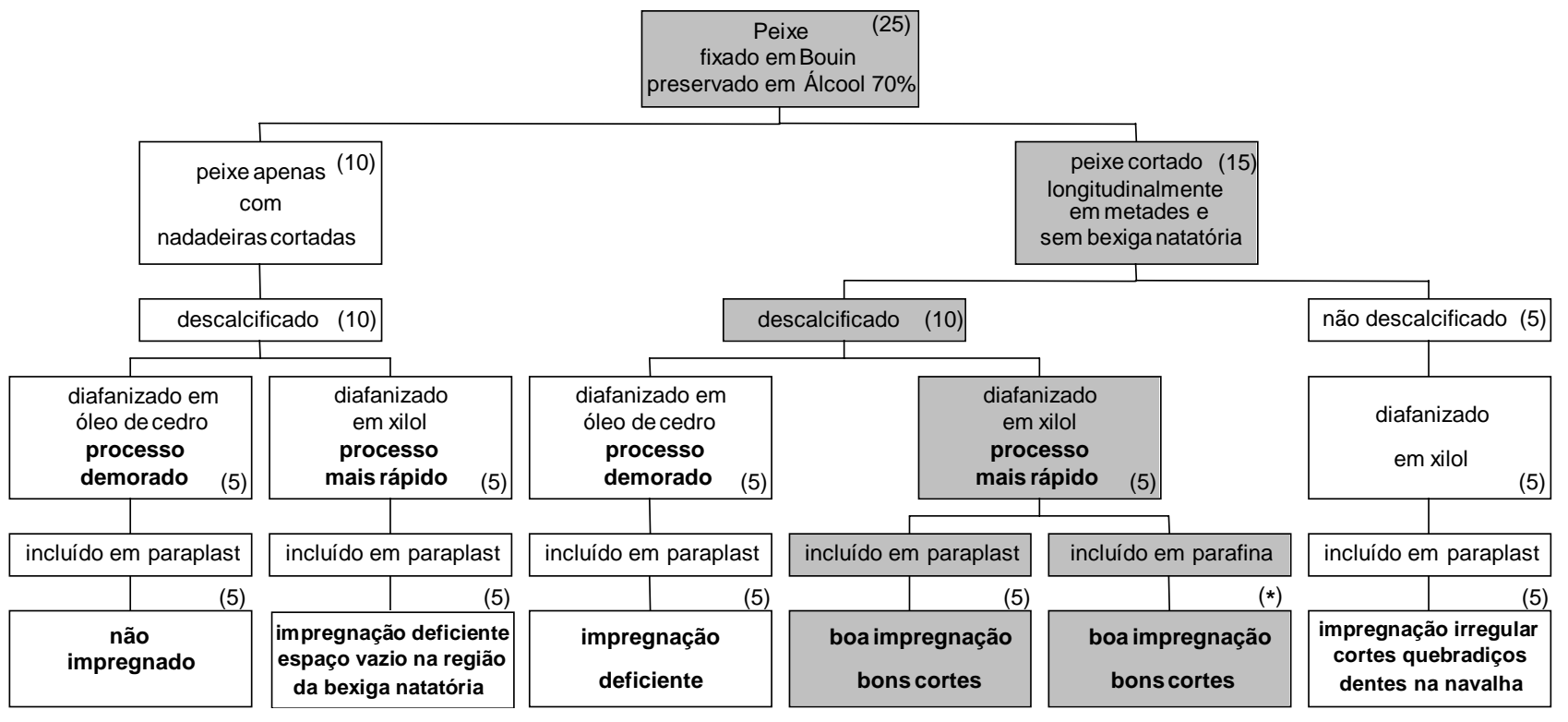

FIGURA 13: Organograma do ajuste do protocolo de diafanização e inclusão de Serrapinnus notomelas adultos inteiros. Os números entre parênteses correspondem ao número de peixes utilizados em cada etapa; $\left(^{*}\right)$ - meio de inclusão testado posteriormente, o qual foi utilizado na maior parte das preparações histológicas do trabalho.

Após a fixação, as peças foram descalcificadas em solução de EDTA a 7\% por 24 horas (para exemplares maiores que 0,4 $\mathrm{g}$ de peso fresco o tempo foi estendido até o limite de $48 \mathrm{~h}$ ) e ao mesmo tempo submetidas a uma corrente elétrica de $80 \mu \mathrm{A}$ (miliamperes), a fim de acelerar a descalcificação dos ossos e escamas. Este método de descalcificação foi baseado no utilizado por IDERIHA et al. (1999). O esquema de montagem de um descalcificador encontra-se nos anexos. O material foi preservado em álcool $70 \%$ até que fosse submetido ao restante do processo de preparação histológica.

A seguir, as metades foram desidratadas em uma bateria de alcoóis, diafanizadas em xilol (sempre em um girador) e incluídas em parafina (em lentilhas, marca Inlab), como se segue: 
Desidratação:

- Álcool 70\% (lavagens sucessivas) *

- Álcool 80\% (1h)*

- Álcool 90\% (1h)*

- Álcool 95\% (1h) *

- Álcool 100\% I (30') *

- Álcool $100 \%$ II (30') *

- Álcool $100 \%$ III (30') *

* temperatura ambiente
Diafanização:

- Xilol I (30') *

- Xilol II $\left(30^{\prime}\right)$ *

- Xilol III(30') opcional *

* temperatura ambiente

Impregnação:

- $\quad$ xilol + parafina 1:1 (30') $60^{\circ} \mathrm{C}$

- $\quad$ xilol + parafina $1: 2\left(30^{\prime}\right) 60^{\circ} \mathrm{C}$

- parafina pura (30') $60^{\circ} \mathrm{C}$

Inclusão: parafina pura

Para a realização dos cortes longitudinais os peixes foram incluídos (em formas de papel alumínio) em decúbito lateral, e para a realização dos cortes transversais, foram incluídos "em pé". Passadas 24 horas do momento da inclusão, o material foi cortado em micrótomo rotativo American Optical com navalhas descartáveis (Leica 108), em espessuras que variaram de 5 a $7 \mu \mathrm{m}$ (a maior parte a $5 \mu \mathrm{m}$ ). Os cortes foram dispostos em lâminas de vidro para microscopia óptica, as quais foram deixadas por $24 \mathrm{~h}$ em estufa a $37^{\circ} \mathrm{C}$ para a secagem e melhor aderência do material.

O material foi corado em HE (hematoxilina-eosina), de acordo com o seguinte protocolo:

- Xilol $100 \%$ I (10')

- Xilol $100 \%$ II (10')

- Álcool $100 \%\left(5^{\prime}\right)$

- Álcool 95\% (5')

- Álcool 70\% (5')

- Lavagem em água corrente

- Lavagem em água destilada

- Hematoxilina (15")

- Lavagem em água corrente
- Eosina (3')

- Álcool 70\% (10")

- Álcool 95\% (10")

- Álcool $100 \%$ I (5')

- Álcool $100 \%$ II (5')

- Álcool + xilol (5')

- Xilol 100\% III (5')

- Xilol 100\% IV (5')

- Montagem c/ bálsamo do Canadá

Além da coloração em hematoxilina-eosina, foi utilizada a coloração pelo método do ácido periódico-Schiff (PAS), a qual possibilita a observação da presença de glicogênio e de substâncias glicoprotéicas, como o muco. A coloração pelo método PAS seguiu o seguinte protocolo:

- Xilol 100\% I (10')

- Xilol 100\% II (10')

- Álcool 100\% (5')

- Álcool 95\% (5')

- Álcool 70\% (5')

- Lavagem em água destilada (5')

- Oxidação em ácido periódico a 0,5\% (5')

- Lavagem em água destilada (5')

- Reativo de Schiff (15')

- Lavagem em água corrente (10')

- 3 banhos de água sulfurosa (2' cada)

- Lavagem em água destilada (5')
Contra-coloração com hematoxilina:

- Hematoxilina (15")

- Lavagem em água corrente

- Álcool 70\% (10")

- Álcool 95\% (10")

- Álcool 100\% I (5')

- Álcool 100\% II (5')

- Álcool + xilol (5')

- Xilol 100\% III (5')

- Xilol 100\% IV (5')

- Montagem c/ bálsamo do Canadá

A figura 14 mostra algumas etapas da preparação histológica de Serrapinnus notomelas. A mesma metodologia foi empregada na preparação dos exemplares de Danio rerio, utilizando o tempo de descalcificação dos menores $S$. notomelas (menores que 0,4 g). 


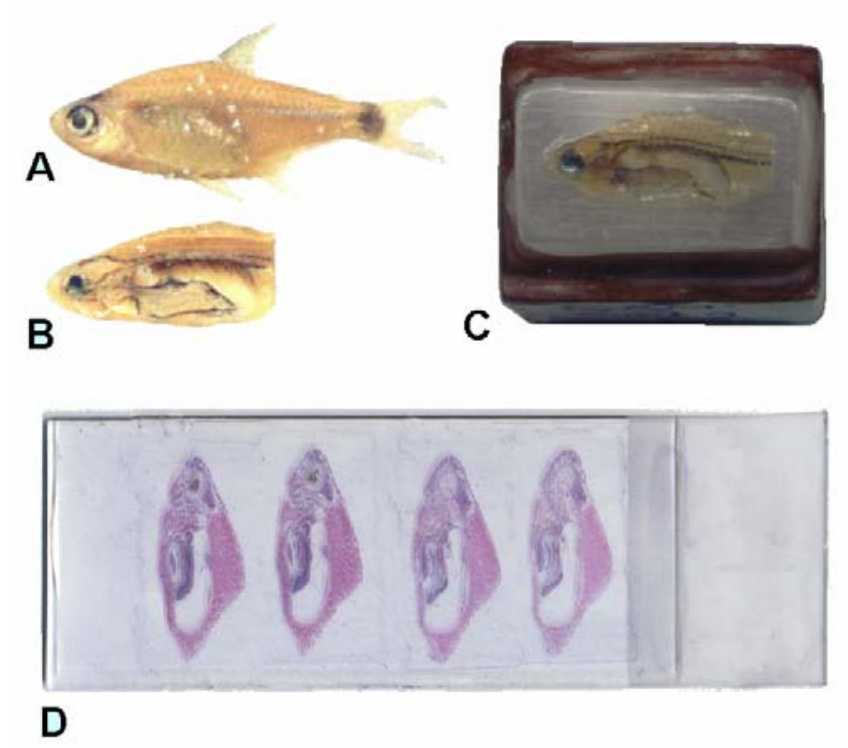

FIGURA 14: Etapas do processo de preparação histológica de Serrapinnus notomelas. A) Peixe fixado (Bouin) e descalcificado; B) Peixe seccionado longitudinalmente, sem nadadeiras e sem cauda (opcional); C) Metade incluída em parafina, pronta para microtomia; D) Lâmina com cortes corados (HE), pronta para a observação em microscópio óptico.

Para a análise dos peixes submetidos aos testes de toxicidade $(\mathrm{N}=5$ peixes por tratamento/localidade), foram preparadas de 4 a 7 lâminas por peixe, com cada lâmina contendo de 4 a 6 cortes. Os cortes foram realizados "de dentro para fora" do peixe, ou seja, como os peixes foram incluídos em metades, foi possível iniciar os cortes da espinha dorsal em direção à pele. Esse procedimento, além de diminuir o desbaste da peça, evita danos à navalha causados por escamas que eventualmente não são descalcificadas.

As lâminas foram observadas em microscópios ópticos marcas Olympus-micronal CBR 2 e fotografadas nos fotomicroscópios Zeiss Axiosphot e Zeiss Axioskop 2 plus (digital).

\subsubsection{Métodos de análise do material preparado}

Para a análise das lâminas foram consideradas uma série de alterações histopatológicas nas brânquias, rins e fígado, conforme mostram as tabelas 5, 6 e 7, que foram classificadas em ordem de gravidade e tiveram a ocorrência anotada. Isso possibilitou a aplicação de dois índices para a avaliação das alterações. Um deles é o VMA (valor médio de avaliação), proposto por SCHWAIGER et al. (1997), calculado a partir de uma análise semiquantitativa baseada em uma escala de severidade e ocorrência das lesões:

grau 1 = sem alterações patológicas;

grau 2 = alterações pontuais brandas a moderadas;

grau 3 = alterações patológicas severas e amplamente distribuídas. 
Estes valores foram determinados separadamente para cada órgão de cada animal e a média e o desvio padrão entre os peixes de cada local foram calculados.

O outro índice utilizado foi o IAH (índice de alterações histológicas) utilizado por POLEKSIC \& MITROVIC-TUTUNDZIC (1994) na avaliação de efeitos crônicos da poluição nas brânquias de três espécies de peixes ciprinídeos. Este índice foi baseado em uma lista de lesões branquiais, sendo cada tipo de lesão classificado, conforme a severidade, em estágios I, II e III.

De acordo com os autores, os estágios foram assim descritos:

Estágio I: Alterações leves em um grau que permita a recuperação da estrutura e função dos tecidos branquiais caso haja melhoria nas condições ambientais. "Sob condições ambientais inalteradas tais lesões devem persistir e, no caso de exposições a longo prazo, as alterações provavelmente progredirão para o segundo estágio".

Estágio II: Alterações mais severas que comprometem a função dos tecidos; lesões reparáveis no caso de melhoria da qualidade da água, exceto quando grandes áreas nas brânquias forem danificadas; lesões que, em situação de poluição crônica ou então de aumento no nível de poluição, ou ainda de deterioração de outras condições ambientais (temperatura, $\mathrm{pH}, \mathrm{OD}$, etc), colocam em risco as funções branquiais, podendo levar a alterações do terceiro estágio.

Estágio III: Alterações em um grau que não permite a restauração da estrutura branquial. "Mesmo com a melhoria da qualidade da água, ou com o fim da exposição aos agentes tóxicos, as alterações desse estágio levarão, mais cedo ou mais tarde, ao dano das funções branquiais vitais e até à morte".

A partir dessa classificação das lesões em estágios, os autores assumiram empiricamente que a cinética das alterações tem um crescimento exponencial. Então:

a) para o primeiro estágio: $10^{\circ}$

b) para o segundo estágio: $10^{1}$

c) para o terceiro estágio: $10^{2}$

Assim, os índices foram calculados de acordo com a seguinte equação:

$$
I=\frac{\sum_{i=1}^{n a} a_{i}+10 \sum_{i=1}^{n b} b_{i}+10^{2} \sum_{i=1}^{n c} c_{i}}{N}
$$

Sendo: a: primeiro estágio de alterações.

b: segundo estágio de alterações.

c: terceiro estágio de alterações.

na: número total de alterações consideradas como sendo do primeiro estágio.

nb: número total de alterações consideradas como sendo do segundo estágio.

nc: número total de alterações consideradas como sendo do terceiro estágio.

$\mathrm{N}$ : número de peixes analisados por tratamento. 
TABELA 6: Alterações histológicas consideradas na análise do rim de Serrapinnus notomelas e de Danio rerio expostos às amostras de sedimento e ao efluente de indústria de papel e celulose. O estágio considerado para cada alteração está indicado na segunda coluna. Baseado em RIGOLIN-SÁ (1998) e em alterações descritas por TAKASHIMA \& HIBIYA (1995).

\begin{tabular}{|c|c|}
\hline \multirow{2}{*}{\multicolumn{2}{|c|}{ a) Alterações no tecido linfóide }} \\
\hline & \\
\hline Perda do contorno celular ou contorno celular atípico & $\mathrm{I}$ \\
\hline \multicolumn{2}{|l|}{ b) Alterações nos glomérulos e túbulos renais } \\
\hline Degeneração hialina tubular leve & $\mathrm{I}$ \\
\hline Degeneração hialina tubular severa & II \\
\hline Hipertrofia das células tubulares & $\mathrm{I}$ \\
\hline Desorganização tubular & $\mathrm{I}$ \\
\hline Desorganização glomerular & $\mathrm{I}$ \\
\hline$>$ Degeneração tubular & II \\
\hline Degeneração glomerular & II \\
\hline Aumento do espaço da cápsula de Bowman & $\mathrm{I}$ \\
\hline Diminuição do espaço da cápsula de Bowman & $\mathrm{I}$ \\
\hline Dilatação dos capilares glomerulares & $\mathrm{I}$ \\
\hline Degeneração citoplasmática das células tubulares & II \\
\hline Degeneração nuclear das células tubulares & II \\
\hline Presença de túbulos em regeneração ou de "novos néfrons" & $\mathrm{I}$ \\
\hline Presença de muitos grânulos PAS-positivos no epitélio tubular & $\mathrm{I}$ \\
\hline Obstrução tubular & $\mathrm{I}$ \\
\hline Aumento do lúmen tubular & I \\
\hline Presença de tecido linfóide na cápsula de Bowman & II \\
\hline Diminuição da freqüência relativa de glomérulos & $\mathrm{I}$ \\
\hline \multicolumn{2}{|l|}{ c) Alterações nos vasos sangüíneos } \\
\hline Dilatação dos vasos sangüíneos & I \\
\hline Hiperemia & II \\
\hline Ruptura dos vasos sangüíneos & II \\
\hline d) Estágio terminal & \\
\hline
\end{tabular}


TABELA 7: Alterações histológicas consideradas na análise do fígado de Serrapinnus notomelas e de Danio rerio expostos às amostras de sedimento e ao efluente de indústria de papel e celulose. O estágio considerado para cada alteração está indicado na segunda coluna. Baseado em RIGOLIN-SÁ (1998).

\begin{tabular}{|c|c|}
\hline ALTERAÇÕES HISTOLÓGICAS & ESTÁGIO \\
\hline \multicolumn{2}{|l|}{ a) Alterações nos hepatócitos } \\
\hline$>$ Desarranjo dos cordões hepáticos & $\mathrm{I}$ \\
\hline$>$ Perda ou atipia do contorno celular & I \\
\hline$>$ Perda ou atipia do contorno nuclear & I \\
\hline$>$ Aumento do volume celular & $\mathrm{I}$ \\
\hline$>$ Aumento do volume nuclear & $\mathrm{I}$ \\
\hline$>$ Atrofia nuclear & II \\
\hline$>$ Intensa vacuolização citoplasmática & I \\
\hline D Vacuolização nuclear & II \\
\hline$>$ Diminuição da freqüência relativa de ocorrência de núcleos & I \\
\hline$>$ Degeneração citoplasmática & II \\
\hline Degeneração nuclear & II \\
\hline$>$ Rompimento celular & II \\
\hline$>$ Diminuição do glicogênio & $\mathrm{I}$ \\
\hline$>$ Estagnação biliar & $\mathrm{I}$ \\
\hline \multicolumn{2}{|l|}{ b) Alterações nos vasos sangüíneos } \\
\hline$>$ Aumento da freqüência relativa de vasos sangüíneos & I \\
\hline$>$ Hiperemia & II \\
\hline$>$ Ruptura de vasos & II \\
\hline$>$ Aumento do volume relativo dos vasos & $\mathrm{I}$ \\
\hline \multicolumn{2}{|l|}{ c) Alterações nos canalículos biliares } \\
\hline$>$ Degeneração dos canalículos biliares & II \\
\hline \multicolumn{2}{|l|}{ d) Estágio terminal } \\
\hline$>$ Necrose (focal ou total) & III \\
\hline
\end{tabular}

É importante salientar que nas preparações com HE, que não preservam lipídeos e nem há reação com o glicogênio, os vacúolos aparecem vazios. Assim, na sistematização dos resultados, só foi considerada "vacuolização citoplasmática" aquela que não correspondeu a vacúolos de glicogênio (pela comparação com o mesmo material corado com PAS) e que, provavelmente, foi devida ao acúmulo excessivo de gordura.

\subsubsection{Análise estatística:}

A análise estatística foi realizada utilizando um programa computacional. $\mathrm{Na}$ análise dos resultados referentes aos testes de toxicidade com sedimento, foram realizadas, para cada bacia, por espécie de peixe, por órgão analisado, comparações entre os índices calculados para a localidade referência com aqueles calculados para as demais localidades. No teste de toxicidade com amostra de efluente final de indústria de papel e celulose foram realizadas comparações entre o grupo controle e os grupos expostos às diferentes concentrações do efluente. Como se tratam, então, de séries de valores de três ou mais grupos de dados, foi aplicado o teste não-paramétrico de Kruskal-Wallis. A hipótese nula é a de que todas as séries de dados são iguais. Para isolar os grupos experimentais que diferiram do grupo controle foi aplicado o teste de comparações múltiplas de Dunn (teste de agrupamento não-paramétrico; 95\% de confiança; $p<0,05$ ). 


\section{RESULTADOS}

\subsection{Testes de toxicidade aguda do dicromato de potássio a Serrapinnus notomelas e Danio rerio.}

As concentrações letais médias (24, 48, 72 e 96 horas) obtidas nos quatro testes de sensibilidade ao dicromato de potássio realizados com Serrapinnus notomelas e no teste realizado com Danio rerio podem ser observadas na figura 15. Os valores (com os intervalos de confiança) das $\mathrm{CL}_{50}$ estão contidos na tabela 27 (anexos).

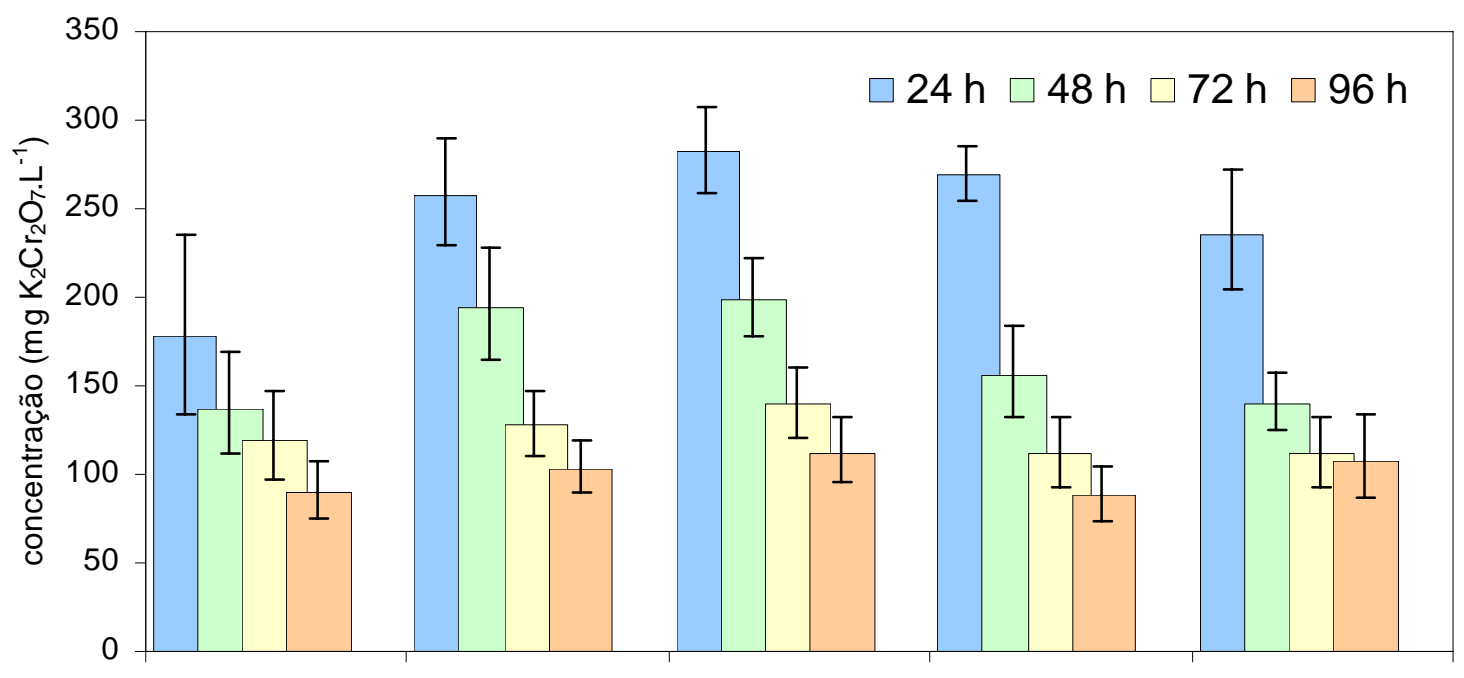

$\begin{array}{llllll}\text { S. notomelas } 1 & \text { S. notomelas } 2 & \text { S. notomelas } 3 & \text { S. notomelas } 4 & \text { D. rerio }\end{array}$

FIGURA 15: Concentrações letais médias $\left(\mathrm{CL}_{50}\right)$ de dicromato de potássio para Serrapinnus notomelas, em 24, 48, 72 e 96 horas, em quatro testes de toxicidade, comparadas à $\mathrm{CL}_{50}$ obtida em um teste similar, realizado com Danio rerio.

\subsubsection{Monitoramento das variáveis físicas e químicas durante os testes de toxicidade com dicromato de potássio.}

Quanto às variáveis físicas e químicas monitoradas durante os testes (tabelas 8 a 12), não houve grandes variações ao longo do tempo, dentro de cada concentração, nos valores de condutividade, temperatura e dureza da água. A manutenção da temperatura em $23 \pm 1,5^{\circ} \mathrm{C}$ só não foi possível nas primeiras 24 horas do teste 2 , devido a uma queda brusca da temperatura, acima da capacidade automática de ajuste dos 
termostatos/aquecedores do banho-maria, fazendo com que fosse necessário ajustá-los manualmente.

Houve um pequeno aumento do $\mathrm{pH}$ do início para o final do teste, provavelmente devido à excreção dos peixes. Quanto às concentrações de oxigênio dissolvido, foi observada uma diminuição ao longo do teste, como o esperado, já que não foi utilizada aeração artificial. Porém, isto provavelmente não interferiu no resultado dos testes, já que esta queda na concentração de $\mathrm{O}_{2}$ ocorreu em todas as concentrações, inclusive no

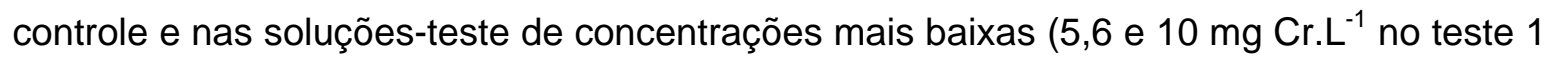

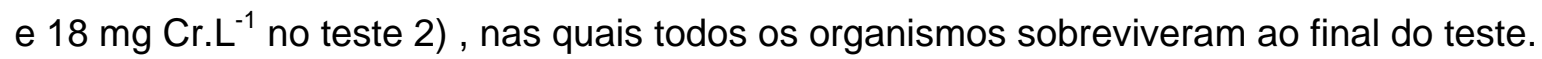

TABELA 8: Características físicas e químicas das soluções teste, monitoradas durante o teste $\mathrm{n}^{-} 1$ de sensibilidade de Serrapinnus notomelas ao dicromato de potássio.

\begin{tabular}{|c|c|c|c|c|c|c|}
\hline $\mathrm{mgCr} \cdot \mathrm{L}^{-1}$ & Horas & $\mathrm{pH}$ & $\begin{array}{c}\text { condutividade } \\
(\mu \mathrm{S} / \mathrm{cm})\end{array}$ & $\begin{array}{c}\mathrm{OD} \\
\left(\mathrm{mg} \mathrm{O}_{2} \cdot \mathrm{L}^{-1}\right)\end{array}$ & $\begin{array}{c}\text { Temperatura } \\
\left({ }^{\circ} \mathrm{C}\right) \\
\end{array}$ & $\begin{array}{c}\text { dureza } \\
\left(\mathrm{mg} \mathrm{CaCO}_{3} \cdot \mathrm{L}^{-1}\right)\end{array}$ \\
\hline \multirow{5}{*}{$\begin{array}{c}0,0 \\
\text { (controle) }\end{array}$} & 0 & 7,50 & 183 & - & 23,0 & 66,0 \\
\hline & 24 & 7,11 & 166 & 5,54 & 22,6 & 78,4 \\
\hline & 48 & 6,97 & 175 & 4,96 & 23,3 & 78,4 \\
\hline & 72 & 7,39 & 167 & 4,69 & 22,6 & 74,2 \\
\hline & 96 & 7,58 & 166 & 4,83 & 22,4 & 70,1 \\
\hline \multirow{5}{*}{5,6} & 0 & 7,34 & 204 & - & 23,0 & 70,1 \\
\hline & 24 & 7,35 & 191 & 5,85 & 22,6 & 78,4 \\
\hline & 48 & 7,39 & 183 & 5,19 & 23,2 & 82,5 \\
\hline & 72 & 7,33 & 186 & 4,30 & 22,6 & 74,2 \\
\hline & 96 & 7,39 & 180 & 4,58 & 22,6 & 74,2 \\
\hline \multirow{5}{*}{10,0} & 0 & 7,15 & 210 & - & 23,0 & 70,1 \\
\hline & 24 & 7,31 & 196 & 5,70 & 22,8 & 70,1 \\
\hline & 48 & 7,45 & 204 & 5,72 & 23,2 & 78,4 \\
\hline & 72 & 7,53 & 194 & 4,27 & 22,6 & 70,1 \\
\hline & 96 & 7,54 & 192 & 4,60 & 22,6 & 74,2 \\
\hline \multirow{5}{*}{18,0} & 0 & 6,92 & 234 & - & 23,0 & 70,1 \\
\hline & 24 & 7,24 & 233 & 5,88 & 22,6 & 82,5 \\
\hline & 48 & 7,36 & 238 & 5,54 & 23,2 & 78,4 \\
\hline & 72 & 7,73 & 230 & 5,11 & 22,4 & 70,1 \\
\hline & 96 & 7,62 & 219 & 4,60 & 22,6 & 66,0 \\
\hline \multirow{5}{*}{32,0} & 0 & 6,68 & 280 & - & 23,0 & 61,9 \\
\hline & 24 & 7,00 & 276 & 5,61 & 22,6 & 74,2 \\
\hline & 48 & 7,22 & 283 & 5,60 & 23,4 & 82,5 \\
\hline & 72 & 7,58 & 287 & 5,22 & 22,4 & 74,2 \\
\hline & 96 & 7,75 & 268 & 5,86 & 22,6 & 74,2 \\
\hline \multirow{5}{*}{56,0} & 0 & 6,43 & 343 & - & 23,0 & 70,1 \\
\hline & 24 & 6,75 & 347 & 6,01 & 22,5 & 74,2 \\
\hline & 48 & 6,95 & 355 & 5,57 & 23,5 & 74,2 \\
\hline & 72 & 7,38 & 365 & 5,79 & 22,6 & 74,2 \\
\hline & 96 & 7,54 & 338 & 5,96 & 22,6 & 74,2 \\
\hline \multirow{5}{*}{100,0} & 0 & 6,19 & 445 & - & 23,0 & 66,0 \\
\hline & 24 & 6,38 & 451 & 6,36 & 22,5 & 74,2 \\
\hline & 48 & 6,53 & 472 & 5,65 & 23,5 & 82,5 \\
\hline & 72 & 6,78 & 477 & 6,92 & 22,5 & 74,2 \\
\hline & 96 & 6,90 & 437 & 6,28 & 22,5 & 74,2 \\
\hline
\end{tabular}

— : não monitorado 
TABELA 9: Características físicas e químicas das soluções teste monitoradas durante o teste $\mathrm{n}^{-} 2$ de sensibilidade de Serrapinnus notomelas ao dicromato de potássio.

\begin{tabular}{|c|c|c|c|c|c|c|}
\hline $\mathrm{mgCr} \cdot \mathrm{L}^{-1}$ & horas & $\mathrm{pH}$ & $\begin{array}{c}\text { condutividade } \\
(\mu \mathrm{S} / \mathrm{cm})\end{array}$ & $\begin{array}{c}\mathrm{OD} \\
\left(\mathrm{mg} \mathrm{O}_{2} \cdot \mathrm{L}^{-1}\right)\end{array}$ & $\begin{array}{c}\text { Temperatura } \\
\left({ }^{\circ} \mathrm{C}\right) \\
\end{array}$ & $\begin{array}{c}\text { dureza } \\
\left(\mathrm{mg} \mathrm{CaCO}_{3} \cdot \mathrm{L}^{-1}\right)\end{array}$ \\
\hline \multirow{5}{*}{$\begin{array}{c}0,0 \\
\text { (controle) }\end{array}$} & 0 & 7,12 & 162 & 7,50 & 22,0 & 82,5 \\
\hline & 24 & 6,44 & 150 & 5,23 & 20,5 & 86,6 \\
\hline & 48 & 6,93 & 158 & 5,16 & 23,4 & 86,6 \\
\hline & 72 & 7,20 & 160 & 5,05 & 24,1 & 90,7 \\
\hline & 96 & 7,47 & 155 & 5,17 & 21,7 & 82,5 \\
\hline \multirow{5}{*}{18,0} & 0 & 6,17 & 213 & 6,94 & 22,0 & 82,5 \\
\hline & 24 & 6,30 & 203 & 5,30 & 20,3 & 86,6 \\
\hline & 48 & 6,90 & 208 & 4,84 & 23,7 & 86,6 \\
\hline & 72 & 7,23 & 208 & 4,97 & 24,4 & 78,4 \\
\hline & 96 & 7,41 & 205 & 4,88 & 21,9 & 86,6 \\
\hline \multirow{5}{*}{32,0} & 0 & 5,97 & 244 & 6,75 & 22,0 & 86,6 \\
\hline & 24 & 6,12 & 240 & 5,41 & 20,2 & 78,4 \\
\hline & 48 & 6,77 & 244 & 5,18 & 23,8 & 82,5 \\
\hline & 72 & 7,12 & 244 & 4,61 & 24,5 & 82,5 \\
\hline & 96 & 7,22 & 245 & 4,67 & 22,0 & 82,5 \\
\hline \multirow{5}{*}{56,0} & 0 & 5,81 & 303 & 7,51 & 22,0 & 82,5 \\
\hline & 24 & 5,94 & 308 & 5,71 & 20,1 & 82,5 \\
\hline & 48 & 6,55 & 309 & 4,69 & 23,8 & 82,5 \\
\hline & 72 & 6,95 & 310 & 4,67 & 24,6 & 90,7 \\
\hline & 96 & 7,14 & 316 & 4,90 & 22,0 & 86,6 \\
\hline \multirow{5}{*}{80,0} & 0 & 5,66 & 354 & 7,25 & 22,0 & 86,6 \\
\hline & 24 & 5,76 & 364 & 5,46 & 20,1 & 82,5 \\
\hline & 48 & 6,33 & 363 & 4,80 & 23,8 & 90,7 \\
\hline & 72 & 6,75 & 363 & 4,43 & 24,5 & 86,6 \\
\hline & 96 & 6,80 & 369 & 5,01 & 22,0 & 82,5 \\
\hline \multirow{5}{*}{130,0} & 0 & 5,51 & 467 & 7,56 & 22,0 & 82,5 \\
\hline & 24 & 5,54 & 473 & 5,59 & 20,1 & 82,5 \\
\hline & 48 & 6,03 & 468 & 5,17 & 23,8 & 82,5 \\
\hline & 72 & 6,42 & 459 & 4,67 & 24,5 & 82,5 \\
\hline & 96 & 6,39 & 464 & 4,88 & 22,1 & 86,6 \\
\hline
\end{tabular}


TABELA 10: Características físicas e químicas das soluções-teste monitoradas durante o teste $\mathrm{n}^{0} 3$ de sensibilidade de Serrapinnus notomelas ao dicromato de potássio.

\begin{tabular}{|c|c|c|c|c|c|c|}
\hline $\mathrm{mgCr} \cdot \mathrm{L}^{-1}$ & horas & $\mathrm{pH}$ & $\begin{array}{c}\text { condutividade } \\
(\mu \mathrm{S} / \mathrm{cm})\end{array}$ & $\begin{array}{c}\mathrm{OD} \\
\left(\mathrm{mg} \mathrm{O}_{2} \cdot \mathrm{L}^{-1}\right)\end{array}$ & $\begin{array}{c}\text { Temperatura } \\
\left({ }^{\circ} \mathrm{C}\right)\end{array}$ & $\begin{array}{c}\text { dureza } \\
\left(\mathrm{mg} \mathrm{CaCO}_{3} \cdot \mathrm{L}^{-1}\right)\end{array}$ \\
\hline \multirow{5}{*}{$\begin{array}{c}0,0 \\
\text { (controle) }\end{array}$} & 0 & 7,64 & 179 & 5,74 & 24,0 & 78,4 \\
\hline & 24 & 7,65 & 176 & 4,96 & 23,7 & 82,5 \\
\hline & 48 & 7,28 & 176 & 5,68 & 22,9 & 78,4 \\
\hline & 72 & 7,09 & 170 & 5,23 & 21,7 & 78,4 \\
\hline & 96 & 7,44 & 174 & 5,69 & 23,1 & 78,4 \\
\hline \multirow{5}{*}{20,0} & 0 & 7,00 & 239 & 5,40 & 24,0 & 86,6 \\
\hline & 24 & 7,40 & 233 & 5,03 & 23,7 & 82,5 \\
\hline & 48 & 7,12 & 234 & 5,64 & 23,2 & 78,4 \\
\hline & 72 & 7,31 & 232 & 4,86 & 21,8 & 82,5 \\
\hline & 96 & 7,45 & 233 & 5,08 & 23,5 & 82,5 \\
\hline \multirow{5}{*}{35,0} & 0 & 6,76 & 282 & 5,04 & 24,0 & 82,5 \\
\hline & 24 & 7,17 & 283 & 5,01 & 23,7 & 82,5 \\
\hline & 48 & 6,99 & 285 & 5,25 & 23,3 & 82,5 \\
\hline & 72 & 7,15 & 278 & 4,74 & 21,9 & 78,4 \\
\hline & 96 & 7,36 & 281 & 5,37 & 23,5 & 82,5 \\
\hline \multirow{5}{*}{50,0} & 0 & 6,61 & 323 & 5,39 & 24,0 & 82,5 \\
\hline & 24 & 6,91 & 323 & 4,82 & 23,7 & 82,5 \\
\hline & 48 & 6,70 & 328 & 5,40 & 23,4 & 82,5 \\
\hline & 72 & 6,92 & 318 & 4,87 & 21,9 & 78,4 \\
\hline & 96 & 7,25 & 322 & 5,18 & 23,4 & 82,5 \\
\hline \multirow{5}{*}{80,0} & 0 & 6,37 & 396 & 4,80 & 24 & 86,6 \\
\hline & 24 & 6,65 & 398 & 4,89 & 23,7 & 82,5 \\
\hline & 48 & 6,42 & 400 & 5,20 & 23,4 & 82,5 \\
\hline & 72 & 6,61 & 391 & 5,16 & 21,9 & 78,4 \\
\hline & 96 & 6,91 & 394 & 5,29 & 23,4 & 78,4 \\
\hline \multirow{5}{*}{120,0} & 0 & 6,18 & 497 & 5,48 & 24 & 82,5 \\
\hline & 24 & 6,39 & 498 & 5,40 & 23,7 & 78,4 \\
\hline & 48 & 6,11 & 498 & 5,60 & 23,4 & 82,5 \\
\hline & 72 & 6,21 & 471 & 5,63 & 21,9 & 78,4 \\
\hline & 96 & 6,44 & 481 & 5,59 & 23,4 & 78,4 \\
\hline
\end{tabular}


TABELA 11: Características físicas e químicas das soluções-teste monitoradas durante o teste $\mathrm{n}^{-} 4$ de sensibilidade de Serrapinnus notomelas ao dicromato de potássio.

\begin{tabular}{|c|c|c|c|c|c|c|}
\hline $\mathrm{mgCr} \cdot \mathrm{L}^{-1}$ & horas & $\mathrm{pH}$ & $\begin{array}{c}\text { condutividade } \\
(\mu \mathrm{S} / \mathrm{cm})\end{array}$ & $\begin{array}{c}\mathrm{OD} \\
\left(\mathrm{mg} \mathrm{O}_{2} \cdot \mathrm{L}^{-1}\right)\end{array}$ & $\begin{array}{c}\text { Temperatura } \\
\left({ }^{\circ} \mathrm{C}\right)\end{array}$ & $\begin{array}{c}\text { dureza } \\
\left(\mathrm{mg} \mathrm{CaCO}_{3} \cdot \mathrm{L}^{-1}\right)\end{array}$ \\
\hline \multirow{5}{*}{$\begin{array}{c}0,0 \\
\text { (controle) }\end{array}$} & 0 & 7,55 & 148 & 7,32 & 22,6 & 45,6 \\
\hline & 24 & 7,33 & 151 & 5,09 & 23,0 & - \\
\hline & 48 & 7,31 & 156 & 4,29 & 23,0 & - \\
\hline & 72 & 7,32 & 158 & 5,03 & 22,3 & - \\
\hline & 96 & 7,33 & 158 & 5,26 & 21,4 & 38,6 \\
\hline \multirow{5}{*}{20,0} & 0 & 6,96 & 155 & 7,35 & 22,5 & 54,4 \\
\hline & 24 & 7,21 & 208 & 5,17 & 23,0 & - \\
\hline & 48 & 7,37 & 211 & 5,16 & 22,7 & - \\
\hline & 72 & 7,40 & 219 & 5,14 & 22,1 & - \\
\hline & 96 & 7,38 & 221 & 5,23 & 21,4 & 40,3 \\
\hline \multirow{5}{*}{40,0} & 0 & 6,72 & 183 & 7,18 & 22,3 & 56,1 \\
\hline & 24 & 7,08 & 256 & 5,25 & 23,0 & - \\
\hline & 48 & 7,29 & 266 & 5,40 & 22,7 & - \\
\hline & 72 & 7,36 & 273 & 5,93 & 21,9 & - \\
\hline & 96 & 7,05 & 274 & 6,48 & 21,3 & 42,1 \\
\hline \multirow{5}{*}{60,0} & 0 & 6,54 & 208 & 7,23 & 22,4 & 56,1 \\
\hline & 24 & 6,80 & 293 & 5,41 & 23,0 & - \\
\hline & 48 & 7,08 & 315 & 6,25 & 22,6 & - \\
\hline & 72 & 7,05 & 321 & 6,05 & 21,9 & - \\
\hline & 96 & 7,10 & 323 & 6,25 & 21,3 & 42,1 \\
\hline \multirow{5}{*}{80,0} & 0 & 6,41 & 229 & 7,31 & 22,4 & 54,4 \\
\hline & 24 & 6,68 & 345 & 5,63 & 23,0 & - \\
\hline & 48 & 6,87 & 363 & 6,80 & 22,7 & - \\
\hline & 72 & 6,94 & 365 & 5,56 & 21,9 & 42,1 \\
\hline & 96 & - & - & - & - & - \\
\hline \multirow{5}{*}{100,0} & 0 & 6,31 & 252 & 7,03 & 22,4 & 54,4 \\
\hline & 24 & 6,52 & 384 & 6,02 & 23,0 & - \\
\hline & 48 & 6,70 & 396 & 7,24 & 22,7 & 42,1 \\
\hline & 72 & - & - & - & - & - \\
\hline & 96 & - & - & - & - & - \\
\hline \multirow{5}{*}{120,0} & 0 & 6,24 & 269 & 7,30 & 22,4 & 52,6 \\
\hline & 24 & 6,43 & 425 & 6,28 & 23,1 & - \\
\hline & 48 & 6,55 & 426 & 7,32 & 22,7 & 42,1 \\
\hline & 72 & - & - & - & - & - \\
\hline & 96 & - & - & - & - & - \\
\hline \multirow{5}{*}{140,0} & 0 & 6,20 & 290 & 7,17 & 22,5 & 52,6 \\
\hline & 24 & 6,36 & 462 & 6,27 & 23,1 & - \\
\hline & 48 & 6,46 & 466 & 7,43 & 22,7 & 42,1 \\
\hline & 72 & - & - & - & - & - \\
\hline & 96 & - & - & - & - & - \\
\hline
\end{tabular}

— : não medido (todos os peixes da concentração mortos) 
TABELA 12: Características físicas e químicas das soluções-teste monitoradas durante o teste $\mathrm{n}-1$ de sensibilidade de Danio rerio ao dicromato de potássio.

\begin{tabular}{|c|c|c|c|c|c|c|}
\hline $\mathrm{mgCr} \cdot \mathrm{L}^{-1}$ & horas & $\mathrm{pH}$ & $\begin{array}{c}\text { condutividade } \\
(\mu \mathrm{S} / \mathrm{cm})\end{array}$ & $\begin{array}{c}\mathrm{OD} \\
\left(\mathrm{mg} \mathrm{O}_{2} \cdot \mathrm{L}^{-1}\right)\end{array}$ & $\begin{array}{c}\text { Temperatura } \\
\left({ }^{\circ} \mathrm{C}\right)\end{array}$ & $\begin{array}{c}\text { dureza } \\
\left(\mathrm{mg} \mathrm{CaCO}_{3} \cdot \mathrm{L}^{-1}\right)\end{array}$ \\
\hline \multirow{5}{*}{$\begin{array}{c}0,0 \\
\text { (controle) }\end{array}$} & 0 & 7,56 & 152 & 7,25 & 22,4 & 45,6 \\
\hline & 24 & 7,37 & 156 & 5,18 & 23,0 & - \\
\hline & 48 & 7,34 & 154 & 4,91 & 22,8 & - \\
\hline & 72 & 7,35 & 155 & 5,24 & 22,3 & - \\
\hline & 96 & 7,38 & 156 & 5,59 & 21,4 & 38,6 \\
\hline \multirow{5}{*}{20,0} & 0 & 6,89 & 158 & 7,22 & 22,4 & 54,4 \\
\hline & 24 & 7,31 & 210 & 5,76 & 23,0 & - \\
\hline & 48 & 7,42 & 211 & 5,67 & 22,7 & - \\
\hline & 72 & 7,42 & 212 & 5,67 & 22,0 & - \\
\hline & 96 & 7,44 & 213 & 6,05 & 21,2 & 40,3 \\
\hline \multirow{5}{*}{40,0} & 0 & 6,73 & 182 & 7,27 & 22,3 & 56,1 \\
\hline & 24 & 7,09 & 256 & 5,87 & 23,0 & - \\
\hline & 48 & 7,28 & 256 & 5,50 & 22,7 & - \\
\hline & 72 & 7,27 & 262 & 5,35 & 21,9 & - \\
\hline & 96 & 7,35 & 263 & 6,60 & 21,2 & 42,1 \\
\hline \multirow{5}{*}{60,0} & 0 & 6,54 & 207 & 7,13 & 22,3 & 56,1 \\
\hline & 24 & 6,94 & 308 & 5,76 & 23,0 & - \\
\hline & 48 & 7,09 & 313 & 6,16 & 22,6 & - \\
\hline & 72 & 7,13 & 315 & 6,33 & 21,9 & - \\
\hline & 96 & 7,17 & 314 & 6,40 & 21,3 & 42,1 \\
\hline \multirow{5}{*}{80,0} & 0 & 6,42 & 232 & 7,10 & 22,4 & 54,4 \\
\hline & 24 & 6,73 & 350 & 6,44 & 23,0 & - \\
\hline & 48 & 6,91 & 354 & 7,40 & 22,6 & - \\
\hline & 72 & 6,93 & 355 & 6,50 & 21,9 & 42,1 \\
\hline & 96 & - & - & - & - & - \\
\hline \multirow{5}{*}{100,0} & 0 & 6,32 & 251 & 6,95 & 22,4 & 54,4 \\
\hline & 24 & 6,62 & 388 & 6,14 & 23,0 & - \\
\hline & 48 & 6,73 & 393 & 6,89 & 22,6 & 42,1 \\
\hline & 72 & - & - & - & - & - \\
\hline & 96 & - & - & - & - & - \\
\hline \multirow{5}{*}{120,0} & 0 & 6,25 & 274 & 7,17 & 22,4 & 52,6 \\
\hline & 24 & 6,48 & 428 & 6,38 & 23,1 & - \\
\hline & 48 & 6,58 & 439 & 7,23 & 22,6 & 42,1 \\
\hline & 72 & - & - & - & - & - \\
\hline & 96 & - & - & - & - & - \\
\hline \multirow{5}{*}{140,0} & 0 & 6,18 & 284 & 7,02 & 22,5 & 52,6 \\
\hline & 24 & 6,40 & 466 & 6,67 & 23,1 & - \\
\hline & 48 & 6,49 & 469 & 7,31 & 22,7 & 42,1 \\
\hline & 72 & - & - & - & - & - \\
\hline & 96 & - & - & - & - & - \\
\hline
\end{tabular}

— : não medido

\subsection{Relação peso-comprimento para Serrapinnus notomelas e Danio rerio}

A homogeneidade das populações de $S$. notomelas e de $D$. rerio utilizadas nos diferentes testes de toxicidade pode ser constatada pelas relações peso-comprimento (total e padrão) representadas na figura16. 

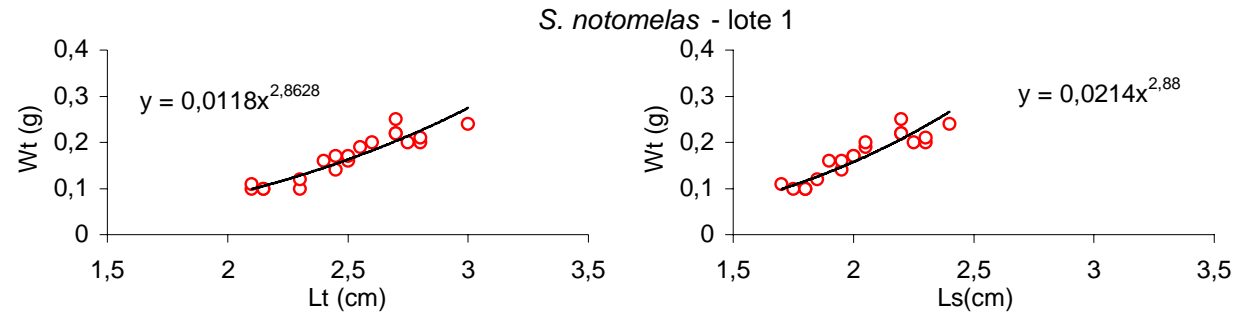

S. notomelas - lote 2
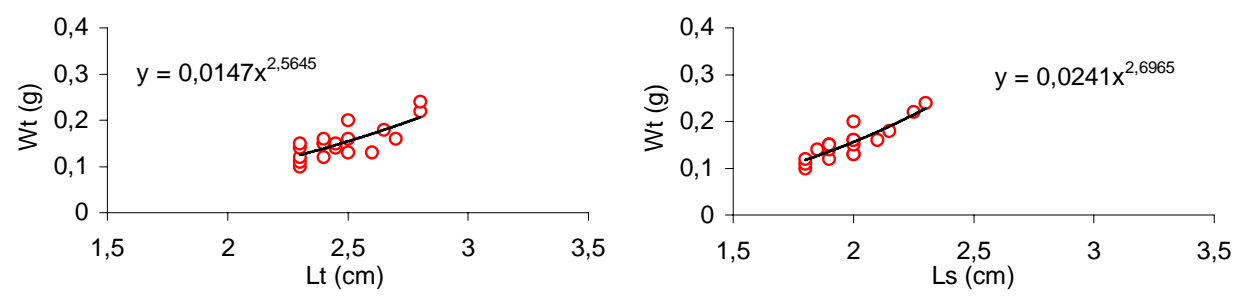

S. notomelas - lote 3
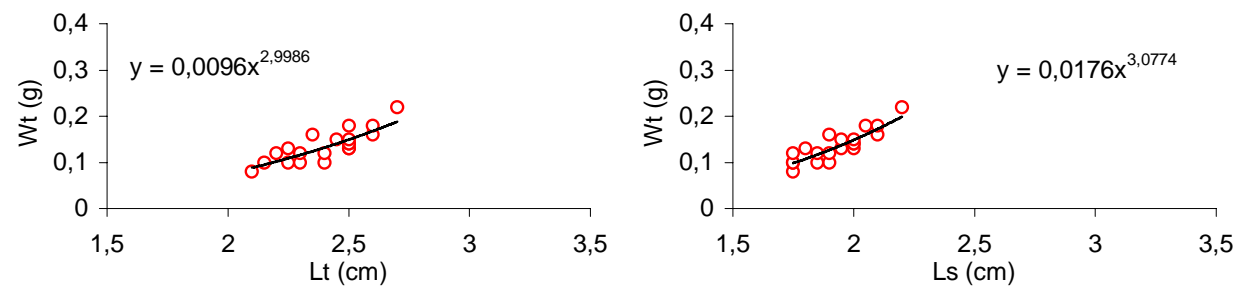

S. notomelas - lote 4
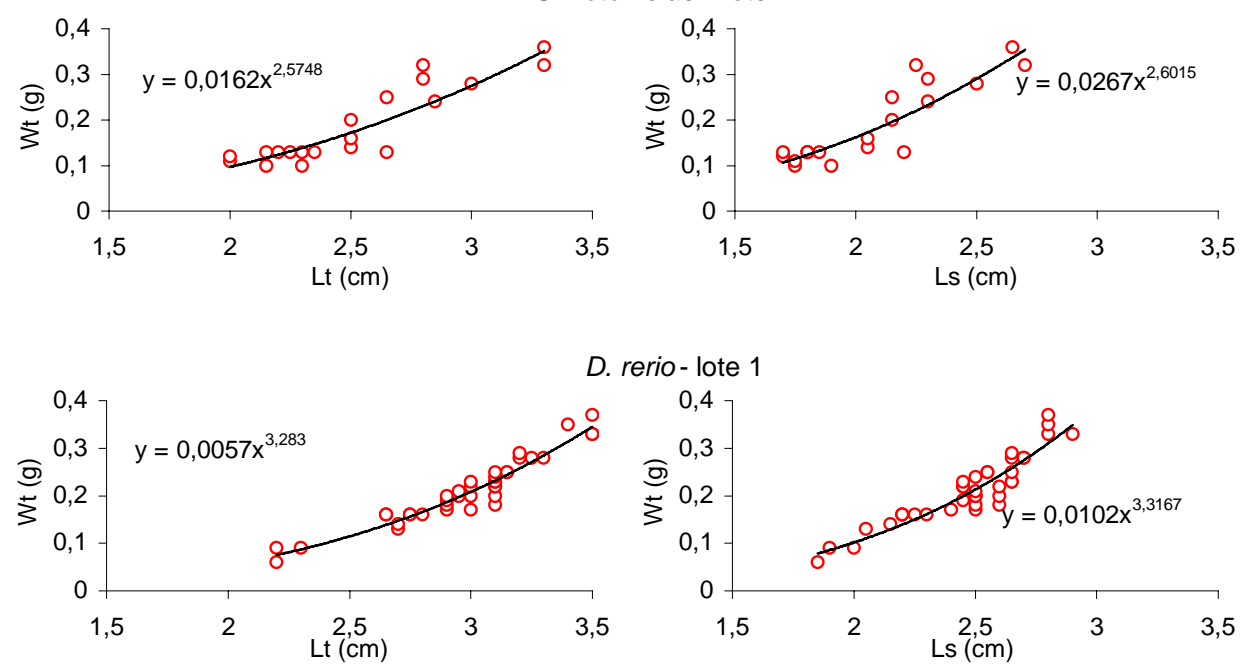

D. rerio - lote 1

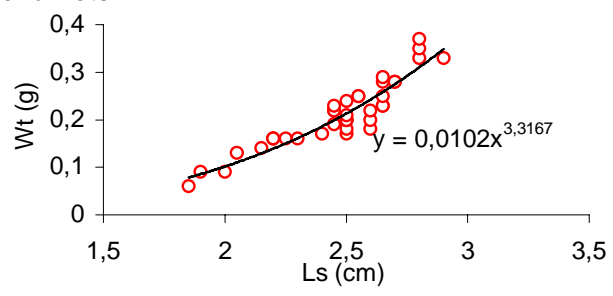

D. rerio - lote 2
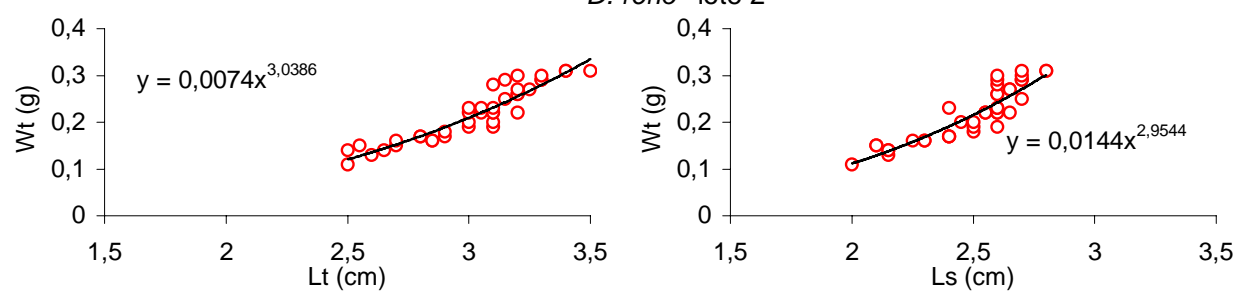

FIGURA 16: Relações peso-comprimento para Serrapinnus notomelas e Danio rerio. Os gráficos da direita contêm as relações peso-comprimento total; os da esquerda, pesocomprimento padrão. 
4.3. Descrição da morfologia interna normal de Serrapinnus notomelas e de Danio rerio.

As figuras 17 a e $17 \mathrm{c}$ mostram cortes longitudinais de Serrapinnus notomelas e Danio rerio, respectivamente, nos quais é possível visualizar a maioria dos órgãos internos do peixe. O grande vazio existente na porção mediana dos peixes corresponde ao espaço ocupado pela bexiga natatória, a qual foi retirada para facilitar a impregnação da parafina e para evitar a formação de bolhas e a conseqüente fragmentação do corte. Para uma melhor visualização das partes, foram feitos esquemas a partir destes cortes, que podem ser observados nas figuras $17 \mathrm{~b}$ e $17 \mathrm{~d}$. No esquema correspondente a $S$. notomelas, a musculatura foi desenhada a partir de outro corte, já que neste esta estrutura aparece fragmentada. A figura 18 mostra cortes transversais seriados de $S$. notomelas desde o epitélio olfatório até o reto. Estes cortes permitiram localizar com maior precisão os órgãos internos, o que auxiliou no processo de microtomia dos cortes longitudinais. Os órgãos-alvo considerados no presente trabalho - brânquias, rim e fígado - são mostrados nas figuras 19 a 27, e fotografias de outros órgãos como o encéfalo, olho, pseudobrânquia e outros encontram-se nos anexos. 
a

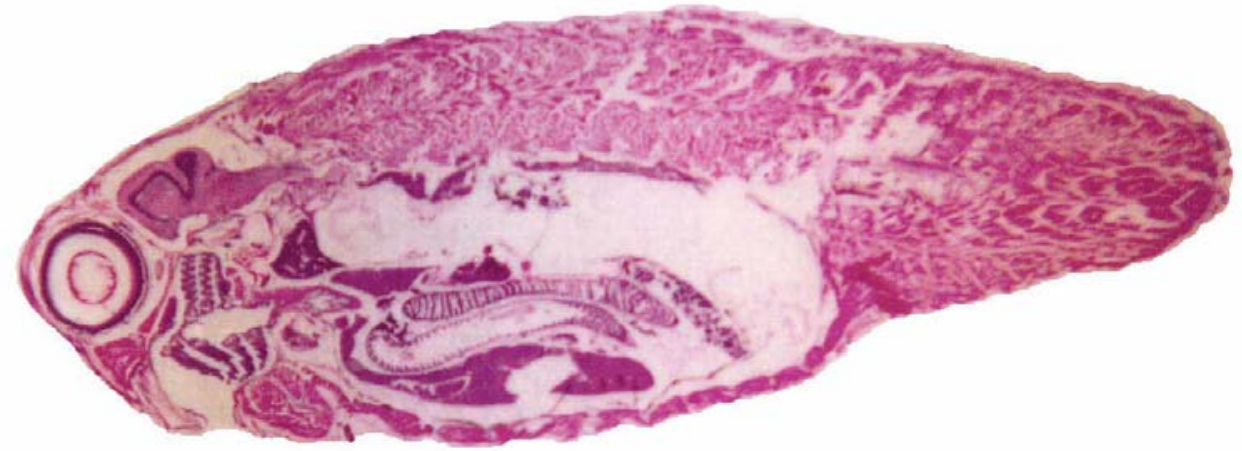

b
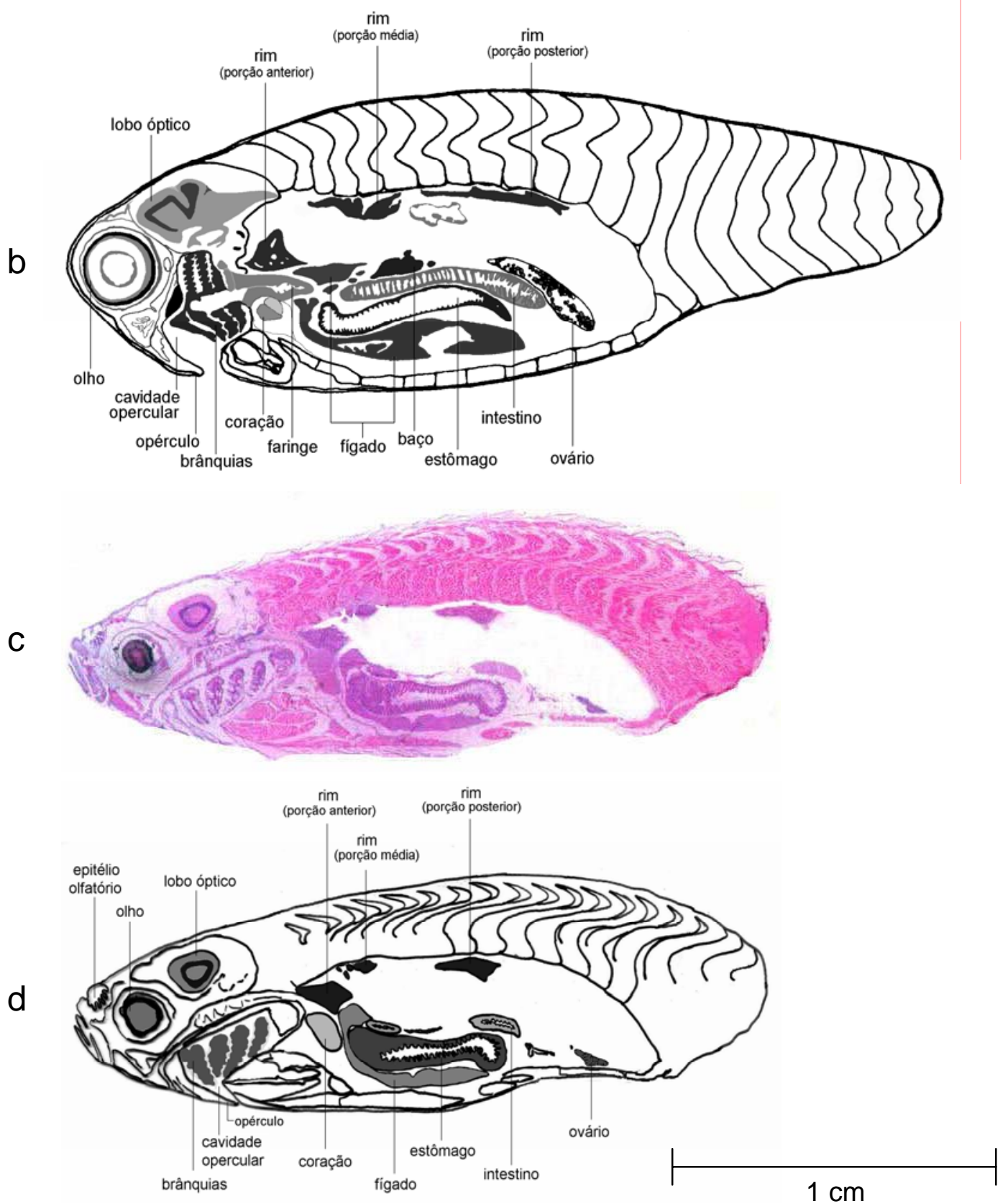

FIGURA 17: Morfologia interna de Serrapinnus notomelas e Danio rerio. a) corte longitudinal de S. notomelas; b) desenho esquemático de "a", com indicações dos principais órgãos; c) corte longitudinal de $D$. rerio; d) desenho esquemático de "c", com indicações dos principais órgãos. (Bouin, HE, $8 \mu \mathrm{m}(\mathrm{a}), 5 \mu \mathrm{m}(\mathrm{c}), \mathrm{X} 4,6$ ) 


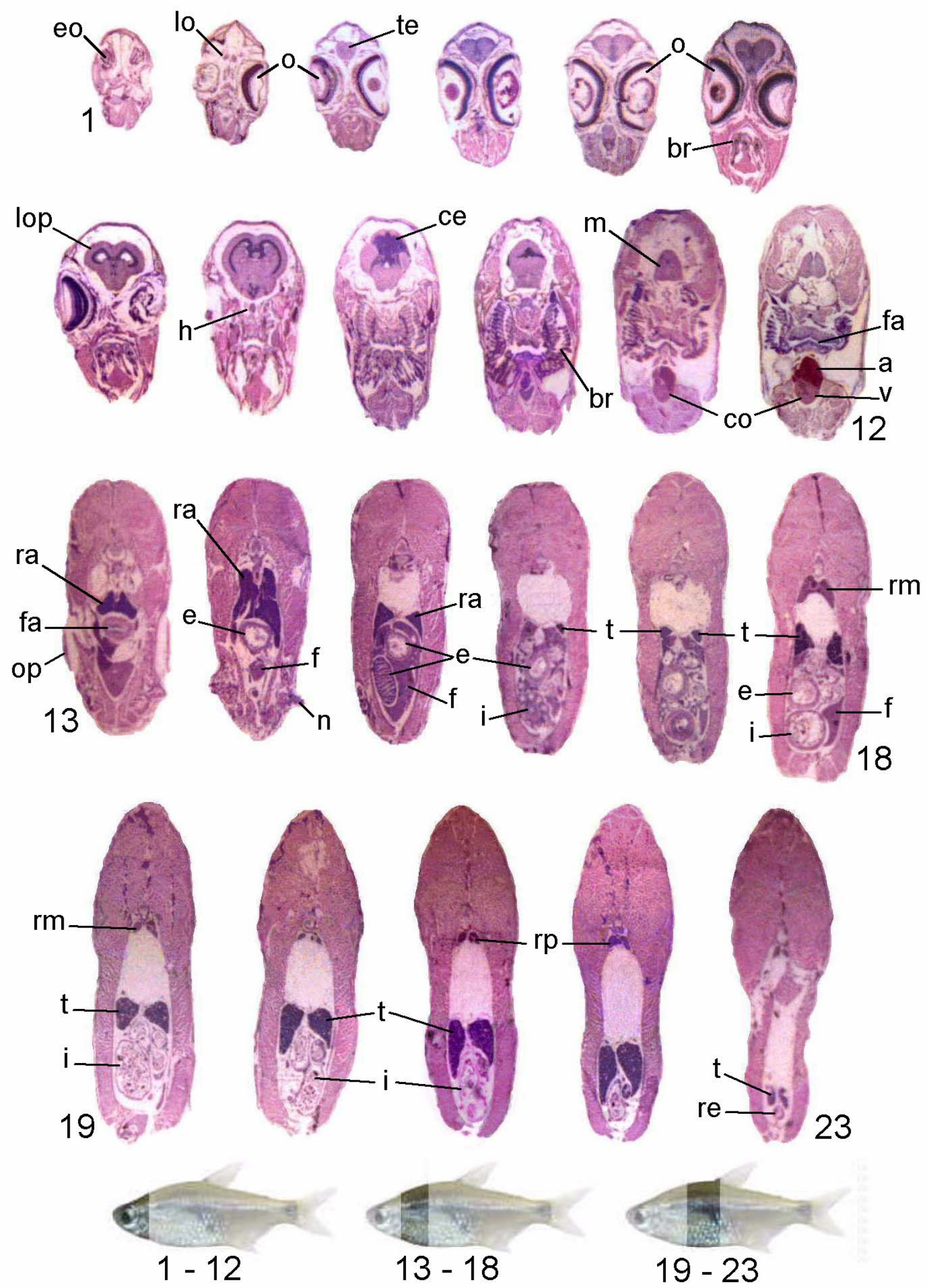

FIGURA 18: Cortes transversais de Serrapinnus notomelas. a - átrio; br - brânquias; ce - cerebelo; co - coração; e - estômago; eo - epitélio olfatório; f - fígado; fa - faringe; h - hipófise; i - intestino; lo - lobo olfatório; lop - lobo óptico; $\mathrm{m}$ - medula; $\mathrm{n}$ - base da nadadeira peitoral; o - olho; op - opérculo; ra - rim anterior; re - reto; rm - rim médio; rp - rim posterior; $\mathrm{t}$ - testículos; te - telencéfalo; $v$ - ventrículo. (Bouin, HE, $6 \mu \mathrm{m}, \mathrm{x} 5,5$ ) 
Serrapinnus notomelas e Danio rerio possuem, em cada lado da faringe, conforme já descrito para a maioria dos teleósteos, 4 arcos branquiais, cada um com duas fileiras de filamentos, os quais contêm, de ambos os lados, as lamelas secundárias. As figuras 19 e 20 mostram, respectivamente, trechos de filamentos branquiais de $S$. notomelas e de $D$. rerio.

Foi possível observar, apenas em Danio rerio, a presença de pseudobrânquia (figura 72 - anexos). Tal estrutura, assim como na carpa, na truta (TAKASHIMA \& HIBIYA, 1995), no guarú, Poecilia reticulata e em outras espécies (LEAKE, 1975), é um órgão bilateral, situado fora da cavidade opercular e apresenta uma aparência glandular pelo fato dos filamentos branquiais estarem completamente "aglutinados" por um tecido glandular.

Os rins das espécies utilizadas neste trabalho foram facilmente identificados e presentes na grande maioria dos cortes realizados para análise histológica. 0 corpúsculo renal, o túbulo contorcido proximal e o túbulo contorcido distal possuem o aspecto característico descrito por TAKASHIMA \& HIBIYA (1995) para a maioria dos teleósteos de água doce. O rim de $S$. notomelas possui as duas porções bem definidas, sendo a anterior (figura 21) constituída, de fato, quase totalmente por tecido linfóide (em alguns poucos cortes foi possível identificar alguns néfrons) e a posterior (figura 24) constituída por muitos néfrons e menor quantidade de tecido linfóide intersticial. A porção anterior encontra-se localizada bilateralmente e logo acima da faringe. Comunicando os "dois" rins anteriores à porção posterior, há dois estreitos prolongamentos que se unem; nesse ponto, o órgão é mais volumoso, de corpo único e ao invés de rim posterior, poderia ser chamado de rim médio, já que se ramifica novamente em duas porções caudais mais estreitas que seguem até quase o extremo posterior da cavidade celomática. O rim de Danio rerio possui anatomia semelhante, com exceção de que a porção posterior é menos extensa. No entanto, não há muita diferença na constituição entre as porções anterior e posterior do rim nessa espécie, sendo que as duas contêm muitos néfrons e tecido linfóide intersticial. A porção anterior (figura 22), inclusive, foi a que proporcionou a melhor observação do tecido renal, devido ao seu maior tamanho e grande quantidade de néfrons. A porção posterior (figura 23) do rim de $D$. rerio, comparada à mesma porção do rim de $S$. notomelas, apresenta maior quantidade de tecido linfóide intersticial, talvez como uma "compensação" da ausência de um rim anterior predominantemente linfóide.

O fígado de $S$. notomelas e de $D$. rerio possui hepatócitos com o aspecto típico descrito para a maioria dos vertebrados. Foi possível, também, observar o arranjo dos cordões hepáticos (figuras 25 a 27), mas nem sempre com uma disposição lobular evidente. 


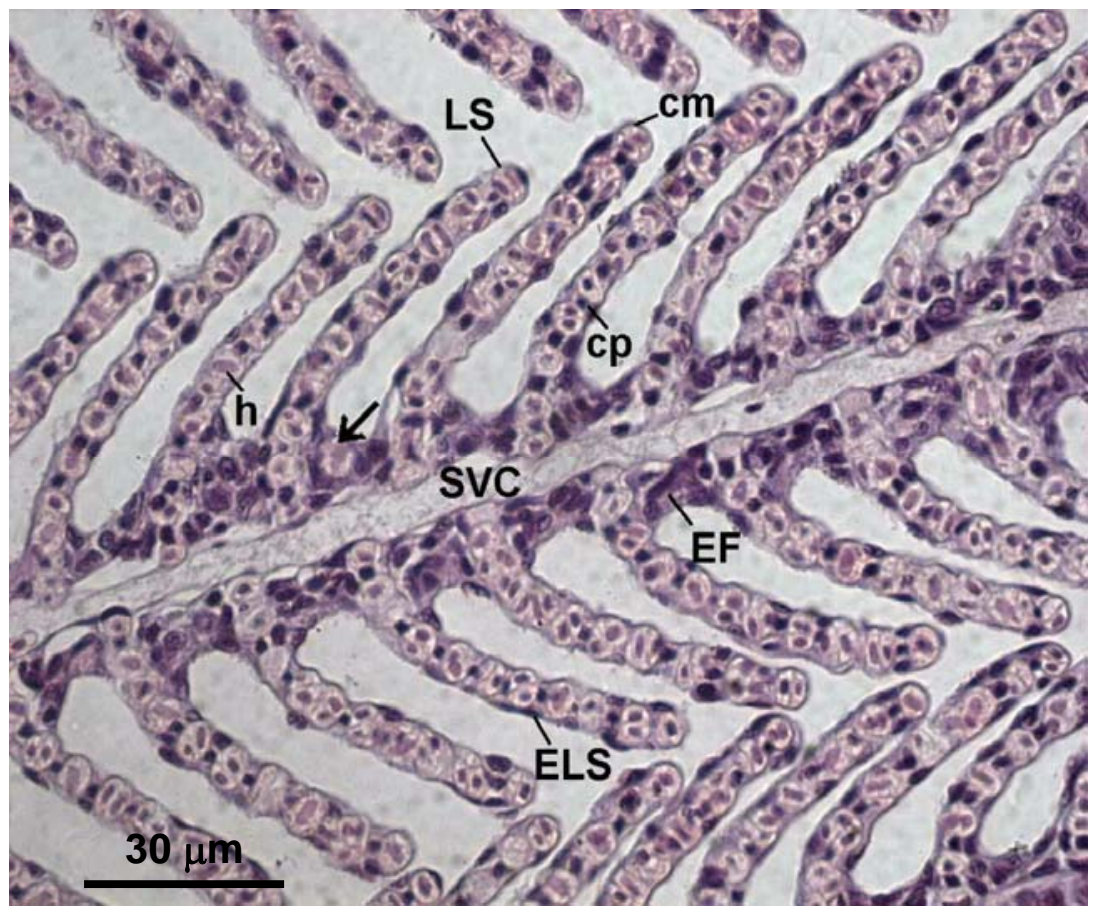

FIGURA 19: Filamento branquial de S. notomelas em corte longitudinal - controle (Ribeirão do Pinhal). cm-canal marginal; cp-célula pilar; EF-epitélio estratificado do filamento; ELS-epitélio pavimentoso das lamelas secundárias; LS - lamela secundária; h-hemácia no lúmen de um capilar lamelar; SVC-seio venoso central. A seta indica uma célula mucosa. Notar os capilares lamelares separados pelas células pilares.

$(\mathrm{HE}, 5 \mu \mathrm{m})$

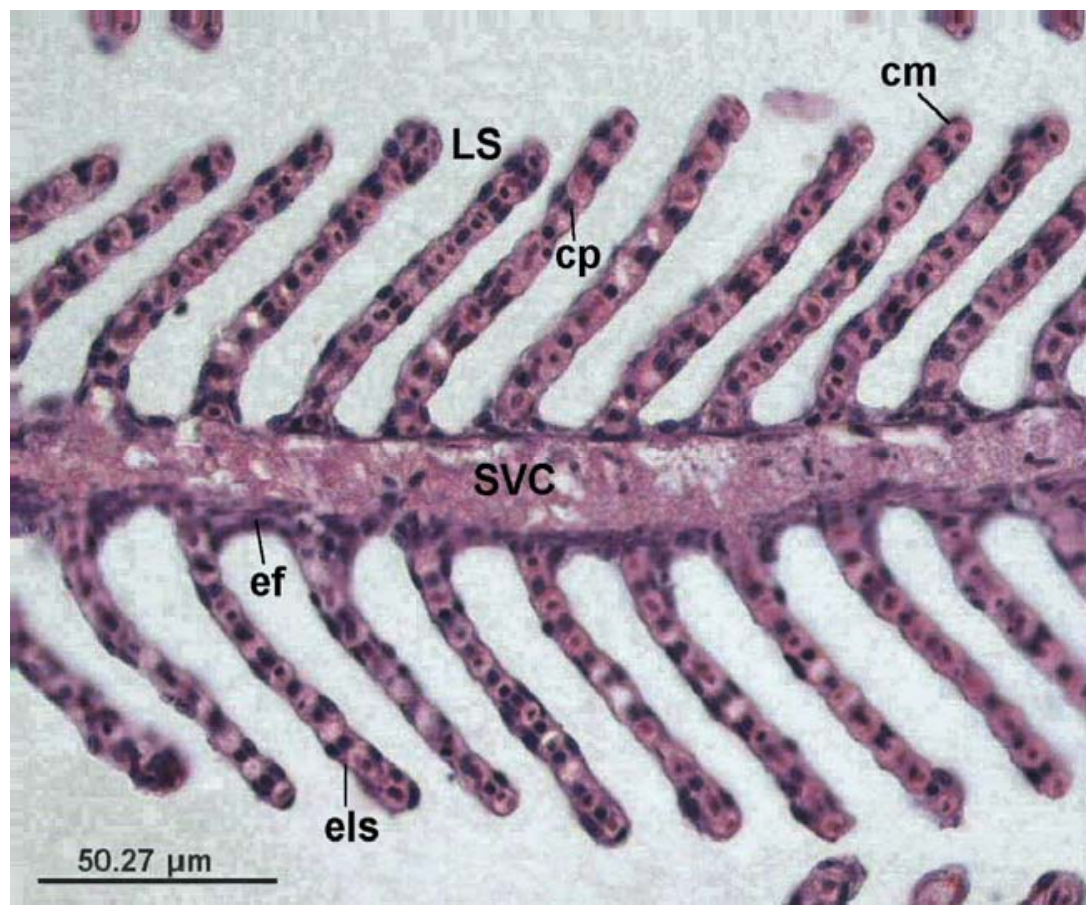

FIGURA 20: Filamento branquial de D. rerio em corte longitudinal - controle (Ribeirão do Pinhal). cm-canal marginal; cp-célula pilar; ef-epitélio estratificado do filamento; elsepitélio pavimentoso das lamelas secundárias; LS - lamela secundária, SVC-seio venoso central. (HE, $7 \mu \mathrm{m})$ 


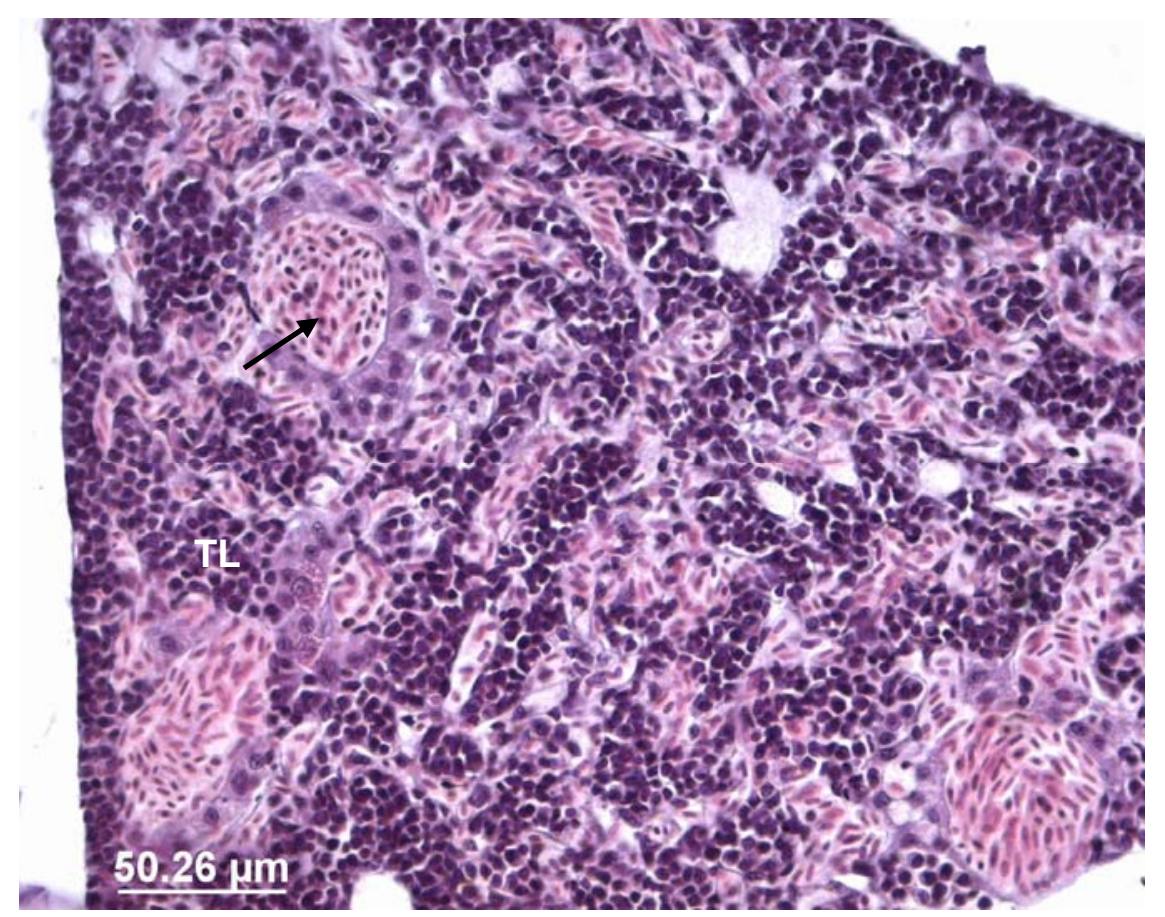

FIGURA 21: Rim anterior de S. notomelas - controle (Ribeirão do Pinhal). Notar a predominância de tecido linfóide (TL) e a intensa rede de vasos sangüíneos. A seta o lúmen de um grande vaso, o qual é rodeado por células interrenais. (HE, $5 \mu \mathrm{m}$ )

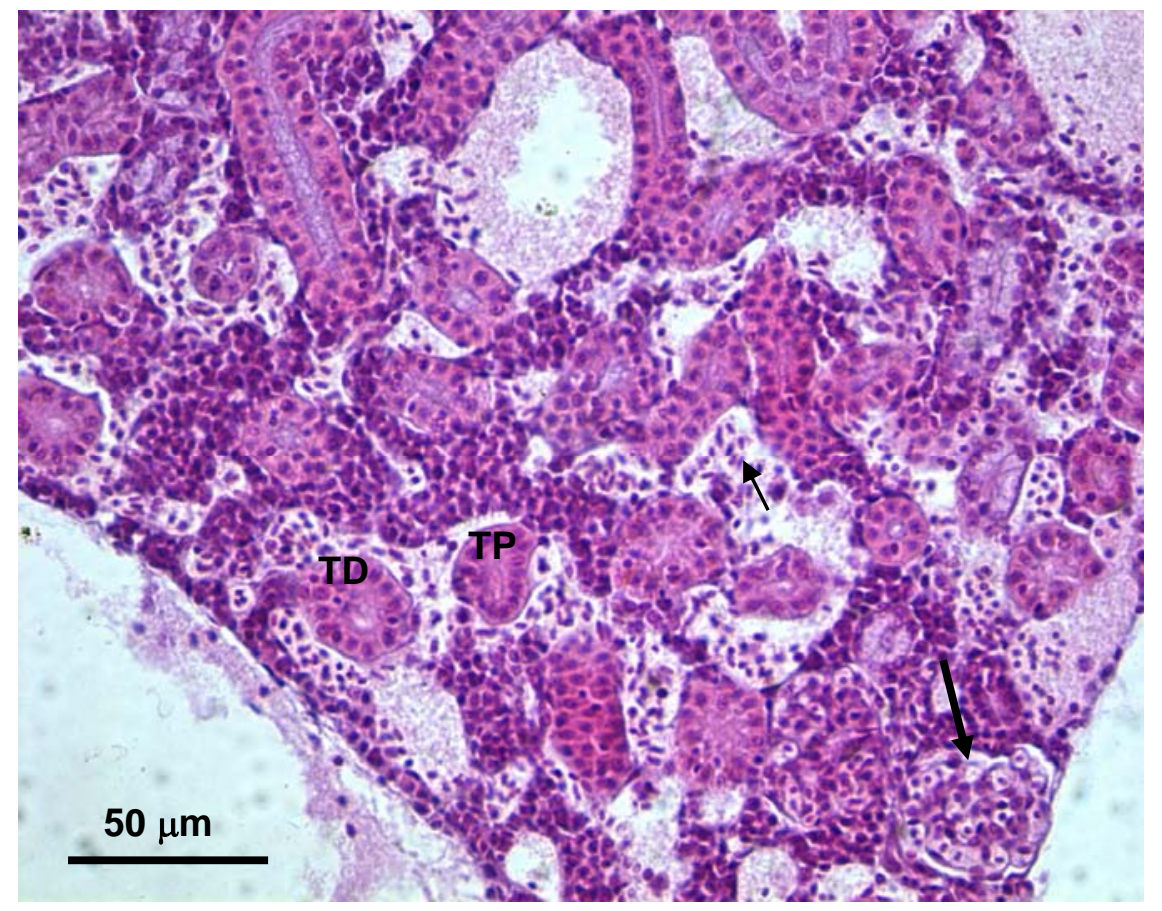

FIGURA 22: Rim anterior de D. rerio - controle (Ribeirão do Pinhal). Notar a presença, além do tecido linfóide (TL), de túbulos e glomérulo (seta). TP-túbulo contorcido proximal (notar lúmen mais opaco, devido à borda em escova do epitélio); TD-túbulo contorcido distal (notar lúmen mais claro). A seta menor aponta hemácias em um vaso. $(\mathrm{HE}, 5 \mu \mathrm{m})$ 


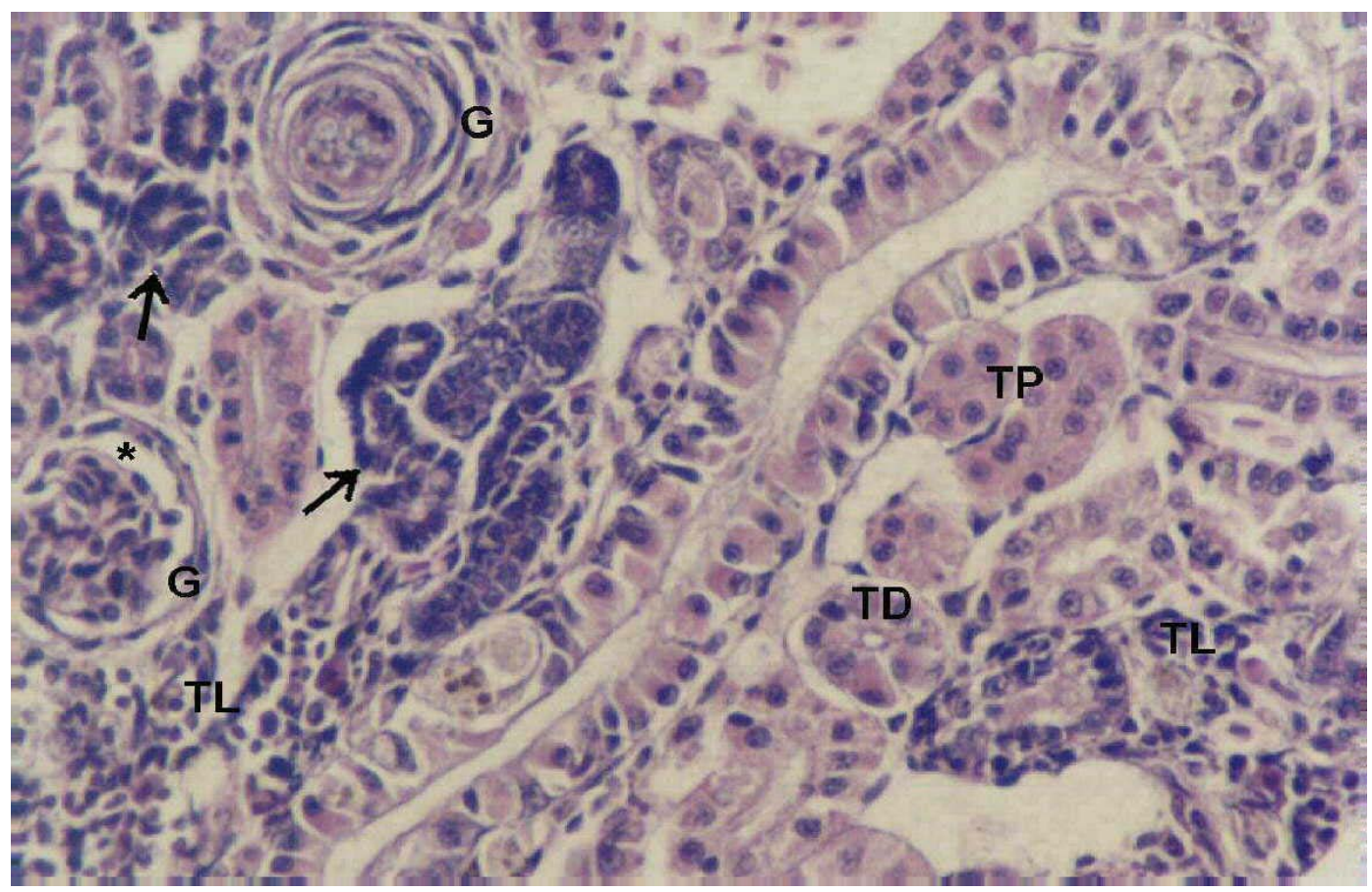

FIGURA 23: Rim médio de $D$. rerio - controle (água de manutenção). Notar a presença de dois glomérulos $(G)$. O asterisco em um deles mostra o espaço intercapsular. No outro, o corte atingiu uma porção mais superficial, o que evidenciou a camada fibrosa externa. Observar o tecido linfóide (TL), o túbulo contorcido distal (TD), o túbulo

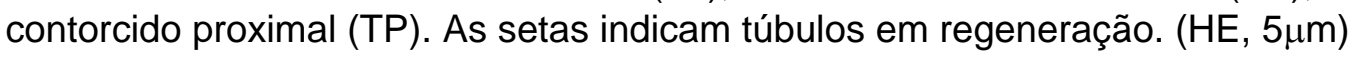

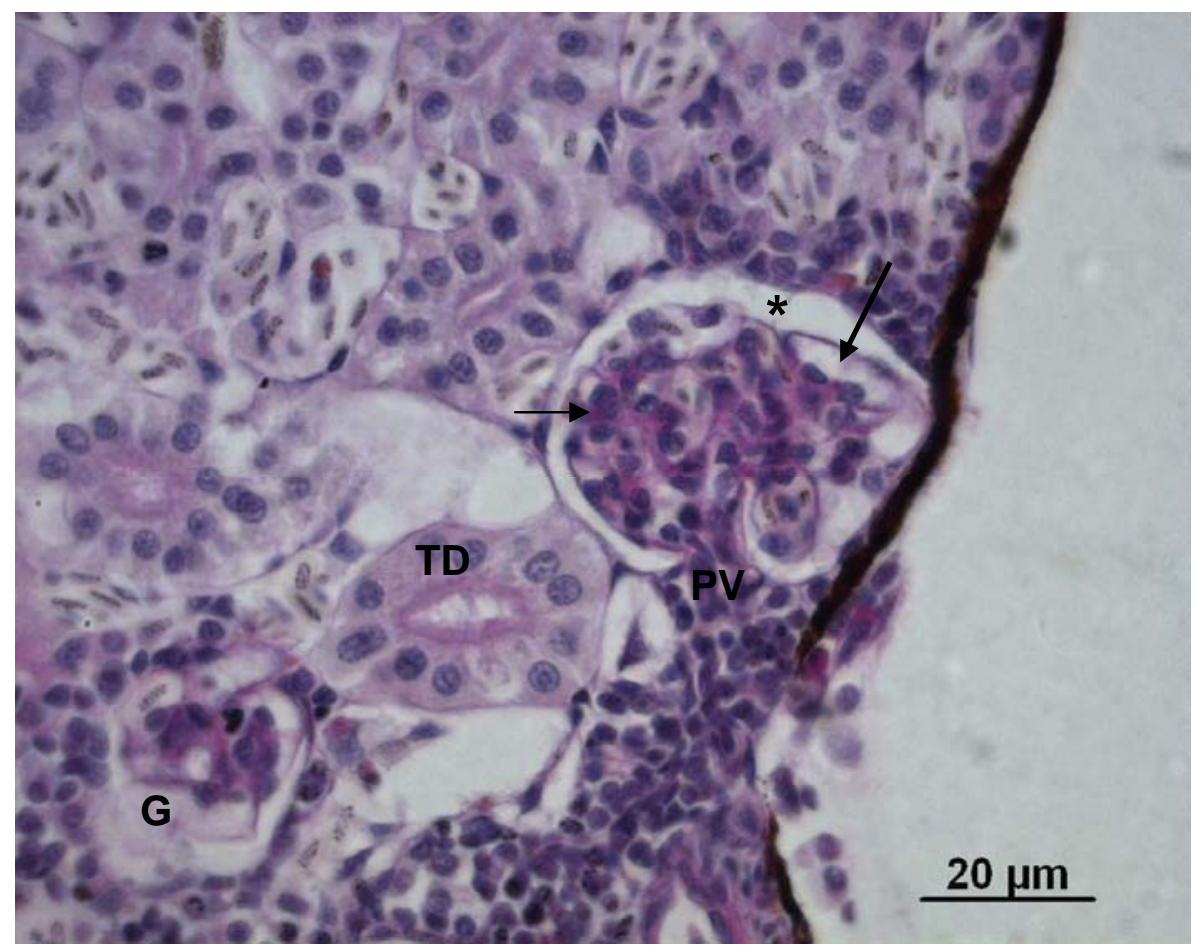

FIGURA 24: Rim médio de S. notomelas - controle (Ribeirão do Pinhal). Notar no glomérulo o espaço intercapsular (asterisco). os capilares glomerulares (seta maior), as células mesangiais (seta menor) e o pólo vascular (PV). O pólo urinário situa-se do lado oposto. Notar um outro glomérulo, menor (G). (PAS-hematoxilina, $5 \mu \mathrm{m}$ ) 


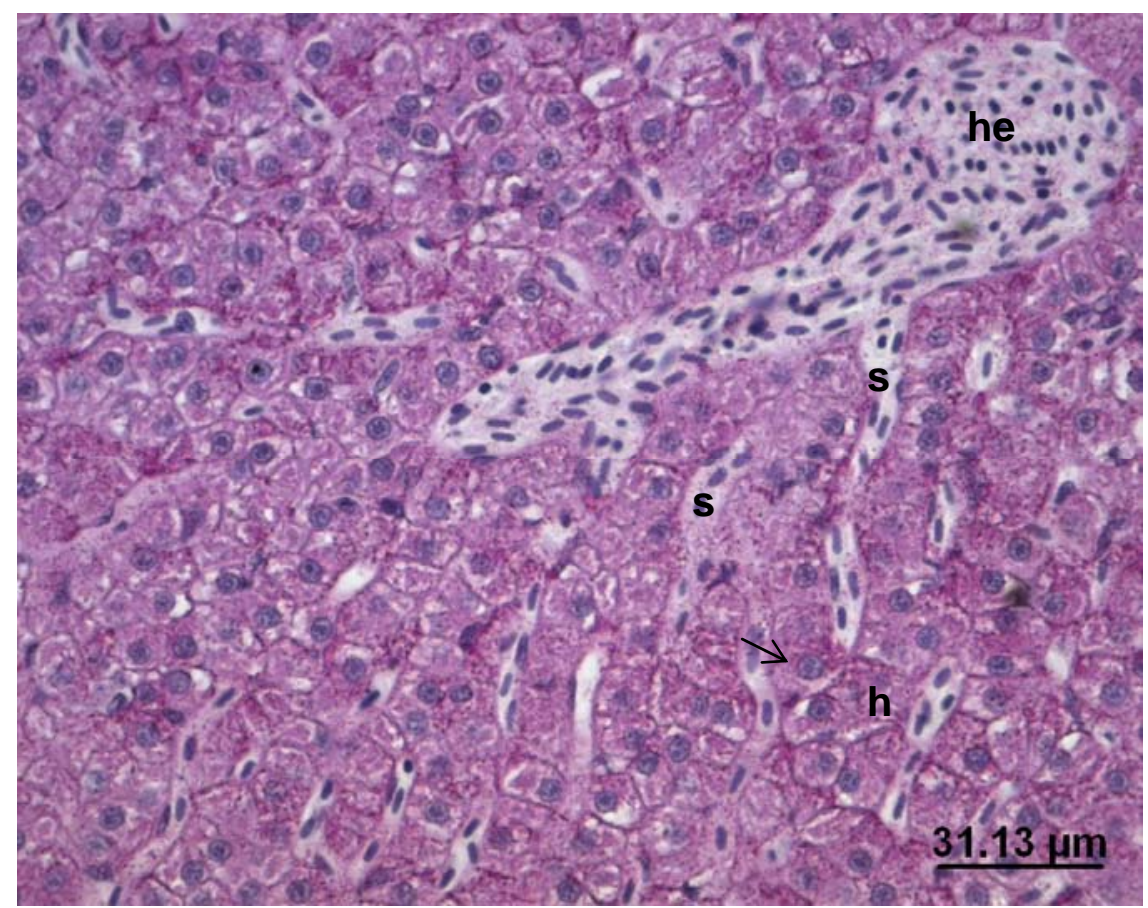

FIGURA 25: Fígado de S. notomelas (controle - Rib. do Pinhal). Observar o arranjo dos cordões hepáticos, delimitados pelos sinusóides (s) que confluem em direção a um vaso de maior calibre. Notar as hemácias (he) no vaso e nos sinusóides. Notar o formato poliédrico dos hepatócitos (h) e os seus núcleos grandes e arredondados (seta). (PAS-hematoxilina, $5 \mu \mathrm{m}$ ).

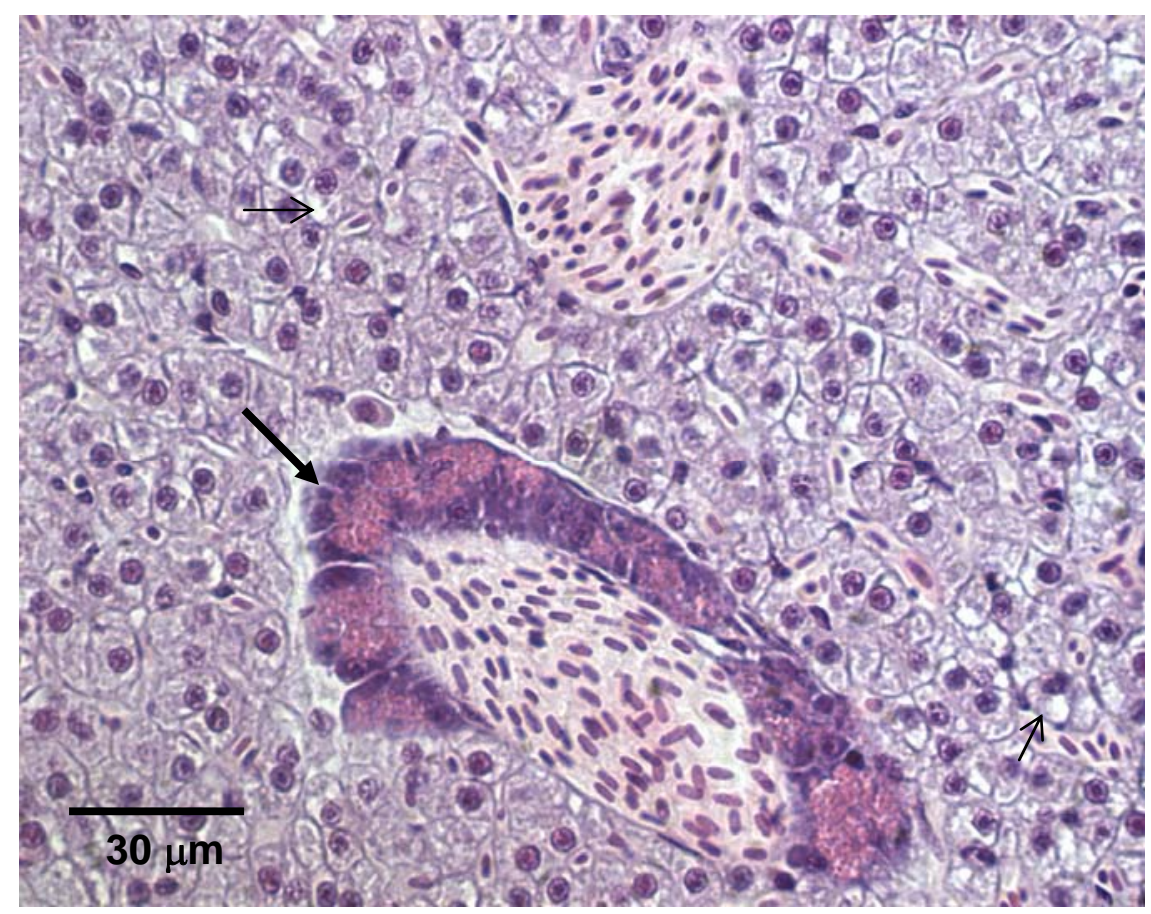

Figura 26: Fígado de S. notomelas (controle- Rib. do Pinhal). Neste corte o formato típico dos hepatócitos está mais evidenciado. Observar a presença de vacúolos (setas menores) no citoplasma dos hepatócitos. Notar a presença de hepatopâncreas (seta maior). (HE, $5 \mu \mathrm{m})$ 


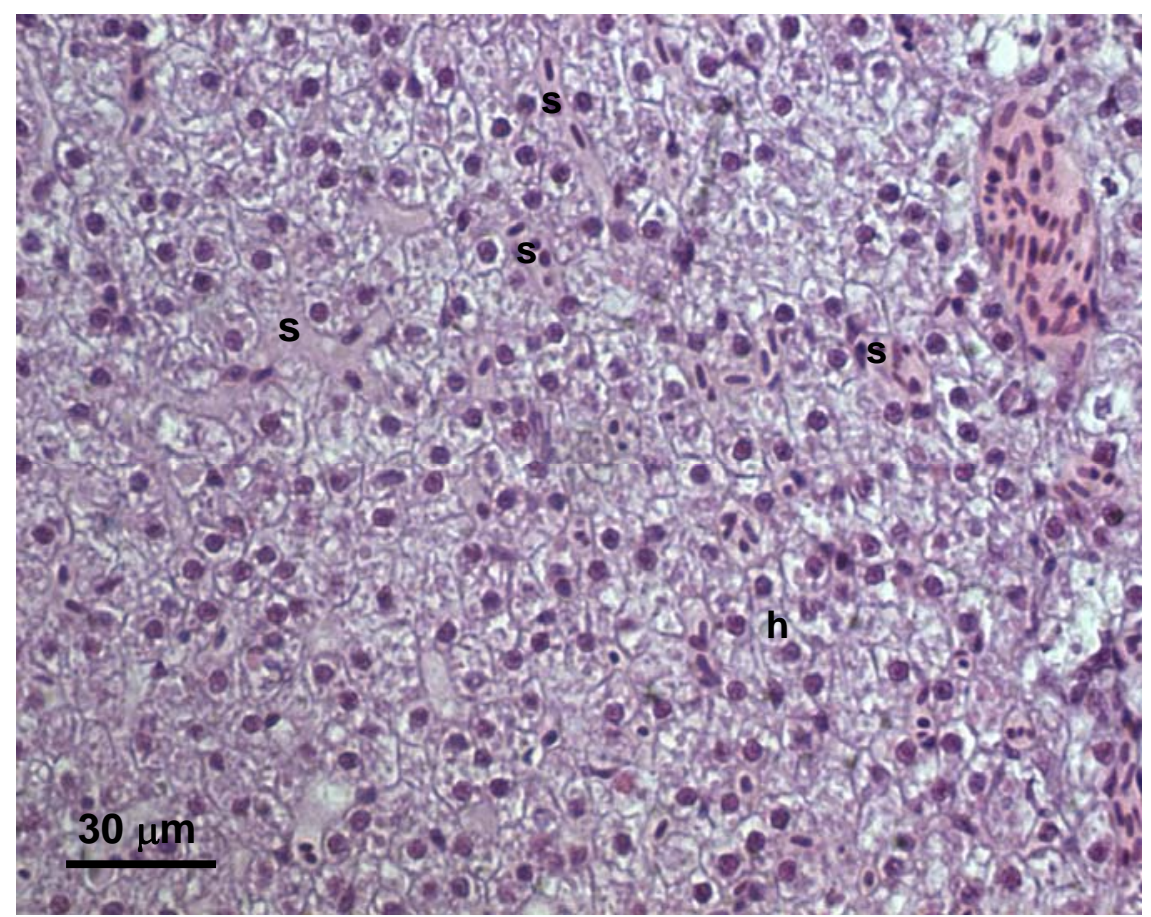

FIGURA 27: Fígado de D. rerio (controle- Rib. do Pinhal). Notar a vacuolização citoplasmática (áreas mais claras no citoplasma), o formato típico dos hepatócitos (h) e a rede de sinusóides (s), como o observado no fígado de $S$. notomelas. (HE, $5 \mu \mathrm{m}$ ). 


\subsection{Testes de toxicidade aguda com o sedimento das várias localidades} amostradas a S. notomelas e a $D$. rerio.

Nenhuma das amostras coletadas causou a mortalidade de nenhum exemplar de $S$. notomelas ou de $D$. rerio em 96 horas de exposição nos testes de toxicidade aguda realizados em laboratório.

\subsubsection{Variáveis físicas e químicas monitoradas ao longo dos testes de toxicidade do sedimento.}

Os valores obtidos para as variáveis $\mathrm{pH}$, temperatura, concentração de oxigênio dissolvido, condutividade, dureza e concentração de amônia não-ionizada nas soluções-teste são apresentados nas tabelas 13 a 18 .

$\mathrm{O}$ menor valor de $\mathrm{pH}$ registrado nos testes com as amostras de sedimento do período chuvoso foi 6,90 (Luiz Antônio/S.n.-chuvoso 96 h) e o maior, 8,22 (Telêmaco Borba 2/D.r.- 72h); para o período seco, o menor e o maior valor de $\mathrm{pH}$ registrados foram, respectivamente, 6,80 (Londrina/D.r. - 96h) e 8,03 (Campinas/ D.r. - 48h). Nos testes realizados com as amostras de sedimento do período chuvoso, observou-se para o pH a tendência de diminuição no decorrer do tempo (com exceção dos tratamentos S. João e Mogi 1 D. rerio), principalmente nas amostras provenientes das bacias dos rios Piracicaba e Mogi-Guaçu. Nas amostras do rio Tibagi houve tendência ao aumento dos valores de $\mathrm{pH}$ no decorrer dos testes. Nos testes com as amostras do período seco as variações de pH foram mais discretas, com exceção dos tratamentos correspondentes ao sedimento de Londrina (para S. notomelas e D. rerio), nos quais os valores diminuiram em mais de 0,7 unidade.

Os valores de condutividade foram maiores nos tratamentos referentes à bacia do rio Piracicaba, com exceção do ponto controle (Ribeirão do Pinhal $-120 \mu \mathrm{S}_{\mathrm{cm}} \mathrm{cm}^{-1}$ IS.n. e D.r. 96h-período seco a $166 \mu$ S.cm ${ }^{-1}$ /S.n. e D.r. Oh-período chuvoso) no qual, assim como no tratamento Londrina (93 $\mu$ S.cm ${ }^{-1}$ IS.n. 96 h-período seco a $147 \mu$ S. $\mathrm{cm}^{-1}$ ID.r. Oh-período seco), foram registrados os menores valores dessa variável. Nos testes com amostras de sedimento da bacia do rio Piracicaba, os valores mais elevados de condutividade foram observados, no período chuvoso, no tratamento Campinas (337 $\mu \mathrm{S} . \mathrm{cm}^{-1}-\mathrm{S}$. notomelas/96h) e, no período seco, em Piracicaba (415 $\mu \mathrm{S} . \mathrm{cm}^{-1}$ - S. notomelas/96h). Altos valores de condutividade também foram observados nos tratamentos Sumaré e Limeira, sendo, neste último, principalmente no período seco. Nos testes com amostras de sedimento provenientes da bacia do rio Mogi Guaçu, de ambos os períodos, não foram observadas grandes variações de condutividade da água nos recipientes-teste entre os tratamentos referentes às localidades desta bacia, como aquelas registradas entre os tratamentos referentes às 
localidades da bacia do rio Piracicaba, com exceção de Luiz Antônio 1 e 2 nos quais foram registrados valores dessa variável abaixo de $100 \mu \mathrm{S} . \mathrm{cm}^{-1}$. Nos tratamentos com amostras do rio Tibagi, os menores valores de condutividade foram registrados para a água dos recipientes-teste com sedimento de Londrina, em ambos os períodos e, entre T. Borba 1 e 2, dois pontos muito próximos, foi notado, do primeiro para o segundo, um aumento nos valores dessa variável, principalmente nos testes com amostras do período seco.

Com relação às variações da condutividade da água no decorrer desses experimentos, houve uma tendência à manutenção ou até ao decréscimo dos valores dessa variável, com exceção dos tratamentos Campinas, Sumaré e Piracicaba, nos quais a tendência foi de aumento da condutividade do início para o final dos testes, em ambos os períodos. O mesmo pôde ser observado no tratamento Limeira do período seco. Nesse mesmo tratamento foi observada, principalmente com $D$. rerio, a única discrepância de valores dessa variável entre réplicas (diferenças de mais de 100 $\left.\mu \mathrm{S} . \mathrm{cm}^{-1}\right)$.

Quanto à concentração de oxigênio dissolvido na água dos recipientes-teste, nos experimentos com ambas as espécies, com amostras do período chuvoso, raramente essa variável atingiu valores inferiores a $5 \mathrm{mg} \mathrm{O}_{2} \cdot \mathrm{L}^{-1}$. Já, nos testes com amostras do período seco, na maioria dos tratamentos foram registrados valores dessa variável entre 4 e $5 \mathrm{mg} \mathrm{O} \mathrm{O}_{2} \mathrm{~L}^{-1}$. Em alguns recipientes-teste a concentração de oxigênio dissolvido chegou a valores ainda inferiores, sendo o menor valor registrado $3,0 \mathrm{mg} \mathrm{O} \mathrm{O}_{2} \cdot \mathrm{L}^{-1}$, em Limeira $/ D$. rerio $-72 \mathrm{~h}$. A variação das concentrações de $\mathrm{O}_{2}$ ao longo dos testes não seguiu um padrão, já que a aeração da água dos recipientes-teste foi corrigida quando necessário.

A temperatura média da água nos recipientes-teste foi maior nos experimentos realizados com as amostras de sedimento das bacias dos rios Piracicaba e Mogi Guaçu do período chuvoso. Durante a realização destes experimentos os recipientesteste permaneceram em um banho-maria com termostatos/aquecedores, pois o laboratório encontrava-se desprovido de aparelho de ar-condicionado. Nestes testes a temperatura inicial $(\mathrm{O} \mathrm{h})$ variou, entre tratamentos, de 25 a $27{ }^{\circ} \mathrm{C}$, mas foi ajustada, ao longo dos experimentos, para que permanecesse em torno de $24{ }^{\circ} \mathrm{C}$. Como os termostatos não possuíam um funcionamento muito preciso a temperatura não permaneceu absolutamente estável, embora tenha oscilado menos. Já os testes de toxicidade com as amostras de sedimento da bacia do rio Tibagi do período chuvoso foram realizados quando o laboratório já dispunha de aparelho de ar-condicionado. Assim, a temperatura variou dentro do estabelecido para os testes, ficando em $23,5 \pm$ $1^{\circ} \mathrm{C}$. O mesmo ocorreu nos testes realizados com as amostras de sedimento das três 
bacias, do período seco. A realização destes testes em uma época do ano de temperaturas amenas (mês de outubro) e o perfeito funcionamento do aparelho de ar condicionado, proporcionaram a manutenção da temperatura em aproximadamente $23^{\circ} \mathrm{C}$.

Nos testes realizados com amostras do período chuvoso, os menores valores de dureza observados foram $41 \mathrm{mg} \mathrm{CaCO} \cdot \mathrm{L}^{-1}$ em Luiz Antônio 1 (D. rerio - 96h) e Luiz Antônio 2 (S. notomelas - 96h), sendo neste último apenas em uma réplica, e os maiores valores foram observados em Campinas (120 a $128 \mathrm{mg} \mathrm{CaCO}_{3} \cdot \mathrm{L}^{-1}$ ) e Sumaré (124 a $132 \mathrm{mg} \mathrm{CaCO}_{3} . \mathrm{L}^{-1}$ ) ao final dos testes com as duas espécies. Já nos testes realizados com as amostras do período seco, os menores valores de dureza observados foram de $51 \mathrm{mg} \mathrm{CaCO}_{3} \cdot \mathrm{L}^{-1}$ em Londrina (para os testes com ambas as espécies), e os maiores valores foram observados em Limeira (máximo de $148 \mathrm{mg}$ $\mathrm{CaCO}_{3} \cdot \mathrm{L}^{-1}$ ), Piracicaba (máximo de $120 \mathrm{mg} \mathrm{CaCO} \cdot \mathrm{L}^{-1}$ ) e T. Borba 2 (126 mg $\mathrm{CaCO}_{3} \cdot \mathrm{L}^{-1}$ ) ao final dos testes com as duas espécies, exceto em Limeira, tratamento no qual houve discrepância dos valores dessa variável entre réplicas no teste com $D$. rerio. Quanto às variações da dureza entre o início e o final dos testes, na maioria dos tratamentos foram observados valores estáveis ou ligeiramente decrescentes. No entanto, em tratamentos como Campinas (período chuvoso), Sumaré (ambos os períodos), Limeira, Piracicaba e T. Borba 2 (período seco) foram observados valores crescentes para essa variável.

Com relação ao monitoramento das concentrações de amônia não-ionizada na água, no início e ao final dos testes, os maiores teores foram observados nas amostras provenientes da bacia do rio Piracicaba (exceto local controle), em ambos os períodos e com as duas espécies. Dessa bacia, destacam-se as localidades Campinas e Sumaré, no período chuvoso, e Limeira, Campinas, Sumaré e Piracicaba, no período seco. $\mathrm{Na}$ água dos recipientes-teste referentes a estas duas últimas localidades, foram observados teores de amônia não-ionizada superiores a $250 \mu \mathrm{g} \cdot \mathrm{L}^{-1}$, ao final dos experimentos com sedimentos coletados na estação seca. Nas outras bacias os teores de amônia não-ionizada foram relativamente baixos na maioria das localidades, principalmente nos sedimentos coletados na estação chuvosa, nos quais, muitas vezes, a amônia apresentava-se totalmente na forma ionizada. Porém, alguns valores discrepantes foram observados, como por exemplo nos tratamentos Ribeirão do Pinhal B - Oh $\left(71,2 \mu \mathrm{g} \mathrm{NH} \mathrm{NH}^{-1}\right)$ e Luiz Antônio $1 \mathrm{~A}$ - $96 \mathrm{~h}\left(120,8 \mu \mathrm{g} \mathrm{NH} \cdot \mathrm{L}^{-1}\right)$.

Quanto às variações das concentrações de amônia não-ionizada observou-se que do início para o final dos testes, em alguns tratamentos, os teores cresceram e em outros, decresceram, não sendo observada, portanto, uma tendência geral na variação. 
TABELA 13. Variações dos valores de pH da água ao longo dos testes de toxicidade com amostras de sedimento coletadas nos períodos seco e chuvoso em diferentes localidades nas bacias dos rios Piracicaba, Mogi Guaçu e Tibagi. Pin = Rib. Pinhal; Lim = Limeira; Cam = Campinas; Sum = Sumaré ; Ame = Americana; Pira = Piracicaba; S.João = São João da Boa Vista; Mogi 1 = Mogi Guaçu 1; Mogi 2 = Mogi Guaçu 2; Psng = Pirassununga; L.Ant.1 = Luiz Antônio 1; L.Ant.2 = Luiz Antônio 2; T.Borba 1 = Telêmaco Borba 1; T.Borba 2 = Telêmaco Borba 2; Londr = Londrina.

S. notomelas $\quad$ pH - 1 ${ }^{-}$Coleta (período chuvoso)

\begin{tabular}{|c|c|c|c|c|c|c|c|c|c|c|c|c|c|c|c|c|c|c|c|c|c|c|c|c|c|c|c|c|c|c|}
\hline & \multicolumn{2}{|c|}{ Pin } & \multicolumn{2}{|c|}{ Lim } & \multicolumn{2}{|c|}{ Cam } & \multicolumn{2}{|c|}{ Sum } & \multicolumn{2}{|c|}{ Ame } & \multicolumn{2}{|c|}{ Pira } & \multicolumn{2}{|c|}{ S.João } & \multicolumn{2}{|c|}{ Mogi 1} & \multicolumn{2}{|c|}{ Mogi 2} & \multicolumn{2}{|c|}{ Psng } & \multicolumn{2}{|c|}{ L.Ant.1 } & \multicolumn{2}{|c|}{ L.Ant.2 } & \multicolumn{2}{|c|}{ T.Borba 1} & \multicolumn{2}{|c|}{ T.Borba 2} & \multicolumn{2}{|c|}{ Londr } \\
\hline & $\mathrm{A}$ & $B$ & $\mathrm{~A}$ & $B$ & $\mathrm{~A}$ & $B$ & $\bar{A}$ & $B$ & $\mathrm{~A}$ & $B$ & $\mathrm{~A}$ & B & $A$ & $B$ & $A$ & $B$ & A & $B$ & A & $B$ & $A$ & $B$ & $A$ & $B$ & $A$ & B & $A$ & $\mathrm{~B}$ & $A$ & $B$ \\
\hline $\mathrm{Oh}$ & 7,69 & 7,64 & 7,55 & 7,90 & 7,65 & 7,63 & 7,97 & 8,00 & 7,58 & 7,78 & 7,80 & 7,75 & 7,56 & 7,70 & 7,77 & 7,75 & 7,64 & 7,64 & 7,70 & 7,78 & 7,47 & 7,52 & 7,10 & 7,38 & 7,72 & 7,77 & 7,70 & 7,64 & 7,66 & 7,75 \\
\hline $24 \mathrm{~h}$ & 7 & 29 & & 735 & & 26 & & & & & & & 47 & & & & & & & & 1 & & 8 & & 46 & & 51 & & 38 & \\
\hline $48 \mathrm{~h}$ & 50 & 63 & 7,45 & 7,42 & 7.41 & 7,43 & 0 & 7,62 & 7,34 & 7,48 & 7,39 & 7. & 38 & 7,58 & 44 & 7,54 & 1 & 7,51 & 7,75 & 7,54 & 7,05 & 7,04 & 21 & j & 77 & 34 & 9 & 3 & 66 & 7,79 \\
\hline $72 \mathrm{~h}$ & 7,60 & 7,72 & 38 & 34 & 7,48 & 42 & 7,59 & 7,66 & 22 & 7,39 & 44 & 7,44 & 7,23 & 7,35 & 7,78 & 7,54 & 7,40 & 7, & 7,6 & 7,5 & 6,98 & 7,01 & 14 & 7,16 & 7,54 & 7,63 & 7,75 &, 72 & 7,93 & 3,00 \\
\hline $96 \mathrm{~h}$ & 7,41 & 7,46 & 7,16 & 7,20 & 7,59 & 7,61 & 7,62 & 7,66 & 7,22 & 7,36 & 7,46 & 7,40 & 7,38 & 7,57 & 7,54 & 7,73 & 7,45 & 7,36 & 7,76 & 7,70 & 7,11 & 6,9 & 7,01 & 6,90 & 7,83 & 7,86 & 7,82 & 7,62 & 7,67 & 7,89 \\
\hline
\end{tabular}
D. rerio

\begin{tabular}{|c|c|c|c|c|c|c|c|c|c|c|c|c|c|c|c|c|c|c|c|c|c|c|c|c|c|c|c|c|c|c|}
\hline & \multicolumn{2}{|c|}{ Pin } & \multicolumn{2}{|c|}{ Lim } & \multicolumn{2}{|c|}{ Cam } & \multicolumn{2}{|c|}{ Sum } & \multicolumn{2}{|c|}{ Ame } & \multicolumn{2}{|c|}{ Pira } & \multicolumn{2}{|c|}{ S.João } & \multicolumn{2}{|c|}{ Mogi 1} & \multicolumn{2}{|c|}{ Mogi 2} & \multicolumn{2}{|c|}{ Psng } & \multicolumn{2}{|c|}{ L.Ant.1 } & \multicolumn{2}{|c|}{ L.Ant.2 } & \multicolumn{2}{|c|}{ T.Borba 1} & \multicolumn{2}{|c|}{ T.Borba 2} & \multicolumn{2}{|c|}{ Londr } \\
\hline & A & B & A & B & A & B & A & B & A & B & A & B & A & B & A & B & A & B & A & B & A & B & A & B & A & B & A & B & A & B \\
\hline $0 \mathrm{~h}$ & 7,73 & 7,76 & 7,77 & 7,65 & 7,61 & 7,69 & 7,85 & 7,88 & 7,69 & 7,70 & 7,65 & 7,74 & 7,66 & 7,64 & 7,66 & 7,61 & 7,62 & 7,70 & 7,68 & 7,66 & 7,43 & 7,45 & 7,28 & 7,54 & 7,77 & 7,78 & 7,85 & 7,82 & 7,76 & 7,71 \\
\hline $24 \mathrm{~h}$ & 7,29 & 7,34 & 7,16 & 7,17 & 7,17 & 7,30 & 7,59 & 7,58 & 7,42 & 7,21 & 7,43 & 7,41 & 7,56 & 7,53 & 7,58 & 7,54 & 7,50 & 7,57 & 7,75 & 7,75 & 7,29 & 7,13 & 7,10 & 7,25 & 7,47 & 7,57 & 7,78 & 7,76 & 7,55 & 7,64 \\
\hline $48 \mathrm{~h}$ & 7,44 & 7,47 & 7,35 & 7,31 & 7,39 & 7,39 & 7,65 & 7,72 & 7,40 & 7,34 & 7,57 & 7,46 & 7,63 & 7,63 & 7,74 & 7,74 & 7,48 & 7,59 & 7,70 & 7,71 & 7,19 & 7,07 & 7,28 & 7,24 & 7,86 & 7,44 & 8,00 & 7,93 & 7,64 & 7,75 \\
\hline $72 \mathrm{~h}$ & 7,57 & 7,55 & 7,14 & 7,33 & 7,40 & 7,50 & 7,55 & 7,64 & 7,30 & 7,19 & 7,62 & 7,39 & 7,43 & 7,74 & 7,64 & 7,64 & 7,32 & 7,45 & 7,72 & 7,63 & 7,16 & 6,96 & 7,19 & 7,13 & 7,73 & 7,71 & 8,14 & 8,22 & 7,95 & 8,01 \\
\hline $96 \mathrm{~h}$ & 7,35 & 7,40 & 7,15 & 7,28 & 7,59 & 7,68 & 7,64 & 7,64 & 7,35 & 7,32 & 7,46 & 7,40 & 7,66 & 7,76 & 7,86 & 7,83 & 7,48 & 7,35 & 7,50 & 7,56 & 7,01 & 6,91 & 7,15 & 7,03 & 7,94 & 7,82 & 8,05 & 8,03 & 7,86 & 7,8 \\
\hline
\end{tabular}

\section{pH - $2^{\mathrm{a}}$ Coleta (período seco)}

\begin{tabular}{|c|c|c|c|c|c|c|c|c|c|c|c|c|c|c|c|c|c|c|c|c|c|c|c|c|c|c|c|c|c|c|}
\hline \multirow{2}{*}{\multicolumn{31}{|c|}{ S. notomelas }} \\
\hline & & & & & & & & & & & & & & & & & & & & & & & & & & & & & & \\
\hline & \multicolumn{2}{|c|}{ Pin } & \multicolumn{2}{|c|}{ Lim } & \multicolumn{2}{|c|}{ Cam } & \multicolumn{2}{|c|}{ Sum } & \multicolumn{2}{|c|}{ Ame } & \multicolumn{2}{|c|}{ Pira } & \multicolumn{2}{|c|}{ S.João } & \multicolumn{2}{|c|}{ Mogi 1} & \multicolumn{2}{|c|}{ Mogi 2} & \multicolumn{2}{|c|}{ Psng } & \multicolumn{2}{|c|}{ L.Ant.1 } & \multicolumn{2}{|c|}{ L.Ant.2 } & \multicolumn{2}{|c|}{ T.Borba 1} & \multicolumn{2}{|c|}{ T.Borba 2} & \multicolumn{2}{|c|}{ Londr } \\
\hline & A & $B$ & A & $\mathrm{B}$ & A & $B$ & A & $B$ & A & $B$ & A & $B$ & A & $B$ & A & $\mathrm{B}$ & A & $B$ & A & $B$ & A & $B$ & A & $B$ & A & B & A & $B$ & A & $B$ \\
\hline $0 \mathrm{~h}$ & 7,54 & 7,55 & 7,68 & 7,70 & 7,63 & 7,57 & 7,46 & 7,55 & 7,41 & 7,37 & 7,39 & 7,27 & 7,56 & 7,67 & 7,40 & 7,41 & 7,48 & 7,45 & 7,26 & 7,42 & 7,38 & 7,31 & 7,26 & 7,11 & 7,56 & 7,69 & 7,69 & 7,91 & 7,53 & 7,56 \\
\hline $24 \mathrm{~h}$ & 7,45 & 7,43 & 69 & 7,75 & 76 & 60 & 7,72 & 7,80 & 7,70 & 7,73 & 7,83 & 7,71 & 7,48 & 7,56 & 47 & 7,4 & 58 & 7,47 & 7,44 & 7,53 & 7,54 & 7,5 & 7,62 & 7,4 & 69 & 7,64 & 7,86 & 7,93 & 7,46 & 7,52 \\
\hline $\mathrm{h}$ & 58 & 7,57 & 74 & 7,87 & 7,91 & 7,84 & 79 & 7,91 & 5 & 7,7 & 6 & 7 & 41 & 7, & 7,53 & 7,2 & 7 & 7, & 7,32 & $\overline{7,3}$ & 7,34 & 7 & 4 & 7,40 & 7,50 & 7, & 7,84 & 0 & 7,39 & 7,43 \\
\hline $2 \mathrm{~h}$ & 7,44 & 7,48 & 83 & 7,74 & 7,94 & 7,74 & 88 & 7,88 & 7,45 & 7,5 & 7,68 & 7, & 7,46 & 7,5 & 52 & 7, & 45 & 7,4 & 7,44 & 7, & 7,52 & 7,5 & 7,60 & 7,4 &, 68 & 7,69 & 7,60 & 7,81 & 7,29 & 7,24 \\
\hline $96 \mathrm{~h}$ & 7,31 & 7,26 & 7,80 & 7,62 & 7,74 & 7,63 & 7,76 & 7,74 & 7,31 & 7,3 & 7,70 & 7,64 & 7,48 & 7,51 & 7,62 & 7,55 & 7,47 & 7,4 & 7,29 & 7,48 & 7,47 & 7,38 & 7,37 & 7,27 & 7,57 & 7,39 & 7,49 & 7,62 & 6,80 & 6,80 \\
\hline \multicolumn{31}{|c|}{ D. rerio } \\
\hline & \multicolumn{2}{|c|}{ Pin } & \multicolumn{2}{|c|}{ Lim } & \multicolumn{2}{|c|}{ Cam } & \multicolumn{2}{|c|}{ Sum } & \multicolumn{2}{|c|}{ Ame } & \multicolumn{2}{|c|}{ Pira } & \multicolumn{2}{|c|}{ S.João } & \multicolumn{2}{|c|}{ Mogi 1} & & gi 2 & $\mathrm{PS}$ & & L.A & nt.1 & L.A & & T.Bo & ba 1 & T.Bo & 2 & Lor & dr \\
\hline & A & B & A & B & A & B & A & B & A & B & A & B & A & B & A & B & A & B & A & B & A & B & A & B & A & B & A & B & A & B \\
\hline $\mathrm{Oh}$ & 7,53 & 7,48 & 7,67 & 7,69 & 7,50 & 7,63 & 7,59 & 7,44 & 7,50 & 7,40 & 7,43 & 7,34 & 7,54 & 7,43 & 7,43 & 7,43 & 7,42 & 7,44 & 7,42 & 7,28 & 7,31 & 7,21 & 7,14 & 7,15 & 7,69 & 7,74 & 7,80 & 7,89 & 7,61 & 7,50 \\
\hline & & 47 & 64 & 700 & 64 & 7,87 & 20 & 776 & 7,80 & & 784 & 782 & 7,55 & 7,41 & 7,51 & 7 & 7,52 & 7,5 & 7,55 & 7,47 & 764 & 7,6 & 7,64 & 7,50 & 7,86 & 776 & 7,86 & 7,89 & 7,61 & 7,36 \\
\hline $3 \mathrm{~h}$ & 63 & 7,55 & 73 & 7,68 & 75 & 8,03 & 7,94 & 7,80 & 7,81 & 7,8 & 7,89 & 7,91 & 7,59 & 7,42 & 7,42 & 7,51 & 7,37 & 7,47 & 7,32 & 7,31 & 7,55 & 7,48 & 7,44 & 7,49 & 7,74 & 7,79 & 7,84 & 7,74 & 7,53 & 7,37 \\
\hline $72 \mathrm{~h}$ & 7,43 & 7,36 & 7,74 & 7,54 & 7,67 & 7,90 & 7,98 & 7,92 & 7,60 & 7,61 & 7,90 & 7,90 & 7,56 & 7,42 & 7,48 & 7,56 & 7,44 & 7,55 & 7,38 & 7,41 & 7,70 & 7,57 & 7,42 & 7,47 & 7,77 & 7,58 & 7,86 & 7,73 & 7,35 & 7,25 \\
\hline $96 \mathrm{~h}$ & 7,28 & 7,33 & 7,59 & 7,32 & 7,52 & 7,50 & 7,85 & 7,76 & 7,49 & 7,40 & 7,82 & 7,80 & 7,56 & 7,49 & 7,54 & 7,54 & 7,54 & 7,49 & 7,46 & 7,26 & 7,63 & 7,51 & 7,32 & 7,36 & 7,49 & 7,48 & 7,60 & 7,36 & 6,90 & 6,82 \\
\hline
\end{tabular}


TABELA 14. Variações dos valores de Condutividade da água $\left(\mu \mathrm{S} \cdot \mathrm{cm}^{-1}\right)$ ao longo dos testes de toxicidade com amostras de sedimento coletadas nos períodos seco e chuvoso em diferentes localidades nas bacias dos rios Piracicaba, Mogi Guaçu e Tibagi. Pin = Rib. Pinhal; Lim = Limeira; Cam = Campinas; Sum = Sumaré; Ame = Americana; Pira = Piracicaba; S. João = São João da Boa Vista; Mogi $1=$ Mogi Guaçu 1; Mogi $2=$ Mogi Guaçu 2; Psng = Pirassununga; L.Ant.1 = Luiz Antônio 1; L.Ant.2 = Luiz Antônio 2; T.Borba 1 = Telêmaco Borba 1; T.Borba 2 = Telêmaco Borba 2; Londr = Londrina.

\section{Condutividade $\left(\mu \mathrm{S} . \mathrm{cm}^{-1}\right)-1^{\mathrm{a}}$ Coleta (período chuvoso)}

\begin{tabular}{|c|c|c|c|c|c|c|c|c|c|c|c|c|c|c|c|c|c|c|c|c|c|c|c|c|c|c|c|c|c|c|}
\hline \multirow{2}{*}{\multicolumn{31}{|c|}{ S. notomelas }} \\
\hline & & & & & & & & & & & & & & & & & & & & & & & & & & & & & & \\
\hline & \multicolumn{2}{|c|}{ Pin } & \multicolumn{2}{|c|}{ Lim } & \multicolumn{2}{|c|}{ Cam } & \multicolumn{2}{|c|}{ Sum } & \multicolumn{2}{|c|}{ Ame } & \multicolumn{2}{|c|}{ Pira } & \multicolumn{2}{|c|}{ S.João } & \multicolumn{2}{|c|}{ Mogi 1} & \multicolumn{2}{|c|}{ Mogi 2} & \multicolumn{2}{|c|}{ Psng } & \multicolumn{2}{|c|}{ L.Ant.1 } & \multicolumn{2}{|c|}{ L.Ant.2 } & \multicolumn{2}{|c|}{ T.Borba 1} & \multicolumn{2}{|c|}{ T.Borba 2} & \multicolumn{2}{|c|}{ Londr } \\
\hline & A & $B$ & A & $B$ & A & $B$ & A & $B$ & A & $B$ & $A$ & $B$ & A & $B$ & A & $B$ & A & $B$ & $A$ & $B$ & A & $B$ & A & $B$ & A & $B$ & $A$ & $B$ & A & $B$ \\
\hline $0 \mathrm{~h}$ & 166 & 160 & 188 & 199 & 229 & 240 & 245 & 241 & 185 & 186 & 169 & 174 & 152 & 153 & 168 & 162 & 144 & 143 & 155 & 155 & 116 & 114 & 146 & 133 & 137 & 136 & 145 & 144 & 134 & 128 \\
\hline $24 \mathrm{~h}$ & 166 & 162 & 196 & 201 & 258 & 262 & 272 & 259 & 183 & 188 & 175 & 179 & 147 & 149 & 170 & 153 & 141 & 136 & 162 & 162 & 104 & 100 & 22 & 114 & 131 & 130 & 138 & 140 & 17 & 119 \\
\hline $48 \mathrm{~h}$ & 63 & 159 & 195 & 199 & 276 & 287 & 284 & 270 & 182 & 186 & 176 & 182 & 145 & 148 & 173 & 163 & 37 & 131 & 162 & 162 & 101 & 91 & 14 & 107 & 130 & 127 & 139 & 138 & 10 & 115 \\
\hline $72 \mathrm{~h}$ & 161 & 158 & 190 & 193 & 308 & 312 & 297 & 277 & 180 & 178 & 183 & 183 & 145 & 149 & 176 & 166 & 137 & 130 & 166 & 166 & 100 & 90 & 112 & 101 & 130 & 125 & 138 & 138 & 107 & 112 \\
\hline $96 \mathrm{~h}$ & 164 & 160 & 189 & 190 & 334 & 337 & 305 & 277 & 176 & 179 & 183 & 183 & 144 & 147 & 177 & 166 & 132 & 125 & 165 & 165 & 95 & 88 & 107 & 96 & 130 & 124 & 140 & 140 & 106 & 110 \\
\hline
\end{tabular}
D. rerio

$\begin{array}{llllllllllllll}\text { Pin } & \text { Lim } & \text { Cam } & \text { Sum } & \text { Ame } & \text { Pira } & \text { S.João } & \text { Mogi } 1 & \text { Mogi } 2 & \text { Psng } & \text { L.Ant.1 } & \text { L.Ant.2 } & \text { T.Borba } 1 & \text { T.Borba 2 } \\ \text { Londr }\end{array}$ \begin{tabular}{ccccccccccccccccccccccccccccccccccc} 
& $\mathrm{A}$ & $\mathrm{B}$ & $\mathrm{A}$ & $\mathrm{B}$ & $\mathrm{A}$ & $\mathrm{B}$ & $\mathrm{A}$ & $\mathrm{B}$ & $\mathrm{A}$ & $\mathrm{B}$ & $\mathrm{A}$ & $\mathrm{B}$ & $\mathrm{A}$ & $\mathrm{B}$ & $\mathrm{A}$ & $\mathrm{B}$ & $\mathrm{A}$ & $\mathrm{B}$ & $\mathrm{A}$ & $\mathrm{B}$ & $\mathrm{A}$ & $\mathrm{B}$ & $\mathrm{A}$ & $\mathrm{B}$ & $\mathrm{A}$ & $\mathrm{B}$ & $\mathrm{A}$ & $\mathrm{B}$ & $\mathrm{A}$ & $\mathrm{B}$ \\
\hline $\mathrm{Oh}$ & 162 & 166 & 191 & 196 & 223 & 227 & 242 & 225 & 184 & 180 & 175 & 170 & 152 & 156 & 164 & 162 & 146 & 147 & 157 & 160 & 124 & 118 & 133 & 134 & 138 & 139 & 152 & 151 & 134 & 133
\end{tabular} \begin{tabular}{rrrlllllllllllllllllllllllllllllllll}
\hline $24 \mathrm{~h}$ & 160 & 166 & 190 & 204 & 243 & 240 & 267 & 264 & 184 & 181 & 178 & 173 & 142 & 147 & 161 & 159 & 137 & 139 & 151 & 152 & 104 & 100 & 113 & 114 & 128 & 134 & 147 & 155 & 119 & 120 \\
\hline $48 \mathrm{~h}$ & 157 & 163 & 188 & 20 & 268 & 267 & 277 & 277 & 179 & 178 & 180 & 176 & 140 & 143 & 160 & 159 & 131 & 134 & 149 & 149 & 97 & 93 & 104 & 105 & 130 & 134 & 149 & 154 & 115 & 1111
\end{tabular}

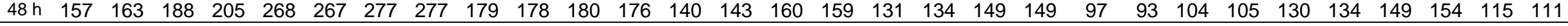

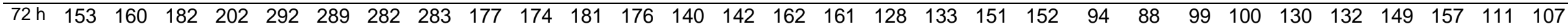

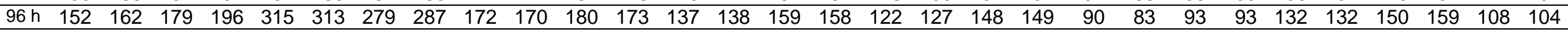

Condutividade $\left(\mu \mathrm{S} . \mathrm{cm}^{-1}\right) \mathbf{2}^{\mathrm{a}}$ Coleta (período seco)

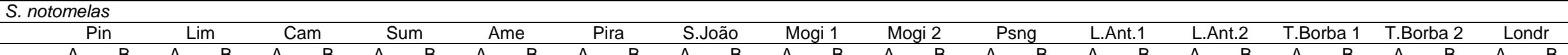
\begin{tabular}{ccccccccccccccccccccccccccccccc} 
& A & B & A & B & A & B & A & B & A & B & A & B & A & B & A & B & A & B & A & B & A & B & A & B & A & B & A & B & A & B \\
\hline $0 \mathrm{~h}$ & 139 & 143 & 249 & 241 & 238 & 236 & 280 & 278 & 187 & 187 & 281 & 283 & 158 & 155 & 165 & 166 & 173 & 174 & 192 & 187 & 166 & 171 & 173 & 176 & 176 & 198 & 200 & 200 & 138 & 134
\end{tabular} \begin{tabular}{lllllllllllllllllllllllllllllllll}
\hline $24 \mathrm{~h}$ & 134 & 138 & 264 & 249 & 252 & 247 & 296 & 292 & 185 & 185 & 313 & 313 & 155 & 152 & 164 & 166 & 172 & 172 & 189 & 181 & 163 & 168 & 168 & 170 & 169 & 193 & 209 & 210 & 119 & 112 \\
\hline $48 \mathrm{~h}$ & 129 & 133 & 296 & 26 & 269 & 268 & 315 & 310 & 184 & 186 & 358 & 351 & 152 & 151 & 163 & 165 & 169 & 171 & 185 & 176 & 158 & 164 & 162 & 161 & 166 & 188 & 215 & 217 & 111 & 101
\end{tabular} $\begin{array}{rlllllllllllllllllllllllllllllllll}48 \mathrm{~h} & 129 & 133 & 296 & 267 & 269 & 268 & 315 & 310 & 184 & 186 & 358 & 351 & 152 & 151 & 163 & 165 & 169 & 171 & 185 & 176 & 158 & 164 & 162 & 161 & 166 & 188 & 215 & 217 & 111 & 101\end{array}$ \begin{tabular}{llllllllllllllllllllllllllllllll}
\hline $72 \mathrm{~h}$ & 124 & 129 & 318 & 285 & 287 & 286 & 329 & 326 & 180 & 184 & 390 & 383 & 150 & 149 & 160 & 163 & 172 & 168 & 179 & 170 & 134 & 159 & 152 & 151 & 165 & 186 & 223 & 222 & 103 & 96
\end{tabular} \begin{tabular}{llllllllllllllllllllllllllllllllll}
\hline $96 \mathrm{~h}$ & 120 & 125 & 324 & 301 & 295 & 297 & 342 & 338 & 178 & 180 & 415 & 397 & 148 & 147 & 160 & 161 & 165 & 163 & 172 & 163 & 140 & 154 & 139 & 138 & 162 & 183 & 224 & 226 & 97 & 93 \\
\hline
\end{tabular} D. rerio

\begin{tabular}{cccccccccccccc}
\hline Pin & Lim & Cam & Sum & Ame & Pira & S.João & Mogi 1 & Mogi 2 & Psng & L.Ant.1 & L.Ant.2 & T.Borba 1 & T.Borba 2 \\
\hline L Londr
\end{tabular}

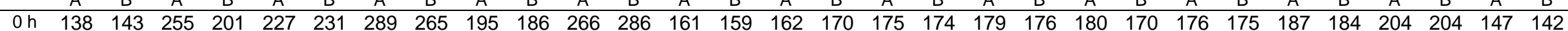
\begin{tabular}{llllllllllllllllllllllllllllllllllll}
\hline $24 \mathrm{~h}$ & 133 & 137 & 266 & 201 & 240 & 241 & 305 & 282 & 190 & 182 & 289 & 323 & 157 & 154 & 158 & 168 & 175 & 172 & 171 & 170 & 186 & 164 & 169 & 167 & 179 & 181 & 213 & 212 & 127 & 125
\end{tabular} \begin{tabular}{lllllllllllllllllllllllllllllllll}
\hline $48 \mathrm{~h}$ & 127 & 131 & 297 & 205 & 258 & 258 & 325 & 302 & 188 & 181 & 324 & 360 & 155 & 148 & 156 & 166 & 175 & 171 & 166 & 172 & 189 & 163 & 162 & 159 & 173 & 176 & 221 & 220 & 116 & 114 \\
\hline
\end{tabular} \begin{tabular}{llllllllllllllllllllllllllllllllll}
\hline $72 \mathrm{~h}$ & 124 & 126 & 322 & 209 & 274 & 276 & 339 & 313 & 191 & 179 & 348 & 385 & 153 & 147 & 149 & 162 & 172 & 171 & 167 & 167 & 192 & 161 & 153 & 148 & 172 & 175 & 231 & 224 & 109 & 114
\end{tabular} \begin{tabular}{lllllllllllllllllllllllllllllllll}
\hline $96 \mathrm{~h}$ & 120 & 121 & 341 & 206 & 285 & 284 & 351 & 327 & 187 & 174 & 367 & 412 & 152 & 143 & 148 & 160 & 167 & 172 & 160 & 163 & 192 & 156 & 142 & 136 & 170 & 169 & 243 & 227 & 104 & 108
\end{tabular} 
TABELA 15. Variações das concentrações de oxigênio dissolvido na água ( $\left.\mathrm{mg} \mathrm{O}_{2} \cdot \mathrm{L}^{-1}\right)$ ao longo dos testes de toxicidade com amostras de sedimento coletadas nos períodos seco e chuvoso em diferentes localidades nas bacias dos rios Piracicaba, Mogi Guaçu e Tibagi. Pin = Rib. Pinhal; Lim = Limeira; Cam = Campinas; Sum = Sumaré; Ame = Americana; Pira = Piracicaba; S.João = São João da Boa Vista; Mogi 1 = Mogi Guaçu 1 ; Mogi 2 = Mogi Guaçu 2; Psng = Pirassununga; L.Ant.1 = Luiz Antônio 1; L.Ant.2 = Luiz Antônio 2; T.Borba 1 = Telêmaco Borba 1; T.Borba 2 = Telêmaco Borba 2; Londr = Londrina.

S. notomelas

Oxigênio Dissolvido (mg. -1 $^{-1}-1^{\mathrm{a}}$ Coleta (período chuvoso)

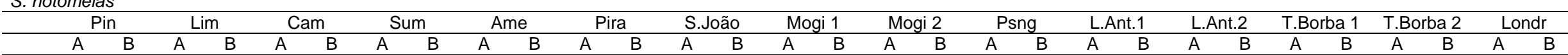
\begin{tabular}{llllllllllllllllllllllllllllllllll}
$0 \mathrm{~h}$ & 5,57 & 5,35 & 5,35 & 5,20 & 5,10 & 4,57 & 5,17 & 4,99 & 5,35 & 5,41 & 5,08 & 5,35 & 5,70 & 6,00 & 5,45 & 5,77 & 5,80 & 5,98 & 5,64 & 5,88 & 5,73 & 5,89 & 4,52 & 5,48 & 4,22 & 4,23 & 4,14 & 4,24 & 4,18 & 4,28 \\
\hline & 5,71 & 5,72 & 5,43 & 5,45 & 5,01 & 4,64 & 5,27 & 5,47 & 5,20 & 5,11 & 5,31 & 5,07 & 5,35 & 5,93 & 3,17 & 5,10 & 4,51 & 4,89 & 4,36 & 4,36 & 5,00 & 5,72 & 5,33 & 5,43 & 5,50 & 5,36 & 5,45 & 5,25 & 5,31 & 5,60
\end{tabular}

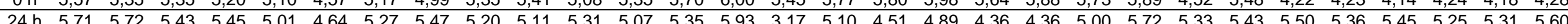
$\begin{array}{llllllllllllllllllllllllllllllll}48 \mathrm{~h} & 5,54 & 5,85 & 5,55 & 5,24 & 5,08 & 4,88 & 4,74 & 4,90 & 5,45 & 5,72 & 5,48 & 5,39 & 5,89 & 5,86 & 4,82 & 5,72 & 5,17 & 5,20 & 5,44 & 4,96 & 4,75 & 5,58 & 5,00 & 4,53 & 5,43 & 5,57 & 5,67 & 5,36 & 5,38 & 5,70\end{array}$ \begin{tabular}{llllllllllllllllllllllllllllllll}
\hline $72 \mathrm{~h}$ & 5,08 & 5,87 & 5,37 & 5,50 & 4,71 & 5,02 & 5,13 & 5,07 & 5,18 & 5,37 & 4,55 & 4,81 & 5,89 & 5,68 & 6,40 & 5,84 & 5,16 & 5,17 & 5,36 & 5,04 & 5,30 & 5,01 & 5,89 & 5,78 & 5,89 & 6,49 & 6,06 & 5,22 & 5,20 & 5,73 \\
\hline
\end{tabular} \begin{tabular}{lllllllllllllllllllllllllllllllllllll}
\hline $96 \mathrm{~h}$ & 5,28 & 5,70 & 5,10 & 5,28 & 4,83 & 5,02 & 4,84 & 4,82 & 4,98 & 5,24 & 5,25 & 5,20 & 6,38 & 6,35 & 5,20 & 6,12 & 5,08 & 4,86 & 5,12 & 5,18 & 5,77 & 5,13 & 4,95 & 5,15 & 5,39 & 5,92 & 5,44 & 4,88 & 5,47 & 6,51 \\
\hline
\end{tabular} D. rerio

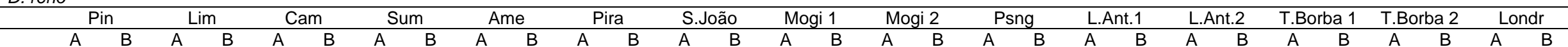

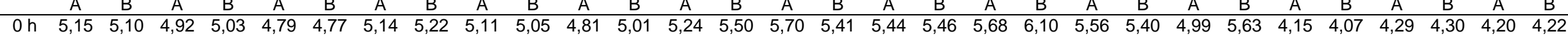
\begin{tabular}{lllllllllllllllllllllllllllllllll}
\hline $24 \mathrm{~h}$ & 5,95 & 5,53 & 5,28 & 5,10 & 4,87 & 5,05 & 5,26 & 5,42 & 4,81 & 4,88 & 4,91 & 5,01 & 4,64 & 4,55 & 5,18 & 5,25 & 4,91 & 5,10 & 5,18 & 4,89 & 5,22 & 5,34 & 4,62 & 5,00 & 5,53 & 5,48 & 5,74 & 5,72 & 5,51 & 5,78
\end{tabular} \begin{tabular}{llllllllllllllllllllllllllllllllllllll}
$24 \mathrm{~h}$ & 5,55 & 5,53 & 5,28 & 5,10 & 4,87 & 5,05 & 5,26 & 5,42 & 4,81 & 4,88 & 4,91 & 5,01 & 4,64 & 4,55 & 5,18 & 5,25 & 4,91 & 5,10 & 5,18 & 4,89 & 5,22 & 5,34 & 4,62 & 5,00 & 5,53 & 5,48 & 5,74 & 5,72 & 5,51 & 5,78 \\
\hline $48 \mathrm{~h}$ & 5,59 & 5,43 & 5,75 & 5,07 & 4,87 & 4,70 & 5,22 & 5,52 & 5,46 & 5,00 & 5,41 & 5,06 & 5,64 & 5,23 & 5,56 & 5,49 & 5,01 & 5,38 & 5,74 & 5,26 & 5,20 & 5,37 & 5,40 & 5,35 & 5,53 & 4,28 & 5,72 & 5,85 & 5,53 & 5,62 \\
\hline
\end{tabular}

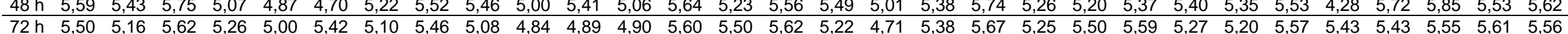
\begin{tabular}{llllllllllllllllllllllllllllllllllllllll}
\hline $96 \mathrm{~h}$ & 5,69 & 5,39 & 5,31 & 5,20 & 4,79 & 5,11 & 5,01 & 5,00 & 5,09 & 4,71 & 4,82 & 5,25 & 5,38 & 5,59 & 5,79 & 5,53 & 4,97 & 5,07 & 4,76 & 4,97 & 5,46 & 5,31 & 5,25 & 4,80 & 5,43 & 5,23 & 5,59 & 6,06 & 5,73 & 5,80 \\
\hline
\end{tabular}

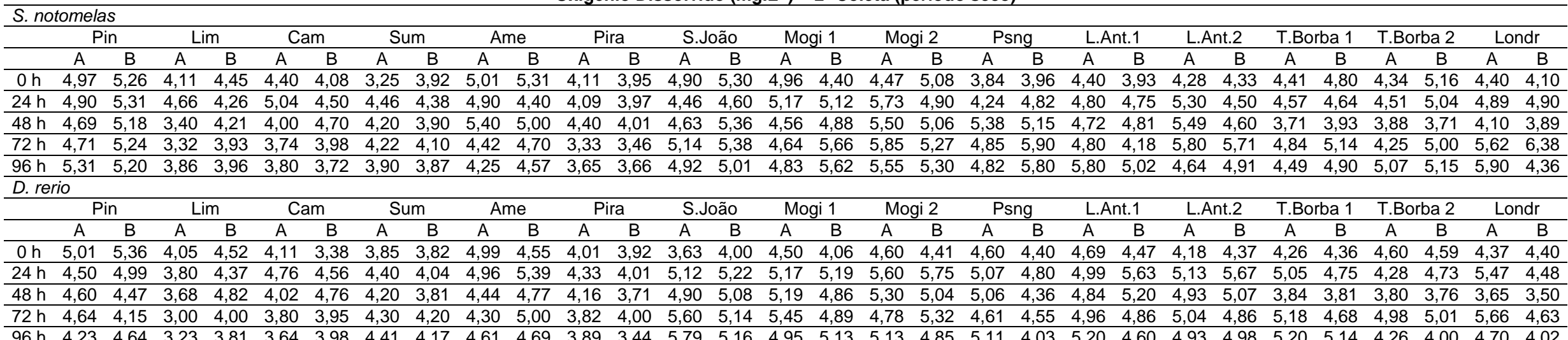

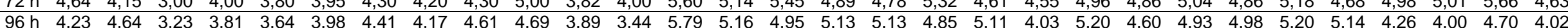


TABELA 16. Variações da temperatura da água $\left({ }^{\circ} \mathrm{C}\right)$ ao longo dos testes de toxicidade com amostras de sedimento coletadas nos períodos seco e chuvoso em diferentes localidades nas bacias dos rios Piracicaba, Mogi Guaçu e Tibagi. Pin = Rib. Pinhal; Lim = Limeira; Cam = Campinas; Sum = Sumaré; Ame = Americana; Pira = Piracicaba; S.João = São João da Boa Vista; Mogi 1 = Mogi Guaçu 1; Mogi $2=$ Mogi Guaçu 2; Psng = Pirassununga; L.Ant.1 = Luiz Antônio 1; L.Ant.2 = Luiz Antônio 2; T.Borba 1 = Telêmaco Borba 1; T.Borba 2 = Telêmaco Borba 2; Londr = Londrina.

\begin{tabular}{|c|c|c|c|c|c|c|c|c|c|c|c|c|c|c|c|c|c|c|c|c|c|c|c|c|c|c|c|c|c|c|}
\hline \multicolumn{31}{|c|}{ Temperatura $\left({ }^{\circ} \mathrm{C}\right)-1^{\mathrm{a}}$ Coleta (período chuvoso) } \\
\hline & tom & & & & & & & & & & & & & & & & & & & & & & & & & & & & & \\
\hline & \multicolumn{2}{|c|}{ Pin } & \multicolumn{2}{|c|}{ Lim } & \multicolumn{2}{|c|}{ Cam } & \multicolumn{2}{|c|}{ Sum } & \multicolumn{2}{|c|}{ Ame } & \multicolumn{2}{|c|}{ Pira } & \multicolumn{2}{|c|}{ S.João } & \multicolumn{2}{|c|}{ Mogi 1} & \multicolumn{2}{|c|}{ Mogi 2} & \multicolumn{2}{|c|}{ Psng } & \multicolumn{2}{|c|}{ L.Ant.1 } & \multicolumn{2}{|c|}{ L.Ant.2 } & \multicolumn{2}{|c|}{ T.Borba 1} & \multicolumn{2}{|c|}{ T.Borba 2} & \multicolumn{2}{|c|}{ Londr } \\
\hline & A & $B$ & A & $B$ & A & $B$ & A & $B$ & $A$ & $B$ & A & $B$ & $A$ & $B$ & A & $B$ & $A$ & $B$ & A & $B$ & $A$ & $B$ & A & $B$ & $A$ & $B$ & $A$ & $B$ & A & $B$ \\
\hline $0 \mathrm{~h}$ & 26,3 & 26,4 & 26,5 & 26,7 & 25,7 & 25,5 & 25,4 & 25,4 & 25,6 & 25,6 & 25,7 & 25,8 & 27,0 & 27,0 & 27,2 & 26,7 & 25,1 & 25,2 & 25,3 & 25,0 & 25,3 & 25,1 & 25,4 & 25,1 & 24,4 & 24,5 & 24,0 & 24,0 & 23,9 & 23,9 \\
\hline $24 \mathrm{~h}$ & 24,2 & 24,4 & 23,9 & 23,9 & 23,9 & 23,9 & 23,9 & 23,9 & 24,0 & 24,0 & 23,9 & 23,9 & 24,6 & 24,8 & 24,5 & 24,5 & 26,6 & 26,4 & 26,6 & 26,4 & 24,4 & 24,5 & 24,3 & 24,2 & 24,0 & 24,0 & 24,0 & 24,0 & 24,0 & 23,9 \\
\hline $48 \mathrm{~h}$ & 24,2 & 24,2 & 24,3 & 24,2 & 24,1 & 24,2 & 24,1 & 24,1 & 24,1 & 24,1 & 24,1 & 24,1 & 24,1 & 24,4 & 23,8 & 23,9 & 24,1 & 24,1 & 24,2 & 24,3 & 24,8 & 24,8 & 25,2 & 25,1 & 22,9 & 22,8 & 22,9 & 22,9 & 22,8 & 22,8 \\
\hline $72 \mathrm{~h}$ & 23,0 & 23,2 & 23,0 & 23,0 & 23,9 & 23,8 & 24,2 & 24,1 & 25,5 & 25,2 & 26,0 & 25,9 & 23,6 & 24,1 & 23,2 & 23,3 & 24,6 & 24,5 & 24,8 & 24,7 & 23,9 & 23,9 & 24,0 & 24,0 & 23,0 & 23,0 & 23,0 & 23,0 & 23,1 & 23,0 \\
\hline $96 \mathrm{~h}$ & 24,5 & 24,6 & 24,5 & 24,3 & 24,8 & 24,5 & 25,4 & 25,0 & 25,8 & 25,5 & 26,0 & 25,7 & 23,4 & 23,7 & 23,3 & 23,3 & 24,9 & 24,7 & 25,1 & 25,0 & 24,5 & 24,4 & 24,6 & 24,5 & 22,6 & 22,6 & 22,7 & 22,7 & 22,7 & 22,6 \\
\hline \multicolumn{31}{|c|}{ D. rerio } \\
\hline & \multicolumn{2}{|c|}{ Pin } & \multicolumn{2}{|c|}{ Lim } & \multicolumn{2}{|c|}{ Cam } & \multicolumn{2}{|c|}{ Sum } & \multicolumn{2}{|c|}{ Ame } & \multicolumn{2}{|c|}{ Pira } & \multirow{2}{*}{\multicolumn{2}{|c|}{ S.João }} & \multicolumn{2}{|c|}{ Mogi 1} & Mo & & & $\mathrm{ng}$ & L.A & nt.1 & L.A & nt.2 & T.Bo & ba 1 & T.Bo & rba 2 & Lol & $\mathrm{ddr}$ \\
\hline & A & $B$ & $A$ & $B$ & $A$ & $B$ & $A$ & $B$ & $A$ & $B$ & $A$ & $B$ & & & $A$ & $B$ & $A$ & $B$ & A & $B$ & A & $B$ & A & $B$ & A & $B$ & $A$ & $B$ & $A$ & $B$ \\
\hline $0 \mathrm{~h}$ & 26,6 & 26,6 & 27,0 & 26,9 & 25,5 & 25,5 & 25,5 & 25,5 & 25,7 & 25,8 & 25,8 & 25,8 & 27,2 & 27,1 & 27,4 & 27,0 & 24,9 & 24,8 & 25,1 & 24,9 & 25,4 & 25,4 & 25,3 & 25,2 & 24,2 & 24,2 & 24,0 & 23,9 & 23,9 & 23,9 \\
\hline $24 \mathrm{~h}$ & 24,1 & 24,1 & 23,9 & 23,9 & 24,0 & 23,9 & 23,9 & 23,9 & 24,0 & 24,0 & 23,9 & 23,9 & 24,5 & 24,5 & 24,4 & 24,4 & 26,7 & 26,5 & 26,7 & 26,6 & 24,2 & 24,2 & 24,4 & 24,3 & 24,1 & 24,1 & 24,0 & 24,0 & 23,9 & 23,9 \\
\hline $48 \mathrm{~h}$ & 24,1 & 24,2 & 24,6 & 24,4 & 24,1 & 24,1 & 24,2 & 24,1 & 24,0 & 24,0 & 24,2 & 24,1 & 23,9 & 23,9 & 23,8 & 23,7 & 24,0 & 24,0 & 24,1 & 24,1 & 25,0 & 24,9 & 25,1 & 25,0 & 23,0 & 23,0 & 22,8 & 22,8 & 22,8 & 22,7 \\
\hline $72 \mathrm{~h}$ & 23,0 & 23,0 & 22,9 & 22,9 & 24,1 & 24,0 & 24,3 & 24,3 & 25,7 & 25,6 & 26,2 & 26,0 & 23,3 & 23,3 & 23,1 & 23,1 & 24,8 & 24,8 & 25,1 & 24,8 & 23,9 & 23,8 & 24,0 & 23,9 & 23,1 & 23,1 & 23,1 & 23,0 & 23,1 & 23,0 \\
\hline $96 \mathrm{~h}$ & 24,4 & 24,5 & 24,6 & 24,5 & 25,1 & 25,0 & 25,4 & 25,2 & 26,0 & 25,8 & 26,5 & 26,0 & 23,3 & 23,3 & 23,2 & 23,2 & 25,0 & 25,0 & 25,3 & 25,1 & 24,5 & 24,4 & 24,7 & 24,5 & 22,7 & 22,7 & 22,7 & 22,6 & 22,6 & 22,6 \\
\hline
\end{tabular}
Temperatura $\left({ }^{\circ} \mathrm{C}\right)-2^{\mathrm{a}}$ Coleta (período seco)

\begin{tabular}{|c|c|c|c|c|c|c|c|c|c|c|c|c|c|c|c|c|c|c|c|c|c|c|c|c|c|c|c|c|c|c|}
\hline \multicolumn{31}{|c|}{ emperatura $\left({ }^{\circ} \mathrm{C}\right)-2^{\mathrm{a}}$ Coleta (período seco) } \\
\hline & & & & & & & & & & & & & & & & & & & & & & & & & & & & & & \\
\hline & \multicolumn{2}{|c|}{ Pin } & \multicolumn{2}{|c|}{ Lim } & \multicolumn{2}{|c|}{ Cam } & \multicolumn{2}{|c|}{ Sum } & \multicolumn{2}{|c|}{ Ame } & \multicolumn{2}{|c|}{ Pira } & \multicolumn{2}{|c|}{ S.João } & \multicolumn{2}{|c|}{ Mogi 1} & \multicolumn{2}{|c|}{ Mogi 2} & \multicolumn{2}{|c|}{ Psng } & \multicolumn{2}{|c|}{ L.Ant.1 } & \multicolumn{2}{|c|}{ L.Ant.2 } & \multicolumn{2}{|c|}{ T.Borba 1} & \multicolumn{2}{|c|}{ T.Borba 2} & \multicolumn{2}{|c|}{ Londr } \\
\hline & A & $B$ & $\mathrm{~A}$ & $B$ & $\mathrm{~A}$ & $B$ & $\mathrm{~A}$ & $\mathrm{~B}$ & $\mathrm{~A}$ & $B$ & $A$ & $B$ & $A$ & B & $A$ & $\mathrm{~B}$ & $A$ & $B$ & A & B & $A$ & $B$ & $A$ & $B$ & $A$ & $B$ & $A$ & $B$ & $\mathrm{~A}$ & $B$ \\
\hline $\mathrm{Oh}$ & 23,3 & 23,4 & 23,0 & 23,0 & 23,1 & 23,1 & 23,0 & 23,0 & 23,2 & 23,1 & 23,0 & 23,0 & 23,3 & 23,4 & 23,0 & 23,0 & 23,1 & 23,1 & 23,0 & 23,0 & 23,2 & 23,1 & 23,0 & 23,0 & 23,9 & 24,0 & 23,8 & 23,8 & 23,8 & 23,8 \\
\hline $24 \mathrm{~h}$ & 3,5 & 3,6 & 7 & n & & 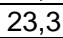 & & 2 & & & & & & 23 & 2 & & & & & 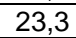 & 4 & 23, & 2 & & 0 & 24,1 & 0 & 1 & 23,9 & \\
\hline $48 \mathrm{~h}$ & 3,9 & 24,1 & 3,7 & 23,7 & & 3,8 & 7 & 23,7 & 7 & 23,7 & & & & 24,1 & 3,7 & & & 23 & 7 & 2 & 3,7 & 23 & 3,6 & 23 & 4,1 & 24 & 4,1 & 24,1 & 24,1 & 1 \\
\hline $72 \mathrm{~h}$ & 3,6 & 23,9 & 3,5 & 23,5 & 3 & 23,4 & 3,4 & 23,4 & 4 & 23,4 & 3 & 23,3 & 6 & 23,9 & 23,5 & 23,5 & 3,5 & 23,4 & 3,4 & 23,4 & 23,4 & 23,4 & 23,3 & 23,3 & 24,1 & 24,1 & 23,8 & 23,8 & 23,8 & 23,9 \\
\hline $96 \mathrm{~h}$ & 23,6 & 23,9 & 3,4 & 23,4 & 3,6 & 23,5 & 3,4 & 23,4 & 23,5 & 23,4 & 3,4 & 23,4 & 3,6 & 23,9 & 23,4 & 23 & 3,6 & 23, & , & 23,4 & 23,5 & 23 & 23,4 & 23 & 23,8 & 23,1 & 23,7 & 23,7 & 23,7 & 23,6 \\
\hline \multicolumn{31}{|c|}{ D. rerio } \\
\hline & \multicolumn{2}{|c|}{ Pin } & \multicolumn{2}{|c|}{ Lim } & \multicolumn{2}{|c|}{ Cam } & \multicolumn{2}{|c|}{ Sum } & \multicolumn{2}{|c|}{ Ame } & \multicolumn{2}{|c|}{ Pira } & \multicolumn{2}{|c|}{ S.João } & \multicolumn{2}{|c|}{ Mogi 1} & Mo & & & ing & L.A & & L.A & & T.BC & ba 1 & T.Bo & ba 2 & & $n d r$ \\
\hline & A & B & A & B & A & B & A & B & A & B & A & B & A & B & A & $B$ & A & $B$ & A & B & A & B & A & $B$ & A & B & A & B & A & B \\
\hline $\mathrm{h}$ & 22,5 & 22,5 & 22,3 & 22,3 & 22,4 & 22,3 & 2 & 223 & 22,5 & 225 & 20 & 22 & 23,0 & 23,0 & 22,9 & 23 & 23,0 & 23 & & 23, & 23,0 & 23,1 & 22,9 & & 23,8 & 23,8 & 23,8 & 23,8 & 23,8 & 238 \\
\hline $4 \mathrm{~h}$ & 2,6 & 22,6 & 2,5 & 22,5 & 7 & 2,5 & 6 & 2,6 & 7 & 2,6 & 6 & 5 &, 3 & 23,3 & 1 & 23 & 23,2 & 23 & 1 & 23 & 23,2 & 23 & 23 & 23,1 & 23,8 & 23,9 & 23,9 & 23,9 & 23,8 & 8 \\
\hline $48 \mathrm{~h}$ & 23,0 & 23,0 & 22,8 & 22,8 & 3,0 & 22,9 & 23,0 & 22,9 & 23,1 & 23,1 & 23,0 & 23,0 & 23,7 & 23,7 & 23,7 & 23,6 & 23,6 & 23 & 23,7 & 23, & 23,7 & 23, & 23,7 & 23 & 24,1 & 24 & 24,1 & 24,1 & 24,1 & 24,1 \\
\hline $72 \mathrm{~h}$ & 3,3 & 23,3 & 3,2 & 23,2 & 3,3 & 23,2 & 23,3 & 3,3 & 23,5 & 23,4 & 23,3 & 23,4 & 3,5 & 23,5 & 23,4 & 23,4 & 23,4 & 23,3 & 23,4 & 23,4 & 23,3 & 23,3 & 23,4 & 23,3 & 23,9 & 23,9 & 23,9 & 23,8 & 23,8 & 23,8 \\
\hline $96 \mathrm{~h}$ & 23,4 & 23,5 & 23,5 & 23,5 & 23,3 & 23,3 & 23,5 & 23,5 & 23,6 & 23,6 & 23,4 & 23,5 & 23,4 & 23,5 & 23,4 & 23,4 & 23,5 & 23,5 & 23,5 & 23,4 & 23,4 & 23,4 & 23,4 & 23,4 & 23,8 & 23,8 & 23,8 & 23,7 & 23,7 & 23,7 \\
\hline
\end{tabular}


TABELA 17. Variações dos valores da dureza da água $\left(\mathrm{mg} \mathrm{CaCO}_{3} \cdot \mathrm{L}^{-1}\right)$ no início (Oh) e ao final (96h) dos testes de toxicidade com amostras de sedimento coletadas nos períodos seco e chuvoso em diferentes localidades nas bacias dos rios Piracicaba, Mogi Guaçu e Tibagi. Pin = Rib. Pinhal; Lim = Limeira; Cam = Campinas; Sum = Sumaré; Ame = Americana; Pira = Piracicaba; S.João = São João da Boa Vista; Mogi $1=$ Mogi Guaçu 1; Mogi 2 = Mogi Guaçu 2; Psng = Pirassununga; L.Ant.1 = Luiz Antônio 1; L.Ant.2 = Luiz Antônio 2; T.Borba 1 = Telêmaco Borba 1; T.Borba $2=$ Telêmaco

Borba 2; Londr = Londrina.

\section{Dureza $\left(\mathrm{mg} \mathrm{CaCO}_{3} \cdot \mathrm{L}^{-1}\right)$ - $1^{\mathrm{a}}$ Coleta (período chuvoso)}

\begin{tabular}{|c|c|c|c|c|c|c|c|c|c|c|c|c|c|c|c|c|c|c|c|c|c|c|c|c|c|c|c|c|c|c|}
\hline \multicolumn{31}{|c|}{ S. notomelas } \\
\hline & \multicolumn{2}{|c|}{ Pin } & \multicolumn{2}{|c|}{ Lim } & \multicolumn{2}{|c|}{ Cam } & \multicolumn{2}{|c|}{ Sum } & \multicolumn{2}{|c|}{ Ame } & \multicolumn{2}{|c|}{ Pira } & \multicolumn{2}{|c|}{ S.João } & \multicolumn{2}{|c|}{ Mogi 1} & \multicolumn{2}{|c|}{ Mogi 2} & \multicolumn{2}{|c|}{ Psng } & \multicolumn{2}{|c|}{ L.Ant.1 } & \multicolumn{2}{|c|}{ L.Ant.2 } & \multicolumn{2}{|c|}{ T.Borba 1} & \multicolumn{2}{|c|}{ T.Borba 2} & \multicolumn{2}{|c|}{ Londr } \\
\hline & A & $B$ & A & $B$ & $A$ & B & A & B & A & B & A & B & A & B & A & $\mathrm{B}$ & A & B & A & B & $A$ & B & A & B & A & $B$ & A & B & $A$ & $B$ \\
\hline $\mathrm{Oh}$ & 78 & 82 & 82 & 78 & 103 & 99 & 111 & 111 & 78 & 78 & 74 & 78 & 70 & 66 & 74 & 70 & 70 & 70 & 78 & 74 & 54 & 54 & 58 & 62 & 67 & 67 & 67 & 72 & 72 & 72 \\
\hline $96 \mathrm{~h}$ & 82 & 82 & 87 & 87 & 120 & 124 & 132 & 124 & 74 & 78 & 78 & 82 & 70 & 66 & 74 & 74 & 66 & 49 & 70 & 74 & 49 & 45 & 58 & 41 & 63 & 51 & 63 & 63 & 59 & 55 \\
\hline \multicolumn{31}{|c|}{ D. rerio } \\
\hline & \multicolumn{2}{|c|}{ Pin } & \multicolumn{2}{|c|}{ Lim } & \multicolumn{2}{|c|}{ Cam } & \multicolumn{2}{|c|}{ Sum } & \multicolumn{2}{|c|}{ Ame } & \multicolumn{2}{|c|}{ Pira } & \multicolumn{2}{|c|}{ S.João } & \multicolumn{2}{|c|}{ Mogi 1} & \multicolumn{2}{|c|}{ Mogi 2} & \multicolumn{2}{|c|}{ Psng } & \multicolumn{2}{|c|}{ L.Ant.1 } & \multicolumn{2}{|c|}{ L.Ant.2 } & T.B & ba 1 & T.B & ba 2 & & \\
\hline & $A$ & $\mathrm{~B}$ & $A$ & $\mathrm{~B}$ & $A$ & $B$ & A & $B$ & $A$ & $B$ & A & B & $A$ & $B$ & A & $\mathrm{B}$ & $A$ & B & $A$ & B & $A$ & $B$ & $A$ & $B$ & $A$ & $B$ & A & $B$ & $A$ & $B$ \\
\hline $0 \mathrm{~h}$ & 82 & 82 & 82 & 82 & 99 & 99 & 115 & 107 & 78 & 78 & 82 & 82 & 62 & 70 & 74 & 70 & 62 & 70 & 74 & 78 & 58 & 54 & 66 & 66 & 72 & 67 & 72 & 76 & 67 & 63 \\
\hline $96 \mathrm{~h}$ & 87 & 82 & 87 & 95 & 128 & 128 & 128 & 132 & 74 & 74 & 74 & 70 & 62 & 66 & 74 & 74 & 58 & 54 & 70 & 74 & 41 & 45 & 54 & 45 & 59 & 59 & 59 & 63 & 55 & 46 \\
\hline
\end{tabular}

Dureza ( $\left.\mathrm{mg} \mathrm{CaCO}_{3} \cdot \mathrm{L}^{-1}\right)-2^{\mathrm{a}}$ Coleta (período seco)

\begin{tabular}{|c|c|c|c|c|c|c|c|c|c|c|c|c|c|c|c|c|c|c|c|c|c|c|c|c|c|c|c|c|c|c|}
\hline \multicolumn{31}{|c|}{ Dureza $\left(\mathrm{mg} \mathrm{CaCO}_{3} \cdot \mathrm{L}^{-1}\right)-2^{\mathrm{a}}$ Coleta (período seco) } \\
\hline \multicolumn{31}{|c|}{ S. notomelas } \\
\hline & \multicolumn{2}{|c|}{ Pin } & \multicolumn{2}{|c|}{ Lim } & \multicolumn{2}{|c|}{ Cam } & \multicolumn{2}{|c|}{ Sum } & \multicolumn{2}{|c|}{ Ame } & \multicolumn{2}{|c|}{ Pira } & \multicolumn{2}{|c|}{ S.João } & \multicolumn{2}{|c|}{ Mogi 1} & \multicolumn{2}{|c|}{ Mogi 2} & \multicolumn{2}{|c|}{ Psng } & \multicolumn{2}{|c|}{ L.Ant.1 } & \multicolumn{2}{|c|}{ L.Ant.2 } & \multicolumn{2}{|c|}{ T.Borba 1} & \multicolumn{2}{|c|}{ T.Borba 2} & \multicolumn{2}{|c|}{ Londr } \\
\hline & A & $\mathrm{B}$ & A & B & A & B & A & $B$ & A & B & A & $\mathrm{B}$ & A & B & A & $\mathrm{B}$ & A & B & A & B & A & $\mathrm{B}$ & A & $\mathrm{B}$ & A & B & A & B & A & $\mathrm{B}$ \\
\hline $\mathrm{Oh}$ & 82 & 82 & 128 & 120 & 87 & 95 & 91 & 91 & 82 & 82 & 91 & 82 & 80 & 80 & 80 & 88 & 84 & 84 & 97 & 97 & 88 & 88 & 93 & 93 & 88 & 110 & 110 & 110 & 72 & 76 \\
\hline $96 \mathrm{~h}$ & 58 & 62 & 148 & 144 & 95 & 95 & 115 & 120 & 82 & 87 & 120 & 115 & 76 & 76 & 80 & 84 & 84 & 80 & 80 & 72 & 72 & 80 & 72 & 76 & 76 & 105 & 118 & 126 & 59 & 51 \\
\hline \multicolumn{31}{|c|}{ D. rerio } \\
\hline & \multicolumn{2}{|c|}{ Pin } & \multicolumn{2}{|c|}{ Lim } & \multicolumn{2}{|c|}{ Cam } & \multicolumn{2}{|c|}{ Sum } & \multicolumn{2}{|c|}{ Ame } & \multicolumn{2}{|c|}{ Pira } & \multicolumn{2}{|c|}{ S.João } & \multicolumn{2}{|c|}{ Mogi 1} & \multicolumn{2}{|c|}{ Mogi 2} & \multicolumn{2}{|c|}{ Psng } & & & & & T.BC & ba 1 & T.Bo & ba 2 & & \\
\hline & $A$ & $B$ & $A$ & $B$ & A & $B$ & A & $B$ & $A$ & $B$ & A & $B$ & $A$ & $B$ & $A$ & $\mathrm{~B}$ & A & $B$ & A & $B$ & A & $B$ & A & $B$ & $A$ & $B$ & $A$ & $B$ & $A$ & $B$ \\
\hline $\mathrm{Oh}$ & 70 & 78 & 99 & 82 & 82 & 87 & 82 & 91 & 99 & 74 & 95 & 87 & 84 & 84 & 88 & 88 & 84 & 84 & 101 & 93 & 97 & 93 & 93 & 84 & 101 & 105 & 105 & 105 & 76 & 72 \\
\hline $96 \mathrm{~h}$ & 66 & 66 & 140 & 91 & 95 & 91 & 111 & 115 & 82 & 78 & 115 & 115 & 72 & 72 & 72 & 84 & 84 & 84 & 72 & 76 & 80 & 72 & 76 & 67 & 84 & 93 & 126 & 122 & 59 & 51 \\
\hline
\end{tabular}


TABELA 18. Variações das concentrações de amônia não-ionizada na água ( $\mu$ g $\mathrm{NH}_{3} \cdot \mathrm{L}^{-1}$ ) ao longo dos testes de toxicidade com amostras de sedimento coletadas nos períodos seco e chuvoso em diferentes localidades nas bacias dos rios Piracicaba, Mogi Guaçu e Tibagi. Pin = Rib. Pinhal; Lim = Limeira; Cam = Campinas; Sum = Sumaré; Ame = Americana; Pira = Piracicaba; S.João = São João da Boa Vista; Mogi 1 = Mogi Guaçu 1; Mogi 2 = Mogi Guaçu 2; Psng = Pirassununga; L.Ant.1 = Luiz Antônio 1; L.Ant.2 = Luiz Antônio 2; T.Borba 1 = Telêmaco Borba 1; T.Borba 2 = Telêmaco Borba 2; Londr = Londrina .

\begin{tabular}{|c|c|c|c|c|c|c|c|c|c|c|c|}
\hline \multicolumn{12}{|c|}{ 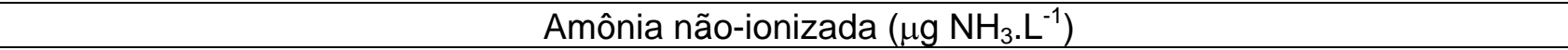 } \\
\hline \multicolumn{6}{|c|}{ Período Chuvoso } & \multicolumn{6}{|c|}{ Período Seco } \\
\hline & & \multicolumn{2}{|c|}{ S. notomelas } & \multicolumn{2}{|c|}{ D. rerio } & & & \multicolumn{2}{|c|}{ S. notomelas } & \multicolumn{2}{|c|}{ D. rerio } \\
\hline & & Oh & $96 \mathrm{~h}$ & Oh & $96 \mathrm{~h}$ & & & Oh & $96 h$ & Oh & $96 \mathrm{~h}$ \\
\hline \multirow{2}{*}{ Rib. Pinhal } & A & 0,3 & 8,4 & 0,0 & 4,1 & \multirow{2}{*}{ Rib. Pinhal } & A & 8,2 & 0,3 & 36,3 & 31,8 \\
\hline & $\mathrm{B}$ & 1,0 & 15,4 & 0,0 & 8,3 & & $\mathrm{~B}$ & 71,2 & 5,9 & - & 15,4 \\
\hline \multirow{2}{*}{ Limeira } & A & 33,6 & 0,9 & 44,4 & 1,6 & \multirow{2}{*}{ Limeira } & A & 159,1 & 2,6 & 118,9 & 161,1 \\
\hline & $\mathrm{B}$ & 70,3 & 1,0 & 41,0 & 10,7 & & $\mathrm{~B}$ & 152,4 & 16,4 & 111,4 & 45,6 \\
\hline \multirow{2}{*}{ Campinas } & $A$ & 91,4 & 135,7 & 67,5 & 128,6 & \multirow{2}{*}{ Campinas } & $A$ & 130,2 & 167,4 & 109,9 & 133,7 \\
\hline & $\mathrm{B}$ & 86,5 & 137,1 & 93,1 & 167,3 & & $B$ & 149,3 & 249,8 & 167,2 & 136,6 \\
\hline \multirow{2}{*}{ Sumaré } & $A$ & 108,7 & 88,4 & 78,3 & 46,2 & \multirow{2}{*}{ Sumaré } & $A$ & 117,1 & 54,0 & 141,7 & 291,3 \\
\hline & $\mathrm{B}$ & 90,7 & 55,1 & 79,1 & 57,9 & & $\mathrm{~B}$ & 135,6 & 78,6 & 97,1 & 252,9 \\
\hline \multirow{2}{*}{ Americana } & $A$ & 25,3 & 0,3 & 36,9 & 0,2 & \multirow{2}{*}{ Americana } & $A$ & 38,6 & 0,1 & 58,3 & 72,4 \\
\hline & $\mathrm{B}$ & 41,7 & 1,1 & 35,1 & 0,3 & & $\mathrm{~B}$ & 30,7 & 0,1 & 33,3 & 28,2 \\
\hline \multirow{2}{*}{ Piracicaba } & $A$ & 0,0 & 16,9 & 5,5 & 14,1 & \multirow{2}{*}{ Piracicaba } & $A$ & 101,7 & 14,3 & 92,7 & 280,1 \\
\hline & $\mathrm{B}$ & 6,0 & 16,9 & 2,0 & 4,7 & & $B$ & 33,0 & 1,5 & 84,4 & 263,0 \\
\hline \multirow{2}{*}{ S. João } & $A$ & 0,0 & 8,1 & 0,0 & 0,0 & \multirow{2}{*}{ S. João } & $A$ & 0,0 & 4,5 & 0,0 & 2,9 \\
\hline & $\mathrm{B}$ & 0,0 & 12,3 & 0,0 & 0,0 & & $\mathrm{~B}$ & 0,0 & 4,2 & 0,1 & 3,9 \\
\hline \multirow{2}{*}{ Mogi 1} & $A$ & 0,0 & 25,8 & 0,0 & 8,1 & \multirow{2}{*}{ Mogi 1} & $A$ & 4,8 & 2,9 & 4,1 & 0,4 \\
\hline & $\mathrm{B}$ & 0,0 & 33,3 & 0,0 & 9,0 & & $\mathrm{~B}$ & 3,3 & 3,5 & 8,2 & 0,5 \\
\hline \multirow{2}{*}{ Mogi 2} & $A$ & 3,7 & 16,5 & 0,0 & 1,1 & \multirow{2}{*}{ Mogi 2} & $A$ & 11,3 & 10,4 & 11,2 & 2,3 \\
\hline & $\mathrm{B}$ & 1,8 & 13,2 & 0,0 & 0,4 & & $\mathrm{~B}$ & 12,3 & 6,1 & 11,7 & 18,6 \\
\hline \multirow{2}{*}{ Pirassun. } & $A$ & 0,0 & 45,9 & 0,0 & 1,3 & & $A$ & 12,2 & 6,8 & 15,7 & 1,6 \\
\hline & $\mathrm{B}$ & 0,7 & 30,1 & 2,0 & 5,5 & Pirassun. & $B$ & 17,5 & 1,9 & 10,7 & 8,9 \\
\hline & $A$ & 10,9 & 9,3 & 4,0 & 2,4 & & $A$ & 16,3 & 21,3 & 14,3 & 120,8 \\
\hline L. Antonio $\perp$ & $\mathrm{B}$ & 6,3 & 5,9 & 0,0 & 2,3 & $\mathrm{~L}$ & $\mathrm{~B}$ & 13,7 & 16,3 & 11,7 & 47,2 \\
\hline I Antônin ? & $A$ & 0,0 & 3,9 & 1,6 & 0,0 & । Antônin 2 & $A$ & 22,9 & 2,5 & 17,6 & 2,5 \\
\hline L. Antonio 2 & $\mathrm{~B}$ & 0,0 & 0,0 & 0,0 & 0,0 & L. Antonio L & $B$ & 16,5 & 4,0 & 19,1 & 0,0 \\
\hline & $A$ & 0,0 & 13,2 & 0,0 & - & & $A$ & 2,6 & 12,9 & 5,9 & 21,9 \\
\hline oa 1 & $B$ & 0,0 & 14,3 & 0,0 & 0,4 & 1 & $B$ & 9,5 & 13,9 & 3,7 & 13,4 \\
\hline T. Borba 2 & $A$ & 0,0 & 18,9 & 0,0 & 0,0 & & $A$ & 13,8 & 19,3 & 15,7 & 73,7 \\
\hline 1. Borna 2 & $\mathrm{~B}$ & 0,0 & 11,2 & 0,0 & 0,0 & 1. Borba 2 & $B$ & 15,7 & 22,8 & 17,8 & 13,0 \\
\hline 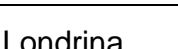 & $A$ & 0,0 & 9,8 & 4,1 & 0,0 & & $A$ & 10,7 & 0,4 & 11,6 & 0,6 \\
\hline Lomumia & B & 0,0 & 3,1 & 4,8 & 0,0 & Lonarina & $B$ & 14,9 & 0,3 & 10,2 & 2,8 \\
\hline
\end{tabular}




\subsubsection{Alterações histológicas mais freqüentes observadas nos peixes expostos às amostras de sedimento dos locais de estudo.}

Embora as amostras de efluente não tenham apresentado toxicidade aguda à S. notomelas ou a $D$. rerio, foram observadas alterações histológicas nos rins, fígado e brânquias desses peixes. A partir da sistematização dessas alterações foi possível, então, calcular o Índice de Alterações Histológicas, IAH e o Valor Médio de Alterações, VMA. Os resultados estão representados nos gráficos das figuras 28 a 30 . É importante lembrar que a referência para as comparações são os locais controle de cada bacia, sendo o Ribeirão Pinhal para a do Piracicaba, a estação S. João (rio Jaguari-Mirim) para a do Mogi Guaçu e o local Telêmaco Borba 1 (rio Tibagi) para a do Tibagi.

Como é possível observar nessas figuras, o sedimento coletado na estação de captação de água de Sumaré, no rio Atibaia, causou alterações histológicas significativas nas brânquias, rim e fígado das duas espécies, conforme indicam ambos os índices utilizados. Os animais (das duas espécies) expostos ao sedimento proveniente do rio Piracicaba, em Piracicaba, apresentaram alterações significativas nas brânquias e rim, refletidas nos valores de ambos os índices, com exceção das alterações nas brânquias de $D$. rerio representadas pelo VMA. No fígado, o sedimento dessa localidade causou alterações significativas apenas em S. notomelas, e somente de acordo com o IAH. O sedimento proveniente da captação de água de Americana, também no rio Piracicaba, provocou alterações histológicas branquiais significativas em $D$. rerio, as quais podem ser constatadas pelos valores do IAH e do VMA. O sedimento da captação de Campinas no rio Atibaia provocou alterações renais importantes em ambas as espécies, produzindo, com exceção do IAH para $S$. notomelas, índices significativamente diferentes daqueles para o local controle. Assim como o sedimento do rio Atibaia, da localidade de Campinas, aquele da localidade de Limeira (rio Jaguari) também causou apenas alterações renais, representadas pelos valores do IAH de S. notomelas e VMA de $D$. rerio.

Com relação às localidades estudadas na bacia do rio Mogi Guaçu, as únicas alterações histológicas significativas foram observadas no rim (IAH) e no fígado (IAH e VMA) de D. rerio exposto ao sedimento de Mogi Guaçu 2. Quanto às amostras provenientes da bacia do rio Tibagi, embora tenham sido observadas algumas alterações importantes, especialmente nas brânquias dos peixes expostos ao tratamento Telêmaco Borba 2, estas não produziram valores de VMA ou do IAH significativos.

Nas tabelas 19 a 21, é possível observar as alterações mais freqüentes em cada órgão e os locais cujos sedimentos acarretaram a maior variedade e intensidade 
de alterações. Os dados brutos das análises histológicas encontram-se nos anexos, a partir da tabela 28.

Nas brânquias de S. notomelas , a congestão vascular e o desprendimento das células do epitélio (figura 31) das lamelas secundárias foram observadas em todos os peixes expostos às amostras de todos os locais. No entanto, a primeira alteração foi a mais freqüente, aparecendo sempre em, no mínimo $60 \%$ dos peixes analisados em cada localidade, ou seja, 3 de 5 peixes expostos. Importantes alterações observadas com freqüência também foram a dilatação e a desorganização dos capilares das lamelas secundárias (figura 31), a hiperplasia das células epiteliais na base e ao longo dessas lamelas, com a conseqüente fusão parcial de algumas delas (figuras 32 e 33). Células mucosas hiperplásicas e hipertrofiadas foram observadas com freqüência, assim como a presença de muco entre as lamelas secundárias (figuras 33 e 35). Dentre as alterações branquiais consideradas de grau II foram observadas apenas rupturas epiteliais e aneurismas (figura 38). Nenhum organismo apresentou alterações de grau III nas brânquias.

Um padrão semelhante de alterações pôde ser observado nas brânquias de $D$. rerio com relação às alterações nos vasos sangüíneos, porém com menores freqüências. Embora muito presentes, as alterações nas células epiteliais também foram menos freqüentes em $D$. rerio, com exceção da hipertrofia, que foi observada em maior freqüência. As alterações nas células mucosas foram quase ausentes nessa espécie. Com relação às alterações de grau II, também foram observados aneurismas (figura 34, que também mostra grande proliferação celular, com fusão completa de lamelas) e ruptura epitelial em um exemplar de $D$. rerio (figura 36). Da mesma forma que na outra espécie, em $D$. rerio também não foi observada necrose ou fibrose nas brânquias.

As alterações renais de grau I mais freqüentes, conforme pode ser observado na tabela 20, foram, para S. notomelas, a dilatação dos capilares glomerulares (que levou, algumas vezes, à diminuição do espaço da cápsula de Bowman), a degeneração hialina leve, a hipertrofia das células tubulares, a desorganização tubular e a ocorrência de túbulos em regeneração e de novos néfrons. Quanto às alterações de grau II, as alterações mais freqüentes foram a degeneração hialina severa, a degeneração tubular e a degeneração glomerular, sendo esta última menos ocorrente. Foi observada, ainda nessa espécie, a ocorrência de necrose em um animal exposto à amostra proveniente de Luiz Antônio 1.

Em D. rerio, além das alterações renais descritas para $S$. notomelas, foi observada hiperemia em peixes de praticamente todos os tratamentos, exceto Ribeirão do Pinhal e Londrina. O aumento do lúmen tubular foi uma alteração 
observada em poucos tratamentos, porém, em Sumaré foi observado no rim de todos os peixes de ambas as espécies e também em Piracicaba em $D$. rerio.

Com relação às alterações hepáticas, as mais freqüentes foram a vacuolização citoplasmática em ambas as espécies e a estagnação biliar, em $S$. notomelas e a diminuição do glicogênio, principalmente em $D$. rerio. Quanto às alterações de grau II, foram observadas degeneração e atrofia nuclear nas duas espécies, vacuolização nuclear em S. notomelas e ruptura celular em D. rerio expostos ao sedimento de Sumaré. Em D. rerio exposto ao sedimento de Mogi Guaçu 2 foram observadas degeneração citoplasmática e necrose, esta última uma alteração de grau III.

A tabela 22 sistematiza os valores (absolutos) calculados para cada índice, por órgão e por espécie de peixe.
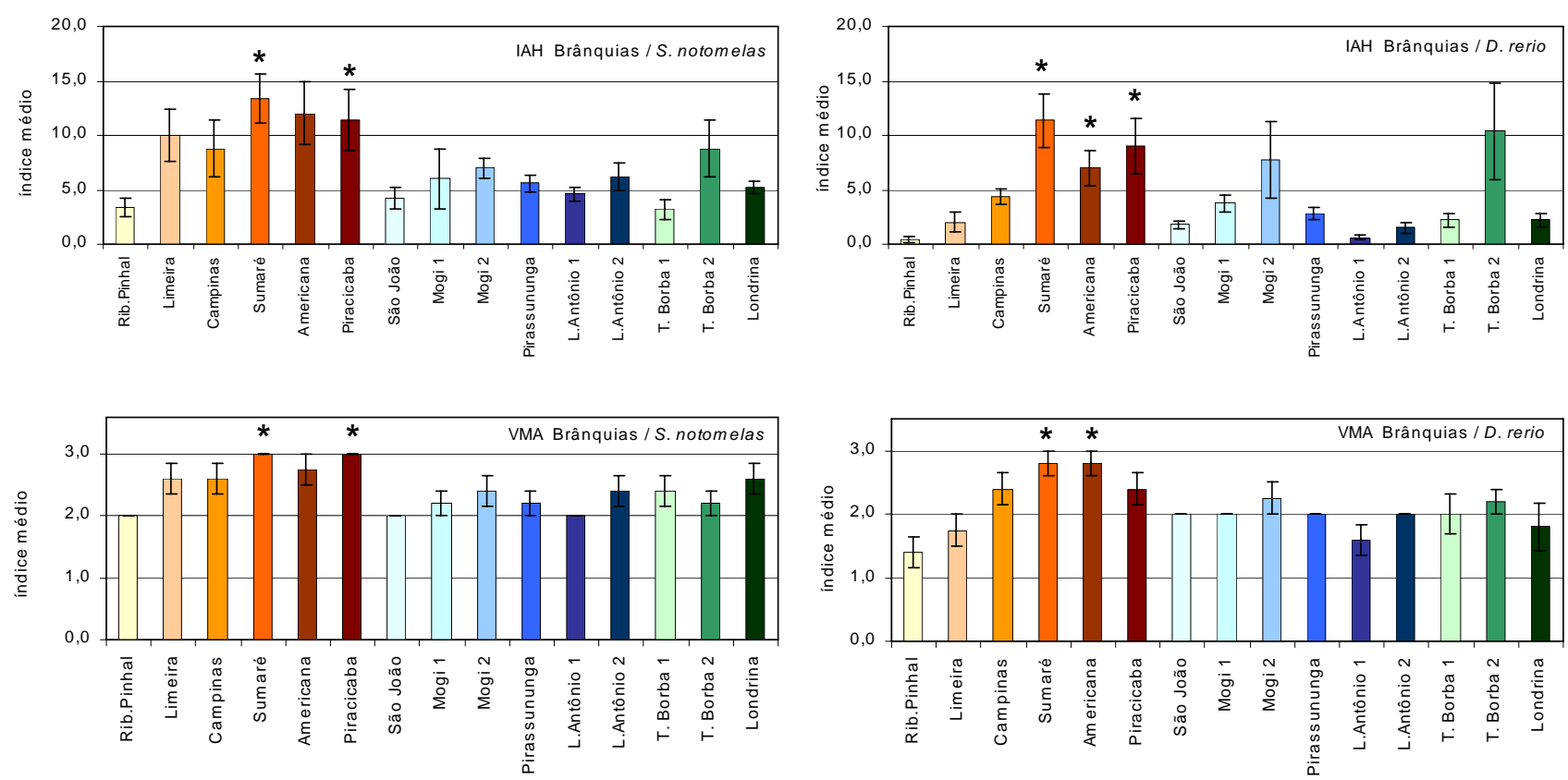

FIGURA 28: Valores do IAH e do VMA calculados a partir das alterações observadas nas brânquias de $S$. notomelas e de $D$. rerio expostos às amostras de sedimento coletadas nas diferentes localidades das bacias dos rios Piracicaba, Mogi-Guaçu e Tibagi. As barras de erros correspondem ao erro padrão da média; os asteriscos indicam diferença significativa entre a localidade referência de uma bacia e as demais localidades da mesma bacia $(P<0,05 ; N=5)$. 

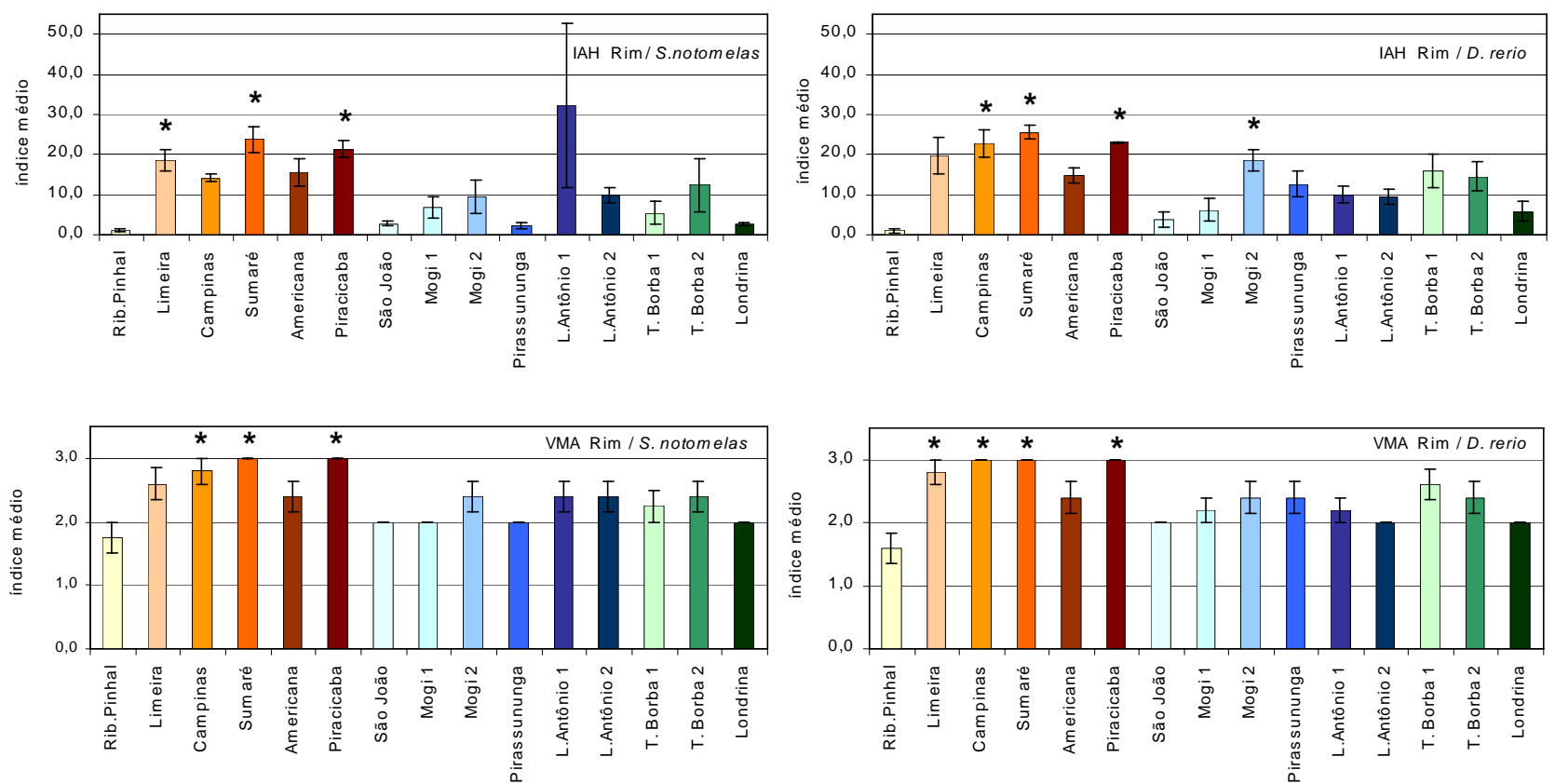

FIGURA 29: Valores do IAH e do VMA calculados a partir das alterações observadas no rim de $S$. notomelas e de $D$. rerio expostos às amostras de sedimento coletadas nas diferentes localidades das bacias dos rios Piracicaba, Mogi-Guaçu e Tibagi. As barras de erros correspondem ao erro padrão da média; os asteriscos indicam diferença significativa entre a localidade referência de uma bacia e as demais localidades da mesma bacia $(P<0,05 ; N=5)$.
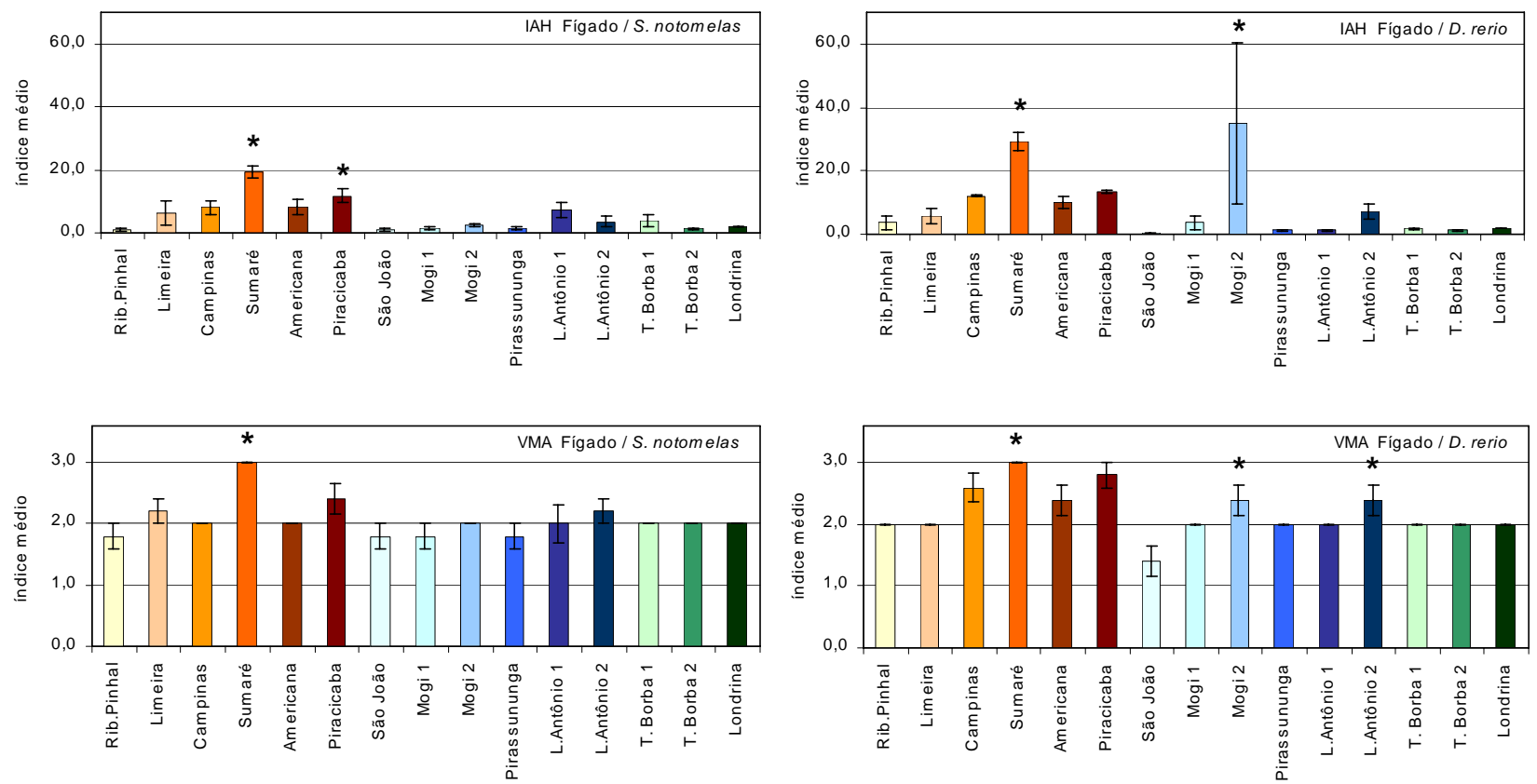

FIGURA 30: Valores do IAH e do VMA calculados a partir das alterações observadas no fígado de $S$. notomelas e de $D$. rerio expostos às amostras de sedimento coletadas nas diferentes localidades das bacias dos rios Piracicaba, Mogi-Guaçu e Tibagi. As barras de erros correspondem ao erro padrão da média; os asteriscos indicam diferença significativa entre a localidade referência de uma bacia e as demais localidades da mesma bacia $(P<0,05 ; N=5)$. 
TABELA 19: Ocorrência das alterações branquiais nos grupos de peixes das duas espécies expostos às amostras de sedimento das diferentes localidades de cada bacia. Os números representam, em porcentagens, o número de peixes que apresentaram o dano, do total de peixes analisados para cada localidade $(\mathrm{N}=5)$. HTCE=hipertrofia das células epiteliais; AdE=adelgamento do epitélio; ELS=elevação do epitélio da lamela scundária (LS); HPBLS: hiperplasia na base das LS.; HPLS=hiperplasia ao longo das LS.; LeuELS= presença de leucócitos; HP/HTCM=hiperplasia/trofia das céls. mucosas; HP/HTCC= hiperplasia/trofia das céls. cloreto; $\mathrm{CCLS}=$ céls cloreto nas LS; MuLS=presença de muco entre as LS; DiC=dilatação de capilares; $\mathrm{DeC}=$ desorganização de capilares; $\mathrm{CV}=$ =congestão vascular; Par=presença de parasitas; FCalgLS=fusão completa de algumas LS; FCtodLS=fusão completa de toas as LS; $\mathrm{DC}=$ degeneração celular: $\mathrm{RE}=$ ruptura epitelial; $\mathrm{Hem}=$ hemorragia; $\mathrm{An}=$ aneurisma; Fib=fibrose; $\mathrm{N}=$ necrose.

\begin{tabular}{|c|c|c|c|c|c|c|c|c|c|c|c|c|c|c|c|c|}
\hline \multicolumn{17}{|c|}{ Serrapinnus notomelas } \\
\hline Alteração & peso & Pin & Lim & Cam & Sum & Ame & Pira & S.J. & Mog1 & Mog2 & Psng & L.A.1 & L.A.2 & T.B.1 & T.B.2 & Lon \\
\hline HTCE & I & 0 & 20 & 0 & 0 & 0 & 20 & 20 & 20 & 20 & 60 & 0 & 20 & 0 & 20 & 0 \\
\hline $\mathrm{AdE}$ & $\mathrm{I}$ & 0 & 0 & 0 & 0 & 0 & 0 & 0 & 0 & 0 & 0 & 0 & 0 & 0 & 0 & 0 \\
\hline ELS & $\mathrm{I}$ & 60 & 60 & 100 & 100 & 100 & 100 & 100 & 80 & 100 & 40 & 60 & 100 & 40 & 60 & 60 \\
\hline HPBLS & $\mathrm{I}$ & 40 & 100 & 40 & 100 & 75 & 60 & 20 & 20 & 60 & 40 & 40 & 40 & 0 & 60 & 20 \\
\hline HPLS & $\mathrm{I}$ & 40 & 60 & 20 & 60 & 50 & 40 & 20 & 20 & 60 & 20 & 40 & 40 & 0 & 20 & 40 \\
\hline FPLS & $\mathrm{I}$ & 20 & 40 & 20 & 80 & 75 & 60 & 80 & 20 & 20 & 60 & 40 & 20 & 0 & 40 & 0 \\
\hline LeuELS & I & 0 & 0 & 0 & 0 & 0 & 0 & 0 & 0 & 0 & 0 & 0 & 0 & 0 & 0 & 0 \\
\hline HP/HTCM & $\mathrm{I}$ & 60 & 80 & 80 & 40 & 50 & 80 & 20 & 20 & 80 & 100 & 40 & 40 & 0 & 0 & 20 \\
\hline HP/HTCC & $\mathrm{I}$ & 0 & 0 & 60 & 40 & 0 & 40 & 0 & 20 & 40 & 0 & 0 & 0 & 0 & 0 & 0 \\
\hline CCLS & $\mathrm{I}$ & 0 & 0 & 0 & 0 & 0 & 0 & 0 & 20 & 20 & 0 & 0 & 0 & 0 & 0 & 0 \\
\hline MuLS & $\mathrm{I}$ & 40 & 0 & 60 & 20 & 50 & 20 & 20 & 20 & 80 & 80 & 20 & 60 & 80 & 0 & 40 \\
\hline DiC & $\mathrm{I}$ & 0 & 20 & 100 & 100 & 100 & 100 & 40 & 40 & 80 & 80 & 80 & 80 & 60 & 100 & 100 \\
\hline $\mathrm{DeC}$ & I & 20 & 100 & 100 & 100 & 100 & 100 & 0 & 40 & 40 & 40 & 20 & 80 & 60 & 80 & 100 \\
\hline $\mathrm{CV}$ & $\mathrm{I}$ & 60 & 60 & 100 & 100 & 100 & 100 & 80 & 60 & 80 & 60 & 80 & 100 & 80 & 100 & 100 \\
\hline Par & $\mathrm{I}$ & 0 & 0 & 0 & 0 & 0 & 0 & 0 & 0 & 0 & 0 & 0 & 0 & 0 & 0 & 0 \\
\hline FCalgLS & $\mathrm{I}$ & 0 & 60 & 0 & 0 & 0 & 20 & 20 & 20 & 20 & 0 & 40 & 40 & 0 & 0 & 40 \\
\hline FCtodLS & II & 0 & 0 & 0 & 0 & 0 & 0 & 0 & 0 & 0 & 0 & 0 & 0 & 0 & 0 & 0 \\
\hline $\mathrm{DC}$ & II & 0 & 0 & 0 & 0 & 0 & 0 & 0 & 0 & 0 & 0 & 0 & 0 & 0 & 0 & 0 \\
\hline $\mathrm{RE}$ & II & 0 & 20 & 20 & 0 & 25 & 20 & 0 & 0 & 0 & 0 & 0 & 0 & 0 & 20 & 0 \\
\hline Hem & II & 0 & 0 & 0 & 0 & 0 & 0 & 0 & 0 & 0 & 0 & 0 & 0 & 0 & 0 & 0 \\
\hline An & II & 0 & 20 & 0 & 60 & 25 & 20 & 0 & 20 & 0 & 0 & 0 & 0 & 0 & 20 & 0 \\
\hline Fib & III & 0 & 0 & 0 & 0 & 0 & 0 & 0 & 0 & 0 & 0 & 0 & 0 & 0 & 0 & 0 \\
\hline $\mathrm{Nec}$ & III & 0 & 0 & 0 & 0 & 0 & 0 & 0 & 0 & 0 & 0 & 0 & 0 & 0 & 0 & 0 \\
\hline \multicolumn{17}{|c|}{ Danio rerio } \\
\hline Alteração & peso & Pin & Lim & Cam & Sum & Ame & Pira & S.J. & Mog1 & Mog2 & Psng & L.A.1 & L.A.2 & T.B.1 & T.B.2 & Lon \\
\hline HTCE & $\mathrm{I}$ & 0 & 40 & 100 & 40 & 60 & 40 & 20 & 25 & 0 & 60 & 0 & 0 & 20 & 40 & 0 \\
\hline $\mathrm{AdE}$ & $\mathrm{I}$ & 0 & 0 & 0 & 0 & 0 & 0 & 0 & 0 & 0 & 0 & 0 & 0 & 0 & 0 & 0 \\
\hline ELS & $\mathrm{I}$ & 0 & 0 & 20 & 0 & 0 & 60 & 80 & 75 & 50 & 40 & 20 & 0 & 60 & 100 & 80 \\
\hline HPBLS & $\mathrm{I}$ & 40 & 20 & 0 & 80 & 40 & 20 & 0 & 75 & 75 & 20 & 20 & 75 & 0 & 40 & 0 \\
\hline HPLS & $\mathrm{I}$ & 0 & 0 & 0 & 80 & 40 & 0 & 0 & 25 & 50 & 40 & 20 & 0 & 0 & 20 & 0 \\
\hline FPLS & I & 0 & 20 & 0 & 20 & 0 & 20 & 20 & 75 & 25 & 0 & 0 & 0 & 0 & 20 & 0 \\
\hline LeuELS & $\mathrm{I}$ & 0 & 0 & 0 & 0 & 0 & 0 & 0 & 0 & 0 & 0 & 0 & 0 & 0 & 0 & 0 \\
\hline HP/HTCM & I & 0 & 0 & 20 & 20 & 0 & 40 & 0 & 0 & 0 & 0 & 0 & 0 & 0 & 0 & 20 \\
\hline HP/HTCC & $\mathrm{I}$ & 0 & 0 & 20 & 0 & 0 & 0 & 0 & 0 & 0 & 0 & 0 & 0 & 0 & 0 & 0 \\
\hline CCLS & $\mathrm{I}$ & 0 & 0 & 0 & 0 & 20 & 0 & 0 & 0 & 0 & 0 & 0 & 0 & 0 & 20 & 0 \\
\hline MuLS & $\mathrm{I}$ & 0 & 0 & 20 & 0 & 0 & U & 0 & 0 & 0 & 0 & 0 & 0 & 0 & 0 & 0 \\
\hline DiC & I & 0 & 20 & 60 & 100 & 100 & 100 & 20 & 25 & 100 & 40 & 0 & 25 & 40 & 40 & 40 \\
\hline $\mathrm{DeC}$ & $\mathrm{I}$ & 0 & 40 & 80 & 100 & 100 & 100 & 0 & 25 & 100 & 0 & 0 & 25 & 20 & 60 & 40 \\
\hline $\mathrm{CV}$ & I & 0 & 20 & 100 & 100 & 100 & 100 & 40 & 25 & 100 & 60 & 0 & 25 & 80 & 100 & 40 \\
\hline Par & I & 0 & 0 & 0 & 0 & 0 & 0 & 0 & 0 & 0 & 0 & 0 & 0 & 0 & 0 & 0 \\
\hline FCalgLS & $\mathrm{I}$ & 0 & 0 & 20 & 0 & 40 & 20 & 0 & 25 & 50 & 20 & 0 & 0 & 0 & 0 & 0 \\
\hline FCtodLS & II & 0 & 0 & 0 & 0 & 0 & 0 & 0 & 0 & 0 & 0 & 0 & 0 & 0 & 0 & 0 \\
\hline $\mathrm{DC}$ & II & 0 & 0 & 0 & 0 & 0 & 0 & 0 & 0 & 0 & 0 & 0 & 0 & 0 & 0 & 0 \\
\hline $\mathrm{RE}$ & II & 0 & 0 & 0 & 0 & 0 & 0 & 0 & 0 & 0 & 0 & 0 & 0 & 0 & 40 & 0 \\
\hline Hem & II & 0 & 0 & 0 & 0 & 0 & 0 & 0 & 0 & 0 & 0 & 0 & 0 & 0 & 20 & 0 \\
\hline An & II & 0 & 0 & 0 & 60 & 20 & 40 & 0 & 0 & 25 & 0 & 0 & 0 & 0 & 0 & 0 \\
\hline Fib & III & 0 & 0 & 0 & 0 & 0 & 0 & 0 & 0 & 0 & 0 & 0 & 0 & 0 & 0 & 0 \\
\hline $\mathrm{Nec}$ & III & 0 & 0 & 0 & 0 & 0 & 0 & 0 & 0 & 0 & 0 & 0 & 0 & 0 & 0 & 0 \\
\hline
\end{tabular}


TABELA 20: Ocorrência das alterações renais nos grupos de peixes das duas espécies expostos às amostras de sedimento das diferentes localidades de cada bacia. Os números representam, em porcentagens, o número de peixes que apresentaram o dano, do total de peixes analisados para cada localidade $(N=5)$. $P C T L=$ perda do contorno ou contorno atípico das células do tecido linfóide; $\mathrm{DHL}=$ degeneração hialina leve; $\mathrm{HTCT}=$ hipertrofia das células tubulares; DesT=desorg. tubular; DesG=desorganização glomerular; $\mathrm{AECB}=$ aumento do espaço da cápsula de Bowman (CB); $\mathrm{DECB}=$ diminuição do espaço da cápsula de Bowman; $\mathrm{DCG}=$ dilatação dos capilares glomerulares; TR/NN=ocorrência de túbulos em regeneração ou de novos néfrons; PAST=presença de material PAS-positivo nas céls tubulares; DFreqG=diminuição da freq. relativa de glomérulos; DilVS=dilatação de vasos sangüíneos; ALumTub=aumento do diâm. do lúmen tubular; ObsTub=obstrução tubular; DHS=degeneração hialina severa; DT=degeneração tubular; DegG=degeneração glomerular; DCTub=deg.citoplasmática das células tubulares; DNTub=deg. nuclear das céls tubulares; TLCB=tecido linfóide na CB; HH=hiperemia; RVS=ruptura de vasos sangüíneos; Nec=necrose.

\begin{tabular}{lccccccccccccccccc}
\hline \multicolumn{1}{l}{ Serrapinnus notomelas } \\
\hline \multicolumn{2}{l|l}{ Alteração } & peso & Pin & Lim & Cam & Sum & Ame & Pira & S.J. & Mog1 & Mog2 & Psng & L.A.1 & L.A.2 & T.B.1 & T.B.2 & Lon \\
\hline PCTL & I & 0 & 0 & 0 & 20 & 0 & 0 & 0 & 0 & 0 & 0 & 0 & 0 & 0 & 0 & 0 \\
\hline DHL & I & 0 & 100 & 100 & 100 & 20 & 80 & 60 & 60 & 20 & 60 & 60 & 40 & 75 & 100 & 80 \\
\hline HTCT & I & 0 & 100 & 100 & 100 & 100 & 80 & 60 & 40 & 40 & 20 & 40 & 20 & 75 & 0 & 0 \\
\hline DesT & I & 25 & 80 & 0 & 20 & 40 & 80 & 20 & 0 & 100 & 0 & 20 & 0 & 25 & 0 & 0 \\
\hline DesG & I & 25 & 0 & 0 & 0 & 40 & 0 & 0 & 0 & 60 & 0 & 0 & 0 & 0 & 0 & 0 \\
\hline AECB & I & 25 & 0 & 20 & 0 & 20 & 0 & 0 & 0 & 0 & 0 & 0 & 0 & 0 & 0 & 0 \\
\hline DECB & I & 0 & 20 & 40 & 0 & 0 & 0 & 0 & 20 & 0 & 60 & 0 & 20 & 0 & 20 & 80 \\
\hline DCG & I & 25 & 40 & 80 & 40 & 80 & 60 & 100 & 100 & 100 & 60 & 20 & 60 & 75 & 80 & 40 \\
\hline TR/NN & I & 0 & 60 & 0 & 0 & 20 & 0 & 40 & 40 & 20 & 20 & 60 & 40 & 50 & 40 & 60 \\
\hline PAST & I & 0 & 20 & 20 & 0 & 0 & 0 & 0 & 20 & 0 & 0 & 20 & 0 & 0 & 0 & 0 \\
\hline DFreqG & I & 0 & 0 & 0 & 0 & 0 & 0 & 0 & 0 & 0 & 20 & 0 & 0 & 0 & 0 & 0 \\
\hline DilVS & I & 0 & 0 & 20 & 0 & 0 & 0 & 0 & 0 & 0 & 0 & 0 & 0 & 0 & 0 & 0 \\
\hline ALumTub & I & 0 & 40 & 40 & 100 & 20 & 40 & 0 & 0 & 0 & 0 & 0 & 0 & 0 & 0 & 0 \\
\hline ObsTub & I & 0 & 0 & 0 & 0 & 20 & 0 & 0 & 0 & 0 & 0 & 0 & 0 & 0 & 0 & 0 \\
\hline DHS & II & 0 & 80 & 100 & 100 & 20 & 80 & 0 & 20 & 0 & 0 & 40 & 20 & 0 & 40 & 0 \\
\hline DegT & II & 0 & 60 & 0 & 20 & 80 & 100 & 0 & 20 & 40 & 0 & 60 & 40 & 25 & 40 & 0 \\
\hline DegG & II & 0 & 0 & 0 & 40 & 20 & 0 & 0 & 0 & 20 & 0 & 0 & 0 & 0 & 20 & 0 \\
\hline DCTub & II & 0 & 0 & 0 & 0 & 0 & 0 & 0 & 0 & 0 & 0 & 0 & 0 & 0 & 0 & 0 \\
\hline DNTub & II & 0 & 0 & 0 & 0 & 0 & 0 & 0 & 0 & 0 & 0 & 0 & 0 & 0 & 0 & 0 \\
\hline TLCB & II & 0 & 0 & 0 & 0 & 0 & 0 & 0 & 0 & 0 & 0 & 0 & 20 & 0 & 0 & 0 \\
\hline HH & II & 0 & 0 & 0 & 40 & 0 & 0 & 0 & 0 & 0 & 0 & 0 & 0 & 0 & 0 & 0 \\
\hline RVS & III & 0 & 0 & 0 & 0 & 0 & 0 & 0 & 0 & 0 & 0 & 0 & 0 & 0 & 0 & 0 \\
\hline Nec & III & 0 & 0 & 0 & 0 & 0 & 0 & 0 & 0 & 0 & 0 & 20 & 0 & 0 & 0 & 0 \\
\hline \hline
\end{tabular}

Danio rerio

\begin{tabular}{lcccccccccccccccc}
\hline Alteração & peso & Pin & Lim & Cam & Sum & Ame & Pira & S.J. & Mog1 & Mog2 & Psng & L.A.1 & L.A.2 & T.B.1 & T.B.2 & Lon \\
\hline PCTL & I & 0 & 0 & 0 & 0 & 0 & 0 & 0 & 0 & 0 & 0 & 0 & 0 & 0 & 0 & 0 \\
\hline DHL & I & 0 & 100 & 100 & 100 & 40 & 100 & 40 & 0 & 0 & 20 & 40 & 20 & 20 & 20 & 0 \\
\hline HTCT & I & 0 & 100 & 20 & 40 & 20 & 60 & 20 & 0 & 20 & 0 & 0 & 0 & 0 & 20 & 20 \\
\hline DesT & I & 0 & 0 & 40 & 0 & 60 & 40 & 0 & 0 & 0 & 0 & 0 & 0 & 0 & 0 & 0 \\
\hline DesG & I & 0 & 0 & 40 & 0 & 0 & 0 & 0 & 0 & 0 & 0 & 0 & 0 & 0 & 0 & 0 \\
\hline AECB & I & 0 & 0 & 0 & 0 & 0 & 0 & 0 & 0 & 0 & 0 & 0 & 0 & 0 & 0 & 0 \\
\hline DECB & I & 20 & 0 & 0 & 60 & 80 & 0 & 20 & 40 & 80 & 60 & 80 & 20 & 80 & 40 & 40 \\
\hline DCG & I & 40 & 80 & 80 & 20 & 40 & 0 & 60 & 100 & 80 & 100 & 0 & 0 & 60 & 80 & 40 \\
\hline TR/NN & I & 0 & 0 & 0 & 0 & 40 & 0 & 40 & 20 & 20 & 20 & 20 & 40 & 20 & 60 & 20 \\
\hline PAST & I & 0 & 20 & 0 & 0 & 0 & 0 & 0 & 40 & 40 & 20 & 40 & 20 & 0 & 0 & 60 \\
\hline DFreqG & I & 0 & 0 & 0 & 40 & 0 & 0 & 0 & 20 & 20 & 40 & 20 & 60 & 20 & 20 & 0 \\
\hline DilVS & I & 20 & 20 & 0 & 0 & 0 & 0 & 0 & 0 & 0 & 0 & 0 & 0 & 0 & 0 & 0 \\
\hline ALumTub & I & 0 & 40 & 0 & 100 & 0 & 100 & 0 & 0 & 0 & 0 & 0 & 0 & 0 & 20 & 0 \\
\hline ObsTub & I & 0 & 20 & 0 & 0 & 0 & 0 & 0 & 0 & 0 & 0 & 0 & 0 & 0 & 0 & 0 \\
\hline DHS & II & 0 & 80 & 100 & 100 & 0 & 100 & 0 & 0 & 0 & 0 & 0 & 0 & 0 & 20 & 0 \\
\hline DegT & II & 0 & 40 & 20 & 20 & 40 & 0 & 0 & 20 & 60 & 60 & 0 & 0 & 20 & 20 & 0 \\
\hline DegG & II & 0 & 0 & 20 & 0 & 0 & 0 & 0 & 0 & 0 & 0 & 20 & 0 & 0 & 0 & 20 \\
\hline DCTub & II & 0 & 0 & 0 & 0 & 0 & 0 & 0 & 0 & 0 & 0 & 0 & 0 & 0 & 0 & 0 \\
\hline DNTub & II & 0 & 0 & 0 & 0 & 0 & 0 & 0 & 0 & 0 & 0 & 0 & 0 & 0 & 0 & 0 \\
\hline TLCB & II & 0 & 0 & 0 & 0 & 0 & 0 & 0 & 0 & 0 & 0 & 0 & 0 & 40 & 0 & 0 \\
\hline HH & II & 0 & 40 & 60 & 100 & 80 & 100 & 20 & 20 & 100 & 40 & 60 & 80 & 80 & 80 & 0 \\
\hline RVS & III & 0 & 0 & 0 & 0 & 0 & 0 & 0 & 0 & 0 & 0 & 0 & 0 & 0 & 0 & 0 \\
\hline Nec & III & 0 & 0 & 0 & 0 & 0 & 0 & 0 & 0 & 0 & 0 & 0 & 0 & 0 & 0 & 0 \\
\hline
\end{tabular}


TABELA 21: Ocorrência das alterações hepáticas nos grupos de peixes das duas espécies expostos às amostras de sedimento das diferentes localidades de cada bacia. Os números representam, em porcentagens, o número de peixes que apresentaram o dano, do total de peixes analisados para cada localidade $(\mathrm{N}=5)$. Des $\mathrm{CH}=$ desorganização/descaracterização dos cordões hepáticos; PContCel=perda ou atipia do contorno dos hepatócitos; PCont Nuc=perda ou atipia do contorno do núcleo dos hepatócitos; AVolCel=aumento do volume celular; $A$ VolNuc= aumento do volume nuclear; VacCit=vacuolização citoplasmática; DFreqNuc=diminuição da freqüência relativa de núcleos; AFreqVas=aumento da freqüência relativa de vasos; AVolVasos=aumento do volume de vasos; DimGlic=diminuição do glicogênio; EstBil=estagnação biliar; HHem=hiperemia; RupVas=ruptura de vasos; DegCanBil=degeneração de canalículos biliares; VacNuc=vacuolização nuclear; DegCit= degeneração citoplasmática; DegNuc=degeneração nuclear; AtrofNuc= atrofia nuclear; RompCel=rompimento celular.

\begin{tabular}{|c|c|c|c|c|c|c|c|c|c|c|c|c|c|c|c|c|}
\hline \multicolumn{17}{|c|}{ Serrapinnus notomelas } \\
\hline Alteração & peso & Pin & Lim & Cam & Sum & Ame & Pira & S.J. & $\operatorname{Mog} 1$ & Mog2 & Psng & L.A.1 & L.A.2 & T.B.1 & T.B.2 & Lon \\
\hline $\mathrm{DesCH}$ & I & 0 & 0 & 0 & 0 & 0 & 20 & 0 & 0 & 0 & 0 & 0 & 0 & 0 & 0 & 0 \\
\hline PContCel & $\mathrm{I}$ & 40 & 0 & 20 & 40 & 0 & 20 & 0 & 0 & 20 & 20 & 20 & 0 & 0 & 20 & 0 \\
\hline PContNuc & I & 0 & 0 & 0 & 0 & 0 & 0 & 40 & 0 & 20 & 0 & 0 & 0 & 0 & 0 & 0 \\
\hline AVolCel & I & 0 & 0 & 0 & 0 & 20 & 0 & 0 & 0 & 0 & 0 & 0 & 0 & 20 & 0 & 0 \\
\hline AVolNuc & $T$ & 0 & 0 & 20 & 60 & 0 & 60 & 0 & 0 & 0 & 0 & 0 & 0 & 20 & 0 & 0 \\
\hline VacCit & $\mathrm{I}$ & 20 & 60 & 20 & 80 & 100 & 100 & 40 & 60 & 100 & 40 & 80 & 80 & 80 & 100 & 100 \\
\hline DFreqNuc & I & 0 & 0 & 0 & 0 & 0 & 20 & 0 & 0 & 40 & 0 & 0 & 0 & 0 & 0 & 0 \\
\hline AFreqVas & $\mathrm{I}$ & 0 & 0 & 0 & 0 & 0 & 0 & 0 & 0 & 0 & 0 & 0 & 0 & 0 & 0 & 0 \\
\hline AVolVas & $\mathrm{I}$ & 0 & 0 & 0 & 0 & 0 & 0 & 0 & 0 & 0 & 0 & 0 & 0 & 0 & 0 & 0 \\
\hline DimGlic & I & 0 & 60 & 40 & 40 & 40 & 80 & 0 & 0 & 0 & 0 & 20 & 0 & 40 & 20 & 20 \\
\hline EstBil & I & 40 & 100 & 100 & 60 & 80 & 80 & 20 & 80 & 60 & 80 & 0 & 80 & 40 & 40 & 80 \\
\hline HHem & II & 0 & 0 & 0 & 0 & 0 & 0 & 0 & 0 & 0 & 0 & 0 & 0 & 0 & 0 & 0 \\
\hline RupVas & II & 0 & 0 & 0 & 0 & 0 & 0 & 0 & 0 & 0 & 0 & 0 & 0 & 0 & 0 & 0 \\
\hline DegCanBil & II & 0 & 0 & 0 & 0 & 0 & 0 & 0 & 0 & 0 & 0 & 0 & 0 & 0 & 0 & 0 \\
\hline VacNuc & II & 0 & 20 & 60 & 20 & 0 & 0 & 0 & 0 & 0 & 0 & 0 & 0 & 0 & 0 & 0 \\
\hline DegCit & II & 0 & 0 & 0 & 0 & 0 & 0 & 0 & 0 & 0 & 0 & 0 & 0 & 0 & 0 & 0 \\
\hline DegNuc & II & 0 & 0 & 0 & 40 & 0 & 0 & 0 & 0 & 0 & 0 & 60 & 20 & 20 & 0 & 0 \\
\hline AtrofNuc & II & 0 & 20 & 0 & 100 & 60 & 80 & 0 & 0 & 0 & 0 & 0 & 0 & 0 & 0 & 0 \\
\hline RompCel & II & 0 & 0 & 0 & 0 & 0 & 0 & 0 & 0 & 0 & 0 & 0 & 0 & 0 & 0 & 0 \\
\hline Necrose & III & 0 & 0 & 0 & 0 & 0 & 0 & 0 & 0 & 0 & 0 & 0 & 0 & 0 & 0 & 0 \\
\hline \multicolumn{17}{|l|}{ Danio rerio } \\
\hline Alteração & peso & Pin & Lim & Cam & Sum & Ame & Pira & S.J. & Mog1 & Mog2 & Psng & L.A.1 & L.A.2 & T.B.1 & T.B.2 & Lon \\
\hline DesCH & $\mathrm{I}$ & 0 & 0 & 0 & 60 & 0 & 20 & 0 & 0 & 20 & 0 & 0 & 0 & 0 & 0 & 0 \\
\hline PContCel & I & 0 & 0 & 20 & 100 & 0 & 100 & 0 & 0 & 40 & 0 & 0 & 0 & 0 & 0 & 0 \\
\hline PContNuc & $\mathrm{I}$ & 0 & 0 & 0 & 100 & 0 & 40 & 0 & 0 & 20 & 0 & 0 & 0 & 0 & 0 & 0 \\
\hline AVolCel & $\mathrm{I}$ & 0 & 0 & 0 & 60 & 0 & 0 & 0 & 0 & 20 & 0 & 0 & 0 & 0 & 0 & 0 \\
\hline AVolNuc & 1 & 0 & 0 & 0 & 20 & 0 & 0 & 0 & 0 & 20 & 0 & 0 & 0 & 0 & 0 & 0 \\
\hline VacCit & $\mathrm{I}$ & 80 & 80 & 100 & 100 & 100 & 100 & 40 & 100 & 100 & 100 & 100 & 100 & 100 & 100 & 100 \\
\hline DFreqNuc & I & 0 & 0 & 0 & 0 & 0 & 0 & 0 & 0 & 20 & 0 & 0 & 0 & 0 & 0 & 0 \\
\hline AFreqVas & I & 0 & 0 & 0 & 0 & 0 & 0 & 0 & 0 & 0 & 0 & 0 & 0 & 0 & 0 & 0 \\
\hline AVolVas & I & 0 & 0 & 0 & 0 & 40 & 0 & 0 & 0 & 0 & 0 & 0 & 0 & 0 & 0 & 0 \\
\hline DimGlic & I & 80 & 100 & 100 & 80 & 60 & 80 & 0 & 60 & 20 & 20 & 20 & 20 & 80 & 40 & 100 \\
\hline EstBil & I & 0 & 0 & 0 & 0 & 0 & 0 & 0 & 0 & 20 & 0 & 0 & 0 & 0 & 0 & 0 \\
\hline HHem & II & 20 & 0 & 0 & 0 & 0 & 0 & 0 & 0 & 0 & 0 & 0 & 0 & 0 & 0 & 0 \\
\hline RupVas & II & 0 & 0 & 0 & 0 & 0 & 0 & 0 & 0 & 0 & 0 & 0 & 0 & 0 & 0 & 0 \\
\hline DegCanBil & II & 0 & 0 & 0 & 0 & 0 & 0 & 0 & 0 & 0 & 0 & 0 & 0 & 0 & 0 & 0 \\
\hline VacNuc & II & 0 & 0 & 0 & 0 & 0 & 0 & 0 & 0 & 0 & 0 & 0 & 0 & 0 & 0 & 0 \\
\hline DegCit & II & 0 & 0 & 0 & 0 & 0 & 0 & 0 & 0 & 40 & 0 & 0 & 0 & 0 & 0 & 0 \\
\hline DegNuc & II & 0 & 0 & 0 & 100 & 0 & 0 & 0 & 20 & 60 & 0 & 0 & 60 & 0 & 0 & 0 \\
\hline AtrofNuc & II & 0 & 40 & 100 & 100 & 80 & 100 & 0 & 0 & 20 & 0 & 0 & 0 & 0 & 0 & 0 \\
\hline RompCel & II & 0 & 0 & 0 & 40 & 0 & 0 & 0 & 0 & 20 & 0 & 0 & 0 & 0 & 0 & 0 \\
\hline Necrose & III & 0 & 0 & 0 & 0 & 0 & 0 & 0 & 0 & 20 & 0 & 0 & 0 & 0 & 0 & 0 \\
\hline
\end{tabular}


TABELA 22: Tabela-resumo da intensidade das alterações em cada órgão (em valores absolutos), segundo o Índice de Alteração Histológica (IAH) e o Valor Médio de Alterações (VMA), nas duas espécies de peixes, após a exposição por 96 horas às amostras de sedimento coletadas nos locais de estudo nas bacias dos rios Piracicaba, Mogi-Guaçu e Tibagi. ( $B=$ brânquias; $R=$ rim; $F=$ fígado)

\begin{tabular}{|c|c|c|c|c|c|c|c|}
\hline \multicolumn{8}{|c|}{ Serrapinnus notomelas } \\
\hline & \multicolumn{3}{|c|}{$\mathrm{IAH}$} & & \multicolumn{3}{|c|}{ VMA } \\
\hline LOCALIDADE & $B$ & $\mathrm{R}$ & $\mathrm{F}$ & LOCALIDADE & $B$ & $\mathrm{R}$ & $\mathrm{F}$ \\
\hline Rib. do Pinhal & & & & Rib. do Pinhal & & & \\
\hline Limeira & & & & Limeira & & & \\
\hline Campinas & & & & Campinas & & & \\
\hline Sumaré & & & & Sumaré & & & \\
\hline Americana & & & & Americana & & & \\
\hline Piracicaba & & & & Piracicaba & & & \\
\hline São João & & & & São João & & & \\
\hline Mogi Guaçu 1 & & & & Mogi Guaçu 1 & & & \\
\hline Mogi Guaçu 2 & & & & Mogi Guaçu 2 & & & \\
\hline Pirassununga & & & & Pirassununga & & & \\
\hline Luiz Antônio 1 & & & & Luiz Antônio 1 & & & \\
\hline Luiz Antônio 2 & & & & Luiz Antônio 2 & & & \\
\hline T. Borba 1 & & & & T. Borba 1 & & & \\
\hline T. Borba 2 & & & & T. Borba 2 & & & \\
\hline Londrina & & & & Londrina & & & \\
\hline \multicolumn{8}{|l|}{ Danio rerio } \\
\hline & \multicolumn{3}{|c|}{$\mathrm{IAH}$} & & \multicolumn{3}{|c|}{ VMA } \\
\hline LOCALIDADE & $\mathrm{B}$ & $\mathrm{R}$ & $\mathrm{F}$ & LOCALIDADE & $\mathrm{B}$ & $\mathrm{R}$ & $\mathrm{F}$ \\
\hline Rib. do Pinhal & & & & Rib. do Pinhal & & & \\
\hline Limeira & & & & Limeira & & & \\
\hline Campinas & & & & Campinas & & & \\
\hline Sumaré & & & & Sumaré & & & \\
\hline Americana & & & & Americana & & & \\
\hline Piracicaba & & & & Piracicaba & & & \\
\hline São João & & & & São João & & & \\
\hline Mogi Guaçu 1 & & & & Mogi Guaçu 1 & & & \\
\hline Mogi Guaçu 2 & & & & Mogi Guaçu 2 & & & \\
\hline Pirassununga & & & & Pirassununga & & & \\
\hline Luiz Antônio 1 & & & & Luiz Antônio 1 & & & \\
\hline Luiz Antônio 2 & & & & Luiz Antônio 2 & & & \\
\hline T. Borba 1 & & & & T. Borba 1 & & & \\
\hline T. Borba 2 & & & & T. Borba 2 & & & \\
\hline Londrina & & & & Londrina & & & \\
\hline
\end{tabular}

LEGENDA

\begin{tabular}{|c|c|}
\hline $\mathrm{IAH}$ & VMA \\
\hline 0-10: órgão funcionalmente normal & grau 1: sem alterações patológicas \\
\hline 11-20: órgão com alt. leves a moderadas & grau 2: alt. pontuais brandas a moderadas \\
\hline 21-50: órgão com alt. moderadas a graves & grau 3: alt. patológicas severas e extensas \\
\hline
\end{tabular}




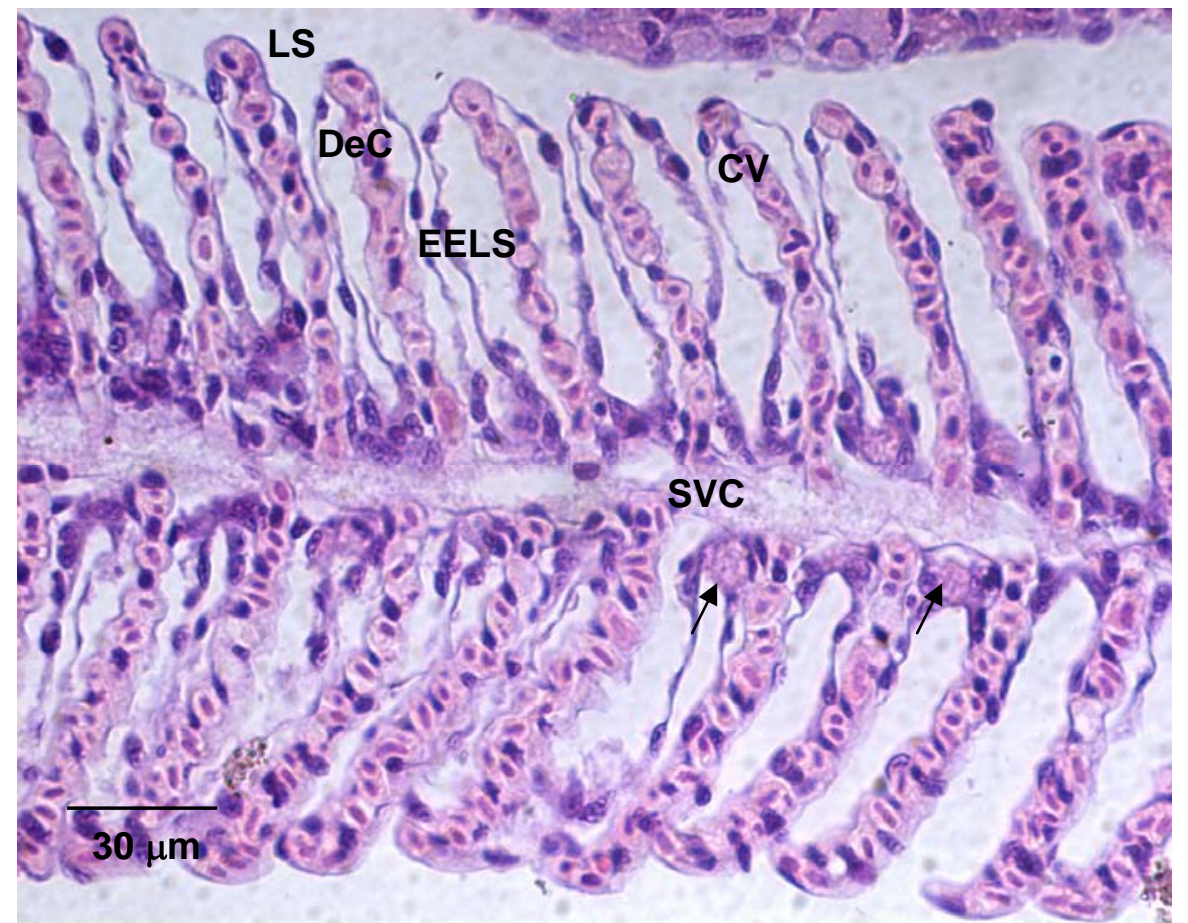

FIGURA 31: Corte longitudinal de um filamento branquial de S. notomelas exposto ao sedimento da localidade de Campinas. Notar a desorganização dos capilares das lamelas secundárias (DeC). Observar as extensas elevações epiteliais (EELS) e a congestão vascular nessas lamelas (CV). LS= lamelas secundárias; SVC=seio venoso central. As setas indicam células mucosas $(\mathrm{HE}, 5 \mu \mathrm{m})$

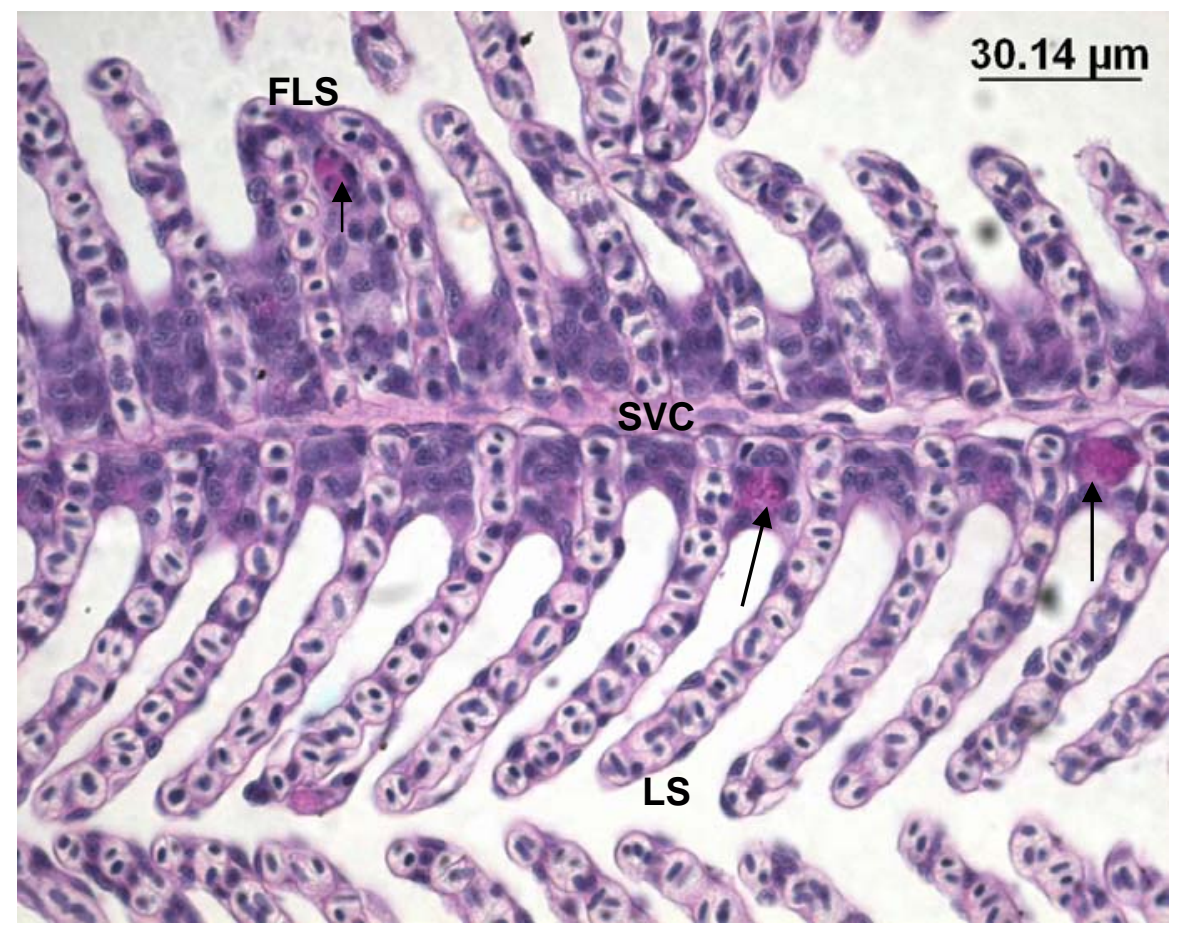

FIGURA 32: Corte longitudinal de um filamento branquial de S. notomelas exposto ao sedimento da localidade de Piracicaba. Notar a proliferação de células epiteliais com a conseqüente fusão de lamelas secundárias (FLS). LS= lamelas secundárias; $\mathrm{SVC}=$ seio venoso central. As setas indicam células mucosas. (PAS-hematoxilina, $5 \mu \mathrm{m})$. 


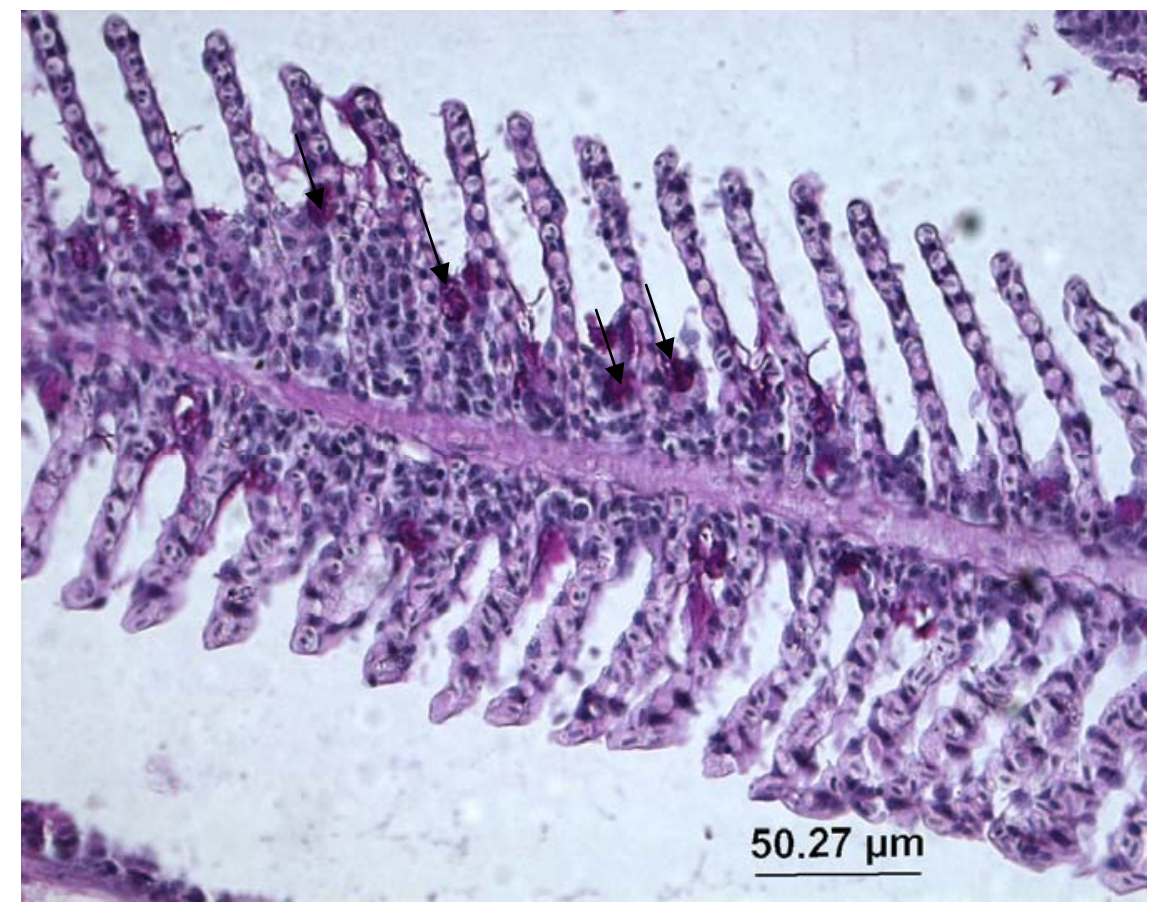

FIGURA 33: Corte longitudinal de um filamento branquial de S. notomelas exposto ao sedimento da localidade de Campinas. Notar a presença de células mucosas (setas) e de muco (corado em lilás) entre as lamelas secundárias. Observar também a proliferação de células epiteliais, ocasionando a fusão parcial de algumas lamelas secundárias (PAS-hematoxilina, $5 \mu \mathrm{m}$ ).

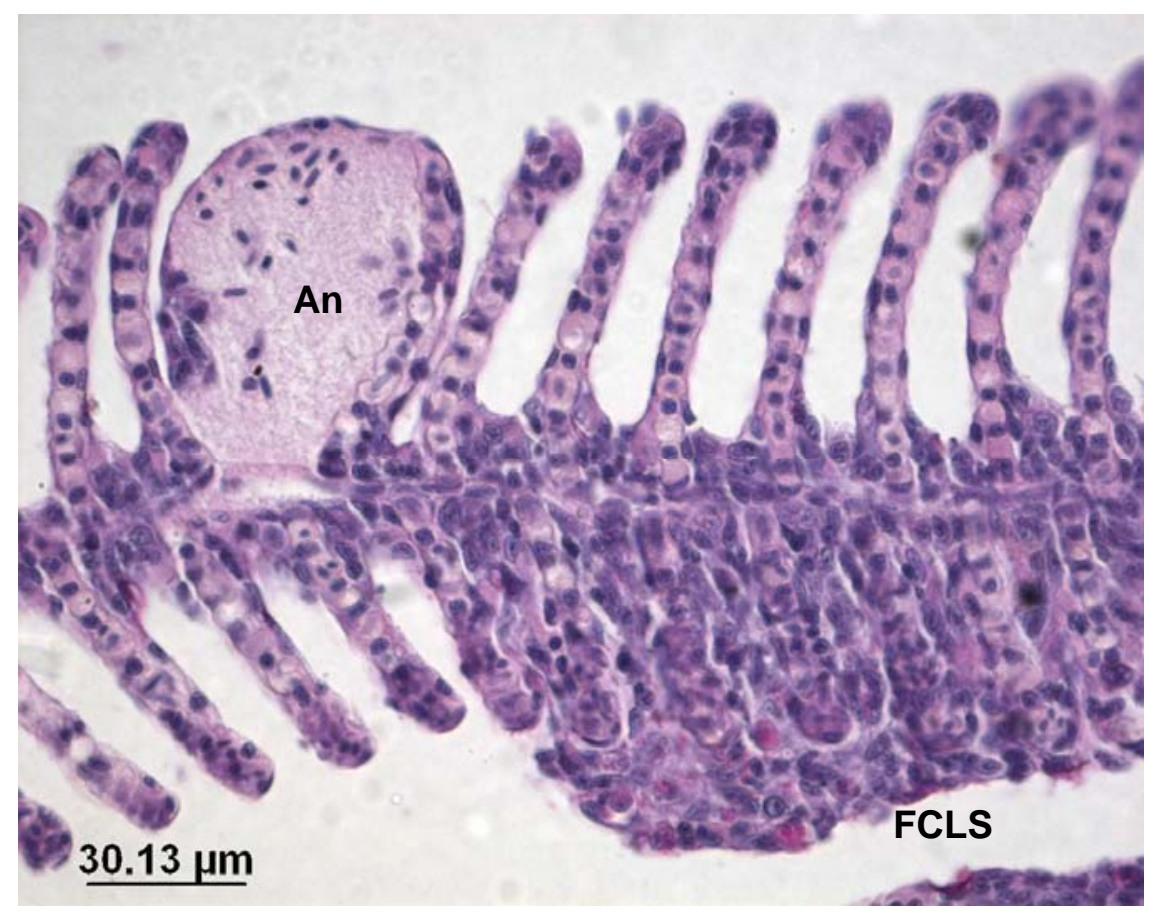

FIGURA 34: Corte longitudinal de um filamento branquial de $D$. rerio, exposto ao sedimento da localidade de Mogi Guaçu 2. Notar o aneurisma lamelar (An) e intensa proliferação de células epiteliais que levou à fusão completa de várias lamelas secundárias (FCLS). (PAS-hematoxilina, $5 \mu \mathrm{m}$ ). 


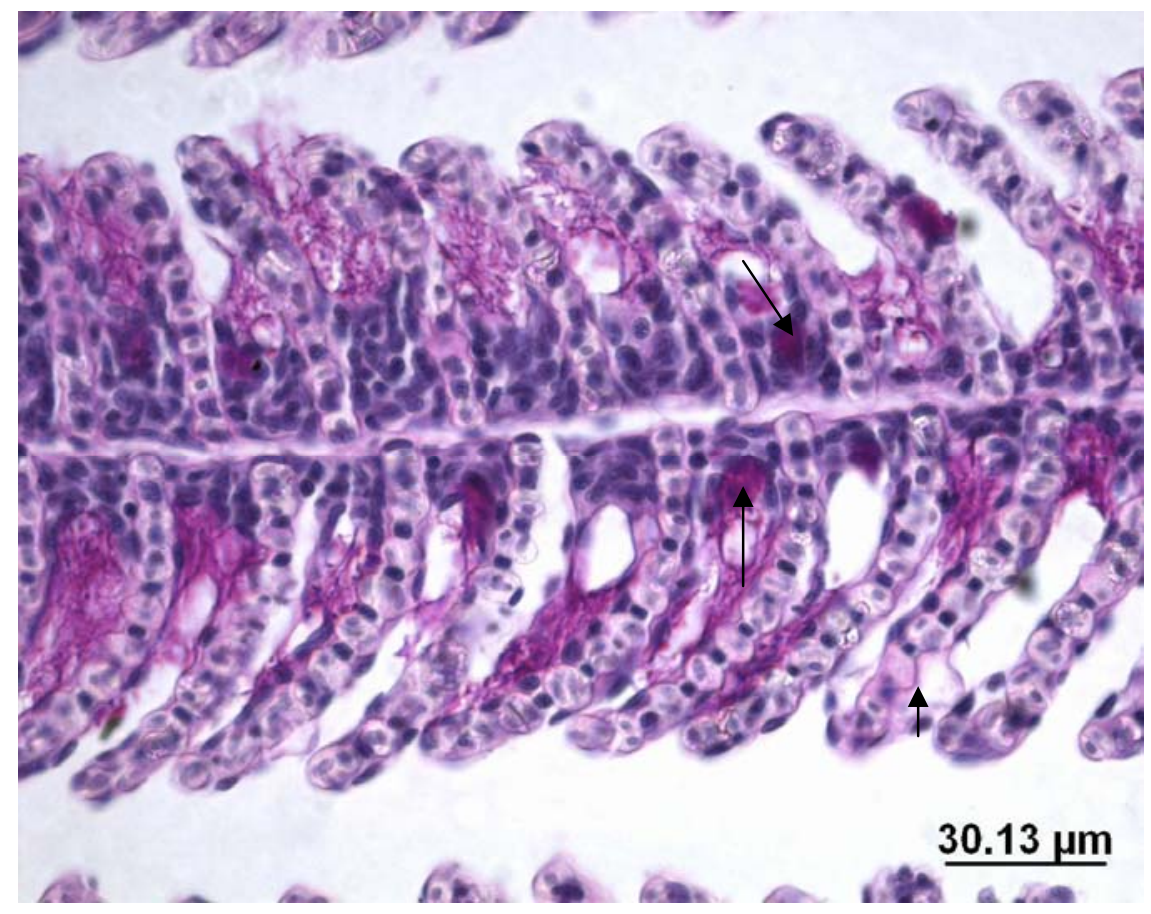

FIGURA 35: Corte longitudinal de um filamento branquial de S. notomelas, exposto ao sedimento da localidade de Pirassununga. Notar a presença de células mucosas (setas) e a intensa secreção de muco entre as lamelas secundárias. A seta menor indica uma elevação epitelial (PAS-hematoxilina, $5 \mu \mathrm{m}$ ).

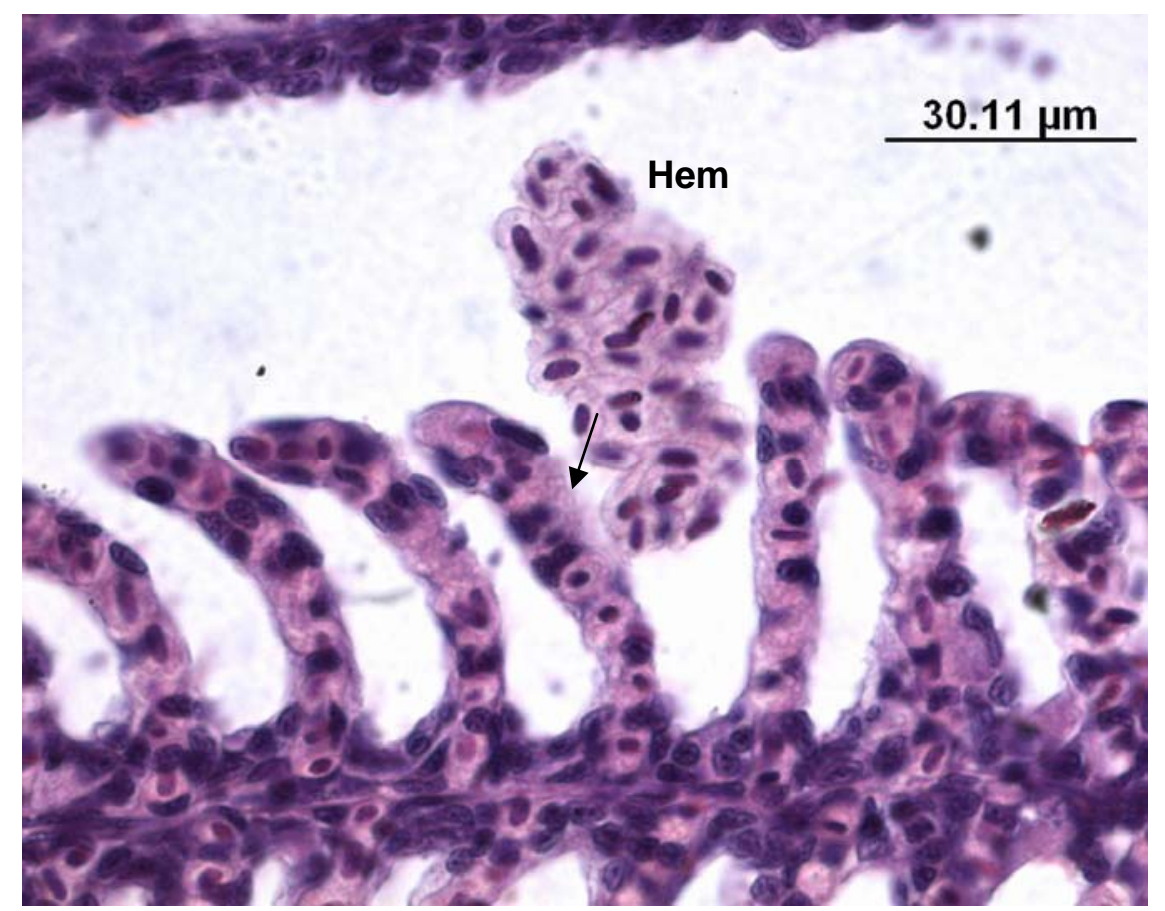

FIGURA 36: Corte longitudinal de um filamento branquial de $D$. rerio exposto ao sedimento da localidade Telêmaco Borba 2. Observar um aglomerado de hemácias (Hem) entre lamelas. A seta aponta um local de ruptura do epitélio de uma lamela secundária. (HE, $5 \mu \mathrm{m})$. 


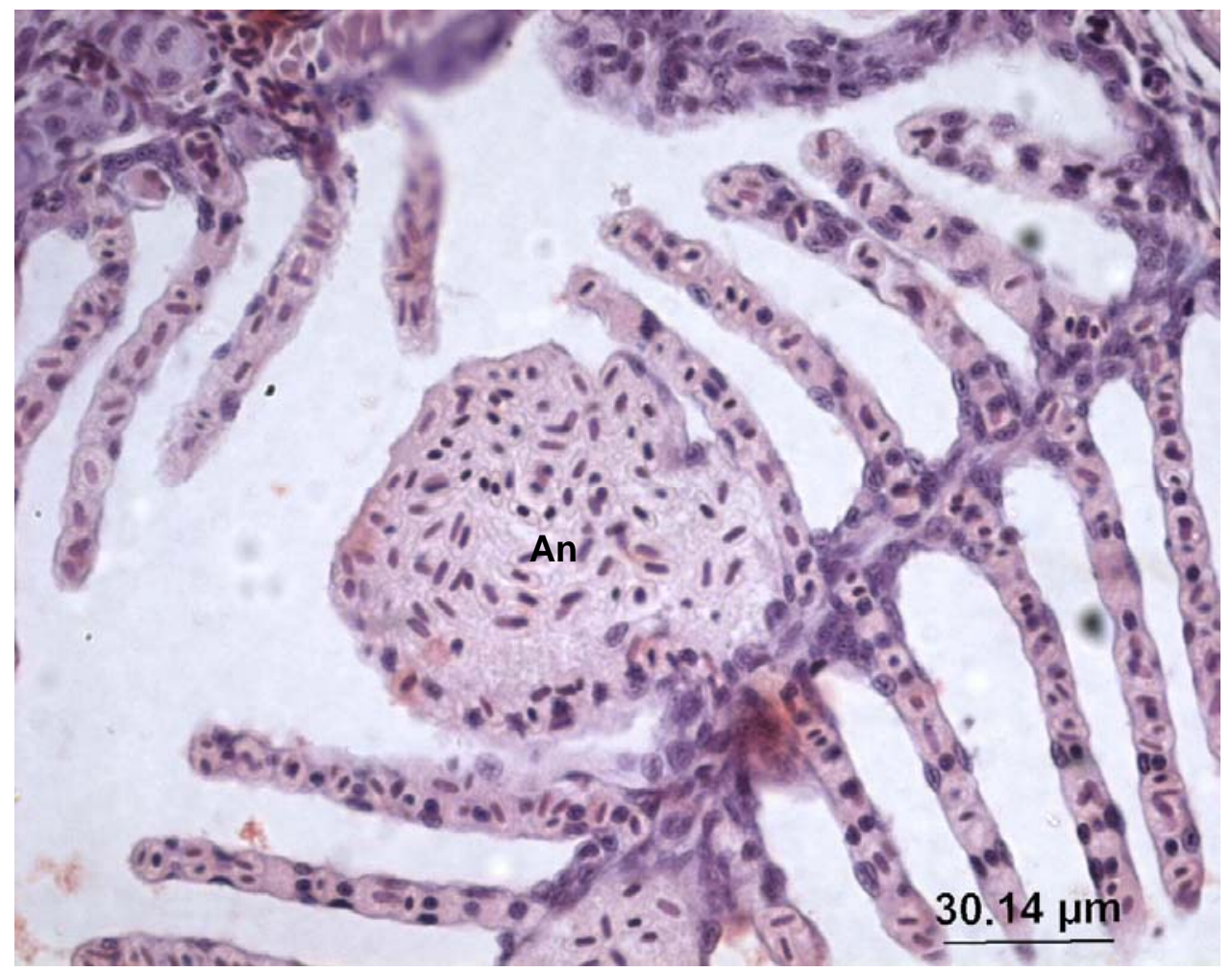

FIGURA 37: Aneurisma (An) em uma lamela secundária em brânquia de $D$. rerio exposto ao sedimento da localidade de Piracicaba. Notar as hemácias no interior do aneurisma. (HE, $5 \mu \mathrm{m})$

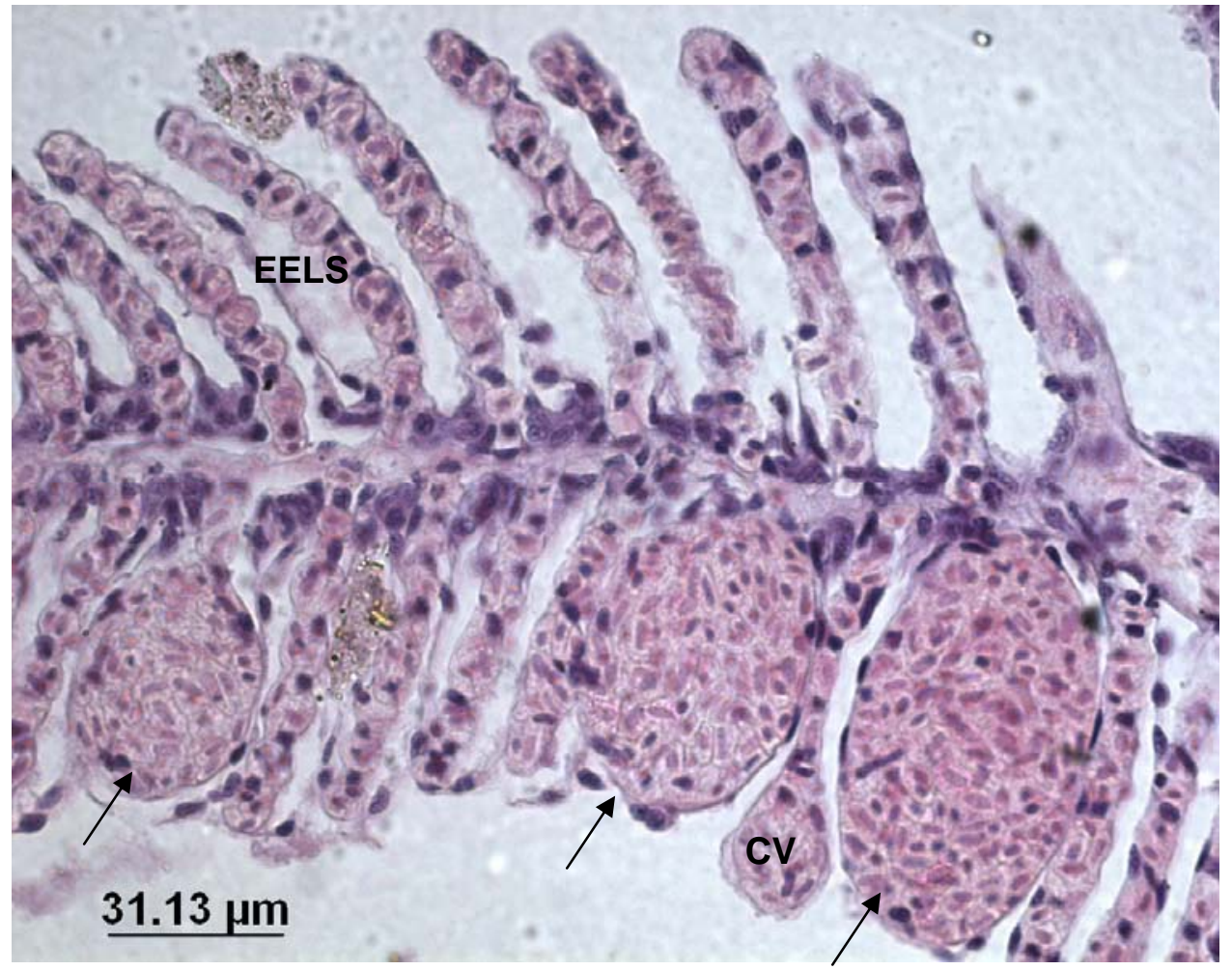

FIGURA 38: Aneurismas (setas) em lamelas secundárias em brânquia de $S$. notomelas exposto ao sedimento da localidade de Sumaré. Notar a congestão vascular (CV) e desorganização dos capilares nas outras lamelas secundárias. EELS=elevação do epitélio da lamela secundária (HE, $5 \mu \mathrm{m})$. 


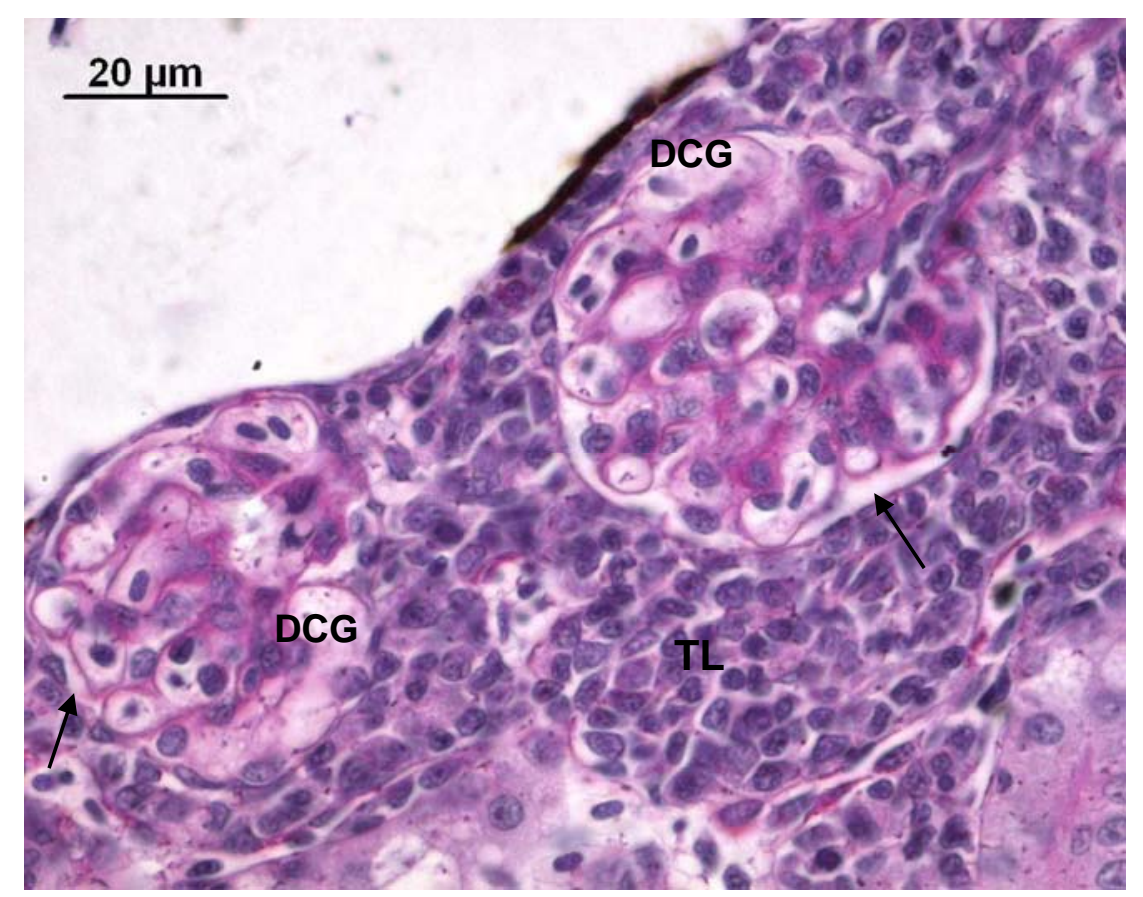

FIGURA 39: Diminuição do espaço da cápsula de Bowman (seta) em rim de $D$. rerio exposto ao sedimento da localidade Mogi Guaçu 2. DCG=dilatação dos capilares glomerulares; $\mathrm{TL}=$ tecido linfóide intersticial. (PAS-hematoxilina, $5 \mu \mathrm{m}$ ).

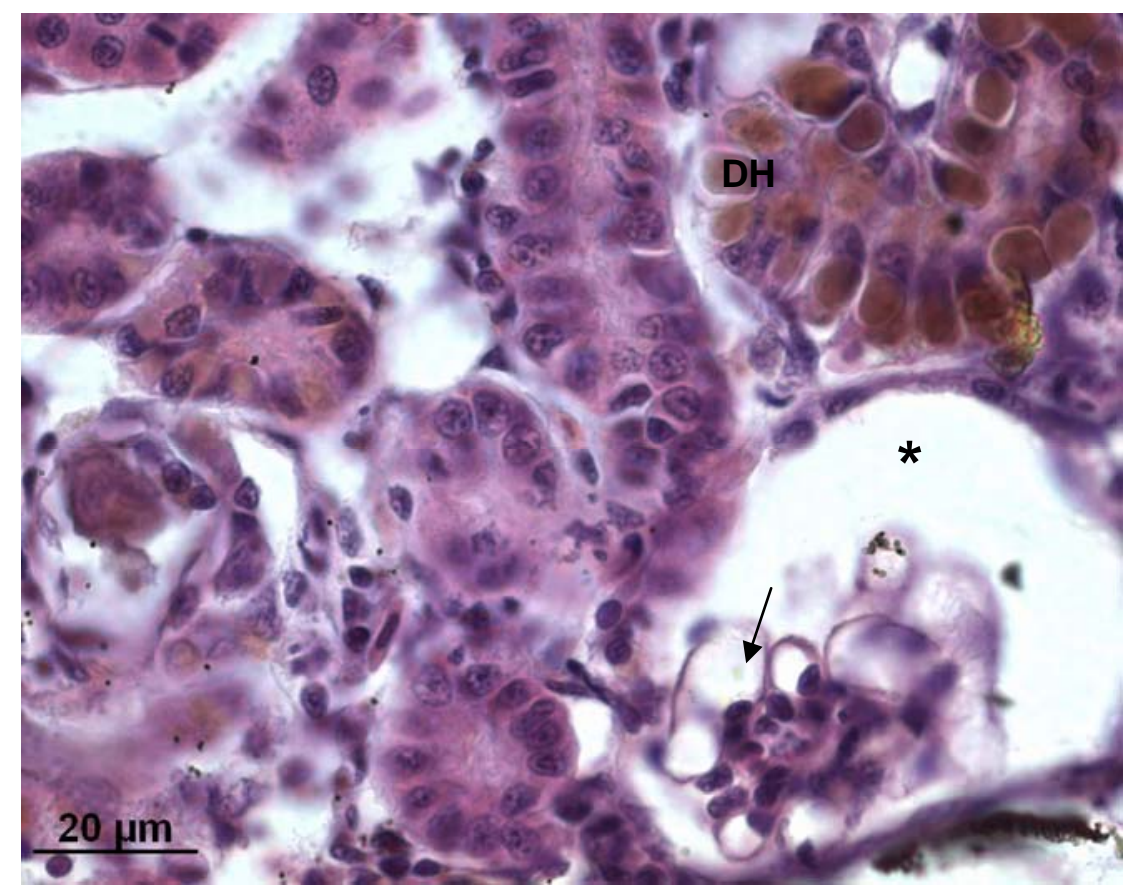

FIGURA 40: Rim de S. notomelas exposto ao sedimento da localidade de Americana. Notar a degeneração de um glomérulo, cujos capilares estão dilatados (seta). Observar o aumento do espaço da cápsula de Bowman (asterisco) e também o processo avançado de degeneração hialina $(\mathrm{DH})$ em um túbulo renal. 


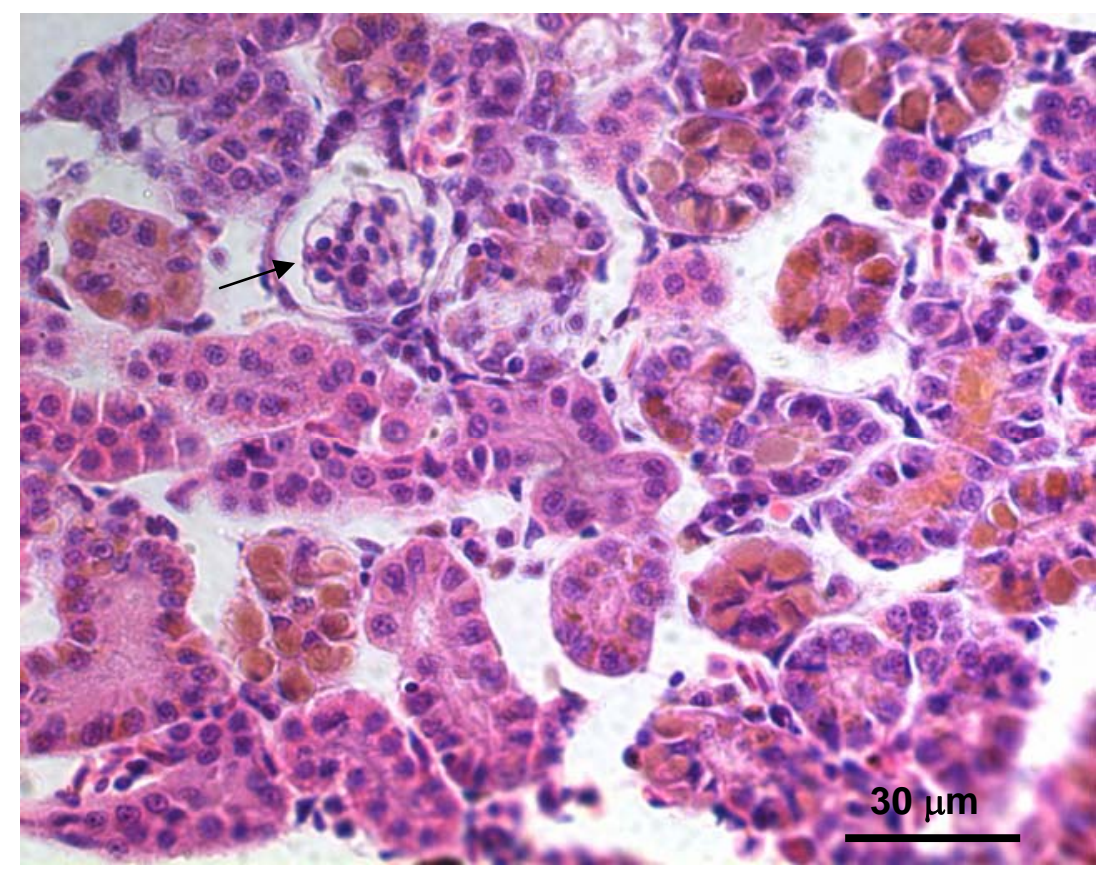

FIGURA 41: Rim de S. notomelas exposto ao sedimento da localidade de Americana. Notar o grande número túbulos renais em degeneração por grânulos (amarelos) infiltrados no citoplasma das células epiteliais. A seta aponta um glomérulo em degeneração. Notar o aumento do espaço da cápsula de Bowman. (HE, 6 $\mu \mathrm{m})$

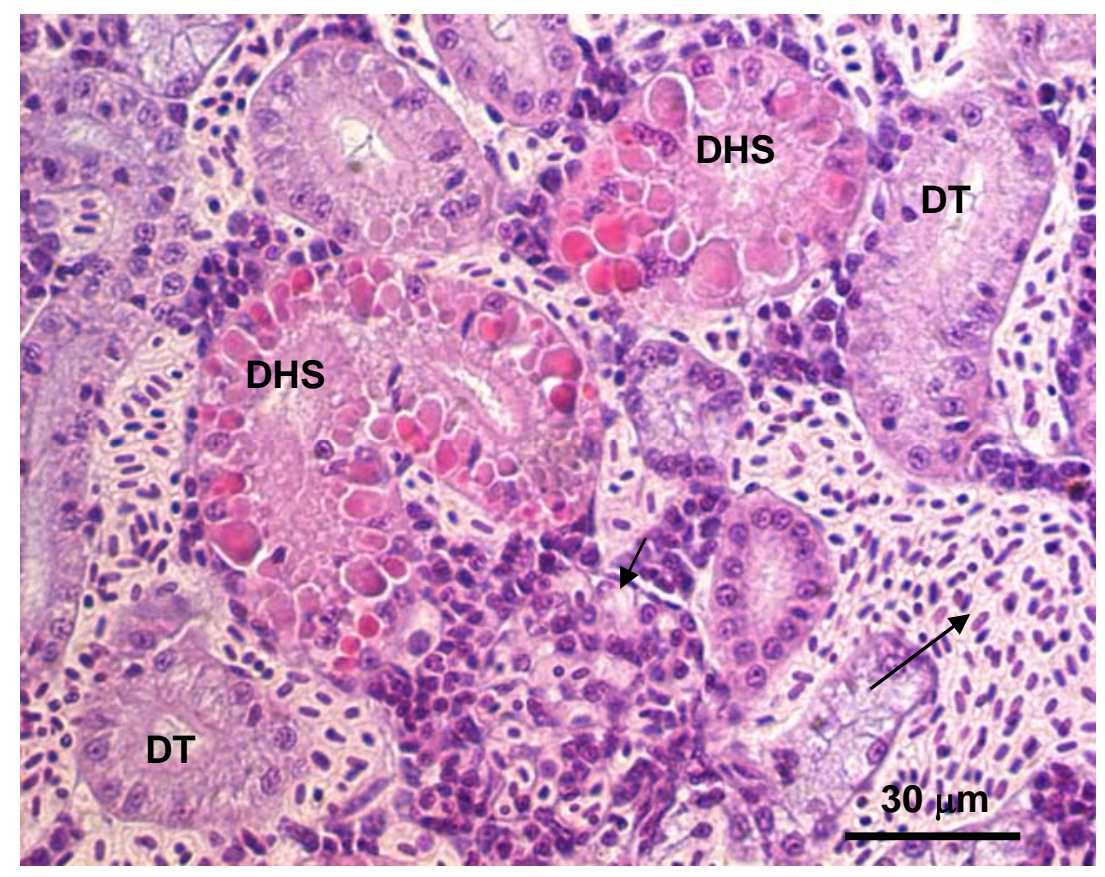

FIGURA 42: Rim de D. rerio exposto ao sedimento da localidade de Limeira. Notar o avançado processo de degeneração hialina em túbulos renais (DHS). Há, ainda, outros túbulos em degeneração, mas aparentemente não dessa natureza (DT). Observar também, em um glomérulo, a diminuição do espaço da cápsula de Bowman (seta) e também a dilatação de vasos sãngüíneos renais (seta maior). (HE, $5 \mu \mathrm{m}$ ) 


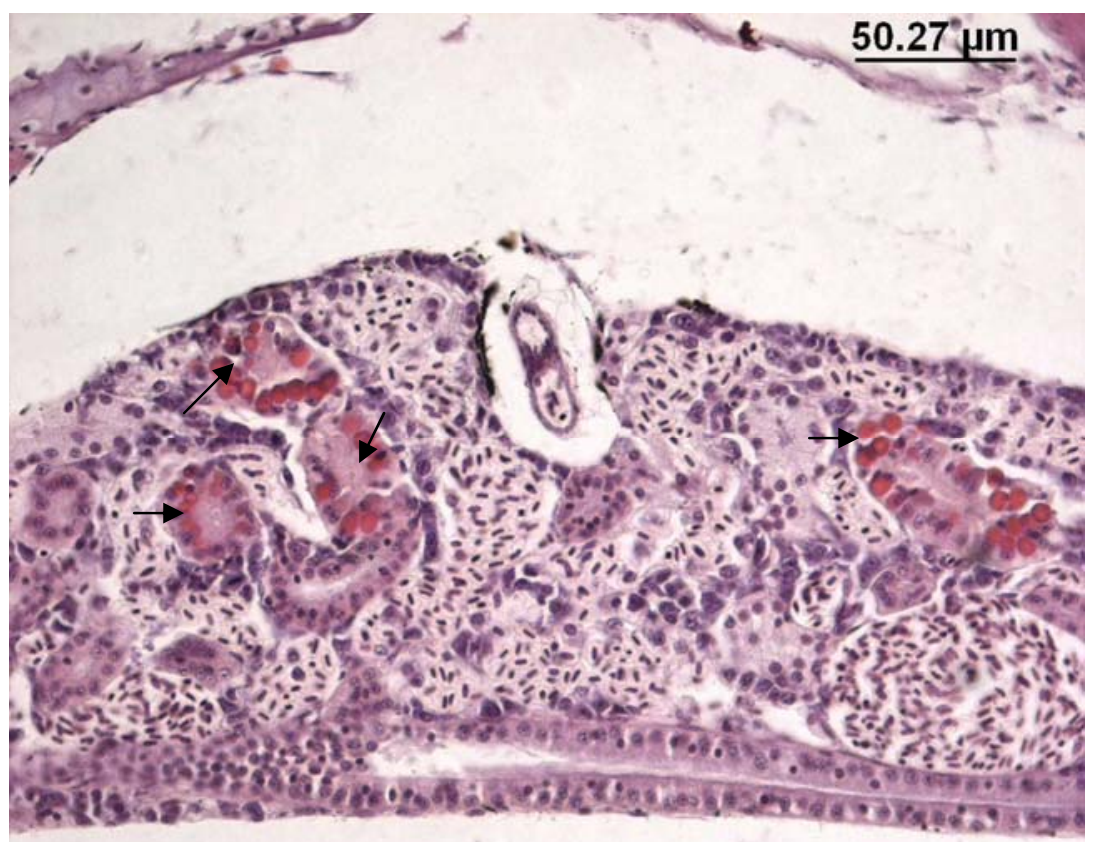

FIGURA 43: Rim de D. rerio exposto ao sedimento da localidade de Piracicaba. Notar a hiperemia, e a degeneração hialina dos túbulos rnais (setas). (HE, $5 \mu \mathrm{m}$ )

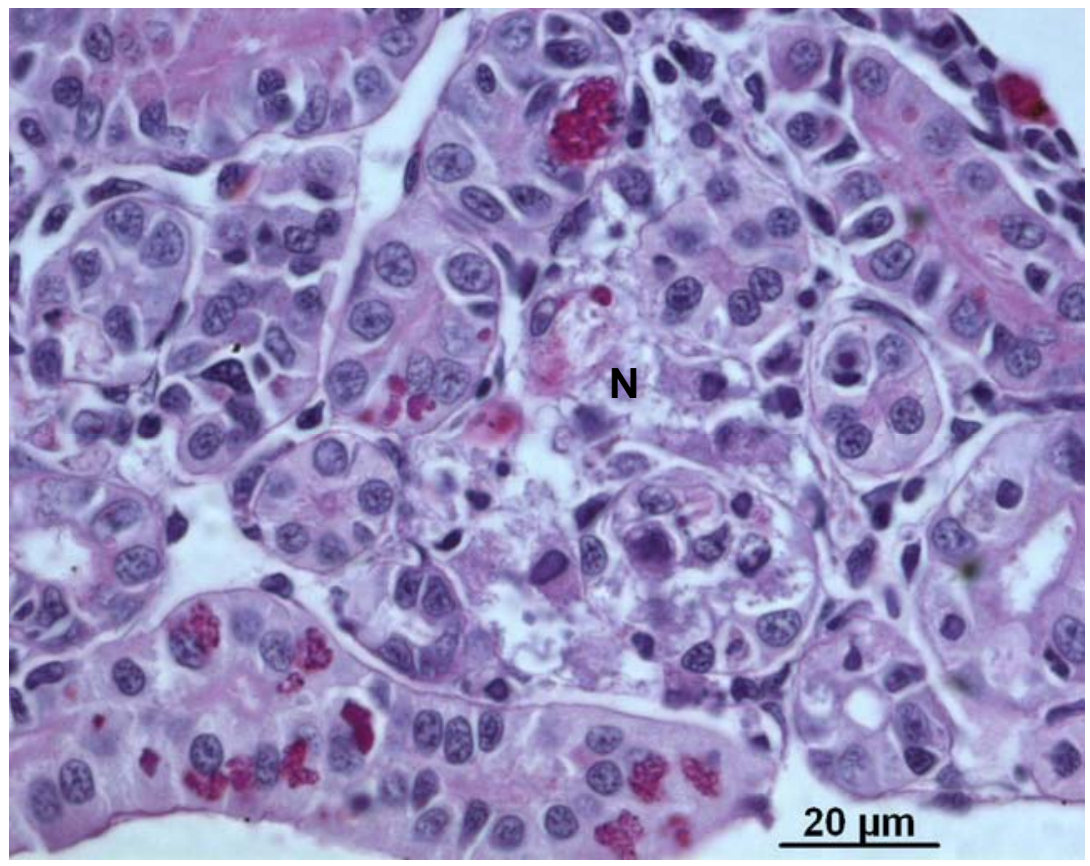

FIGURA 44: Necrose em rim de S. notomelas exposto ao sedimento de Luiz Antônio 1. Observar a área central necrosada (N), com a completa desorganização dos túbulos. Notar também a presença de substância PAS-positiva (em lilás) no interior das células epiteliais tubulares. (PAS-hematoxilina, $5 \mu \mathrm{m}$ ) 


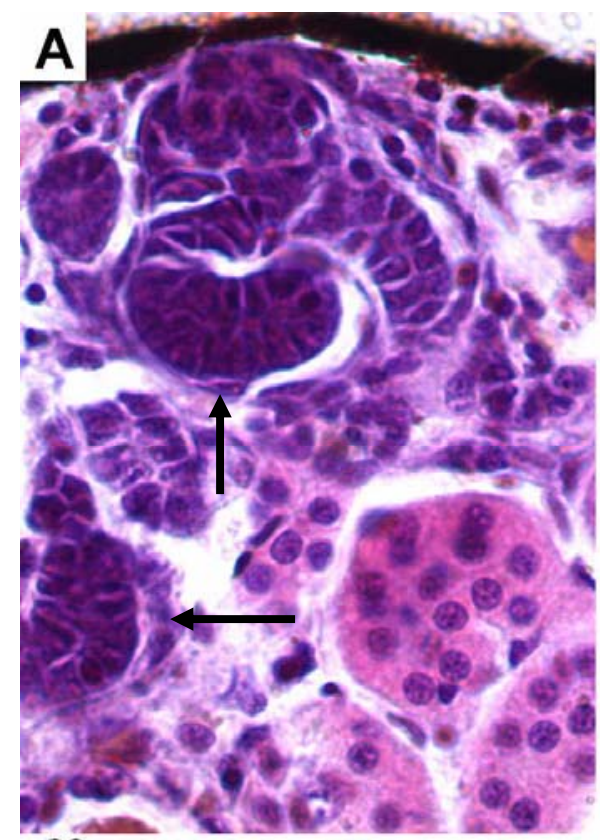

$20 \mu \mathrm{m}$

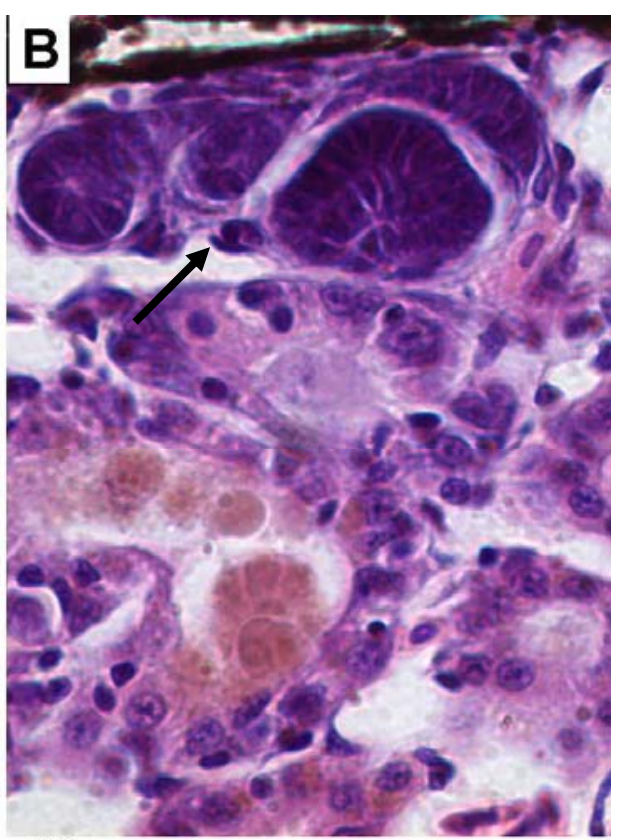

$20 \mu \mathrm{m}$
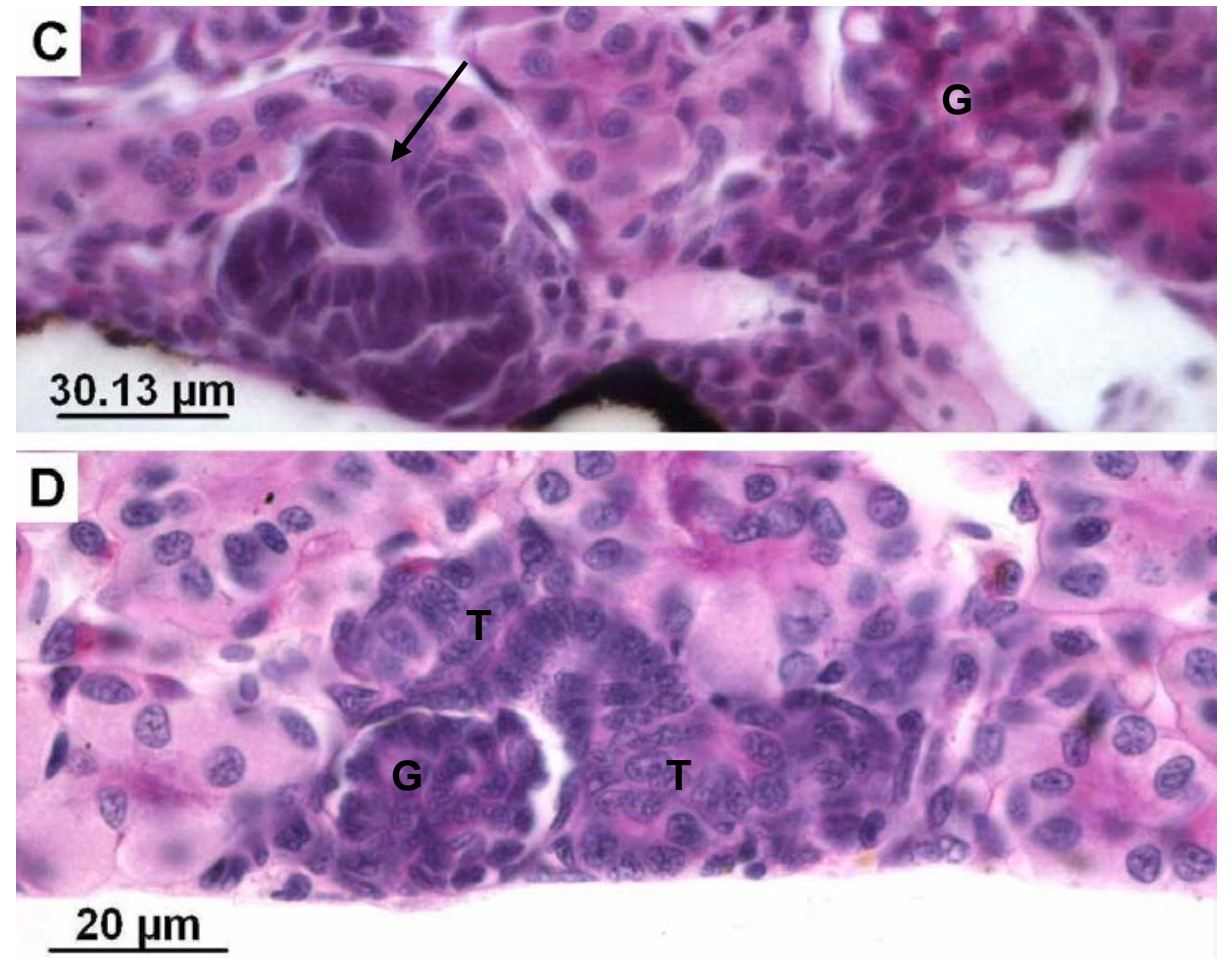

FIGURA 45: A e B - Novos néfrons (setas) no rim de S. notomelas exposto ao sedimento da localidade de Americana. Notar as estruturas em forma de "C". Notar em $B$ a presença de uma substância de coloração amarela no lúmen de um túbulo degenerado (HE, $5 \mu \mathrm{m}$ ). Em C é possível observar um novo néfron em formação (estágio inicial) no rim de $S$. notomelas exposto ao sedimento da localidade de Pirassununga; $\mathrm{G}=$ glomérulo. Em $\mathrm{D}$, um novo néfron em estado mais adiantado de formação no rim de $S$. notomelas exposto ao sedimento da localidade de São João. Neste novo néfron já é possível identificar o glomérulo $(G)$ e os túbulos (T) (PAShematoxilina, $5 \mu \mathrm{m}$ ) 


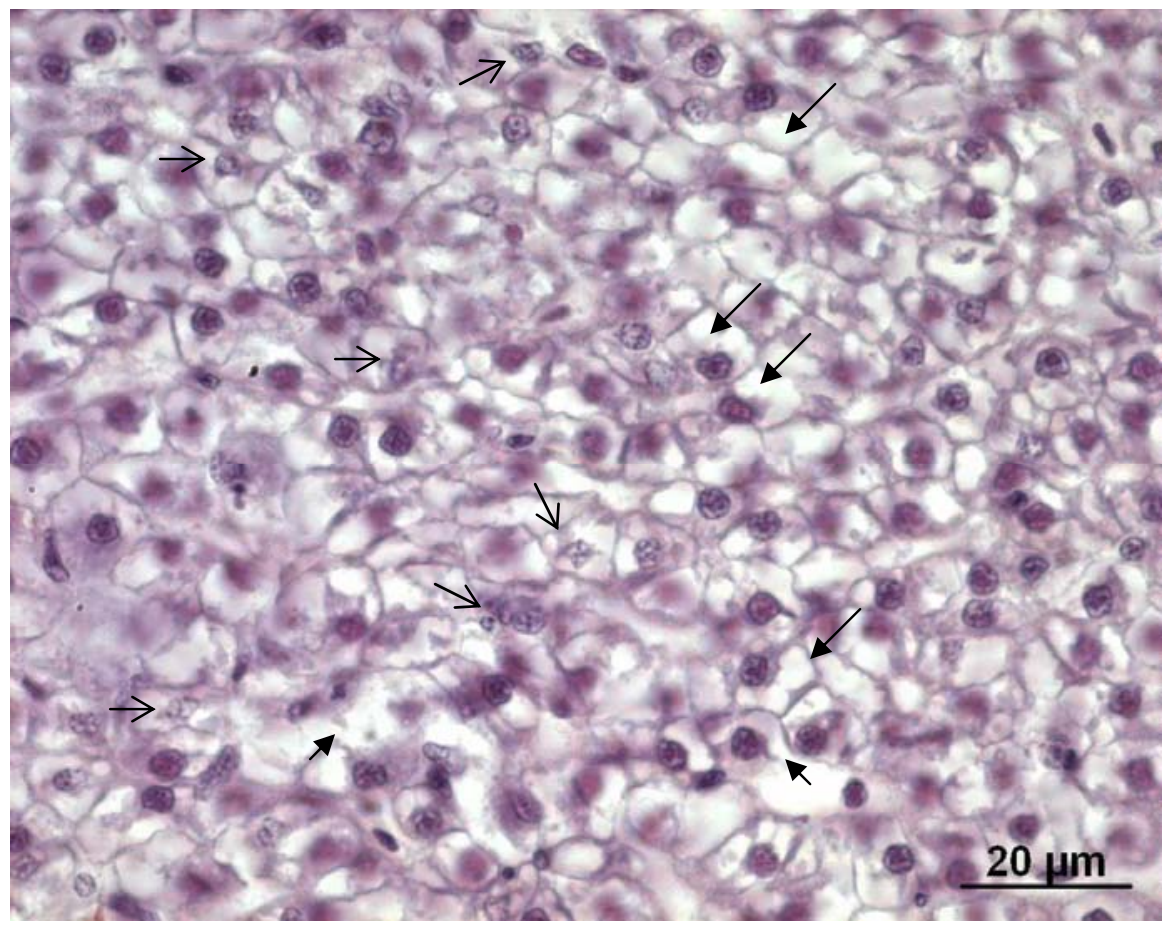

FIGURA 46: Fígado de $D$. rerio exposto ao sedimento da localidade de Sumaré. Notar a intensa vacuolização citoplasmática (setas maiores), o grande número de núcleos com contorno atípico, o rompimento celular (cabeças de setas)e a descaracterização dos cordões hepáticos. (HE, $5 \mu \mathrm{m})$.

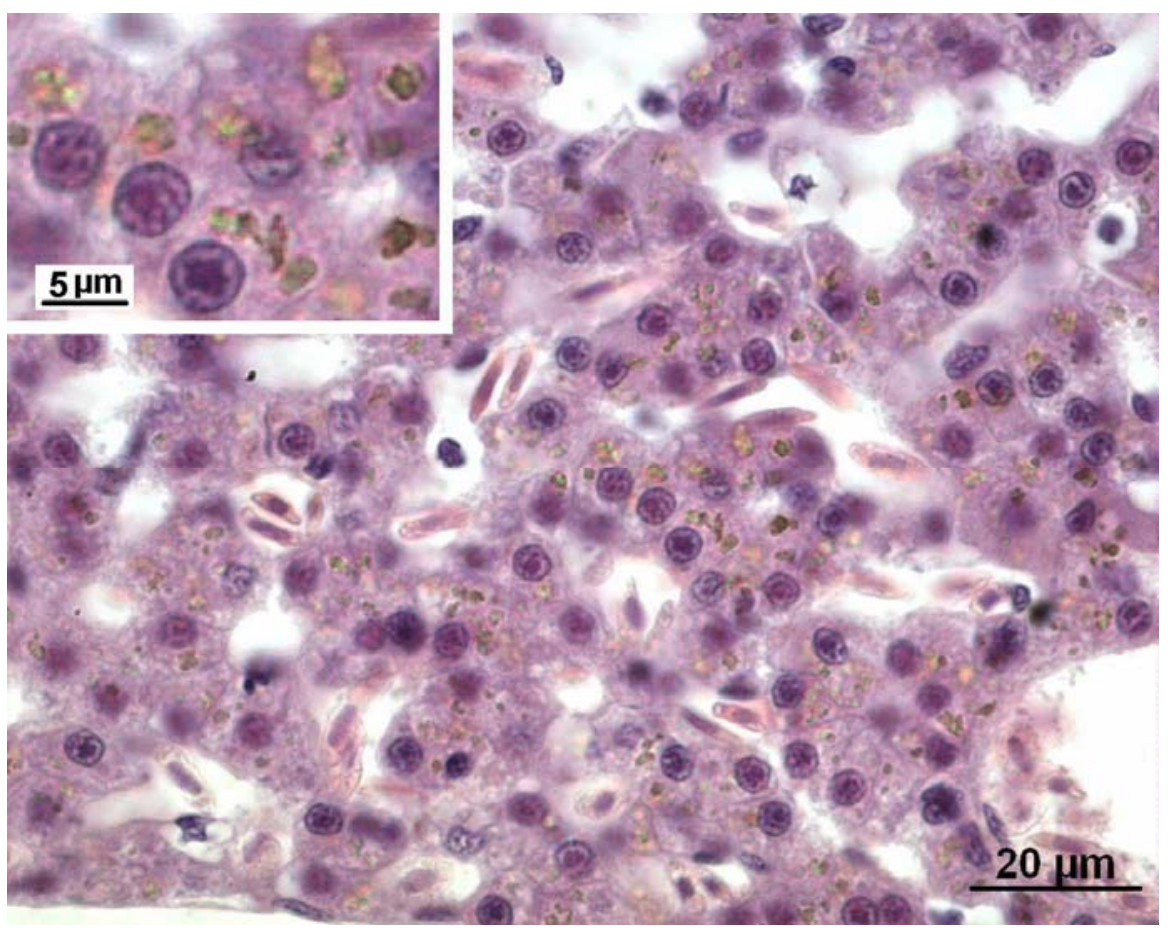

FIGURA 47: Estagnação biliar no fígado de S. notomelas exposto ao sedimento da localidade de Americana. Notar a aglomeração de grânulos amarelados no citoplasma dos hepatócitos (colestase). Observar também que os hepatócitos não apresentam contorno e forma bem definidos. (HE, $6 \mu \mathrm{m}$ ) 


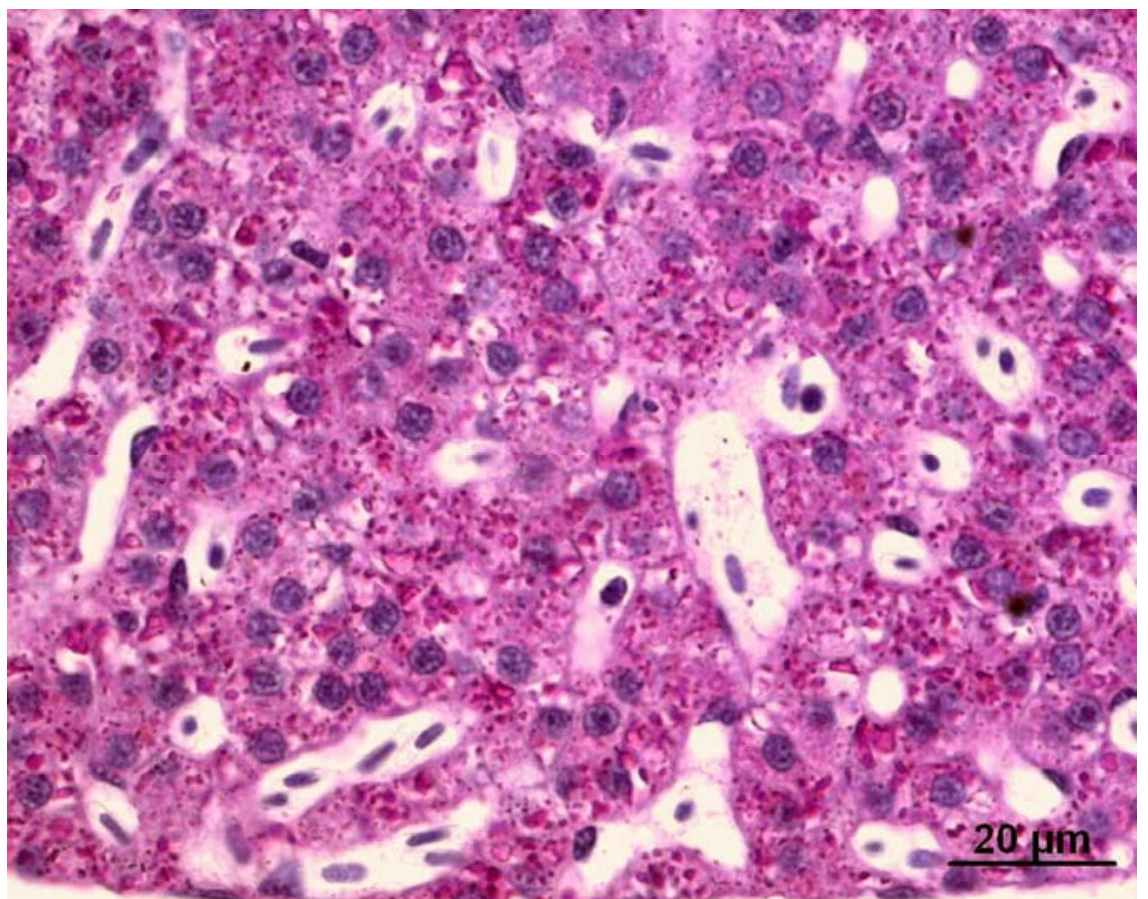

FIGURA 48: Fígado de S. notomelas exposto ao sedimento da localidade Luiz Antônio 1. Notar a quantidade relativamente alta de grânulos de glicogênio nos hepatócitos. (PAS-hematoxilina, $5 \mu \mathrm{m}$ ).

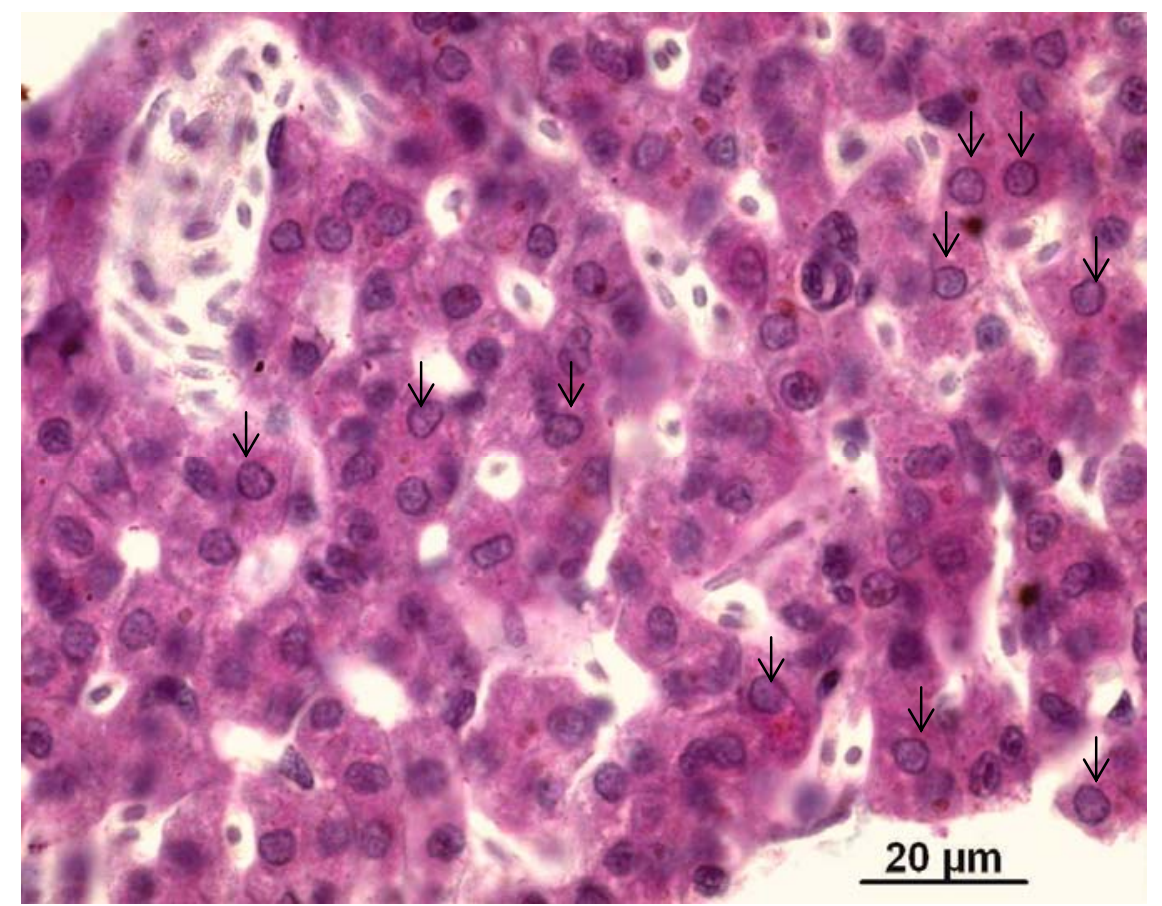

FIGURA 49: Fígado de $S$. notomelas exposto ao sedimento da localidade Luiz Antônio 2. Observar a quantidade reduzida de glicogênio nos hepatócitos. (PAShematoxilina, $5 \mu \mathrm{m}$ ). Notar a alta ocorrência de degeneração vacuolar nuclear (setas). (PAS-hematoxilina, $5 \mu \mathrm{m}$ ). 

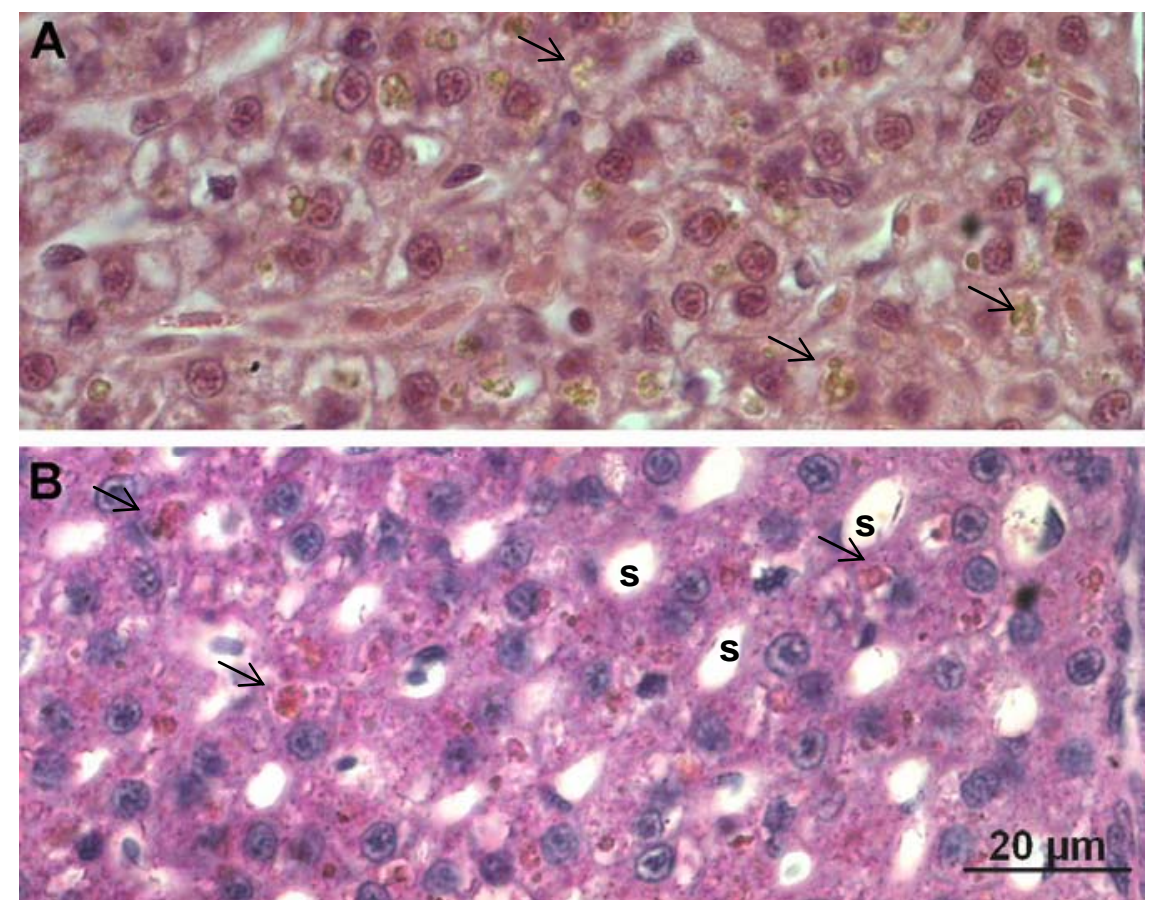

FIGURA 50: Fígado de S. notomelas exposto ao sedimento da localidade S. João. A e $B$ correspondem ao mesmo animal. Porém, em A a coloração utilizada foi HE e em B, PAS contra-corado com hematoxilina. Comprova-se, assim, que os grânulos (setas) não correspondem a glicogênio, mas provavelmente à estagnação de bile nos hepatócitos, pois não apareceram corados fortemente em B. Observar em B os sinusóides (s) em secção transversal e os vacúolos no citoplasma dos hepatócitos (áreas mais claras).

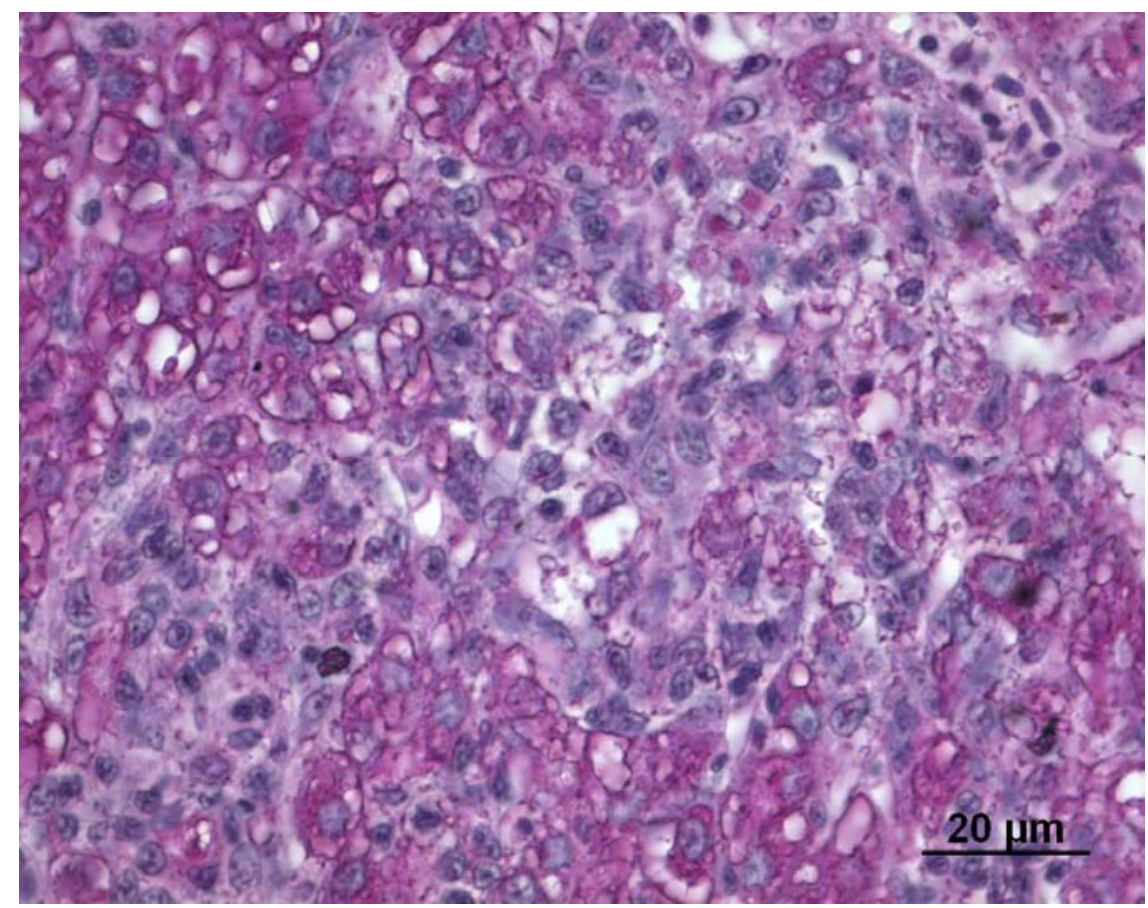

FIGURA 51: Necrose do tecido hepático de D. rerio exposto ao sedimento da localidade de Mogi Guaçu 2. Notar, na área central, a desorganização do tecido, cujas células não têm contorno definido e muitos núcleos aparecem atrofiados. Observar nas áreas adjacentes os grandes vacúolos no citoplasma dos hepatócitos e a ausência de reservas de glicogênio. (PAS-hematoxilina, $5 \mu \mathrm{m}$ ). 


\subsection{Testes de toxicidade in situ com Serrapinnus notomelas}

Os experimentos foram realizados nas três bacias com sucesso, desde a aclimatação preliminar dos peixes, o transporte aos locais de estudo, a instalação das câmaras até o monitoramento diário e o recolhimento ao final das 96 horas. Os peixes, aclimatados previamente em laboratório, apresentavam excelente estado de saúde, já que não ocorreu a morte de nenhum indivíduo, bem como não foi observado comportamento de estresse. Aqueles peixes que não foram utilizados em eventuais remontagens retornaram todos vivos e saudáveis ao laboratório, o que comprova que Serrapinnus notomelas resiste bem ao transporte e ao manuseio constante, desde que bem aclimatados previamente.

Considerando que em trabalhos de campo experimentais os imprevistos podem ser muitos e de natureza variável, foram poucas as intercorrências durante os testes in situ realizados. Nos testes realizados na bacia do rio Tibagi o único problema ocorreu em Londrina, quando os 10 peixes de uma das câmaras foram "roubados", da mesma maneira que 8 peixes de outra câmara instalada no rio Jaguari Mirim, na bacia do rio Mogi Guaçu. A única explicação para o desaparecimento destes animais é o roubo, já que em ambos os casos não havia aberturas na malha das câmaras e estas apresentavam o parafuso de segurança da tampa completamente desatarrachado (Tibagi) ou mal colocado (Jaguari-Mirim), evidenciando que foram violadas.

Outra intercorrência ocorreu em Mogi Guaçu, à montante da fábrica de papel, quando após uma forte chuva e consequente elevação do nível da água e aumento da correnteza, uma das câmaras desprendeu-se do fundo e foi fortemente agitada pela força da água, o que provocou a morte de 7 peixes provavelmente por estresse, já que na réplica, que estava melhor instalada - as duplicatas são instaladas próximas protegida da forte correnteza, não ocorreu a morte de nenhum dos peixes.

Com relação às mortes ocorridas por problemas de qualidade da água (substâncias tóxicas ou baixa concentração de oxigênio dissolvido), estas ocorreram somente na bacia do rio Piracicaba, em Campinas e Sumaré, no rio Atibaia e em Piracicaba, no rio Piracicaba. Em Campinas, ocorreu a mortalidade de todos os peixes, das duas câmaras, em apenas 24 horas de exposição. No entanto, este fato não foi devido propriamente aos efeitos tóxicos das substâncias presentes na água, mas muito provavelmente à baixa concentração de oxigênio, o que causou também uma alta mortandade de peixes (principalmente bagres) no rio Atibaia naquele dia, conforme foi possível observar. No momento do monitoramento (13:30, do dia 08/12/02) a concentração de oxigênio dissolvido era de 5,95 mg. $\mathrm{L}^{-1}$, coincidindo com a leitura realizada pelos técnicos da estação de captação $\left(5,8 \mathrm{mg} \cdot \mathrm{L}^{-1}\right)$. Segundo os 
registros na estação de captação de água, a concentração de oxigênio dissolvido na água variou, às 04:00, de 0,1 a 0,5 mg. $\mathrm{L}^{-1}$. De acordo com os registros, observa-se que é comum a concentração de oxigênio atingir valores muito baixos à noite, principalmente após uma chuva não muito forte. Isto pode ser atribuído a um ribeirão com alta carga de esgotos provenientes de Valinhos, que tem a vazão aumentada por uma chuva localizada (que aumenta o aporte de esgoto no rio Atibaia); quando a chuva é forte e abrange áreas mais extensas na região, aumenta a vazão (e a diluição) também do rio Atibaia, minimizando o impacto e evitando a mortandade de peixes. De fato, observando um trecho à montante da captação, foi possível verificar que só havia peixes mortos à jusante do referido ribeirão.

No mesmo dia (08/12, 24 horas de teste), uma das câmaras foi reinstalada com 7 peixes e outra com 10 peixes foi reinstalada no dia 10/12 (72 h). Isto foi feito para que pudessem ser analisados peixes expostos a este ambiente, mesmo que por períodos de tempo mais curtos. Da remontagem até o final, não houve mortalidade de nenhum organismo.

Em Piracicaba, a mortalidade de todos os peixes no segundo dia de exposição, provavelmente também foi devida à queda na concentração de oxigênio dissolvido, já que, além de ter ocorrido alta mortalidade, nesse dia foi registrada a concentração de apenas $0,97 \mathrm{mg} \mathrm{O} \mathrm{O}_{2} \cdot \mathrm{L}^{-1}$ na água do local. Em laboratório pôde ser observado que a espécie Serrapinnus notomelas tolera baixas concentrações de oxigênio. No teste com efluente, por exemplo, a concentração deste gás atingiu $0,80 \mathrm{mg} \cdot \mathrm{L}^{-1}$ e nenhum organismo morreu. No entanto, no ambiente natural há estressores que estão ausentes nas condições controladas de laboratório. Uma situação de baixo teor de $\mathrm{O}_{2}$, aliada à variações de temperatura, correnteza, eventuais parasitas e agentes tóxicos é mais difícil de ser fisiologicamente contornada do que a mesma condição sem este estresse adicional. No entanto, dos 10 peixes colocados na câmara na remontagem (72 $2^{a}$ hora, no dia 10/12/02), 5 morreram em 24 horas de exposição. Nesse episódio talvez a causa não seja a concentração de $\mathrm{O}_{2}$ dissolvido, pois, embora baixa $(1,78$ $\left.\mathrm{mg} \cdot \mathrm{L}^{-1}\right)$, a concentração deste gás provavelmente não desceu abaixo deste nível, pois a medida foi tomada às 07:00, e na primeira montagem do teste os peixes resistiram à teores mais baixos nas primeiras 24 horas.

Nas localidades restantes todos os organismos resistiram às 96 horas de exposição e foram, então, fixados para posterior análise histológica. Nos locais considerados altamente impactados, como Americana, Campinas e Sumaré, alguns peixes foram retirados ainda vivos como uma precaução contra os eventos ocorridos em Campinas e Piracicaba. Se houvesse novos eventos de mortalidade em massa, alguns estariam "salvos" para serem analisados. 
As variáveis monitoradas, bem como as observações diárias, estão contidas nas tabelas $23 \mathrm{~A}$ à $23 \mathrm{O}$. As eventuais intercorrências estão assinaladas (numeradas) com a respectiva observação abaixo de cada tabela.

TABELAS 23 A à 23 O: Número de organismos mortos, variáveis físicas e químicas monitoradas e observações realizadas ao longo dos testes in situ nos locais de estudo nas bacias dos rios Tibagi, Piracicaba e Mogi Guaçu.

Obs.: * nível da água em $0 \mathrm{~h}$ classificado como baixo, médio ou alto (de acordo com observações em outras épocas e informações de pescadores e ribeirinhos); nos demais dias, variações relativas ao dia anterior $(0 \mathrm{~h}=0 \mathrm{~cm})$; ${ }^{* \star}$ clima: parc. nublado.=parcialmente nublado.

tabela $23 \mathrm{~A}$

\begin{tabular}{|c|c|c|c|c|c|c|c|c|c|c|c|}
\hline \multicolumn{2}{|c|}{ Localidade: } & Telêt & co Bork & $11-r i$ & Tibagi, & mon & te da & labin & & & \\
\hline \multicolumn{2}{|c|}{ tempo / data } & $\mathrm{Oh}$ & $6 / 11 / 01$ & $24 \mathrm{~h}$ & //11/01 & $48 \mathrm{~h}$ & $8 / 11 / 01$ & $72 \mathrm{~h}$ & 9/11/01 & $96 \mathrm{~h}$ & $0 / 11 / 01$ \\
\hline \multicolumn{2}{|l|}{ réplica } & A & $B$ & A & $B$ & A & $B$ & A & $B$ & A & $B$ \\
\hline \multicolumn{2}{|c|}{$\mathrm{n}^{\circ}$ - mortos / total } & $0 / 10$ & $0 / 10$ & $0 / 10$ & $0 / 10$ & $0 / 10$ & $0 / 10$ & $0 / 10$ & $0 / 10$ & $0 / 10$ & $0 / 10$ \\
\hline \multicolumn{2}{|l|}{$\mathrm{pH}$} & \multicolumn{2}{|c|}{6,54} & \multicolumn{2}{|c|}{6,86} & \multicolumn{2}{|c|}{6,91} & \multicolumn{2}{|c|}{6,93} & \multicolumn{2}{|c|}{7,00} \\
\hline \multicolumn{2}{|c|}{ Temp. água $\left({ }^{\circ} \mathrm{C}\right)$} & \multirow{2}{*}{\multicolumn{2}{|c|}{$\begin{array}{l}22,6 \\
8,89\end{array}$}} & \multirow{2}{*}{\multicolumn{2}{|c|}{$\frac{22,4}{8,5}$}} & \multicolumn{2}{|c|}{21,3} & \multicolumn{2}{|c|}{21,5} & \multicolumn{2}{|c|}{21,9} \\
\hline \multirow{2}{*}{\multicolumn{2}{|c|}{ O.D. $\left(\mathrm{mg} \mathrm{O}_{2} \mathrm{~L}^{-1}\right)$}} & & & & & & & \multirow{2}{*}{\multicolumn{2}{|c|}{$\frac{8,74}{22}$}} & \multicolumn{2}{|c|}{8,80} \\
\hline Cond. $\left(\mathrm{mS} \mathrm{cm}^{-1}\right)$ & & \multicolumn{2}{|c|}{22} & \multicolumn{2}{|c|}{22} & \multicolumn{2}{|c|}{24} & & & & \\
\hline \multicolumn{2}{|c|}{ Dur. $\left(\mathrm{mg} \mathrm{CaCo}_{3} \cdot \mathrm{L}^{-1}\right)$} & \multicolumn{2}{|c|}{10,5} & \multicolumn{2}{|c|}{11,2} & \multicolumn{2}{|c|}{9,2} & \multicolumn{2}{|c|}{7,9} & \multicolumn{2}{|c|}{7,9} \\
\hline \multirow{2}{*}{$\begin{array}{l}\text { Caract. } \\
\text { água* }\end{array}$} & cor & \multicolumn{2}{|c|}{ turva } & \multicolumn{2}{|c|}{ turva } & \multicolumn{2}{|c|}{ turva } & \multicolumn{2}{|c|}{ turva } & \multicolumn{2}{|c|}{ turva } \\
\hline & nível & \multirow{2}{*}{\multicolumn{2}{|c|}{$\begin{array}{c}\text { médio } \\
\text { parc.nublado }\end{array}$}} & \multicolumn{2}{|c|}{$+10 \mathrm{~cm}$} & & $\mathrm{~cm}$ & & & & $\mathrm{~cm}$ \\
\hline Clima ${ }^{\star \star}$ & & & & & & & ado & nul & ado & enso & rado \\
\hline
\end{tabular}

tabela $23 \mathrm{~B}$

Localidade: Telêmaco Borba 2 - rio Tibagi, à jusante da Klabin

\begin{tabular}{|c|c|c|c|c|c|c|c|c|c|c|c|}
\hline \multirow{2}{*}{\multicolumn{2}{|c|}{\begin{tabular}{|l|} 
tempo / data \\
réplica
\end{tabular}}} & $\mathrm{Oh}$ & $6 / 11 / 01$ & $24 \mathrm{~h}$ & $7 / 11 / 0$ & $48 \mathrm{~h}$ & $8 / 11 / 0$ & $72 \mathrm{~h}$ & $9 / 11 /($ & $96 \mathrm{~h}$ & $0 / 11 / 01$ \\
\hline & & $A$ & $B$ & A & $B$ & $A$ & $B$ & A & $B$ & $A$ & $B$ \\
\hline \multicolumn{2}{|c|}{$n^{\circ}$ mortos / total } & $0 / 10$ & $0 / 10$ & $0 / 10$ & $0 / 10$ & $0 / 10$ & $0 / 10$ & $0 / 10$ & $0 / 1$ & $0 / 10$ & $0 / 10$ \\
\hline \multicolumn{2}{|l|}{$\mathrm{pH}$} & \multicolumn{2}{|c|}{6,57} & \multicolumn{2}{|c|}{6,56} & \multicolumn{2}{|c|}{6,94} & \multicolumn{2}{|c|}{6,90} & \multicolumn{2}{|c|}{6,93} \\
\hline \multicolumn{2}{|c|}{ Temp. água $\left({ }^{\circ} \mathrm{C}\right)$} & \multicolumn{2}{|c|}{23,4} & \multicolumn{2}{|c|}{22,2} & \multicolumn{2}{|c|}{21,4} & \multicolumn{2}{|c|}{21,4} & \multicolumn{2}{|c|}{21,6} \\
\hline \multicolumn{2}{|c|}{ O.D. $\left(\mathrm{mg} \mathrm{O}_{2} . \mathrm{L}^{-1}\right)$} & & & \multirow{2}{*}{\multicolumn{2}{|c|}{$\frac{0,05}{25}$}} & \multirow{2}{*}{\multicolumn{2}{|c|}{$\frac{8,76}{24}$}} & \multicolumn{2}{|c|}{8,34} & \multicolumn{2}{|c|}{8,57} \\
\hline \multicolumn{2}{|c|}{ Cond. $\left(\mathrm{mS} . \mathrm{cm}^{-1}\right)$} & \multicolumn{2}{|c|}{25} & & & & & & & & \\
\hline \multicolumn{2}{|c|}{ Dur. $\left(\mathrm{mg} \mathrm{CaCO}_{3} \mathrm{~L}^{-1}\right)$} & \multicolumn{2}{|c|}{11,6} & \multicolumn{2}{|c|}{11,2} & \multicolumn{2}{|c|}{10,5} & \multicolumn{2}{|c|}{8,5} & \multicolumn{2}{|c|}{8,5} \\
\hline \multirow{2}{*}{$\begin{array}{l}\text { Caract. } \\
\text { água* }\end{array}$} & cor & \multicolumn{2}{|c|}{ turva } & \multicolumn{2}{|c|}{ turva } & \multicolumn{2}{|c|}{ turva } & \multicolumn{2}{|c|}{ turva } & \multicolumn{2}{|c|}{ turva } \\
\hline & nível & \multicolumn{2}{|c|}{ médio } & \multicolumn{2}{|c|}{$+10 \mathrm{~cm}$} & \multicolumn{2}{|c|}{0} & \multicolumn{2}{|c|}{0} & \multicolumn{2}{|c|}{$-10 \mathrm{~cm}$} \\
\hline Clima $^{\star \star}$ & & $\mathrm{pe}$ & ublado & & & & & & & & $\mathrm{au}$ \\
\hline
\end{tabular}

tabela $23 \mathrm{C}$

\begin{tabular}{|c|c|c|c|c|c|c|c|c|c|c|c|}
\hline \multicolumn{2}{|c|}{ Localidade: } & \multicolumn{10}{|c|}{ Londrina - rio Tibagi, bairro do Limoeiro (zona rural) } \\
\hline \multicolumn{2}{|c|}{ tempo / data } & $\mathrm{Oh}$ & $4 / 11 / 01$ & $24 \mathrm{~h}$ & 5/11/01 & $48 \mathrm{~h}$ & $/ 11 / 01$ & $72 \mathrm{~h}$ & /11/01 & $96 \mathrm{~h}$ & 3/11/01 \\
\hline \multicolumn{2}{|l|}{ réplica } & $A$ & $B$ & $A$ & B & $A$ & $B$ & $A$ & $B$ & $A$ & B \\
\hline \multicolumn{2}{|c|}{$\mathrm{n}^{\circ}$ mortos / total } & $0 / 10$ & $0 / 10$ & $0 / 10$ & $0 / 10$ & $0 / 10$ & $0 / 0^{1}$ & $0 / 10$ & - & $0 / 10$ & - \\
\hline \multicolumn{2}{|l|}{$\mathrm{pH}$} & \multicolumn{2}{|c|}{7,40} & \multicolumn{2}{|c|}{7,41} & \multicolumn{2}{|c|}{7,43} & \multicolumn{2}{|c|}{7,40} & \multicolumn{2}{|c|}{7,40} \\
\hline \multicolumn{2}{|c|}{ Temp. água $\left({ }^{\circ} \mathrm{C}\right)$} & \multirow{2}{*}{\multicolumn{2}{|c|}{$\begin{array}{l}25,7 \\
7,22\end{array}$}} & \multirow{2}{*}{\multicolumn{2}{|c|}{26,3}} & \multirow{2}{*}{\multicolumn{2}{|c|}{$\begin{array}{l}26,2 \\
7,29\end{array}$}} & & & \multirow{2}{*}{\multicolumn{2}{|c|}{$\begin{array}{l}25,1 \\
726\end{array}$}} \\
\hline \multicolumn{2}{|c|}{ O.D. $\left(\mathrm{mg} \mathrm{O}_{2} \cdot \mathrm{L}^{-1}\right)$} & & & & & & & \multicolumn{2}{|c|}{$\begin{array}{l}25,9 \\
7,25\end{array}$} & & \\
\hline \multirow{2}{*}{\multicolumn{2}{|c|}{$\begin{array}{l}\text { Cond. }\left(\mathrm{mS} \mathrm{cm}^{-1}\right) \\
\text { Dur. }\left(\mathrm{mg} \mathrm{CaCo}_{2} \mathrm{~L}^{-1}\right)\end{array}$}} & \multicolumn{2}{|c|}{39} & \multicolumn{2}{|c|}{43} & \multicolumn{2}{|c|}{40} & \multicolumn{2}{|c|}{39} & \multicolumn{2}{|c|}{40} \\
\hline & & \multicolumn{2}{|c|}{11,8} & \multicolumn{2}{|c|}{11,2} & \multicolumn{2}{|c|}{10,5} & \multicolumn{2}{|c|}{9,2} & \multicolumn{2}{|c|}{9,2} \\
\hline \multirow{2}{*}{$\begin{array}{l}\text { Caract. } \\
\text { água }^{*}\end{array}$} & cor & \multicolumn{2}{|c|}{ pouco turva } & \multirow{2}{*}{\multicolumn{2}{|c|}{ pouco turva }} & \multicolumn{2}{|c|}{ pouco turva } & \multicolumn{2}{|c|}{ pouco turva } & \multicolumn{2}{|c|}{ pouco turva } \\
\hline & nível & \multirow{2}{*}{\multicolumn{2}{|c|}{ médio }} & & & & & & & & \\
\hline Clima** & & & & \multicolumn{2}{|c|}{ noro nublado } & enso & rado & enso & rado & ensc & rado \\
\hline
\end{tabular}

${ }^{1}$ todos os peixes roubados em uma réplica $(48 \mathrm{~h})$. 
tabela $23 \mathrm{D}$

\begin{tabular}{|c|c|c|c|c|c|c|c|c|c|c|c|}
\hline \multirow{2}{*}{\multicolumn{2}{|c|}{$\begin{array}{l}\text { Localidade: } \\
\text { tempo / data }\end{array}$}} & \multicolumn{10}{|c|}{ Ribeirão do Pinhal (próximo à captação da Águas de Limeira no rio Jaguari) } \\
\hline & & $0 \mathrm{~h}$ & $7 / 12 / 01$ & $24 \mathrm{~h}$ & $8 / 12 / 0$ & $48 \mathrm{~h}$ & $9 / 12 / 01$ & $72 \mathrm{~h}$ & $0 / 12 / 01$ & $96 \mathrm{~h}$ & $11 / 12 / 01$ \\
\hline \multicolumn{2}{|c|}{ réplica } & $A$ & $B$ & $A$ & B & $A$ & $B$ & $A$ & $B$ & $A$ & $\mathrm{~B}$ \\
\hline \multicolumn{2}{|c|}{$\mathrm{n}^{\mathrm{o}}$ mortos / total } & $0 / 10$ & $0 / 10$ & $0 / 10$ & $0 / 10$ & $0 / 10$ & $0 / 10$ & $0 / 10$ & $0 / 10$ & $0 / 10$ & $0 / 10$ \\
\hline \multicolumn{2}{|l|}{$\mathrm{pH}$} & \multicolumn{2}{|c|}{7,48} & \multicolumn{2}{|c|}{7,45} & \multicolumn{2}{|c|}{7,35} & \multicolumn{2}{|c|}{7,33} & \multicolumn{2}{|c|}{7,15} \\
\hline \multicolumn{2}{|c|}{ Temp. água $\left({ }^{\circ} \mathrm{C}\right)$} & \multirow{2}{*}{\multicolumn{2}{|c|}{$\frac{26,0}{5,75}$}} & \multirow{2}{*}{\multicolumn{2}{|c|}{$\frac{26,4}{6,64}$}} & \multicolumn{2}{|c|}{26,4} & \multicolumn{2}{|c|}{24,9} & \\
\hline \multicolumn{2}{|c|}{ O.D. $\left(\mathrm{mg} \mathrm{O}_{2} \cdot \mathrm{L}^{-1}\right)$} & & & & & \multirow{2}{*}{\multicolumn{2}{|c|}{$\begin{array}{c}6,51 \\
58\end{array}$}} & \multirow{2}{*}{\multicolumn{2}{|c|}{$\frac{6,77}{46}$}} & \multicolumn{2}{|c|}{6,63} \\
\hline \multicolumn{2}{|c|}{ Cond. $\left(\mathrm{mS} . \mathrm{cm}^{-1}\right)$} & \multicolumn{2}{|c|}{66} & \multicolumn{2}{|c|}{60} & & & & & & 6 \\
\hline \multicolumn{2}{|c|}{ Dur. $\left(\mathrm{mg} \mathrm{CaCo}_{3} \cdot \mathrm{L}^{-1}\right)$} & \multicolumn{2}{|c|}{8,8} & \multicolumn{2}{|c|}{ - } & \multicolumn{2}{|c|}{8,8} & \multicolumn{2}{|c|}{-} & \multicolumn{2}{|c|}{8,8} \\
\hline Caract. & cor & \multirow{2}{*}{\multicolumn{2}{|c|}{$\begin{array}{l}\text { pouco turva } \\
\text { médio }\end{array}$}} & \multicolumn{2}{|c|}{ turva } & \multicolumn{2}{|c|}{ turva } & \multicolumn{2}{|c|}{ muito turva } & \multicolumn{2}{|c|}{ muito turva } \\
\hline água* & nível & & & \multicolumn{2}{|c|}{$+40 \mathrm{~cm}$} & & & & & & 0 \\
\hline Clima** & & \multicolumn{2}{|c|}{ médio } & chi & isco & & ado & & isco & & lado \\
\hline
\end{tabular}

tabela $23 \mathrm{E}$

\begin{tabular}{|c|c|c|c|c|c|c|c|c|c|c|c|}
\hline \multirow{3}{*}{\multicolumn{2}{|c|}{\begin{tabular}{|l|}
\multicolumn{1}{|c|}{ Localidade: } \\
tempo / data \\
réplica \\
\end{tabular}}} & \multicolumn{10}{|c|}{ Limeira - rio Jaguari (captação) } \\
\hline & & \multirow{2}{*}{$\frac{\mathrm{Oh}}{\mathrm{A}}$} & \multirow{2}{*}{$07 / 12 / 01$} & \multicolumn{2}{|c|}{$24 \mathrm{~h} \quad 08 / 12 / 01$} & \multicolumn{2}{|c|}{$48 \mathrm{~h} \quad 09 / 12 / 01$} & \multicolumn{2}{|c|}{$72 \mathrm{~h} \quad 10 / 12 / 01$} & \multicolumn{2}{|c|}{$96 \mathrm{~h} \quad 11 / 12 / 01$} \\
\hline & & & & $A$ & $B$ & $A$ & $B$ & $A$ & $B$ & $A$ & $B$ \\
\hline \multirow{2}{*}{\multicolumn{2}{|c|}{$\begin{array}{l}\mathrm{n}^{\mathrm{o}} \text { mortos / total } \\
\mathrm{pH} \\
\end{array}$}} & $0 / 10$ & $0 / 10$ & $0 / 10$ & $0 / 10$ & $0 / 10$ & $0 / 10$ & $0 / 10$ & $0 / 10$ & $0 / 10$ & $0 / 10$ \\
\hline & & \multicolumn{2}{|c|}{7,27} & \multicolumn{2}{|c|}{7,20} & \multicolumn{2}{|c|}{7,20} & \multicolumn{2}{|c|}{7,29} & \multicolumn{2}{|c|}{7,17} \\
\hline \multicolumn{2}{|c|}{ Temp. água $\left({ }^{\circ} \mathrm{C}\right)$} & \multicolumn{2}{|c|}{26,0} & \multicolumn{2}{|c|}{26,5} & \multicolumn{2}{|c|}{25,1} & \multicolumn{2}{|c|}{25,5} & \multicolumn{2}{|c|}{25,0} \\
\hline \multirow{2}{*}{\multicolumn{2}{|c|}{ O.D. $\left(\mathrm{mg} \mathrm{O}_{2} \cdot \mathrm{L}^{-1}\right)$}} & \multirow{2}{*}{\multicolumn{2}{|c|}{$\begin{array}{l}5,15 \\
83\end{array}$}} & \multirow{2}{*}{\multicolumn{2}{|c|}{$\begin{array}{c}5,62 \\
77\end{array}$}} & \multirow{2}{*}{\multicolumn{2}{|c|}{$\begin{array}{c}6,36 \\
59\end{array}$}} & \multirow{2}{*}{\multicolumn{2}{|c|}{$\begin{array}{c}6,14 \\
53\end{array}$}} & \multirow{2}{*}{\multicolumn{2}{|c|}{$\frac{5,46}{58}$}} \\
\hline & & & & & & & & & & & \\
\hline \multicolumn{2}{|c|}{ Dur. $\left(\mathrm{mg} \mathrm{CaCo}_{3} \mathrm{~L}^{-1}\right)$} & \multicolumn{2}{|c|}{12,3} & \multicolumn{2}{|c|}{ - } & \multicolumn{2}{|c|}{12,3} & \multicolumn{2}{|c|}{ - } & \multicolumn{2}{|c|}{12,3} \\
\hline \multirow{2}{*}{$\begin{array}{l}\text { Caract. } \\
\text { água* }\end{array}$} & cor & \multicolumn{2}{|c|}{ pouco turva } & \multicolumn{2}{|c|}{ turva } & \multicolumn{2}{|c|}{ turva } & \multicolumn{2}{|c|}{ muito turva } & muit & turva \\
\hline & nível & & & & $\mathrm{cm}$ & & & & & & \\
\hline Clima** & & parc. & ublado & parc & blado & nul & ado & chu & isco & nuk & ado \\
\hline
\end{tabular}

tabela $23 \mathrm{~F}$

\begin{tabular}{|c|c|c|c|c|c|c|c|c|c|c|c|}
\hline \multicolumn{2}{|c|}{ Localidade: } & \multicolumn{10}{|c|}{ Campinas - rio Atibaia (captação próxima à Valinhos) } \\
\hline \multicolumn{2}{|c|}{ tempo / data } & $0 \mathrm{~h}$ & $7 / 12 / 01$ & $24 \mathrm{~h}$ & $8 / 12 / 01$ & $24 \mathrm{~h}(\mathrm{I}$ & $112 / 01$ & $48 \mathrm{~h}(\mathrm{I}$ & $/ 12 / 01$ & $72 \mathrm{~h}(I I)$ & $12 / 01$ \\
\hline \multicolumn{2}{|l|}{ réplica } & $A$ & $B$ & A & $B$ & A & $B$ & $A$ & B & A & $B$ \\
\hline \multicolumn{2}{|c|}{$\mathrm{n}^{\circ}$ mortos / total } & $0 / 10$ & $0 / 10$ & $10 / 10$ & $10 / 10$ & - & $0 / 7^{1}$ & - & $0 / 6^{2}$ & $0 / 10^{3}$ & $0 / 6$ \\
\hline \multicolumn{2}{|l|}{$\mathrm{pH}$} & \multicolumn{2}{|c|}{7,18} & \multicolumn{2}{|c|}{7,18} & \multicolumn{2}{|c|}{7,23} & \multicolumn{2}{|c|}{7,08} & \multicolumn{2}{|c|}{7,15} \\
\hline \multicolumn{2}{|c|}{ Temp. água $\left({ }^{\circ} \mathrm{C}\right)$} & \multirow{2}{*}{\multicolumn{2}{|c|}{$\frac{26,0}{5,64}$}} & \multirow{2}{*}{\multicolumn{2}{|c|}{$\begin{array}{l}25,0 \\
5,95\end{array}$}} & \multirow{2}{*}{\multicolumn{2}{|c|}{$\frac{24,6}{6,7}$}} & \multicolumn{2}{|c|}{24,1} & \multicolumn{2}{|c|}{23,8} \\
\hline \multicolumn{2}{|c|}{ O.D. $\left(\mathrm{mg} \mathrm{O}_{2} \cdot \mathrm{L}^{-1}\right)$} & & & & & & & & & & \\
\hline \multirow{2}{*}{\multicolumn{2}{|c|}{ Cond. $\left(\mathrm{mS}^{-\mathrm{cm}^{-1}}\right)^{-1}$}} & \multicolumn{2}{|c|}{102} & \multicolumn{2}{|c|}{91} & \multicolumn{2}{|c|}{63} & \multicolumn{2}{|c|}{58} & \multicolumn{2}{|c|}{66} \\
\hline & $\left.\mathrm{CO}_{3} \mathrm{~L}^{-1}\right)$ & \multicolumn{2}{|c|}{14,0} & \multicolumn{2}{|c|}{ - } & \multicolumn{2}{|c|}{10,5} & \multicolumn{2}{|c|}{ - } & \multicolumn{2}{|c|}{12,3} \\
\hline \multirow{2}{*}{$\begin{array}{l}\text { Caract. } \\
\text { água* }\end{array}$} & cor & \multirow{2}{*}{\multicolumn{2}{|c|}{ pouco turva }} & \multicolumn{2}{|c|}{ turva } & \multicolumn{2}{|c|}{ turva } & \multicolumn{2}{|c|}{ turva } & \multicolumn{2}{|c|}{ turva } \\
\hline & nível & \multirow{2}{*}{\multicolumn{2}{|c|}{ médio }} & \multicolumn{2}{|c|}{$+15 \mathrm{~cm}$} & & & & & +1 & \\
\hline Clima** & & & & parc. 1 & ublado & par & ublado & ens & rado & nub & do \\
\hline
\end{tabular}

${ }^{1}$ remontagem de uma câmara com 7 peixes em 08/11; ${ }^{2}$ retirada de 1 peixe vivo em 09/12 (24 $\mathrm{h}$ de exposição), por garantia; ${ }^{3}$ remontagem de uma câmara com 10 peixes em 10/12 (p/ exposição de apenas 24 horas). 
tabela $23 \mathrm{G}$

\begin{tabular}{|c|c|c|c|c|c|c|c|c|c|c|c|}
\hline \multirow{2}{*}{\multicolumn{2}{|c|}{$\begin{array}{l}\text { Localidade: } \\
\text { tempo / data }\end{array}$}} & \multicolumn{10}{|c|}{ Sumaré - rio Atibaia (captação próxima à Paulinia) } \\
\hline & & $\mathrm{Oh}$ & $7 / 12 / 01$ & $24 \mathrm{~h}$ & $8 / 12 / 01$ & $48 \mathrm{~h}$ & $9 / 12 / 01$ & Oh (II) & $112 / 01$ & $24 \mathrm{~h}(\mathrm{II})$ & $/ 12 / 01$ \\
\hline \multicolumn{2}{|c|}{ réplica } & A & B & A & $B$ & A & $\mathrm{B}$ & A & $\mathrm{B}$ & A & $\mathrm{B}$ \\
\hline \multicolumn{2}{|c|}{$\mathrm{n}^{\circ}$ mortos / total } & $0 / 10$ & $0 / 10$ & $0 / 10$ & $0 / 10$ & $10 / 10$ & $10 / 10$ & $0 / 10^{1}$ & - & $0 / 10$ & $0 / 10$ \\
\hline \multicolumn{2}{|l|}{$\mathrm{pH}$} & \multicolumn{2}{|c|}{7,31} & \multicolumn{2}{|c|}{7,31} & \multicolumn{2}{|c|}{7,50} & \multicolumn{2}{|c|}{7,15} & \multicolumn{2}{|c|}{7,15} \\
\hline \multicolumn{2}{|c|}{ Temp. água $\left({ }^{\circ} \mathrm{C}\right)$} & \multirow{2}{*}{\multicolumn{2}{|c|}{$\begin{array}{l}27,0 \\
2,87\end{array}$}} & \multirow{2}{*}{\multicolumn{2}{|c|}{$\begin{array}{l}27,8 \\
2,71\end{array}$}} & \multicolumn{2}{|c|}{27,0} & \multicolumn{2}{|c|}{25,8} & \multicolumn{2}{|c|}{24,9} \\
\hline \multicolumn{2}{|c|}{ O.D. $\left(\mathrm{mg} \mathrm{O}_{2 .} \mathrm{L}^{-1}\right)$} & & & & & & & & & & \\
\hline \multicolumn{2}{|c|}{ Cond. $\left(\mathrm{mS} . \mathrm{cm}^{-1}\right)$} & \multicolumn{2}{|c|}{338} & \multicolumn{2}{|c|}{338} & \multicolumn{2}{|c|}{218} & \multicolumn{2}{|c|}{$\frac{4,00}{119}$} & \multicolumn{2}{|c|}{115} \\
\hline Dur. (mg & $\mathrm{CO}_{3} \cdot \mathrm{L}^{-1}$ & \multicolumn{2}{|c|}{21,0} & \multicolumn{2}{|c|}{ - } & \multicolumn{2}{|c|}{15,8} & \multicolumn{2}{|c|}{ - } & \multicolumn{2}{|c|}{12,3} \\
\hline \multirow{2}{*}{$\begin{array}{l}\text { Caract. } \\
\text { água* }\end{array}$} & cor & \multirow{2}{*}{\multicolumn{2}{|c|}{$\begin{array}{c}\text { pouco turva } \\
\text { médio }\end{array}$}} & \multicolumn{2}{|c|}{ pouco turva } & \multicolumn{2}{|c|}{ pouco turva } & \multicolumn{2}{|c|}{ pouco turva } & \multirow{2}{*}{\multicolumn{2}{|c|}{ turva }} \\
\hline & nível & \multirow{2}{*}{\multicolumn{2}{|c|}{ médio }} & \multirow{2}{*}{\multicolumn{2}{|c|}{$\begin{array}{c}0 \\
\end{array}$}} & \multirow{2}{*}{\multicolumn{2}{|c|}{0}} & & & & \\
\hline Clima $^{\star \star}$ & & & & & & & & & & nuk & ado \\
\hline
\end{tabular}

${ }^{1}$ remontagem de uma câmara com 10 peixes em 10/12.

tabela $23 \mathrm{H}$

\begin{tabular}{|c|c|c|c|c|c|c|c|c|c|c|c|}
\hline \multirow{2}{*}{\multicolumn{2}{|c|}{$\begin{array}{l}\text { Localidade: } \\
\text { tempo / data }\end{array}$}} & \multicolumn{10}{|c|}{ Americana - rio Piracicaba (captação) } \\
\hline & & $\mathrm{Oh}$ & $7 / 12 / 01$ & $24 \mathrm{~h}$ & $8 / 12 / 01$ & $48 \mathrm{~h}$ & $9 / 12 / 01$ & $72 \mathrm{~h}$ & /12/01 & $96 \mathrm{~h}$ & $1 / 12 / 01$ \\
\hline \multicolumn{2}{|c|}{$\frac{\text { tempo / data }}{\text { réplica }}$} & $A$ & $B$ & $A$ & $B$ & $A$ & $B$ & $A$ & $B$ & $A$ & $B$ \\
\hline \multicolumn{2}{|c|}{$\begin{array}{l}\text { réplica } \\
\mathrm{n}^{\circ} \text { mortos / total }\end{array}$} & $0 / 10$ & $0 / 10$ & $0 / 10$ & $0 / 10$ & $0 / 10^{1}$ & $0 / 10^{1}$ & $0 / 7$ & $0 / 7$ & $0 / 7$ & $0 / 7$ \\
\hline \multicolumn{2}{|l|}{$\mathrm{pH}$} & \multicolumn{2}{|c|}{7,38} & \multicolumn{2}{|c|}{7,25} & \multicolumn{2}{|c|}{7,32} & \multicolumn{2}{|c|}{7,20} & \multicolumn{2}{|c|}{7,12} \\
\hline \multicolumn{2}{|c|}{ Temp. água $\left({ }^{\circ} \mathrm{C}\right)$} & \multicolumn{2}{|c|}{27,0} & \multicolumn{2}{|c|}{26,0} & \multicolumn{2}{|c|}{25,5} & \multicolumn{2}{|c|}{25,6} & \multicolumn{2}{|c|}{25,7} \\
\hline \multicolumn{2}{|c|}{ O.D. $\left(\mathrm{mg} \mathrm{O}_{2} \mathrm{~L}^{-1}\right)$} & & & \multirow{2}{*}{\multicolumn{2}{|c|}{$\frac{4,67}{107}$}} & & & & & & 05 \\
\hline Cond. $(\mathrm{m}$ & $\left(\mathrm{cm}^{-1}\right)$ & \multicolumn{2}{|c|}{151} & & & \multicolumn{2}{|c|}{97} & \multicolumn{2}{|c|}{148} & \multicolumn{2}{|c|}{158} \\
\hline \multicolumn{2}{|c|}{ Dur. $\left(\mathrm{mg} \mathrm{CaCo}_{3} \cdot \mathrm{L}^{-1}\right)$} & \multicolumn{2}{|c|}{15,8} & \multicolumn{2}{|c|}{-} & \multicolumn{2}{|c|}{15,8} & \multicolumn{2}{|c|}{ - } & \multicolumn{2}{|c|}{14,0} \\
\hline \multirow{2}{*}{$\begin{array}{l}\text { Caract. } \\
\text { água* }\end{array}$} & cor & \multicolumn{2}{|c|}{$\begin{array}{c}\text { pouco turva } \\
\text { médio }\end{array}$} & \multicolumn{2}{|c|}{ turva } & \multicolumn{2}{|c|}{ turva } & \multicolumn{2}{|c|}{ turva } & \multicolumn{2}{|c|}{ turva } \\
\hline & nível & \multirow{2}{*}{\multicolumn{2}{|c|}{ médio }} & \multicolumn{2}{|c|}{$+30 \mathrm{~cm}$} & \multicolumn{2}{|c|}{$+10 \mathrm{~cm}$} & & & & j \\
\hline Clima $^{\star \star}$ & & & ublado & parc. & ablado & nub & ado & chi & SCO & & lado \\
\hline
\end{tabular}

${ }^{1}$ nenhum peixe morreu; porém, foram retirados 3 de cada câmara, por garantia.

tabela 23 I

\begin{tabular}{|c|c|c|c|c|c|c|c|c|c|c|c|}
\hline \multirow{3}{*}{\multicolumn{2}{|c|}{\begin{tabular}{|l|}
\multicolumn{1}{|c}{ Localidade: } \\
tempo / data \\
réplica \\
\end{tabular}}} & \multicolumn{10}{|c|}{ Piracicaba - rio Piracicaba (antiga captação) } \\
\hline & & \multirow{2}{*}{$\begin{array}{r}0 \mathrm{~h} \\
\mathrm{~A}\end{array}$} & \multirow{2}{*}{$07 / 12 / 01$} & \multicolumn{2}{|c|}{$24 \mathrm{~h} \quad 08 / 12 / 01$} & \multicolumn{2}{|c|}{$48 \mathrm{~h} \quad 09 / 12 / 01$} & \multicolumn{2}{|c|}{ Oh (II) $10 / 12 / 01$} & \multicolumn{2}{|c|}{$24 \mathrm{~h}(\mathrm{II}) 11 / 12 / 01$} \\
\hline & & & & A & $B$ & A & $B$ & $A$ & $B$ & $A$ & $B$ \\
\hline \multicolumn{2}{|c|}{$\mathrm{n}^{\mathrm{o}}$ mortos / total } & $0 / 10$ & $0 / 10$ & $1 / 10$ & $0 / 10$ & $10 / 10$ & $10 / 10$ & - & $0 / 10^{1}$ & - & $5 / 10$ \\
\hline \multicolumn{2}{|l|}{$\mathrm{pH}$} & \multicolumn{2}{|c|}{7,22} & \multicolumn{2}{|c|}{7,19} & \multicolumn{2}{|c|}{7,15} & \multicolumn{2}{|c|}{6,95} & \multicolumn{2}{|c|}{7,19} \\
\hline \multicolumn{2}{|c|}{ Temp. água $\left({ }^{\circ} \mathrm{C}\right)$} & \multicolumn{2}{|c|}{26,0} & \multicolumn{2}{|c|}{27,0} & \multicolumn{2}{|c|}{26,2} & \multicolumn{2}{|c|}{24,9} & \multicolumn{2}{|c|}{25,3} \\
\hline \multicolumn{2}{|c|}{ O.D. $\left(\mathrm{mg} \mathrm{O}_{2} \cdot \mathrm{L}^{-1}\right)$} & \multirow{2}{*}{\multicolumn{2}{|c|}{$\begin{array}{c}1,52 \\
251\end{array}$}} & & & \multirow{2}{*}{\multicolumn{2}{|c|}{$\begin{array}{c}0,97 \\
190\end{array}$}} & \multirow{2}{*}{\multicolumn{2}{|c|}{$\begin{array}{r}2,00 \\
138\end{array}$}} & \multicolumn{2}{|c|}{1,78} \\
\hline \multicolumn{2}{|c|}{ Cond. $\left(\mathrm{mS}^{\mathrm{c}} \mathrm{cm}^{-1}\right)$} & & & \multicolumn{2}{|c|}{$\begin{array}{l}1,22 \\
257\end{array}$} & & & & & & \\
\hline \multicolumn{2}{|c|}{ Dur. $\left(\mathrm{mg} \mathrm{CaCo}_{3} \cdot \mathrm{L}^{-1}\right)$} & \multicolumn{2}{|c|}{28,0} & \multicolumn{2}{|c|}{ - } & \multicolumn{2}{|c|}{19,3} & \multicolumn{2}{|c|}{ - } & \multicolumn{2}{|c|}{31,6} \\
\hline Caract. & cor & \multicolumn{2}{|c|}{ pouco turva } & \multicolumn{2}{|c|}{ pouco turva } & \multicolumn{2}{|c|}{ pouco turva } & & & & \\
\hline água* & nível & & & & $\mathrm{cm}$ & +2( & $\mathrm{cm}$ & & $\mathrm{cm}$ & & $\mathrm{cm}$ \\
\hline Clima $^{\star \star}$ & & & ado & $\mathrm{nu}$ & ado & nub & ado & & ado & parc. & iblado \\
\hline
\end{tabular}

${ }^{1}$ remontagem de uma câmara com 10 peixes em 10/12. 
tabela $23 \mathrm{~J}$

\begin{tabular}{|c|c|c|c|c|c|c|c|c|c|c|c|}
\hline \multirow{2}{*}{\multicolumn{2}{|c|}{$\begin{array}{l}\text { Localidade: } \\
\text { tempo / data }\end{array}$}} & \multicolumn{10}{|c|}{ São João da Boa Vista - rio Jaguari-Mirim (próximo á captação) } \\
\hline & & $0 \mathrm{~h}$ & $3 / 12 / 01$ & $24 \mathrm{~h}$ & $4 / 12 / 01$ & $48 \mathrm{~h}$ & $5 / 12 / 01$ & $72 \mathrm{~h}$ & $6 / 12 / 01$ & $96 \mathrm{~h}$ & $17 / 12 / 01$ \\
\hline \multicolumn{2}{|l|}{ réplica } & $A$ & $B$ & $A$ & $\mathrm{~B}$ & $A$ & $B$ & $A$ & $B$ & $A$ & $\mathrm{~B}$ \\
\hline \multicolumn{2}{|c|}{$\mathrm{n}^{\mathrm{o}}$ mortos / total } & $0 / 10$ & $0 / 10$ & $0 / 10$ & $0 / 10$ & $0 / 10$ & 0/10 & $0 / 10$ & $0 / 10$ & $0 / 10$ & $(8 ?) / 10$ \\
\hline \multicolumn{2}{|l|}{$\mathrm{pH}$} & \multicolumn{2}{|c|}{7,33} & \multicolumn{2}{|c|}{ não monit. } & \multicolumn{2}{|c|}{7,08} & \multicolumn{2}{|c|}{ não monit. } & \multicolumn{2}{|c|}{6,99} \\
\hline \multicolumn{2}{|c|}{ Temp. água $\left({ }^{\circ} \mathrm{C}\right)$} & \multirow{2}{*}{\multicolumn{2}{|c|}{$\frac{23,1}{6,68}$}} & \multirow{2}{*}{\multicolumn{2}{|c|}{$\frac{\text { não monit. }}{\text { não monit. }}$}} & \multirow{2}{*}{\multicolumn{2}{|c|}{$\frac{22,8}{5,3}$}} & \multicolumn{2}{|c|}{ não monit. } & \multicolumn{2}{|c|}{24,0} \\
\hline \multicolumn{2}{|c|}{ O.D. $\left(\mathrm{mg} \mathrm{O}_{2} \cdot \mathrm{L}^{-1}\right)$} & & & & & & & \multirow{2}{*}{\multicolumn{2}{|c|}{ nao monit. }} & & 50 \\
\hline \multicolumn{2}{|c|}{ Cond. $\left(\mathrm{mS} . \mathrm{cm}^{-1}\right)$} & \multicolumn{2}{|c|}{$\begin{array}{c}0,00 \\
58\end{array}$} & \multicolumn{2}{|c|}{ não monit. } & \multicolumn{2}{|c|}{64} & & & \multicolumn{2}{|c|}{45} \\
\hline \multicolumn{2}{|c|}{ Dur. $\left(\mathrm{mg} \mathrm{CaCo}{ }_{3} \cdot \mathrm{L}^{-1}\right)$} & \multicolumn{2}{|c|}{10,5} & \multicolumn{2}{|c|}{ não monit. } & \multicolumn{2}{|c|}{10,5} & \multicolumn{2}{|c|}{ não monit. } & \multicolumn{2}{|c|}{10,5} \\
\hline Caract. & cor & \multirow{2}{*}{\multicolumn{2}{|c|}{$\begin{array}{l}\text { pouco turva } \\
\text { médio }\end{array}$}} & \multirow{2}{*}{\multicolumn{2}{|c|}{ não monit. }} & \multicolumn{2}{|c|}{ turva } & \multicolumn{2}{|c|}{ não monit. } & \multicolumn{2}{|c|}{ turva } \\
\hline \multirow{2}{*}{$\frac{\text { água* }}{\text { Clima }^{\star *}}$} & nível & & & & & & & não & onit. & & $\mathrm{jcm}$ \\
\hline & & \multicolumn{2}{|c|}{ chuvisco } & \multicolumn{2}{|c|}{ não monit. } & & & não & onit. & cét & limpo \\
\hline
\end{tabular}

${ }^{1}$ desapareceram 8 peixes de uma das réplicas. A câmara foi violada, pois o parafuso da tampa encontrava-se desatarrachado. Os 2 peixes restantes estavam vivos.

tabela $23 \mathrm{~K}$

\begin{tabular}{|c|c|c|c|c|c|c|c|c|c|c|c|}
\hline \multirow{2}{*}{\multicolumn{2}{|c|}{\begin{tabular}{|l} 
Localidade: \\
tempo / data \\
\end{tabular}}} & \multicolumn{10}{|c|}{ Mogi Guaçu 1 - rio Mogi Guaçu (à montante da International Paper) } \\
\hline & & $0 \mathrm{~h}$ & 3/12/01 & $24 \mathrm{~h}$ & $4 / 12 / 01$ & $48 \mathrm{~h}$ & $5 / 12 / 01$ & $72 \mathrm{~h}$ & $6 / 12 / 01$ & $96 \mathrm{~h}$ & 7/12/01 \\
\hline \multicolumn{2}{|l|}{ réplica } & A & $\mathrm{B}$ & A & B & A & B & A & $\mathrm{B}$ & A & $\mathrm{B}$ \\
\hline \multicolumn{2}{|c|}{$\mathrm{n}^{\mathrm{O}}$ mortos / total } & $0 / 10$ & $0 / 10$ & $0 / 10$ & $0 / 10$ & $0 / 10$ & $0 / 10$ & $6 / 10^{1}$ & $0 / 10$ & $7 / 10$ & $0 / 10$ \\
\hline \multicolumn{2}{|l|}{$\mathrm{pH}$} & \multicolumn{2}{|c|}{7,18} & \multicolumn{2}{|c|}{7,12} & \multicolumn{2}{|c|}{7,00} & \multicolumn{2}{|c|}{6,93} & \multicolumn{2}{|c|}{6,92} \\
\hline \multicolumn{2}{|c|}{ Temp. água $\left({ }^{\circ} \mathrm{C}\right)$} & \multirow{2}{*}{\multicolumn{2}{|c|}{$\frac{24,6}{5,02}$}} & \multirow{2}{*}{\multicolumn{2}{|c|}{$\frac{23,8}{591}$}} & \multicolumn{2}{|c|}{23,7} & \multicolumn{2}{|c|}{23,3} & \multicolumn{2}{|c|}{24,7} \\
\hline \multicolumn{2}{|c|}{ O.D. $\left(\mathrm{mg} \mathrm{O}_{2} \cdot \mathrm{L}^{-1}\right)$} & & & & & & & & & & 58 \\
\hline \multicolumn{2}{|c|}{ Cond. $\left(\mathrm{mS} \mathrm{cm}^{-1}\right)$} & \multicolumn{2}{|c|}{56} & \multicolumn{2}{|c|}{58} & \multicolumn{2}{|c|}{$\frac{5,81}{51}$} & \multicolumn{2}{|c|}{53} & \multicolumn{2}{|c|}{$\frac{0,58}{40}$} \\
\hline \multicolumn{2}{|c|}{ Dur. $\left(\mathrm{mg} \mathrm{CaCo}_{3} \mathrm{~L}^{-1}\right)$} & \multicolumn{2}{|c|}{8,8} & \multicolumn{2}{|c|}{8,8} & \multicolumn{2}{|c|}{8,8} & \multicolumn{2}{|c|}{ não monit. } & \multicolumn{2}{|c|}{8,8} \\
\hline Caract. & cor & \multirow{2}{*}{\multicolumn{2}{|c|}{ turva }} & \multirow{2}{*}{\multicolumn{2}{|c|}{$\begin{array}{c}\text { turva } \\
+10 \mathrm{~cm}\end{array}$}} & \multicolumn{2}{|c|}{ turva } & \multicolumn{2}{|c|}{ muito turva } & \multicolumn{2}{|c|}{ muito turva } \\
\hline \multirow{2}{*}{$\frac{\text { água }^{*}}{C \operatorname{lima} a^{\star *}}$} & nível & \multirow{2}{*}{\multicolumn{2}{|c|}{$\frac{\text { médio }}{\text { chuva }}$}} & & & & & & $\mathrm{cm}$ & & $\mathrm{cm}$ \\
\hline & & & & \multicolumn{2}{|c|}{$\frac{+10 \mathrm{~cm}}{\text { chuvisco }}$} & & & chu & isco & ensc & arado \\
\hline
\end{tabular}

${ }^{1}$ mortalidade decorrente da agitação da câmara, a qual estava mais exposta à correnteza que a outra réplica. As chuvas elevaram em $60 \mathrm{~cm}$ o nível da água e aumentaram muito a correnteza.

tabela $23 \mathrm{~L}$

\begin{tabular}{|c|c|c|c|c|c|c|c|c|c|c|c|}
\hline \multicolumn{2}{|c|}{ Localidade: } & $\mathrm{Mc}$ & uac & rIO M & I Guaç & $x$ & te da I & ternati & $P$ & & \\
\hline \multicolumn{2}{|c|}{ tempo / data } & $\mathrm{Oh}$ & $3 / 12 / 01$ & $24 \mathrm{~h}$ & $4 / 12 / 01$ & $48 \mathrm{~h}$ & $5 / 12 / 01$ & $72 \mathrm{~h}$ & 6/12/01 & $96 \mathrm{~h}$ & $7 / 12 / 01$ \\
\hline \multicolumn{2}{|l|}{ réplica } & A & $B$ & A & $B$ & A & $B$ & A & $B$ & A & $B$ \\
\hline \multicolumn{2}{|c|}{$\mathrm{n}^{0}$ - mortos / total } & $0 / 10$ & $0 / 10$ & $0 / 10$ & $0 / 10$ & $0 / 10$ & $0 / 10$ & $0 / 10$ & $0 / 10$ & $0 / 10$ & $0 / 10$ \\
\hline \multicolumn{2}{|l|}{$\mathrm{pH}$} & \multicolumn{2}{|c|}{ não monit. } & \multicolumn{2}{|c|}{6,80} & \multicolumn{2}{|c|}{6,94} & \multicolumn{2}{|c|}{6,97} & \multicolumn{2}{|c|}{3,83} \\
\hline \multicolumn{2}{|c|}{ Temp. água $\left({ }^{\circ} \mathrm{C}\right)$} & \multirow{2}{*}{\multicolumn{2}{|c|}{$\frac{\text { não monit. }}{\text { não monit. }}$}} & \multirow{2}{*}{\multicolumn{2}{|c|}{$\begin{array}{l}23,8 \\
5,00\end{array}$}} & \multirow{2}{*}{\multicolumn{2}{|c|}{$\frac{23,7}{4,40}$}} & \multicolumn{2}{|c|}{23,4} & \multicolumn{2}{|c|}{24,6} \\
\hline \multicolumn{2}{|c|}{ O.D. $\left(\mathrm{mg} \mathrm{O}_{2} \cdot \mathrm{L}^{-1}\right)$} & & & & & & & & & & \\
\hline \multicolumn{2}{|c|}{ Cond. $\left(\mathrm{mS} \mathrm{cm}^{-1}\right)$} & \multicolumn{2}{|c|}{ não monit. } & \multicolumn{2}{|c|}{90} & \multicolumn{2}{|c|}{77} & \multicolumn{2}{|c|}{$\frac{0,00}{70}$} & \multicolumn{2}{|c|}{$\begin{array}{c}0,40 \\
52\end{array}$} \\
\hline \multicolumn{2}{|c|}{ Dur. $\left(\mathrm{mg} \mathrm{CaCo}{ }_{3} \cdot \mathrm{L}^{-1}\right)$} & \multicolumn{2}{|c|}{ não monit. } & \multicolumn{2}{|c|}{10,5} & \multicolumn{2}{|c|}{10,5} & \multicolumn{2}{|c|}{ não monit. } & \multicolumn{2}{|c|}{10,5} \\
\hline Caract. & cor & \multicolumn{2}{|c|}{ turva } & \multicolumn{2}{|c|}{ turva } & \multicolumn{2}{|c|}{ turva } & \multicolumn{2}{|c|}{ muito turva } & \multicolumn{2}{|c|}{ muito turva } \\
\hline$\frac{\text { água* }^{*}}{\text { Clima** }}$ & nível & \multicolumn{2}{|c|}{ médio } & \multicolumn{2}{|c|}{$+10 \mathrm{~cm}$} & & $\mathrm{~cm}$ & & $\mathrm{~cm}$ & +6 & $\mathrm{~cm}$ \\
\hline $\operatorname{Clima}^{\star \star}$ & & chuva & ntensa & chu & isco & & & chu & isco & enso & arado \\
\hline
\end{tabular}


tabela $23 \mathrm{M}$

\begin{tabular}{|c|c|c|c|c|c|c|c|c|c|c|c|}
\hline \multirow{2}{*}{\multicolumn{2}{|c|}{\begin{tabular}{|l|} 
Localidade: \\
tempo / data
\end{tabular}}} & \multicolumn{10}{|c|}{ Pirassununga - rio Mogi Guaçu (entre os afluentes rib. Roque e rio Jag.Mirim) } \\
\hline & & $0 \mathrm{~h}$ & $13 / 12 / 01$ & $24 \mathrm{~h}$ & $4 / 12 / 0$ & $48 \mathrm{~h}$ & $5 / 12 / 01$ & $72 \mathrm{~h}$ & $6 / 12 / 01$ & $96 \mathrm{~h}$ & $7 / 12 / 01$ \\
\hline \multicolumn{2}{|l|}{ réplica } & $\mathrm{A}$ & $B$ & A & $B$ & A & B & A & B & A & $\mathrm{B}$ \\
\hline \multicolumn{2}{|c|}{$\mathrm{n}^{0}-\mathrm{mortos} /$ total } & $0 / 10$ & $0 / 10$ & $0 / 10$ & $0 / 10$ & $0 / 10$ & $0 / 10$ & $0 / 10$ & $0 / 10$ & $0 / 10$ & $0 / 10$ \\
\hline \multicolumn{2}{|l|}{$\mathrm{pH}$} & \multicolumn{2}{|c|}{7,01} & \multicolumn{2}{|c|}{6,90} & \multicolumn{2}{|c|}{7,00} & \multicolumn{2}{|c|}{6,95} & \multicolumn{2}{|c|}{6,68} \\
\hline \multicolumn{2}{|c|}{ Temp. água $\left({ }^{\circ} \mathrm{C}\right)$} & \multicolumn{2}{|c|}{25,6} & \multicolumn{2}{|c|}{24,7} & \multicolumn{2}{|c|}{24,0} & \multicolumn{2}{|c|}{24,5} & \multicolumn{2}{|c|}{24,5} \\
\hline \multirow{2}{*}{\multicolumn{2}{|c|}{ O.D. $\left(\mathrm{mg} \mathrm{O}_{2} \cdot \mathrm{L}^{-1}\right)$}} & & 55 & & & & & & & \multirow{2}{*}{\multicolumn{2}{|c|}{$\frac{5,17}{44}$}} \\
\hline & & \multicolumn{2}{|c|}{54} & \multicolumn{2}{|c|}{49} & \multicolumn{2}{|c|}{45} & \multicolumn{2}{|c|}{57} & & \\
\hline \multicolumn{2}{|c|}{ Dur. $\left(\mathrm{mg} \mathrm{CaCo}_{3} \cdot \mathrm{L}^{-1}\right)$} & \multicolumn{2}{|c|}{8,8} & \multicolumn{2}{|c|}{8,8} & \multicolumn{2}{|c|}{8,8} & \multicolumn{2}{|c|}{ não monit. } & \multicolumn{2}{|c|}{7,0} \\
\hline \multirow{2}{*}{$\begin{array}{l}\text { Caract. } \\
\text { água* }\end{array}$} & cor & \multicolumn{2}{|c|}{ turva } & \multicolumn{2}{|c|}{ turva } & \multicolumn{2}{|c|}{ turva } & \multicolumn{2}{|c|}{ muito turva } & \multicolumn{2}{|c|}{ muito turva } \\
\hline & nível & \multirow{2}{*}{\multicolumn{2}{|c|}{ médio }} & \multicolumn{2}{|c|}{ médio } & \multicolumn{2}{|c|}{$+10 \mathrm{~cm}$} & & $\mathrm{~cm}$ & +4 & $\mathrm{~cm}$ \\
\hline Clima** & & & & & lado & cht & isco & & isco & parc. & ublado \\
\hline
\end{tabular}

tabela $23 \mathrm{~N}$

\begin{tabular}{|c|c|c|c|c|c|c|c|c|c|c|c|}
\hline \multicolumn{2}{|c|}{ Localidade: } & Luiz A & OnIO 1 & rio $\mathrm{Mc}$ & I Guas & (à mol & ante o & VCP) & & & \\
\hline \multicolumn{2}{|c|}{ tempo / data } & $\mathrm{Oh}$ & $3 / 12 / 01$ & $24 \mathrm{~h}$ & $4 / 12 / 0$ & $48 \mathrm{~h}$ & $5 / 12 / 01$ & $72 \mathrm{~h}$ & $6 / 12 / 01$ & $96 \mathrm{~h}$ & $7 / 12 / 01$ \\
\hline \multicolumn{2}{|l|}{ réplica } & A & $B$ & A & $B$ & A & $B$ & A & $B$ & $A$ & $B$ \\
\hline \multicolumn{2}{|c|}{$\mathrm{n}^{\circ}$ mortos / total } & $0 / 10$ & $0 / 10$ & $0 / 10$ & $0 / 10$ & $0 / 10$ & $0 / 10$ & $0 / 10$ & $0 / 10$ & $0 / 10$ & $0 / 10$ \\
\hline \multicolumn{2}{|l|}{$\mathrm{pH}$} & \multicolumn{2}{|c|}{7,15} & \multicolumn{2}{|c|}{7,12} & \multicolumn{2}{|c|}{ não monit. } & \multicolumn{2}{|c|}{7,14} & \multicolumn{2}{|c|}{6,90} \\
\hline \multicolumn{2}{|c|}{ Temp. água $\left({ }^{\circ} \mathrm{C}\right)$} & \multirow{2}{*}{\multicolumn{2}{|c|}{$\frac{25,7}{6,24}$}} & \multicolumn{2}{|c|}{25,2} & \multicolumn{2}{|c|}{ monit. } & \multicolumn{2}{|c|}{25,4} & \multicolumn{2}{|c|}{24,8} \\
\hline \multicolumn{2}{|c|}{ O.D. $\left(\mathrm{mg} \mathrm{O}_{2} \cdot \mathrm{L}^{-1}\right)$} & & & & & \multirow{2}{*}{\multicolumn{2}{|c|}{ nao monit. }} & & & & \\
\hline \multicolumn{2}{|c|}{ Cond. $\left(\mathrm{mS} . \mathrm{cm}^{-1}\right)$} & \multicolumn{2}{|c|}{62} & \multicolumn{2}{|c|}{$\begin{array}{c}0,4 \perp \\
62\end{array}$} & & & \multicolumn{2}{|c|}{$\begin{array}{l}0,01 \\
52\end{array}$} & \multicolumn{2}{|c|}{52} \\
\hline \multicolumn{2}{|c|}{ Dur. $\left(\mathrm{mg} \mathrm{CaCO}_{3} \cdot \mathrm{L}^{-1}\right)$} & \multicolumn{2}{|c|}{8,8} & \multicolumn{2}{|c|}{ não monit. } & \multicolumn{2}{|c|}{ não monit. } & \multicolumn{2}{|c|}{ não monit. } & \multicolumn{2}{|c|}{8,8} \\
\hline Caract. & cor & \multirow{2}{*}{\multicolumn{2}{|c|}{$\begin{array}{c}\text { pouco turva } \\
\text { médio }\end{array}$}} & \multicolumn{2}{|c|}{ pouco turva } & \multicolumn{2}{|c|}{ não monit. } & \multicolumn{2}{|c|}{ turva } & \multicolumn{2}{|c|}{ turva c/ espuma } \\
\hline água* & nível & & & \multicolumn{2}{|c|}{$+10 \mathrm{~cm}$} & não & onit. & & $\mathrm{cm}$ & & $\mathrm{cm}$ \\
\hline Clima** & & \multicolumn{2}{|c|}{ médio } & cht & isco & não & Ionit. & & Iva & parc. & ublado \\
\hline
\end{tabular}

tabela 230

\begin{tabular}{|c|c|c|c|c|c|c|c|c|c|c|c|}
\hline \multirow{3}{*}{\multicolumn{2}{|c|}{\begin{tabular}{l}
\multicolumn{1}{c}{ Localidade: } \\
tempo / data \\
réplica
\end{tabular}}} & \multicolumn{10}{|c|}{ Luiz Antônio 2 - rio Mogi Guaçu (à jusante da VCP) } \\
\hline & & \multicolumn{2}{|c|}{$0 \mathrm{~h} \quad 13 / 12 / 01$} & \multicolumn{2}{|c|}{$24 \mathrm{~h} \quad 14 / 12 / 01$} & \multicolumn{2}{|c|}{$48 \mathrm{~h} \quad 15 / 12 / 01$} & \multicolumn{2}{|c|}{$72 \mathrm{~h} \quad 16 / 12 / 01$} & \multicolumn{2}{|c|}{$96 \mathrm{~h} 17 / 12 / 01$} \\
\hline & & A & $\mathrm{B}$ & A & B & A & B & A & $\mathrm{B}$ & A & $\mathrm{B}$ \\
\hline \multicolumn{2}{|c|}{$\mathrm{n}^{\mathrm{O}}$ mortos / total } & $0 / 10$ & $0 / 10$ & $0 / 10$ & $0 / 10$ & $0 / 10$ & $0 / 10$ & $0 / 10$ & $0 / 10$ & $0 / 10$ & $0 / 10$ \\
\hline \multicolumn{2}{|c|}{$\mathrm{pH}$} & \multicolumn{2}{|c|}{7,08} & \multicolumn{2}{|c|}{6,80} & \multicolumn{2}{|c|}{ não monit. } & \multicolumn{2}{|c|}{7,16} & \multicolumn{2}{|c|}{6,92} \\
\hline \multirow{2}{*}{\multicolumn{2}{|c|}{$\begin{array}{l}\text { Temp. água }\left(^{\circ} \mathrm{C}\right) \\
\text { O.D. }\left(\mathrm{mg} \mathrm{O}_{2} \cdot \mathrm{L}^{-1}\right)\end{array}$}} & \multirow{2}{*}{\multicolumn{2}{|c|}{$\begin{array}{l}26,4 \\
5,92\end{array}$}} & \multirow{2}{*}{\multicolumn{2}{|c|}{$\begin{array}{l}25,2 \\
5,28\end{array}$}} & \multicolumn{2}{|c|}{ não monit. } & \multicolumn{2}{|c|}{25,2} & \multicolumn{2}{|c|}{24,9} \\
\hline & & & & & & não & onit. & & & & \\
\hline \multicolumn{2}{|c|}{ Cond. $\left(\mathrm{mS}_{\mathrm{cm}} \mathrm{cm}^{-1}\right)$} & \multicolumn{2}{|c|}{62} & \multicolumn{2}{|c|}{63} & \multicolumn{2}{|c|}{ não monit. } & \multicolumn{2}{|c|}{55} & \multicolumn{2}{|c|}{53} \\
\hline \multicolumn{2}{|c|}{ Dur. $\left(\mathrm{mg} \mathrm{CaCo}_{3} \mathrm{~L}^{-1}\right)$} & \multicolumn{2}{|c|}{8,8} & \multicolumn{2}{|c|}{ não monit. } & \multicolumn{2}{|c|}{ não monit. } & \multicolumn{2}{|c|}{ não monit. } & \multicolumn{2}{|c|}{8,8} \\
\hline \multirow{2}{*}{$\begin{array}{l}\text { Caract. } \\
\text { água }^{*}\end{array}$} & cor & \multicolumn{2}{|c|}{ pouco turva } & \multicolumn{2}{|c|}{ pouco turva } & \multicolumn{2}{|c|}{ não monit. } & \multicolumn{2}{|c|}{ turva } & turva c & espuma \\
\hline & nível & & & & $\mathrm{cm}$ & não & onit. & +5 & $\mathrm{~cm}$ & +6 & $\mathrm{~cm}$ \\
\hline Clima $^{\star \star}$ & & & & chu & isco & não & onit. & & & & ublado \\
\hline
\end{tabular}




\subsection{Análises físicas e químicas da água e do sedimento de diferentes localidades nas bacias dos rios Piracicaba, Mogi-Guaçu e Tibagi.}

Os resultados das análises de nutrientes na água dos locais de estudo estão representados nas figuras 52 a 60 .

Com relação aos nutrientes nitrito, nitrato, amônio, nitrogênio total, fosfato total, fosfato inorgânico, fosfato orgânico e fósforo total, as maiores concentrações foram encontradas, de maneira geral, nas amostras de água provenientes das localidades da bacia do rio Piracicaba, com exceção do ribeirão do Pinhal, que é o ponto controle. Nesta bacia, as maiores concentrações, para todos os nutrientes analisados, foram encontradas nas amostras coletadas no rio Atibaia, em Sumaré, e no rio Piracicaba, em Piracicaba. Na bacia do rio Mogi Guaçu, as concentrações destes nutrientes variaram pouco de local para local, tendo apresentado as localidades São João, Mogi 1 e Mogi 2 teores ligeiramente mais elevados que os das outras localidades. Na bacia do rio Tibagi, a localidade de Londrina se destacou pela ocorrência de maiores concentrações de fosfato total no período chuvoso e de fosfato orgânico no período seco.

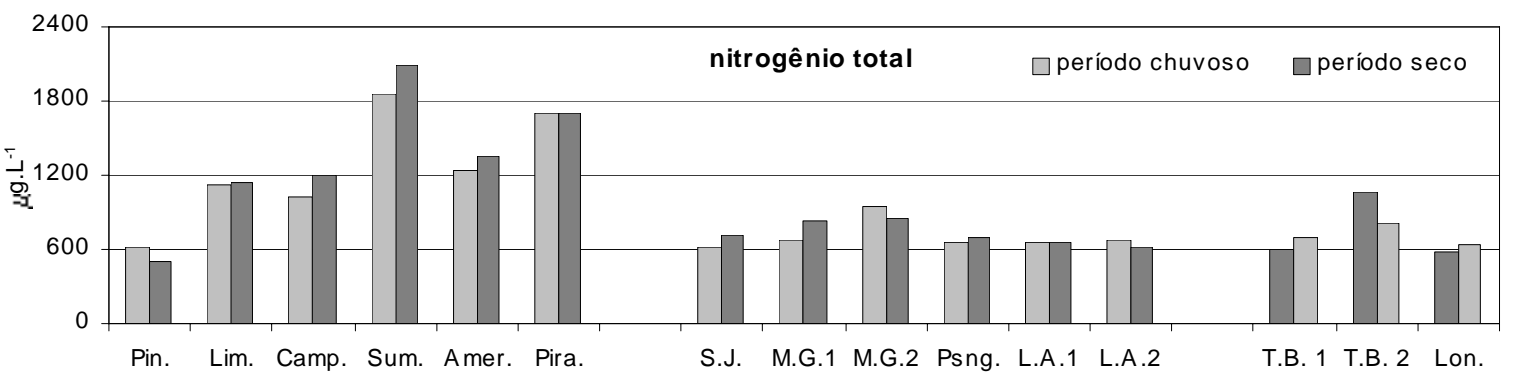

FIGURA 52: Concentrações de nitrogênio total (em $\mu \mathrm{g} \cdot \mathrm{L}^{-1}$ ) em diferentes localidades das bacias dos rios Piracicaba, Mogi Guaçu e Tibagi, em duas coletas. Notar a inversão dos períodos chuvoso e seco para a bacia do rio Tibagi. $\quad$ Pin. $=$ Rib. Pinhal; Lim. = Limeira; Camp. = Campinas; Sum. = Sumaré; Amer. = Americana; Pira. $=$ Piracicaba; S.J. $=$ S.João da Boa Vista; M.G.1 = Mogi Guaçu à montante da Int. Paper; M.G.2 = Mogi Guaçu à jusante da Int. Paper; Psng. = Pirassununga; L.A.1 = Rio Mogi-Guaçu em Luiz Antônio à montante da VCP; L.A.2 = Rio Mogi-Guaçu em Luiz Antônio à jusante da VCP; T.B.1 = Rio Tibagi em Telêmaco Borba à montante da Klabin; T.B.2 = Rio Tibagi em Telêmaco Borba à jusante da Klabin; Lon = Rio Tibagi em Londrina. 

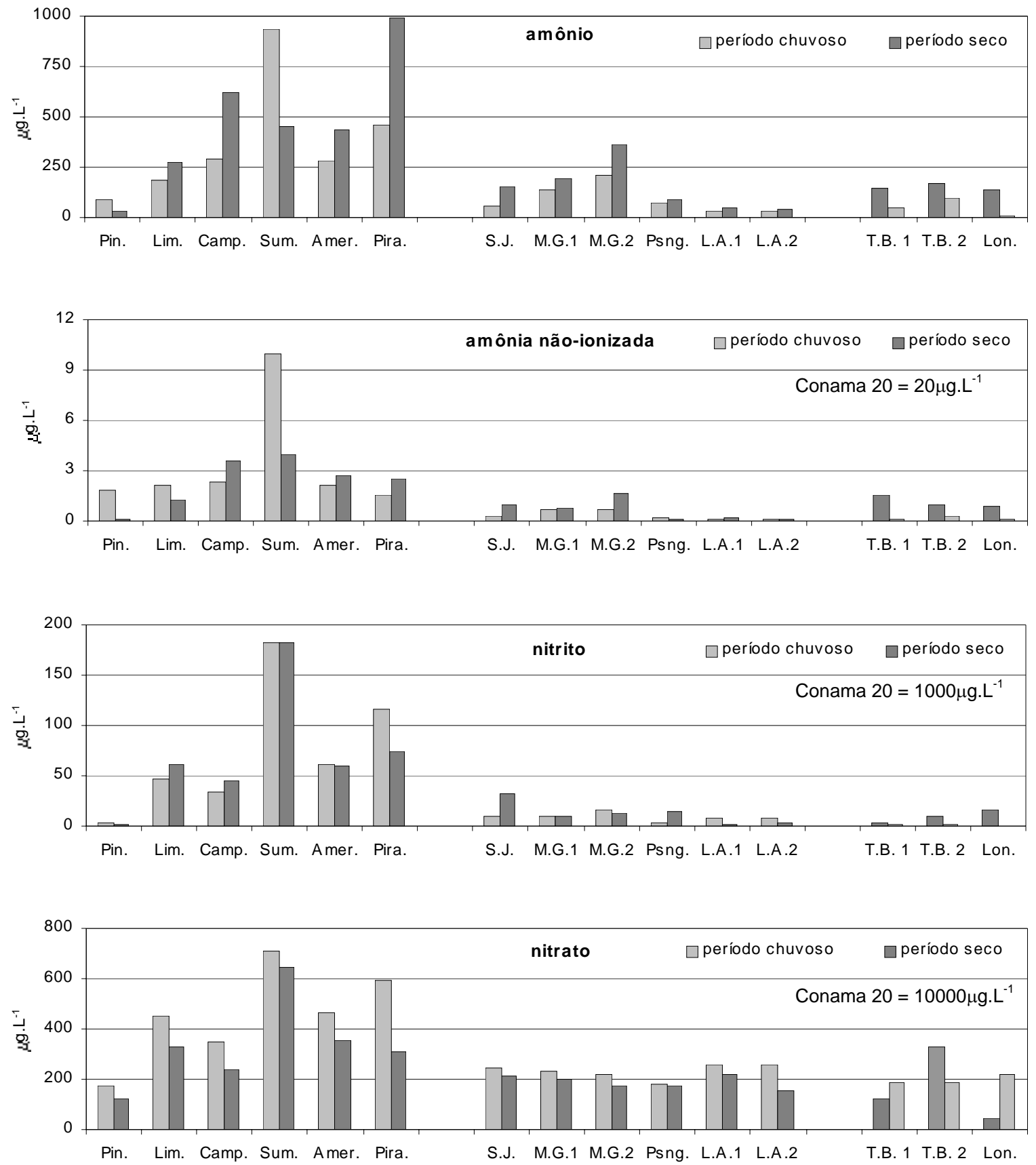

FIGURA 53: Concentrações de amônio, amônia não ionizada, nitrito e nitrato (em $\left.\mu \mathrm{g} . \mathrm{L}^{-1}\right)$ em diferentes localidades das bacias dos rios Piracicaba, Mogi Guaçu e Tibagi, em duas coletas. Notar a inversão dos períodos chuvoso e seco para a bacia do rio Tibagi. $\quad$ Pin. $=$ Rib. Pinhal; Lim. $=$ Limeira; Camp. $=$ Campinas; Sum. $=$ Sumaré; Amer. $=$ Americana; Pira. $=$ Piracicaba; S.J. = S.João da Boa Vista; M.G.1 = Mogi Guaçu à montante da Int. Paper; M.G.2 = Mogi Guaçu à jusante da Int. Paper; Psng. = Pirassununga; L.A.1 = Rio Mogi-Guaçu em Luiz Antônio à montante da VCP; L.A.2 = Rio Mogi-Guaçu em Luiz Antônio à jusante da VCP; T.B.1 = Rio Tibagi em Telêmaco Borba à montante da Klabin; T.B.2 = Rio Tibagi em Telêmaco Borba à jusante da Klabin; Lon = Rio Tibagi em Londrina. 

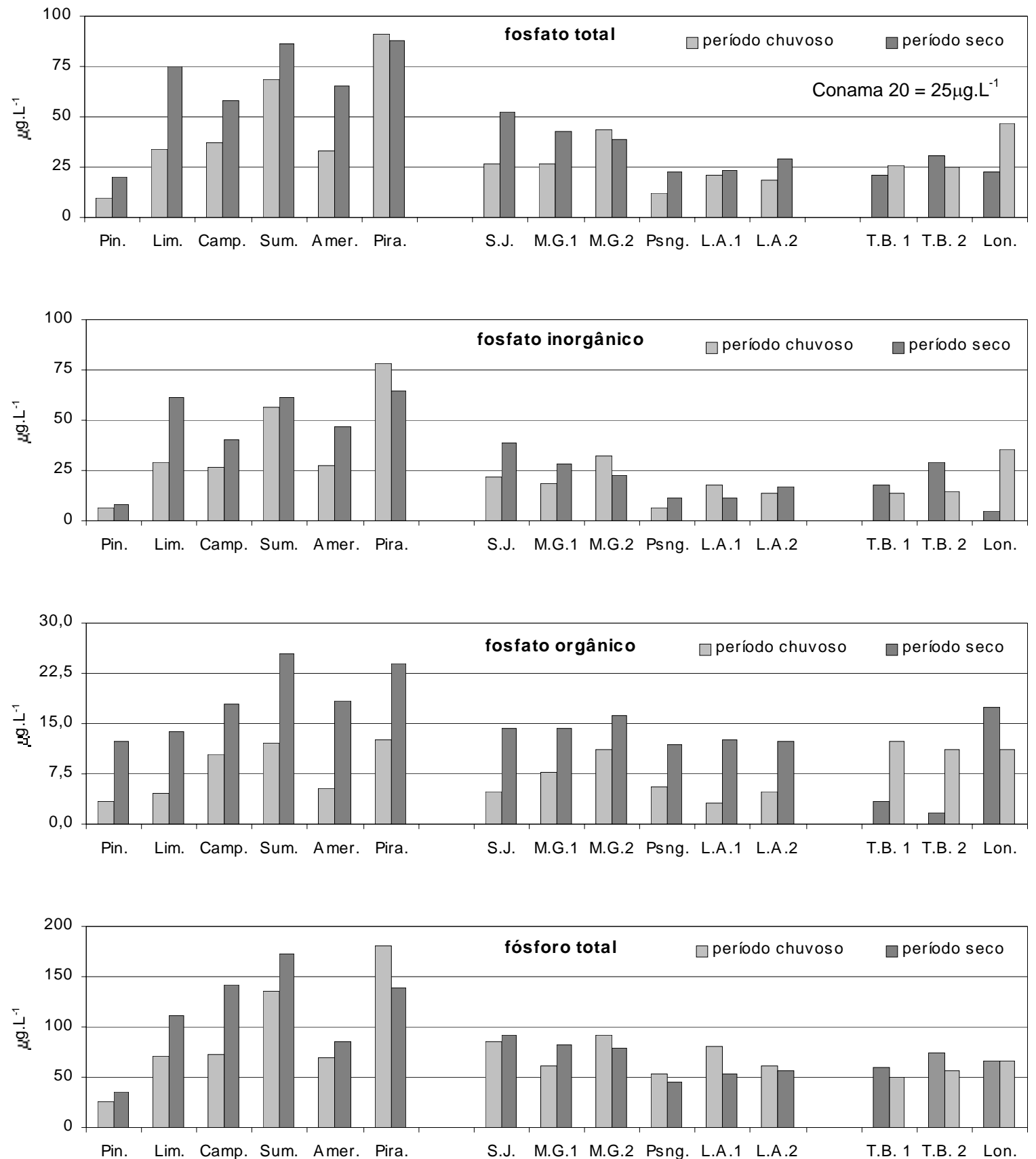

FIGURA 54: Concentrações de fosfato total, fosfato inorgânico, fosfato orgânico e fósforo total (em $\mu \mathrm{g} . \mathrm{L}^{-1}$ ) em diferentes localidades das bacias dos rios Piracicaba, Mogi Guaçu e Tibagi, em duas coletas. Notar a inversão dos períodos chuvoso e seco para a bacia do rio Tibagi. $\quad$ Pin. $=$ Rib. Pinhal; Lim. = Limeira; Camp. $=$ Campinas; Sum. $=$ Sumaré; Amer. $=$ Americana; Pira. $=$ Piracicaba; S.J. $=$ S.João da Boa Vista; M.G.1 $=$ Mogi Guaçu à montante da Int. Paper; M.G.2 = Mogi Guaçu à jusante da Int. Paper; Psng. = Pirassununga; L.A.1 = Rio Mogi-Guaçu em Luiz Antônio à montante da VCP; L.A.2 = Rio Mogi-Guaçu em Luiz Antônio à jusante da VCP; T.B.1 = Rio Tibagi em Telêmaco Borba à montante da Klabin; T.B.2 = Rio Tibagi em Telêmaco Borba à jusante da Klabin; Lon = Rio Tibagi em Londrina. 
Ainda na bacia do rio Tibagi, os teores de nitrato e nitrogênio total foram ligeiramente maiores na localidade de Telêmaco Borba 2, principalmente no período seco. É importante salientar que as primeiras coletas foram realizadas em março/2000 nas bacias dos rios Piracicaba e Mogi Guaçu e em junho/2000 na bacia do rio Tibagi, correspondendo ao final do período chuvoso nas duas primeiras bacias e ao período seco nesta última bacia. Na segunda etapa de coletas, porém, ocorreu o contrário, ou seja, estas foram realizadas em setembro/2000 nas três bacias, correspondendo ao final do período seco nas bacias dos rios Piracicaba e Mogi-Guaçu e ao período chuvoso na bacia do rio Tibagi, onde as chuvas normalmente ocorrem antes. Com relação aos teores dos nutrientes entre os dois períodos, não houve a predominância das maiores concentrações em um período, com exceção do fosfato orgânico das amostras de água das bacias dos rios Piracicaba e Mogi Guaçu, que apresentaram maiores concentrações desse nutriente no período seco.

Quanto aos teores de amônia não ionizada, que foram calculados levando em consideração o pH e a temperatura medidos nos locais de coleta, as maiores concentrações foram encontradas nas amostras de água do rio Atibaia, na captação de Sumaré.

Com relação aos metais analisados, as maiores concentrações de zinco foram observadas em Piracicaba e Mogi 2 no período chuvoso e em Luiz Antônio 1 e 2 no período seco. Em contraste, nesta última localidade foi observada a menor concentração desse metal no período chuvoso. No período seco, a menor concentração de níquel na água foi observada em S. João.

As localidades de Sumaré, Americana e Piracicaba foram aquelas em que foram registradas as maiores concentrações de chumbo, níquel, cobre e cromo na água (todos no período chuvoso, exceto em Sumaré, onde este último metal foi detectado apenas no período seco). Os metais zinco, ferro e manganês estiveram presentes em todas as amostras, nos dois períodos, em teores mais elevados nas localidades de Piracicaba e Mogi 2. As concentrações de manganês estiveram altas também em São João. O cádmio foi detectado nas localidades de Limeira, Campinas, Sumaré, Americana, Piracicaba, São João, Mogi 1, Mogi 2, Pirassununga (em todas no período seco), Telêmaco Borba 2 e Londrina (no período chuvoso). As maiores concentrações desse metal foram detectadas na água do rio Piracicaba, em Piracicaba e do rio Mogi Guaçu, na localidade Mogi Guaçu 2. Surpreendentemente, foram detectados os metais zinco, chumbo e níquel no ribeirão do Pinhal, no período chuvoso. 

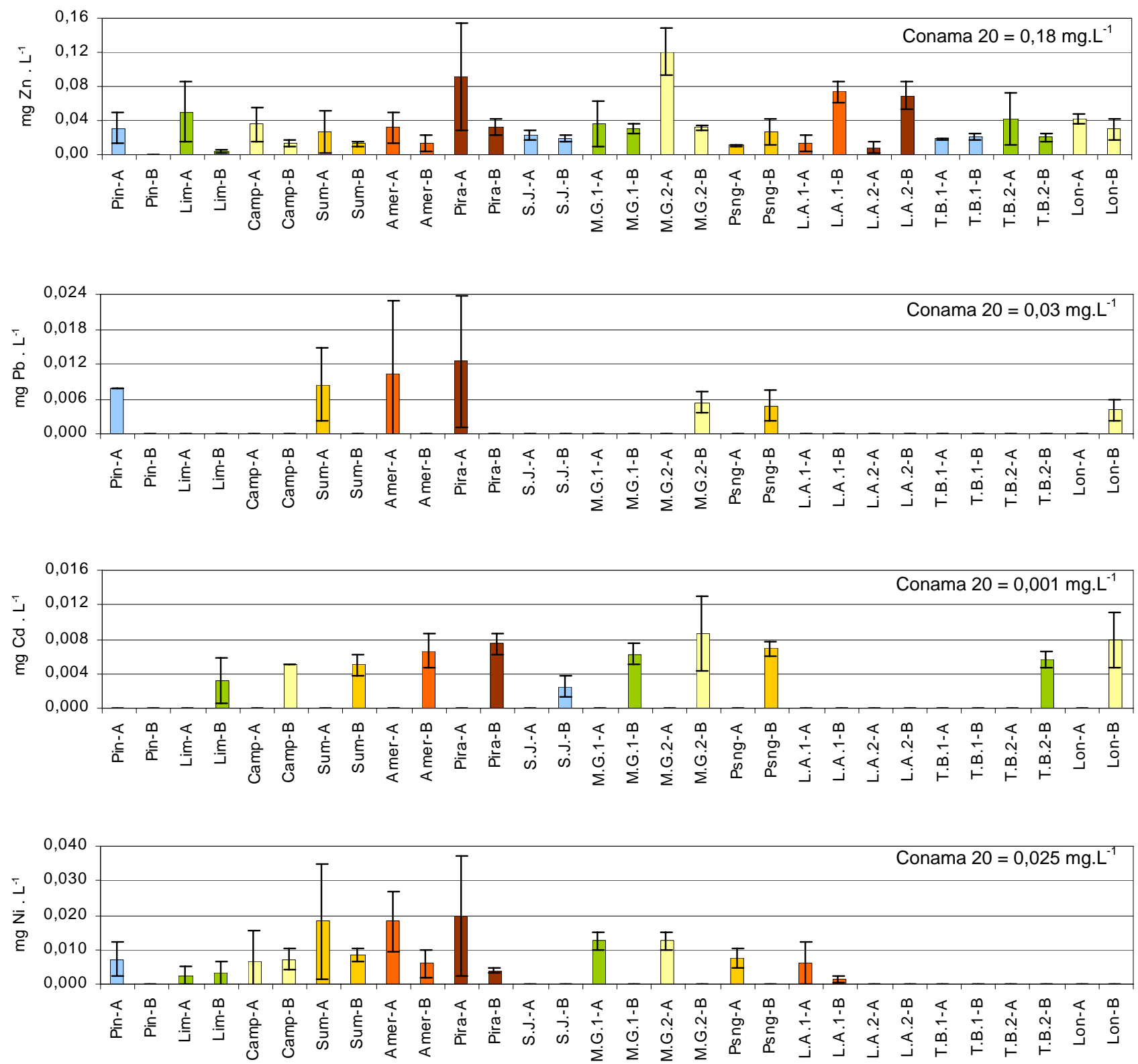

FIGURA 55: Concentrações $\left(\mathrm{mg}^{\mathrm{L}} \mathrm{L}^{-1}\right)$ dos metais zinco, chumbo, cádmio e níquel nos períodos chuvoso e seco, na água dos locais de estudo das bacias dos rios Piracicaba, Mogi Guaçu e Tibagi. As letras A e B correspondem, respectivamente ao período chuvoso e seco, para as bacias dos rios Piracicaba e Mogi Guaçu e o inverso para a bacia do rio Tibagi. Pin. = Rib. Pinhal; Lim. = Limeira; Camp. = Campinas; Sum. = Sumaré; Amer. = Americana; Pira. = Piracicaba; S.J. = S.João da Boa Vista; M.G.1 = Mogi Guaçu à montante da Int. Paper; M.G.2 = Mogi Guaçu à jusante da Int. Paper; Psng. = Pirassununga; L.A.1 = Rio Mogi-Guaçu em Luiz Antônio à montante da VCP; L.A.2 = Rio Mogi-Guaçu em Luiz Antônio à jusante da VCP; T.B.1 = Rio Tibagi em Telêmaco Borba à montante da Klabin; T.B.2 = Rio Tibagi em Telêmaco Borba à jusante da Klabin; Lon = Rio Tibagi em Londrina. 

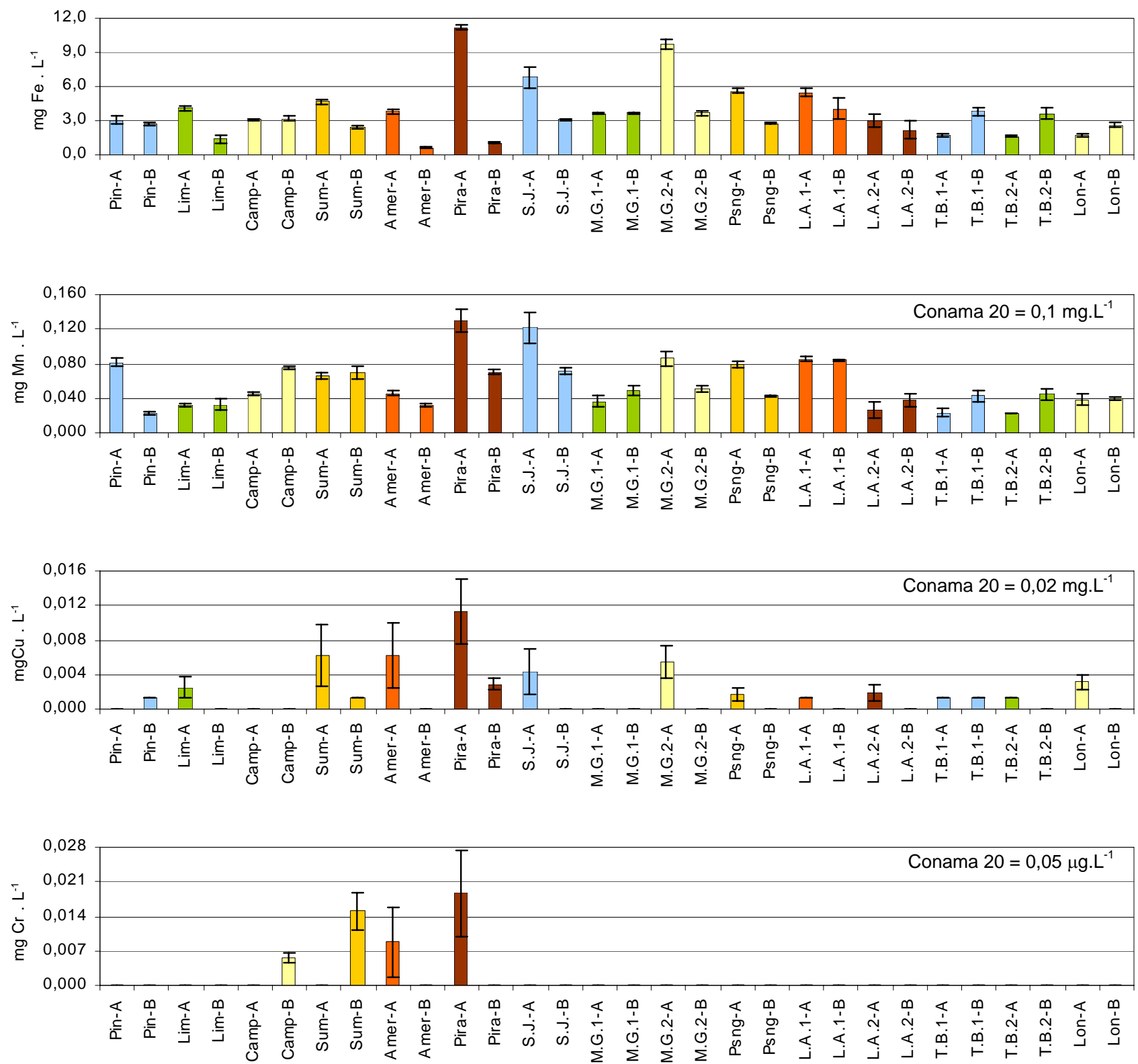

FIGURA 56: Concentrações (mg. $\left.\mathrm{L}^{-1}\right)$ dos metais ferro, manganês, cobre e cromo nos períodos chuvoso e seco, na água dos locais de estudo das bacias dos rios Piracicaba, Mogi Guaçu e Tibagi. As letras A e B correspondem, respectivamente, ao período chuvoso e seco, para as bacias dos rios Piracicaba e Mogi Guaçu e o inverso para a bacia do rio Tibagi. Pin. $=$ Rib. Pinhal; Lim. $=$ Limeira; Camp. $=$ Campinas; Sum. $=$ Sumaré; Amer. = Americana; $\quad$ Pira. $=$ Piracicaba; S.J. = S.João da Boa Vista; M.G.1 = Mogi Guaçu à montante da Int. Paper; M.G.2 = Mogi Guaçu à jusante da Int. Paper; Psng. = Pirassununga; $\quad$ L.A.1 = Rio Mogi-Guaçu em Luiz Antônio à montante da VCP; L.A.2 = Rio Mogi-Guaçu em Luiz Antônio à jusante da VCP; T.B.1 = Rio Tibagi em Telêmaco Borba à montante da Klabin; T.B.2 = Rio Tibagi em Telêmaco Borba à jusante da Klabin; Lon = Rio Tibagi em Londrina. 
As concentrações mais elevadas dos metais analisados no sedimento, com exceção do manganês e do níquel, foram observadas nas localidades da bacia do rio Piracicaba. Em Piracicaba foram detectados os maiores teores de cromo, cobre e zinco; as mais altas concentrações de ferro, manganês e níquel (estes dois últimos somente para a bacia), foram observadas em Sumaré, localidade na qual ainda foi detectado, juntamente com Campinas, o maior teor de chumbo no sedimento.

Nas amostras de sedimento provenientes das localidades da bacia do rio Mogi Guaçu foram detectadas as mais baixas concentrações de metais. Dos metais considerados mais tóxicos, apenas o chumbo, na localidade Mogi Guaçu 1, no período chuvoso, foi detectado em concentrações próximas àquelas observadas em algumas localidades da bacia do rio Piracicaba, como Limeira e Americana. Nas localidades de Luiz Antônio 1 e 2, foram detectados, principalmente no período seco, os mais altos teores de ferro, manganês, cobre e cromo na bacia. Além disso, essas duas localidades foram as únicas da bacia, além de Mogi Guaçu 1, em cujos sedimentos foi detectado o chumbo.

Com relação à bacia do rio Tibagi, a localidade de Londrina se destacou pelo sedimento com os mais altos teores de todos os metais analisados, sendo que o níquel e o manganês foram detectados nas maiores concentrações entre todos os locais das três bacias.

Quanto à granulometria e aos teores de matéria orgânica dos sedimentos nos locais de estudo, na bacia do rio Piracicaba o Ribeirão do Pinhal é o que possui, na média dos períodos, o sedimento mais arenoso (89\%-período seco) e com menor teor de matéria orgânica (1,3\%-período seco). Constituição semelhante foi observada no sedimento do rio Piracicaba, em Piracicaba, mas apenas na amostra do período chuvoso (91\% de areia e menos de $1 \%$ de M.O.). Os sedimentos mais argilosos, dentre as amostras do período chuvoso, foram observados nas amostras do rio Atibaia, em Sumaré (90\%) e em Campinas (67\%), as quais também contiveram os maiores teores de matéria orgânica (4,9 e 5,8\%, respectivamente). Considerando-se as amostras do período seco, foram observadas no sedimento do rio Jaguari, em Limeira (75\% de argila e 9,2\% de M.O.) Também foram observados altos teores de matéria orgânica nas amostras desse período nos sedimentos das localidades de Piracicaba $(9,1 \%)$ e Americana (10,9\%).

Nos sedimentos provenientes da bacia do rio Mogi Guaçu, não foram observadas grandes diferenças na granulometria entre as amostras dos períodos chuvoso e seco, com exceção daquelas referentes às localidades Luiz Antônio 1 e 2. Nesses locais, as amostras da primeira coleta (período chuvoso) foram predominantemente argilosas (aproximadamente $80 \%$ de argila, nas amostras de 
ambas as localidades), além de conterem os mais altos teores de matéria orgânica (mais de 6\%) entre os sedimentos das localidades dessa bacia. Nas outras localidades da bacia os sedimentos são predominantemente arenosos, sendo o de Mogi Guaçu 1 aquele com maior porcentagem de areia (mais de 94\%) e menor porcentagem de matéria orgânica (menos de 1\%).

Entre as amostras do rio Tibagi, as de Telêmaco Borba 1 foram as mais arenosas (mais de $85 \%$ de areia) e com menores teores de matéria orgânica (menos de $2 \%$ ) e as de Londrina as mais argilosas (71\% de argila no período chuvoso) e com maiores teores de matéria orgânica (6,9\%, no período chuvoso).
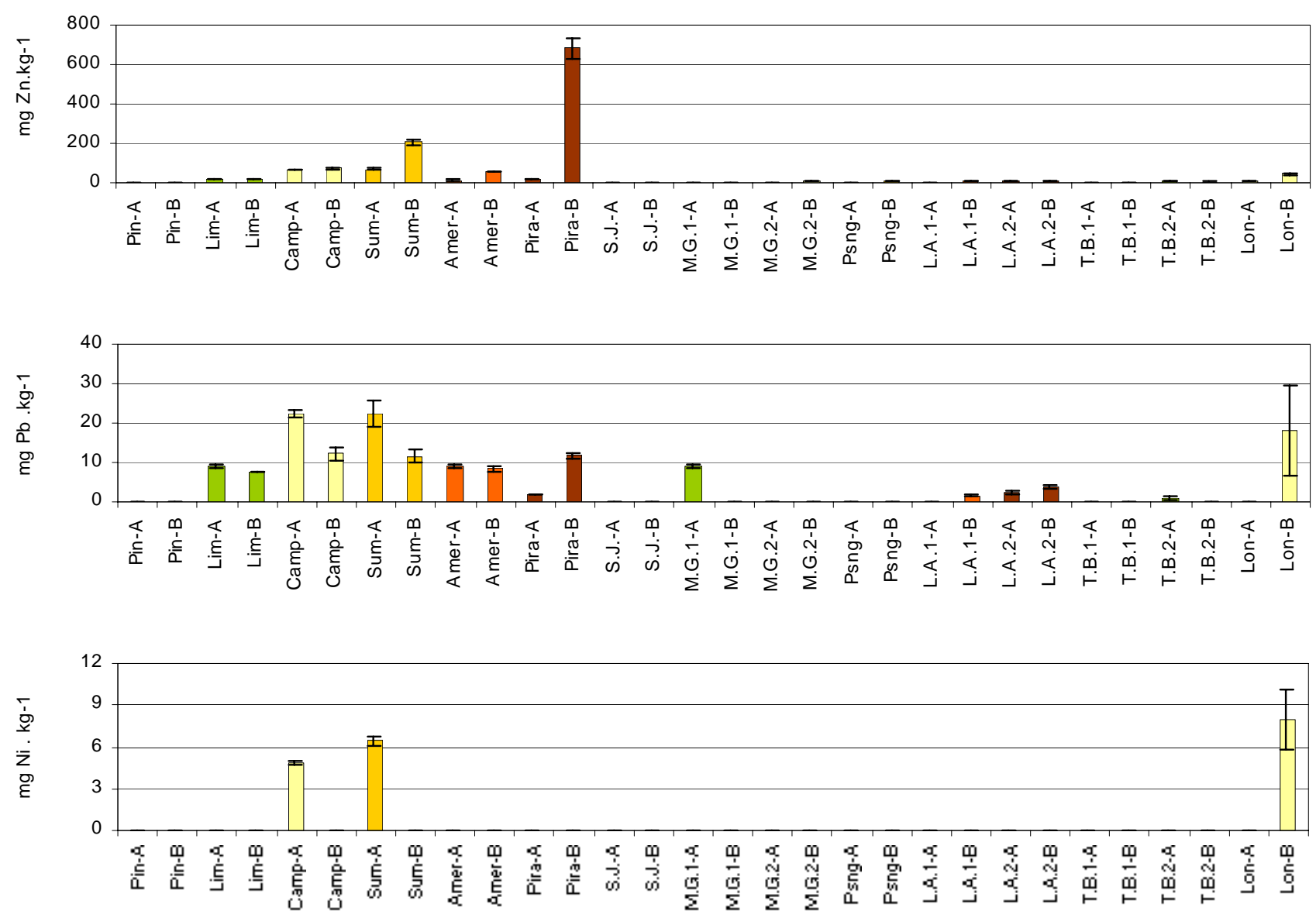

FIGURA 57: Concentrações $\left(\mathrm{mg}^{\mathrm{K}} \mathrm{Kg}^{-1}\right.$ ) dos metais zinco, chumbo e níquel nos períodos chuvoso e seco, no sedimento dos locais de estudo das bacias dos rios Piracicaba, Mogi Guaçu e Tibagi. As letras A e B correspondem, respectivamente ao período chuvoso e seco, para as bacias dos rios Piracicaba e Mogi Guaçu e o inverso para a bacia do rio Tibagi. Pin. = Rib. Pinhal; Lim. = Limeira; Camp. = Campinas; Sum. = Sumaré; Amer. $=$ Americana; Pira. $=$ Piracicaba; S.J. $=$ S.João da Boa Vista; M.G.1 $=$ Mogi Guaçu à montante da Int. Paper; M.G.2 = Mogi Guaçu à jusante da Int. Paper; Psng. = Pirassununga; L.A.1 = Rio Mogi-Guaçu em Luiz Antônio à montante da VCP; L.A.2 = Rio Mogi-Guaçu em Luiz Antônio à jusante da VCP; T.B.1 = Rio Tibagi em Telêmaco Borba à montante da Klabin; T.B.2 = Rio Tibagi em Telêmaco Borba à jusante da Klabin; Lon = Rio Tibagi em Londrina. 

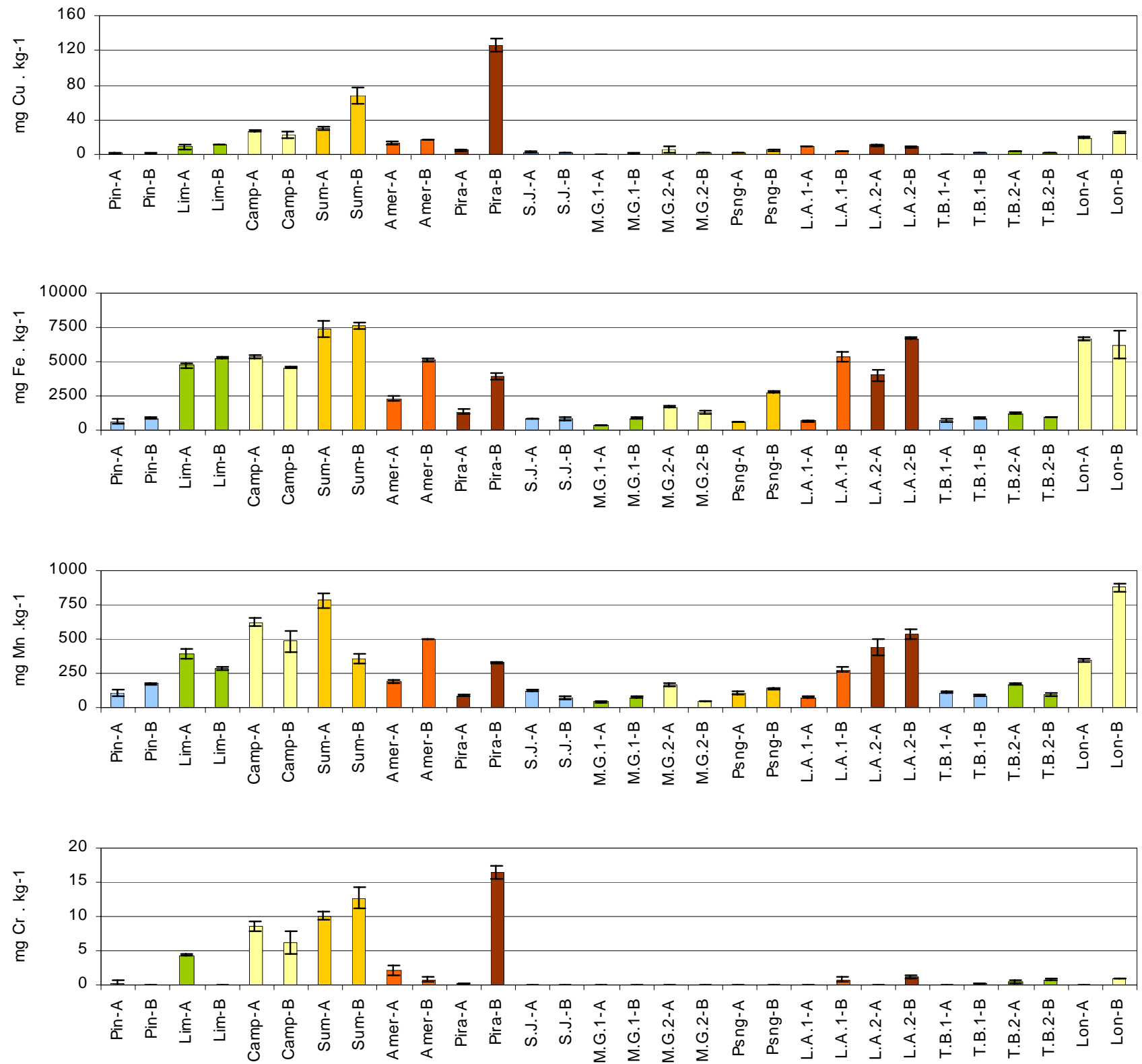

FIGURA 58: Concentrações ( $\mathrm{mg} \cdot \mathrm{Kg}^{-1}$ ) dos metais cobre, ferro, manganês e cromo nos períodos chuvoso e seco, no sedimento dos locais de estudo das bacias dos rios Piracicaba, Mogi Guaçu e Tibagi. As letras A e B correspondem, respectivamente, ao período chuvoso e seco, para as bacias dos rios Piracicaba e Mogi Guaçu e o inverso para a bacia do rio Tibagi. Pin. $=$ Rib. Pinhal; Lim. $=$ Limeira; Camp. $=$ Campinas; Sum. $=$ Sumaré; Amer. = Americana; $\quad$ Pira. $=$ Piracicaba; S.J. = S.João da Boa Vista; M.G.1 = Mogi Guaçu à montante da Int. Paper; M.G.2 = Mogi Guaçu à jusante da Int. Paper; Psng. = Pirassununga; $\quad$ L.A.1 = Rio Mogi-Guaçu em Luiz Antônio à montante da VCP; L.A.2 = Rio Mogi-Guaçu em Luiz Antônio à jusante da VCP; T.B.1 = Rio Tibagi em Telêmaco Borba à montante da Klabin; T.B.2 = Rio Tibagi em Telêmaco Borba à jusante da Klabin; Lon = Rio Tibagi em Londrina. 


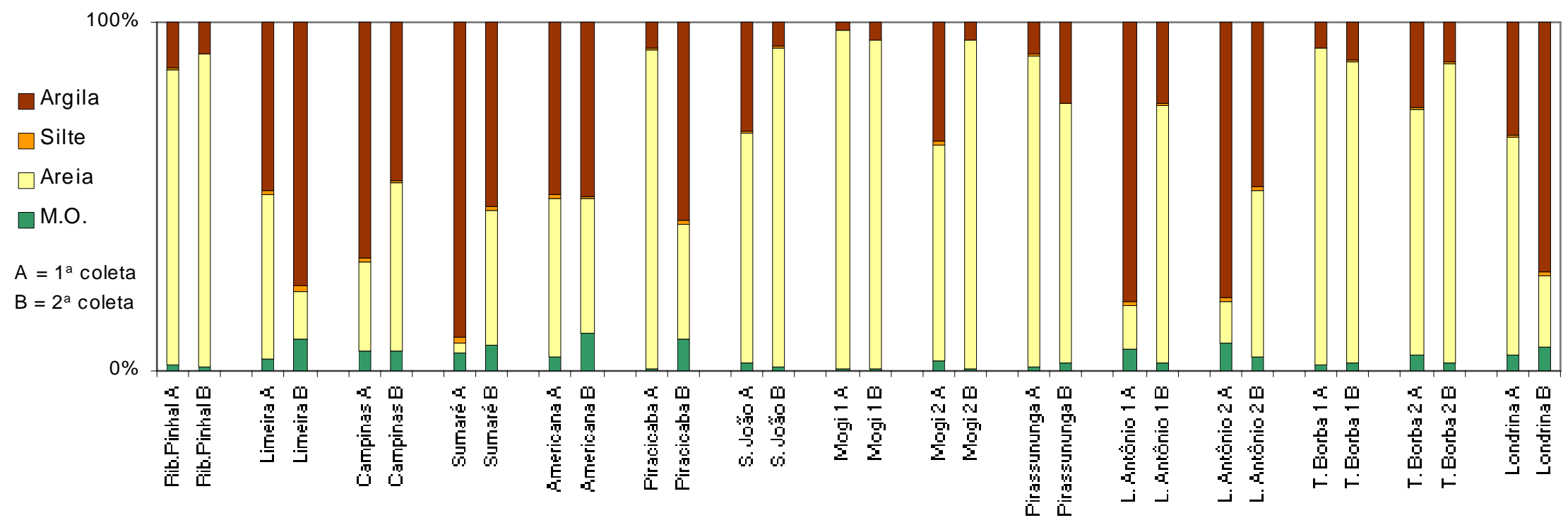

FIGURA 59: Porcentagens de argila, silte, areia, argila e matéria orgânica nas amostras de sedimento coletadas nas diferentes localidades nas bacias dos rios Piracicaba, Mogi Guaçu e Tibagi. As letras A e B correspondem, respectivamente, ao período chuvoso e seco, para as bacias dos rios Piracicaba e Mogi Guaçu e o inverso para a bacia do rio Tibagi. 

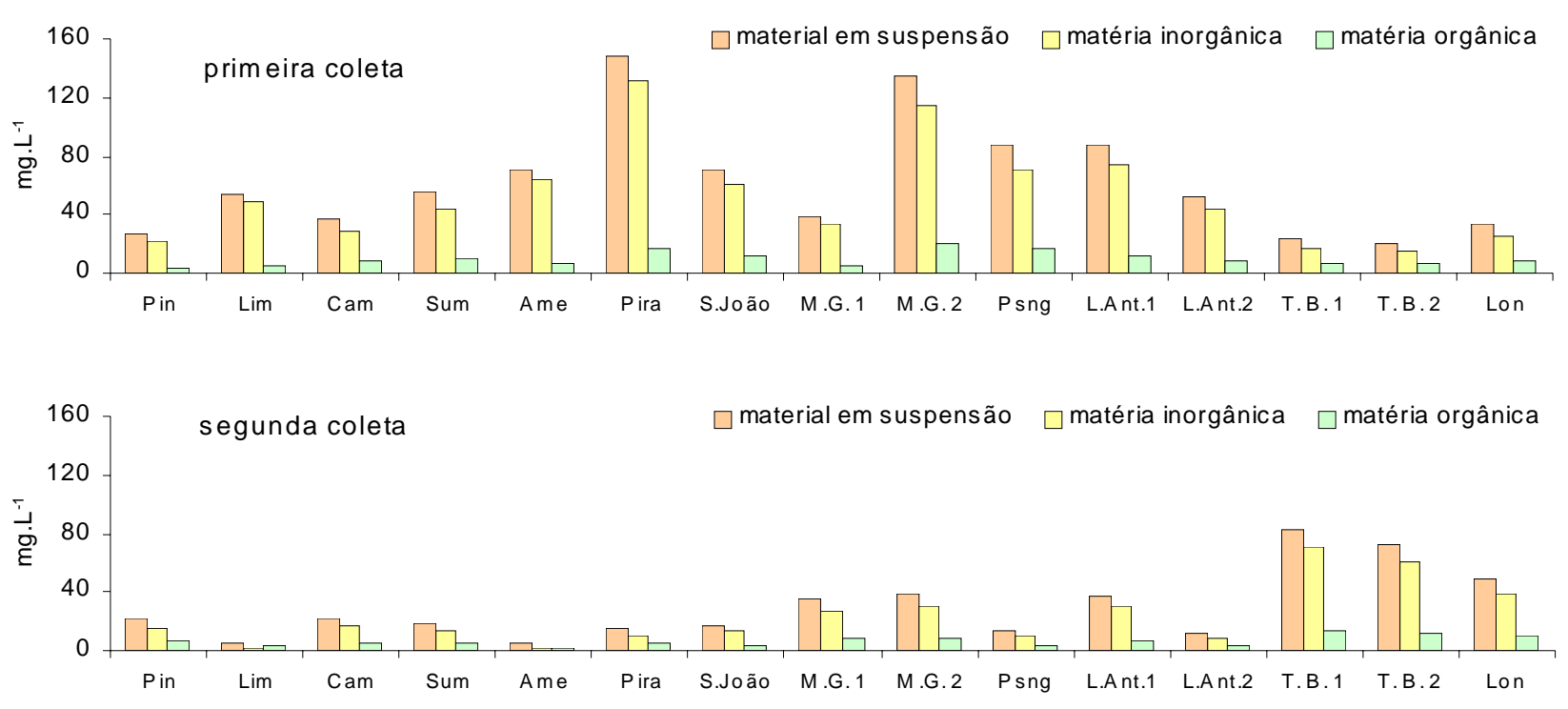

FIGURA 60: Concentrações de material em suspensão, matéria orgânica e matéria inorgânica nas amostras de água coletadas nas diferentes localidades nas bacias dos rios Piracicaba, Mogi Guaçu e Tibagi. A primeira e a segunda coletas correspondem, respectivamente, ao período chuvoso e seco, para as bacias dos rios Piracicaba e Mogi Guaçu e o inverso para a bacia do rio Tibagi. 

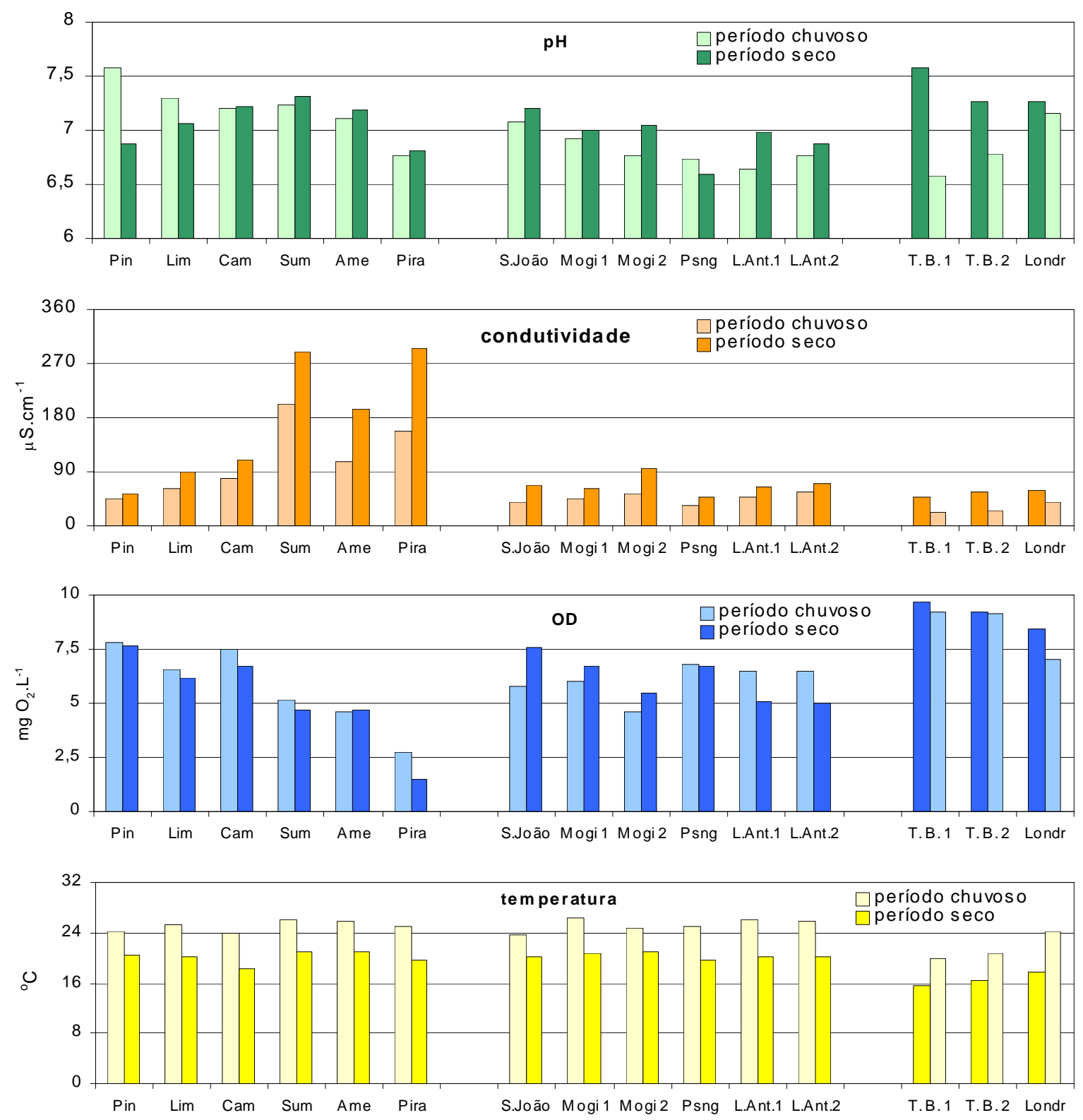

FIGURA 61: Valores de $\mathrm{pH}$, condutividade $\left(\mu \mathrm{S} . \mathrm{cm}^{-1}\right)$, concentração de oxigênio dissolvido ( $\mathrm{mg} \mathrm{O}_{2} \cdot \mathrm{L}^{-1}$ ) e temperatura $\left({ }^{\circ} \mathrm{C}\right)$ no momento das coletas das amostras de água e de sedimento nas diferentes localidades das bacias dos rios Piracicaba, Mogi Guaçu e Tibagi. Notar a inversão dos períodos chuvoso e seco para a bacia do rio Tibagi. Pin. = Rib. Pinhal; Lim. = Limeira; Cam. = Campinas; Sum. = Sumaré; Ame. = Americana; Pira. = Piracicaba; S.João. = S.João da Boa Vista; Mogi 1 = Mogi Guaçu à montante da Int. Paper; Mogi $\mathbf{2}$ = Mogi Guaçu à jusante da Int. Paper; Psng. = Pirassununga; $\quad$ L.Aant. 1 = Rio Mogi-Guaçu em Luiz Antônio à montante da VCP; L.Aant. 2 = Rio Mogi-Guaçu em Luiz Antônio à jusante da VCP; T.B.1 = Rio Tibagi em Telêmaco Borba à montante da Klabin; $\quad$ T.B.2 = Rio Tibagi em Telêmaco Borba à jusante da Klabin; Londr = Rio Tibagi em Londrina. 
4.7. Teste de toxicidade aguda $(96 \mathrm{~h})$ do efluente de indústria de papel e celulose a Serrapinnus notomelas

Nestes testes não foi observada a mortalidade de nenhum dos organismos expostos, mesmo nos recipientes com efluente puro, ou seja, sem diluição, nos quais a concentração de oxigênio atingiu níveis críticos, como $0,80 \mathrm{mgO}_{2} \cdot \mathrm{L}^{-1}$.

\subsubsection{Monitoramento das variáveis físicas e químicas durante o teste de toxicidade do efluente}

Os valores das variáveis monitoradas no decorrer do teste podem ser observados na tabela 24.

TABELA 24: Características físicas e químicas monitoradas durante o teste de toxicidade do efluente final de indústria de papel e celulose a Serrapinnus notomelas.

\begin{tabular}{|c|c|c|c|c|c|c|}
\hline$\%$ & horas & $\mathrm{pH}$ & $\begin{array}{c}\text { condutividade } \\
\left(\mu \mathrm{S} . \mathrm{cm}^{-1}\right)\end{array}$ & $\begin{array}{c}\mathrm{OD} \\
\left(\mathrm{mg} \mathrm{O}_{2} \cdot \mathrm{L}^{-1}\right)\end{array}$ & $\begin{array}{c}\text { temperatura } \\
\left({ }^{\circ} \mathrm{C}\right)\end{array}$ & $\begin{array}{c}\text { dureza } \\
\left(\mathrm{mg} \mathrm{CaCO}_{3} \cdot \mathrm{L}^{-1}\right)\end{array}$ \\
\hline \multirow{5}{*}{$\begin{array}{c}0,0 \\
\text { (controle) }\end{array}$} & 0 & 7,37 & 152 & 5,87 & 24,7 & - \\
\hline & 24 & 7,12 & 151 & 4,05 & 26,7 & 66,0 \\
\hline & 48 & 7,09 & 153 & 4,96 & 23,8 & - \\
\hline & 72 & 7,14 & 151 & 4,93 & 23,5 & - \\
\hline & 96 & 7,10 & 156 & 4,70 & 23,8 & 66,0 \\
\hline \multirow{5}{*}{5} & 0 & 7,45 & 209 & 4,91 & 24,7 & - \\
\hline & 24 & 7,16 & 206 & 3,61 & 26,7 & 66,0 \\
\hline & 48 & 7,16 & 207 & 3,90 & 23,5 & - \\
\hline & 72 & 7,22 & 204 & 3,72 & 23,4 & - \\
\hline & 96 & 7,23 & 207 & 3,95 & 23,8 & 66,0 \\
\hline \multirow{5}{*}{20} & 0 & 7,39 & 396 & 4,97 & 24,6 & - \\
\hline & 24 & 7,23 & 389 & 3,21 & 26,7 & 78,4 \\
\hline & 48 & 7,24 & 399 & 3,88 & 23,4 & - \\
\hline & 72 & 7,31 & 387 & 4,20 & 23,5 & - \\
\hline & 96 & 7,33 & 387 & 4,03 & 23,7 & 70,1 \\
\hline \multirow{5}{*}{40} & 0 & 7,33 & 633 & 4,53 & 24,5 & - \\
\hline & 24 & 7,31 & 606 & 2,32 & 26,7 & 86,6 \\
\hline & 48 & 7,30 & 643 & 3,31 & 23,4 & - \\
\hline & 72 & 7,37 & 621 & 3,80 & 23,5 & - \\
\hline & 96 & 7,42 & 623 & 3,71 & 23,7 & 82,5 \\
\hline \multirow{5}{*}{60} & 0 & 7,28 & 868 & 3,38 & 24,5 & - \\
\hline & 24 & 7,34 & 805 & 1,47 & 26,7 & 99,0 \\
\hline & 48 & 7,34 & 875 & 2,60 & 23,4 & - \\
\hline & 72 & 7,42 & 846 & 2,94 & 23,5 & - \\
\hline & 96 & 7,45 & 845 & 3,13 & 23,7 & 99,0 \\
\hline \multirow{5}{*}{80} & 0 & 7,22 & 1087 & 1,95 & 24,3 & - \\
\hline & 24 & 7,44 & 1047 & 1,48 & 26,7 & 115,5 \\
\hline & 48 & 7,44 & 1102 & 1,72 & 23,4 & - \\
\hline & 72 & 7,52 & 1062 & 2,59 & 23,5 & - \\
\hline & 96 & 7,59 & 1065 & 2,97 & 23,7 & 115,5 \\
\hline \multirow{5}{*}{100} & 0 & 7,22 & 1307 & 0,83 & 24,3 & - \\
\hline & 24 & 7,46 & 1250 & 1,46 & 26,7 & 123,7 \\
\hline & 48 & 7,46 & 1322 & 0,80 & 23,4 & - \\
\hline & 72 & 7,61 & 1273 & 0,96 & 23,6 & - \\
\hline & 96 & 7,55 & 1277 & 1,91 & 23,7 & 119,6 \\
\hline
\end{tabular}


Os valores do $\mathrm{pH}$ e da condutividade variaram pouco em uma mesma concentração ao longo do teste. A condutividade foi muito maior nas concentrações mais elevadas, indicando que o efluente é uma solução altamente iônica (o maior valor medido foi de $1322 \mu \mathrm{S} / \mathrm{cm}$ em 100\% de efluente, contra $156 \mu \mathrm{S} / \mathrm{cm}$ no controle). Os menores valores de oxigênio dissolvido foram observados para a concentração 100\%, devido aos altos teores de matéria orgânica presentes neste tipo de efluente, o que resulta em uma elevada demanda bioquímica de oxigênio (DBO). Os valores para o efluente puro variaram de 0,80 a $1,91 \mathrm{mg} \cdot \mathrm{L}^{-1}$. Observou-se uma elevação na temperatura, após 24 horas, de cerca de 2 graus com relação ao início do teste, devido a uma desregulagem dos termostatos do banho-maria, no qual estavam imersos os recipientes-teste. Os termostatos foram, então, regulados e a temperatura manteve-se estável até o final do experimento, em torno de $23,5^{\circ} \mathrm{C}$.

\subsubsection{Alterações histológicas observadas nos peixes expostos ao efluente de indústria de papel e celulose}

Embora não tenha sido observada a morte de nenhum dos peixes expostos, várias alterações histológicas ocorreram. Da mesma forma que nos testes de toxicidade com amostras de sedimento, foram calculados o Indice de Alterações Histológicas (IAH) e o Valor Médio de Aterações (VMA). Os índices calculados para as concentrações $0 \%$ (controle), 20\%,60\% e 100\% estão representados na figura 62 e a tabela 25 mostra as freqüências das diferentes alterações branquiais, renais e hepáticas observadas em cada uma dessas concentrações.

Nos gráficos é possível observar que, embora os valores do IAH e do VMA calculados para as brânquias, rim e fígado tenham sido crescentes conforme 0 aumento das concentrações, apenas as concentrações de 60\% e 100\% apresentaram valores desses índices significativamente maiores que os do controle, com exceção do IAH calculado para as brânquias dos peixes expostos à concentração de $20 \%$, o qual também foi significativamente superior ao do controle. No entanto, conforme pode ser observado na tabela 25, já na concentração de 5\% ocorreram alterações histológicas em $100 \%$ dos peixes analisados, como a elevação epitelial e a congestão vascular nas brânquias e a vacuolização citoplasmática nos hepatócitos. Além disso, em 80 \% dos peixes analisados foi observada degeneração hialina leve nos túbulos renais e, ainda no rim, alterações de grau II como as degenerações tubular e glomerular em um dos peixes. No fígado foi observado, ainda na concentração de 5\%, a diminuição relativa do glicogênio hepático (em $80 \%$ dos peixes), o aumento do volume dos hepatócitos (em $40 \%$ dos peixes) e a vacuolização nuclear (em $20 \%$ dos peixes). 
Algumas das alterações histológicas mais freqüentes podem ser visualizadas nas figuras 63 a 69 .
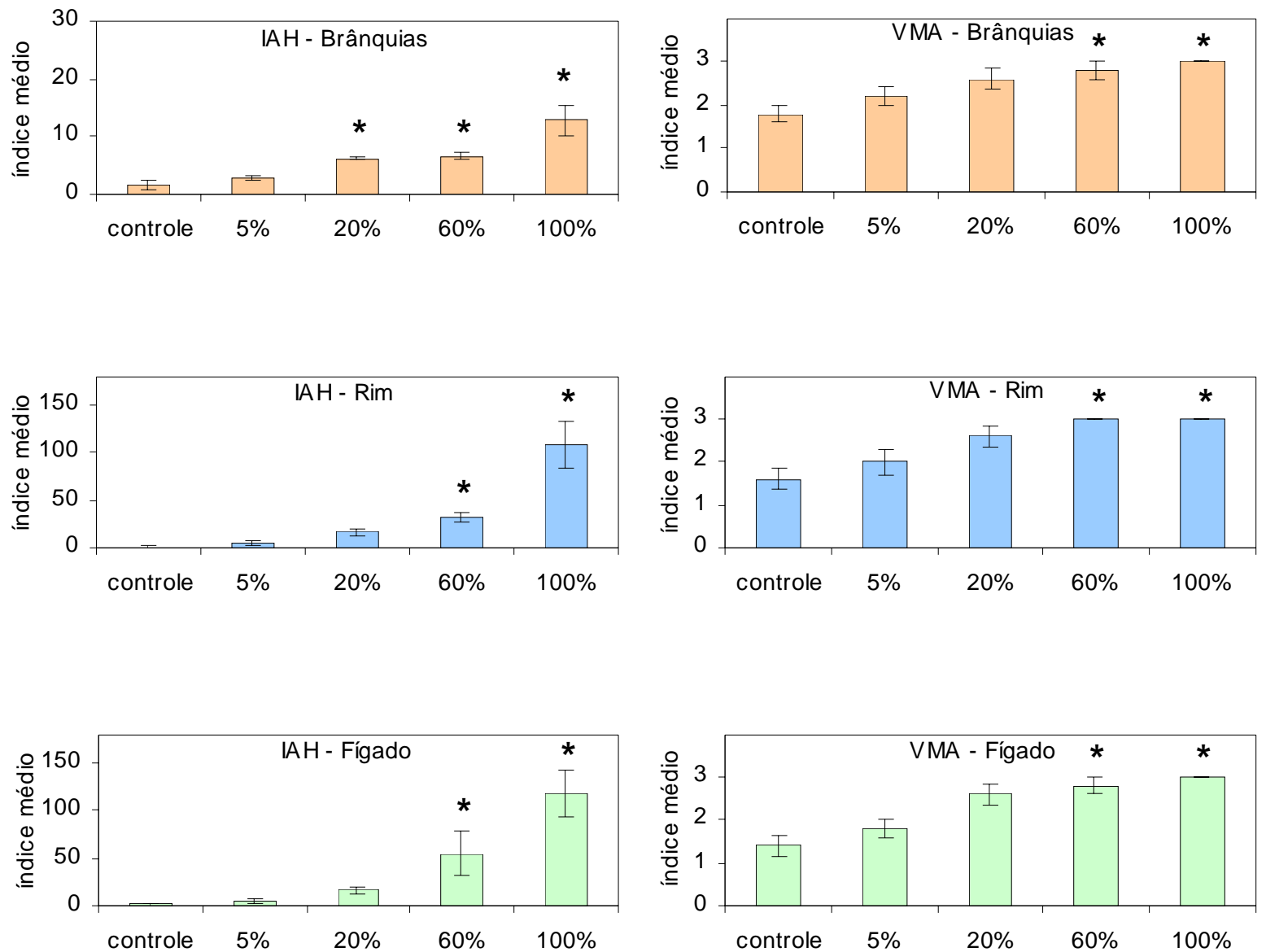

FIGURA 62: Índices de Alterações Histológicas e Valores Médios de Alterações calculados a partir das alterações observadas nas brânquias, rim e fígado de Serrapinnus notomelas expostos a diferentes concentrações do efluente final de indústria de papel e celulose. As barras de erros correspondem ao erro padrão da média; os asteriscos indicam diferença estatisticamente significativa com relação ao grupo controle. $(P<0,05 ; N=5)$. 
TABELA 25: Porcentagem de ocorrência das alterações histológicas no grupo de peixes (Serrapinnus notomelas) (N) exposto a cada concentração do efluente final de indústria de papel e celulose e ao controle (0\%). (Legendas na página seguinte)

\begin{tabular}{|c|c|c|c|c|c|c|c|c|c|c|c|c|c|c|c|c|c|c|c|c|}
\hline \multicolumn{7}{|c|}{ BRÂNQUIAS } & \multicolumn{7}{|c|}{ RIM } & \multicolumn{7}{|c|}{ FÍGADO } \\
\hline & & $\mathrm{col}$ & sentra & ões d & o eflue & nte & & & & entr & ões c & o eflue & nte & & & con & centra & ões d & o eflue & nte \\
\hline Alter. & peso & $0 \%$ & $5 \%$ & $20 \%$ & $60 \%$ & $100 \%$ & Alter. & peso & $0 \%$ & $5 \%$ & $20 \%$ & $60 \%$ & $100 \%$ & Alter. & peso & $0 \%$ & $5 \%$ & $20 \%$ & $60 \%$ & $100 \%$ \\
\hline HTCE & I & 0 & 0 & 0 & 0 & 0 & PCTL & I & 0 & 0 & 0 & 0 & 0 & DesCH & I & 0 & 0 & 0 & 20 & 100 \\
\hline $\mathrm{AdE}$ & I & 0 & 0 & 0 & 0 & 0 & $\mathrm{DHL}$ & I & 0 & 80 & 40 & 80 & 100 & PContCel & I & 0 & 0 & 60 & 60 & 100 \\
\hline ELS & $\mathrm{I}$ & 60 & 100 & 100 & 100 & 100 & HTCT & $\mathrm{I}$ & 0 & 0 & 20 & 20 & 100 & PContNuc & $I$ & 0 & 0 & 0 & 0 & 100 \\
\hline HPBLS & $I$ & 40 & 20 & 100 & 80 & 100 & DesT & $I$ & 0 & 0 & 60 & 0 & 100 & AVolCel & $I$ & 0 & 40 & 0 & 0 & 100 \\
\hline HPLS & $I$ & 0 & 0 & 40 & 60 & 80 & DesG & 1 & 0 & 0 & 0 & 0 & 100 & AVolNuc & 1 & 0 & 0 & 0 & 60 & 100 \\
\hline FPLS & $I$ & 20 & 20 & 80 & 80 & 100 & AECB & $I$ & 0 & 0 & 0 & 0 & 0 & VacCit & $I$ & 100 & 100 & 100 & 100 & 80 \\
\hline LeuELS & $I$ & 0 & 0 & 0 & 0 & 0 & DECB & $I$ & 20 & 0 & 0 & 60 & 100 & DFreqNuc & $I$ & 0 & 0 & 0 & 0 & 0 \\
\hline HP/HTCM & $I$ & 0 & 20 & 0 & 0 & 0 & DCG & $I$ & 20 & 0 & 100 & 100 & 100 & AFreqVas & 1 & 0 & 0 & 0 & 0 & 0 \\
\hline $\mathrm{HP} / \mathrm{HTCC}$ & $I$ & 0 & 20 & 0 & 0 & 0 & TR/NN & $I$ & 60 & 20 & 20 & 40 & 40 & AVolVas & $I$ & 0 & 0 & 0 & 0 & 60 \\
\hline CCLS & $I$ & 0 & 0 & 0 & 0 & 0 & PAST & $I$ & 0 & 0 & 0 & 40 & 0 & DimGlic & $I$ & 20 & 80 & 80 & 80 & 100 \\
\hline MuLS & $I$ & 0 & 0 & 0 & 0 & 0 & DFreqG & $I$ & 0 & 0 & 0 & 20 & 20 & Est Bil & 1 & 20 & 0 & 0 & 0 & 0 \\
\hline $\mathrm{DiC}$ & $I$ & 0 & 20 & 100 & 100 & 100 & DilVS & 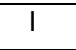 & 0 & 0 & 0 & 0 & 100 & HHem & II & 0 & 0 & 0 & 60 & 100 \\
\hline $\mathrm{DeC}$ & $I$ & 0 & 0 & 100 & 60 & 100 & ALumTub & $I$ & 0 & 0 & 0 & 0 & 100 & RupVas & II & 0 & 0 & 0 & 0 & 0 \\
\hline $\mathrm{CV}$ & $I$ & 40 & 100 & 100 & 100 & 100 & ObsTub & I & 0 & 0 & 0 & 0 & 0 & DegCanBil & II & 0 & 0 & 0 & 0 & 100 \\
\hline Par & $I$ & 0 & 0 & 0 & 0 & 0 & DHS & II & 0 & 0 & 20 & 20 & 100 & VacNuc & II & 0 & 20 & 80 & 80 & 100 \\
\hline FCalgLS & $I$ & 0 & 0 & 0 & 60 & 40 & DT & II & 0 & 20 & 60 & 100 & 100 & DegCit & II & 0 & 0 & 0 & 0 & 0 \\
\hline FCtodLS & II & 0 & 0 & 0 & 0 & 0 & DegG & II & 0 & 20 & 40 & 60 & 100 & DegNuc & II & 0 & 0 & 20 & 80 & 100 \\
\hline$\overline{D C}$ & II & 0 & 0 & 0 & 0 & 0 & DCTub & II & 0 & 0 & 0 & 0 & 0 & AtrofNuc & II & 0 & 0 & 40 & 100 & 100 \\
\hline $\mathrm{RE}$ & II & 0 & 0 & 0 & 0 & 0 & DNTub & II & 0 & 0 & 0 & 0 & 0 & RompCel & II & 0 & 0 & 0 & 0 & 0 \\
\hline $\mathrm{Hem}$ & II & 0 & 0 & 0 & 0 & 0 & TLCB & II & 0 & 0 & 0 & 0 & 0 & Necrose & III & 0 & 0 & 0 & 20 & 60 \\
\hline $\mathrm{An}$ & II & 0 & 0 & 0 & 0 & 60 & $\mathrm{HH}$ & II & 0 & 0 & 20 & 100 & 100 & & & & & & & \\
\hline Fib & III & 0 & 0 & 0 & 0 & 0 & RVS & III & 0 & 0 & 0 & 0 & 0 & & & & & & & \\
\hline $\mathrm{Nec}$ & III & 0 & 0 & 0 & 0 & 0 & $\mathrm{Nec}$ & III & 0 & 0 & 0 & 0 & 60 & & & & & & & \\
\hline
\end{tabular}


Legendas da tabela 25:

Alterações Branquiais: HTCE=hipertrofia das células epiteliais; AdE=adelgamento do epitélio; ELS=elevação do epitélio da lamela scundária (LS); HPBLS: hiperplasia na base das LS.; HPLS=hiperplasia ao longo das LS.; LeuELS= presença de leucócitos; HP/HTCM=hiperplasia/trofia das céls. mucosas; HP/HTCC= hiperplasia/trofia das céls. cloreto; CCLS=céls cloreto nas LS; MuLS=presença de muco entre as LS; DiC=dilatação de capilares; DeC=desorganização de capilares; CV=congestão vascular; Par=presença de parasitas; FCalgLS=fusão completa de algumas LS; FCtodLS=fusão completa de toas as LS; DC=degeneração celular: RE=ruptura epitelial; Hem=hemorragia; An=aneurisma; Fib=fibrose; N=necrose.

Alterações Renais: $P C T L=$ perda do contorno ou contorno atípico das células do tecido linfóide; $D H L=$ degeneração hialina leve; $H T C T=h i p e r t r o f i a$

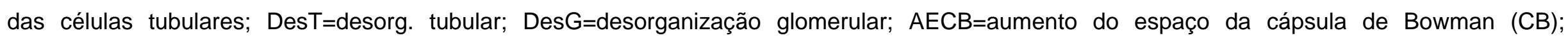
$\mathrm{DECB}=$ diminuição do espaço da cápsula de Bowman; $\mathrm{DCG}=$ dilatação dos capilares glomerulares; TR/NN=ocorrência de túbulos em regeneração ou de novos néfrons; PAST=presença de material PAS-positivo nas céls tubulares; DFreqG=diminuição da freq. relativa de glomérulos; DilVS=dilatação de vasos sangüíneos; ALumTub=aumento do diâm. do lúmen tubular; ObsTub=obstrução tubular; DHS=degeneração hialina severa; DT=degeneração tubular; DegG=degeneração glomerular; DCTub=deg.citoplasmática das células tubulares; DNTub=deg. nuclear das céls tubulares; TLCB=tecido linfóide na CB; HH=hiperemia; RVS=ruptura de vasos sangüíneos; Nec=necrose.

Alterações Hepáticas: DesCH=desorganização/descaracterização dos cordões hepáticos; PContCel=perda ou atipia do contorno dos hepatócitos; PCont Nuc=perda ou atipia do contorno do núcleo dos hepatócitos; AVolCel=aumento do volume celular; AVolNuc= aumento do volume nuclear; VacCit=vacuolização citoplasmática; DFreqNuc=diminuição da freqüência relativa de núcleos; AFreqVas=aumento da freqüência relativa de vasos; AVolVasos=aumento do volume de vasos; DimGlic=diminuição do glicogênio; EstBil=estagnação biliar; HHem=hiperemia; RupVas=ruptura de vasos; DegCanBil=degeneração de canalículos biliares; VacNuc=vacuolização nuclear; DegCit= degeneração citoplasmática; DegNuc=degeneração nuclear; AtrofNuc= atrofia nuclear; RompCel=rompimento celular. 
FIGURA 63: Detalhes de filamentos branquiais de Serrapinnus notomelas exposto a efluente final de indústria de papel e celulose a $5 \%$ (96h), em cortes longitudinais. A) EE-elevações epiteliais nas lamelas secundárias; hiperplasia do epitélio estratificado do filamento branquial e a conseqüente fusão de lamelas secundárias (seta); Bouin, $\mathrm{HE}, \quad x$ 640. B) EE-elevações epiteliais; Bouin, HE, x 500 .
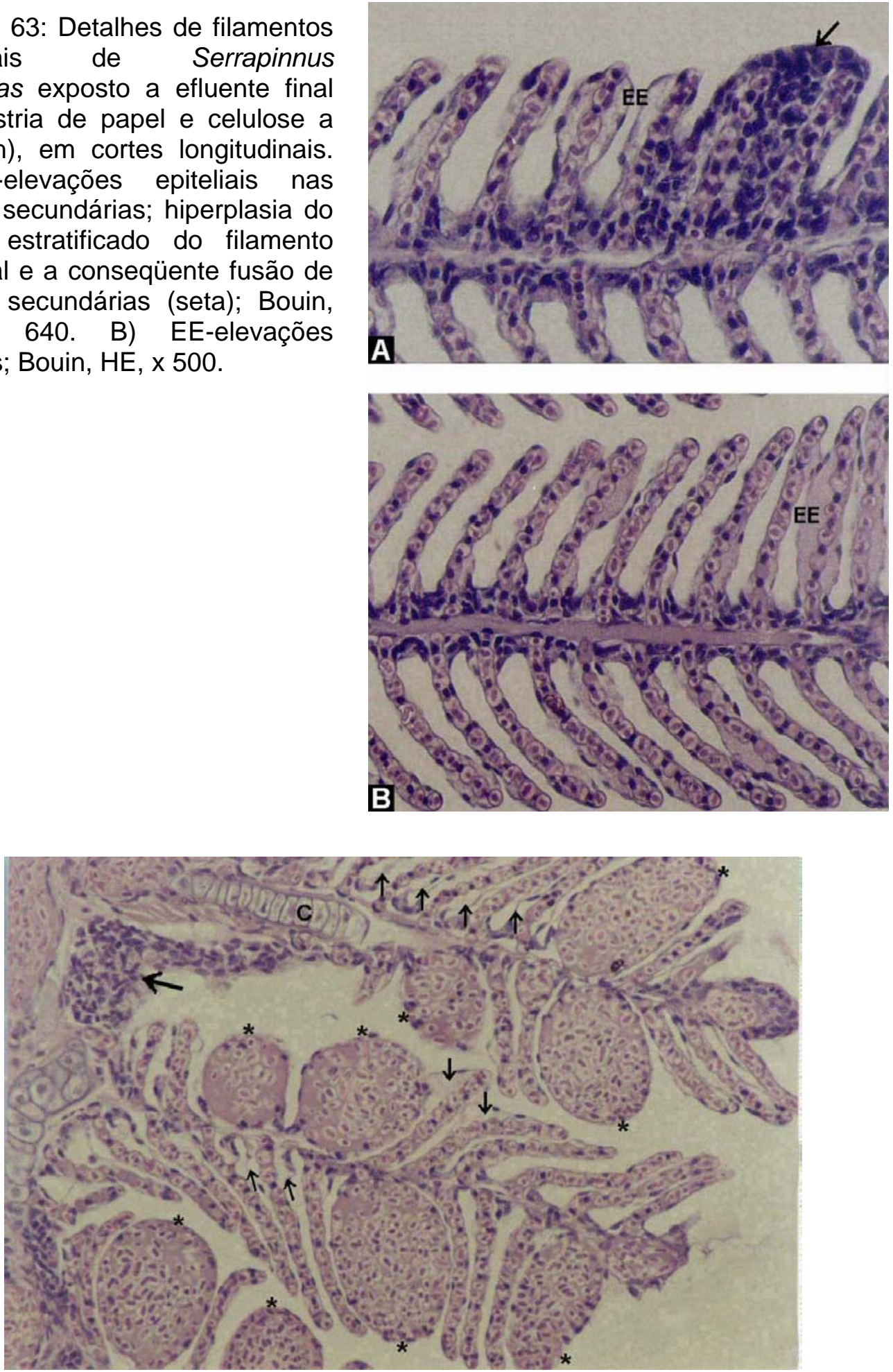

FIGURA 64: Filamentos branquiais de Serrapinnus notomelas exposto a efluente final de indústria de papel e celulose a 100\% (96h), em cortes longitudinais. Aneurismas nas lamelas secundárias (asteriscos); elevações epiteliais (setas menores); proliferação das células do epitélio estratificado do filamento (seta maior); C cartilagem do filamento; Bouin, HE, x 320. 


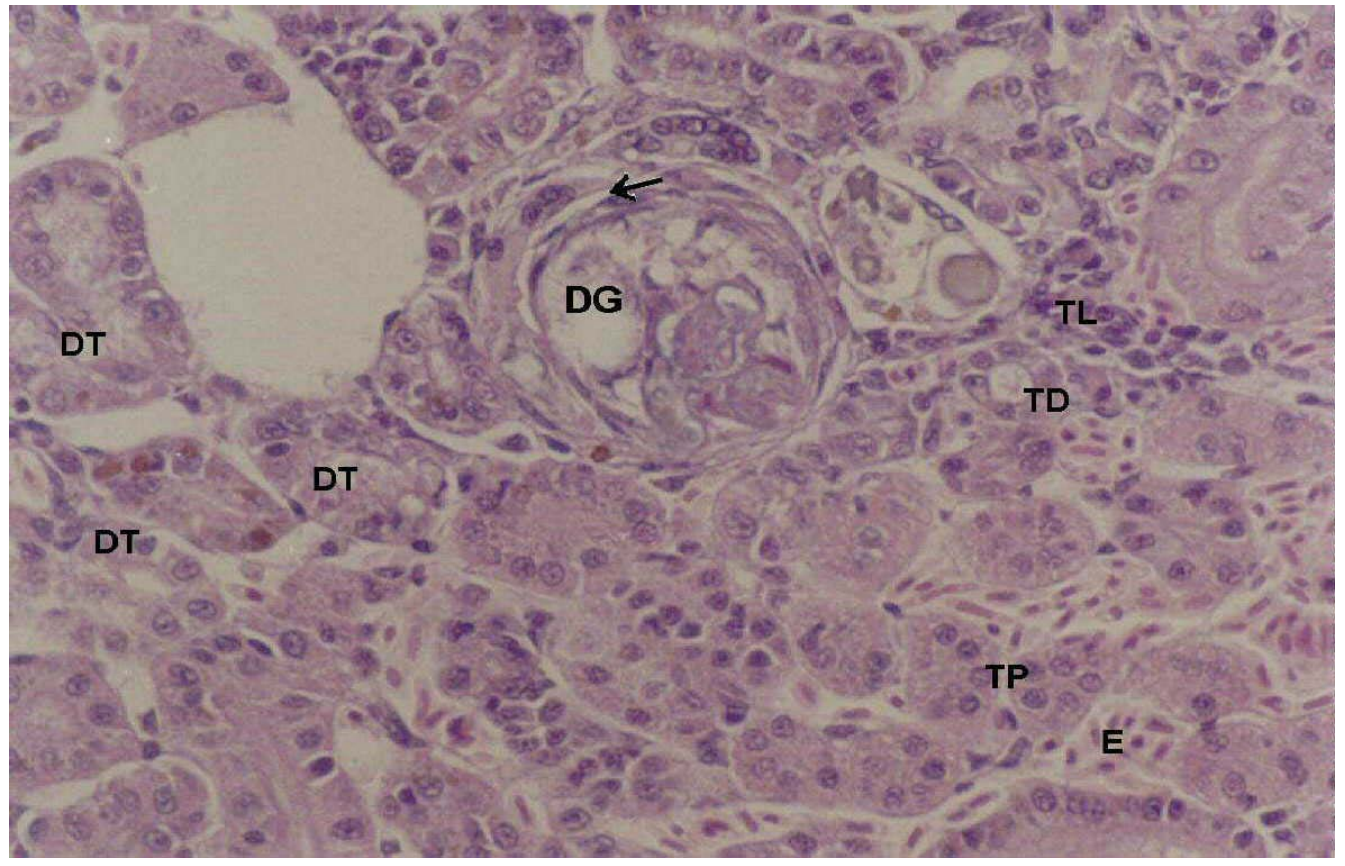

FIGURA 65: Rim posterior de Serrapinnus notomelas exposto a efluente final de indústria de papel e celulose a 20\% (96h). DG-degeneração glomerular; DT-início de degeneração tubular. Espaço intercapsular (seta) praticamente inexistente, devido à dilatação dos capilares glomerulares; TP - túbulo contorcido proximal; TD - túbulo contorcido distal; TL-tecido linfóide; Notar a grande quantidade de eritrócitos (E) entre os túbulos. Bouin, HE, x 500 .
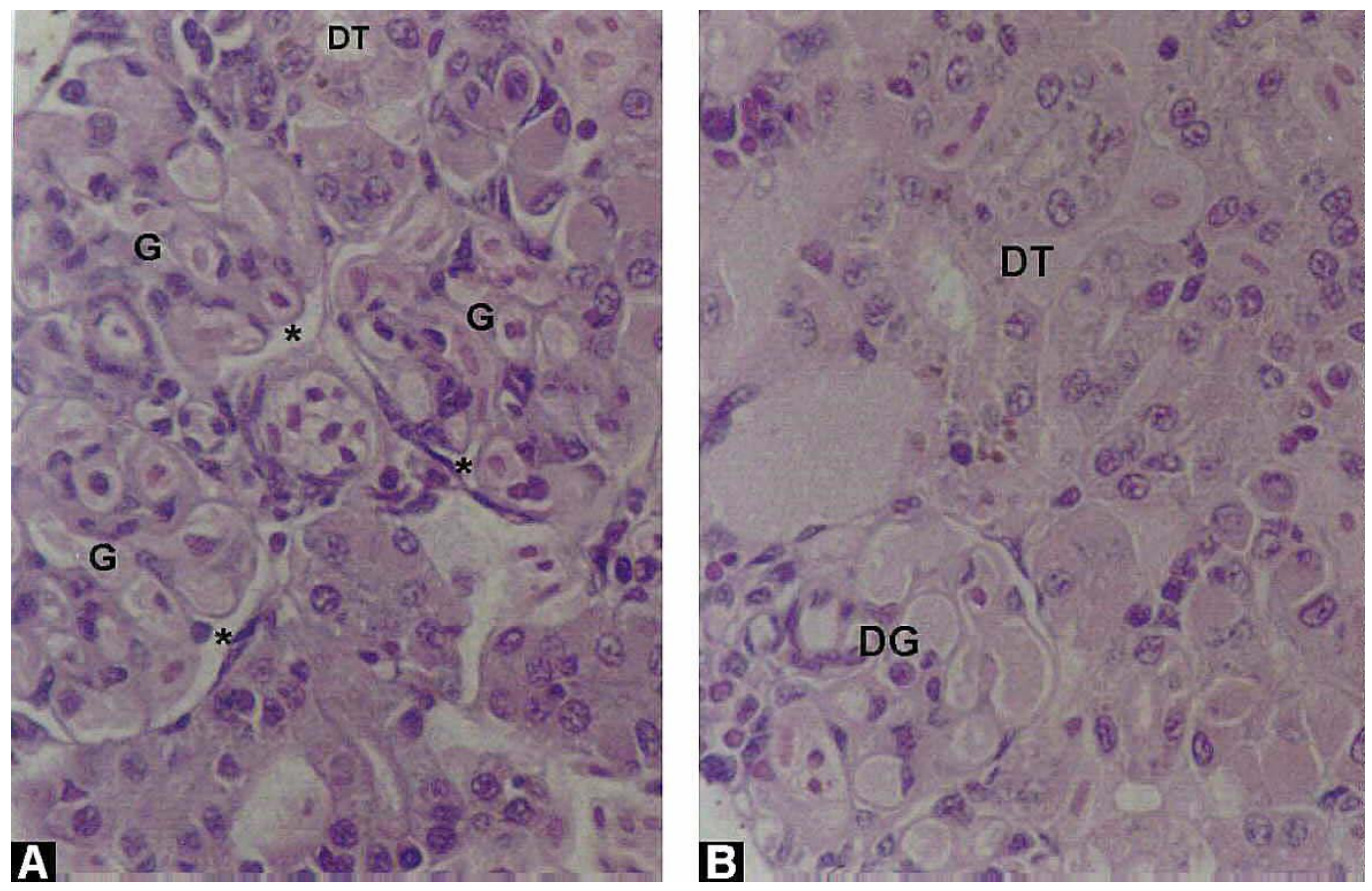

FIGURA 66: Rim posterior de Serrapinnus notomelas exposto a efluente final de indústria de papel e celulose a $60 \%$ (96h). A) G-glomérulos com capilares dilatados e a conseqüente redução do espaço da cápsula de Bowman (asteriscos); DTdegeneração tubular. B) DT-degeneração tubular, caracterizando a necrose desta porção do tecido renal. A e B, Bouin, HE, x 640 . 


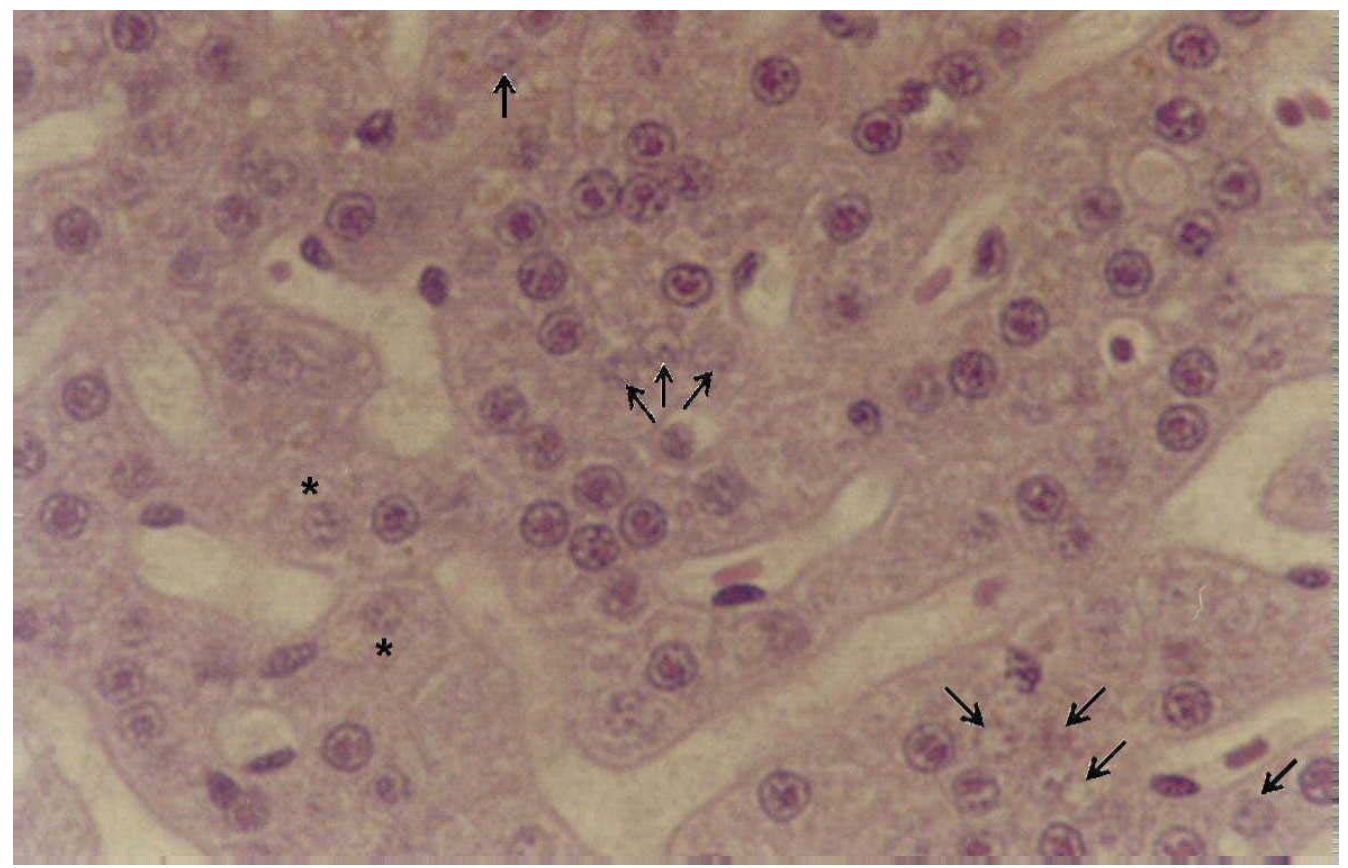

FIGURA 67: Fígado de Serrapinnus notomelas exposto a efluente final de indústria de papel e celulose a 5\%. Observar a degeneração vacuolar do núcleo dos hepatócitos (setas) e a hipertrofia de alguns hepatócitos, acompanhada da degeneração do núcleo. (asteriscos). Bouin, HE, x 1000.

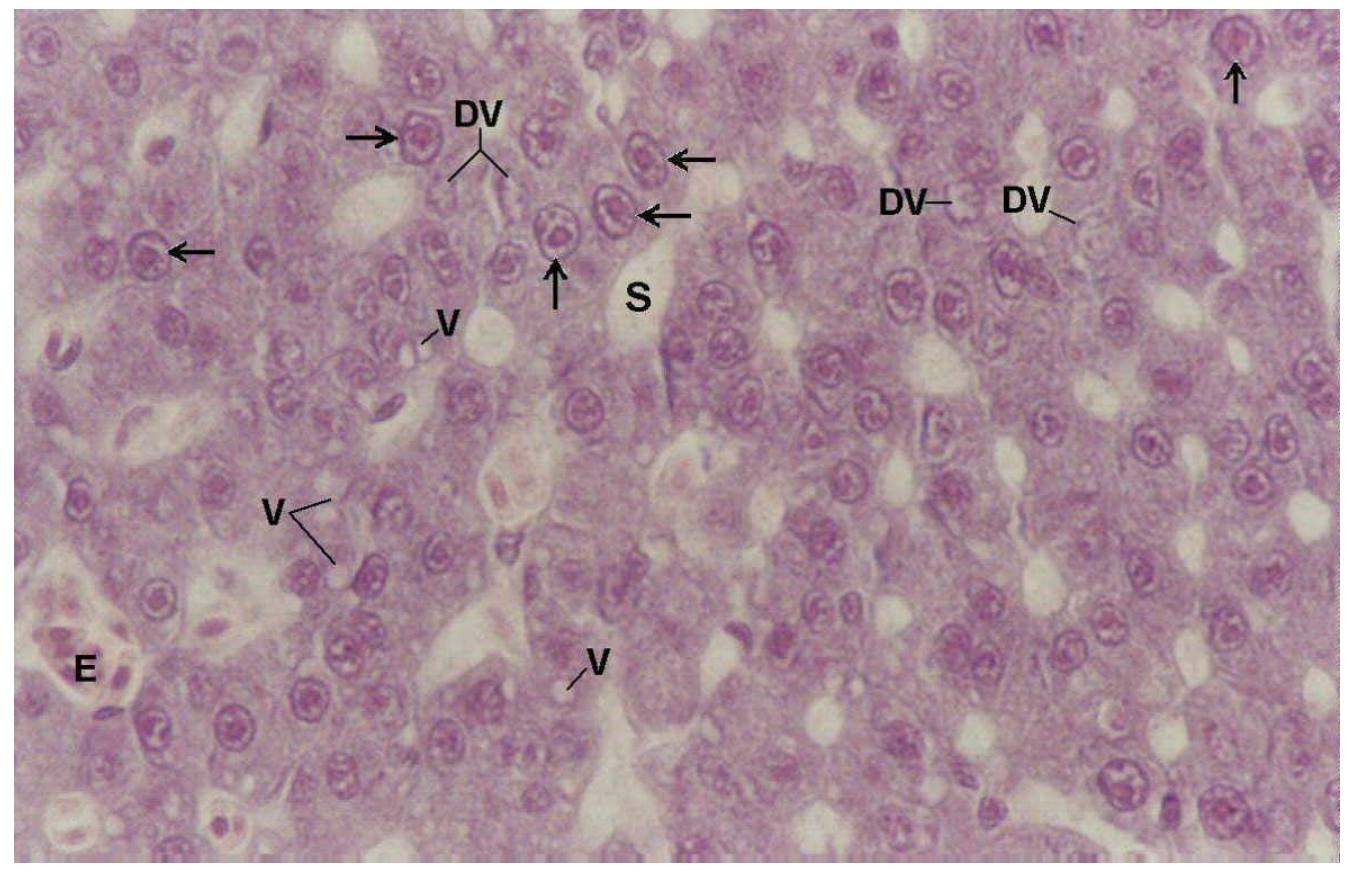

FIGURA 68: Fígado de Serrapinnus notomelas exposto a efluente final de indústria de papel e celulose a 60\%: Observar a desorganização dos cordões hepáticos, com a degeneração de hepatócitos e a perda de definição do epitélio dos sinusóides (S). Notar a presença de hepatócitos com núcleos hipertrofiados (setas) e núcleos com degeneração vacuolar (DV). V-vacúolos no citoplasma de hepatócitos; E-eritrócitos em um sinusóide dilatado. Bouin, HE, x 800. 


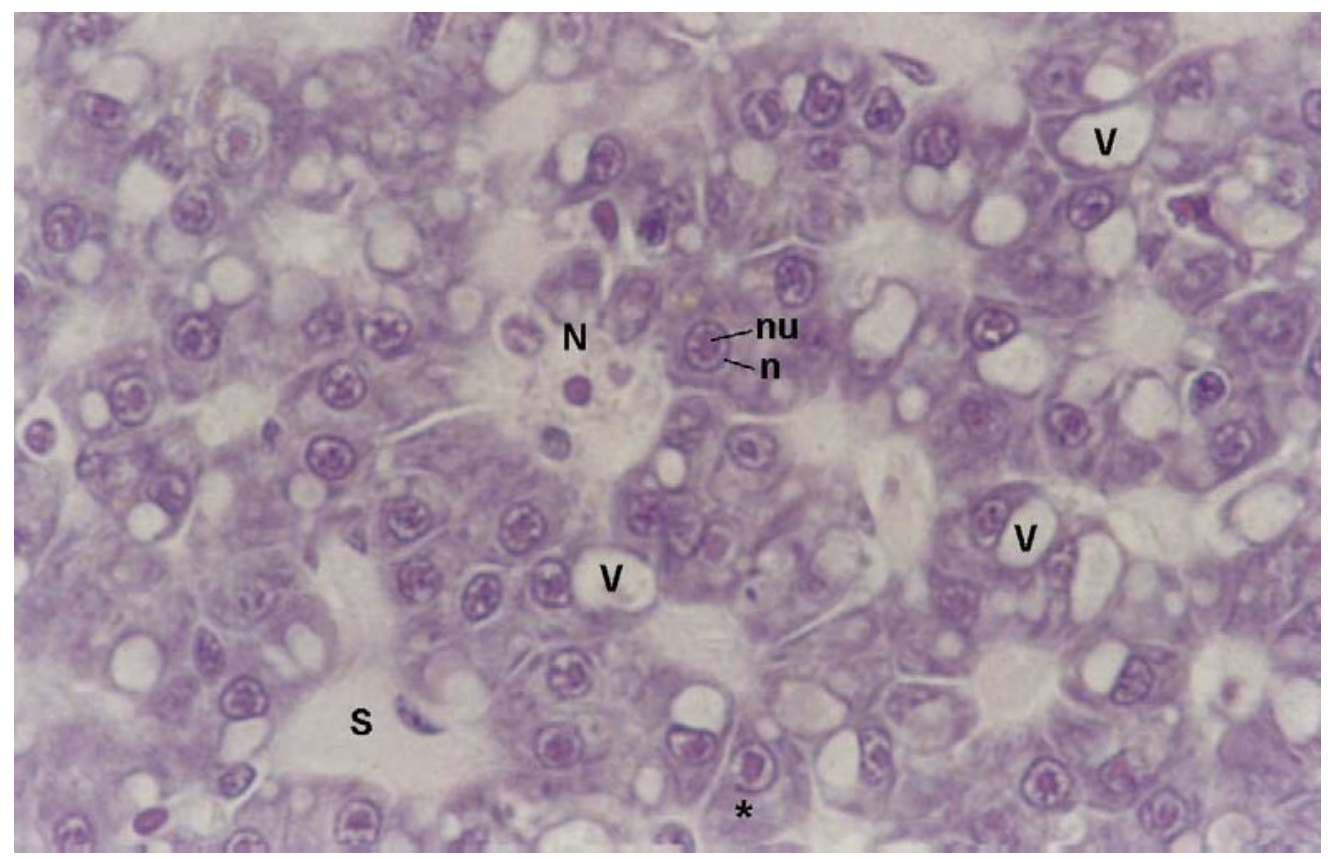

FIGURA 69: Fígado de Serrapinnus notomelas exposto a efluente final de indústria de papel e celulose a $100 \%$ (96h). Nesta situação extrema, notar a área necrosada (N) do tecido hepático, o completo desarranjo dos cordões, o rompimento do epitélio dos sinusóides (S) e a hipertrofia de núcleos (n) e nucléolos (nu), além da presença de numerosos e volumosos vacúolos no citoplasma dos hepatócitos. Bouin, HE, x 1000. 


\section{DISCUSSÃO}

\subsection{Sensibilidade de Serrapinnus notomelas comparada à de outras espécies de} peixe utilizadas como organismos-teste.

Os testes de toxicidade aguda do dicromato de potássio a $S$. notomelas indicaram que esta espécie possui sensibilidade semelhante a de outras espécies testadas anteriormente por MELETTI (1997), como o guarú (Poecilia reticulata) e Danio rerio (paulistinha), espécies amplamente utilizadas em testes de toxicidade. No entanto, outras duas espécies de pequeno porte, Hyphessobrycon eques e Serrapinnus stenodon apresentaram maior sensibilidade à essa substância em 24 horas de exposição, conforme pode ser observado na figura 70 .

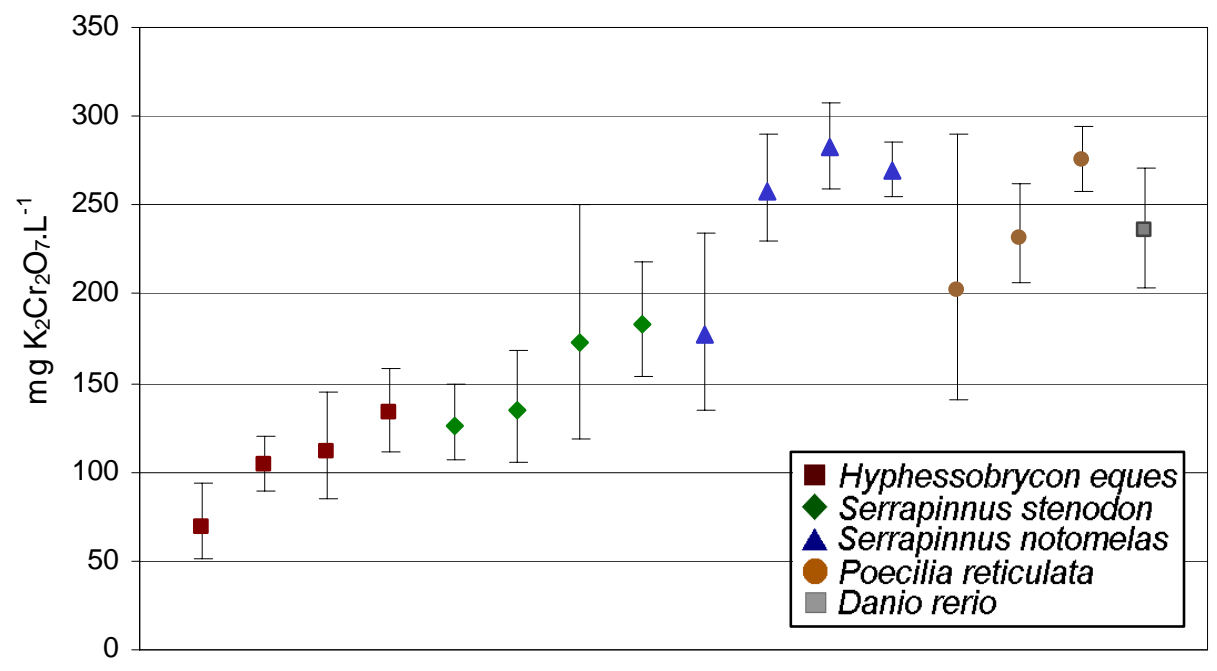

FIGURA 70: Concentrações letais médias $24 \mathrm{~h}\left(\mathrm{em} \mathrm{mg} \mathrm{Cr} \cdot \mathrm{L}^{-1}\right.$ ) calculadas nos testes de toxicidade com dicromato de potássio, para Serrapinnus notomelas, comparadas à calculada para Danio rerio e àquelas observadas por MELETTI (1997) em testes com Serrapinnus stenodon, Hyphessobrycon eques e Poecilia reticulata.

Por outro lado, foram observados valores bem menores de $\mathrm{CL}_{50}$ nos testes com 96 horas de duração. Obviamente é esperado que, quanto mais longo o período de exposição, menor seja o valor da $\mathrm{CL}_{50}$. No entanto, a diferença entre os valores das $\mathrm{CL}_{50} 24 \mathrm{~h}$ e $96 \mathrm{~h}$ foi aproximadamente o dobro da diferença observada em testes com uma outra espécie de caracídeo, Hyphessobrycon callistus, testada por DAMATO 
(1997). Enquanto para $H$. callistus foram observados valores de $C_{50} 24 \mathrm{~h}$ e $96 \mathrm{~h}$ de, respectivamente, 210 e $118 \mathrm{mg} \mathrm{K}_{2} \mathrm{Cr}_{2} \mathrm{O}_{7} \cdot \mathrm{L}^{-1}$, para $\mathrm{S}$. notomelas estes valores foram de $282\left(24 \mathrm{~h}\right.$ ) e $112 \mathrm{mg} \mathrm{K}_{2} \mathrm{Cr}_{2} \mathrm{O}_{7} \cdot \mathrm{L}^{-1}$ (96h) (considerando o teste $\mathrm{n}^{\mathrm{0}} 3$ de $\mathrm{S}$. notomelas no qual foram observados os maiores valores de $\mathrm{CL}_{50}$ ). Isto indica que $S$. notomelas resiste bem no início do teste, resultando em altos valores de $\mathrm{CL}_{50} 24 \mathrm{~h}$, mas a resistência diminui ao longo do tempo, o que a aproxima, em termos de $\mathrm{CL}_{50} 96 \mathrm{~h}$, de $H$. callistus e de outra espécie considerada sensível, Marone sexatilis ( $\mathrm{CL}_{50}$ de 75 a 99 $\mathrm{mg} \mathrm{K}_{2} \mathrm{Cr}_{2} \mathrm{O}_{7} \cdot \mathrm{L}^{-1}$ ) (DAMATO, 1997).

\subsection{Amplitude de variações de fatores em testes ecotoxicológicos de laboratório e no campo.}

As oscilações nos valores de algumas das variáveis monitoradas ao longo dos testes com sedimento com as duas espécies ocorreram provavelmente, dentro de cada tratamento, devido a alterações momentâneas na quantidade de partículas suspensas na água. No momento da montagem dos testes, é natural que ocorra a suspensão de partículas de sedimento e, no decorrer tempo do experimento, que haja uma gradual sedimentação. Nesse processo, partículas que interferem em variáveis tais como $\mathrm{pH}$, condutividade e dureza podem ser ressuspensas e se precipitar, fazendo com que os valores dessas variáveis se alterem discretamente, como foi observado. Além disso, a introdução do eletrodo na água, por mais cuidadosa que seja, provoca a agitação dos peixes que, por sua vez, causam ligeira ressuspensão de partículas, principalmente dos sedimentos mais argilosos. Elevações nos valores do $\mathrm{pH}$ poderiam ser atribuídas à excreção dos peixes, se o meio (água+sedimento) não possuísse composição tão heterogênea. Os sedimentos testados possuíam baixos teores de matéria orgânica (figura 60) e a decomposição desta ao longo dos testes também não explicaria a queda do pH observada em alguns tratamentos. Comparando os valores dessa variável monitorada nos testes com os do monitoramento no momento das coletas, observa-se que, nos testes, esses valores foram mais elevados. É importante considerar que, nos testes, a água de diluição utilizada foi a mesma da de cultivo e não a dos locais de estudo. Porém, a água de cultivo possui pH em torno de 7,2 a 7,5 e, portanto, pode ser responsável por essa diferença do $\mathrm{pH}$, mas não pela variação temporal.

Com relação aos valores de condutividade da água, estes também foram mais elevados nos recipientes-teste que no campo, nos tratamentos de todas as bacias, com exceção daqueles locais que apresentaram os mais altos valores no campo, como Sumaré, Americana e Piracicaba. Na bacia do rio Piracicaba, tanto os valores de condutividade medidos nos recipientes-teste quanto aqueles medidos no campo, 
apresentaram um aumento no sentido montante-jusante ou - quando não é possível estabelecer essa relação espacial - no sentido menos impactado (menor carga de contaminantes) - mais impactado (maior carga de contaminantes). Esse padrão também pode ser observado nas concentrações de alguns nutrientes analisados, conforme discutido adiante. Antes, porém, é preciso explicar o sentido montantejusante, ou o sentido de menor-maior impacto (presumido), já que se tratam de corpos d'água distintos e que os pontos não estão, necessariamente, no sentido montantejusante. O ribeirão do Pinhal encontra-se à montante do local de coleta na captação de Limeira, no rio Jaguari. Porém, neste as coletas foram realizadas antes da confluência com o ribeirão do Pinhal. Por outro lado, o rio Jaguari atravessa áreas de atividades industrial e agrícola mais intensas, além de ser maior também o seu percurso até a confluência com o ribeirão do Pinhal. Assim, presume-se que o rio Jaguari receba maiores quantidades de efluentes industriais e domésticos que o Ribeirão do Pinhal, tanto que este foi escolhido como local controle. O local de coleta em Campinas, no rio Atibaia, está a montante do local de coleta na captação de Sumaré, no mesmo rio. Depois desse ponto, o rio Atibaia une-se ao Jaguari, formando o Piracicaba. Tanto pela extensão percorrida, quanto pelos municípios por onde passam e pela dinâmica das águas dos rios Jaguari e Atibaia (até Campinas), não é possível estabelecer a relação entre eles. No entanto, ambos estão a montante do local de captação de Americana, no rio Piracicaba que, por sua vez, está a montante do local de coleta em Piracicaba, no mesmo rio. Assim, podemos considerar o seguinte diagrama:

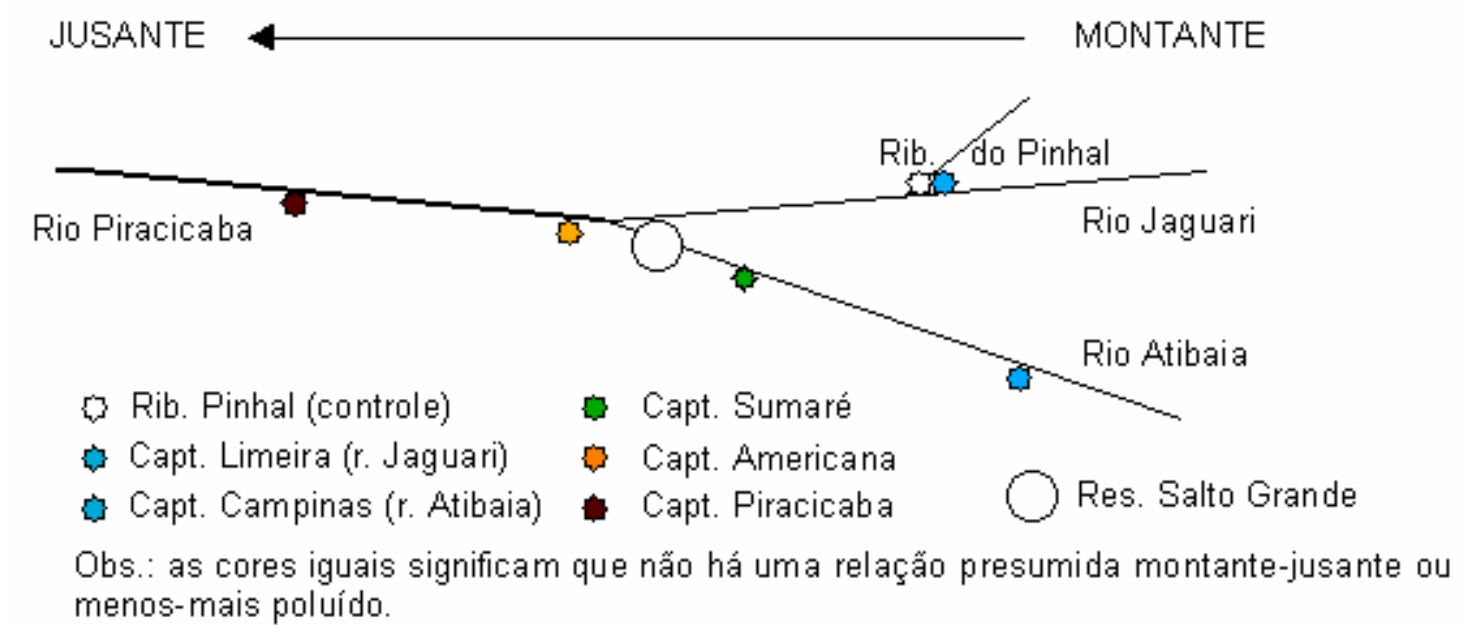

Assim, como a condutividade é uma medida indireta da concentração de substâncias iônicas dissolvidas na água e, portanto, da concentração de muitos poluentes, os menores valores dessa variável foram observados no Ribeirão do 
Pinhal, como o esperado, e aumentaram no sentido Limeira/Campinas - Piracicaba. Porém, em Americana houve diminuição nos valores desta variável, assim como aconteceu com as concentrações de alguns nutrientes analisados. Isto pode ser explicado pela presença do reservatório de Salto Grande, situado imediatamente a montante da confluência dos rios Jaguari e Atibaia e, portanto do início do rio Piracicaba, onde se situa a captação da cidade de Americana. Os reservatórios são conhecidos por funcionarem como bacias de sedimentação, pois, devido à característica lêntica desses corpos d'água, muitas substâncias precipitam, adsorvidas ou não a partículas em suspensão, sendo, assim, detectadas em menores concentrações na coluna d'água.

A diferença entre os valores observados para essa variável na água dos tratamentos Telêmaco Borba 1 e Telêmaco Borba 2, do período seco, é provavelmente devida a substâncias presentes no sedimento, oriundas do efluente de papel e celulose da Klabin, já que os valores da condutividade da água no momento da coleta também foram mais elevados a jusante da fábrica (T.B.1 $=49 \mu \mathrm{S} . \mathrm{cm}^{-1}$; T.B.2 $\left.=57 \mu \mathrm{S} . \mathrm{cm}^{-1}\right)$. Durante um teste de toxicidade, substâncias presentes em maiores concentrações no sedimento tendem a se difundir para a coluna d'água, em direção a um equilíbrio. Um pequeno aumento dos valores de condutividade da água dos testes também foi observado nos tratamentos de Mogi Guaçu 1 (a montante da International Paper) para Mogi Guaçu 2 (a jusante da mesma fábrica), assim como na água dos mesmos locais no momento da coleta do período seco (M.G.1 = $63 \mu \mathrm{S} . \mathrm{cm}^{-1} ;$ M.G.2 = $95 \mu \mathrm{S} . \mathrm{cm}^{-1}$ ). Observando-se os valores de condutividade no teste com o efluente de indústria de papel e celulose, é possível constatar a alta condutividade dessa mistura, que quando pura, ultrapassou $1300 \mu \mathrm{S} . \mathrm{cm}^{-1}$.

Com relação às diferenças dos valores de condutividade da água dos recipientes entre os testes das duas estações, as maiores variações foram observadas no tratamento Piracicaba. Nesse tratamento, a água do teste utilizando amostras coletadas no período seco teve valores de condutividade muito superiores do que aquela do teste com amostras do período chuvoso, como também foi observado na água do rio no momento da coleta. O aumento da condutividade da água observado do início para o final dos experimentos na maioria dos recipientes-teste com amostras de sedimento da bacia do rio Piracicaba é devido à difusão de substâncias iônicas do sedimento para a coluna d'água. O acúmulo de excretas dos peixes não levaria a esses aumentos da condutividade, já que nos recipientes-teste com amostras de sedimento das outras bacias os valores dessa variável permaneceram relativamente estáveis ou, algumas vezes, foram até menores ao final do teste. O fato do sedimento 
proveniente da localidade de Piracicaba apresentar-se "mais iônico" no período seco foi devido à sua própria constituição, como pode ser observado na figura 59, que mostra as porcentagens dos diferentes componentes, argila, silte, areia e matéria orgânica. No período chuvoso a velocidade da correnteza desse rio, particularmente, aumenta muito, dificultando (ou impedindo) a sedimentação de partículas menores e o sedimento fica, então com constituição mais arenosa. No período seco, quando a correnteza diminui, aumenta a deposição de partículas mais finas e de matéria orgânica. De acordo com BURTON (1991), a granulometria é um fator importante a ser considerado na interação sedimento-contaminante. Partículas menores que $63 \mu \mathrm{m}$ tendem a predominar em áreas de deposição (locais de baixa correnteza ou "remansos") e, quando há contaminantes presentes, estes normalmente encontram-se mais associados com partículas dessa dimensão.

Algumas diferenças observadas entre a água dos recipientes-teste e a água dos rios com relação às variáveis monitoradas, levanta uma questão importante em testes de toxicidade com sedimento: é mais apropriado utilizar como meio aquoso a própria água do rio ou a água de cultivo? A opção por um ou outro método dependerá dos objetivos e dos organismos utilizados no trabalho. Se o objetivo for testar a toxicidade das substâncias presentes no sedimento apenas, a utilização de água do local de coleta pode dificultar a interpretação dos resultados, caso essa água também contenha substâncias tóxicas. Por outro lado, se o objetivo for o de realizar uma avaliação do todo (água+sedimento), certamente a utilização de água do mesmo local deverá ser o melhor procedimento. A utilização de água de cultivo ou reconstituída como meio aquoso tem a vantagem da maior praticidade, já que elimina o transporte e o armazenamento em refrigerador, especialmente em testes com peixes, que demandam grandes volumes. Além disso, garante que os efeitos observados ocorreram em virtude apenas de agentes tóxicos presentes no sedimento. Nesse caso é preciso considerar, contudo, que substâncias presentes no sedimento do experimento não estarão em equilíbrio com a água superficial e substâncias que na outra condição (água do local) permaneceriam ligadas ao sedimento (ao menos teoricamente, numa situação ideal de não ruptura do equilíbrio), nessa nova situação poderão se difundir com maior intensidade para a coluna d'água. Porém, quando são testadas amostras de sedimento provenientes de ambientes lóticos deve-se considerar a grande variação temporal da qualidade da água (principalmente nas regiões altamente industrializadas, cujos corpos d'água recebem cargas qualitativa e quantitativamente variáveis de contaminantes) e que, nesse caso, dificilmente sedimento e coluna d'água estão, no ambiente, em total equilíbrio em algum momento. 
MELETTI (1997), testando a toxicidade de sedimentos da bacia do rio Piracicaba a espécies de peixe de pequeno porte (Poecilia reticulata, Serrapinnus stenodon e Hyphessobrycon bifasciatus), utilizou como meio aquoso a água dos mesmos locais de coleta de sedimento e observou toxicidade aguda nos tratamentos referentes aos locais comprovadamente mais impactados. Mesmo tendo sido testados os conjuntos água-sedimento, as mortalidades observadas certamente deveram-se mais a substâncias contidas no sedimento e que passaram para a coluna d'água durante os testes do que a substâncias presentes originalmente na água, pois, antes da realização destes testes com água e sedimento, foram expostos curimbatás (Prochilodus lineatus) em estágio larval apenas às amostras de água dos locais e não foi constatada toxicidade aguda. É importante destacar que essas larvas foram mais sensíveis ao dicromato de potássio que os alevinos da mesma espécie e que as outras espécies testadas em estágio adulto.

No presente trabalho optou-se pela realização dos testes com amostras de sedimento utilizando como meio aquoso a mesma água de manutenção ou cultivo por recomendação da metologia seguida (BURTON \& MacPHERSON, 1995; BURTON, 1991) e também porque a utilização da água do local seria inviabilizada pelo grande volume de água que seria necessário (devido ao grande número de locais amostrados) coletar, transportar e, principalmente, refrigerar.

Outra diferença na metodologia empregada no presente trabalho com relação ao realizado por MELETTI (1997) foi a forma de utilização do sedimento. No referido trabalho foram utilizadas amostras de sedimento bruto não misturado que, a princípio, correspondem mais fielmente às condições do sedimento no campo, já que são mantidas as estruturas física e química das amostras. A mistura de uma amostra de sedimento é realizada, normalmente, a fim de serem removidos materiais (vivos ou não) que possam interferir no experimento, e/ou para homogeneizar a amostra. No trabalho citado, foram observadas discrepâncias entre as duas repetições, as quais foram atribuídas a diferenças na composição das amostras destinadas a cada uma. De fato, a toxicidade pode variar entre os estratos do sedimento e também de uma amostragem (dragagem) para outra. Assim, se não é feita a mistura da amostra, eventualmente as repetições poderão conter sedimentos com composições diferentes o suficiente para produzirem resultados conflitantes. A toxicidade de um sedimento, segundo STEMMER et al. (1990, apud BURTON \& MaCPHERSON, 1995) pode variar, resultando numa amplitude de variação de 0 a 100\% na mortalidade dos organismosteste expostos a amostras que, no campo, encontram-se separadas por apenas alguns centímetros de distância e que possuem a mesma constituição granulométrica e água superficial. A amostragem composta (dragagens em diferentes pontos) é útil, 
portanto para evitar os efeitos da variação espacial da qualidade dos sedimentos. Porém, as amostras precisam ser misturadas para evitar falsos negativos e também os efeitos de uma amostra muito contaminada, mas que não reflete a situação de todo o local. No entanto, BURTON \& MacPHERSON (1995), alertam para o fato de que a manipulação das amostras de sedimento - para remover grandes fragmentos e organismos habitantes naturais do sedimento que possam interferir no teste de toxicidade e ainda para melhor homogeneizar a amostra - pode resultar na introdução de oxigênio em ambientes anaeróbios; na ruptura dos gradientes ou microambientes redox e microbiológicos; na alteração das condições de equilíbrio de substâncias associadas com a água intersiticial e com partículas de sedimento; e ainda na introdução de novos compostos via processos de dessorção e oxidação.

Segundo os mesmos autores, infelizmente "dispomos de poucos dados para quantificar algumas dessas muitas alterações que podem ocorrer durante a amostragem, o manuseio e o preparo das amostras para os testes de toxicidade. Portanto, não é possível predizer se os efeitos terão conseqüências significativas para os objetivos do estudo. Pode ser que as alterações que ocorrerem não afetem significativamente a toxicidade mensurável".

Com relação às baixas concentrações de oxigênio dissolvido (menores que 4,0 $\mathrm{mg} \cdot \mathrm{L}^{-1}$ ) observadas principalmente nos tratamentos Limeira, Campinas, Sumaré e Piracicaba da estação seca, estas foram devidas, provavelmente, aos teores mais elevados de matéria orgânica desses sedimentos (refletindo em maiores demandas bioquímicas de oxigênio). Esses baixos valores de oxigênio dissolvido na água não foram, em nenhuma localidade, uma condição constante, duradoura e não levariam, per se, a alterações histológicas ou fisiológicas significativas. Embora a concentração mínima "ideal" de oxigênio dissolvido na água para os peixes seja de $5 \mathrm{mg} \cdot \mathrm{L}^{-1}$ (valor inclusive considerado como limite para corpos d'água de classe 2 pela Resolução CONAMA de 1986), a tolerância à hipóxia das espécies testadas é bem maior, conforme pode ser observado no monitoramento do teste com efluente de indústria de papel e celulose. HEATH (1987) cita que foram observadas lesões severas nas brânquias, rim, fígado e baço do "catfish" após 72 horas em $1,5 \mathrm{mg} \mathrm{O}_{2} \cdot \mathrm{L}^{-1}$ e que lesões menos severas foram observadas no epitélio branquial de trutas marrons que morreram em água contendo de 0,3 a $1,5 \mathrm{mg} \mathrm{O}_{2} . \mathrm{L}^{-1}$. No entanto, baixas concentrações de oxigênio dissolvido, embora toleráveis, podem levar a um gasto excessivo de energia para a manutenção da homeostase e, assim, a um estado de estresse fisiológico. Como resposta à diminuição da tensão de oxigênio dissolvido na água é observado em muitos peixes um aumento na ventilação, o que pode elevar a 
tomada e a acumulação de metais como o cádmio, o cromo e o chumbo, pelas brânquias (HEATH, 1987).

Com relação às medições realizadas no momento das coletas, apenas em Piracicaba, Americana e Sumaré (período seco) foram detectadas concentrações de oxigênio dissolvido abaixo de $5 \mathrm{mg} \cdot \mathrm{L}^{-1}$. Esses valores seguiram aquela mesma tendência de variação montante-jusante discutida para os valores de condutividade.

Foram detectados na água dos recipientes-teste teores de amônia não ionizada muito superiores àqueles observados na água dos locais de coleta. Isto se deve (1) à manipulação, já que logo no início dos experimentos os valores são mais elevados que os observados in situ e (2) ao caráter estático do experimento (não renovação da água), pois a concentração de amônia aumentou em direção ao final dos testes. Com relação à manipulação, BURTON (in HOFFMAN et al.,1995) lembra que a ruptura da estrutura do sedimento que ocorre durante a coleta e a manipulação antes dos testes resulta na criação de novos microambientes com novas fontes de nutrientes, o que pode aumentar a atividade das comunidades microbianas e levar, assim, à produção de substâncias tais como a amônia. Além da manipulação, o fator tempo de armazenamento do sedimento pode contribuir para o aumento dos teores de amônia, como demonstraram MOORE et al. (1995), que realizaram testes de toxicidade com sedimentos estocados por períodos muito longos (até 740 dias), com poliquetos marinhos, e observaram picos periódicos na concentração de amônia das amostras, provocadas possivelmente pela sucessão de comunidades microbianas. Concluíram, assim, que o tempo de estocagem afeta a concentração de amônia intersticial e, possivelmente, a toxicidade do sedimento e, por isso, consideram importante que a concentração de amônia seja monitorada durante os testes de toxicidade. OTHOUDT et al.(1991) testaram a toxicidade de amostras de sedimento armazenadas a $4^{\circ} \mathrm{C}$ por períodos de até 112 dias (período mais curto que o do trabalho anterior, além de tratar-se de sedimentos de água doce), a Daphnia magna e a Chironomus tentans e não observaram diferenças significativas com relação às amostras armazenadas por uma semana. De qualquer forma, o tempo de armazenamento não deve ter influenciado significativamente a qualidade das amostras no presente trabalho (pelo menos no referente aos teores de amônia), já que os sedimentos ficaram armazenados por períodos muito mais curtos de tempo (1 semana).

As maiores concentrações de amônia não-ionizada foram observadas, in situ, em Sumaré $\left(9,94 \mu \mathrm{g} \cdot \mathrm{L}^{-1}\right.$ no período chuvoso e $3,93 \mu \mathrm{g} \cdot \mathrm{L}^{-1}$ no período seco), abaixo, portanto do limite estabelecido em $20 \mu \mathrm{g} \cdot \mathrm{L}^{-1}$ pela Resolução CONAMA no 20 . Durante os testes este limite não foi ultrapassado na maioria dos tratamentos referentes às localidades das bacias dos rios Mogi Guaçu (com exceção de Mogi 1 e Pirassununga 
no período chuvoso e Luiz Antônio 1 e 2 no período seco) e Tibagi (com exceção de T. Borba2 ao final do teste com amostra do período seco). Porém, na água dos tratamentos referentes às localidades Piracicaba e Sumaré, na bacia do rio Piracicaba, foram detectados teores superiores a $250 \mu \mathrm{g} \cdot \mathrm{L}^{-1}$, conforme já descrito. Estes valores são muito superiores aos estipulados por lei e, dependendo do tempo de exposição, podem ser danosos aos peixes. De acordo com ALABASTER \& LLOYD (1982), a maioria dos estudos a respeito da toxicidade da amônia não-ionizada a peixes revelou concentrações letais médias entre 200 e $2000 \mu \mathrm{g} \cdot \mathrm{L}^{-1}$. Da mesma maneira que o discutido com relação aos baixos teores de oxigênio dissolvido, essas concentrações mais altas de amônia não-ionizada, se não são diretamente prejudiciais aos peixes, podem agravar os efeitos provocados por outras substâncias.

A temperatura da água dos recipientes-teste variou menos nos testes com amostras do período seco, por motivos já explicados. Os valores mais altos dessa variável, observados nos testes com amostras do período chuvoso, contribuíram para um percentual maior de amônia não-ionizada. Porém, foram observados teores mais elevados dessa forma de amônia durante os testes com amostras do período seco, pois nestas, as concentrações do íon amônio foram muito maiores. Essas diferenças observadas nos testes são úteis para o entendimento da influência da temperatura (e também do $\mathrm{pH}$ ) sobre o percentual de amônia não-ionizada e também para previsões do que pode ocorrer (e certamente ocorre em algumas das localidades estudadas) em laboratório e no campo. Então, cabe aqui uma extrapolação:

Nos testes com amostras do período seco, no tratamento Sumaré com $D$. rerio foi observada temperatura de $23,5^{\circ} \mathrm{C}, \mathrm{pH} 7,76$ e $8846 \mu \mathrm{g} \cdot \mathrm{L}^{-1}$ de amônia, sendo que desta, 2,9\% estavam na forma não ionizada, correspondendo a concentração de $253 \mu \mathrm{g} \cdot \mathrm{L}^{-1}$. Se a temperatura, nesse caso, atingisse $25,5^{\circ} \mathrm{C}$ e $0 \mathrm{pH} 7,88$ (valores observados no mesmo tratamento, no período chuvoso), desses $8846 \mu \mathrm{g} \cdot \mathrm{L}^{-1}, 4,3 \%$, ou $381 \mu \mathrm{g} \cdot \mathrm{L}^{-1}$, corresponderiam à forma não-ionizada. Se a temperatura chegasse, então a $27{ }^{\circ} \mathrm{C}$, conforme já observado para um tratamento com amostra oriunda de Limeira, a forma não-ionizada atingiria $424 \mu \mathrm{g} \cdot \mathrm{L}^{-1}$, quase o dobro, portanto, da concentração de fato observada. Embora não tenham sido observadas concentrações de amônia dessa ordem in situ, os valores de $\mathrm{pH}$ e de temperatura não estão distantes do real. Supondo que fossem observados valores para essas variáveis iguais aos observados em Limeira ( $\mathrm{pH}$ e temperatura mais elevados), os teores de amônia não ionizada in situ ultrapassariam em 40\% o limite estabelecido pelo CONAMA 20 para os rios da classe 2 . 
As diferenças observadas entre os valores de algumas das variáveis monitoradas in situ e durante os testes refletem a condição estimativa desses experimentos. Esta característica, no entanto, não os invalida ou não os torna instrumentos "irreais", pois, as condições de laboratório, embora mais estressantes em determinados aspectos, em outros poupa os organismos de adversidades às quais estariam vulneráveis no ambiente natural. Além disso, o fato desses testes reproduzirem condições ambientais mais severas permite que sejam detectados efeitos em curto prazo que, no ambiente natural, poderiam ocorrer somente em exposições mais prolongadas e muitas vezes inviáveis de serem executadas em laboratório.

Com relação às variações sazonais das variáveis monitoradas em campo, foi possível observar, conforme o esperado, temperaturas da água mais elevadas no período chuvoso em todas as localidades estudadas. Os valores de condutividade foram menores no período chuvoso, devido à maior diluição pela água das chuvas. A solubilidade do oxigênio diminui com o aumento da temperatura da água. Assim, é esperado que nos meses mais frios do ano a concentração desse gás dissolvido na água seja mais elevada (assim como nas regiões mais frias - vide os altos valores de OD registrados na bacia do rio Tibagi; nessa bacia contribui para isso, também, a forte correnteza do rio Tibagi). No entanto, os meses mais frios costumam ser, principalmente nas bacias dos rios Piracicaba e Mogi Guaçu, os com menores precipitações. Assim, nos corpos d'água que recebem maior carga orgânica, a concentração de oxigênio dissolvido será também dependente do quanto essa carga é diluída pela água das chuvas. Assim, no período chuvoso, a maior diluição pela água das chuvas levou a concentrações mais elevadas de oxigênio dissolvido na maioria das localidades estudadas na bacia do rio Piracicaba. Nessa bacia é interessante notar a localidade Americana, cujos valores de oxigênio dissolvido foram próximos nas duas estações, provavelmente devido ao efeito do reservatório imediatamente à montante. Na bacia do rio Mogi-Guaçu foi observada concentração de oxigênio dissolvido abaixo de $5 \mathrm{mg} \cdot \mathrm{L}^{-1}$ apenas na localidade Mogi Guaçu 2, no período chuvoso.

\subsection{Concentração de nutrientes na água e metais na água e no sedimento das diferentes localidades estudadas}

Se por um lado, devido à menor diluição, muitas vezes são observadas concentrações mais elevadas de nutrientes na água durante o período de menor precipitação, por outro, no período chuvoso fertilizantes presentes no escoamento superficial, oriundo principalmente de áreas agrícolas, podem levar à situação inversa. 
A primeira situação somente pôde ser constatada, como já observado, para os teores de fosfato orgânico, nas bacias dos rios Piracicaba e Mogi Guaçu, pois as concentrações dos outros nutrientes foram mais elevadas, ora no período seco, ora no chuvoso, variando de local para local.

É interessante observar que as concentrações de amônia não-ionizada em Sumaré foram maiores que em Piracicaba, nos dois períodos. Porém, nessa última localidade, a concentração do íon amônio foi muito maior que em Sumaré no período seco. Fica novamente evidente, então, o papel da temperatura e do $\mathrm{pH}$ na concentração desse íon. O mesmo aconteceu na localidade Ribeirão do Pinhal, na qual as concentrações do íon amônio foram sensivelmente menores que as das outras localidades, mas a de amônia não ionizada, na primeira coleta, foi equivalente às concentrações dos demais locais, com exceção de Sumaré. Ainda assim, o teor de amônia não ionizada nesse local, menor que $2 \mu \mathrm{g} \cdot \mathrm{L}^{-1}$, foi baixo.

Com relação aos metais, com exceção do cádmio e, em algumas localidades, do manganês, as concentrações de metais na água foram, de modo geral, maiores no período chuvoso, provavelmente pela ressuspensão destes do sedimento pela chuva e também devido ao escoamento superficial de áreas urbanas e rurais, onde alguns desses metais podem ocorrer por serem componentes de insumos agrícolas.

Com relação aos limites estabelecidos pelo CONAMA 20, todas as localidades, exceto Ribeirão do Pinhal, Pirassununga e Luiz Antônio 1, apresentaram concentrações de fosfato total superiores ao limite de $0,025 \mathrm{mg} \cdot \mathrm{L}^{-1}$. Em todas as localidades em que foi detectado o metal cádmio, as concentrações estiveram acima do limite estabelecido de $0,001 \mathrm{mg} \cdot \mathrm{L}^{-1}$. Os teores de níquel, considerando os desvios, poderiam ter ultrapassado o limite de $0,025 \mathrm{mg} \cdot \mathrm{L}^{-1}$ nas localidades de Sumaré, Americana e Piracicaba. Em Piracicaba e São João, as concentrações de manganês estiveram acima do limite de $0,1 \mathrm{mg} \cdot \mathrm{L}^{-1}$, no período chuvoso.

O mesmo padrão descrito para a condutividade nas localidades da bacia do rio Piracicaba foi observado para os nutrientes, ou seja, as menores concentrações foram observadas no local controle (Rib. do Pinhal), seguidas por concentrações semelhantes em Limeira e Campinas e aumentando, desta última localidade para Sumaré; já no rio Piracicaba, em Americana, após a confluência dos rios Jaguari e Atibaia as concentrações dos nutrientes analisados diminuíram com relação a Sumaré (efeito do reservatório), voltando a aumentar em direção à Piracicaba.

As maiores concentrações de amônio e de fosfato total, observadas no alto/médio Mogi-Guaçu e também no rio Jaguari-Mirim devem-se provavelmente à maior atividade industrial na região das cidades de Mogi Guaçu e Mogi Mirim e também à atividade agrícola intensa (com predominância de culturas rotativas) nas 
regiões citadas e na região de São João da Boa Vista. Já na região de Luiz Antônio predominam culturas perenes ou que demandam menores quantidades de insumos, como a cana-de-açúcar e os citros.

Entre os locais estudados na bacia do rio Tibagi, os maiores teores de fosfato orgânico observados na localidade de Londrina, no período seco devem-se, provavelmente, à maior atividade agrícola da região.

Os maiores teores dos metais cobre, chumbo, cádmio, cromo e níquel detectados na água principalmente nas localidades da bacia do rio Piracicaba e também no trecho do alto/médio Mogi-Guaçu correspondem à maior concentração industrial dessas regiões. As concentrações dos metais no sedimento ilustram ainda melhor essa tendência, pois não consideram apenas a situação momentânea da qualidade da água, que está sujeita a variações mais bruscas ao longo do tempo, dependendo dos eventos climáticos e das atividades antrópicas. Nas amostras de sedimento da bacia do rio Piracicaba foram observadas as maiores concentrações de dos metais cobre, cromo, zinco, chumbo e níquel, principalmente nas localidades Campinas, Sumaré, Americana e Piracicaba, onde a atividade industrial é mais intensa. O efeito "tampão" da represa de Salto Grande pode mais uma vez ser notado, devido aos teores muito mais baixos da maioria dos metais do que aqueles observados para Sumaré, localidade imediatamente a montante da represa. Nas bacias dos rios Mogi-Guaçu e Tibagi, as maiores concentrações de ferro e manganês em localidades como Luiz Antônio 1 e 2 e Londrina coincidem com o grande número de minerações de areia e argila que há nessas regiões. Com relação a Londrina, onde também foram detectadas concentrações elevadas de níquel, chumbo e cobre, é importante ressaltar que o local de coleta no rio Tibagi situa-se a aproximadamente 300 metros a jusante da confluência com o ribeirão Cambé, o qual atravessa a região metropolitana de Londrina, onde vários outros córregos e ribeirões nele deságuam. Entre esses tributários estão o ribeirão Capivara, que recebe os efluentes de uma indústria de baterias e o ribeirão dos Periquitos, que recebe o chorume do aterro sanitário da cidade (350 toneladas de lixo/dia).

A Resolução 20/86 do CONAMA (BRASIL, 1986) não estabelece concentrações máximas de metais no sedimento. Um órgão ambiental canadense, o "Canadian Council of Ministers of the Environment" (CCME), estabelece, no guia de nome "Canadian Sediment Quality Guidelines for the Protection of Aquatic Life", concentrações máximas para várias substâncias, dentre elas os seguintes metais (em $\mathrm{mg} \cdot \mathrm{Kg}^{-1}$ de sedimento seco): 


\begin{tabular}{ccccccc}
\hline & $\mathrm{Cd}$ & $\mathrm{Cr}$ & $\mathrm{Cu}$ & $\mathrm{Hg}$ & $\mathrm{Pb}$ & $\mathrm{Zn}$ \\
\hline ISQG & 0,6 & 37,3 & 35,7 & 0,17 & 35 & 123 \\
\hline PEL & 3,5 & 90 & 197 & 0,486 & 91,3 & 315 \\
\hline
\end{tabular}

ISQG: guia provisório de qualidade de sedimentos PEL: nível de efeito provável

(CCME, 2002)

Comparando esses valores com os observados no presente trabalho, apenas as concentrações de zinco e de cobre nos sedimentos de Sumaré $\left(207,1 \mathrm{mgZn} . \mathrm{Kg}^{-1}\right.$; $\left.67,6 \mathrm{mgCu} . \mathrm{Kg}^{-1}\right)$ e de Piracicaba (681,3 mgZn. Kg $\left.{ }^{-1} ; 125,7 \mathrm{mgCu} . \mathrm{Kg}^{-1}\right)$, coletadas no período seco, apresentaram valores superiores a pelo menos um dos dois níveis estabelecidos pelo CCME.

Embora esses valores também confirmem o maior grau de contaminação dos sedimentos das localidades Sumaré e Piracicaba, várias outras substâncias presentes nesses e nos outros sedimentos podem ter sido responsáveis pelas alterações observadas nos peixes. Além disso, a complexidade e a variabilidade dos fatores envolvidos na toxicidade dos metais (e de outras substâncias) nos sedimentos torna difícil o estabelecimento de níveis confiáveis de contaminação. Assim, mesmo os outros metais, observados abaixo dos níveis apresentados acima, podem ter ocasionado algum tipo de efeito, já que as características climáticas, de constituição física e química dos sedimentos, de fauna bentônica, entre outras, variam muito de ambiente para ambiente. Assim, esforços devem ser realizados para 0 estabelecimento de níveis de segurança com relação à contaminação de sedimentos para os ecossistemas brasileiros.

\subsection{Alterações histopatológicas observadas nos peixes expostos às amostras de sedimento dos locais de estudo}

\subsubsection{Alterações no tecido branquial}

As brânquias, a pele e o trato digestivo são locais potenciais na absorção de agentes tóxicos presentes na água. Devido a características como a grande superfície de absorção, a pequena distância de difusão e o grande fluxo contracorrente entre a água e o sangue, as brânquias são consideradas o órgão dominante na tomada de substâncias da água. No entanto, a pele também pode ser uma importante rota de absorção em peixes de pequeno porte, tais como os guarús (Poecilia reticulata), devido à alta razão superfície/volume (BARRON in HOFFMAN et al., 1995).

No tecido branquial, uma das alterações mais freqüentes observadas neste estudo foi a elevação epitelial, caracterizada pelo "deslocamento" da camada externa do epitélio da lamela secundária e que constitui uma das primeiras alterações observadas nas brânquias dos peixes nos casos de exposição aguda a agentes 
tóxicos (HEATH, 1987; MÜLLER \& LLOYD, 1994), como óleos, detergentes, amônia, fenóis, ácidos e metais como mercúrio, níquel, cádmio, zinco e cobre. De acordo com HUGHES (In YASUNO \& WHITTON, 1988), o zinco e o níquel acarretam alterações epiteliais mais evidentes, enquanto que o cromo tem menor efeito. Muitas vezes são formados edemas entre as camadas do epitélio, onde podem ser observados leucócitos infiltrados (HEATH, 1987), caracterizando um processo inflamatório que pode ser interpretado como uma resposta de defesa a agentes tóxicos (TAKASHIMA \& HIBYIA, 1995). Outras alterações epiteliais importantes e de ocorrência freqüente nos peixes analisados, foram a hipertrofia e, principalmente, a hiperplasia que correspondem, respectivamente, ao aumento do volume e à proliferação celular. TAKASHIMA \& HIBIYA (1995) classificaram estas duas alterações como progressivas e caracterizadas pelo aumento das funções das células e tecidos, provocado pela alteração das atividades fisiológicas destes. Como decorrência da hiperplasia das células epiteliais, pode haver a fusão das lamelas secundárias. O grau da fusão depende da intensidade e localização da hiperplasia. A fusão será parcial se a hiperplasia se restringir à base ou somente a uma porção das lamelas secundárias, conforme observado principalmente em $\mathrm{S}$. notomelas expostos aos tratamentos com os sedimentos do rio Piracicaba nas localidades de Sumaré, Americana, Piracicaba, S. João e Pirassununga, e em $D$. rerio expostos ao tratamento com o sedimento do ponto 1 do rio Mogi Guaçu (Mogi 1); porém, se a hiperplasia estiver presente ao longo dos filamentos a fusão será total, considerando, obviamente, que as células hiperplásicas preencham todo o espaço interlamelar. Fusões completas de algumas lamelas secundárias foram observadas principalmente em $S$. notomelas expostos ao tratamento com o sedimento de Limeira e em $D$. rerio expostos ao tratamento com o sedimento da localidade Mogi Guaçu 2. Em casos extremos de hiperplasia, a fusão de lamelas pode ocorrer em todo o filamento e, se presente em filamentos adjacentes, pode haver até mesmo a fusão de filamentos, situação não observada em nenhum dos peixes expostos aos sedimentos ou aos efluentes das indústrias de papel e celulose, no presente estudo.

As células mucosas foram observadas, nas duas espécies, entre as lamelas secundárias, sendo mais evidenciadas nas preparações com PAS, já que o muco é uma glicoproteína e, portanto, PAS-positivo. Segundo HEATH (1987), metais como o cádmio, o chumbo, o zinco e o cobre (MILLER \& MacKAY, 1980) estimulam a secreção de muco por estas células. Os metais foram encontrados em concentrações mais elevadas principalmente na bacia do rio Piracicaba (com exceção do local controle) e os sedimentos de todas as localidades dessa bacia resultaram em alterações nas células mucosas, bem como em grande produção de muco (com 
exceção de Limeira) nas brânquias de S. notomelas. Porém, outros metais que não aqueles analisados, ou agentes tóxicos de outra natureza, também devem ocasionar esse tipo de alteração, pois os tratamentos com os sedimentos das localidades Mogi 2 e principalmente de Pirassununga foram os que acarretaram a produção de muco em maior intensidade e em um maior número de animais, e nessas localidades as concentrações dos metais analisados foram muito baixas (esses locais estão à jusante do derramamento de lixívia contendo mercúrio, metal não analisado no presente trabalho). Assim como no caso da elevação epitelial, as alterações como a hiperplasia das células epiteliais e a hipersecreção de muco levam a um aumento da barreira água-sangue, podendo também ser consideradas um mecanismo de defesa contra agentes tóxicos (POLEKSIC \& MITROVIC-TUTUNDZIC In MÜLLER \& LLOYD, 1994).

Assim como as células mucosas, as células de cloreto podem se tornar hiperplásicas e/ou hipertrofiadas, em função de determinados agentes tóxicos presentes na água. Nos peixes de água doce, devido à perda de sais por difusão através das brânquias e pele, principalmente, estas células transportam sódio e cloreto da água para o sangue. O nitrito e os metais zinco, cobre e cádmio, têm sido associados à proliferação dessas células, que aparecem em poucas horas, quando o peixe é exposto a esses elementos. Em alguns peixes de água doce isto pode ser devido à diminuição da osmolalidade provocada por esses metais, especialmente o cobre e o zinco. Com relação ao nitrito, que compete com o cloreto no transporte ativo realizado por essas células, a proliferação delas parece ser um mecanismo compensatório para manter os níveis plasmáticos de cloreto (HEATH, 1987). COSTA E FERNANDES (2002), porém, observaram que o número de células cloreto diminuiu nas lamelas secundárias e não foi alterado nos filamentos do tambaqui (Colossoma macropomum) exposto ao nitrito. No presente trabalho a espessura dos cortes $(5 \mu \mathrm{m})$, não foi adequada a uma análise que possibilitasse a contagem sistemática dessas células.

Nos peixes em que ocorreu a dilatação dos capilares das lamelas secundárias, freqüentemente foi observada congestão vascular, caracterizada pela estagnação do sangue. Devido ao pequeno diâmetro desses capilares, raramente são observados, em condições normais, mais de dois eritrócitos ocupando o lúmen. No caso de congestão, muitos eritrócitos são observados, e em situações severas esse quadro pode terminar em um aneurisma - situação em que o sistema de células pilares encontra-se quase ou completamente ausente - ou até mesmo em uma hemorragia, caso haja ruptura epitelial e extravasamento de sangue. Conforme já citado, aneurismas puderam ser observados com freqüência nas brânquias de $S$. notomelas e de $D$. rerio expostos ao sedimento do rio Atibaia, na localidade Sumaré. 
No presente trabalho não foram observadas alterações regressivas, que são aquelas causadas pela hipofunção de células e tecidos e envolvem atrofia, degeneração e necrose. No caso das brânquias, muitos agentes patológicos podem levar a edemas epiteliais, vacuolizações e necrose na lamela secundária, além da destruição de células mucosas, situação em que é possível observar a excessiva secreção de muco no filamento branquial (TAKASHIMA \& HIBYIA ,1995). No presente estudo, a secreção copiosa de muco observada nos peixes de alguns tratamentos, porém, não pôde ser relacionada à destruição de células mucosas, as quais sempre foram observadas intactas nessas situações.

As alterações observadas no tecido branquial, por prejudicarem o fluxo sangüíneo, como é o caso das congestões e aneurismas e por aumentarem a barreira água-sangue, como o fazem as elevações epiteliais, a hiperplasia e a hipertrofia celular, comprometem a função primordial das brânquias de realizarem as trocas gasosas (na maioria dos teleósteos), além de prejudicarem funções importantes como a manutenção dos equilíbrios ácido-básico e osmótico.

\subsubsection{Alterações no tecido renal}

Entre as alterações renais que ocorreram em maior freqüência e intensidade nos peixes (tanto em $S$. notomelas quanto em $D$. rerio) expostos aos sedimentos contaminados, estão as alterações tubulares observadas principalmente nos animais expostos às amostras provenientes do rio Atibaia, em Sumaré e Campinas, do rio Jaguari, em Limeira e do rio Piracicaba, em Piracicaba e Americana (neste último local em menor grau). Nestes animais, foram observadas alterações do tipo "cloudy swelling" no rim, caracterizada por células epiteliais tubulares "inchadas" ou hipertrofiadas, com grânulos finos eosinófilos no citoplasma (descritas nas tabelas como "hipertrofia das células tubulares"). Muito freqüentes foram também a degeneração por glóbulos hialinos, caracterizada pela presença de grandes grânulos eosinófilos no citoplasma que, segundo TAKASHIMA \& HIBYIA (1995), podem ser produzidos dentro da própria célula ou formados pela reabsorção do excesso de substâncias protéicas eventualmente filtradas no glomérulo. Muitas das alterações tubulares observadas nos peixes são indiretamente provocadas por distúrbios metabólicos causados pela exposição a agrotóxicos e a metais pesados. A maioria das alterações renais tubulares é encontrada nas células epiteliais, e muitas dessas alterações são degenerativas e podem culminar em necrose. De acordo com os autores, ainda não está muito claro se a "cloudy swelling" e a degeneração hialina sempre precedem a necrose, mas é possível que, em alguns casos, a ordem da alteração seja a seguinte: (1) "cloudy swelling", (2) degeneração por grânulos hialinos 
e (3) necrose. Neste último caso são observados núcleos picnóticos e intensa vacuolização do citoplasma.

Nos experimentos realizados foi observada, principalmente em indivíduos de $D$. rerio expostos aos sedimentos das localidades da bacia do rio Mogi Guaçu (exceto na localidade de São João) e também ao sedimento da localidade Londrina, no rio Tibagi, a presença de material PAS-positivo no interior das células epiteliais tubulares. De acordo com TAKASHIMA \& HIBYIA (1995), o glicogênio pode se infiltrar no epitélio tubular e levar, ocasionalmente, à necrose e à gradual destruição das células epiteliais. Tal efeito foi observado em um exemplar de $S$. notomelas exposto ao sedimento do rio Mogi Guaçu na localidade Luiz Antônio 1.

A dilatação dos capilares glomerulares, ocorrente em S. notomelas e D. rerio expostos aos sedimentos de todas as localidades (com exceção de Piracicaba, Luiz Antônio 1 e Luiz Antônio 2 para $D$. rerio) foi uma das alterações mais freqüentemente observadas. De acordo com TAKASHIMA \& HIBYIA (1995), essa alteração ocorre em condições patológicas devido a alterações da lâmina basal, o que é normalmente acompanhado por alterações dos podócitos e das células endoteliais, como a hiperplasia. Nesse caso, todo o glomérulo se torna hiperplásico, aumenta de tamanho, o que pode levar à diminuição do espaço da cápsula de Bowman (ou espaço intercapsular). Outras vezes o glomérulo pode ser pressionado por capilares dilatados, o que ocorre quando há hiperemia. Este último estado, descrito por TAKASHIMA \& HIBYIA (1995) como sendo uma condição estagnante do fluxo sangüíneo arterial, foi observado nos rins de $D$. rerio expostos aos sedimentos de quase todas as localidades estudadas, com destaque para Sumaré, Piracicaba e Mogi Guaçu 2, tratamentos nos quais todos os peixes analisados apresentaram a alteração. Essa diminuição do espaço capsular pode comprometer o processo de filtração e, portanto, toda a função renal. Opostamente, o aumento do espaço da cápsula de Bowman observado em alguns exemplares de $S$. notomelas pode ser causado pela atrofia ou degeneração glomerular (figura 40).

Após dano renal induzido por agentes tóxicos, pode haver a produção de néfrons inteiramente novos (REIMSCHUESSEL, 2001; TAKASHIMA \& HIBIYA, 1995). Porém, essa condição é diferente da recuperação de túbulos pré-existentes. Nesta, ocorre apenas a substituição de células danificadas por novas células epiteliais tubulares (REIMSCHUESSEL, 2001); é o que foi denominado, no presente trabalho, de "túbulos em regeneração". De acordo com o autor, o desenvolvimento de novos néfrons foi anteriormente observado em "goldfishes" (Carassius auratus) expostos ao hexaclorobutadieno, gentamicina e cloreto de mercúrio e também na truta arco-íris (Oncorhynchus mykiss) exposta ao tetracloroetileno. A presença de muitos néfrons 
novos em peixes nativos adultos, conforme observaram CORMIER et al. (1995) pode ser um indício de que o dano induzido pelo agente tóxico ocorreu recentemente. De acordo com REIMSCHUESSEL (2001) e CORMIER et al.,1995, "peixes normais apresentam aglomerados basófilos de células localizadas nos interstícios, freqüentemente próximos a um tubo coletor. No entanto, quando induzidos por agentes tóxicos, esses aglomerados podem aparecer em novos néfrons. Essas formações apresentam aspecto "crescente", tomando, depois, a forma de um "C". Como estas células continuam a se dividir, elas formam um túbulo em forma de "S" no qual o lúmen é geralmente visível. As células de uma extremidade do estágio "S" invaginam e os capilares que avançam para o interior começam a formar o glomérulo. As células da outra extremidade do estágio "S" proliferam e formam os túbulos do néfron que eventualmente se fundem com um tubo coletor pré-existente. Nesse ponto, podem ser observadas em seção transversal múltiplos túbulos intensamente basófilos em cada néfron. Os novos néfrons amadurecem em várias semanas, desenvolvendo os segmentos proximais e distais e tornando-se mais eosinófilos, conforme as células se diferenciam em seu estado adulto". Descrições detalhadas da anatomia do rim dos teleósteos de água doce e dos processos de regeneração renal são encontradas em REIMSCHUESSEL (2001).

Estruturas semelhantes às descritas pelos autores foram observadas em S. notomelas e $D$. rerio expostos às amostras de sedimento de quase todas as localidades estudadas. As exceções, ou seja, os tratamentos cujos peixes não apresentaram novos néfrons ou túbulos em regeneração foram aqueles presumivelmente mais impactados, como Sumaré e Piracicaba e aquele que pode ser considerado o melhor tratamento controle, que é Ribeirão do Pinhal. A partir desse achado, é possível considerar duas hipóteses:

1) A presença de novos néfrons não é um evento freqüente em situações de nãopoluição.

2) O tempo de exposição foi suficiente para a danificação e o subseqüente início da regeneração renal.

Se as duas hipóteses estiverem corretas, é explicada a não ocorrência de novos néfrons nos peixes expostos ao sedimento da localidade Ribeirão do Pinhal e a ocorrência nos outros locais menos impactados que Piracicaba e Sumaré. A ausência de novos néfrons nos peixes expostos aos sedimentos de Piracicaba e Sumaré poderia ser devida, então, a um grau de comprometimento fisiológico desses peixes que impediria qualquer regeneração tecidual.

CORMIER et al. (1995), investigando duas espécies de peixes ("Atlantic tomcod", Microgadus tomcod e "Brown bullhead", Ameiurus nebulosus) coletados em 
rios impactados e em rios "controle", embora tenham observado um maior número de néfrons em desenvolvimento nos peixes provenientes dos locais reconhecidamente mais impactados, sugerem que dois fatores devem ser melhor estudados antes que os néfrons em desenvolvimento possam ser amplamente utilizados na avaliação de xenobióticos nefrotóxicos. Primeiramente, estressores naturais tais como a salinidade e a carga orgânica necessitam ser avaliados. Além disso, os tipos de compostos e misturas e as doses relacionadas ao aparecimento dessas estruturas precisam ser determinadas.

\subsubsection{Alterações no tecido hepático}

Conforme já exposto, a vacuolização citoplasmática nos hepatócitos pode ser uma medida indireta, porém não muito precisa, da quantidade de glicogênio ou de lipídeos nessas células. Assim, foram considerados apenas vacúolos muito grandes e numerosos, já que a presença de gordura não significa, por si só, algum estado patológico. TAKASHIMA \& HIBYIA (1995) alertam para o fato de que o termo degeneração por gorduras refere-se a uma condição patológica na qual há numerosas células com alto conteúdo de gordura, mas que apresentam, também, algum indício de degeneração, como a atrofia nuclear. RIGOLIN-SÁ (1998), estudando a toxicidade do herbicida Roundup e do acaricida Omite ao bagre Ramdhia hilarii, chama a atenção para o fato de que a presença de vacuolização observada nos peixes expostos a essas substâncias foi devida à diminuição da concentração de glicogênio no fígado e aumento na quantidade de lipídeos e que estes, por sua vez, podem combinar-se com agentes tóxicos, os quais seriam acumulados nas células. Citando RODRIGUES (1994), a mesma autora lembra que a diminuição do glicogênio e o acúmulo de lipídios poderiam prejudicar as atividades metabólicas realizadas pelos hepatócitos.

As tabelas com os dados brutos das alterações observadas (anexo I) permitem visualizar melhor os resultados com relação à vacuolização citoplasmática, pois consideram não só o número de organismos nos quais o evento ocorreu, como também a intensidade de ocorrência (pequena, média ou grande vacuolização). É possível notar que em $S$. notomelas houve grande variação com relação à intensidade da vacuolização e ao número de organismos que a apresentaram. No entanto, na maioria dos exemplares de $D$. rerio de cada tratamento foi observada alta vacuolização (com exceção daqueles do tratamento correspondente à localidade São João, no rio Jaguari Mirim, onde foi observada somente em 2 peixes). Assim, são necessários estudos mais específicos para elucidar se a alta vacuolização citoplasmática no fígado dos peixes dessa espécie constitui uma alteração histológica (negativa) ou se é um evento comum que só deve ser considerado como uma 
alteração quando associado a algum tipo de degeneração, conforme sugerido por TAKASHIMA \& HIBYIA (1995).

A atrofia nuclear foi observada em $S$. notomelas e em $D$. rerio com maior freqüência nos tratamentos com os sedimentos das localidades Sumaré, Americana e Piracicaba, na bacia do rio Piracicaba, sendo que nessa segunda espécie também foi observada em todos os peixes do tratamento com o sedimento da localidade Campinas.

Com relação aos estoques de glicogênio, estes diminuíram mais em $D$. rerio que em S. notomelas. Nos testes com $D$. rerio, pelo menos um peixe exposto em cada tratamento (com exceção do sedimento da localidade S. João, na bacia do rio Mogi Guaçu) teve redução dessas reservas. É preciso considerar que $D$. rerio possui menor massa corpórea, é mais ativo (conforme observado no decorrer dos testes) e, portanto deve ter metabolismo mais alto que a outra espécie. Deve ser considerado, ainda, que os peixes permaneceram em jejum por 120 horas ( 24 horas antecedentes aos testes + o período de duração dos testes). No entanto, é interessante notar que nos testes com S. notomelas, tratamentos como Limeira e Piracicaba tiveram um maior número de peixes com reservas de glicogênio diminuídas. Com relação aos testes com amostras de sedimento da bacia do rio Piracicaba, com $D$. rerio, na maioria dos peixes de cada tratamento foi observada a redução de glicogênio, inclusive no local referência. Nos testes referentes à bacia do rio Mogi Guaçu apenas naqueles expostos aos sedimentos da localidade Mogi 1 foi detectada essa condição; nos testes com amostras do rio Tibagi, na maioria dos peixes dessa espécie foi observada a redução do glicogênio nos tratamentos T. Borba 1 e Londrina. Embora possa ser observada alguma tendência, do tipo "peixes expostos às amostras das bacias dos rios Piracicaba e Tibagi tiveram, de forma geral, maior depleção nas reservas de glicogênio", este parâmetro não deve ser considerado isoladamente, já que a própria condição - adversa - dos testes pode levar a tal alteração em espécies de peixe desse porte.

Uma alteração interessante observada nos hepatócitos da maioria dos peixes da espécie S. notomelas expostos aos sedimentos de Limeira, Campinas, Sumaré, Americana, Piracicaba, Mogi 1, Mogi 2, Pirassununga, Luiz Antônio 2 e Londrina foi a estagnação biliar. Em preparações com HE, a bile estagnada aparece como grânulos amarelo-amarronzados (TAKASHIMA \& HIBYIA, 1995) ou verde-amarronzados (PACHECO \& SANTOS, 2002) dentro das células . Esta alteração, denominada colestase, é uma manifestação de uma condição patofisiológica, atribuída à falha do metabolismo ou da excreção de pigmentos biliares. Para que a bilirrubina possa ser excretada, ela deve se solubilizar na água, o que ocorre somente por meio da 
conjugação com o ácido glucurônico. Então, uma diminuição na capacidade de ligação da bilirrubina a esse ácido pode ser a razão para a disfunção hepática (PACHECO \& SANTOS, 2002).

A alta ocorrência de atrofia nuclear observada nos peixes de ambas as espécies, expostos aos sedimentos das localidades Sumaré, Americana, Piracicaba e Campinas, na bacia do rio Piracicaba (neste último apenas em $D$. rerio) pode ser um indício de evolução para a picnose. No tratamento com o sedimento de Sumaré foi observada, ainda, degeneração nuclear nas duas espécies e rompimento celular em hepatócitos de $D$. rerio, o que demonstra o elevado grau de hepatotoxicidade dos agentes tóxicos presentes nesse sedimento.

A ocorrência de necrose (e de todas as outras alterações associadas) em um único espécimen de $D$. rerio exposto ao sedimento da localidade Mogi Guaçu 2, apesar de poder constituir um fato isolado, deve servir de alerta para novas investigações, pois o sedimento dessa localidade ocasionou alterações importantes também em outros órgãos em peixes dessa espécie, como aneurismas lamelares e degenerações tubulares.

\subsection{Toxicidade do efluente de indústria de papel e celulose a Serrapinnus notomelas.}

Pelos resultados obtidos no teste de toxicidade aguda (96h) realizado, o efluente poderia ser considerado não-tóxico a Serrapinnus notomelas, já que não ocorreu a mortalidade de nenhum organismo, mesmo daqueles expostos ao efluente puro. Porém, puderam ser observadas alterações histológicas em todos os peixes expostos ao efluente, desde as menores concentrações testadas. As elevações epiteliais nas lamelas secundárias, nas brânquias e a dilatação de capilares glomerulares nos rins, que são consideradas alterações "leves", se não levam os peixes à morte de modo direto, podem interferir na homeostase, de maneira a limitar a capacidade destes animais de enfrentarem condições ambientais desfavoráveis. Já as alterações provocadas pelas maiores concentrações testadas foram tão severas (aneurismas nas brânquias, necroses renais tubulares e glomerulares, necrose hepática, entre outras) que fatalmente os animais não sobreviveriam a um período de exposição mais prolongado. No entanto, um teste de toxicidade que considere todo o ciclo de vida do peixe pode durar 60 dias ou mais. Já, um teste de toxicidade aguda (96 h) aliado às análises histopatológicas pode fornecer resultados em até 10 dias. Isso não significa que este procedimento possa substituir os testes de toxicidade crônica - pois os parâmetros analisados não são, necessariamente, os mesmos - mas que pode constituir uma ferramenta de monitoramento ao mesmo tempo ágil e 
sensível. Desta maneira, a preparação histológica destes pequenos peixes pode ser bastante útil na avaliação do potencial tóxico de efluentes e de outros agentes tóxicos, mesmo em curtos períodos de exposição.

As indústrias de papel e celulose têm, de fato, investido nos processos de produção e de tratamento de efluentes de modo a minimizar os impactos destes nos corpos receptores e algumas delas realizam testes de toxicidade periódicos com seus efluentes. A indústria que cedeu a amostra do efluente, por exemplo, realiza testes de toxicidade aguda (96 h) com $D$. rerio e, da mesma forma como o observado no presente trabalho, também não constata toxicidade aguda, sendo que nenhum organismo morre mesmo quando exposto ao efluente final puro (Àrea de Meio Ambiente - Klabin, comunicação pessoal). No entanto, a não observação de mortalidade de peixes nos testes de toxicidade aguda com o efluente final não quer dizer que seus efeitos não sejam prejudiciais à saúde desses organismos, conforme pôde ser observado nas análises histológicas das brânquias, rim e fígado.

Nos peixes expostos ao efluente puro, em todos foram observadas nas brânquias, elevações epiteliais, hiperplasia pelo menos na base das lamelas secundárias, com a conseqüente fusão parcial destas (em $40 \%$ foi observada a fusão completa), dilatação e desorganização dos capilares lamelares e congestão vascular. Nessa concentração, em 3 de 5 peixes, ou 60\%, foram observados aneurismas lamelares. No rim desses animais foi observado um número maior de alterações consideradas graves em todos os animais analisados, como a degeneração hialina severa, as degenerações tubulares e glomerular e a hiperemia; em 60\% destes foi observada, ainda, a ocorrência de necrose. Com relação às alterações de grau I, das 13 consideradas foram observadas 8 com 100\% de ocorrência. No fígado, foi observada a ocorrência de necrose também em $60 \%$ dos peixes analisados. Neste órgão, ainda nos peixes expostos ao efluente puro, também foram observadas alterações importantes em todos os organismos analisados, como a degeneração dos canalículos biliares, a vacuolização e a degeneração e a atrofia nuclear. Foi alto também o número de alterações menos graves (grau I) observadas em todos os animais analisados. Considerando todas essas alterações e o fato de que não foram eventuais, por terem ocorrido na maioria ou em todos os animais analisados, de fato seria uma questão de tempo de exposição para que a mortalidade ocorresse, pois as funções branquiais e, principalmente renais e hepáticas já se apresentavam comprometidas. Os danos epiteliais nas lamelas secundárias e principalmente as alterações renais observadas, tais como as degenerações glomerular e tubular em todos os animais analisados constituem um importante indicativo de um sério comprometimento dos processos osmorregulatórios. No fígado, a própria degeneração 
nuclear (e, conseqüentemente, celular) já indica comprometimento das funções hepáticas. A degeneração dos hepatócitos desses animais muito provavelmente está associada à deficiência da irrigação sangüínea, indicada pela descaracterização dos sinusódes (e, portanto, dos cordões hepáticos). A degeneração dos canalículos biliares certamente levaria à estagnação biliar, que não foi observada nesses animais provavelmente devido à própria ausência ou baixa produção de bile. A total ausência (observada) de glicogênio hepático nesses animais é um forte indício do processo de detoxificação que deve ter ocorrido já nas primeiras horas de exposição, ainda quando deveria haver alguma função hepática.

É evidente que a exposição de peixes a um efluente puro constitui uma situação irreal, já que sempre ocorrerá a diluição no corpo receptor. Porém, é útil para que sejam expostas as deficiências de um monitoramento baseado apenas em testes de toxicidade aguda. É importante salientar, ainda, que algumas dessas alterações citadas ocorreram significativamente já na concentração de 20\%, o que reforça a idéia de que a mortalidade ocorreria em uma exposição mais prolongada, mesmo em concentrações menores.

PACHECO \& SANTOS (2002) expuseram a enguia européia (Anguilla anguilla L.) ao efluente de indústria de papel e celulose a 12,5\% e observaram no fígado, após 30 dias de exposição, o aumento na densidade de agregados de macrófagos pigmentados (com os pigmentos marrons, melanina, lipofucsina, ceróides e hemossiderina), perda de células do parênquima hepático, necrose dispersa e inflamação focal. A presença de agregados desses macrófagos é um indicativo de lesões no fígado. Considerando, então, que essa alteração está relacionada com condições necrótico-degenerativas, os autores inferiram que a capacidade de biotransformação do fígado poderia estar substancialmente reduzida, o que certamente levou à diminuição da resistência aos contaminantes e à baixa sobrevivência observada.

No presente trabalho observou-se a perda de contorno nos hepatócitos dos peixes expostos às concentrações mais elevadas do efluente e a degeneração dos canalículos biliares, naqueles expostos ao efluente puro. Essas duas alterações aparecem nos cortes histológicos, como se os hepatócitos estivessem separados por um espaço mais largo do que o diâmetro normal dos canalículos biliares. Essa separação entre hepatócitos adjacentes foi observada também nas enguias expostas ao efluente por PACHECO \& SANTOS (2002), que relacionaram tal alteração ao processo de necrose no qual ocorre a degeneração de proteínas estruturais na membrana dos hepatócitos, as quais mantêm o parênquima hepático como um tecido compacto e homogêneo. Assim, a desorganização dos cordões hepáticos também 
poderia ser considerada um estágio inicial desse processo que, na continuidade da exposição a tais substâncias, culminaria na necrose do tecido.

Os mesmos autores observaram, ainda, hemossiderose no baço, que é um indicativo do aumento no catabolismo eritrocítico. As resinas ácidas e outros compostos hemolíticos presentes nos efluentes de indústria de papel e celulose podem acelerar a taxa de destruição eritrocítica, levando à hemossiderose esplênica e, segundo HIBYIA (1992, apud PACHECO \& SANTOS, 2002), o aumento da hemólise pode levar ao decréscimo no número de eritrócitos maduros no sangue circulante.

Nos rins os autores observaram danos glomerulares capazes de prejudicar o processo de filtração glomerular. Alterações nos túbulos renais da enguia exposta ao mesmo efluente puderam ser observadas por SANTOS et al. (1990, apud PACHECO \& SANTOS, 2002).

A menor concentração testada no presente trabalho foi de $5 \%$ do efluente final, que, pressupõe-se, raramente ocorre nos corpos receptores estudados. Se fossem considerados, por exemplo, os valores das vazões mínimas do rio Tibagi e a vazão máxima de lançamento do efluente da indústria instalada nesse rio, em Telêmaco Borba, chegar-se-ia a concentrações entre 0,95 a 1,6 \% do efluente no rio. Considerando que foram observadas alterações histológicas provocadas pelo efluente a 5\% em 96h, concentrações menores podem causar alterações em exposições mais prolongadas, conforme o constatado por DUBÉ \& MACLATCHY (2000). Os autores expuseram uma espécie de peixe estuarina à concentração de $1 \%$ do efluente final de uma indústria de papel e celulose e observaram alterações significativas, como a redução de até $92 \%$ da testosterona plasmática. Os achados desse e dos outros trabalhos já mencionados que descreveram perturbações endócrinas causadas pelos efluentes de indústria de papel e celulose nos peixes indicam que estes podem ter as capacidades de sobrevivência e de reprodução comprometidas. Estudos fisiológicos e histopatológicos em peixes expostos a concentrações próximas às encontradas no ambiente e por períodos de tempo mais prolongados poderão averiguar com precisão, juntamente com estudos in situ, o impacto desse e de outros tipos de atividade industrial sobre a ictiofauna.

Os resultados das análises histopatológicas, assim como das análises fisicas e químicas das amostras de água e de sedimento indicam o elevado grau de comprometimento dos rios Atibaia e Piracicaba com relação às condições para a manutenção da vida aquática e para a utilização de seus recursos e alertam para o processo de degradação em andamento nos trechos estudados dos rios Jaguari, Mogi-Guaçu e Tibagi. 
O presente trabalho demonstrou que os testes de toxicidade com peixes de pequeno porte, aliados às análises histopatológicas constituem uma importante ferramenta na avaliação da toxicidade dos sedimentos e de efluentes. Assim, estes experimentos, assim como os testes in situ, devem ser utilizados sistematicamente a fim de que as metodologias possam ser padronizadas e esses instrumentos sejam rotineiramente utilizados na avaliação dos impactos ambientais. 


\section{CONCLUSÕES}

- Embora os sedimentos não tenham provocado toxicidade aguda a Serrapinnus notomelas ou a Danio rerio, foi possível observar alterações histológicas importantes nas brânquias, rim e fígado desses peixes, que evidenciam o alto grau de contaminação dos sedimentos principalmente das localidades da bacia do rio Piracicaba.

- As análises histopatológicas e as análises químicas da água e do sedimento indicaram que as localidades Sumaré (rio Atibaia) e Piracicaba (rio Piracicaba), em primeiro lugar e também as localidades Campinas (rio Atibaia), Limeira (rio Jaguari) e Americana (rio Piracicaba), encontram-se em elevado grau de degradação ambiental no que diz respeito às condições para a manutenção da vida aquática e à possibilidade de utilização desses corpos d'água para o consumo humano ou animal. Nessa bacia, o trecho do ribeirão do Pinhal, após a represa do Tatu, apesar de não ser uma localidade totalmente isenta de impactos advindos das atividades antrópicas, pode ser considerado um bom local controle para testes de toxicidade de sedimentos, com peixes. Na bacia do rio Mogi Guaçu, embora o sedimento do rio Jaguari-Mirim, no ponto estudado, não tenha provocado alterações histológicas graves nos órgãos dos peixes, seria recomendável a escolha de outro ponto controle nessa bacia.

- Os resultados das análises físicas e químicas e algumas alterações histológicas provocadas por sedimentos provenientes das localidades estudadas na bacia do rio Mogi-Guaçu indicaram que um processo preocupante de degradação já está em andamento. Assim, medidas preventivas devem ser tomadas para que esses recursos se mantenham propícios ao desenvolvimento e manutenção da vida aquática, e em diversas localidades o uso da água para abastecimento humano não deveria ser feito sem uma avaliação prévia adequada. 
- Assim como o observado para a bacia do rio Mogi-Guaçu, as análises histológicas e as análises físicas e químicas das amostras de água e de sedimento coletadas nas localidades estudadas na bacia do rio Tibagi indicaram que estudos mais detalhados devem ser realizados e medidas devem ser tomadas para que os recursos naturais nessa bacia possam ser utilizados sustentavelmente e de maneira a garantir a preservação da biota, impedindo a degradação observada em bacias como a do rio Piracicaba.

- Efluentes que não causam toxicidade aguda aos peixes como é o caso dos efluentes das indústrias de papel e celulose testadas neste estudo, mas que são suspeitos de provocar efeitos em outros níveis, devem ter a toxicidade testada por meio de ferramentas mais sensíveis, tais como as análises histopatológicas.

- A inclusão de pequenos peixes inteiros constituiu um método prático, simples e relativamente barato para a avaliação de alterações em múltiplos órgãos de peixes utilizados como organismos-teste em ensaios ecotoxicológicos.

- As câmaras desenvolvidas para os testes in situ com peixes resistiram às intempéries e adversidades, não provocaram estresse nos organismos e poderão ser utilizadas com segurança em trabalhos futuros.

- A utilização da espécie de peixe nativa Serrapinnus notomelas como organismo-teste deve ser intensificada, pois a espécie teve sensibilidade ao dicromato de potássio semelhante à de espécies exóticas padronizadas. Além disso, a espécie é de fácil adaptação às condições de laboratório e resistente ao transporte e ao manuseio, conforme demonstraram os testes in situ. 


\section{RECOMENDAÇÕES}

- A utilização da espécie de peixe nativa Serrapinnus notomelas como organismo-teste deve ser alvo de novos estudos que visem a sua padronização como organismo teste, devido às qualidades já descritas. É importante, ainda, que sejam realizados estudos histológicos de outros órgãos-alvos e também estudos sobre a biologia e o comportamento dessa e de outras espécies nativas para proporcionar a produção controlada em cativeiro e também como subsídio para a interpretação de resultados experimentais.

- Realizar um maior número de análises físicas e químicas no monitoramento dos testes com sedimentos, tais como a determinação de metais na água dos recipientes-teste, de sulfetos volatilizáveis por ácidos (AVS) e a medição do potencial redox, a fim de que os efeitos da manipulação e a origem da toxicidade possam ser melhor compreendidos.

- Realizar testes de toxicidade in situ intensivos de modo a viabilizar essa técnica como rotina no monitoramento ambiental.

- Aprofundar o estudo das alterações histológicas, como a ocorrência de novos néfrons observada no presente trabalho, que possam atuar como biomarcadores ambientais.

- Intensificar os estudos a respeito do potencial tóxico dos efluentes de indústria de papel e celulose que não provocam efeitos agudos aos peixes mas que geralmente acarretam efeitos crônicos que diminuem a resistência dos organismos, e que fazem com que parte da energia que seria investida em crescimento e reprodução seja canalizada para a detoxificação, diminuindo o potencial reprodutivo ou a sobrevivência dos jovens (capacidade desses animais de enfrentarem situações adversas) e que podem, assim, comprometer a existência das populações. 


\section{REFERÊNCIAS BIBLIOGRÁFICAS}

ABEL, P.D. (1989). Water Pollution Biology - Ellis Horwood Limited Chichester, England. 232pp.

ABNT (1993). NBR 12714: Água - Ensaio de Toxicidade Aguda com Peixes - Parte I Sistema Estático. Rio de Janeiro.15pp.

ALABASTER, J.S.; LLOYD, R. (1982). Water quality criteria for freshwater fish. $2^{\underline{a}}$ edição. London, Butterworth Scientific. 361 pp.

ALMEIDA, J.S. (2002). Avaliação da qualidade do sedimento do ribeirão Cambé (Londrina, PR) por meio de parâmetros funcionais de curimbas (Prochilodus lineatus). (Monografia) Universidade Estadual de Londrina. Londrina, PR. 67 pp.

AMERICAN PUBLIC HEALTH ASSOCIATION (1989). Standard methods for examination of water and wastewater, $17^{\text {th }}$ ed. Washington, DC., APHA.

AMERICAN SOCIETY FOR TESTING AND MATERIALS (ASTM), 1994. Standard guide for collection, storage, characterization, and manipulation of sediments for toxicological testing. Designation E 1391-94. 14pp.

ANKLEY, G.T.; MATTSON, V.R.; LEONARD, E.N. WEST, C.W.; BENNETT, J. L. 1993. Predicting the acute toxicity of copper in freshwater sediments: evaluation of the role of acid-volatile sulfide. Environ. Tox. Chem., 12, 315-320.

BARRON, M.G., 1995. Bioaccumulation and bioconcentration in aquatic organisms. In: HOFFMAN, D.J. ; RATTNER, B.A. ; BURTON, G.A., Jr.; CAIRNS, J., Jr. (1995) Handbook of Ecotoxicology. Boca Raton, Lewis Publishers. Cap. 30, p. 652-666.

BENNEMANN, S.T., SILVA-SOUZA, A.T., ROCHA, G.R.A. (1995). Composicion ictiofaunistica en cinco localidades de la Cuenca del rio Tibagi, PR - Brasil. Interciencia, v.20, p.7-13.

BORDAS, F.; BOURG, A. (2001). Effect of solid/liquid ratio on the remobilization of Cu, $\mathrm{Pb}, \mathrm{Cd}$, and $\mathrm{Zn}$ from polluted river sediment - Modeling of the results obtained and determination of association constants between the metals and the sediment. Water Air Soil Pollut. 128: 391-400.

BORGMANN, U. \& NORWOOD, W.P. (1999). Sediment toxicity testing using large water-sediment ratios: an alternative to water renewal. Environ. Pollut. 106: 333339.

BOUDOU, A.; RIBEYRE, F. (1989). Aquatic Ecotoxicology: Fundamental Concepts and Methodologies.Vol. II. Boca Raton, CRC Press.

BRASIL, (1986). Ministério do Desenvolvimento Urbano e Meio Ambiente, CONAMA Resolução nº 20, de 18/06/1986. Diário Oficial da União, 30 de Julho de 1986. 
BRITSKI, H.A. (1972). Peixes de Água Doce do Estado de São Paulo: Sistemática. Poluição e Piscicultura, 79-108. Faculdade de Saúde Pública da USP - Instituto de Pesca da C.P.R.N. da Secretaria da Agricultura, São Paulo.

BURTON G.A.,Jr. \& MacPHERSON, C. (1995). Sediment toxicity testing: issues and methods. In HOFFMAN, D.J. ; RATTNER, B.A. ; BURTON, G.A., Jr.; CAIRNS, J., Jr. (1995) Handbook of Ecotoxicology. Boca Raton, Lewis Publishers. Cap. 5, p. 70-103.

BURTON G.A.,Jr. (1995). "Aquatic Ecotoxicology" - Pre Congress Short Courses XXVI SIL International Congress. Universidade de São Paulo, Escola de Engenharia de São Carlos, São Carlos, 19 e 20 de julho de 1995.

BURTON, G.A., Jr., (1991). Assessing the toxicity of freshwater sediments. Environmental Toxicology and Chemistry, v.10, p.1585-1627 - Annual Review.

BURTON, G.A., Jr., (1992). Sediment Toxicity Assessment. Florida, Lewis Publishers.

BURTON, G.A., Jr., (1994). Why test sediments? In: HOFFMAN, D.J. ; RATTNER, B.A. ; BURTON, G.A., Jr.; CAIRNS, J., Jr. eds. Handbook of Ecotoxicology. Boca Raton, Lewis Publishers.

CAIRNS, J., Jr.; SPARKS, R.E.; WALLER, W.T. (1973). The use of fish as sensors in industrial waste lines to prevent fish kills. Hidrobiologia, v. 41, n. 2, pp. 151-167.

CANADIAN Council of Ministers of the Environment (CCME), 2002. Summary of Existing Canadian Environmental Quality Guidelines - Summary Table. 12 pp. disponível na internet na página: http://www.ccme.ca/assets/pdf/e1_062.pdf

CÂMARA MUNICIPAL DE MOGI-GUAÇU - site na Internet: http://www.camaramogiguacu.sp.gov.br/conhecendoriomogiguacu.htm. Data da consulta: 23/12/2002.

CANOEIROS de Porto Ferreira - site na Internet: www.canoeirosdeportoferreira.com.br. Data da consulta: 23/12/2002.

CHAPMAN, D.V. (1989). Concepts and strategies for biological monitoring. London: GEMS Monitoring and Assessment Research Center, 1989. 25pp.

CHENG, S.H.; WAI, A.W.K.; SO, C.H.; WU, R.S.S.; 2000. Cellular and molecular basis of cadmium-induced deformities in zebrafish embryos. Environ. Tox. Chem, v.19, n. $12,3024-3031$.

COMITÊ DA BACIA HIDROGRÁFICA DO RIO MOGI GUAÇU - site na Internet: http://www.fcav.unesp.br/Departamentos/engenharia/caract/cbhmogi/lndex.htm. Data da consulta: 23/12/2002.

COMITÊ DA BACIA HIDROGRÁFICA DO RIO TIBAGI - site na Internet: http://www.copati.org.br/tibagi/fisicos/hidrografia.html. Data da consulta: 31/12/2002.

COMPANHIA DE SANEAMENTO E TECNOLOGIA AMBIENTAL (CETESB), 2002. Relatório de Qualidade das Águas do Estado de São Paulo - 2001 
COMPANHIA DE TECNOLOGIA DE SANEAMENTO AMBIENTAL (1990). Procedimentos para Utilização de Testes de Toxicidade no Controle de Efluentes Líquidos - Série Manuais № 6 . São Paulo, CETESB. 17pp.

COMPANHIA DE TECNOLOGIA DE SANEAMENTO AMBIENTAL (1990). Procedimentos para Utilização de Testes de Toxicidade no Controle de Efluentes Líquidos - Série Manuais № 6 . São Paulo, CETESB. 17pp.

COMPANHIA DE TECNOLOGIA DE SANEAMENTO AMBIENTAL. (1995). Relatório de qualidade das águas interiores do Estado de São Paulo - 1994. Série Relatórios. São Paulo, CETESB.

COMPANHIA DE TECNOLOGIA E SANEAMENTO AMBIENTAL (CETESB), 1977. Estudo da recuperação do trecho do rio Mogi-Guaçu após descarga acidental de lixívia negra - relatório final. CETESB, São Paulo. 31pp. Apud EYSINK, G.G.J.; MORAES, R.P. (1988) Subsídios para manejo e recuperação de ecossistemas aquáticos contaminados por metais pesados. In: DIAS, L.E. \& WILSON, J. (ed) Recuperação de áreas degradadas. Sociedade Brasileira de Recuperação de Áreas Degradadas. p. 235-246.

COPE, W.G.; WIENER, J.G.; STEINGRAEBER, M.T. (1996). Test system for exposing fish to resuspended, contaminated sediment. Environ. Pollut. Vol. 91, 2: 177-182.

CORMIER, S.M.; NEIHEISEL, T. W.; WERNSING, P; RACINE, R.N.; REIMSCHUESSEL, R. 1995. New nephron development in fish from polluted waters: a possible biomarkers.Ecotox. 4, 157-168.

CORSON, W. (1990). Manual Global de Ecologia. São Paulo, Augustus. 413 pp.

COSTA, O. T. F., FERNANDES, M. N., 2002. Chloride cells changes induced by nitrite exposure in the Amazonian fish In: Aquatic Toxicology: Mechanisms and Consequences; Ed.Vancouver, American Fisheries Society, 2002.

DAMATO, M. (1997). Estudo da influência do nível de tratamento de efluentes de refinaria de petróleo na sua toxicidade, empregando diferentes espécies indicadoras. São Paulo, 614 p. Tese (Doutorado) - Escola Politécnica, Universidade de São Paulo.

DOUDOROFF, P.; ANDERSON, B.G.; BURDICK, G.E.; GALTSOFF, P.S.; HART, W.B.; PATRICK, R.; STRONG, E.R.; SURBER, E.W.; VAN HORN, W.M. (1951). Bio-assay methods for the evaluation of acute toxicity of industrial wastes to fish. Sewage and Industrial Wastes. v.23, n.11, p.1380-97.

DRUMMOND, R.A.; CARLSON, R.W. (1977). Procedures for measuring cough (gill purge) rates of fish. EPA-600/3-77-133. Duluth, Minn.: USEPA Environmental Research Laboratory, 1977. apud RAND, G.M. \& PETROCELLI, S.R. (1985). Fundamentals of Aquatic Toxicology - Methods and Applications. Hemisphere Publishing Corporation, Washington.

DUBÉ, M.G.; MACLATCHY, D.L. 2000. Endocrine responses of Fundulus heteroclitus to effluent from a bleached-kraft pulp mill before and after installation of reverse osmosis treatment of a waste stream. Environ. Toxicol. Chem., 19, 2788-2796. 
DUBÉ, M.G.; MACLATCHY, D.L. 2001.Identification and treatment of a waste stream at a bleached-kraft pulp mill that depresses a sex steroid in the mummichog (Fundulus heteroclitus). Environ. Toxicol. Chem., 20, 985-995.

EYSINK, G.G.J.; MORAES, R.P. (1988) Subsídios para manejo e recuperação de ecossistemas aquáticos contaminados por metais pesados. In: DIAS, L.E. \& WILSON, J. (ed) Recuperação de áreas degradadas. Sociedade Brasileira de Recuperação de Áreas Degradadas. p. 235-246.

FONSECA, A.L. (1991). A biologia das espécies Daphnia laevis, Ceriodaphnia silvestrii (Crustacea, Cladocera) e Poecilia reticulata (Pisces, Poecilidae) e o comportamento destes em testes de toxicidade aquática com efluentes industriais. São Carlos, 210 pp. Dissertação - Escola de Engenharia de São Carlos, Universidade de São Paulo.

FONSECA, A.L. (1997). Avaliação da qualidade da água na bacia do rio Piracicaba através de testes de toxicidade com invertebrados. São Carlos, 211 pp. Tese Escola de Engenharia de São Carlos, Universidade de São Paulo.

FOURNIE, J.W.; HAWKINS, W.E.; KROL, R.M.; WOLFE, M.J. (1996). Preparation of whole small fish for histological evaluation. In: OSTRANDER, G.K. (ed) (1996). Techniques in Aquatic Toxicology. Cap. 30. CRC Press, Boca Raton. 686 pp.

GALVÃO, J.B.; GRIECO, V.M.; ARAÚJO, R. P. A.; ORTOLANO, M.R. ; BERTOLETTI, E.; RAMOS, M.L.L.C. (1987). Treatability studies and toxicity reduction in pulp and paper mill effluents. In: The second IAWPRC symposium on forest industry waste waters. Tampere, Finland. 18 - 28p.

GEERTZ-HANSEN, P.; RASMUSSEN, G. (1994). Influence of ochre and acidification on the survival and hatching of brown trout eggs (Salmo trutta). In: MÜLLER, R.; LLOYD, R., ed. Sublethal and chronic effects of pollutants on freshwater fish. cap 18 , p. $196-210$.

GEORGE, L.L.; ALVES, C.E.R.; CASTRO, R.R.L., 1998. Histologia Comparada. 2a. ed. Roca, São Paulo. 286 pp.

GODOY,M.P. (1975). Peixes do Brasil - Subordem Characoidei. 1a ed. Vol I. São Paulo, Franciscana.

GOLTERMAN,H.L.; CLYMO.R.S.; OHNSTAD.R., 1978 Methods for physical and chemical analysis of freshwater. $2^{\underline{a}}$ ed. Oxford, Blackwell Science Publishers.

GÓMEZ, S.; VILLAR, C.; BONETTO, C. 1998. Zinc toxicity in the fish Cnesterodon decemmaculatus in the Paraná River and Rio de La Plata Estuary. Environ. Pol. 99, 159-165.

GRANDE, M., REZENDE, M. O. O., ROCHA, O., 2003. Distribuição de Compostos Organoclorados nas Águas e Sedimentos da Bacia do rio Piracicaba/SP, Brasil. Química Nova. , v.26, n.5, p.678-686.

HANSEN, J.A.; MARR, J.C.A.; LIPTON, J.; CACELA, D.; BERGMAN, H.L. 1999a. Differences in neurobehavioral responses of chinook salmon (Oncorhynchus tshawytscha) and rainbow trout (Oncorhynchus mykiss) exposed to copper and cobalt: behavioral avoidance. Environ. Toxicol. Chem., 18, 1972-1978. 
HANSEN, J.A.; ROSE, J.D.; JENKINS, R.A.; GEROW, K.G.; BERGMAN, H.L. 1999b. Chinook salmon (Oncorhynchus tshawytscha) and rainbow trout (Oncorhynchus mykiss) exposed to copper: neurophysiological and histological effects on the olfactoty system. Environ. Toxicol. Chem., 18, 1979-1991.

HEATH, A.G. (1987). Water Pollution and Fish Physiology. Boca Raton, CRC Press. 245pp.

HOFFMAN, D.J. ; RATTNER, B.A. ; BURTON, G.A., Jr.; CAIRNS, J., Jr. (1995) Handbook of Ecotoxicology. Boca Raton, Lewis Publishers, 755 pp.

HOLLIS, L.; MCGEER; MCDONALD, D.G.; WOOD, C.M. 2000. Protective effects of calcium against chronic waterborne cadmium exposure to juvenile rainbow trout. Environ. Toxicol. Chem., 19, 2725-2734.

HOSS, S.; HENSCHELL, T.; HAITZER, M.; TRAUNSPURGER, W.; STEINBERG, C.E.W. 2001. Toxicity of cadmium to Caenorhabditis elegans (Nematoda) in whole sediment and pore water - The ambiguous role of organic matter. Environ. Toxicol. Chem., 20, 2794-2801.

HUGHES, G.M., 1988. Changes in blood of fish following exposure to heavy metals and acid. In: YASUNO, M.; WHITTON, B.A.. Biological monitoring of environmental pollution. Tokai University Press, Tokio. p. 11-18.

IDERIHA, N.M.; MASCARENHAS, N.M.F.; DE LIMA, T.S.; CUNHA, M.A.A. (1999). Reparo de falha óssea induzido por matriz óssea desmineralizada, em ratos: método alternativo para o processamento do tecido ósseo. Simpósio de Atualização em Técnicas de Microscopia, Curitiba.

INSTITUTO BRASILEIRO DE GEOGRAFIA E ESTATÍSTICA - IBGE. (1980). Carta Internacional do Mundo ao Milionésimo - Folha Paranapanema-SF-22-IBGE. Escala 1:250.000.

INSTITUTO BRASILEIRO DO MEIO AMBIENTE E DOS RECURSOS NATURAIS RENOVÁVEIS - IBAMA. (1990). Manual de Testes para Avaliação da Ecotoxicidade de Agentes Químicos. Brasília, IBAMA.

JØRGENSEN, S.E. (1990). Developments in Environmental Modelling 16. Amsterdam, Elsevier Science Publishers.

KARELS, A; SOIMASUO, M.; OIKARI, A. 1999. Effects of pulp and paper mill effluents on reproduction, bile conjugates and liver MFO (mixed funcion oxygenase) activity in fish at Southern Lake Saimaa, Finland. Wat. Sci. Tech., 40 - 109-114.

KWAK, H.I.; BAE, M.O.; LEE, M.H.; LEE, Y.S.; LEE, B.J.; KANG, K.S.; CHAE, C.H.; SUNG, H.J.; SHIN, J.S.; KIM, J.H.; MAR, W.C.; SHEEN, Y.Y.; CHO, M.H. 2001. Effects of nonyphenol, bisphenol $A$, and their mixture on the viviparous swordtail fish (Xiphophorus helleri). Environ. Toxicol. Chem., 20, 787-795.

LANDIS, W.G.; YU, M.H. (1995). Introduction to Environmental Toxicology - Impacts of Chemicals Upon Ecological Systems. Lewis Publishers, Boca Raton. 328 pp.

LEAKE, L.D. (1975). Comparative Histology. An introduction to the microscopic structure of animals. Academic Press, Londres. 738 pp. 
LEPP, H.J.T. \& OIKARI, A.O.J. 1999. The occurrence and bioavailability of retene and resin acids in sediments of a lake receiving BKME (bleached kraft mill effluent). Wat. Sci. Tech., 40, 131-138.

LEVIN, S.A.; KIMBALL, K. (1984). New perspectives in ecotoxicology. Environ. Manage. 8: 375-442. Apud WEINSTEIN, D.A.; BIRK, E.M. (1989). The effects of chemicals on the structure of terrestrial ecosystems: mechanisms and patterns of change. 181-209. In: LEVIN, S.A.; HARWELL, M.A.; KELLY, J.R.; KIMBALL, K.D. (1989). Ecotoxicology: problems and approaches. Springer-Verlag, New York. 547 pp.

LLOYD, R. (1992). Pollution and Freshwater Fish. Fishing News Books, Oxford. 176 pp.

MACKERETH,F.J.H.; TALLING, J.F. (1978). Water analysis: some revised methods for limnologists. Kendal Freshwater Biol.Assoc., Sci.Publ. n.36.

MARSH, M.C. 1908. Notes on the dissolved content of water in its effect upon fishes. Fourth International Fishery Congress, Washingon, U.S.A., 22-26 de setembro de 1908. In Notes on the dissolved content of water in its effect upon fishes Bulletin of US Bureau of Fisheries, 28: 891-906, 1943.

MASON, C.F. (1996). Biology of Freshwater Pollution 3rd. edition. Longman, Essex. $193 \mathrm{pp}$.

MAUND, S.J.; HAMER, M.J.; LANE, M.C.G.; FARRELLY, E.; RAPLEY, J.H.; GOGGIN, U.M.; GENTLE, W.E. 2002. Partitioning, bioavailability, and toxicity of the pyrethroid inseticide cypermethrin in sediments. Environ. Toxicol. Chem., 21, 9-15.

MC LEAY, D.J. \& BROWN, D.A. (1975). Effects of acute exposure to bleached kraft pulp mill effluent on carbohydrate metabolism of juvenile coho salmon (Oncorhynchus kisutch) during rest and exercise. J. Fish. Res. Bd. Can., 32, 753. Apud HEATH, A.G. (1987). Water Pollution and Fish Physiology. Boca Raton, CRC Press. 245pp.

MC LEAY, D.J. (1973). Effects of a 12-hr and 25-day exposure to kraft pulp mill effluent on the blood and tissues of juvenile coho salmon (Oncorhynchus kisutch). J. Fish. Res. Bd. Can., 30, 395. Apud HEATH, A.G. (1987). Water Pollution and Fish Physiology. Boca Raton, CRC Press. 245pp.

McLEOD, J.C.; SMITH, L.L.Jr. (1966). Effect of pulpmill fiber on oxygen consumption and swimming endurance of the fathead minnow, Pimephales promelas. Trans. Am. Fish. Soc., 95, 71. apud HEATH, A. G. (1987). Water Pollution and Fish Physiology. CRC Press, Boca Raton. 245pp.

MELETTI, P.C. \& ROCHA, O. (2002). Development of a chamber for in situ toxicity tests with small fishes. Braz. J. Biol., 62: 187-190.

MELETTI, P.C. (1997) - Avaliação da qualidade da água na bacia do rio Piracicaba, SP, através de parâmetros ecotoxicológicos (Dissertação). 149 pp. Escola de Engenharia de São Carlos, Universidade de São Paulo.

MILLER, T.G. \& MACKAY, W.C., 1980. The effects of hardness, alkalinity and pH of test water on the toxicity of copper to rainbow trout (Salmo gairdneri). Wat. Res. 14: 129-133. 
MOORE, D.W.; DILLON, T.M.; GAMBLE, E.W. 1995. Long-term storage of sediments: implications for sediment toxicity testing. Environm. Pol., 89, 147-154.

MOZETO, A. A. (1999). Sedimentos e particulados lacustres: amostragens e análises biogeoquímicas. Laboratório de Biogeoquímica Ambiental - Departamento de Química. Universidade Federal de São Carlos. São Carlos - SP. 24p.

NADDY, R.B.; STUBBLEFIELD, W.A.; MAY, J.R.; TUCKER, S.A.; HOCKETT, J.R. 2002. The effect of calcium and magnesium ratios on the toxicity of copper to five aquatic species in freshwater. Environ. Toxicol. Chem., 21, 347-352.

OLIVEIRA-RIBEIRO, C.A.; FANTA, E.; TURCATTI, N.M.;CARDOSO, R.J.; CARVALHO, C.S. 1996. Lethal effects of inorganic mercury on cells and tissues of Trichomycterus brasiliensis (Pisces; Siluroidei). Biocell, 20 (3): 171-178.

OLIVEIRA-RIBEIRO, C.A.; FERNANDES, L.M.; CARVALHO, C.S.; CARDOSO, R.I.; TURCATTI, N.M. 1994. Acute effects of mercuric cloride on the olfactory epithelium of Trichomycterus brasiliensis. Ecotox. Environ. Safety, 31, 104-109.

ORGANIZAÇÃO Não-Governamental Piracicaba 2010 - site na Internet: http://www.piracicaba2010.com.br/index/dinam ambiental.htm. Data da consulta: 23/12/2002.

OTHOUDT, R.A.; GIESY, J.P.; GRZYB, K.R.; VERBRUGGE, D.A.; HOKE, R.A.; DRAKE, J.B.; ANDERSON, D. (1991). Evaluation of the Effects of Storage Time on the Toxicity of Sediments. Chemosphere. 22: 801-807.

OVERSTREET, R. M. (1987). Aquatic pollution problems, Southeastern U.S. coasts: histopathological indicators. Aquatic Toxicology, 11, 213-239.

PACHECO, M. \& SANTOS, M.A., 2002. Biotransfomation, genotoxic, and histopathological effects of environmental contaminants in European eel (Anguilla anguilla L.). Ecotoxicol. Environ. Saf., 53, 331-347.

PARROT, J.L.; JARDINE, J.J.; BLUNT, B.R.; MCCARTHY, L.H.; McMASTER, M.E.; WOOD, C.S.; ROBERTS, J.; CAREY, J.H. 1999. Comparing biological responses to mill process changes: a study of steroid concentrations in goldfish exposed to effluent and waste streams from a Canadian bleached sulphite mill. Wat. Sci. Tech. 40, 115-122.

PASCOE, D.; EVANS, S. A.; WOODWORTH, J. 1986. Heavy metal toxicity to fish and the influence of water hardness. Arch. Environ. Contam. Toxicol., 15, 481-487.

PETTS, G.; CALOW, P. (1996). River Restoration. Blackwell Science, Oxford. 231pp.

POLEKSIC \& MITROVIC-TUTUNDZIC, 1994. Fish gills as a monitor of sublethal and chronic effects of pollution. In: MÜLLER, R. \& LLOYD, R. Sublethal and chronic effects of pollutants on freshwater fish. Fishing New Books, Cambridge. p.339-352.

PREFEITURA do município de Leme - site na Internet: http://www.leme.sp.gov.br/tur mogi.asp. Data da consulta: 23/12/2002. 
PROGRAMA de Investimentos para Recuperação e Proteção das Bacias (P.I.R.B.) dos Rios Piracicaba e Capivari - Consórcio Intermunicipal das Bacias dos Rios Piracicaba e Capivari (1992). São Paulo, Governo de São Paulo.

RAND, G.M.; PETROCELLI, S.R. (ed) (1985). Fundamentals of Aquatic Toxicology: Methods and Applications. Hemisphere Publishing - Washington, USA. 666pp.

REARDON, J.; FOREMAN, J.A.; SEARCY, R.L. (1966). New reactants for the colorimetric determination of ammonia. Clin. Chim. Acta, 14:403-405.

REDE Internacional dos Organismos de Bacia (RIOB) - site na Internet: http://www.riob.org/relob/relob_bpiracicaba.htm. Data da consulta: 23/12/2002.

REIMSCHUESSEL, R. (2001). A fish model of renal regeneration and development. ILAR Journal, 42 : 285-291.

RICHARDS, J.G.; CURTIS, P.J.; BURNISON, B.K.;PLAYLE, R.C. 2001. Effects of natural organic matter source on reducing metal toxicity to rainbow trout (Oncorhynchus mykiss) and on metal binding to their gills. Environ. Toxicol. Chem., 20, 1159-1166.

RIGOLIN de SÁ, O. (1998). Avaliação da toxicidade do herbicida Roundup (glifosato) e do acaricida Omite (propargito) nas fases iniciais da ontogenia do bagre, Rhamdia hilarii (Valenciennes, 1840) (Pimelodidae, Siluriformes). Tese de Doutoramento. Universidade Federal de São Carlos, São Carlos. 309pp.

RODRIGUES, E. L. 1994 Alterações morfológicas em hematócitos de Brachydanio rerio (Hamilton-Buchanan, 1822, 1823) exposto à ação do organofosforado dimetoato 500 em dose subletal. (Dissertação) 77pp. Mestrado em Biologia Celular, Universidade Federal do Paraná.

ROSA, J. (1997). Avaliação da atividade mutagênica de efluentes de indústrias de celulose determinada por ensaio de curta duração com Salmonella typhimurium Teste de Ames. São Carlos, 215 pp. Dissertação - Escola de Engenharia de São Carlos / Universidade de São Paulo.

ROSS, M.H. \& ROWRELL, L.J. 1998. Histologia - texto e atlas. $2^{\text {a }}$. ed. Ed. Panamericana, São Paulo. 779 pp.

SANTOS,M.A., PIRES,F., HALL,A.,1990. Metabolic effects of kraft mill effluents on the eel Anguilla anguilla. L.Ecotoxicol.Environ.Saf. 20,10 -19. apud PACHECO, M. \& SANTOS, M.A., 2002. Biotransfomation, genotoxic, and histopathological effects of environmental contaminants in European eel (Anguilla anguilla L.). Ecotoxicol. Environ. Saf., 53, 331-347.

SCHWAIGER,J.; WANKE, R.; ADAM, S.; PAWERT, M.; HONNEN, W.; TRIEBSKORN,R. (1997). The use of histopatological indicators to evaluate contaminant-related stress in fish. Journal of Aquatic Ecosystem Stress and Recovery 6: 75-86.

SIMPSON, S.L. 2001. A rapid screening method for acid-volatile sulfide in sediments. Environ. Toxicol. Chem., 12, 2657-2661. 
SISTEMA MUNICIPAL DE ÁGUA E ESGOTO (SEMAE) - site na Internet: http://www.semaepiracicaba.org.br/bacia.htm. Data da consulta: 23/12/2002.

SOARES, A.M.V.M. (1990). Ecotoxicologia e Determinação de Riscos Ecológicos. Prática e Perspectivas. In: $2^{\text {a }}$ CONFERÊNCIA NACIONAL SOBRE A QUALIDADE DO AMBIENTE. Lisboa, 1990. Vol 1, B43-B52.

STEMMER, B.L.; BURTON, G.A.,Jr.; SASSON-BRICKSON, G. (1990). Effect of sediment spatial variance and collection method on cladoceran toxicity and indigenous microbial activity determinations. Environ. Toxicol. Chem., 9, 1035. Apud BURTON G.A.,Jr. \& MacPHERSON, C. (1995). Sediment toxicity testing: issues and methods. In HOFFMAN, D.J. ; RATTNER, B.A. ; BURTON, G.A., Jr.; CAIRNS, J., Jr. (1995) Handbook of Ecotoxicology. Boca Raton, Lewis Publishers. Cap. 5, p. 70-103.

STRICKLAND, J.D. \& PARSONS, T.R. (1965). A manual of sea water analysis: with a special reference to more common micronutrients and particulate organic natural. $2^{\mathrm{a}}$ ed. Ottawa Crown.

SUGUIO, K. 1973. Introdução à Sedimentologia. Ed. Edgard Blucher Ltda. São Paulo, $\mathrm{SP}, 317 \mathrm{pp}$.

TAKASHIMA, F.; HIBIYA, T. (eds) (1995). An Atlas of Fish Histology - Normal and Pathological Features. Kodansha Ltd., Tóquio. 195 pp.

TAYLOR, L.N.; MCGEER, J.C.; WOOD, C.M.; MCDONALD, D.G. 2000. Physiological effects of chronic exposure to rainbow trout (Oncorhynchus mykiss) in hard and soft water: evaluation of chronic indicators. Environ. Toxicol. Chem., 9, 2298-2308.

TEIXEIRA, C; TUNDISI, J.G.; KUTNER, M.B. (1965). Plankton studies in a mangrove II. The standing stock and some ecological factors. Bolm. Inst. Oceanogr. São Paulo. v.24, p. 23-41.

THURSTON, R.V.; CHAKOUMAKOS, C.; RUSSO, R.C. (1981b). Effect of flutuating exposures on the acute toxicity of ammonia to rainbow trout (Salmo gairdneri) and cutthroat trout (S. clarki). Wat. Research, v.15, p.911-917.

THURSTON, R.V.; RUSSO, R.C.; VIPOGRADOV, G.A. (1981a). Ammonia toxicity to fishes. Effect of $\mathrm{pH}$ on the toxicity of the un-ionized ammonia species. Environmental Science \& Technology, v.15, n.7, p.837-840.

TRAN, D; BOUDOU, A.; MASSABUAU, J.C., 2001. How water oxygenation level influences cadmium accumulation pattern in the asiatic clam Corbicula fluminea: a laboratory and field study. Environ. Tox. Chem. v.20, n.9 2073-2080.

VALDERRAMA, J.C. (1981). The simultaneous analysis of total nitrogen and phosphorus in natural waters. v.10, p.109-122.

VARGAS-BOLDRINI, C; PÁDUA, H.B.; NAVAS-PEREIRA, D.; KAWAKAMI-RESENDE, E \& JURAS, A.A. 1983. Contaminação por mercúrio nos rios Mogi-Guaçu e Pardo (SP). Revista DAE, SABESP, São Paulo. 43: 106-117.Apud EYSINK, G.G.J.; MORAES, R.P. (1988) Subsídios para manejo e recuperação de ecossistemas aquáticos contaminados por metais pesados. In: DIAS, L.E. \& WILSON, J. (ed) Recuperação de áreas degradadas. Sociedade Brasileira de Recuperação de Áreas Degradadas. p. 235-246. 
VISWANATHAN, P. N. ; JAFFERY, F. N. ; MISRA, V. \& CHAWLA, G. - (1988). Biomonitoring and Freshwater Ecotoxicology: An Over View (Cap 5). in KRUIJF, H. A. M. ; ZWART, D. ; RAY, P. K. \& VISWANATHAN, P.N. (editores). Manual on Aquatic Ecotoxicology. Kluwer Academic Publishers. Dordrecht. 332pp.

VOTORANTIN CELULOSE E PAPEL - página na Internet: http://www.vcp.com.br/vcp/ . Data da consulta: 07/12/2002.

WEINSTEIN, D.A.; BIRK, E.M. (1989). The effects of chemicals on the structure of terrestrial ecosystems: mechanisms and patterns of change. 181-209. In: LEVIN, S.A.; HARWELL, M.A.; KELLY, J.R.; KIMBALL, K.D. (1989). Ecotoxicology: problems and approaches. Springer-Verlag, New York. 547 pp.

WESTER, P.W.; CANTON, J.H. (1991). The usefulness of histopathology in aquatic toxicity studies. Comp. Biochem. Physiol. Vol 100C, No. 1/2, pp. 115-117.

WESTER, P.W.; ROGHAIR, C.J. (1994). Monitoring of sublethal chronic effects in fish: the pathomorphological approach. In: MÜLLER, R.; LLOYD, R. (1994). Sublethal and Chronic Effects of Pollutants on Freshwater Fish. Fishing News Books, Cambridge. Cap.1, p. 5-14.

WORKSHOP DO PROJETO "ASPECTOS DA FAUNA E FLORA DA BACIA DO RIO TIBAGI" - 10 ANOS. Universidade Estadual de Londrina, fevereiro de 2000.

YOUNG, B. \& HEATH, J.W. 2000. Wheater's Functional Histology - A text and colour atlas. $4^{\mathrm{a}}$.ed. Churchill Livingstone, Sydney. $413 \mathrm{pp}$. 


\section{ANEXOS}

TABELA 26: Composição da ração em flocos Alcon Basic ${ }^{\circledR}$ para peixes tropicais, de acordo com as informações contidas no rótulo da embalagem.

\section{Composição básica}

Camarão fresco, farinha de peixe, proteína hidrolisada de soja, farinha de milho, farinha de trigo, farinha de algas marinhas, cenoura desidratada, leveduras, sal, óleo de soja refinado, vitamina C estabilizada, suplemento vitamínico-mineral, aditivo pigmentante, antioxidante BHT.

\begin{tabular}{|c|c|c|c|c|c|c|c|c|}
\hline \multicolumn{9}{|c|}{ Enriquecimento por $\mathrm{Kg}$ de produto } \\
\hline $\begin{array}{c}\text { Vitamina } \\
\mathrm{A}\end{array}$ & $\begin{array}{c}\text { Vitamina } \\
\mathrm{D}_{3}\end{array}$ & $\begin{array}{c}\text { Vitamina } \\
\mathrm{E}\end{array}$ & $\begin{array}{c}\text { Vitamina } \\
\mathrm{B}_{1}\end{array}$ & $\begin{array}{c}\text { Vitamina } \\
\mathrm{B}_{2}\end{array}$ & $\begin{array}{c}\text { Vitamina } \\
\mathrm{B}_{6}\end{array}$ & $\begin{array}{c}\text { Vitamina } \\
\mathrm{B}_{12}\end{array}$ & $\begin{array}{l}\text { Pantotenato } \\
\text { de cálcio }\end{array}$ & $\begin{array}{l}\text { Vit. C } \\
\text { estab. }\end{array}$ \\
\hline $30.000 \mathrm{UI}$ & $5.000 \mathrm{UI}$ & $82 \mathrm{mg}$ & $6,7 \mathrm{mg}$ & $25 \mathrm{mg}$ & $6,7 \mathrm{mg}$ & $33 \mu \mathrm{g}$ & $50 \mathrm{mg}$ & $250 \mathrm{mg}$ \\
\hline \multicolumn{9}{|c|}{ Níveis de garantia } \\
\hline$\underset{*}{\text { umidade }}$ & \multicolumn{2}{|c|}{$\begin{array}{l}\text { proteína } \\
\text { bruta ** }\end{array}$} & $\begin{array}{c}\text { extrato } \\
\text { etéreo ** }\end{array}$ & $\begin{array}{c}\text { matéria } \\
\text { fibrosa * }\end{array}$ & $\begin{array}{c}\text { matéria } \\
\text { mineral * }\end{array}$ & \multicolumn{2}{|c|}{$\begin{array}{c}\text { cálcio } \\
\star\end{array}$} & $\begin{array}{c}\text { fósforo } \\
\star \star\end{array}$ \\
\hline $8,00 \%$ & \multicolumn{2}{|c|}{$45,00 \%$} & $5,00 \%$ & $5,00 \%$ & $10,00 \%$ & \multicolumn{2}{|c|}{$5,00 \%$} & $0,65 \%$ \\
\hline
\end{tabular}

TABELA 27: Valores das concentrações letais médias $\left(\mathrm{CL}_{50}\right)$ de dicromato de potássio calculados (de acordo com HAMILTON et al., 1977) nos testes de toxicidade com Serrapinnus notomelas e Danio rerio em 24, 48, 72 e 96 horas de exposição.

\begin{tabular}{|c|c|c|}
\hline \multicolumn{3}{|c|}{ S. notomelas - teste 1 (preliminar) } \\
\hline & $\begin{array}{c}\text { CL 50 } \\
\left(\mathrm{mg} \mathrm{K}_{2} \mathrm{Cr}_{2} \mathrm{O}_{7} \cdot \mathrm{L}^{-1}\right)\end{array}$ & $\begin{array}{c}\text { intervalo de } \\
\text { confiança ( } 95 \%)\end{array}$ \\
\hline $24 \mathrm{~h}$ & 177,6 & $134,4-234,6$ \\
\hline $48 \mathrm{~h}$ & 137,4 & $111,61-169,1$ \\
\hline $72 \mathrm{~h}$ & 119,2 & $96,7-146,9$ \\
\hline $96 \mathrm{~h}$ & 89,7 & $74,5-108,1$ \\
\hline \multicolumn{3}{|c|}{ S. notomelas - teste 2} \\
\hline & $\begin{array}{c}\text { CL } 50 \\
\left(\mathrm{mg} \mathrm{K}_{2} \mathrm{Cr}_{2} \mathrm{O}_{7} \cdot \mathrm{L}^{-1}\right)\end{array}$ & $\begin{array}{c}\text { intervalo de } \\
\text { confiança (95\%) }\end{array}$ \\
\hline $24 \mathrm{~h}$ & 257,8 & $229,4-289,6$ \\
\hline $48 h$ & 193,5 & $164,5-227,5$ \\
\hline $72 \mathrm{~h}$ & 127,6 & $110,2-147,2$ \\
\hline $96 \mathrm{~h}$ & 103,5 & $89,8-119,2$ \\
\hline \multicolumn{3}{|c|}{ S. notomelas - teste 3} \\
\hline & $\begin{array}{c}\mathbf{C L} \mathbf{5 0} \\
\left(\mathrm{mg} \mathrm{K}_{2} \mathrm{Cr}_{2} \mathrm{O}_{7} \cdot \mathrm{L}^{-1}\right)\end{array}$ & $\begin{array}{c}\text { intervalo de } \\
\text { confiança (95\%) }\end{array}$ \\
\hline $24 \mathrm{~h}$ & 282,3 & $259,2-307,4$ \\
\hline $48 \mathrm{~h}$ & 198,8 & $178,2-221,8$ \\
\hline $72 \mathrm{~h}$ & 139,5 & $121,2-160,4$ \\
\hline $96 \mathrm{~h}$ & 112,2 & $95,4-131,9$ \\
\hline
\end{tabular}

\begin{tabular}{|c|c|c|}
\hline \multicolumn{3}{|c|}{ S. notomelas - teste 4} \\
\hline & $\begin{array}{c}\text { CL } 50 \\
\left(\mathrm{mg} \mathrm{K}_{2} \mathrm{Cr}_{2} \mathrm{O}_{7} \cdot \mathrm{L}^{-1}\right)\end{array}$ & $\begin{array}{c}\text { intervalo de } \\
\text { confiança (95\%) }\end{array}$ \\
\hline $24 h$ & 269,6 & $255,1-284,9$ \\
\hline $48 \mathrm{~h}$ & 156,3 & $132,6-184,2$ \\
\hline $72 \mathrm{~h}$ & 111,1 & $93,2-132,4$ \\
\hline $96 \mathrm{~h}$ & 87,7 & $73,9-104,1$ \\
\hline \multicolumn{3}{|c|}{ D. rerio - teste 1} \\
\hline & $\begin{array}{c}\mathbf{C L} \mathbf{5 0} \\
\left(\mathrm{mg} \mathrm{K}_{2} \mathrm{Cr}_{2} \mathrm{O}_{7} \cdot \mathrm{L}^{-1}\right)\end{array}$ & $\begin{array}{c}\text { intervalo de } \\
\text { confiança (95\%) }\end{array}$ \\
\hline $24 \mathrm{~h}$ & 235,2 & $203,9-271,4$ \\
\hline $48 \mathrm{~h}$ & 139,7 & $124,5-156,7$ \\
\hline $72 \mathrm{~h}$ & 111,1 & $93,2-132,4$ \\
\hline $96 \mathrm{~h}$ & 107,8 & $86,8-133,9$ \\
\hline
\end{tabular}


As tabelas 28 a 33 contêm os dados brutos das análises histológicas das brânquias, rins e fígado dos peixes expostos às amostras de sedimento das localidades estudadas e ao efluente final de indústria de papel e celulose.

TABELAS 28 A a 28 O: alterações branquiais observadas nos peixes Serrapinnus notomelas e Danio rerio expostos às localidades Ribeirão do Pinhal, Jaguari, Campinas, Sumaré, Americana, Piracicaba, São João da Boa Vista, Mogi Guaçu 1, Mogi Guaçu 2, Pirassununga, Luiz Antônio 1, Luiz Antônio 2, Telêmaco Borba 1, Telêmaco Borba 2 e Londrina. Os sinais de + indicam a freqüência de ocorrência das alterações, sendo + = baixa freqüência, ++ = média freqüência e $+++=$ alta freqüência de ocorrência da alteração. Os traços $(-)$ indicam a não observação do órgão nos cortes.

As abreviações significam: HTCE=hipertrofia das células epiteliais; AdE=adelgamento do epitélio; ELS=elevação do epitélio da lamela scundária (LS); HPBLS: hiperplasia na base das LS.; HPLS=hiperplasia ao longo das LS.; LeuELS= presença de leucócitos; $\mathrm{HP} / \mathrm{HTCM}=$ hiperplasia/trofia das céls. mucosas; HP/HTCC $=$ hiperplasia/trofia das céls. cloreto; CCLS=céls cloreto nas LS; MuLS=presença de muco entre as LS; DiC=dilatação de capilares; DeC=desorganização de capilares; $C V=$ congestão vascular; Par=presença de parasitas; FCalgLS=fusão completa de algumas LS; FCtodLS=fusão completa de toas as LS; $\mathrm{DC}=$ degeneração celular: RE=ruptura epitelial; Hem=hemorragia; An=aneurisma; Fib=fibrose; $\mathrm{N}=$ necrose.

TABELA 28 A - RIBEIRÃO DO PINHAL

\begin{tabular}{|l|c|c|c|c|c|c|l|l|l|l|l|l|l|l|}
\hline \multicolumn{9}{|c|}{ Serrapinnus notomelas } & \multicolumn{9}{|c|}{ Danio rerio } \\
\hline Alterações & peso & Sn1 & Sn2 & Sn3 & Sn4 & Sn5 & Alterações & peso & Dr1 & Dr2 & Dr3 & Dr4 & Dr5 \\
\hline HTCE & I & & & & & & HTCE & I & & & & & \\
\hline AdE & I & & & & & & AdE & I & & & & & \\
\hline ELS & I & + & & & + & + & ELS & I & & & & & \\
\hline HPBLS & I & + & & & & + & HPBLS & I & + & & & & + \\
\hline HPLS & I & & & & ++ & + & HPLS & I & & & & & \\
\hline FPLS & I & & & & & + & FPLS & I & & & & & \\
\hline LeuELS & I & & & & & & LeuELS & I & & & & & \\
\hline HP/HTCM & I & + & & + & & ++ & HP/HTCM & I & & & & & \\
\hline HP/HTCC & I & & & & & & HP/HTCC & I & & & & & \\
\hline CCLS & I & & & & & & CCLS & I & & & & & \\
\hline MuLS & I & & & ++ & & ++ & MuLS & I & & & & & \\
\hline DiC & I & & & & & & DiC & I & & & & & \\
\hline DeC & I & & & + & & & DeC & I & & & & & \\
\hline CV & I & + & + & ++ & & & CV & I & & & & & \\
\hline Par & I & & & & & & Par & I & & & & & \\
\hline FCalgLS & I & & & & & & FCalgLS & I & & & & & \\
\hline FCtodLS & II & & & & & & FCtodLS & II & & & & & \\
\hline DC & II & & & & & & DC & II & & & & & \\
\hline RE & II & & & & & & RE & II & & & & & \\
\hline Hem & II & & & & & & Hem & II & & & & & \\
\hline An & II & & & & & & An & II & & & & & \\
\hline Fib & III & & & & & & Fib & III & & & & & \\
\hline Nec & III & & & & & & Nec & III & & & & & \\
\hline VMA: $2,00 \pm 0,0$ & 2 & 2 & 2 & 2 & 2 & VMA: $1,40 \pm 0,55$ & 2 & 1 & 1 & 1 & 2 \\
\hline IAH: $3,40 \pm 1,95$ & 4 & 1 & 4 & 2 & 6 & IAH: $0,40 \pm 0,55$ & 1 & 0 & 0 & 0 & 1 \\
\hline
\end{tabular}


TABELA 28 B -LIMEIRA

\begin{tabular}{|l|c|c|c|c|c|c|l|l|l|l|l|l|l|l|}
\hline \multicolumn{9}{|c|}{ Serrapinnus notomelas } & \multicolumn{9}{|c|}{ Danio rerio } \\
\hline Alterações & peso & Sn1 & Sn2 & Sn3 & Sn4 & Sn5 & Alterações & peso & Dr1 & Dr2 & Dr3 & Dr4 & - \\
\hline HTCE & I & + & & & & & HTCE & I & & ++ & + & & \\
\hline AdE & I & & & & & & AdE & I & & & & & \\
\hline ELS & I & + & + & + & & & ELS & I & & & & & \\
\hline HPBLS & I & + & + & +++ & + & + & HPBLS & I & & & & + & \\
\hline HPLS & I & +++ & ++ & ++ & & & HPLS & I & & & & & \\
\hline FPLS & I & & & +++ & + & & FPLS & I & & & & + & \\
\hline LeuELS & I & & & & & & LeuELS & I & & & & & \\
\hline HP/HTCM & I & & + & + & ++ & ++ & HP/HTCM & I & & & & & \\
\hline HP/HTCC & I & & & & & & HP/HTCC & I & & & & & \\
\hline CCLS & I & & & & & & CCLS & I & & & & & \\
\hline MuLS & I & & & & & & MuLS & I & & & & & \\
\hline DiC & I & & & + & & & DiC & I & & & + & & \\
\hline DeC & I & + & ++ & + & + & + & DeC & I & & & + & + & \\
\hline CV & I & ++ & + & & & +++ & CV & I & & & + & & \\
\hline Par & I & & & & & & Par & I & & & & & \\
\hline FCalgLS & I & + & + & + & & & FCalgLS & I & & & & & \\
\hline FCtodLS & II & & & & & & FCtodLS & II & & & & & \\
\hline DC & II & & & & & & DC & II & & & & & \\
\hline RE & II & & & & & + & RE & II & & & & & \\
\hline Hem & II & & & & & & Hem & II & & & & & \\
\hline An & II & + & & & & & An & II & & & & & \\
\hline Fib & III & & & & & & Fib & III & & & & & \\
\hline Nec & III & & & & & & Nec & III & & & & & \\
\hline VMA: $2,60 \pm 0,55$ & 3 & 2 & 3 & 2 & 3 & VMA: $1,75 \pm 0,50$ & 1 & 2 & 2 & 2 & - \\
\hline IAH: $10,00 \pm 5,34$ & 17 & 7 & 8 & 4 & 14 & IAH: $2,00 \pm 1,83$ & 0 & 1 & 4 & 3 & \\
\hline
\end{tabular}

TABELA 28 C - CAMPINAS

\begin{tabular}{|l|c|c|c|c|c|c|l|l|l|l|l|l|c|c|}
\hline \multicolumn{9}{|c|}{ Serrapinnus notomelas } & \multicolumn{9}{|c|}{ Danio rerio } \\
\hline Alterações & peso & Sn1 & Sn2 & Sn3 & Sn4 & Sn5 & Alterações & peso & Dr1 & Dr2 & Dr3 & Dr4 & Dr5 \\
\hline HTCE & I & & & & & & HTCE & I & ++ & ++ & ++ & ++ & + \\
\hline AdE & I & & & & & & AdE & I & & & & & \\
\hline ELS & I & +++ & + & +++ & + & +++ & ELS & I & & & & & + \\
\hline HPBLS & I & +++ & & & & +++ & HPBLS & I & & & & & \\
\hline HPLS & I & & & & & ++ & HPLS & I & & & & & \\
\hline FPLS & I & & & & & ++ & FPLS & I & & & & & \\
\hline LeuELS & I & & & & & & LeuELS & I & & & & & \\
\hline HP/HTCM & I & ++ & & + & ++ & +++ & HP/HTCM & I & & & + & & \\
\hline HP/HTCC & I & + & + & + & & & HP/HTCC & I & & + & & & \\
\hline CCLS & I & & & & & & CCLS & I & & & & & \\
\hline MuLS & I & & & ++ & ++ & + & MuLS & I & & & + & & \\
\hline DiC & I & +++ & ++ & +++ & + & + & DiC & I & & ++ & ++ & ++ & \\
\hline DeC & I & +++ & ++ & +++ & + & ++ & DeC & I & & + & +++ & ++ & ++ \\
\hline CV & I & ++ & ++ & ++ & + & + & CV & I & ++ & +++ & +++ & ++ & + \\
\hline Par & I & & & & & & Par & I & & & & & \\
\hline FCalgLS & I & & & & & & FCalgLS & I & & & & + & \\
\hline FCtodLS & II & & & & & & FCtodLS & II & & & & & \\
\hline DC & II & & & & & & DC & II & & & & & \\
\hline RE & II & & & & & + & RE & II & & & & & \\
\hline Hem & II & & & & & & Hem & II & & & & & \\
\hline An & II & & & & & & An & II & & & & & \\
\hline Fib & III & & & & & & Fib & III & & & & & \\
\hline NeC & III & & & & & & NeC & III & & & & & \\
\hline VMA: $2,60 \pm 0,55$ & 3 & 2 & 3 & 2 & 3 & VMA: 2,40 $\pm 0,55$ & 2 & 3 & 3 & 2 & 2 \\
\hline IAH: $8,80 \pm 5,76$ & 7 & 5 & 7 & 6 & 19 & IAH: $4,40 \pm 1,52$ & 2 & 5 & 6 & 5 & 4 \\
\hline
\end{tabular}


TABELA 28 D - SUMARÉ

\begin{tabular}{|l|c|c|c|c|c|c|l|l|l|l|l|c|c|c|}
\hline \multicolumn{9}{|c|}{ Serrapinnus notomelas } & \multicolumn{9}{|c|}{ Danio rerio } \\
\hline Alterações & peso & Sn1 & Sn2 & Sn3 & Sn4 & Sn5 & Alteracões & peso & Dr1 & Dr2 & Dr3 & Dr4 & Dr5 \\
\hline HTCE & I & & & & & & HTCE & I & & & + & & + \\
\hline AdE & I & & & & & & AdE & I & & & & & \\
\hline ELS & I & + & ++ & +++ & +++ & +++ & ELS & I & & & & & \\
\hline HPBLS & I & ++ & ++ & ++ & + & + & HPBLS & I & + & + & + & + & \\
\hline HPLS & I & + & + & ++ & & & HPLS & I & + & + & + & + & \\
\hline FPLS & I & & + & ++ & + & + & FPLS & I & & + & & & \\
\hline LeuELS & I & & & & & & LeuELS & I & & & & & \\
\hline HP/HTCM & I & ++ & & + & & & HP/HTCM & I & & + & & & \\
\hline HP/HTCC & I & + & & & & + & HP/HTCC & I & & & & & \\
\hline CCLS & I & & & & & & CCLS & I & & & & & \\
\hline MuLS & I & ++ & & & & & MuLS & I & & & & & \\
\hline DiC & I & + & +++ & +++ & +++ & +++ & DiC & I & ++ & ++ & +++ & +++ & ++ \\
\hline DeC & I & ++ & +++ & +++ & +++ & +++ & DeC & I & ++ & ++ & +++ & +++ & ++ \\
\hline CV & I & +++ & +++ & +++ & +++ & +++ & CV & I & ++ & +++ & +++ & +++ & ++ \\
\hline Par & I & & & & & & Par & I & & & & & \\
\hline FCalgLS & I & & & & & & FCalgLS & I & & & & & \\
\hline FCtodLS & II & & & & & & FCtodLS & II & & & & & \\
\hline DC & II & & & & & & DC & II & & & & & \\
\hline RE & II & & & & & & RE & II & & & & & \\
\hline Hem & II & & & & & & Hem & II & & & & & \\
\hline An & II & & + & ++ & +++ & & An & II & + & & + & + & \\
\hline Fib & III & & & & & & Fib & III & & & & & \\
\hline NeC & III & & & & & & NeC & III & & & & & \\
\hline VMA: $3,00 \pm 0,00$ & 3 & 3 & 3 & 3 & 3 & VMA: $2,80 \pm 0,45$ & 3 & 3 & 3 & 3 & 2 \\
\hline IAH: $13,40 \pm 5,03$ & 9 & 17 & 18 & 16 & 7 & IAH: $11,40 \pm 5,50$ & 15 & 7 & 16 & 15 & 4 \\
\hline
\end{tabular}

TABELA 28 E - AMERICANA

\begin{tabular}{|l|c|c|c|c|c|c|l|l|l|l|l|l|c|c|}
\hline \multicolumn{7}{|c|}{ Serrapinnus notomelas } & \multicolumn{9}{|c|}{ Danio rerio } \\
\hline Alterações & peso & Sn1 & Sn2 & Sn3 & - & Sn5 & Alterações & peso & Dr1 & Dr2 & Dr3 & Dr4 & Dr5 \\
\hline HTCE & I & & & & & & HTCE & I & & & + & + & + \\
\hline AdE & I & & & & & & AdE & I & & & & & \\
\hline ELS & I & +++ & +++ & +++ & & + & ELS & I & & & & & \\
\hline HPBLS & I & + & ++ & & & ++ & HPBLS & I & & & + & & + \\
\hline HPLS & I & + & & & & + & HPLS & I & & ++ & & & + \\
\hline FPLS & I & + & ++ & + & & & FPLS & I & & & & & \\
\hline LeuELS & I & & & & & & LeuELS & I & & & & & \\
\hline HP/HTCM & I & & ++ & +++ & & & HP/HTCM & I & & & & & \\
\hline HP/HTCC & I & & & & & & HP/HTCC & I & & & & & \\
\hline CCLS & I & & & & & & CCLS & I & & & & & + \\
\hline MuLS & I & & +++ & + & & & MuLS & I & & & & & \\
\hline DiC & I & +++ & ++ & +++ & & ++ & DiC & I & +++ & +++ & +++ & ++ & +++ \\
\hline DeC & I & +++ & +++ & +++ & & +++ & DeC & I & +++ & +++ & +++ & ++ & +++ \\
\hline CV & I & +++ & ++ & +++ & & ++ & CV & I & +++ & +++ & +++ & ++ & +++ \\
\hline Par & I & & & & & & Par & I & & & & & \\
\hline FCalgLS & I & & & & & & FCalgLS & I & & + & & & + \\
\hline FCtodLS & II & & & & & & FCtodLS & II & & & & & \\
\hline DC & II & & & & & & DC & II & & & & & \\
\hline RE & II & + & & & & & RE & II & & & & & \\
\hline Hem & II & & & & & & Hem & II & & & & & \\
\hline An & II & & & + & & & An & II & + & & & & \\
\hline Fib & III & & & & & & Fib & III & & & & & \\
\hline Nec & III & & & & & & Nec & III & & & & & \\
\hline VMA: $2,75 \pm 0,50$ & 3 & 3 & 3 & - & 2 & VMA: $2,80 \pm 0,45$ & 3 & 3 & 3 & 2 & 3 \\
\hline IAH: $12,00 \pm 5,83$ & 17 & 8 & 17 & - & 6 & IAH: $7,00 \pm 3,67$ & 13 & 5 & 5 & 4 & 8 \\
\hline
\end{tabular}


TABELA $28 \mathrm{~F}$ - PIRACICABA

\begin{tabular}{|l|c|c|c|c|c|c|l|l|l|l|l|l|c|c|}
\hline \multicolumn{9}{|c|}{ Serrapinnus notomelas } & \multicolumn{9}{|c|}{ Danio rerio } \\
\hline Alterações & peso & Sn1 & Sn2 & Sn3 & Sn4 & Sn5 & Alteracões & peso & Dr1 & Dr2 & Dr3 & Dr4 & Dr5 \\
\hline HTCE & I & + & & & & & HTCE & I & & & & + & + \\
\hline AdE & I & & & & & & AdE & I & & & & & \\
\hline ELS & I & + & +++ & +++ & +++ & + & ELS & I & ++ & & + & & ++ \\
\hline HPBLS & I & & ++ & & +++ & ++ & HPBLS & I & ++ & & & & \\
\hline HPLS & I & + & & & & + & HPLS & I & & & & & \\
\hline FPLS & I & + & + & & +++ & & FPLS & I & + & & & & \\
\hline LeuELS & I & & & & & & LeuELS & I & & & & & \\
\hline HP/HTCM & I & & + & ++ & +++ & + & HP/HTCM & I & & & & + & + \\
\hline HP/HTCC & I & + & & & & + & HP/HTCC & I & & & & & \\
\hline CCLS & I & & & & & & CCLS & I & & & & & \\
\hline MuLS & I & & + & & & & MuLS & I & & & & & \\
\hline DiC & I & ++ & +++ & ++ & +++ & +++ & DiC & I & +++ & +++ & ++ & + & + \\
\hline DeC & I & ++ & +++ & ++ & +++ & +++ & DeC & I & +++ & +++ & ++ & + & ++ \\
\hline CV & I & ++ & +++ & ++ & +++ & +++ & CV & I & +++ & +++ & ++ & + & + \\
\hline Par & I & & & & & & Par & I & & & & & \\
\hline FCalgLS & I & & & & & + & FCalgLS & I & & + & & & \\
\hline FCtodLS & II & & & & & & FCtodLS & II & & & & & \\
\hline DC & II & & & & & & DC & II & & & & & \\
\hline RE & II & + & & & & & RE & II & & & & & \\
\hline Hem & II & & & & & & Hem & II & & & & & \\
\hline An & II & & ++ & & & & An & II & + & +++ & & & \\
\hline Fib & III & & & & & & Fib & III & & & & & \\
\hline NeC & III & & & & & & NeC & III & & & & & \\
\hline VMA: $3,00 \pm 0,00$ & 3 & 3 & 3 & 3 & 3 & VMA: $2,40 \pm 0,55$ & 3 & 3 & 2 & 2 & 2 \\
\hline IAH: $11,40 \pm 6,19$ & 18 & 18 & 5 & 7 & 9 & IAH: 9,00 $\pm 5,57$ & 16 & 14 & 4 & 5 & 6 \\
\hline
\end{tabular}

TABELA 28 G - SÃO JOÃO DA BOA VISTA

\begin{tabular}{|l|c|c|c|c|c|c|l|l|l|l|l|l|l|l|}
\hline \multicolumn{9}{|c|}{ Serrapinnus notomelas } & \multicolumn{9}{|c|}{ Danio rerio } \\
\hline Alterações & peso & Sn1 & Sn2 & Sn3 & Sn4 & Sn5 & Alterações & peso & Dr1 & Dr2 & Dr3 & Dr4 & Dr5 \\
\hline HTCE & I & & + & & & & HTCE & I & & & + & & \\
\hline AdE & I & & & & & & AdE & I & & & & & \\
\hline ELS & I & + & + & + & + & + & ELS & I & + & & + & + & ++ \\
\hline HPBLS & I & & + & & & & HPBLS & I & & & & & \\
\hline HPLS & I & & + & & & & HPLS & I & & & & & \\
\hline FPLS & I & + & + & & + & + & FPLS & I & + & & & & \\
\hline LeuELS & I & & & & & & LeuELS & I & & & & & \\
\hline HP/HTCM & I & & + & & & & HP/HTCM & I & & & & & \\
\hline HP/HTCC & I & & & & & & HP/HTCC & I & & & & & \\
\hline CCLS & I & & & & & & CCLS & I & & & & & \\
\hline MuLS & I & + & & & & & MuLS & I & & & & & \\
\hline DiC & I & & & + & + & & DiC & I & & + & & & \\
\hline DeC & I & & & & & & DeC & I & & & & & \\
\hline CV & I & + & + & + & ++ & & CV & I & & + & ++ & & \\
\hline Par & I & & & & & & Par & I & & & & & \\
\hline FCalgLS & I & & + & & & & FCalgLS & I & & & & & \\
\hline FCtodLS & II & & & & & & FCtodLS & II & & & & & \\
\hline DC & II & & & & & & DC & II & & & & & \\
\hline RE & II & & & & & & RE & II & & & & & \\
\hline Hem & II & & & & & & Hem & II & & & & & \\
\hline An & II & & & & & & An & II & & & & & \\
\hline Fib & III & & & & & & Fib & III & & & & & \\
\hline NeC & III & & & & & & NeC & III & & & & & \\
\hline VMA: $2,00 \pm 0,00$ & 2 & 2 & 2 & 2 & 2 & VMA: $2,00 \pm 0,00$ & 2 & 2 & 2 & 2 & 2 \\
\hline IAH: $4,20 \pm 2,28$ & 4 & 8 & 3 & 4 & 2 & IAH: $1,80 \pm 0,84$ & 2 & 2 & 3 & 1 & 1 \\
\hline
\end{tabular}


TABELA 28 H - MOGI GUAÇU 1

\begin{tabular}{|l|c|c|c|c|c|c|l|l|l|l|l|l|l|l|}
\hline \multicolumn{7}{|c|}{ Serrapinnus notomelas } & \multicolumn{9}{|c|}{ Danio rerio } \\
\hline Alterações & peso & Sn1 & Sn2 & Sn3 & Sn4 & Sn5 & Alterações & peso & Dr1 & - & Dr3 & Dr4 & Dr5 \\
\hline HTCE & I & & + & & & & HTCE & I & & & & + & \\
\hline AdE & I & & & & & & AdE & I & & & & & \\
\hline ELS & I & ++ & +++ & ++ & & ++ & ELS & I & ++ & & + & & + \\
\hline HPBLS & I & + & & & & & HPBLS & I & & & + & + & + \\
\hline HPLS & I & & & & & ++ & HPLS & I & + & & & & \\
\hline FPLS & I & + & & & & & FPLS & I & & & + & + & + \\
\hline LeuELS & I & & & & & & LeuELS & I & & & & & \\
\hline HP/HTCM & I & & & & & + & HP/HTCM & I & & & & & \\
\hline HP/HTCC & I & & ++ & & & & HP/HTCC & I & & & & & \\
\hline CCLS & I & & + & & & & CCLS & I & & & & & \\
\hline MuLS & I & & & & & ++ & MuLS & I & & & & & \\
\hline DiC & I & & +++ & & + & & DiC & I & ++ & & & & \\
\hline DeC & I & & +++ & & + & & DeC & I & ++ & & & & \\
\hline CV & I & & +++ & + & + & & CV & I & ++ & & & & \\
\hline Par & I & & & & & & Par & I & & & & & \\
\hline FCalgLS & I & & & & & ++ & FCalgLS & I & + & & & & \\
\hline FCtodLS & II & & & & & & FCtodLS & II & & & & & \\
\hline DC & II & & & & & & DC & II & & & & & \\
\hline RE & II & & & & & & RE & II & & & & & \\
\hline Hem & II & & & & & & Hem & II & & & & & \\
\hline An & II & & + & & & & An & II & & & & & \\
\hline Fib & III & & & & & & Fib & III & & & & & \\
\hline NeC & III & & & & & & Nec & III & & & & & \\
\hline VMA: $2,20 \pm 0,45$ & 2 & 3 & 2 & 2 & 2 & VMA: $2,00 \pm 0,00$ & 2 & - & 2 & 2 & 2 \\
\hline IAH: $6,00 \pm 6,24$ & 3 & 17 & 2 & 3 & 5 & IAH: 3,75 $\pm 1,50$ & 6 & - & 3 & 3 & 3 \\
\hline
\end{tabular}

TABELA 28 I - MOGI GUAÇU 2

\begin{tabular}{|l|c|c|c|c|c|c|l|l|l|l|l|l|l|l|}
\hline \multicolumn{9}{|c|}{ Serrapinnus notomelas } & \multicolumn{9}{|c|}{ Danio rerio } \\
\hline Alterações & peso & Sn1 & Sn2 & Sn3 & Sn4 & Sn5 & Alteraç̃es & peso & Dr1 & Dr2 & - & Dr4 & Dr5 \\
\hline HTCE & I & & & & + & & HTCE & I & & & & & \\
\hline AdE & I & & & & & & AdE & I & & & & & \\
\hline ELS & I & +++ & + & + & + & + & ELS & I & + & + & & & \\
\hline HPBLS & I & + & & + & & + & HPBLS & I & + & + & & + & \\
\hline HPLS & I & + & + & & & + & HPLS & I & + & +++ & & & \\
\hline FPLS & I & & & & & + & FPLS & I & & + & & & \\
\hline LeuELS & I & & & & & & LeuELS & I & & & & & \\
\hline HP/HTCM & I & + & +++ & & +++ & ++ & HP/HTCM & I & & & & & \\
\hline HP/HTCC & I & & & & + & + & HP/HTCC & I & & & & & \\
\hline CCLS & I & & & & + & & CCLS & I & & & & & \\
\hline MuLS & I & & ++ & + & + & ++ & MuLS & I & & & & & \\
\hline DiC & I & & + & + & ++ & + & DiC & I & ++ & + & & ++ & + \\
\hline DeC & I & & & + & + & & DeC & I & ++ & + & & ++ & \\
\hline CV & I & & ++ & + & ++ & + & CV & I & ++ & + & & ++ & + \\
\hline Par & I & & & & & & Par & I & & & & & \\
\hline FCalgLS & I & & + & & & & FCalgLS & I & + & ++ & & & \\
\hline FCtodLS & II & & & & & & FCtodLS & II & & & & & \\
\hline DC & II & & & & & & DC & II & & & & & \\
\hline RE & II & & & & & & RE & II & & & & & \\
\hline Hem & II & & & & & & Hem & II & & & & & \\
\hline An & II & & & & & & An & II & & + & & & \\
\hline Fib & III & & & & & & Fib & III & & & & & \\
\hline NeC & III & & & & & & NeC & III & & & & & \\
\hline VMA: $2,40 \pm 0,55$ & 2 & 3 & 2 & 3 & 2 & VMA: $2,25 \pm 0,50$ & 2 & 3 & - & 2 & 2 \\
\hline IAH: $7,00 \pm 2,12$ & 4 & 7 & 6 & 9 & 9 & IAH: $7,75 \pm 7,14$ & 7 & 18 & - & 4 & 2 \\
\hline
\end{tabular}


TABELA $28 \mathrm{~J}$ - PIRASSUNUNGA

\begin{tabular}{|l|c|c|c|c|c|c|l|l|l|l|l|c|c|c|}
\hline \multicolumn{9}{|c|}{ Serrapinnus notomelas } & \multicolumn{9}{|c|}{ Danio rerio } \\
\hline Alterações & peso & Sn1 & Sn2 & Sn3 & Sn4 & Sn5 & Alteracões & peso & Dr1 & Dr2 & Dr3 & Dr4 & Dr5 \\
\hline HTCE & I & + & & + & + & & HTCE & I & + & & + & & + \\
\hline AdE & I & & & & & & AdE & I & & & & & \\
\hline ELS & I & & & & + & + & ELS & I & & + & & & + \\
\hline HPBLS & I & + & & & & + & HPBLS & I & & & & + & \\
\hline HPLS & I & & + & & & & HPLS & I & & & + & ++ & \\
\hline FPLS & I & + & + & & & + & FPLS & I & & & & & \\
\hline LeuELS & I & & & & & & LeuELS & I & & & & & \\
\hline HP/HTCM & I & + & ++ & +++ & ++ & +++ & HP/HTCM & I & & & & & \\
\hline HP/HTCC & I & & & & & & HP/HTCC & I & & & & & \\
\hline CCLS & I & & & & & & CCLS & I & & & & & \\
\hline MuLS & I & ++ & +++ & +++ & & +++ & MuLS & I & & & & & \\
\hline DiC & I & + & & + & + & ++ & DiC & I & & + & & & ++ \\
\hline DeC & I & & & & + & + & DeC & I & & & & & \\
\hline CV & I & & & ++ & + & ++ & CV & I & & ++ & & + & ++ \\
\hline Par & I & & & & & & Par & I & & & & & \\
\hline FCalgLS & I & & & & & & FCalgLS & I & & & & + & \\
\hline FCtodLS & II & & & & & & FCtodLS & II & & & & & \\
\hline DC & II & & & & & & DC & II & & & & & \\
\hline RE & II & & & & & & RE & II & & & & & \\
\hline Hem & II & & & & & & Hem & II & & & & & \\
\hline An & II & & & & & & An & II & & & & & \\
\hline Fib & III & & & & & & Fib & III & & & & & \\
\hline NeC & III & & & & & & NeC & III & & & & & \\
\hline VMA: $2,20 \pm 0,45$ & 2 & 2 & 2 & 2 & 3 & VMA: $2,00 \pm 0,00$ & 2 & 2 & 2 & 2 & 2 \\
\hline IAH: $5,60 \pm 1,67$ & 6 & 4 & 4 & 6 & 8 & IAH: $2,80 \pm 1,30$ & 1 & 3 & 2 & 4 & 4 \\
\hline
\end{tabular}

TABELA $28 \mathrm{~K}$ - LUIZ ANTÔNIO 1

\begin{tabular}{|l|c|c|c|c|c|c|l|l|l|l|l|l|l|}
\hline \multicolumn{9}{|c|}{ Serrapinnus notomelas } & \multicolumn{9}{|c|}{ Danio rerio } \\
\hline Alterações & peso & Sn1 & Sn2 & Sn3 & Sn4 & Sn5 & Alterações & peso & Dr1 & Dr2 & Dr3 & Dr4 & Dr5 \\
\hline HTCE & I & & & & & & HTCE & I & & & & & \\
\hline AdE & I & & & & & & AdE & I & & & & & \\
\hline ELS & I & ++ & ++ & ++ & & & ELS & I & & + & & & \\
\hline HPBLS & I & & & & + & + & HPBLS & I & & & + & & \\
\hline HPLS & I & & & & + & + & HPLS & I & & & & & + \\
\hline FPLS & I & & & & + & + & FPLS & I & & & & & \\
\hline LeuELS & I & & & & & & LeuELS & I & & & & & \\
\hline HP/HTCM & I & + & & & + & & HP/HTCM & I & & & & & \\
\hline HP/HTCC & I & & & & & & HP/HTCC & I & & & & & \\
\hline CCLS & I & & & & & & CCLS & I & & & & & \\
\hline MuLS & I & ++ & & & & & MuLS & I & & & & & \\
\hline DiC & I & ++ & + & + & & ++ & DiC & I & & & & & \\
\hline DeC & I & + & & & & & DeC & I & & & & & \\
\hline CV & I & ++ & + & ++ & & ++ & CV & I & & & & & \\
\hline Par & I & & & & & & Par & I & & & & & \\
\hline FCalgLS & I & & + & & & + & FCalgLS & I & & & & & \\
\hline FCtodLS & II & & & & & & FCtodLS & II & & & & & \\
\hline DC & II & & & & & & DC & II & & & & & \\
\hline RE & II & & & & & & RE & II & & & & & \\
\hline Hem & II & & & & & & Hem & II & & & & & \\
\hline An & II & & & & & & An & II & & & & & \\
\hline Fib & III & & & & & & Fib & III & & & & & \\
\hline Nec & III & & & & & & Nec & III & & & & & \\
\hline VMA: $2,00 \pm 0,00$ & 2 & 2 & 2 & 2 & 2 & VMA: $1,60 \pm 0,55$ & 1 & 2 & 2 & 1 & 2 \\
\hline IAH: $4,60 \pm 1,34$ & 6 & 4 & 3 & 4 & 6 & IAH: $0,60 \pm 0,55$ & 0 & 1 & 1 & 0 & 1 \\
\hline
\end{tabular}


TABELA 28 L - LUIZ ANTÔNIO 2

\begin{tabular}{|l|c|c|c|c|c|c|l|l|l|l|l|l|l|l|}
\hline \multicolumn{9}{|c|}{ Serrapinnus notomelas } & \multicolumn{9}{|c|}{ Danio rerio } \\
\hline Alterações & peso & Sn1 & Sn2 & Sn3 & Sn4 & Sn5 & Alteracões & peso & - & Dr2 & Dr3 & Dr4 & Dr5 \\
\hline HTCE & I & & + & & & & HTCE & I & & & & & \\
\hline AdE & I & & & & & & AdE & I & & & & & \\
\hline ELS & I & + & + & ++ & +++ & +++ & ELS & I & & & & & \\
\hline HPBLS & I & & & ++ & & + & HPBLS & I & & + & + & & + \\
\hline HPLS & I & & & ++ & & + & HPLS & I & & & & & \\
\hline FPLS & I & & & ++ & & & FPLS & I & & & & & \\
\hline LeuELS & I & & & & & & LeuELS & I & & & & & \\
\hline HP/HTCM & I & & & & + & ++ & HP/HTCM & I & & & & & \\
\hline HP/HTCC & I & & & & & & HP/HTCC & I & & & & & \\
\hline CCLS & I & & & & & & CCLS & I & & & & & \\
\hline MuLS & I & & ++ & + & & ++ & MuLS & I & & & & & \\
\hline DiC & I & & ++ & + & +++ & +++ & DiC & I & & & & ++ & \\
\hline DeC & I & & ++ & + & +++ & +++ & DeC & I & & & & ++ & \\
\hline CV & I & + & ++ & ++ & +++ & +++ & CV & I & & & & ++ & \\
\hline Par & I & & & & & & Par & I & & & & & \\
\hline FCalgLS & I & & & + & & + & FCalgLS & I & & & & & \\
\hline FCtodLS & II & & & & & & FCtodLS & II & & & & & \\
\hline DC & II & & & & & & DC & II & & & & & \\
\hline RE & II & & & & & & RE & II & & & & & \\
\hline Hem & II & & & & & & Hem & II & & & & & \\
\hline An & II & & & & & & An & II & & & & & \\
\hline Fib & III & & & & & & Fib & III & & & & & \\
\hline Nec & III & & & & & & Nec & III & & & & & \\
\hline VMA: $2,40 \pm 0,55$ & 2 & 2 & 2 & 3 & 3 & VMA: $2,00 \pm 0,00$ & - & 2 & 2 & 2 & 2 \\
\hline IAH: $6,20 \pm 2,95$ & 2 & 6 & 9 & 5 & 9 & IAH: $1,50 \pm 1,00$ & - & 1 & 1 & 3 & 1 \\
\hline
\end{tabular}

TABELA 28 M - TELÊMACO BORBA 1

\begin{tabular}{|l|c|c|c|c|c|c|l|l|l|l|l|l|l|l|}
\hline \multicolumn{7}{|c|}{ Serrapinnus notomelas } & \multicolumn{9}{|c|}{ Danio rerio } \\
\hline Alterações & peso & Sn1 & Sn2 & Sn3 & Sn4 & Sn5 & Alterações & peso & Dr1 & Dr2 & Dr3 & Dr4 & Dr5 \\
\hline HTCE & I & & & & & & HTCE & I & & + & & & \\
\hline AdE & I & & & & & & AdE & I & & & & & \\
\hline ELS & I & & ++ & + & & & ELS & I & + & & +++ & + & \\
\hline HPBLS & I & & & & & & HPBLS & I & & & & & \\
\hline HPLS & I & & & & & & HPLS & I & & & & & \\
\hline FPLS & I & & & & & & FPLS & I & & & & & \\
\hline LeuELS & I & & & & & & LeuELS & I & & & & & \\
\hline HP/HTCM & I & & & & & & HP/HTCM & I & & & & & \\
\hline HP/HTCC & I & & & & & & HP/HTCC & I & & & & & \\
\hline CCLS & I & & & & & & CCLS & I & & & & & \\
\hline MuLS & I & + & ++ & ++ & & + & MuLS & I & & & & & \\
\hline DiC & I & & +++ & +++ & & ++ & DiC & I & & & ++ & + & \\
\hline DeC & I & & +++ & +++ & & ++ & DeC & I & & & +++ & & \\
\hline CV & I & & +++ & +++ & + & ++ & CV & I & + & + & ++ & + & \\
\hline Par & I & & & & & & Par & I & & & & & \\
\hline FCalgLS & I & & & & & & FCalgLS & I & & & & & \\
\hline FCtodLS & II & & & & & & FCtodLS & II & & & & & \\
\hline DC & II & & & & & & DC & II & & & & & \\
\hline RE & II & & & & & & RE & II & & & & & \\
\hline Hem & II & & & & & & Hem & II & & & & & \\
\hline An & II & & & & & & An & II & & & & & \\
\hline Fib & III & & & & & & Fib & III & & & & & \\
\hline NeC & III & & & & & & NeC & III & & & & & \\
\hline VMA: $2,40 \pm 0,55$ & 2 & 3 & 3 & 2 & 2 & VMA: 2,00 $\pm 0,71$ & 2 & 2 & 3 & 2 & 1 \\
\hline IAH: $3,20 \pm 2,05$ & 1 & 5 & 5 & 1 & 4 & IAH: $2,20 \pm 1,48$ & 2 & 2 & 4 & 3 & 0 \\
\hline
\end{tabular}


TABELA $28 \mathrm{~N}$ - TELÊMACO BORBA 2

\begin{tabular}{|l|c|c|c|c|c|c|l|l|l|l|l|l|c|c|}
\hline \multicolumn{9}{|c|}{ Serrapinnus notomelas } & \multicolumn{9}{|c|}{ Danio rerio } \\
\hline Alterações & peso & Sn1 & Sn2 & Sn3 & Sn4 & Sn5 & Alteracões & peso & Dr1 & Dr2 & Dr3 & Dr4 & Dr5 \\
\hline HTCE & I & & & + & & & HTCE & I & & + & + & & \\
\hline AdE & I & & & & & & AdE & I & & & & & \\
\hline ELS & I & + & & & + & +++ & ELS & I & +++ & + & + & + & + \\
\hline HPBLS & I & & + & + & & ++ & HPBLS & I & & + & + & & \\
\hline HPLS & I & & & & + & & HPLS & I & & & + & & \\
\hline FPLS & I & & & + & & ++ & FPLS & I & & + & & & \\
\hline LeuELS & I & & & & & & LeuELS & I & & & & & \\
\hline HP/HTCM & I & & & & & & HP/HTCM & I & & & & & \\
\hline HP/HTCC & I & & & & & & HP/HTCC & I & & & & & \\
\hline CCLS & I & & & & & & CCLS & I & & & + & & \\
\hline MuLS & I & & & & & & MuLS & I & & & & & \\
\hline DiC & I & ++ & + & + & ++ & +++ & DiC & I & & + & & + & \\
\hline DeC & I & ++ & + & & ++ & +++ & DeC & I & ++ & ++ & & + & \\
\hline CV & I & ++ & + & + & ++ & +++ & CV & I & ++ & + & + & + & + \\
\hline Par & I & & & & & & Par & I & & & & & \\
\hline FCalgLS & I & & & & & & FCalgLS & I & & & & & \\
\hline FCtodLS & II & & & & & & FCtodLS & II & & & & & \\
\hline DC & II & & & & & & DC & II & & & & & \\
\hline RE & II & & + & & & & RE & II & & + & & & + \\
\hline Hem & II & & & & & & Hem & II & & + & & & \\
\hline An & II & & & & & ++ & An & II & & & & & \\
\hline Fib & III & & & & & & Fib & III & & & & & \\
\hline NeC & III & & & & & & NeC & III & & & & & \\
\hline VMA: $2,20 \pm 0,45$ & 2 & 2 & 2 & 2 & 3 & VMA: $2,20 \pm 0,45$ & 2 & 3 & 2 & 2 & 2 \\
\hline IAH: $8,80 \pm 5,72$ & 4 & 14 & 5 & 5 & 16 & IAH: $10,40 \pm 9,91$ & 3 & 27 & 6 & 4 & 12 \\
\hline
\end{tabular}

TABELA 280 - LONDRINA

\begin{tabular}{|l|c|c|c|c|c|c|l|l|l|l|l|l|l|l|}
\hline \multicolumn{9}{|c|}{ Serrapinnus notomelas } & \multicolumn{9}{|c|}{ Danio rerio } \\
\hline Alterações & peso & Sn1 & Sn2 & Sn3 & Sn4 & Sn5 & Alterações & peso & Dr1 & Dr2 & Dr3 & Dr4 & Dr5 \\
\hline HTCE & I & & & & & & HTCE & I & & & & & \\
\hline AdE & I & & & & & & AdE & I & & & & & \\
\hline ELS & I & ++ & & ++ & & + & ELS & I & + & + & + & & +++ \\
\hline HPBLS & I & & & & + & & HPBLS & I & & & & & \\
\hline HPLS & I & + & ++ & & & & HPLS & I & & & & & \\
\hline FPLS & I & & & & & & FPLS & I & & & & & \\
\hline LeuELS & I & & & & & & LeuELS & I & & & & & \\
\hline HP/HTCM & I & ++ & & & & & HP/HTCM & I & & +++ & & & \\
\hline HP/HTCC & I & & & & & & HP/HTCC & I & & & & & \\
\hline CCLS & I & & & & & & CCLS & I & & & & & \\
\hline MuLS & I & & ++ & & & + & MuLS & I & & & & & \\
\hline DiC & I & +++ & +++ & ++ & ++ & +++ & DiC & I & & & & ++ & +++ \\
\hline DeC & I & +++ & +++ & ++ & ++ & ++ & DeC & I & & & & + & +++ \\
\hline CV & I & +++ & +++ & ++ & ++ & +++ & CV & I & & & & ++ & +++ \\
\hline Par & I & & & & & & Par & I & & & & & \\
\hline FCalgLS & I & + & + & & & & FCalgLS & I & & & & & \\
\hline FCtodLS & II & & & & & & FCtodLS & II & & & & & \\
\hline DC & II & & & & & & DC & II & & & & & \\
\hline RE & II & & & & & & RE & II & & & & & \\
\hline Hem & II & & & & & & Hem & II & & & & & \\
\hline An & II & & & & & & An & II & & & & & \\
\hline Fib & III & & & & & & Fib & III & & & & & \\
\hline Nec & III & & & & & & NeC & III & & & & & \\
\hline VMA: $2,60 \pm 0,55$ & 3 & 3 & 2 & 2 & 3 & VMA: $1,80 \pm 0,84$ & 1 & 2 & 1 & 2 & 3 \\
\hline IAH: $5,20 \pm 1,30$ & 7 & 6 & 4 & 4 & 5 & IAH: $2,20 \pm 1,30$ & 1 & 2 & 1 & 3 & 4 \\
\hline
\end{tabular}


TABELAS 29 A a 29 O: alterações renais observadas nos peixes Serrapinnus notomelas e Danio rerio expostos às localidades Ribeirão do Pinhal, Jaguari, Campinas, Sumaré, Americana, Piracicaba, São João da Boa Vista, Mogi Guaçu 1, Mogi Guaçu 2, Pirassununga, Luiz Antônio 1, Luiz Antônio 2, Telêmaco Borba 1, Telêmaco Borba 2 e Londrina. Os sinais de + indicam a freqüência de ocorrência das alterações, sendo + = baixa freqüência, $++=$ média freqüência e $+++=$ alta freqüência de ocorrência da alteração. Os traços $(-)$ indicam a não observação do órgão nos cortes.

As abreviações significam: PCTL= perda do contorno ou contorno atípico das células do tecido linfóide; $\mathrm{DHL}=$ degeneração hialina leve; HTCT=hipertrofia das células tubulares;

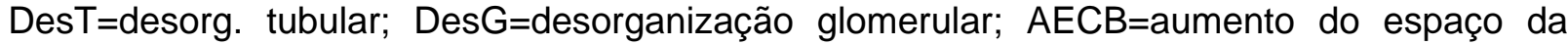
cápsula de Bowman ( $\mathrm{CB}$ ); $\mathrm{DECB}=$ diminuição do espaço da cápsula de Bowman; DCG=dilatação dos capilares glomerulares; TR/NN=ocorrência de túbulos em regeneração ou de novos néfrons; PAST=presença de material PAS-positivo nas céls tubulares; DFreqG=diminuição da freq. relativa de glomérulos; DilVS=dilatação de vasos sangüíneos; ALumTub=aumento do diâm. do lúmen tubular; ObsTub=obstrução tubular; DHS=degeneração hialina severa; DegT=degeneração tubular; DegG=degeneração glomerular; DCTub=deg.citoplasmática das células tubulares; DNTub=deg. nuclear das céls tubulares; TLCB=tecido linfóide na $\mathrm{CB}$; $\mathrm{HH}=$ hiperemia; RVS=ruptura de vasos sangüíneos; $\mathrm{Nec}=$ necrose.

TABELA 29 A - RIBEIRÃO DO PINHAL

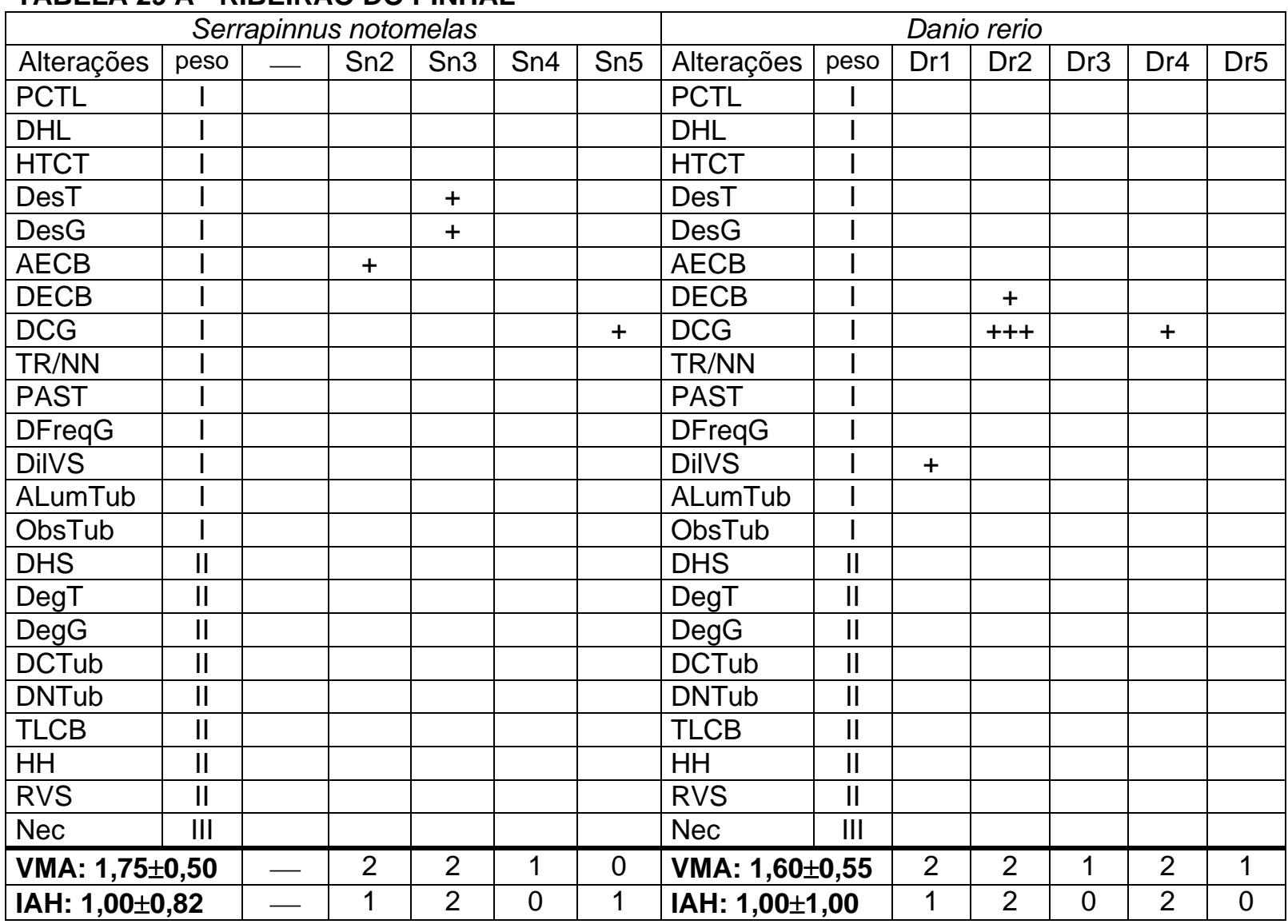


TABELA 29 B - LIMEIRA

\begin{tabular}{|c|c|c|c|c|c|c|c|c|c|c|c|c|c|}
\hline \multicolumn{7}{|c|}{ Serrapinnus notomelas } & \multicolumn{7}{|c|}{ Danio rerio } \\
\hline Alterações & peso & Sn1 & Sn2 & Sn3 & Sn4 & Sn5 & Alterações & peso & Dr1 & Dr2 & Dr3 & Dr4 & Dr5 \\
\hline PCTL & $\mathrm{I}$ & & & & & & PCTL & 1 & & & & & \\
\hline $\mathrm{DHL}$ & 1 & + & + & +++ & + & +++ & $\mathrm{DHL}$ & 1 & + & + & + & + & + \\
\hline HTCT & 1 & ++ & +++ & +++ & + & +++ & HTCT & 1 & +++ & +++ & ++ & + & ++ \\
\hline DesT & 1 & ++ & ++ & + & & + & DesT & 1 & & & & & \\
\hline DesG & 1 & & & & & & DesG & 1 & & & & & \\
\hline AECB & $\mathrm{I}$ & & & & & & AECB & $\mathrm{I}$ & & & & & \\
\hline $\mathrm{DECB}$ & 1 & & & & & + & DECB & 1 & & & & & \\
\hline DCG & 1 & & + & & & +++ & DCG & 1 & & ++++ & +++ & + & ++ \\
\hline TR/NN & $\mathrm{I}$ & & + & + & ++ & & TR/NN & $\mathrm{I}$ & & & & & \\
\hline PAST & 1 & & & & + & & PAST & I & & & & & ++ \\
\hline DFregG & $\mathrm{I}$ & & & & & & DFregG & 1 & & & & & \\
\hline DilVS & 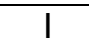 & & & & & & DilVS & 1 & & + & & & \\
\hline ALumTub & 1 & + & & & & + & ALumTub & I & & ++ & & & ++ \\
\hline ObsTub & 1 & & & & & & ObsTub & 1 & & & & & + \\
\hline DHS & II & ++++ & & + & + & ++++ & DHS & II & +++ & ++++ & +++ & & + \\
\hline DegT & II & +++ & + & & & + & DegT & II & & ++ & & & ++ \\
\hline DegG & II & & & & & & DegG & II & & & & & \\
\hline DCTub & II & & & & & & DCTub & II & & & & & \\
\hline DNTub & II & & & & & & DNTub & II & & & & & \\
\hline TLCB & II & & & & & & TLCB & II & & & & & \\
\hline $\mathrm{HH}$ & II & & & & & & $\mathrm{HH}$ & II & & + & & + & \\
\hline RVS & II & & & & & & RVS & II & & & & & \\
\hline $\mathrm{Nec}$ & III & & & & & & $\mathrm{Nec}$ & III & & & & & \\
\hline \multicolumn{2}{|c|}{ VMA: $2,60 \pm 0,55$} & 3 & 2 & $\overline{3}$ & 2 & 3 & \multicolumn{2}{|c|}{ VMA: $2,80 \pm 0,45$} & 3 & 3 & 3 & 2 & 3 \\
\hline \multicolumn{2}{|c|}{ IAH: $18,60 \pm 5,90$} & 24 & 15 & 14 & 14 & 26 & \multicolumn{2}{|c|}{ IAH:19,80 $\pm 10,28$} & 12 & 35 & 13 & 13 & 26 \\
\hline
\end{tabular}

TABELA 29 C - CAMPINAS

\begin{tabular}{|c|c|c|c|c|c|c|c|c|c|c|c|c|c|}
\hline \multicolumn{7}{|c|}{ Serrapinnus notomelas } & \multicolumn{7}{|c|}{ Danio rerio } \\
\hline Alterações & peso & Sn1 & Sn2 & Sn3 & Sn4 & Sn5 & Alterações & peso & Dr1 & Dr2 & Dr3 & Dr4 & Dr5 \\
\hline PCTL & $\mathrm{I}$ & & & & & & PCTL & I & & & & & \\
\hline $\mathrm{DHL}$ & $\mathrm{I}$ & +++ & +++ & +++ & +++ & + & $\mathrm{DHL}$ & $\mathrm{I}$ & +++ & + & + & +++ & + \\
\hline HTCT & $\mathrm{I}$ & +++ & +++ & +++ & +++ & + & HTCT & I & + & & & & \\
\hline DesT & $\mathrm{I}$ & & & & & & DesT & $\mathrm{I}$ & + & & + & & \\
\hline DesG & $\mathrm{I}$ & & & & & & DesG & $\mathrm{I}$ & + & + & & & \\
\hline AECB & $\mathrm{I}$ & & & + & & & AECB & $\mathrm{I}$ & & & & & \\
\hline DECB & $\mathrm{I}$ & & & + & & + & DECB & $\mathrm{I}$ & & & & & \\
\hline DCG & $\mathrm{I}$ & & ++ & ++ & + & +++ & DCG & $\mathrm{I}$ & + & + & & ++ & + \\
\hline TR/NN & $\mathrm{I}$ & & & & & & TR/NN & I & & & & & \\
\hline PAST & $\mathrm{I}$ & & & & & + & PAST & $\mathrm{I}$ & & & & & \\
\hline DFreqG & 1 & & & & & & DFreqG & $\mathrm{I}$ & & & & & \\
\hline DilVS & $\mathrm{I}$ & & & + & & & DilVS & $\mathrm{I}$ & & & & & \\
\hline ALumTub & $\mathrm{I}$ & & + & ++ & & & ALumTub & I & & & & & \\
\hline ObsTub & $\mathrm{I}$ & & & & & & ObsTub & $\mathrm{I}$ & & & & & \\
\hline DHS & II & + & +++ & +++ & + & + & DHS & II & +++ & +++ & +++ & +++ & +++ \\
\hline DegT & II & & & & & & DegT & II & & ++ & & & \\
\hline DegG & II & & & & & & DegG & II & & + & & & \\
\hline DCTub & II & & & & & & DCTub & II & & & & & \\
\hline DNTub & II & & & & & & DNTub & II & & & & & \\
\hline TLCB & II & & & & & & TLCB & II & & & & & \\
\hline $\mathrm{HH}$ & II & & & & & & $\mathrm{HH}$ & II & + & & + & & + \\
\hline RVS & II & & & & & & RVS & II & & & & & \\
\hline $\mathrm{Nec}$ & III & & & & & & $\mathrm{Nec}$ & III & & & & & \\
\hline \multicolumn{2}{|c|}{ VMA: $2,80 \pm 0,45$} & 3 & 3 & 3 & 3 & 2 & \multicolumn{2}{|c|}{ VMA: $3,00 \pm 0,00$} & 3 & 3 & 3 & 3 & 3 \\
\hline \multicolumn{2}{|c|}{ IAH: $14,20 \pm 1,92$} & 12 & 14 & 17 & 13 & 15 & \multicolumn{2}{|c|}{ IAH: $22,80 \pm 7,53$} & 25 & 33 & 22 & 12 & 22 \\
\hline
\end{tabular}


TABELA 29 D - SUMARÉ

\begin{tabular}{|c|c|c|c|c|c|c|c|c|c|c|c|c|c|}
\hline \multicolumn{7}{|c|}{ Serrapinnus notomelas } & \multicolumn{7}{|c|}{ Danio rerio } \\
\hline Alterações & peso & Sn1 & Sn2 & Sn3 & Sn4 & Sn5 & Alterações & peso & Dr1 & Dr2 & Dr3 & Dr4 & Dr5 \\
\hline PCTL & 1 & & & & + & & PCTL & 1 & & & & & \\
\hline $\mathrm{DHL}$ & $\mathrm{I}$ & +++ & ++ & +++ & +++ & +++ & $\mathrm{DHL}$ & $\mathrm{I}$ & + & + & + & +++ & +++ \\
\hline HTCT & $\mathrm{I}$ & +++ & ++ & +++ & +++ & + & HTCT & $\mathrm{I}$ & & +++ & & & +++ \\
\hline DesT & $\mathrm{I}$ & ++ & & & & & DesT & 1 & & & & & \\
\hline DesG & $\mathrm{I}$ & & & & & & DesG & $\mathrm{I}$ & & & & & \\
\hline AECB & 1 & & & & & & AECB & I & & & & & \\
\hline DECB & $\mathrm{I}$ & & & & & & DECB & $\mathrm{I}$ & + & & + & & + \\
\hline DCG & $\mathrm{I}$ & & + & & +++ & & DCG & I & & ++ & & & \\
\hline TR/NN & 1 & & & & & & TR/NN & $\mathrm{I}$ & & & & & \\
\hline PAST & 1 & & & & & & PAST & I & & & & & \\
\hline DFreqG & $\mathrm{I}$ & & & & & & DFreqG & $\mathrm{I}$ & & & & + & + \\
\hline DilVS & $\mathrm{I}$ & & & & & & DilVS & $\mathrm{I}$ & & & & & \\
\hline ALumTub & $\mathrm{I}$ & + & + & + & + & + & ALumTub & $\mathrm{I}$ & + & + & + & + & + \\
\hline ObsTub & $\mathrm{I}$ & & & & & & ObsTub & $\mathrm{I}$ & & & & & \\
\hline DHS & II & +++ & +++ & +++ & + & + & DHS & II & +++ & +++ & +++ & +++ & +++ \\
\hline DegT & II & +++ & & & & & DegT & II & & & & +++ & \\
\hline DegG & II & +++ & & & + & & DegG & II & & & & & \\
\hline DCTub & II & & & & & & DCTub & II & & & & & \\
\hline DNTub & II & & & & & & DNTub & II & & & & & \\
\hline TLCB & II & & & & & & TLCB & II & & & & & \\
\hline $\mathrm{HH}$ & II & & & + & & + & $\mathrm{HH}$ & II & + & + & + & + & + \\
\hline RVS & II & & & & & & RVS & II & & & & & \\
\hline $\mathrm{Nec}$ & III & & & & & & $\mathrm{Nec}$ & III & & & & & \\
\hline \multicolumn{2}{|c|}{ VMA: $3,00 \pm 0,00$} & 3 & 3 & 3 & 3 & 3 & \multicolumn{2}{|c|}{ VMA: $3,00 \pm 0,00$} & 3 & 3 & 3 & 3 & 3 \\
\hline \multicolumn{2}{|c|}{ IAH: $23,80 \pm 7,12$} & 34 & 14 & 23 & 25 & 23 & \multicolumn{2}{|c|}{ IAH: $25,60 \pm 4,22$} & 23 & 24 & 23 & 33 & 25 \\
\hline
\end{tabular}

TABELA 29 E - AMERICANA

\begin{tabular}{|c|c|c|c|c|c|c|c|c|c|c|c|c|c|}
\hline \multicolumn{7}{|c|}{ Serrapinnus notomelas } & \multicolumn{7}{|c|}{ Danio rerio } \\
\hline Alterações & peso & Sn1 & Sn2 & Sn3 & Sn4 & Sn5 & Alterações & peso & Dr1 & Dr2 & Dr3 & Dr4 & Dr5 \\
\hline PCTL & 1 & & & & & & PCTL & I & & & & & \\
\hline $\mathrm{DHL}$ & $\mathrm{I}$ & & & & +++ & & $\mathrm{DHL}$ & $\mathrm{I}$ & & & + & ++ & \\
\hline HTCT & $\mathrm{I}$ & +++ & + & + & +++ & + & HTCT & $\mathrm{I}$ & + & & & & \\
\hline DesT & $\mathrm{I}$ & + & & & + & & DesT & $\mathrm{I}$ & + & & + & & + \\
\hline DesG & $\mathrm{I}$ & + & & & + & & DesG & $\mathrm{I}$ & & & & & \\
\hline AECB & $\mathrm{I}$ & & & & +++ & & AECB & $\mathrm{I}$ & & & & & \\
\hline DECB & $\mathrm{I}$ & & & & & & DECB & $\mathrm{I}$ & + & + & + & + & \\
\hline DCG & $\mathrm{I}$ & +++ & + & + & +++ & & DCG & $\mathrm{I}$ & + & & & & + \\
\hline TR/NN & $\mathrm{I}$ & & & & + & & TR/NN & I & +++ & & & & + \\
\hline PAST & $\mathrm{I}$ & & & & & & PAST & $\mathrm{I}$ & & & & & \\
\hline DFreqG & 1 & & & & & & DFreqG & $\mathrm{I}$ & & & & & \\
\hline DilVS & $\mathrm{I}$ & & & & & & DilVS & $\mathrm{I}$ & & & & & \\
\hline ALumTub & $\mathrm{I}$ & & & & ++ & & ALumTub & 1 & & & & & \\
\hline ObsTub & $\mathrm{I}$ & & & & ++ & & ObsTub & $\mathrm{I}$ & & & & & \\
\hline DHS & II & & & & +++ & & DHS & II & & & & & \\
\hline DegT & II & + & + & + & & + & DegT & II & + & & & + & \\
\hline DegG & II & & & & ++ & & DegG & II & & & & & \\
\hline DCTub & II & & & & & & DCTub & II & & & & & \\
\hline DNTub & II & & & & & & DNTub & II & & & & & \\
\hline TLCB & II & & & & & & TLCB & II & & & & & \\
\hline $\mathrm{HH}$ & II & & & & & & $\mathrm{HH}$ & II & & + & + & + & + \\
\hline RVS & II & & & & & & RVS & II & & & & & \\
\hline $\mathrm{Nec}$ & III & & & & & & $\mathrm{Nec}$ & III & & & & & \\
\hline \multicolumn{2}{|c|}{ VMA: $2,40 \pm 0,55$} & 3 & 2 & 2 & 3 & 2 & \multicolumn{2}{|c|}{ VMA: $2,40 \pm 0,55$} & 3 & 2 & 2 & 3 & 2 \\
\hline \multicolumn{2}{|c|}{ IAH: $15,60 \pm 7,57$} & 14 & 12 & 12 & 29 & 11 & \multicolumn{2}{|c|}{ IAH: $14,80 \pm 4,27$} & 15 & 11 & 13 & 22 & 13 \\
\hline
\end{tabular}


TABELA $29 \mathrm{~F}$ - PIRACICABA

\begin{tabular}{|c|c|c|c|c|c|c|c|c|c|c|c|c|c|}
\hline \multicolumn{7}{|c|}{ Serrapinnus notomelas } & \multicolumn{7}{|c|}{ Danio rerio } \\
\hline Alterações & peso & Sn1 & Sn2 & Sn3 & Sn4 & Sn5 & Alterações & peso & Dr1 & Dr2 & Dr3 & Dr4 & Dr5 \\
\hline PCTL & $\mathrm{I}$ & & & & & & PCTL & 1 & & & & & \\
\hline $\mathrm{DHL}$ & 1 & + & + & + & & +++ & $\mathrm{DHL}$ & 1 & +++ & ++++ & +++ & +++ & +++ \\
\hline HTCT & 1 & +++ & + & + & & ++ & HTCT & 1 & & & +++ & +++ & +++ \\
\hline DesT & 1 & + & + & ++ & + & & DesT & 1 & +++ & & & & + \\
\hline DesG & 1 & & & & & & DesG & 1 & & & & & \\
\hline AECB & $\mathrm{I}$ & & & & & & $\mathrm{AECB}$ & 1 & & & & & \\
\hline DECB & 1 & & & & & & DECB & 1 & & & & & \\
\hline DCG & 1 & & & + & + & + & DCG & 1 & & & & & \\
\hline TR/NN & $\mathrm{I}$ & & & & & & TR/NN & $\mathrm{I}$ & & & & & \\
\hline PAST & 1 & & & & & & PAST & I & & & & & \\
\hline DFregG & $\mathrm{I}$ & & & & & & DFregG & 1 & & & & & \\
\hline DilVS & 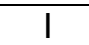 & & & & & & DilVS & 1 & & & & & \\
\hline ALumTub & 1 & & + & + & & & ALumTub & 1 & + & ++ & + & + & + \\
\hline ObsTub & 1 & & & & & & ObsTub & 1 & & & & & \\
\hline DHS & II & & +++ & ++++ & + & + & DHS & II & ++++ & ++++ & +++ & +++ & +++ \\
\hline DegT & II & + & + & +++ & ++ & + & DegT & II & & & & & \\
\hline DegG & II & & & & & & DegG & II & & & & & \\
\hline DCTub & II & & & & & & DCTub & II & & & & & \\
\hline DNTub & II & & & & & & DNTub & II & & & & & \\
\hline TLCB & II & & & & & & TLCB & II & & & & & \\
\hline $\mathrm{HH}$ & II & & & & & & $\mathrm{HH}$ & II & + & + & + & + & + \\
\hline RVS & II & & & & & & RVS & II & & & & & \\
\hline $\mathrm{Nec}$ & III & & & & & & $\mathrm{Nec}$ & III & & & & & \\
\hline \multicolumn{2}{|c|}{ VMA: $3,00 \pm 0,00$} & 3 & 3 & $\overline{3}$ & 3 & 3 & \multicolumn{2}{|c|}{ VMA: $3,00 \pm 0,00$} & 3 & 3 & 3 & 3 & 3 \\
\hline \multicolumn{2}{|c|}{ IAH: $21,40 \pm 4,83$} & 13 & 24 & 25 & 22 & 23 & \multicolumn{2}{|c|}{ IAH: $23,00 \pm 0,71$} & 23 & 22 & 23 & 23 & 24 \\
\hline
\end{tabular}

TABELA 29 G - SÃO JOÃO DA BOA VISTA

\begin{tabular}{|c|c|c|c|c|c|c|c|c|c|c|c|c|c|}
\hline \multicolumn{7}{|c|}{ Serrapinnus notomelas } & \multicolumn{7}{|c|}{ Danio rerio } \\
\hline Alterações & peso & Sn1 & Sn2 & Sn3 & Sn4 & Sn5 & Alterações & peso & Dr1 & Dr2 & Dr3 & Dr4 & Dr5 \\
\hline PCTL & $\mathrm{I}$ & & & & & & PCTL & I & & & & & \\
\hline $\mathrm{DHL}$ & $\mathrm{I}$ & & + & + & & + & $\mathrm{DHL}$ & $\mathrm{I}$ & & & + & + & \\
\hline HTCT & $\mathrm{I}$ & + & + & & & + & HTCT & I & + & & & & \\
\hline DesT & $\mathrm{I}$ & & & & & + & DesT & $\mathrm{I}$ & & & & & \\
\hline DesG & $\mathrm{I}$ & & & & & & DesG & $\mathrm{I}$ & & & & & \\
\hline AECB & $\mathrm{I}$ & & & & & & AECB & $\mathrm{I}$ & & & & & \\
\hline DECB & $\mathrm{I}$ & & & & & & DECB & I & + & & & & \\
\hline DCG & $\mathrm{I}$ & + & + & + & ++ & ++ & DCG & $\mathrm{I}$ & & ++ & + & & ++ \\
\hline TR/NN & $\mathrm{I}$ & & & & ++ & + & TR/NN & $\mathrm{I}$ & & + & & & ++ \\
\hline PAST & $\mathrm{I}$ & & & & & & PAST & $\mathrm{I}$ & & & & & \\
\hline DFreqG & $\mathrm{I}$ & & & & & & DFreqG & $\mathrm{I}$ & & & & & \\
\hline DilVS & $\mathrm{I}$ & & & & & & DilVS & $\mathrm{I}$ & & & & & \\
\hline ALumTub & I & & & & & & ALumTub & I & & & & & \\
\hline ObsTub & $\mathrm{I}$ & & & & & & ObsTub & $\mathrm{I}$ & & & & & \\
\hline DHS & II & & & & & & DHS & II & & & & & \\
\hline DegT & II & & & & & & DegT & II & & & & & \\
\hline DegG & II & & & & & & DegG & II & & & & & \\
\hline DCTub & II & & & & & & DCTub & II & & & & & \\
\hline DNTub & II & & & & & & DNTub & II & & & & & \\
\hline TLCB & II & & & & & & TLCB & II & & & & & \\
\hline $\mathrm{HH}$ & II & & & & & & $\mathrm{HH}$ & II & + & & & & \\
\hline RVS & II & & & & & & RVS & II & & & & & \\
\hline $\mathrm{Nec}$ & III & & & & & & $\mathrm{Nec}$ & III & & & & & \\
\hline \multicolumn{2}{|c|}{ VMA: $2,00 \pm 0,00$} & 2 & 2 & 2 & 2 & 2 & \multicolumn{2}{|c|}{ VMA: $2,00 \pm 0,00$} & 2 & 2 & 2 & 2 & 2 \\
\hline \multicolumn{2}{|c|}{ IAH: $2,80 \pm 1,30$} & 2 & 3 & 2 & 2 & 5 & \multicolumn{2}{|c|}{ IAH: $3,80 \pm 4,60$} & 12 & 2 & 2 & 1 & 2 \\
\hline
\end{tabular}


TABELA 29 H - MOGI GUAÇU 1

\begin{tabular}{|c|c|c|c|c|c|c|c|c|c|c|c|c|c|}
\hline \multicolumn{7}{|c|}{ Serrapinnus notomelas } & \multicolumn{7}{|c|}{ Danio rerio } \\
\hline Alterações & peso & Sn1 & Sn2 & Sn3 & Sn4 & Sn5 & Alterações & peso & Dr1 & Dr2 & Dr3 & Dr4 & Dr5 \\
\hline PCTL & $\mathrm{I}$ & & & & & & PCTL & $\mathrm{I}$ & & & & & \\
\hline $\mathrm{DHL}$ & $\mathrm{I}$ & + & & ++ & & + & $\mathrm{DHL}$ & $\mathrm{I}$ & & & & & \\
\hline HTCT & $\mathrm{I}$ & & & + & & + & HTCT & $\mathrm{I}$ & & & & & \\
\hline DesT & $\mathrm{I}$ & & & & & & DesT & 1 & & & & & \\
\hline DesG & $\mathrm{I}$ & & & & & & DesG & $\mathrm{I}$ & & & & & \\
\hline AECB & $\mathrm{I}$ & & & & & & AECB & $\mathrm{I}$ & & & & & \\
\hline DECB & $\mathrm{I}$ & & & & & + & DECB & $\mathrm{I}$ & ++ & & & & +++ \\
\hline DCG & $\mathrm{I}$ & ++ & + & + & ++ & + & DCG & $\mathrm{I}$ & +++ & +++ & ++ & ++ & ++ \\
\hline TR/NN & $\mathrm{I}$ & & ++ & & ++ & & TR/NN & $\mathrm{I}$ & ++ & & & & \\
\hline PAST & $\mathrm{I}$ & + & & & & & PAST & 1 & & & & ++ & + \\
\hline DFreqG & $\mathrm{I}$ & & & & & & DFreqG & $\mathrm{I}$ & & & + & & \\
\hline DilVS & $\mathrm{I}$ & & & & & & DilVS & $\mathrm{I}$ & & & & & \\
\hline ALumTub & 1 & & & & & & ALumTub & $\mathrm{I}$ & & & & & \\
\hline ObsTub & $\mathrm{I}$ & & & & & & ObsTub & $\mathrm{I}$ & & & & & \\
\hline DHS & II & & & + & & & DHS & II & & & & & \\
\hline DegT & II & + & & & & & DegT & II & ++ & & & & \\
\hline DegG & II & & & & & & DegG & II & & & & & \\
\hline DCTub & II & & & & & & DCTub & II & & & & & \\
\hline DNTub & II & & & & & & DNTub & II & & & & & \\
\hline TLCB & II & & & & & & TLCB & II & & & & & \\
\hline $\mathrm{HH}$ & II & & & & & & $\mathrm{HH}$ & II & & & & & + \\
\hline RVS & II & & & & & & RVS & II & & & & & \\
\hline $\mathrm{Nec}$ & III & & & & & & $\mathrm{Nec}$ & III & & & & & \\
\hline \multicolumn{2}{|c|}{ VMA: $2,00 \pm 0,00$} & 2 & 2 & 2 & 2 & 2 & \multicolumn{2}{|c|}{ VMA: $2,20 \pm 0,45$} & 3 & 2 & 2 & 2 & 2 \\
\hline \multicolumn{2}{|c|}{ IAH: $6,80 \pm 5,72$} & 13 & 2 & 13 & 2 & 4 & \multicolumn{2}{|c|}{ IAH: $6,20 \pm 6,22$} & 13 & 1 & 2 & 2 & 13 \\
\hline
\end{tabular}

TABELA 29 I - MOGI GUAÇU 2

\begin{tabular}{|c|c|c|c|c|c|c|c|c|c|c|c|c|c|}
\hline \multicolumn{7}{|c|}{ Serrapinnus notomelas } & \multicolumn{7}{|c|}{ Danio rerio } \\
\hline Alterações & peso & Sn1 & Sn2 & Sn3 & Sn4 & Sn5 & Alterações & peso & Dr1 & Dr2 & Dr3 & Dr4 & Dr5 \\
\hline PCTL & 1 & & & & & & PCTL & I & & & & & \\
\hline $\mathrm{DHL}$ & $\mathrm{I}$ & & & + & & & $\mathrm{DHL}$ & $\mathrm{I}$ & & & & & \\
\hline HTCT & $\mathrm{I}$ & & + & & & + & HTCT & I & & & +++ & & \\
\hline DesT & $\mathrm{I}$ & + & + & + & + & + & DesT & $\mathrm{I}$ & & & & & \\
\hline DesG & $\mathrm{I}$ & + & & ++ & + & & DesG & $\mathrm{I}$ & & & & & \\
\hline AECB & $\mathrm{I}$ & & & & & & AECB & $\mathrm{I}$ & & & & & \\
\hline DECB & $\mathrm{I}$ & & & & & & DECB & $\mathrm{I}$ & + & + & + & + & \\
\hline DCG & $\mathrm{I}$ & ++ & ++ & +++ & ++ & ++ & DCG & $\mathrm{I}$ & +++ & +++ & +++ & + & \\
\hline TR/NN & $\mathrm{I}$ & ++ & & & & & TR/NN & $\mathrm{I}$ & ++ & & & & \\
\hline PAST & $\mathrm{I}$ & & & & & & PAST & I & & & & + & + \\
\hline DFreqG & $\mathrm{I}$ & & & & & & DFreqG & $\mathrm{I}$ & & & & & + \\
\hline DilVS & $\mathrm{I}$ & & & & & & DilVS & $\mathrm{I}$ & & & & & \\
\hline ALumTub & $\mathrm{I}$ & & & & & & ALumTub & 1 & & & & & \\
\hline ObsTub & $\mathrm{I}$ & & & & & & ObsTub & $\mathrm{I}$ & & & & & \\
\hline DHS & II & & & & & & DHS & II & & & & & \\
\hline DegT & II & + & & + & & & DegT & II & + & & ++ & & ++ \\
\hline DegG & II & + & & & & & DegG & II & & & & & \\
\hline DCTub & II & & & & & & DCTub & II & & & & & \\
\hline DNTub & II & & & & & & DNTub & II & & & & & \\
\hline TLCB & II & & & & & & TLCB & II & & & & & \\
\hline $\mathrm{HH}$ & II & & & & & & $\mathrm{HH}$ & II & + & + & + & + & + \\
\hline RVS & II & & & & & & RVS & II & & & & & \\
\hline $\mathrm{Nec}$ & III & & & & & & $\mathrm{Nec}$ & III & & & & & \\
\hline \multicolumn{2}{|c|}{ VMA: $2,40 \pm 0,55$} & 3 & 2 & 3 & 2 & 2 & \multicolumn{2}{|c|}{ VMA: $2,40 \pm 0,55$} & 3 & 2 & 3 & 2 & 2 \\
\hline \multicolumn{2}{|c|}{ IAH: $9,40 \pm 9,45$} & 24 & 3 & 14 & 3 & 3 & \multicolumn{2}{|c|}{ IAH: $18,60 \pm 5,59$} & 23 & 12 & 23 & 13 & 22 \\
\hline
\end{tabular}


TABELA $29 \mathrm{~J}$ - PIRASSUNUNGA

\begin{tabular}{|c|c|c|c|c|c|c|c|c|c|c|c|c|c|}
\hline \multicolumn{7}{|c|}{ Serrapinnus notomelas } & \multicolumn{7}{|c|}{ Danio rerio } \\
\hline Alterações & peso & Sn1 & Sn2 & Sn3 & Sn4 & Sn5 & Alterações & peso & Dr1 & Dr2 & Dr3 & Dr4 & Dr5 \\
\hline PCTL & $\mathrm{I}$ & & & & & & PCTL & 1 & & & & & \\
\hline $\mathrm{DHL}$ & $\mathrm{I}$ & ++ & & & + & + & $\mathrm{DHL}$ & $\mathrm{I}$ & +++ & & & & \\
\hline HTCT & $\mathrm{I}$ & & & & & + & HTCT & $\mathrm{I}$ & & & & & \\
\hline DesT & $\mathrm{I}$ & & & & & & DesT & $\mathrm{I}$ & & & & & \\
\hline DesG & $\mathrm{I}$ & & & & & & DesG & $\mathrm{I}$ & & & & & \\
\hline AECB & $\mathrm{I}$ & & & & & & AECB & $\mathrm{I}$ & & & & & \\
\hline DECB & 1 & & + & + & & + & DECB & $\mathrm{I}$ & & & + & ++ & + \\
\hline DCG & $\mathrm{I}$ & & + & + & & + & DCG & $\mathrm{I}$ & + & + & + & +++ & + \\
\hline TR/NN & $\mathrm{I}$ & & & & & +++ & TR/NN & $\mathrm{I}$ & + & & & & \\
\hline PAST & 1 & & & & & & PAST & I & & ++ & & & \\
\hline DFreqG & $\mathrm{I}$ & & + & & & & DFreqG & $\mathrm{I}$ & + & + & & & \\
\hline DilVS & 1 & & & & & & DilVS & $\mathrm{I}$ & & & & & \\
\hline ALumTub & 1 & & & & & & ALumTub & I & & & & & \\
\hline ObsTub & I & & & & & & ObsTub & I & & & & & \\
\hline DHS & II & & & & & & DHS & II & & & & & \\
\hline DegT & II & & & & & & DegT & II & + & + & + & & \\
\hline DegG & II & & & & & & DegG & II & & & & & \\
\hline DCTub & II & & & & & & DCTub & II & & & & & \\
\hline DNTub & II & & & & & & DNTub & II & & & & & \\
\hline TLCB & II & & & & & & TLCB & II & & & & & \\
\hline $\mathrm{HH}$ & II & & & & & & $\mathrm{HH}$ & II & & & + & + & \\
\hline RVS & II & & & & & & RVS & II & & & & & \\
\hline $\mathrm{Nec}$ & III & & & & & & $\mathrm{Nec}$ & III & & & & & \\
\hline \multicolumn{2}{|c|}{ VMA: $2,00 \pm 0,00$} & 2 & 2 & 2 & 2 & 2 & \multicolumn{2}{|c|}{ VMA: $2,40 \pm 0,55$} & 3 & 2 & 3 & 2 & 2 \\
\hline \multicolumn{2}{|c|}{ IAH: $2,40 \pm 1,67$} & 1 & 3 & 2 & 1 & 5 & \multicolumn{2}{|c|}{ IAH: $12,60 \pm 7,13$} & 14 & 13 & 22 & 12 & 2 \\
\hline
\end{tabular}

TABELA $29 \mathrm{~K}$ - LUIZ ANTÔNIO 1

\begin{tabular}{|c|c|c|c|c|c|c|c|c|c|c|c|c|c|}
\hline \multicolumn{7}{|c|}{ Serrapinnus notomelas } & \multicolumn{7}{|c|}{ Danio rerio } \\
\hline Alterações & peso & Sn1 & Sn2 & Sn3 & Sn4 & Sn5 & Alterações & peso & Dr1 & Dr2 & Dr3 & Dr4 & Dr5 \\
\hline PCTL & 1 & & & & & & PCTL & $\mathrm{I}$ & & & & & \\
\hline $\mathrm{DHL}$ & $\mathrm{I}$ & & ++ & +++ & ++ & & $\mathrm{DHL}$ & $\mathrm{I}$ & +++ & & & ++ & \\
\hline HTCT & $\mathrm{I}$ & & & & + & ++ & HTCT & $\mathrm{I}$ & & & & & \\
\hline DesT & $\mathrm{I}$ & & + & & & & DesT & I & & & & & \\
\hline DesG & $\mathrm{I}$ & & & & & & DesG & $\mathrm{I}$ & & & & & \\
\hline AECB & $\mathrm{I}$ & & & & & & AECB & $\mathrm{I}$ & & & & & \\
\hline DECB & $\mathrm{I}$ & & & & & & DECB & $\mathrm{I}$ & & ++ & +++ & + & ++ \\
\hline DCG & I & + & & & & & DCG & $\mathrm{I}$ & & & & & \\
\hline TR/NN & $\mathrm{I}$ & ++++ & & ++ & & + & TR/NN & $\mathrm{I}$ & & & & & + \\
\hline PAST & 1 & & +++ & & & & PAST & I & & & + & + & \\
\hline DFreqG & 1 & & & & & & DFreqG & $\mathrm{I}$ & + & & & & \\
\hline DilVS & 1 & & & & & & DilVS & $\mathrm{I}$ & & & & & \\
\hline ALumTub & $\mathrm{I}$ & & & & & & ALumTub & I & & & & & \\
\hline ObsTub & $\mathrm{I}$ & & & & & & ObsTub & $\mathrm{I}$ & & & & & \\
\hline DHS & II & & & + & + & & DHS & II & & & & & \\
\hline DegT & II & & ++ & + & & + & DegT & II & & & & & \\
\hline DegG & II & & & & & & DegG & II & & ++ & & & \\
\hline DCTub & II & & & & & & DCTub & II & & & & & \\
\hline DNTub & II & & & & & & DNTub & II & & & & & \\
\hline TLCB & II & & & & & & TLCB & II & & & & & \\
\hline $\mathrm{HH}$ & II & & & & & & $\mathrm{HH}$ & II & & & + & + & + \\
\hline RVS & II & & & & & & RVS & II & & & & & \\
\hline $\mathrm{Nec}$ & III & & + & & & & $\mathrm{Nec}$ & III & & & & & \\
\hline \multicolumn{2}{|c|}{ VMA: $2,40 \pm 0,55$} & 2 & 3 & 3 & 2 & 2 & \multicolumn{2}{|c|}{ VMA: $2,20 \pm 0,45$} & 2 & 3 & 2 & 2 & 2 \\
\hline \multicolumn{2}{|c|}{ IAH:32,20 $\pm 45,72$} & 2 & 113 & 22 & 12 & 12 & \multicolumn{2}{|c|}{ IAH: $10,00 \pm 4,53$} & 2 & 11 & 12 & 13 & 12 \\
\hline
\end{tabular}


TABELA 29 L - LUIZ ANTÔNIO 2

\begin{tabular}{|c|c|c|c|c|c|c|c|c|c|c|c|c|c|}
\hline \multicolumn{7}{|c|}{ Serrapinnus notomelas } & \multicolumn{7}{|c|}{ Danio rerio } \\
\hline Alterações & peso & Sn1 & Sn2 & Sn3 & Sn4 & Sn5 & Alterações & peso & Dr1 & Dr2 & Dr3 & Dr4 & Dr5 \\
\hline PCTL & 1 & & & & & & PCTL & 1 & & & & & \\
\hline $\mathrm{DHL}$ & $\mathrm{I}$ & & & +++ & & ++ & $\mathrm{DHL}$ & $\mathrm{I}$ & & & + & & \\
\hline HTCT & $\mathrm{I}$ & + & & & & & HTCT & $\mathrm{I}$ & & & & & \\
\hline DesT & $\mathrm{I}$ & & & & & & DesT & I & & & & & \\
\hline DesG & $\mathrm{I}$ & & & & & & DesG & $\mathrm{I}$ & & & & & \\
\hline AECB & $\mathrm{I}$ & & & & & & AECB & I & & & & & \\
\hline DECB & $\mathrm{I}$ & & ++ & & & & DECB & 1 & & +++ & & & \\
\hline DCG & $\mathrm{I}$ & + & + & & ++ & & DCG & $\mathrm{I}$ & & & & & \\
\hline TR/NN & $\mathrm{I}$ & & & & + & +++ & TR/NN & $\mathrm{I}$ & & ++ & & & + \\
\hline PAST & 1 & & & & & & PAST & I & + & & & & \\
\hline DFreqG & $\mathrm{I}$ & & & & & & DFreqG & $\mathrm{I}$ & & & + & + & + \\
\hline DilVS & $\mathrm{I}$ & & & & & & DilVS & I & & & & & \\
\hline ALumTub & $\mathrm{I}$ & & & & & & ALumTub & $\mathrm{I}$ & & & & & \\
\hline ObsTub & $\mathrm{I}$ & & & & & & ObsTub & $\mathrm{I}$ & & & & & \\
\hline DHS & II & & & + & & & DHS & II & & & & & \\
\hline DegT & II & ++ & +++ & & & & DegT & II & & & & & \\
\hline DegG & II & & & & & & DegG & II & & & & & \\
\hline DCTub & II & & & & & & DCTub & II & & & & & \\
\hline DNTub & II & & & & & & DNTub & II & & & & & \\
\hline TLCB & II & & & & + & & TLCB & II & & & & & \\
\hline $\mathrm{HH}$ & II & & & & & & $\mathrm{HH}$ & II & + & + & + & + & \\
\hline RVS & II & & & & & & RVS & II & & & & & \\
\hline $\mathrm{Nec}$ & III & & & & & & $\mathrm{Nec}$ & III & & & & & \\
\hline \multicolumn{2}{|c|}{ VMA: $2,40 \pm 0,55$} & 3 & 3 & 2 & 2 & 2 & \multicolumn{2}{|c|}{ VMA: $2,00 \pm 0,00$} & 2 & 2 & 2 & 2 & 2 \\
\hline \multicolumn{2}{|c|}{ IAH: $9,80 \pm 4,38$} & 12 & 12 & 11 & 12 & 2 & \multicolumn{2}{|c|}{ IAH: $9,60 \pm 4,28$} & 11 & 12 & 12 & 11 & 2 \\
\hline
\end{tabular}

TABELA 29 M - TELÊMACO BORBA 1

\begin{tabular}{|c|c|c|c|c|c|c|c|c|c|c|c|c|c|}
\hline \multicolumn{7}{|c|}{ Serrapinnus notomelas } & \multicolumn{7}{|c|}{ Danio rerio } \\
\hline Alterações & peso & Sn1 & Sn2 & Sn3 & Sn4 & - & Alterações & peso & Dr1 & Dr2 & Dr3 & Dr4 & Dr5 \\
\hline PCTL & $\mathrm{I}$ & & & & & & PCTL & $\mathrm{I}$ & & & & & \\
\hline $\mathrm{DHL}$ & $\mathrm{I}$ & + & & + & + & & $\mathrm{DHL}$ & $\mathrm{I}$ & + & & & & \\
\hline HTCT & I & + & ++ & +++ & & & HTCT & I & & & & & \\
\hline DesT & $\mathrm{I}$ & & & +++ & & & DesT & $\mathrm{I}$ & & & & & \\
\hline DesG & $\mathrm{I}$ & & & & & & DesG & $\mathrm{I}$ & & & & & \\
\hline AECB & I & & & & & & AECB & I & & & & & \\
\hline DECB & $\mathrm{I}$ & & & & & & DECB & $\mathrm{I}$ & & + & + & + & +++ \\
\hline DCG & $\mathrm{I}$ & + & +++ & ++ & & & DCG & $\mathrm{I}$ & & & +++ & +++ & ++ \\
\hline TR/NN & 1 & & ++ & & + & & TR/NN & I & & & + & & \\
\hline PAST & $\mathrm{I}$ & & & & & & PAST & $\mathrm{I}$ & & & & & \\
\hline DFreqG & I & & & & & & DFreqG & I & & + & & & \\
\hline DilVS & 1 & & & & & & DilVS & I & & & & & \\
\hline ALumTub & $\mathrm{I}$ & & & & & & ALumTub & $\mathrm{I}$ & & & & & \\
\hline ObsTub & $\mathrm{I}$ & & & & & & ObsTub & $\mathrm{I}$ & & & & & \\
\hline DHS & II & & & & & & DHS & II & & & & & \\
\hline DegT & II & & & + & & & DegT & II & & & + & & \\
\hline DegG & II & & & & & & DegG & II & & & & & \\
\hline DCTub & II & & & & & & DCTub & II & & & & & \\
\hline DNTub & II & & & & & & DNTub & II & & & & & \\
\hline TLCB & II & & & & & & TLCB & II & & & & +++ & + \\
\hline $\mathrm{HH}$ & II & & & & & & $\mathrm{HH}$ & II & & + & + & + & + \\
\hline RVS & II & & & & & & RVS & II & & & & & \\
\hline $\mathrm{Nec}$ & III & & & & & & $\mathrm{Nec}$ & III & & & & & \\
\hline \multicolumn{2}{|c|}{ VMA: $2,25 \pm 0,50$} & 2 & 2 & 3 & 2 & - & \multicolumn{2}{|c|}{ VMA: $2,60 \pm 0,55$} & 2 & 2 & 3 & 3 & 3 \\
\hline \multicolumn{2}{|c|}{ IAH: $5,50 \pm 5,69$} & 3 & 3 & 14 & 2 & - & \multicolumn{2}{|c|}{ IAH: $16,00 \pm 9,51$} & 1 & 12 & 23 & 22 & 22 \\
\hline
\end{tabular}


TABELA $29 \mathrm{~N}$ - TELÊMACO BORBA 2

\begin{tabular}{|c|c|c|c|c|c|c|c|c|c|c|c|c|c|}
\hline \multicolumn{7}{|c|}{ Serrapinnus notomelas } & \multicolumn{7}{|c|}{ Danio rerio } \\
\hline Alterações & peso & Sn1 & Sn2 & Sn3 & Sn4 & Sn5 & Alterações & peso & Dr1 & Dr2 & Dr3 & Dr4 & Dr5 \\
\hline PCTL & $\mathrm{I}$ & & & & & & PCTL & 1 & & & & & \\
\hline $\mathrm{DHL}$ & $\mathrm{I}$ & +++ & ++ & + & + & ++ & $\mathrm{DHL}$ & 1 & & +++ & & & \\
\hline HTCT & $\mathrm{I}$ & & & & & & HTCT & $\mathrm{I}$ & & & & + & \\
\hline DesT & 1 & & & & & & DesT & 1 & & & & & \\
\hline DesG & $\mathrm{I}$ & & & & & & DesG & 1 & & & & & \\
\hline AECB & $\mathrm{I}$ & & & & & & AECB & $\mathrm{I}$ & & & & & \\
\hline DECB & 1 & + & & & & & DECB & 1 & + & & & & +++ \\
\hline DCG & $\mathrm{I}$ & + & & + & ++ & + & DCG & $\mathrm{I}$ & + & ++ & + & & + \\
\hline TR/NN & $\mathrm{I}$ & +++ & +++ & & & & TR/NN & $\mathrm{I}$ & ++ & & +++ & & ++ \\
\hline PAST & 1 & & & & & & PAST & 1 & & & & & \\
\hline DFreqG & $\mathrm{I}$ & & & & & & DFreqG & $\mathrm{I}$ & & & & & + \\
\hline DilVS & $\mathrm{I}$ & & & & & & DilVS & 1 & & & & & \\
\hline ALumTub & 1 & & & & & & ALumTub & 1 & & + & & & \\
\hline ObsTub & $\mathrm{I}$ & & & & & & ObsTub & 1 & & & & & \\
\hline DHS & II & + & & & & ++ & DHS & II & & + & & & \\
\hline DegT & II & + & & & & ++ & DegT & II & & & ++ & & \\
\hline DegG & II & + & & & & & DegG & II & & & & & \\
\hline DCTub & II & & & & & & DCTub & II & & & & & \\
\hline DNTub & II & & & & & & DNTub & II & & & & & \\
\hline TLCB & II & & & & & & TLCB & II & & & & & \\
\hline $\mathrm{HH}$ & II & & & & & & $\mathrm{HH}$ & II & & + & + & + & + \\
\hline RVS & II & & & & & & RVS & II & & & & & \\
\hline $\mathrm{Nec}$ & III & & & & & & $\mathrm{Nec}$ & III & & & & & \\
\hline \multicolumn{2}{|c|}{ VMA: $2,40 \pm 0,55$} & 3 & 2 & 2 & 2 & 3 & \multicolumn{2}{|c|}{ VMA: $2,40 \pm 0,55$} & 2 & 3 & 3 & 2 & 2 \\
\hline \multicolumn{2}{|c|}{ IAH: $12,40 \pm 14,86$} & 34 & 2 & 2 & 2 & 22 & \multicolumn{2}{|c|}{ IAH: $14,60 \pm 8,26$} & 3 & 23 & 22 & 11 & 14 \\
\hline
\end{tabular}

TABELA 290 - LONDRINA

\begin{tabular}{|c|c|c|c|c|c|c|c|c|c|c|c|c|c|}
\hline \multicolumn{7}{|c|}{ Serrapinnus notomelas } & \multicolumn{7}{|c|}{ Danio rerio } \\
\hline Alterações & peso & Sn1 & Sn2 & Sn3 & Sn4 & Sn5 & Alterações & peso & Dr1 & Dr2 & Dr3 & Dr4 & Dr5 \\
\hline PCTL & 1 & & & & & & PCTL & I & & & & & \\
\hline $\mathrm{DHL}$ & $\mathrm{I}$ & + & + & + & & + & $\mathrm{DHL}$ & $\mathrm{I}$ & & & & & \\
\hline HTCT & $\mathrm{I}$ & & & & & & HTCT & I & & + & & & \\
\hline DesT & $\mathrm{I}$ & & & & & & DesT & 1 & & & & & \\
\hline DesG & $\mathrm{I}$ & & & & & & DesG & 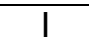 & & & & & \\
\hline AECB & $\mathrm{I}$ & & & & & & AECB & $\mathrm{I}$ & & & & & \\
\hline DECB & $\mathrm{I}$ & + & +++ & + & + & & DECB & I & ++ & & + & & \\
\hline DCG & $\mathrm{I}$ & & +++ & & & + & DCG & $\mathrm{I}$ & & & + & + & \\
\hline TR/NN & $\mathrm{I}$ & + & & & + & + & TR/NN & $\mathrm{I}$ & & & + & & \\
\hline PAST & $\mathrm{I}$ & & & & & & PAST & I & + & & & + & + \\
\hline DFreqG & $\mathrm{I}$ & & & & & & DFreqG & $\mathrm{I}$ & & & & & \\
\hline DilVS & $\mathrm{I}$ & & & & & & DilVS & $\mathrm{I}$ & & & & & \\
\hline ALumTub & I & & & & & & ALumTub & I & & & & & \\
\hline ObsTub & $\mathrm{I}$ & & & & & & ObsTub & $\mathrm{I}$ & & & & & \\
\hline DHS & II & & & & & & DHS & II & & & & & \\
\hline DegT & II & & & & & & DegT & II & & & & & \\
\hline DegG & II & & & & & & DegG & II & & & + & & \\
\hline DCTub & II & & & & & & DCTub & II & & & & & \\
\hline DNTub & II & & & & & & DNTub & II & & & & & \\
\hline TLCB & II & & & & & & TLCB & II & & & & & \\
\hline $\mathrm{HH}$ & II & & & & & & $\mathrm{HH}$ & II & & & & & \\
\hline RVS & II & & & & & & RVS & II & & & & & \\
\hline $\mathrm{Nec}$ & III & & & & & & $\mathrm{Nec}$ & III & & & & & \\
\hline \multicolumn{2}{|c|}{ VMA: $2,00 \pm 0,00$} & 2 & 2 & 2 & 2 & 2 & \multicolumn{2}{|c|}{ VMA: $2,00 \pm 0,00$} & 2 & 2 & 2 & 2 & 2 \\
\hline \multicolumn{2}{|c|}{ IAH: $2,60 \pm 0,55$} & 3 & 3 & 2 & 2 & 3 & \multicolumn{2}{|c|}{ IAH: $5,80 \pm 5,72$} & 2 & 11 & 13 & 2 & 1 \\
\hline
\end{tabular}


TABELAS 30 A a 30 O: alterações hepáticas observadas nos peixes Serrapinnus notomelas e Danio rerio expostos às localidades Ribeirão do Pinhal, Jaguari, Campinas, Sumaré, Americana, Piracicaba, São João da Boa Vista, Mogi Guaçu 1, Mogi Guaçu 2, Pirassununga, Luiz Antônio 1, Luiz Antônio 2, Telêmaco Borba 1, Telêmaco Borba 2 e Londrina. Os sinais de + indicam a freqüência de ocorrência das alterações, sendo $+=$ baixa freqüência,$++=$ média freqüência $e+++=$ alta freqüência de ocorrência da alteração. Os traços (-) indicam a não observação do órgão nos cortes.

As abreviações significam: DesCH=desorganização/descaracterização dos cordões hepáticos; PContCel=perda ou atipia do contorno dos hepatócitos; PCont Nuc=perda ou atipia do contorno do núcleo dos hepatócitos; AVolCel=aumento do volume celular; AVolNuc = aumento do volume nuclear; VacCit=vacuolização citoplasmática; DFreqNuc=diminuição da freqüência relativa de núcleos; AFreqVas=aumento da freqüência relativa de vasos; AVolVasos=aumento do volume de vasos; DimGlic=diminuição do glicogênio; EstBil=estagnação biliar; HHem=hiperemia; RupVas=ruptura de vasos; DegCanBil=degeneração de canalículos biliares; VacNuc=vacuolização nuclear; DegCit= degeneração citoplasmática; DegNuc=degeneração nuclear; AtrofNuc= atrofia nuclear; RompCel=rompimento celular.

TABELA 30 A - RIBEIRÃO DO PINHAL

\begin{tabular}{|c|c|c|c|c|c|c|c|c|c|c|c|c|c|}
\hline \multicolumn{7}{|c|}{ Serrapinnus notomelas } & \multicolumn{7}{|c|}{ Danio rerio } \\
\hline Alterações & peso & Sn1 & Sn2 & Sn3 & Sn4 & Sn5 & Alterações & peso & Dr1 & Dr2 & Dr3 & Dr4 & Dr5 \\
\hline $\mathrm{DesCH}$ & $\mathrm{I}$ & & & & & & DesCH & $\mathrm{I}$ & & & & & \\
\hline PContCel & 1 & + & + & & & & PContCel & I & & & & & \\
\hline PContNuc & $\mathrm{I}$ & & & & & & PContNuc & $\mathrm{I}$ & & & & & \\
\hline AVolCel & $\mathrm{I}$ & & & & & & AVolCel & $\mathrm{I}$ & & & & & \\
\hline AVolNuc & 1 & & & & & & AVolNuc & 1 & & & & & \\
\hline VacCit & $\mathrm{I}$ & & & & +++ & & VacCit & $\mathrm{I}$ & +++ & +++ & +++ & +++ & \\
\hline DFreqNuc & $\mathrm{I}$ & & & & & & DFreqNuc & $\mathrm{I}$ & & & & & \\
\hline AFreqVas & $\mathrm{I}$ & & & & & & AFreqVas & $\mathrm{I}$ & & & & & \\
\hline AVolVas & $\mathrm{I}$ & & & & & & AVolVas & $\mathrm{I}$ & & & & & \\
\hline DimGlic & $\mathrm{I}$ & & & & & & DimGlic & $\mathrm{I}$ & + & + & + & & + \\
\hline EstBil & I & & + & + & & & EstBil & I & & & & & \\
\hline HHem & II & & & & & & HHem & II & & & + & & \\
\hline RupVas & II & & & & & & RupVas & II & & & & & \\
\hline DegCanBil & II & & & & & & DegCanBil & II & & & & & \\
\hline VacNuc & II & & & & & & VacNuc & II & & & & & \\
\hline DegCit & II & & & & & & DegCit & II & & & & & \\
\hline DegNuc & II & & & & & & DegNuc & II & & & & & \\
\hline AtrofNuc & II & & & & & & AtrofNuc & II & & & & & \\
\hline RompCel & II & & & & & & RompCel & II & & & & & \\
\hline Necrose & III & & & & & & Necrose & III & & & & & \\
\hline \multicolumn{2}{|c|}{ VMA: $1,80 \pm 0,45$} & 2 & 2 & 2 & 2 & 1 & \multicolumn{2}{|c|}{ VMA: $2,00 \pm 0,00$} & 2 & 2 & 2 & 2 & 2 \\
\hline \multicolumn{2}{|c|}{ IAH: $1,00 \pm 0,71$} & 1 & 2 & 1 & 1 & 0 & \multicolumn{2}{|c|}{ IAH: $3,60 \pm 4,72$} & 2 & 2 & 12 & 1 & 1 \\
\hline
\end{tabular}


TABELA 30 B - LIMEIRA

\begin{tabular}{|c|c|c|c|c|c|c|c|c|c|c|c|c|c|}
\hline \multicolumn{7}{|c|}{ Serrapinnus notomelas } & \multicolumn{7}{|c|}{ Danio rerio } \\
\hline Alterações & peso & Sn1 & Sn2 & Sn3 & Sn4 & Sn5 & Alterações & peso & Dr1 & Dr2 & Dr3 & Dr4 & Dr5 \\
\hline DesCH & $\mathrm{I}$ & & & & & & DesCH & $\mathrm{I}$ & & & & & \\
\hline PContCel & 1 & & & & & & PContCel & I & & & & & \\
\hline PContNuc & $\mathrm{I}$ & & & & & & PContNuc & 1 & & & & & \\
\hline AVolCel & $\mathrm{I}$ & & & & & & AVolCel & $\mathrm{I}$ & & & & & \\
\hline AVolNuc & $\mathrm{I}$ & & & & & & AVolNuc & I & & & & & \\
\hline VacCit & 1 & & ++ & & +++ & +++ & VacCit & 1 & +++ & +++ & +++ & & +++ \\
\hline DFreqNuc & $\mathrm{I}$ & & & & & & DFreqNuc & $\mathrm{I}$ & & & & & \\
\hline AFreqVas & $\mathrm{I}$ & & & & & & AFreqVas & $\mathrm{I}$ & & & & & \\
\hline AVolVas & $\mathrm{I}$ & & & & & & AVolVas & 1 & & & & & \\
\hline DimGlic & $\mathrm{I}$ & + & + & & + & & DimGlic & $\mathrm{I}$ & + & + & + & + & + \\
\hline EstBil & 1 & + & +++ & +++ & + & + & EstBil & $\mathrm{I}$ & & & & & \\
\hline HHem & II & & & & & & HHem & II & & & & & \\
\hline RupVas & II & & & & & & RupVas & II & & & & & \\
\hline DegCanBil & II & & & & & & DegCanBil & II & & & & & \\
\hline VacNuc & II & & & + & & & VacNuc & II & & & & & \\
\hline DegCit & II & & & & & & DegCit & II & & & & & \\
\hline DegNuc & II & & & & & & DegNuc & II & & & & & \\
\hline AtrofNuc & II & & & ++ & & & AtrofNuc & II & + & & & & + \\
\hline RompCel & II & & & & & & RompCel & II & & & & & \\
\hline Necrose & III & & & & & & Necrose & III & & & & & \\
\hline \multicolumn{2}{|c|}{ VMA: $2,20 \pm 0,45$} & 2 & 2 & 3 & 2 & 2 & \multicolumn{2}{|c|}{ VMA: $2,00 \pm 0,00$} & 2 & 2 & 2 & 2 & 2 \\
\hline \multicolumn{2}{|c|}{ IAH: $6,20 \pm 8,29$} & 2 & 3 & 21 & 3 & 2 & IAH: $5,80 \pm$ & & 12 & 2 & 2 & 1 & 12 \\
\hline
\end{tabular}

TABELA $30 \mathrm{C}$ - CAMPINAS

\begin{tabular}{|c|c|c|c|c|c|c|c|c|c|c|c|c|c|}
\hline & Ser & apinn & noto & elas & & & & & Dani & rerio & & & \\
\hline Alterações & peso & Sn1 & Sn2 & Sn3 & Sn4 & Sn5 & Alterações & peso & Dr1 & Dr2 & Dr3 & Dr4 & Dr5 \\
\hline $\mathrm{DesCH}$ & $\mathrm{I}$ & & & & & & DesCH & $\mathrm{I}$ & & & & & \\
\hline PContCel & $\mathrm{I}$ & & + & & & & PContCel & 1 & & ++ & & & \\
\hline PContNuc & 1 & & & & & & PContNuc & 1 & & & & & \\
\hline AVolCel & $\mathrm{I}$ & & & & & & AVolCel & $\mathrm{I}$ & & & & & \\
\hline AVolNuc & I & & & + & & & AVolNuc & $\mathrm{I}$ & & & & & \\
\hline VacCit & 1 & & ++ & & & & VacCit & 1 & +++ & +++ & +++ & +++ & +++ \\
\hline DFreqNuc & 1 & & & & & & DFreqNuc & $\mathrm{I}$ & & & & & \\
\hline AFreqVas & $\mathrm{I}$ & & & & & & AFreqVas & 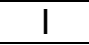 & & & & & \\
\hline AVolVas & 1 & & & & & & AVolVas & $\mathrm{I}$ & & & & & \\
\hline DimGlic & $\mathrm{I}$ & + & + & & & & DimGlic & 1 & + & + & + & + & + \\
\hline EstBil & I & + & + & ++ & ++ & +++ & EstBil & $\mathrm{I}$ & & & & & \\
\hline HHem & II & & & & & & HHem & II & & & & & \\
\hline RupVas & II & & & & & & RupVas & II & & & & & \\
\hline DegCanBil & II & & & & & & DegCanBil & II & & & & & \\
\hline VacNuc & II & + & & + & & + & VacNuc & II & & & & & \\
\hline DegCit & II & & & & & & DegCit & II & & & & & \\
\hline DegNuc & II & & & & & & DegNuc & II & & & & & \\
\hline AtrofNuc & II & & & & & & AtrofNuc & II & +++ & +++ & +++ & + & + \\
\hline RompCel & II & & & & & & RompCel & II & & & & & \\
\hline Necrose & III & & & & & & Necrose & III & & & & & \\
\hline VMA: 2,00 & $=0,00$ & 2 & 2 & 2 & 2 & 2 & VMA: 2,60 & 0,55 & 3 & 3 & 3 & 2 & 2 \\
\hline IAH: $8,00 \pm$ & 5,15 & 12 & 4 & 12 & 1 & 11 & IAH: 12,20 & 0,45 & 12 & 13 & 12 & 12 & 12 \\
\hline
\end{tabular}


TABELA $30 \mathrm{D}$ - SUMARÉ

\begin{tabular}{|c|c|c|c|c|c|c|c|c|c|c|c|c|c|}
\hline \multicolumn{7}{|c|}{ Serrapinnus notomelas } & \multicolumn{7}{|c|}{ Danio rerio } \\
\hline Alterações & peso & Sn1 & Sn2 & Sn3 & Sn4 & Sn5 & Alterações & peso & Dr1 & Dr2 & Dr3 & Dr4 & Dr5 \\
\hline DesCH & $\mathrm{I}$ & & & & & & DesCH & 1 & + & & & +++ & +++ \\
\hline PContCel & $\mathrm{I}$ & & & + & +++ & & PContCel & 1 & ++ & + & + & +++ & +++ \\
\hline PContNuc & $\mathrm{I}$ & & & & & & PContNuc & 1 & + & + & + & ++ & ++ \\
\hline AVolCel & $\mathrm{I}$ & & & & & & AVolCel & 1 & + & + & & + & \\
\hline AVolNuc & $\mathrm{I}$ & & + & ++ & + & & AVolNuc & $\mathrm{I}$ & & & + & & \\
\hline VacCit & $\mathrm{I}$ & + & ++ & + & +++ & & VacCit & 1 & +++ & +++ & ++ & +++ & ++ \\
\hline DFreqNuc & $\mathrm{I}$ & & & & & & DFreqNuc & 1 & & & & & \\
\hline AFreqVas & $\mathrm{I}$ & & & & & & AFreqVas & $\mathrm{I}$ & & & & & \\
\hline AVolVas & $\mathrm{I}$ & & & & & & AVolVas & 1 & & & & & \\
\hline DimGlic & $\mathrm{I}$ & + & + & + & + & & DimGlic & $\mathrm{I}$ & + & + & & + & + \\
\hline EstBil & $\mathrm{I}$ & + & & +++ & & + & EstBil & 1 & & & & & \\
\hline HHem & II & & & & & & HHem & II & & & & & \\
\hline RupVas & II & & & & & & RupVas & II & & & & & \\
\hline DegCanBil & II & & & & & & DegCanBil & II & & & & & \\
\hline VacNuc & II & & & & & + & VacNuc & II & & & & & \\
\hline DegCit & II & & & & & & DegCit & II & & & & & \\
\hline NúclMitót & II & + & +++ & & & & DegNuc & II & + & + & + & + & + \\
\hline AtrofNuc & II & ++ & + & ++ & +++ & + & AtrofNuc & II & +++ & +++ & + & +++ & +++ \\
\hline RompCel & II & & & & & & RompCel & II & + & & & + & \\
\hline Necrose & III & & & & & & Necrose & III & & & & & \\
\hline \multicolumn{2}{|c|}{ VMA: $3,00 \pm 0,00$} & 3 & 3 & 3 & 3 & 3 & \multicolumn{2}{|c|}{ VMA: $3,00 \pm 0,00$} & 3 & 3 & 3 & 3 & 3 \\
\hline \multicolumn{2}{|c|}{ IAH: $19,20 \pm 4,38$} & 23 & 23 & 15 & 14 & 21 & \multicolumn{2}{|c|}{ IAH: $29,40 \pm 6,50$} & 36 & 25 & 24 & 37 & 25 \\
\hline
\end{tabular}

TABELA $30 \mathrm{E}$ - AMERICANA

\begin{tabular}{|c|c|c|c|c|c|c|c|c|c|c|c|c|c|}
\hline \multicolumn{7}{|c|}{ Serrapinnus notomelas } & \multicolumn{7}{|c|}{ Danio rerio } \\
\hline Alterações & peso & Sn1 & Sn2 & Sn3 & Sn4 & Sn5 & Alterações & peso & Dr1 & Dr2 & Dr3 & Dr4 & Dr5 \\
\hline $\mathrm{DesCH}$ & $\mathrm{I}$ & & & & & & $\mathrm{DesCH}$ & $\mathrm{I}$ & & & & & \\
\hline PContCel & $\mathrm{I}$ & & & & & & PContCel & $\mathrm{I}$ & & & & & \\
\hline PContNuc & $\mathrm{I}$ & & & & & & PContNuc & 1 & & & & & \\
\hline AVolCel & $\mathrm{I}$ & & & + & & & AVolCel & $\mathrm{I}$ & & & & & \\
\hline AVolNuc & $\mathrm{I}$ & & & & & & AVolNuc & $\mathrm{I}$ & & & & & \\
\hline VacCit & 1 & + & + & ++ & ++ & ++ & VacCit & 1 & ++ & ++ & +++ & +++ & +++ \\
\hline DFreqNuc & $\mathrm{I}$ & & & & & & DFreqNuc & $\mathrm{I}$ & & & & & \\
\hline AFreqVas & $\mathrm{I}$ & & & & & & AFreqVas & $\mathrm{I}$ & & & & & \\
\hline AVolVas & $\mathrm{I}$ & & & & & & AVolVas & $\mathrm{I}$ & & & & + & + \\
\hline DimGlic & $\mathrm{I}$ & & & + & & + & DimGlic & $\mathrm{I}$ & + & + & & + & \\
\hline EstBil & $\mathrm{I}$ & + & + & & +++ & ++ & EstBil & $\mathrm{I}$ & & & & & \\
\hline HHem & II & & & & & & HHem & II & & & & & \\
\hline RupVas & II & & & & & & RupVas & II & & & & & \\
\hline DegCanBil & II & & & & & & DegCanBil & II & & & & & \\
\hline VacNuc & II & & & & & & VacNuc & II & & & & & \\
\hline DegCit & II & & & & & & DegCit & II & & & & & \\
\hline DegNuc & II & & & & & & DegNuc & II & & & & & \\
\hline AtrofNuc & II & + & + & + & & & AtrofNuc & II & ++ & & + & +++ & + \\
\hline RompCel & II & & & & & & RompCel & II & & & & & \\
\hline Necrose & III & & & & & & Necrose & III & & & & & \\
\hline \multicolumn{2}{|c|}{ VMA: $2,00 \pm 0,00$} & 2 & 2 & 2 & 2 & 2 & \multicolumn{2}{|c|}{ VMA: $2,40 \pm 0,55$} & 3 & 2 & 2 & 3 & 2 \\
\hline \multicolumn{2}{|c|}{ IAH: $8,40 \pm 5,41$} & 12 & 12 & 13 & 2 & 3 & IAH: 10,00 & $-4,53$ & 12 & 2 & 11 & 13 & 12 \\
\hline
\end{tabular}


TABELA $30 \mathrm{~F}$ - PIRACICABA

\begin{tabular}{|c|c|c|c|c|c|c|c|c|c|c|c|c|c|}
\hline \multicolumn{7}{|c|}{ Serrapinnus notomelas } & \multicolumn{7}{|c|}{ Danio rerio } \\
\hline Alterações & peso & Sn1 & $\mathrm{Sn} 2$ & Sn3 & Sn4 & Sn5 & Alterações & peso & Dr1 & Dr2 & Dr3 & Dr4 & Dr5 \\
\hline DesCH & $\mathrm{I}$ & & & & & + & DesCH & $\mathrm{I}$ & & & + & & \\
\hline PContCel & $\mathrm{I}$ & & & & + & & PContCel & $\mathrm{I}$ & + & + & + & + & + \\
\hline PContNuc & $\mathrm{I}$ & & & & & & PContNuc & 1 & & + & + & & \\
\hline AVolCel & $\mathrm{I}$ & & & & & & AVolCel & $\mathrm{I}$ & & & & & \\
\hline AVolNuc & $\mathrm{I}$ & & + & & + & + & AVolNuc & 1 & & & & & \\
\hline VacCit & 1 & ++ & ++ & ++ & ++ & ++ & VacCit & 1 & +++ & +++ & +++ & +++ & +++ \\
\hline DFreqNuc & $\mathrm{I}$ & + & & & & & DFreqNuc & 1 & & & & & \\
\hline AFreqVas & $\mathrm{I}$ & & & & & & AFreqVas & $\mathrm{I}$ & & & & & \\
\hline AVolVas & $\mathrm{I}$ & & & & & & AVolVas & 1 & & & & & \\
\hline DimGlic & $\mathrm{I}$ & + & + & ++ & + & & DimGlic & $\mathrm{I}$ & & + & + & + & + \\
\hline EstBil & 1 & ++ & & + & ++++ & ++++ & EstBil & 1 & & & & & \\
\hline HHem & II & & & & & & HHem & II & & & & & \\
\hline RupVas & II & & & & & & RupVas & II & & & & & \\
\hline DegCanBil & II & & & & & & DegCanBil & II & & & & & \\
\hline VacNuc & II & & & & & & VacNuc & II & & & & & \\
\hline DegCit & II & & & & & & DegCit & II & & & & & \\
\hline DegNuc & II & & & & & & DegNuc & II & & & & & \\
\hline AtrofNuc & II & & + & + & ++ & ++ & AtrofNuc & II & +++ & +++ & +++ & +++ & + \\
\hline RompCel & II & & & & & & RompCel & II & & & & & \\
\hline Necrose & III & & & & & & Necrose & III & & & & & \\
\hline \multicolumn{2}{|c|}{ VMA: $2,40 \pm 0,55$} & 2 & 2 & 2 & 3 & 3 & \multicolumn{2}{|c|}{ VMA: $2,80 \pm 0,45$} & 3 & 3 & 3 & 3 & 2 \\
\hline \multicolumn{2}{|c|}{ IAH: $11,80 \pm 4,44$} & 4 & 13 & 13 & 15 & 14 & \multicolumn{2}{|c|}{ IAH: $13,40 \pm 1,14$} & 12 & 14 & 15 & 13 & 13 \\
\hline
\end{tabular}

TABELA 30 G - SÃO JOÃO DA BOA VISTA

\begin{tabular}{|c|c|c|c|c|c|c|c|c|c|c|c|c|c|}
\hline \multicolumn{7}{|c|}{ Serrapinnus notomelas } & \multicolumn{7}{|c|}{ Danio rerio } \\
\hline Alterações & peso & Sn1 & $\mathrm{Sn} 2$ & Sn3 & Sn4 & Sn5 & Alterações & peso & Dr1 & Dr2 & Dr3 & Dr4 & Dr5 \\
\hline $\mathrm{DesCH}$ & $\mathrm{I}$ & & & & & & DesCH & $\mathrm{I}$ & & & & & \\
\hline PContCel & $\mathrm{I}$ & & & & & & PContCel & $\mathrm{I}$ & & & & & \\
\hline PContNuc & $\mathrm{I}$ & & + & + & & & PContNuc & $\mathrm{I}$ & & & & & \\
\hline AVolCel & $\mathrm{I}$ & & & & & & AVolCel & $\mathrm{I}$ & & & & & \\
\hline AVolNuc & $\mathrm{I}$ & & & & & & AVolNuc & $\mathrm{I}$ & & & & & \\
\hline VacCit & $\mathrm{I}$ & +++ & & +++ & & & VacCit & $\mathrm{I}$ & +++ & +++ & & & \\
\hline DFreqNuc & $\mathrm{I}$ & & & & & & DFreqNuc & $\mathrm{I}$ & & & & & \\
\hline AFreqVas & $\mathrm{I}$ & & & & & & AFreqVas & $\mathrm{I}$ & & & & & \\
\hline AVolVas & 1 & & & & & & AVolVas & $\mathrm{I}$ & & & & & \\
\hline DimGlic & $\mathrm{I}$ & & & & & & DimGlic & $\mathrm{I}$ & & & & & \\
\hline EstBil & I & & & & & +++ & EstBil & I & & & & & \\
\hline HHem & II & & & & & & HHem & II & & & & & \\
\hline RupVas & II & & & & & & RupVas & II & & & & & \\
\hline DegCanBil & II & & & & & & DegCanBil & II & & & & & \\
\hline VacNuc & II & & & & & & VacNuc & II & & & & & \\
\hline DegCit & II & & & & & & DegCit & II & & & & & \\
\hline DegNuc & II & & & & & & DegNuc & II & & & & & \\
\hline AtrofNuc & II & & & & & & AtrofNuc & II & & & & & \\
\hline RompCel & II & & & & & & RompCel & II & & & & & \\
\hline Necrose & III & & & & & & Necrose & III & & & & & \\
\hline \multicolumn{2}{|c|}{ VMA: $1,80 \pm 0,45$} & 2 & 2 & 2 & 1 & 2 & \multicolumn{2}{|c|}{ VMA: $1,40 \pm 0,55$} & 2 & 2 & 1 & 1 & 1 \\
\hline \multicolumn{2}{|c|}{ IAH: $1,00 \pm 0,71$} & 1 & 1 & 2 & 0 & 1 & \multicolumn{2}{|c|}{ IAH: $0,40 \pm 0,55$} & 1 & 1 & 0 & 0 & 0 \\
\hline
\end{tabular}


TABELA 30 H - MOGI GUAÇU 1

\begin{tabular}{|c|c|c|c|c|c|c|c|c|c|c|c|c|c|}
\hline \multicolumn{7}{|c|}{ Serrapinnus notomelas } & \multicolumn{7}{|c|}{ Danio rerio } \\
\hline Alterações & peso & Sn1 & Sn2 & Sn3 & Sn4 & Sn5 & Alterações & peso & Dr1 & Dr2 & Dr3 & Dr4 & Dr5 \\
\hline DesCH & 1 & & & & & & $\mathrm{DesCH}$ & $\mathrm{I}$ & & & & & \\
\hline PContCel & I & & & & & & PContCel & I & & & & & \\
\hline PContNuc & I & & & & & & PContNuc & I & & & & & \\
\hline AVolCel & I & & & & & & AVolCel & I & & & & & \\
\hline AVolNuc & I & & & & & & AVolNuc & $\mathrm{I}$ & & & & & \\
\hline VacCit & I & & + & + & & +++ & VacCit & I & +++ & +++ & +++ & +++ & +++ \\
\hline DFreqNuc & I & & & & & & DFreqNuc & $\mathrm{I}$ & & & & & \\
\hline AFreqVas & I & & & & & & AFreqVas & I & & & & & \\
\hline AVolVas & I & & & & & & AVolVas & I & & & & & \\
\hline DimGlic & I & & & & & & DimGlic & I & & + & & + & + \\
\hline EstBil & I & + & ++ & ++ & & ++ & EstBil & I & & & & & \\
\hline HHem & II & & & & & & HHem & II & & & & & \\
\hline RupVas & II & & & & & & RupVas & II & & & & & \\
\hline DegCanBil & II & & & & & & DegCanBil & II & & & & & \\
\hline VacNuc & II & & & & & & VacNuc & II & & & & & \\
\hline DegCit & II & & & & & & DegCit & II & & & & & \\
\hline DegNuc & II & & & & & & DegNuc & II & & & & + & \\
\hline AtrofNuc & II & & & & & & AtrofNuc & II & & & & & \\
\hline RompCel & II & & & & & & RompCel & II & & & & & \\
\hline Necrose & III & & & & & & Necrose & III & & & & & \\
\hline \multicolumn{2}{|c|}{ VMA: $1,80 \pm 0,45$} & 2 & 2 & 2 & 1 & 2 & \multicolumn{2}{|c|}{ VMA: $2,00 \pm 0,00$} & 2 & 2 & 2 & 2 & 2 \\
\hline \multicolumn{2}{|c|}{ 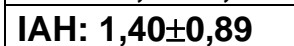 } & 1 & 2 & 2 & 0 & 2 & \multicolumn{2}{|c|}{ IAH: $3,60 \pm 4,72$} & 1 & 2 & 1 & 12 & 2 \\
\hline
\end{tabular}

TABELA 30 I - MOGI GUAÇU 2

\begin{tabular}{|c|c|c|c|c|c|c|c|c|c|c|c|c|c|}
\hline \multicolumn{7}{|c|}{ Serrapinnus notomelas } & \multicolumn{7}{|c|}{ Danio rerio } \\
\hline Alterações & peso & Sn1 & Sn2 & Sn3 & Sn4 & Sn5 & Alterações & peso & Dr1 & Dr2 & Dr3 & Dr4 & Dr5 \\
\hline DesCH & $\mathrm{I}$ & & & & & & DesCH & $\mathrm{I}$ & & & +++ & & \\
\hline PContCel & $\mathrm{I}$ & & + & & & & PContCel & 1 & + & & ++ & & \\
\hline PContNuc & $\mathrm{I}$ & & + & & & & PContNuc & 1 & & & + & & \\
\hline AVolCel & $\mathrm{I}$ & & & & & & AVolCel & 1 & & & ++ & & \\
\hline AVolNuc & $\mathrm{I}$ & & & & & & AVolNuc & $\mathrm{I}$ & & & ++ & & \\
\hline VacCit & $\mathrm{I}$ & + & ++ & ++ & +++ & + & VacCit & 1 & +++ & ++ & ++ & + & +++ \\
\hline DFreqNuc & $\mathrm{I}$ & & & + & & + & DFreqNuc & $\mathrm{I}$ & + & & & & \\
\hline AFreqVas & $\mathrm{I}$ & & & & & & AFreqVas & $\mathrm{I}$ & & & & & \\
\hline AVolVas & $\mathrm{I}$ & & & & & & AVolVas & 1 & & & & & \\
\hline DimGlic & $\mathrm{I}$ & & & & & & DimGlic & $\mathrm{I}$ & + & & & & \\
\hline EstBil & $\mathrm{I}$ & & + & + & +++ & & EstBil & $\mathrm{I}$ & + & & & & \\
\hline HHem & II & & & & & & HHem & II & & & & & \\
\hline RupVas & II & & & & & & RupVas & II & & & & & \\
\hline DegCanBil & II & & & & & & DegCanBil & II & & & & & \\
\hline VacNuc & II & & & & & & VacNuc & II & & & & & \\
\hline DegCit & II & & & & & & DegCit & II & & & + & & + \\
\hline DegNuc & II & & & & & & DegNuc & II & +++ & ++ & & & + \\
\hline AtrofNuc & II & & & & & & AtrofNuc & II & & & ++ & & \\
\hline RompCel & II & & & & & & RompCel & II & & & ++ & & \\
\hline Necrose & III & & & & & & Necrose & III & & & + & & \\
\hline \multicolumn{2}{|c|}{ VMA: $2,00 \pm 0,00$} & 2 & 2 & 2 & 2 & 2 & \multicolumn{2}{|c|}{ VMA: $2,40 \pm 0,55$} & 3 & 3 & 2 & 2 & 2 \\
\hline \multicolumn{2}{|c|}{ IAH: $2,60 \pm 1,14$} & 1 & 4 & 3 & 3 & 2 & \multicolumn{2}{|c|}{ 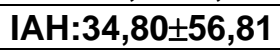 } & 15 & 11 & 136 & 1 & 11 \\
\hline
\end{tabular}


TABELA $30 \mathrm{~J}$ - PIRASSUNUNGA

\begin{tabular}{|c|c|c|c|c|c|c|c|c|c|c|c|c|c|}
\hline \multicolumn{7}{|c|}{ Serrapinnus notomelas } & \multicolumn{7}{|c|}{ Danio rerio } \\
\hline Alterações & peso & Sn1 & Sn2 & Sn3 & Sn4 & Sn5 & Alterações & peso & Dr1 & Dr2 & Dr3 & Dr4 & Dr5 \\
\hline DesCH & 1 & & & & & & $\mathrm{DesCH}$ & $\mathrm{I}$ & & & & & \\
\hline PContCel & I & & ++ & & & & PContCel & I & & & & & \\
\hline PContNuc & I & & & & & & PContNuc & I & & & & & \\
\hline AVolCel & I & & & & & & AVolCel & I & & & & & \\
\hline AVolNuc & I & & & & & & AVolNuc & I & & & & & \\
\hline VacCit & I & + & +++ & & & & VacCit & I & +++ & +++ & +++ & +++ & +++ \\
\hline DFreqNuc & I & & & & & & DFreqNuc & $\mathrm{I}$ & & & & & \\
\hline AFreqVas & I & & & & & & AFreqVas & I & & & & & \\
\hline AVolVas & I & & & & & & AVolVas & I & & & & & \\
\hline DimGlic & I & & & & & & DimGlic & I & & + & & & \\
\hline EstBil & I & ++ & ++ & + & + & & EstBil & I & & & & & \\
\hline HHem & II & & & & & & HHem & II & & & & & \\
\hline RupVas & II & & & & & & RupVas & II & & & & & \\
\hline DegCanBil & II & & & & & & DegCanBil & II & & & & & \\
\hline VacNuc & II & & & & & & VacNuc & II & & & & & \\
\hline DegCit & II & & & & & & DegCit & II & & & & & \\
\hline DegNuc & II & & & & & & DegNuc & II & & & & & \\
\hline AtrofNuc & II & & & & & & AtrofNuc & II & & & & & \\
\hline RompCel & II & & & & & & RompCel & II & & & & & \\
\hline Necrose & III & & & & & & Necrose & III & & & & & \\
\hline \multicolumn{2}{|c|}{ VMA: $1,80 \pm 0,45$} & 2 & 2 & 2 & 2 & 1 & \multicolumn{2}{|c|}{ VMA: $2,00 \pm 0,00$} & 2 & 2 & 2 & 2 & 2 \\
\hline \multicolumn{2}{|c|}{ 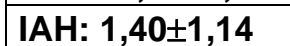 } & 2 & 3 & 1 & 1 & 0 & \multicolumn{2}{|c|}{ IAH: $1,20 \pm 0,45$} & 1 & 2 & 1 & 1 & 1 \\
\hline
\end{tabular}

TABELA $30 \mathrm{~K}$ - LUIZ ANTÔNIO 1

\begin{tabular}{|c|c|c|c|c|c|c|c|c|c|c|c|c|c|}
\hline \multicolumn{7}{|c|}{ Serrapinnus notomelas } & \multicolumn{7}{|c|}{ Danio rerio } \\
\hline Alterações & peso & Sn1 & Sn2 & Sn3 & Sn4 & Sn5 & Alterações & peso & Dr1 & Dr2 & Dr3 & Dr4 & Dr5 \\
\hline DesCH & $\mathrm{I}$ & & & & & & DesCH & 1 & & & & & \\
\hline PContCel & $\mathrm{I}$ & + & & & & & PContCel & 1 & & & & & \\
\hline PContNuc & $\mathrm{I}$ & & & & & & PContNuc & 1 & & & & & \\
\hline AVolCel & $\mathrm{I}$ & & & & & & AVolCel & 1 & & & & & \\
\hline AVolNuc & $\mathrm{I}$ & & & & & & AVolNuc & $\mathrm{I}$ & & & & & \\
\hline VacCit & I & ++ & +++ & & + & +++ & VacCit & 1 & ++ & ++ & + & +++ & +++ \\
\hline DFreqNuc & $\mathrm{I}$ & & & & & & DFreqNuc & $\mathrm{I}$ & & & & & \\
\hline AFreqVas & $\mathrm{I}$ & & & & & & AFreqVas & $\mathrm{I}$ & & & & & \\
\hline AVolVas & 1 & & & & & & AVolVas & 1 & & & & & \\
\hline DimGlic & $\mathrm{I}$ & & & & & + & DimGlic & 1 & & & + & & \\
\hline EstBil & $\mathrm{I}$ & & & & & & EstBil & $\mathrm{I}$ & & & & & \\
\hline HHem & II & & & & & & HHem & II & & & & & \\
\hline RupVas & II & & & & & & RupVas & II & & & & & \\
\hline DegCanBil & II & & & & & & DegCanBil & II & & & & & \\
\hline VacNuc & II & & & & & & VacNuc & II & & & & & \\
\hline DegCit & II & & & & & & DegCit & II & & & & & \\
\hline DegNuc & II & & + & & + & ++ & DegNuc & II & & & & & \\
\hline AtrofNuc & II & & & & & & AtrofNuc & II & & & & & \\
\hline RompCel & II & & & & & & RompCel & II & & & & & \\
\hline Necrose & III & & & & & & Necrose & III & & & & & \\
\hline \multicolumn{2}{|c|}{ VMA: $2,00 \pm 0,71$} & 2 & 2 & 1 & 2 & 3 & \multicolumn{2}{|c|}{ VMA: $2,00 \pm 0,00$} & 2 & 2 & 2 & 2 & 2 \\
\hline \multicolumn{2}{|c|}{ IAH: $7,20 \pm 5,72$} & 2 & 11 & 0 & 11 & 12 & \multicolumn{2}{|c|}{ IAH: $1,20 \pm 0,45$} & 1 & 1 & 2 & 1 & 1 \\
\hline
\end{tabular}


TABELA $30 \mathrm{~L}$ - LUIZ ANTÔNIO 2

\begin{tabular}{|c|c|c|c|c|c|c|c|c|c|c|c|c|c|}
\hline \multicolumn{7}{|c|}{ Serrapinnus notomelas } & \multicolumn{7}{|c|}{ Danio rerio } \\
\hline Alterações & peso & Sn1 & Sn2 & Sn3 & Sn4 & Sn5 & Alterações & peso & Dr1 & Dr2 & Dr3 & Dr4 & Dr5 \\
\hline $\mathrm{DesCH}$ & $\mathrm{I}$ & & & & & & DesCH & $\mathrm{I}$ & & & & & \\
\hline PContCel & $\mathrm{I}$ & & & & & & PContCel & $\mathrm{I}$ & & & & & \\
\hline PContNuc & I & & & & & & PContNuc & I & & & & & \\
\hline AVolCel & $\mathrm{I}$ & & & & & & AVolCel & $\mathrm{I}$ & & & & & \\
\hline AVolNuc & 1 & & & & & & AVolNuc & $\mathrm{I}$ & & & & & \\
\hline VacCit & 1 & ++ & & + & + & ++ & VacCit & I & + & +++ & +++ & +++ & + \\
\hline DFreqNuc & $\mathrm{I}$ & & & & & & DFreqNuc & $\mathrm{I}$ & & & & & \\
\hline AFreqVas & $\mathrm{I}$ & & & & & & AFreqVas & $\mathrm{I}$ & & & & & \\
\hline AVolVas & I & & & & & & AVolVas & I & & & & & \\
\hline DimGlic & $\mathrm{I}$ & & & & & & DimGlic & $\mathrm{I}$ & & & & + & \\
\hline EstBil & $\mathrm{I}$ & ++ & + & & + & ++ & EstBil & $\mathrm{I}$ & & & & & \\
\hline HHem & II & & & & & & HHem & II & & & & & \\
\hline RupVas & II & & & & & & RupVas & II & & & & & \\
\hline DegCanBil & II & & & & & & DegCanBil & II & & & & & \\
\hline VacNuc & II & & +++ & & & & VacNuc & II & & + & ++ & ++ & \\
\hline DegCit & II & & & & & & DegCit & II & & & & & \\
\hline DegNuc & II & & & & & & DegNuc & II & & & & & \\
\hline AtrofNuc & II & & & & & & AtrofNuc & II & & & & & \\
\hline RompCel & II & & & & & & RompCel & II & & & & & \\
\hline Necrose & III & & & & & & Necrose & III & & & & & \\
\hline \multicolumn{2}{|c|}{ VMA: $2,20 \pm 0,45$} & 2 & 3 & 2 & 2 & 2 & \multicolumn{2}{|c|}{ VMA: $2,40 \pm 0,55$} & 2 & 2 & 3 & 3 & 2 \\
\hline \multicolumn{2}{|c|}{ IAH: $3,60 \pm 4,16$} & 2 & 11 & 1 & 2 & 2 & \multicolumn{2}{|c|}{ IAH: $7,20 \pm 5,67$} & 1 & 11 & 11 & 12 & 1 \\
\hline
\end{tabular}

TABELA $30 \mathrm{M}$ - TELÊMACO BORBA 1

\begin{tabular}{|c|c|c|c|c|c|c|c|c|c|c|c|c|c|}
\hline \multicolumn{7}{|c|}{ Serrapinnus notomelas } & \multicolumn{7}{|c|}{ Danio rerio } \\
\hline Alterações & peso & Sn1 & Sn2 & Sn3 & Sn4 & Sn5 & Alterações & peso & Dr1 & Dr2 & Dr3 & Dr4 & Dr5 \\
\hline DesCH & $\mathrm{I}$ & & & & & & DesCH & 1 & & & & & \\
\hline PContCel & $\mathrm{I}$ & & & & & & PContCel & 1 & & & & & \\
\hline PContNuc & $\mathrm{I}$ & & & & & & PContNuc & 1 & & & & & \\
\hline AVolCel & $\mathrm{I}$ & + & & & & & AVolCel & 1 & & & & & \\
\hline AVolNuc & $\mathrm{I}$ & + & & & & & AVolNuc & $\mathrm{I}$ & & & & & \\
\hline VacCit & I & ++ & ++ & & + & ++ & VacCit & 1 & +++ & +++ & +++ & +++ & +++ \\
\hline DFreqNuc & $\mathrm{I}$ & & & & & & DFreqNuc & $\mathrm{I}$ & & & & & \\
\hline AFreqVas & $\mathrm{I}$ & & & & & & AFreqVas & $\mathrm{I}$ & & & & & \\
\hline AVolVas & 1 & & & & & & AVolVas & 1 & & & & & \\
\hline DimGlic & $\mathrm{I}$ & & & $\begin{array}{ll}++ \\
++\end{array}$ & ++ & & DimGlic & 1 & & + & + & + & + \\
\hline EstBil & $\mathrm{I}$ & & & + & & ++ & EstBil & $\mathrm{I}$ & & & & & \\
\hline HHem & II & & & & & & HHem & II & & & & & \\
\hline RupVas & II & & & & & & RupVas & II & & & & & \\
\hline DegCanBil & II & & & & & & DegCanBil & II & & & & & \\
\hline VacNuc & II & & & & & & VacNuc & II & & & & & \\
\hline DegCit & II & & & & & & DegCit & II & & & & & \\
\hline DegNuc & II & & & & + & & DegNuc & II & & & & & \\
\hline AtrofNuc & II & & & & & & AtrofNuc & II & & & & & \\
\hline RompCel & II & & & & & & RompCel & II & & & & & \\
\hline Necrose & III & & & & & & Necrose & III & & & & & \\
\hline \multicolumn{2}{|c|}{ VMA: $2,00 \pm 0,00$} & 2 & 2 & 2 & 2 & 2 & \multicolumn{2}{|c|}{ VMA: $2,00 \pm 0,00$} & 2 & 2 & 2 & 2 & 2 \\
\hline \multicolumn{2}{|c|}{ IAH: $4,00 \pm 4,53$} & 3 & 1 & 2 & 12 & 2 & \multicolumn{2}{|c|}{ IAH: $1,80 \pm 0,45$} & 1 & 2 & 2 & 2 & 2 \\
\hline
\end{tabular}


TABELA $30 \mathrm{~N}$ - TELÊMACO BORBA 2

\begin{tabular}{|c|c|c|c|c|c|c|c|c|c|c|c|c|c|}
\hline \multicolumn{7}{|c|}{ Serrapinnus notomelas } & \multicolumn{7}{|c|}{ Danio rerio } \\
\hline Alterações & peso & Sn1 & Sn2 & Sn3 & Sn4 & Sn5 & Alterações & peso & Dr1 & Dr2 & Dr3 & Dr4 & Dr5 \\
\hline DesCH & 1 & & & & & & $\mathrm{DesCH}$ & $\mathrm{I}$ & & & & & \\
\hline PContCel & I & + & & & & & PContCel & $\mathrm{I}$ & & & & & \\
\hline PContNuc & I & & & & & & PContNuc & I & & & & & \\
\hline AVolCel & I & & & & & & AVolCel & I & & & & & \\
\hline AVolNuc & I & & & & & & AVolNuc & I & & & & & \\
\hline VacCit & I & ++ & +++ & ++ & +++ & ++ & VacCit & I & +++ & +++ & +++ & +++ & +++ \\
\hline DFreqNuc & I & & & & & & DFreqNuc & I & & & & & \\
\hline AFreqVas & I & & & & & & AFreqVas & I & & & & & \\
\hline AVolVas & I & & & & & & AVolVas & I & & & & & \\
\hline DimGlic & I & & + & & & & DimGlic & I & & + & + & & \\
\hline EstBil & I & & & & +++ & +++ & EstBil & I & & & & & \\
\hline HHem & II & & & & & & HHem & II & & & & & \\
\hline RupVas & II & & & & & & RupVas & II & & & & & \\
\hline DegCanBil & II & & & & & & DegCanBil & II & & & & & \\
\hline VacNuc & II & & & & & & VacNuc & II & & & & & \\
\hline DegCit & II & & & & & & DegCit & II & & & & & \\
\hline DegNuc & II & & & & & & DegNuc & II & & & & & \\
\hline AtrofNuc & II & & & & & & AtrofNuc & II & & & & & \\
\hline RompCel & II & & & & & & RompCel & II & & & & & \\
\hline Necrose & III & & & & & & Necrose & III & & & & & \\
\hline \multicolumn{2}{|c|}{ VMA: $2,00 \pm 0,00$} & 2 & 2 & 2 & 2 & 2 & \multicolumn{2}{|c|}{ VMA: $2,00 \pm 0,00$} & 2 & 2 & 2 & 2 & 2 \\
\hline \multicolumn{2}{|c|}{ IAH: $1,40 \pm 0,55$} & 1 & 2 & 2 & 1 & 1 & \multicolumn{2}{|c|}{ IAH: $1,40 \pm 0,55$} & 1 & 2 & 2 & 1 & 1 \\
\hline
\end{tabular}

TABELA 300 - LONDRINA

\begin{tabular}{|c|c|c|c|c|c|c|c|c|c|c|c|c|c|}
\hline \multicolumn{7}{|c|}{ Serrapinnus notomelas } & \multicolumn{7}{|c|}{ Danio rerio } \\
\hline Alterações & peso & Sn1 & Sn2 & Sn3 & Sn4 & Sn5 & Alterações & peso & Dr1 & Dr2 & Dr3 & Dr4 & Dr5 \\
\hline DesCH & $\mathrm{I}$ & & & & & & DesCH & 1 & & & & & \\
\hline PContCel & $\mathrm{I}$ & & & & & & PContCel & 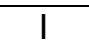 & & & & & \\
\hline PContNuc & $\mathrm{I}$ & & & & & & PContNuc & 1 & & & & & \\
\hline AVolCel & $\mathrm{I}$ & & & & & & AVolCel & 1 & & & & & \\
\hline \begin{tabular}{|l} 
AVolNuc \\
\end{tabular} & $\mathrm{I}$ & & & & & & AVolNuc & 1 & & & & & \\
\hline VacCit & I & + & + & + & ++ & ++ & VacCit & 1 & +++ & +++ & +++ & +++ & +++ \\
\hline DFreqNuc & $\mathrm{I}$ & & & & & & DFreqNuc & 1 & & & & & \\
\hline AFreqVas & $\mathrm{I}$ & & & & & & AFreqVas & $\mathrm{I}$ & & & & & \\
\hline AVolVas & $\mathrm{I}$ & & & & & & AVolVas & 1 & & & & & \\
\hline DimGlic & $\mathrm{I}$ & & & & + & & DimGlic & 1 & + & + & + & + & + \\
\hline EstBil & 1 & ++ & ++ & +++ & & + & EstBil & 1 & & & & & \\
\hline HHem & II & & & & & & HHem & II & & & & & \\
\hline RupVas & II & & & & & & RupVas & II & & & & & \\
\hline DegCanBil & II & & & & & & DegCanBil & II & & & & & \\
\hline VacNuc & II & & & & & & VacNuc & II & & & & & \\
\hline DegCit & II & & & & & & DegCit & II & & & & & \\
\hline DegNuc & II & & & & & & DegNuc & II & & & & & \\
\hline AtrofNuc & II & & & & & & AtrofNuc & II & & & & & \\
\hline RompCel & II & & & & & & RompCel & II & & & & & \\
\hline Necrose & III & & & & & & Necrose & III & & & & & \\
\hline \multicolumn{2}{|c|}{ VMA: $2,00 \pm 0,00$} & 2 & 2 & 2 & 2 & 2 & \multicolumn{2}{|c|}{ VMA: $2,00 \pm 0,00$} & 2 & 2 & 2 & 2 & 2 \\
\hline \multicolumn{2}{|c|}{ IAH: $2,00 \pm 0,00$} & 2 & 2 & 2 & 2 & 2 & \multicolumn{2}{|c|}{ IAH: $2,00 \pm 0,00$} & 2 & 2 & 2 & 2 & 2 \\
\hline
\end{tabular}


TABELA 31: Alterações branquiais observadas no peixe Serrapinnus notomelas exposto às concentrações $0 \%$ (controle), 5\%, 20\%, 60\% e 100\% do efluente final de indústria de papel e celulose. Os sinais de + indicam a freqüência de ocorrência das alterações, sendo $+=$ baixa freqüência, $++=$ média freqüência $e+++=$ alta freqüência de ocorrência da alteração.

As abreviações significam: HTCE=hipertrofia das células epiteliais; AdE=adelgamento do epitélio; ELS=elevação do epitélio da lamela scundária (LS); HPBLS: hiperplasia na base das LS.; HPLS=hiperplasia ao longo das LS.; LeuELS= presença de leucócitos; HP/HTCM=hiperplasia/trofia das céls. mucosas; HP/HTCC= hiperplasia/trofia das céls. cloreto; CCLS=céls cloreto nas LS; MuLS=presença de muco entre as LS; DiC=dilatação de capilares; DeC=desorganização de capilares; CV=congestão vascular; Par=presença de parasitas; FCalgLS=fusão completa de algumas LS; FCtodLS=fusão completa de toas as LS; $\mathrm{DC}=$ degeneração celular: RE=ruptura epitelial; Hem=hemorragia; An=aneurisma; Fib=fibrose; $\mathrm{N}=$ necrose.

\begin{tabular}{|c|c|c|c|c|c|c|c|c|c|c|c|c|c|}
\hline \multicolumn{7}{|c|}{ CONTROLE } & \multicolumn{7}{|l|}{$5 \%$} \\
\hline Alterações & peso & Sn1 & Sn2 & Sn3 & Sn4 & Sn5 & Alterações & peso & Sn1 & Sn2 & Sn3 & Sn4 & Sn5 \\
\hline HTCE & 1 & & & & & & HTCE & 1 & & & & & \\
\hline AdE & $\mathrm{I}$ & & & & & & AdE & $\mathrm{I}$ & & & & & \\
\hline ELS & 1 & + & & ++ & & + & ELS & I & ++ & ++ & +++ & + & ++ \\
\hline HPBLS & 1 & + & & ++ & & & HPBLS & 1 & & & + & & \\
\hline HPLS & 1 & & & & & & HPLS & I & & & & & \\
\hline FPLS & 1 & & & + & & & FPLS & I & & & + & & \\
\hline LeuELS & 1 & & & & & & LeuELS & 1 & & & & & \\
\hline HP/HTCM & $\mathrm{I}$ & & & & & & HP/HTCM & I & ++ & & & & \\
\hline HP/HTCC & 1 & & & & & & HP/HTCC & 1 & + & & & & \\
\hline CCLS & 1 & & & & & & CCLS & 1 & & & & & \\
\hline MuLS & $\mathrm{I}$ & & & & & & MuLS & I & & & & & \\
\hline $\mathrm{DiC}$ & 1 & & & & & & DiC & 1 & & & & & \\
\hline $\mathrm{DeC}$ & $\mathrm{I}$ & & & & & & $\mathrm{DeC}$ & I & & & & & \\
\hline $\mathrm{CV}$ & $\mathrm{I}$ & & + & ++ & & & CV & $\mathrm{I}$ & + & ++ & ++ & ++ & + \\
\hline Par & 1 & & & & & & Par & I & & & & & \\
\hline FCalgLS & $\mathrm{I}$ & & & & & & FCalgLS & 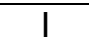 & & & & & \\
\hline FCtodLS & II & & & & & & FCtodLS & II & & & & & \\
\hline $\mathrm{DC}$ & II & & & & & & DC & II & & & & & \\
\hline $\mathrm{RE}$ & II & & & & & & RE & II & & & & & \\
\hline Hem & II & & & & & & Hem & II & & & & & \\
\hline An & II & & & & & & An & II & & & & & \\
\hline Fib & III & & & & & & Fib & III & & & & & \\
\hline $\mathrm{NeC}$ & III & & & & & & $\mathrm{Nec}$ & III & & & & & \\
\hline \multicolumn{2}{|c|}{ VMA: $1,80 \pm 0,45$} & 2 & 2 & 2 & 1 & 2 & \multicolumn{2}{|c|}{ VMA: $2,20 \pm 0,45$} & 2 & 2 & 3 & 2 & 2 \\
\hline \multicolumn{2}{|c|}{ IAH: $1,60 \pm 1,52$} & 2 & 1 & 4 & 0 & 1 & \multicolumn{2}{|c|}{ IAH: $2,80 \pm 1,10$} & 4 & 2 & 4 & 2 & 2 \\
\hline
\end{tabular}


TABELA 31 - CONTINUAÇÃO

\begin{tabular}{|c|c|c|c|c|c|c|c|c|c|c|c|c|c|}
\hline \multicolumn{7}{|l|}{$20 \%$} & \multicolumn{7}{|l|}{$60 \%$} \\
\hline Alterações & peso & Sn1 & Sn2 & Sn3 & Sn4 & Sn5 & Alterações & peso & Sn1 & Sn2 & Sn3 & Sn4 & Sn5 \\
\hline HTCE & $\mathrm{I}$ & & & & & & HTCE & $\mathrm{I}$ & & & & & \\
\hline AdE & $\mathrm{I}$ & & & & & & AdE & 1 & & & & & \\
\hline ELS & I & + & + & + & + & + & ELS & I & + & +++ & +++ & +++ & ++ \\
\hline HPBLS & $\mathrm{I}$ & ++ & + & +++ & + & ++ & HPBLS & 1 & +++ & ++ & + & ++ & + \\
\hline HPLS & $\mathrm{I}$ & & + & ++ & & & HPLS & $\mathrm{I}$ & + & + & & ++ & \\
\hline FPLS & $\mathrm{I}$ & ++ & & + & + & + & FPLS & $\mathrm{I}$ & + & + & & + & + \\
\hline LeuELS & $\mathrm{I}$ & & & & & & LeuELS & 1 & & & & & \\
\hline HP/HTCM & $\mathrm{I}$ & & & & & & HP/HTCM & I & & & & & \\
\hline HP/HTCC & $\mathrm{I}$ & & & & & & HP/HTCC & 1 & & & & & \\
\hline CCLS & $\mathrm{I}$ & & & & & & CCLS & 1 & & & & & \\
\hline MuLS & $\mathrm{I}$ & & & & & & MuLS & $\mathrm{I}$ & & & & & \\
\hline $\mathrm{DiC}$ & I & ++ & ++ & +++ & + & ++ & DiC & 1 & ++ & ++ & +++ & +++ & ++ \\
\hline $\mathrm{DeC}$ & $\mathrm{I}$ & ++ & ++ & +++ & ++ & ++ & $\mathrm{DeC}$ & 1 & & + & + & +++ & \\
\hline $\mathrm{CV}$ & $I$ & +++ & ++ & +++ & ++ & +++ & CV & 1 & +++ & +++ & +++ & +++ & ++ \\
\hline Par & I & & & & & & Par & 1 & & & & & \\
\hline FCalgLS & $\mathrm{I}$ & & & & & & FCalgLS & 1 & + & + & & + & \\
\hline FCtodLS & II & & & & & & FCtodLS & II & & & & & \\
\hline DC & II & & & & & & DC & II & & & & & \\
\hline $\mathrm{RE}$ & II & & & & & & RE & II & & & & & \\
\hline Hem & II & & & & & & Hem & II & & & & & \\
\hline An & II & & & & & & An & II & & & & & \\
\hline Fib & III & & & & & & Fib & III & & & & & \\
\hline $\mathrm{Nec}$ & III & & & & & & $\mathrm{Nec}$ & III & & & & & \\
\hline \multicolumn{2}{|c|}{ VMA: $2,60 \pm 0,55$} & 3 & 2 & 3 & 2 & 3 & \multicolumn{2}{|c|}{ VMA: $2,80 \pm 0,45$} & 3 & 3 & 3 & 3 & 2 \\
\hline \multicolumn{2}{|c|}{ IAH: $6,20 \pm 0,45$} & 6 & 6 & 7 & 6 & 6 & \multicolumn{2}{|c|}{ IAH: $6,60 \pm 1,52$} & 7 & 8 & 5 & 8 & 5 \\
\hline
\end{tabular}

\begin{tabular}{|l|c|c|c|c|c|c|}
\hline $\mathbf{1 0 0 \%}$ & \multicolumn{7}{|c|}{} \\
\hline Alterações & peso & Sn1 & Sn2 & Sn3 & Sn4 & Sn5 \\
\hline HTCE & I & & & & & \\
\hline AdE & I & & & & & \\
\hline ELS & I & +++ & +++ & +++ & +++ & +++ \\
\hline HPBLS & I & ++ & ++ & ++ & ++ & ++ \\
\hline HPLS & I & + & ++ & ++ & + & \\
\hline FPLS & I & + & ++ & ++ & + & + \\
\hline LeuELS & I & & & & & \\
\hline HP/HTCM & I & & & & & \\
\hline HP/HTCC & I & & & & & \\
\hline CCLS & I & & & & & \\
\hline MuLS & I & & & & & \\
\hline DiC & I & +++ & +++ & +++ & +++ & +++ \\
\hline DeC & I & +++ & +++ & +++ & ++ & +++ \\
\hline CV & I & +++ & +++ & +++ & +++ & ++ \\
\hline Par & I & & & & & \\
\hline FCalgLS & I & & + & + & & \\
\hline FCtodLS & II & & & & & \\
\hline DC & II & & & & & \\
\hline RE & II & & & & & \\
\hline Hem & II & & & & & \\
\hline An & II & + & ++ & +++ & & \\
\hline Fib & III & & & & & \\
\hline NeC & III & & & & & \\
\hline VMA: $\mathbf{3 , 0 0 \pm 0 , 0 0}$ & 3 & 3 & 3 & 3 & 3 \\
\hline IAH: $\mathbf{1 2 , 8 0 \pm 5 , 7 6}$ & 17 & 17 & 17 & 7 & 6 \\
\hline
\end{tabular}


TABELA 32: Alterações renais observadas no peixe Serrapinnus notomelas exposto às concentrações $0 \%$ (controle), 5\%, 20\%, 60\% e 100\% do efluente final de indústria de papel e celulose. Os sinais de + indicam a freqüência de ocorrência das alterações, sendo $+=$ baixa freqüência, $++=$ média freqüência e +++ = alta freqüência de ocorrência da alteração.

As abreviações significam: PCTL= perda do contorno ou contorno atípico das células do tecido linfóide; $\mathrm{DHL}=$ degeneração hialina leve; HTCT=hipertrofia das células tubulares;

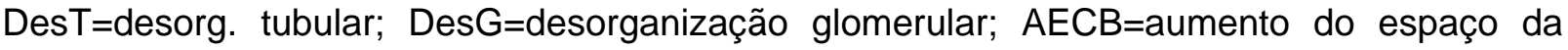
cápsula de Bowman ( $\mathrm{CB})$; $\mathrm{DECB}=$ diminuição do espaço da cápsula de Bowman; DCG=dilatação dos capilares glomerulares; TR/NN=ocorrência de túbulos em regeneração ou de novos néfrons; PAST=presença de material PAS-positivo nas céls tubulares; DFreqG=diminuição da freq. relativa de glomérulos; DilVS=dilatação de vasos sangüíneos; ALumTub=aumento do diâm. do lúmen tubular; ObsTub=obstrução tubular; DHS=degeneração hialina severa; DegT=degeneração tubular; DegG=degeneração glomerular; DCTub=deg.citoplasmática das células tubulares; DNTub=deg. nuclear das céls tubulares; TLCB=tecido linfóide na $\mathrm{CB}$; $\mathrm{HH}=$ hiperemia; RVS=ruptura de vasos sangüíneos; $\mathrm{Nec}=$ necrose.

\begin{tabular}{|c|c|c|c|c|c|c|c|c|c|c|c|c|c|}
\hline \multicolumn{7}{|c|}{ CONTROLE } & \multicolumn{7}{|l|}{$5 \%$} \\
\hline Alterações & peso & Sn1 & Sn2 & Sn3 & Sn4 & Sn5 & Alterações & peso & Sn1 & Sn2 & Sn3 & Sn4 & Sn5 \\
\hline PCTL & $\mathrm{I}$ & & & & & & PCTL & $\mathrm{I}$ & & & & & \\
\hline $\mathrm{DHL}$ & $\mathrm{I}$ & & & & & & $\mathrm{DHL}$ & $\mathrm{I}$ & + & + & + & + & \\
\hline HTCT & I & & & & & & HTCT & 1 & & & & & \\
\hline DesT & $\mathrm{I}$ & & & & & & DesT & 1 & & & & & \\
\hline DesG & $\mathrm{I}$ & & & & & & DesG & $\mathrm{I}$ & & & & & \\
\hline AECB & I & & & & & & AECB & 1 & & & & & \\
\hline DECB & I & & & & + & & DECB & I & & & & & \\
\hline DCG & $\mathrm{I}$ & & & & + & & DCG & $\mathrm{I}$ & & & & & \\
\hline TR/NN & I & + & ++ & & + & & TR/NN & I & & & ++ & & \\
\hline PAST & $\mathrm{I}$ & & & & & & PAST & $\mathrm{I}$ & & & & & \\
\hline DFreqG & $\mathrm{I}$ & & & & & & DFreqG & $\mathrm{I}$ & & & & & \\
\hline DilVS & 1 & & & & & & DilVS & I & & & & & \\
\hline ALT & $\mathrm{I}$ & & & & & & ALT & $\mathrm{I}$ & & & & & \\
\hline ObsLT & $\mathrm{I}$ & & & & & & ObsLT & 1 & & & & & \\
\hline DHS & II & & & & & & DHS & II & & & & & \\
\hline DegT & II & & & & & & DegT & II & + & & & & \\
\hline DegG & II & & & & & & DegG & II & & +++ & & & \\
\hline DCTub & II & & & & & & DCTub & II & & & & & \\
\hline DNTub & II & & & & & & DNTub & II & & & & & \\
\hline TLCB & II & & & & & & TLCB & II & & & & & \\
\hline $\mathrm{HH}$ & II & & & & & & $\mathrm{HH}$ & II & & & & & \\
\hline RVS & II & & & & & & RVS & II & & & & & \\
\hline $\mathrm{Nec}$ & III & & & & & & $\mathrm{Nec}$ & III & & & & & \\
\hline \multicolumn{2}{|c|}{ VMA: $1,60 \pm 0,55$} & 2 & 2 & 1 & 2 & 1 & \multicolumn{2}{|c|}{ VMA: $2,00 \pm 0,71$} & 2 & 3 & 2 & 2 & 1 \\
\hline \multicolumn{2}{|c|}{ IAH: $1,00 \pm 1,22$} & 1 & 1 & 0 & 3 & 0 & \multicolumn{2}{|c|}{ IAH: $5,00 \pm 5,52$} & 11 & 11 & 2 & 1 & 0 \\
\hline
\end{tabular}


TABELA 32 - CONTINUAÇÃO

\begin{tabular}{|c|c|c|c|c|c|c|c|c|c|c|c|c|c|}
\hline \multicolumn{7}{|l|}{$20 \%$} & \multicolumn{7}{|l|}{$60 \%$} \\
\hline Alterações & peso & Sn1 & Sn2 & Sn3 & Sn4 & Sn5 & Alterações & peso & Sn1 & Sn2 & Sn3 & Sn4 & Sn5 \\
\hline PCTL & I & & & & & & PCTL & I & & & & & \\
\hline $\mathrm{DHL}$ & $\mathrm{I}$ & ++ & & & +++ & & $\mathrm{DHL}$ & $\mathrm{I}$ & +++ & & + & ++ & + \\
\hline HTCT & 1 & & + & & & & HTCT & 1 & & ++ & & & \\
\hline DesT & I & + & + & ++ & & & DesT & I & & & & & \\
\hline DesG & 1 & & & & & & DesG & 1 & & & & & \\
\hline AECB & 1 & & & & & & AECB & 1 & & & & & \\
\hline DECB & I & & & & & & DECB & I & & + & + & +++ & \\
\hline DCG & $\mathrm{I}$ & +++ & + & ++ & +++ & + & DCG & $\mathrm{I}$ & +++ & +++ & +++ & +++ & ++ \\
\hline TR/NN & $\mathrm{I}$ & & & & + & & TR/NN & $\mathrm{I}$ & & & + & + & \\
\hline PAST & $\mathrm{I}$ & & & & & & PAST & $\mathrm{I}$ & & + & & + & \\
\hline DFreqG & $\mathrm{I}$ & & & & & & DFreqG & $\mathrm{I}$ & & + & & & \\
\hline DilVS & 1 & & & & & & DilVS & 1 & & & & & \\
\hline ALT & $\mathrm{I}$ & & & & & & ALT & 1 & & & & & \\
\hline ObsLT & 1 & & & & & & ObsLT & I & & & & & \\
\hline DHS & II & + & & & & & DHS & II & & & +++ & & \\
\hline DegT & II & ++ & + & +++ & & & DegT & II & ++ & ++ & +++ & +++ & ++ \\
\hline DegG & II & & & + & ++ & & DegG & II & & + & + & +++ & \\
\hline DCTub & II & & & & & & DCTub & II & & & & & \\
\hline DNTub & II & & & & & & DNTub & II & & & & & \\
\hline TLCB & II & & & & & & TLCB & II & & & & & \\
\hline $\mathrm{HH}$ & II & & & & + & & $\mathrm{HH}$ & II & + & + & + & + & + \\
\hline RVS & II & & & & & & RVS & II & & & & & \\
\hline $\mathrm{Nec}$ & III & & & & & & $\mathrm{Nec}$ & III & & & & & \\
\hline \multicolumn{2}{|c|}{ VMA: $2,60 \pm 0,55$} & 3 & 2 & 3 & 3 & 2 & \multicolumn{2}{|c|}{ VMA: $3,00 \pm 00$} & 3 & 3 & 3 & 3 & 3 \\
\hline \multicolumn{2}{|c|}{ IAH: $16,40 \pm 9,58$} & 23 & 13 & 22 & 23 & 1 & \multicolumn{2}{|c|}{ IAH: $31,60 \pm 9,50$} & 22 & 35 & 44 & 35 & 22 \\
\hline
\end{tabular}

\begin{tabular}{|l|c|c|c|c|c|c|}
\hline $\mathbf{1 0 0 \%}$ & \multicolumn{7}{|c|}{} \\
\hline Alterações & peso & Sn1 & Sn2 & Sn3 & Sn4 & Sn5 \\
\hline PCTL & I & & & & & \\
\hline DHL & I & +++ & +++ & +++ & +++ & +++ \\
\hline HTCT & I & +++ & +++ & +++ & +++ & +++ \\
\hline DesT & I & +++ & +++ & +++ & +++ & +++ \\
\hline DesG & I & +++ & +++ & +++ & +++ & +++ \\
\hline AECB & I & & & & & \\
\hline DECB & I & +++ & +++ & +++ & +++ & +++ \\
\hline DCG & I & +++ & +++ & +++ & +++ & +++ \\
\hline TR/NN & I & & + & & + & \\
\hline PAST & I & & & & & \\
\hline DFreqG & I & + & & & & \\
\hline DilVS & I & ++ & ++ & ++ & +++ & ++ \\
\hline ALT & I & +++ & +++ & +++ & +++ & +++ \\
\hline ObSLT & I & & & & & \\
\hline DHS & II & +++ & +++ & +++ & ++ & +++ \\
\hline DegT & II & +++ & +++ & +++ & +++ & +++ \\
\hline DegG & II & +++ & +++ & +++ & +++ & +++ \\
\hline DCTub & II & & & & & \\
\hline DNTub & II & & & & & \\
\hline TLCB & II & & & & & \\
\hline HH & II & + & + & + & + & + \\
\hline RVS & II & & & & & \\
\hline NeC & III & + & + & & + & \\
\hline VMA: $\mathbf{3 , 0 0 \pm 0 , 0 0}$ & 3 & 3 & 3 & 3 & 3 \\
\hline IAH: $\mathbf{1 0 8 , 6 \pm 5 5 , 3 2}$ & 149 & 149 & 48 & 149 & 48 \\
\hline
\end{tabular}


TABELA 33: Alterações hepáticas observadas no peixe Serrapinnus notomelas exposto às concentrações $0 \%$ (controle), 5\%, 20\%, 60\% e 100\% do efluente final de indústria de papel e celulose. Os sinais de + indicam a freqüência de ocorrência das alterações, sendo $+=$ baixa freqüência, $++=$ média freqüência $e+++=$ alta freqüência de ocorrência da alteração.

As abreviações significam: DesCH=desorganização/descaracterização dos cordões hepáticos; PContCel=perda ou atipia do contorno dos hepatócitos; PCont Nuc=perda ou atipia do contorno do núcleo dos hepatócitos; AVolCel=aumento do volume celular; AVolNuc= aumento do volume nuclear; VacCit=vacuolização citoplasmática; DFreqNuc=diminuição da freqüência relativa de núcleos; AFreqVas=aumento da freqüência relativa de vasos; AVolVasos=aumento do volume de vasos; DimGlic=diminuição do glicogênio; EstBil=estagnação biliar; HHem=hiperemia; RupVas=ruptura de vasos; DegCanBil=degeneração de canalículos biliares; VacNuc=vacuolização nuclear; DegCit= degeneração citoplasmática; DegNuc=degeneração nuclear; AtrofNuc= atrofia nuclear; RompCel=rompimento celular.

\begin{tabular}{|c|c|c|c|c|c|c|c|c|c|c|c|c|c|}
\hline \multicolumn{7}{|c|}{ CONTROLE } & \multicolumn{7}{|l|}{$5 \%$} \\
\hline Alterações & peso & Sn1 & Sn2 & Sn3 & Sn4 & Sn5 & Alterações & peso & Sn1 & Sn2 & Sn3 & Sn4 & Sn5 \\
\hline $\mathrm{DesCH}$ & 1 & & & & & & DesCH & $\mathrm{I}$ & & & & & \\
\hline PContCel & $\mathrm{I}$ & & & & & & PContCel & $\mathrm{I}$ & & & & & \\
\hline PContNuc & 1 & & & & & & PContNuc & I & & & & & \\
\hline AVolCel & $\mathrm{I}$ & & & & & & AVolCel & $\mathrm{I}$ & + & & & + & \\
\hline AVolNuc & $\mathrm{I}$ & & & & & & AVolNuc & $\mathrm{I}$ & & & & & \\
\hline VacCit & 1 & ++ & ++ & + & +++ & + & VacCit & I & + & + & + & + & + \\
\hline DFreqNuc & $\mathrm{I}$ & & & & & & DFreqNuc & $\mathrm{I}$ & & & & & \\
\hline AFreqVas & $\mathrm{I}$ & & & & & & AFreqVas & $\mathrm{I}$ & & & & & \\
\hline AVolVas & $\mathrm{I}$ & & & & & & AVolVas & $\mathrm{I}$ & & & & & \\
\hline DimGlic & $\mathrm{I}$ & & & & + & & DimGlic & $\mathrm{I}$ & + & + & + & + & \\
\hline EstBil & $\mathrm{I}$ & & + & & & & EstBil & $\mathrm{I}$ & & & & & \\
\hline HHem & II & & & & & & HHem & II & & & & & \\
\hline RupVas & II & & & & & & RupVas & II & & & & & \\
\hline DegCanBil & II & & & & & & DegCanBil & II & & & & & \\
\hline VacNuc & II & & & & & & VacNuc & II & + & & & & \\
\hline DegCit & II & & & & & & DegCit & II & & & & & \\
\hline DegNuc & II & & & & & & DegNuc & II & & & & & \\
\hline AtrofNuc & II & & & & & & AtrofNuc & II & & & & & \\
\hline RompCel & II & & & & & & RompCel & II & & & & & \\
\hline Necrose & III & & & & & & Necrose & III & & & & & \\
\hline \multicolumn{2}{|c|}{ VMA: $1,40 \pm 0,55$} & 1 & 2 & 1 & 2 & 1 & \multicolumn{2}{|c|}{ VMA: $1,80 \pm 0,45$} & 2 & 2 & 2 & 2 & 1 \\
\hline \multicolumn{2}{|c|}{ IAH: $1,40 \pm 0,55$} & 1 & 2 & 1 & 2 & 1 & \multicolumn{2}{|c|}{ IAH: $4,20 \pm 4,97$} & 13 & 2 & 2 & 3 & 1 \\
\hline
\end{tabular}


TABELA 33 - CONTINUAÇÃO

\begin{tabular}{|c|c|c|c|c|c|c|c|c|c|c|c|c|c|}
\hline \multicolumn{7}{|l|}{$20 \%$} & \multicolumn{7}{|l|}{$60 \%$} \\
\hline Alterações & peso & Sn1 & Sn2 & Sn3 & Sn4 & Sn5 & Alterações & peso & Sn1 & Sn2 & Sn3 & Sn4 & Sn5 \\
\hline DesCH & I & & & & & & DesCH & I & + & & & & \\
\hline PContCel & I & ++ & + & & + & & PContCel & $\mathrm{I}$ & + & + & & + & \\
\hline PContNuc & $\mathrm{I}$ & & & & & & PContNuc & $\mathrm{I}$ & & & & & \\
\hline AVolCel & I & & & & & & AVolCel & I & & & & & \\
\hline AVolNuc & $\mathrm{I}$ & & & & & & AVolNuc & $\mathrm{I}$ & + & ++ & & + & \\
\hline VacCit & I & ++ & ++ & +++ & ++ & ++ & VacCit & $\mathrm{I}$ & +++ & +++ & + & ++ & ++ \\
\hline DFreqNuc & I & & & & & & DFreqNuc & I & & & & & \\
\hline AFreqVas & I & & & & & & AFreqVas & $\mathrm{I}$ & & & & & \\
\hline AVolVas & $\mathrm{I}$ & & & & & & AVolVas & $\mathrm{I}$ & & & & & \\
\hline DimGlic & I & + & + & & + & + & DimGlic & I & + & + & & + & + \\
\hline EstBil & $\mathrm{I}$ & & & & & & EstBil & $\mathrm{I}$ & & & & & \\
\hline HHem & II & & & & & & HHem & II & + & + & & + & \\
\hline RupVas & II & & & & & & RupVas & II & & & & & \\
\hline DegCanBil & II & & & & & & DegCanBil & II & & & & & \\
\hline VacNuc & II & + & + & + & + & & VacNuc & II & + & + & + & + & \\
\hline DegCit & II & & & & & & DegCit & II & & & & & \\
\hline DegNuc & II & + & & & & & DegNuc & II & ++ & +++ & + & + & \\
\hline AtrofNuc & II & & + & + & & & AtrofNuc & II & ++ & ++ & ++ & + & + \\
\hline RompCel & II & & & & & & RompCel & II & & & & & \\
\hline Necrose & III & & & & & & Necrose & III & + & & & & \\
\hline VMA: 2,60 & 0,55 & 3 & 3 & 3 & 2 & 2 & VMA: 2,80 & 0,45 & 3 & 3 & 3 & 3 & 2 \\
\hline IAH: 16,40 & 9,04 & 23 & 23 & 21 & 13 & 2 & IAH: $55,2 \pm$ & 51,88 & 145 & 44 & 31 & 44 & 12 \\
\hline
\end{tabular}

\begin{tabular}{|l|c|c|c|c|c|c|}
\hline $100 \%$ \\
\hline Alterações & peso & Sn1 & Sn2 & Sn3 & Sn4 & Sn5 \\
\hline DesCH & I & + & + & ++ & ++ & + \\
\hline PContCel & I & +++ & +++ & +++ & +++ & +++ \\
\hline PContNuc & I & ++ & ++ & +++ & +++ & + \\
\hline AVolCel & I & + & + & ++ & ++ & + \\
\hline AVolNuc & I & + & ++ & ++ & ++ & + \\
\hline VacCit & I & + & & + & ++ & + \\
\hline DFreqNuc & I & & & & & \\
\hline AFreqVas & I & & & & & \\
\hline AVolVas & I & + & & + & + & \\
\hline DimGlic & I & + & + & + & + & + \\
\hline EstBil & I & & & & & \\
\hline HHem & II & + & + & + & + & + \\
\hline RupVas & II & & & & & \\
\hline DegCanBil & II & + & + & + & + & + \\
\hline VacNuc & II & ++ & + & ++ & ++ & ++ \\
\hline DegCit & II & & & & & \\
\hline DegNuc & II & ++ & ++ & ++ & +++ & ++ \\
\hline AtrofNuc & II & + & + & + & + & + \\
\hline RompCel & II & & & & & \\
\hline Necrose & III & + & & + & + & \\
\hline VMA: 3,00 $\mathbf{0 , 0 0}$ & 3 & 3 & 3 & 3 & 3 \\
\hline IAH:117,4 $\mathbf{5 5 , 5 9}$ & 158 & 56 & 158 & 158 & 57 \\
\hline
\end{tabular}


As figuras 71 a 76 mostram órgãos que puderam ser bem visualizados nos cortes dos peixes inteiros, mas que não foram considerados nas análises das alterações histológicas.

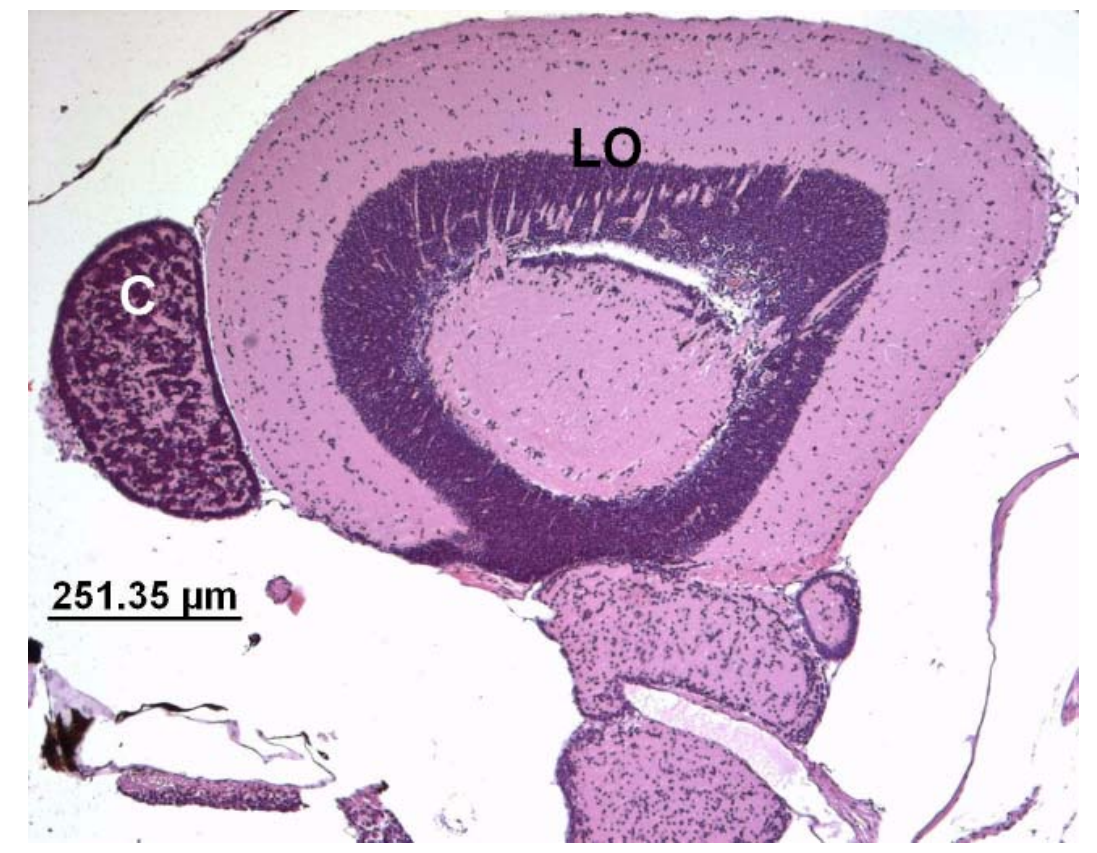

FIGURA 71: Encéfalo de S. notomelas. LO = lobo óptico; C= cerebelo. (HE, 5 $\mu \mathrm{m})$.

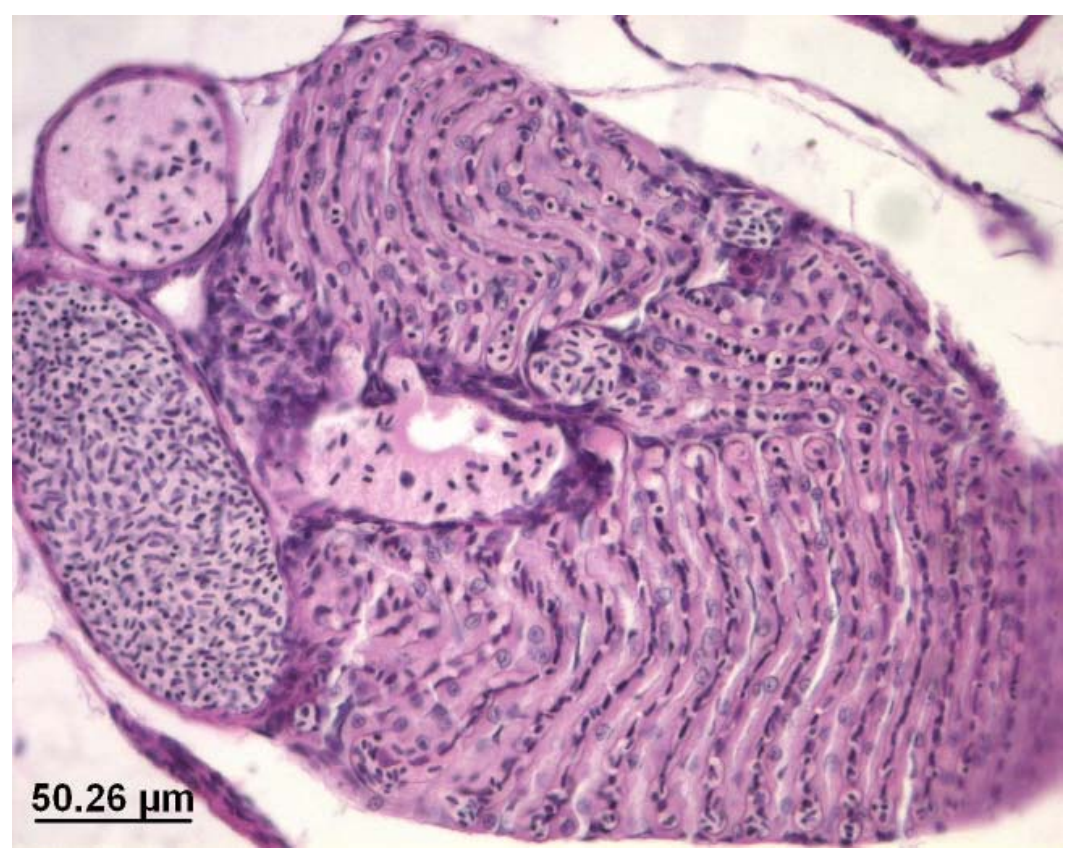

FIGURA 72: Pseudobrânquia de D. rerio. (PAS - hematoxilina; $5 \mu \mathrm{m}$ ). 


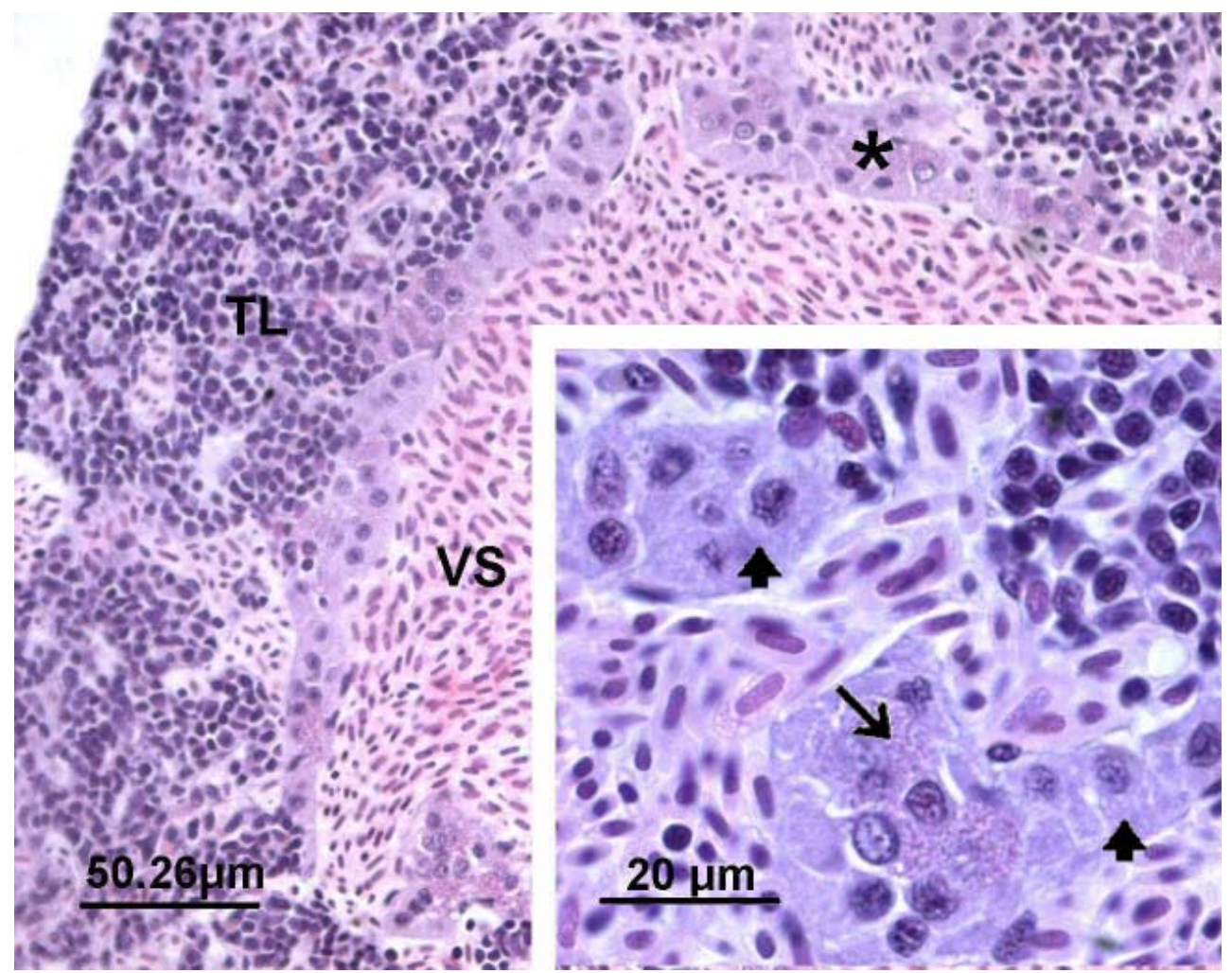

FIGURA 73: Rim anterior de S. notomelas. Notar a disposição do tecido inter-renal e das células cromafins (asterisco) ao redor do vaso sangüineo (VS); TL = tecido linfóide. No aumento, a seta indica células cromafins e as cabeças de setas indicam partes do tecido inter-renal. (HE, $5 \mu \mathrm{m})$.

OBS.: Nos peixes, a glândula inter-renal é homóloga ao córtex das glândulas suprarenais nos mamíferos. As células dessa glândula normalmente encontram-se dispostas no rim anterior, circundando a veia pós-cardinal e suas ramificações, e secretam corticóides, especialmente o cortisol. Já, as células cromafins são homólogas à medula das supra-renais, secretando, assim, epinefrina e norepinefrina (Takashima \& Hibiya, 1995). Em S. notomelas essas células aparecem isoladas ou agrupadas entre as células inter-renais. 


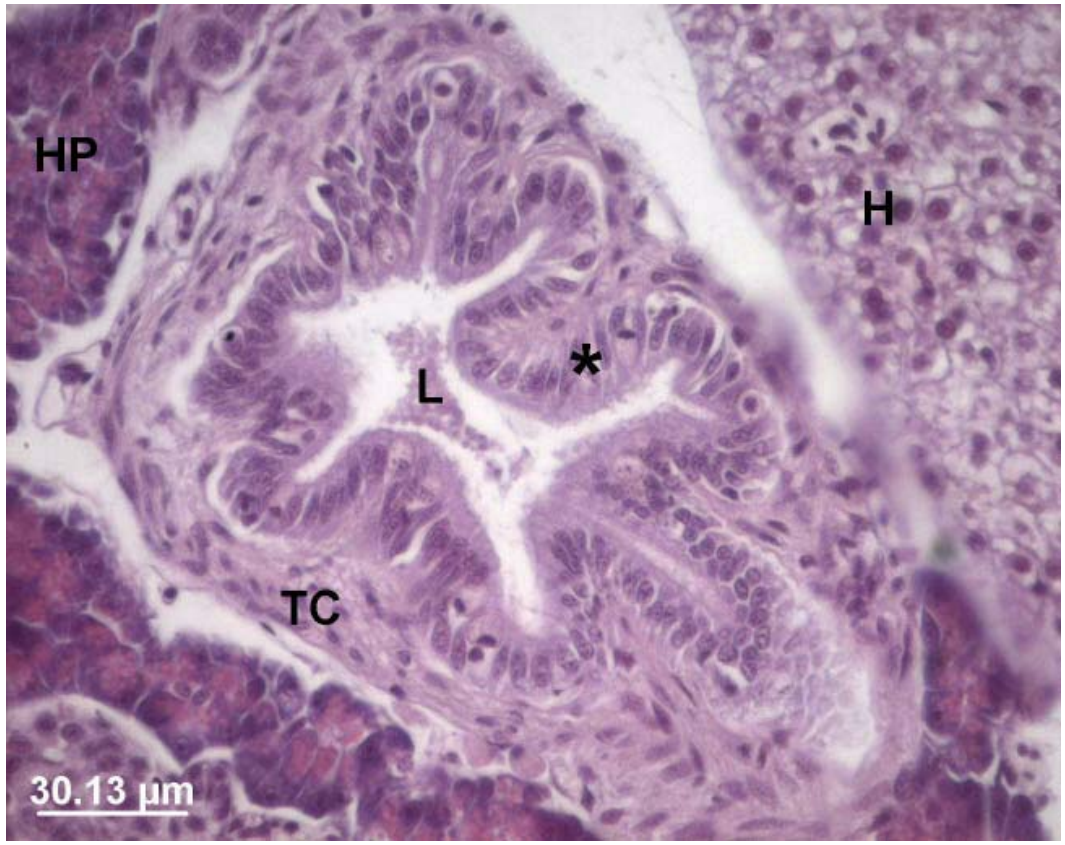

FIGURA 74: Duto biliar no fígado de $D$. rerio. $\mathrm{L}=$ lúmen do duto; $\mathrm{H}=$ hepatócitos; $\mathrm{HP}=$ hepatopâncreas; TC = tecido conjuntivo. $\mathrm{O}$ asterisco indica a parede do duto, formada por células colunares. (HE, $5 \mu \mathrm{m})$.

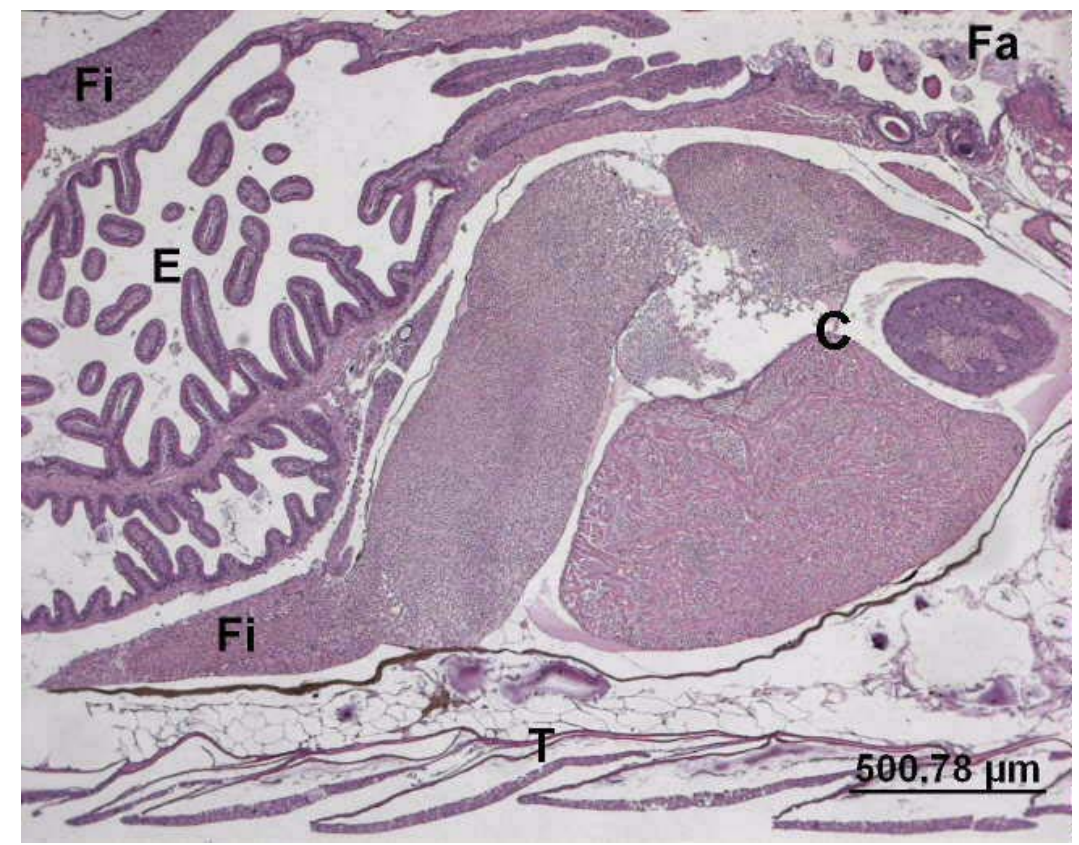

FIGURA 75: Corte de D. rerio mostrando o coração (C), porções do estômago (E), da faringe $(\mathrm{Fa})$, do fígado $(\mathrm{Fi})$ e do tegumento $(\mathrm{T})$, na qual é possível observar as escamas. 

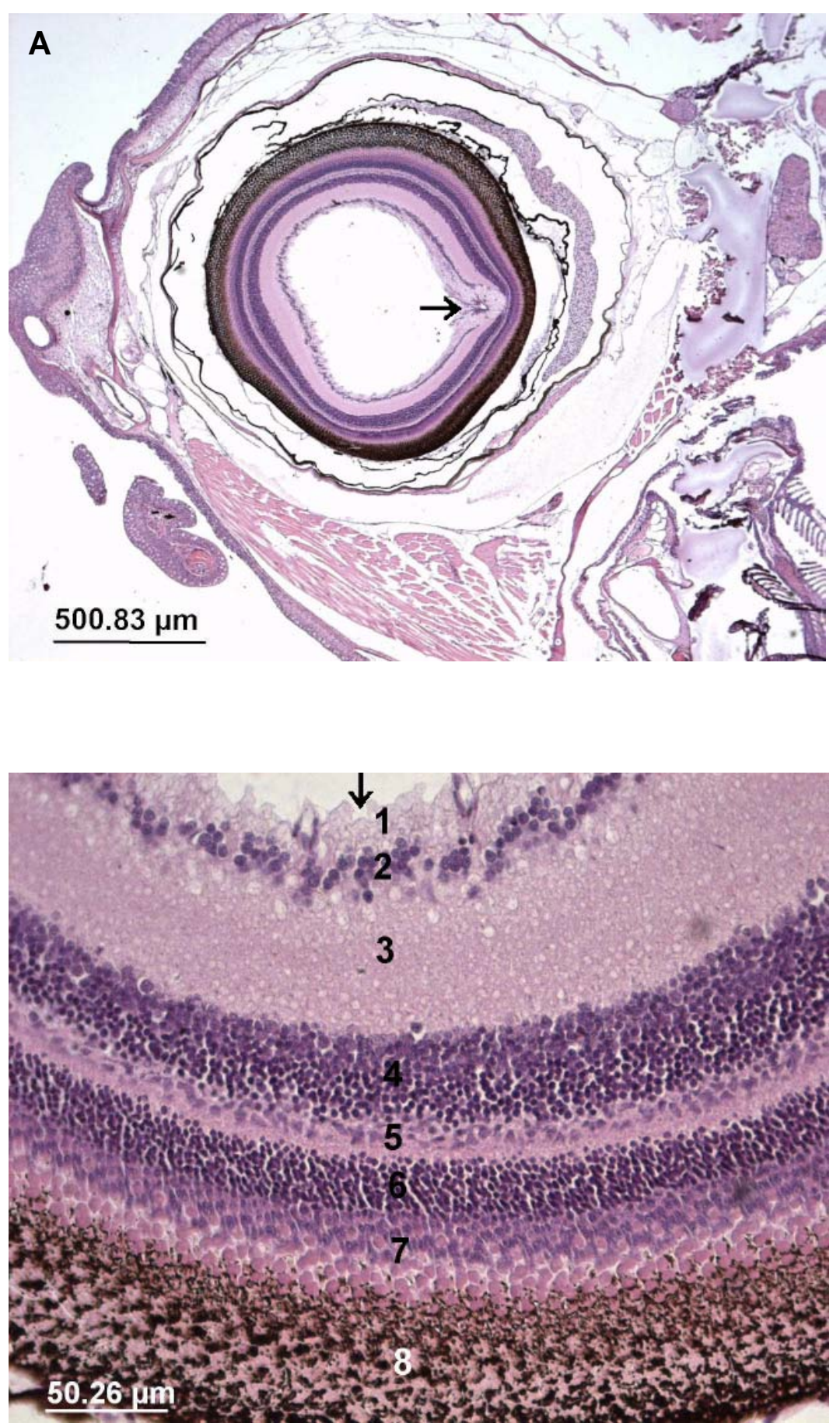

FIGURA 76: A - Corte do olho de D. rerio. A seta indica o disco óptico. B - camadas da retina de $D$. rerio. 1 - fibras nervosas; 2 - camada de células ganglionares; 3 camada plexiforme interna; 4 - camada nuclear interna; 5 - camada plexiforme externa; 6 - camada nuclear externa; 7 - cones e bastonetes; 8 - camada de pigmento. A seta indica o sentido de incidência da luz. (HE, $5 \mu \mathrm{m}$ ). 
As figuras 77 a 81 mostram os aparatos desenvolvidos para as diferentes etapas desse trabalho.

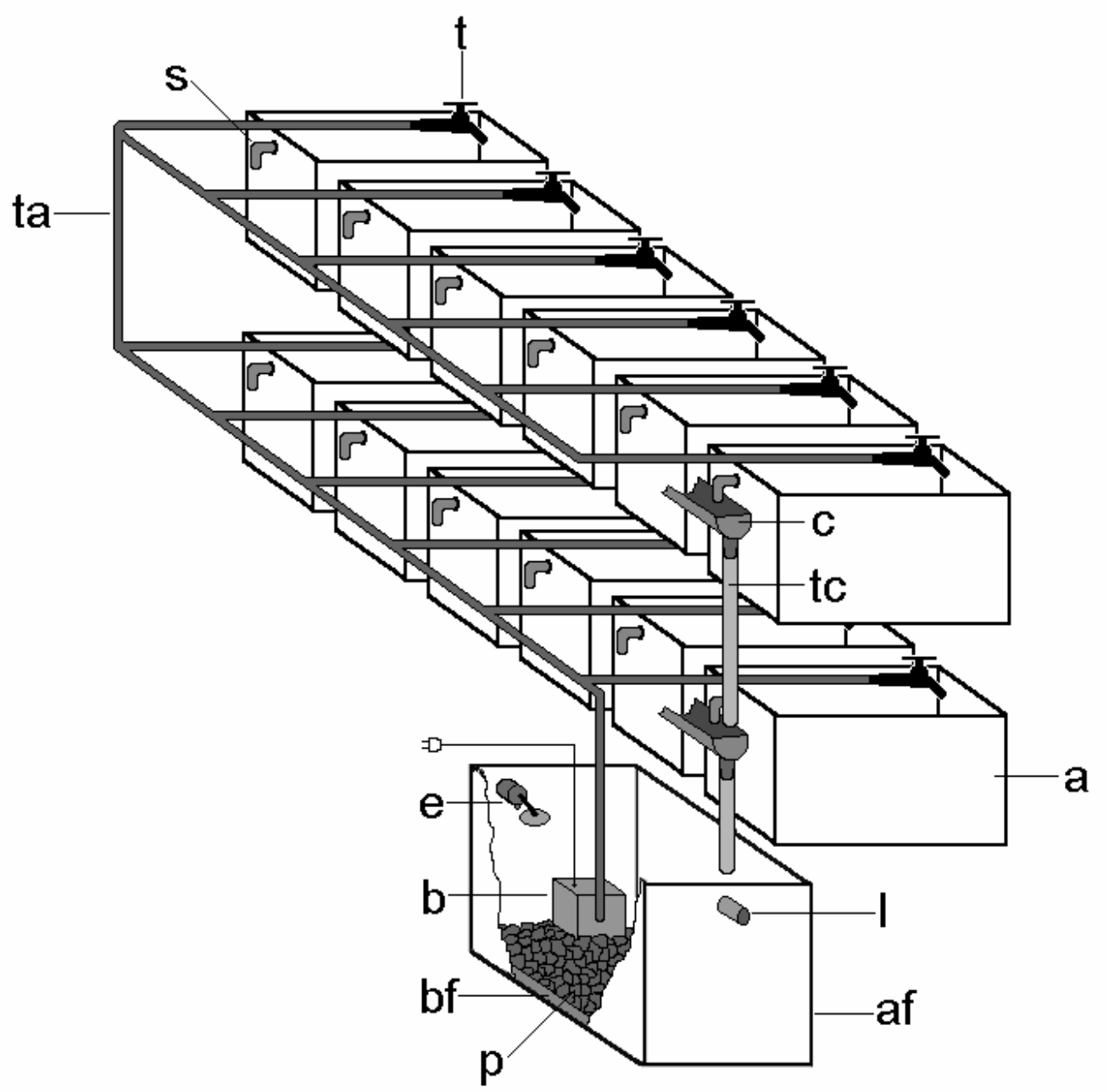

FIGURA 77: Esquema de montagem do sistema de manutenção de peixes de pequeno porte. O fluxo de entrada (do filtro para os aquários) é controlado por torneiras. A saída de água (dos aquários para o filtro) é superficial, de fluxo livre por cotovelo, cuja rotação para cima da linha d'água interrompe a saída. (não representado no esquema). A extremidade do cotovelo possui tela plástica que evita a sucção de peixes menores. Os aquários contêm tampas acrílicas leves e de fácil manuseio. A estante (visível na figura 9) tem estrutura de ferro, pintada com tinta epóxi, atóxica.

\section{Componentes:}

$\mathrm{a}=$ aquário de medidas $(\mathrm{em} \mathrm{cm}) 20 \mathrm{~cm}$ de largura $X 40 \mathrm{~cm}$ de comprimento $\times 25 \mathrm{~cm}$ de altura;

af = aquário-filtro onde são instalados os aeradores e o aquecedor com termostato;

$\mathrm{b}=$ bomba elétrica submersa marca Better modelo 600;

$\mathrm{bf}=$ base (tipo filtro biológico) para as pedras;

$c=$ calha de PVC;

e = entrada de água com bóia;

I = ladrão para escoamento da água do filtro em eventual pane do sistema;

$\mathrm{p}=$ pedriscos para filtro biológico para aquários;

$\mathrm{s}=$ saída de água dos aquários (de 1/2 polegada, com cotovelo externo fixo e interno móvel e com tela plástica);

$\mathrm{t}$ = torneira de plástico com rosca de $1 / 2$ polegada;

ta = tubos de alimentação (entrada de água) de PVC de $1 / 2$ polegada;

tc $=$ tubos coletores de água das calhas .

*Obs.: é recomendada a utilização de aquários $2 \mathrm{~cm}$ mais altos e tubos de saída de água dos aquários de $3 / 4$ de polegada, ao invés de $1 / 2$ polegada. 


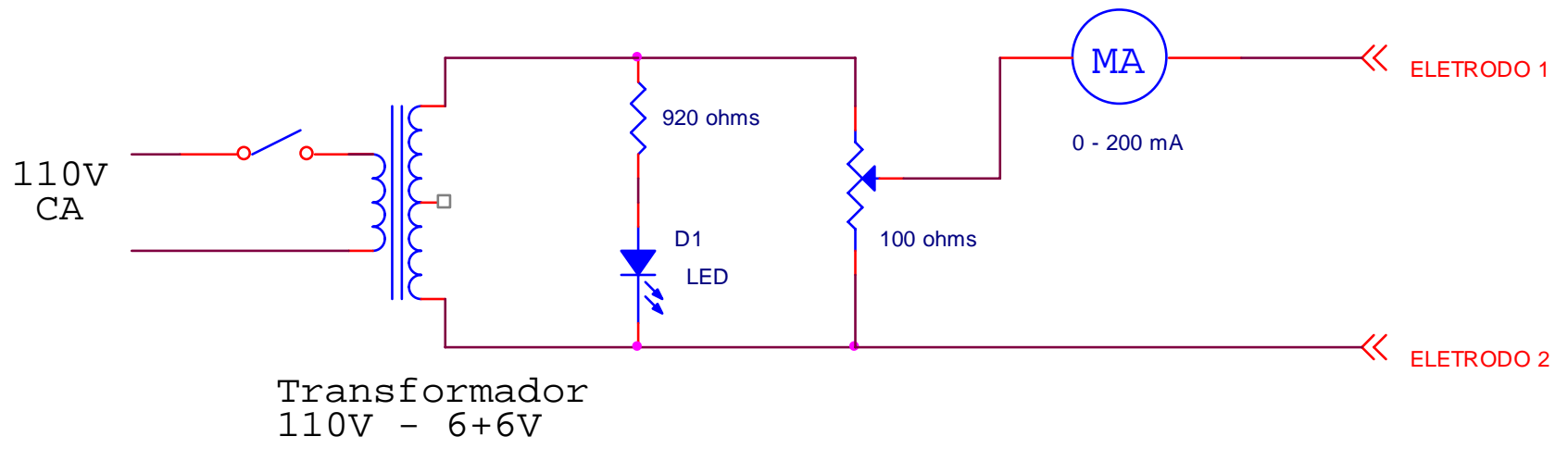

FIGURA 78: Esquema de montagem do descalcificador. Este aparelho foi montado com base em um pré-existente no laboratório de Histologia da UEL, e cujo projeto é de autoria desconhecida.

Componentes:

1 transformador $110 \mathrm{~V} 6+6 \mathrm{~V}$

1 resistor de 920 ohms

1 plugue

01 led

1 potenciômetro de 100 ohms

cabos flexíveis

1 caixa para montagem

2 eletrodos de carvão

1 microamperímetro com escala de 0 a $200 \mathrm{~mA}$

2 garras de jacaré para preensão dos eletrodos

1 cuba de vidro pequena $(100 \mathrm{~mL})$

1 chave on-off

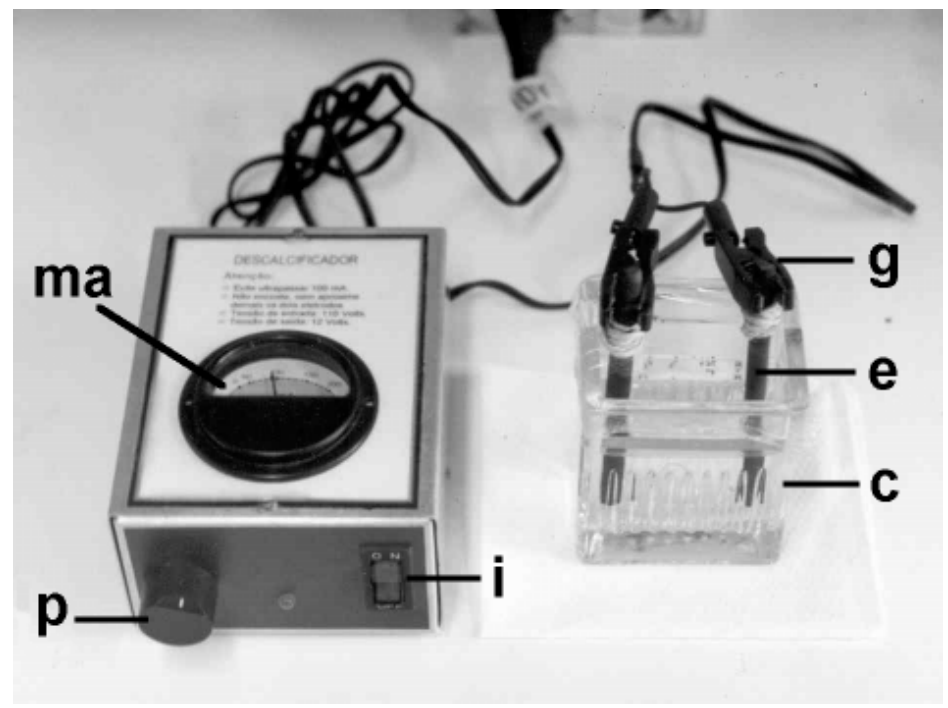

FIGURA 79: Descalcificador. c = cuba na qual são colocados os peixes em metades e a solução de EDTA; e = eletrodos de carvão; $g$ = garras para preensão dos eletrodos; i = botão interruptor; ma = microamperímetro; $\mathrm{p}$ = botão do potenciômetro. 


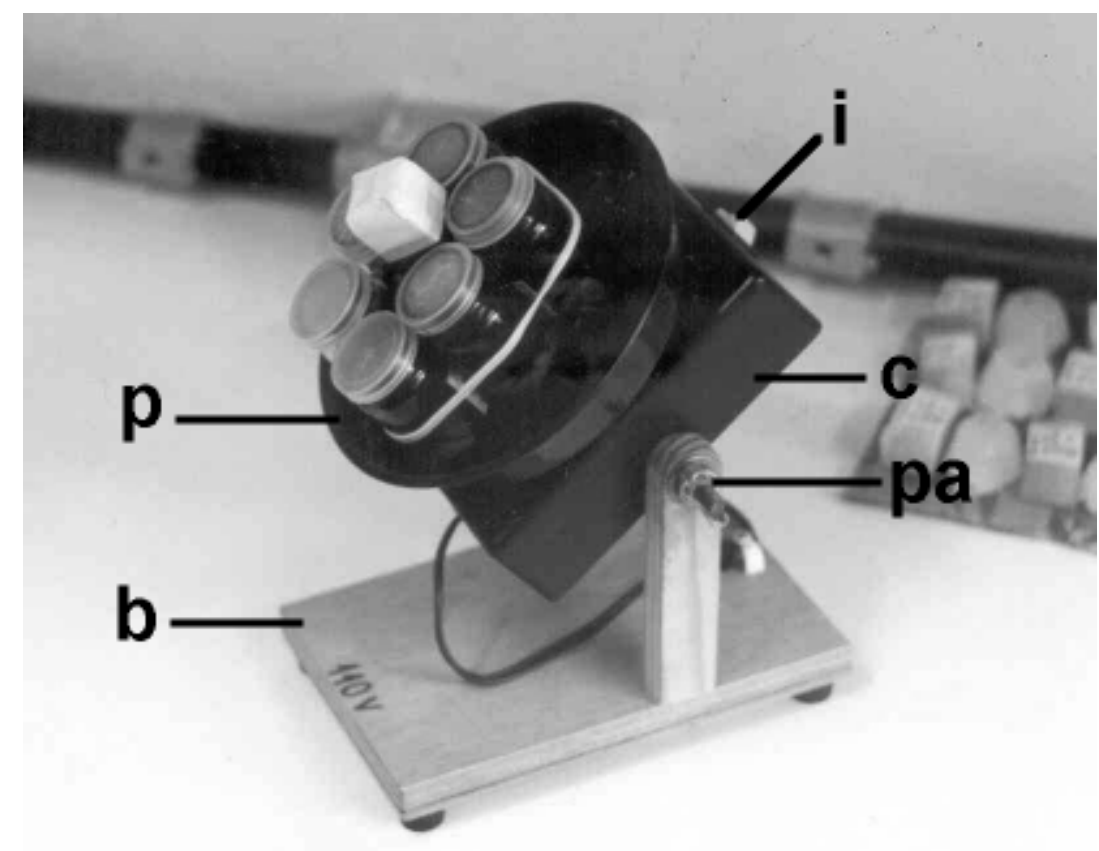

FIGURA 80: Girador para materiais em preparação histológica. b = base de madeira; c = caixa plástica para montagem do motor; $\mathrm{i}=$ interruptor; $\mathrm{p}=$ prato giratório para suporte dos frascos contendo o material; pa = parafuso de ajuste do ângulo.

O girador tem a função de otimizar o contato do material com as substâncias durante os processos de desidratação e diafanização.

\section{Componentes:}

1 motor para prato giratório de forno de microondas*

1 chave on-off

1 caixa plástica para montagem do motor cabo flexível e plugue

1 base de madeira

1 parafuso de comprimento suficiente para atravessar a caixa e o suporte de madeira

1 porca tipo borboleta para regulagem do ângulo

1 prato plástico de $100 \mathrm{~mm}$ de diâmetro

1 pedaço de acrílico ou de outro material, de medida $2 \times 2 \times 6 \mathrm{~cm}$, para ser instalado no centro do prato anéis elásticos para prender os frascos frascos de vidro com tampa

* o motor para prato giratório de forno microondas possui velocidade fixa aproximada de 3 rotações por minuto e gira em sentido aleatório a cada vez que é ligado. 


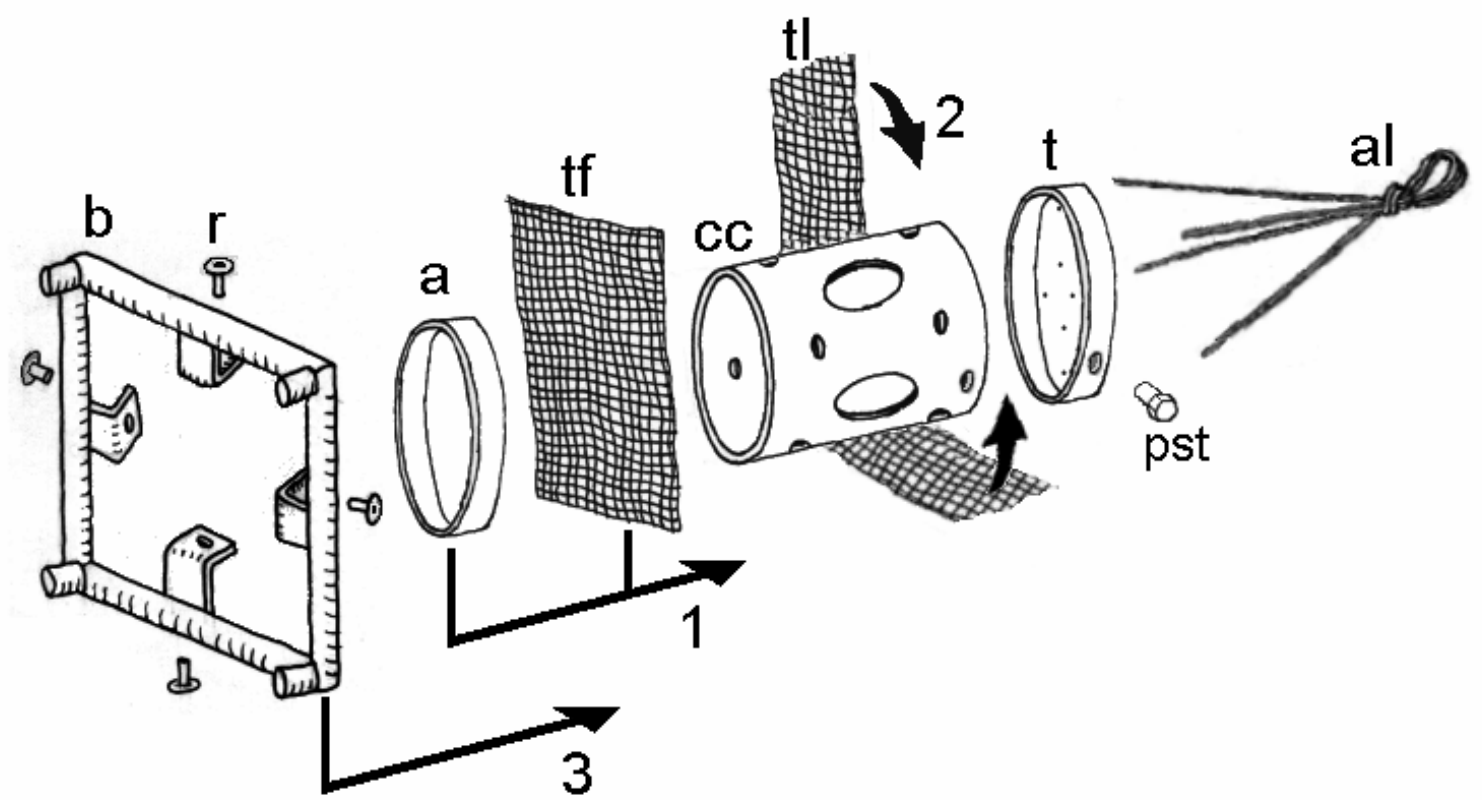

FIGURA 81: Partes e seqüência para montagem de uma câmara para teste de toxicidade in situ com peixes de pequeno porte (MELETTI \& ROCHA, 2002). a=anel de preensão da tela da abertura do fundo; al=alça de corda de nylon; $b=b a s e$ de ferro; $\mathrm{cc}=$ corpo da câmara; pst=parafuso de segurança da tampa; $r=r e b i t e ; ~ t=t a m p a ; t f=t e l a$ da abertura do fundo; $\mathrm{tl}=$ tela das aberturas laterais.

\section{Descrição:}

corpo da câmara: tubo de PVC de $150 \mathrm{~mm}$ de diâmetro e $200 \mathrm{~mm}$ de altura.

tampa e anel: "cap" de PVC para tubo de $150 \mathrm{~mm}$, serrado transversalmente, originando uma tampa e um anel de $35 \mathrm{~mm}$ cada. A tampa possui 9 orifícios de $2,5 \mathrm{~mm}$ cada, que evitam o aprisionamento de bolhas de ar no interior da câmara. $\mathrm{O}$ anel tem função de prender a tela sob pressão (o que facilita a troca, pois não é utilizada cola) no fundo do corpo da câmara.

telas de nylon: malha de $2 \mathrm{~mm}$, sendo a do fundo cortada em quadrados de $200 \mathrm{~mm}$ de lado (e aparados após a fixação com o anel) e a lateral cortada em tiras de, no mínimo 85 $\mathrm{mm}$ de largura.

arrebites: 4, de aço inoxidável, de medida $4,0 \mathrm{~mm}$, prendem o corpo da câmara à base.

parafuso: 1, de aço inoxidável, de $20 \times 5 \mathrm{~mm}$, evita o desencaixe da tampa.

corda de nylon: de $3,5 \mathrm{~mm}$ de espessura, forma a alça de imersão e emersão do aparato. A alça de 4 pontas é presa ao corpo da câmara por orifícios e nós internos.

base de ferro: construída com barras de secção circular, com espessura de $19 \mathrm{~mm}$, possui $250 \mathrm{~mm}$ de lado, 4 pés de $20 \mathrm{~mm}$ nos cantos e suportes em "L" para fixação à câmara. Possui peso aproximado de $2,250 \mathrm{~kg}$. Revestida com pintura eletrostática à pó, do tipo epóxi, atóxica. A base confere estabilidade durante a imersão e permite a fixação do aparato junto ao sedimento, sem que este invada demasiadamente a câmara.

abertura inferior: Possui diâmetro igual ao diâmetro interno do corpo da câmara (145 $\mathrm{mm})$. É fechada com a tela maior e permite contato com o sedimento.

aberturas laterais: 4, diametralmente opostas duas a duas, com diâmetro de $55 \mathrm{~mm}$ cada. Permitem a constante renovação da água no interior da câmara. Para a colagem das telas nas aberturas laterais deve-se proceder da seguinte maneira: prender a tira de tela provisoriamente com elásticos ao redor do tubo. A seguir, aplicar a cola ao redor das aberturas, no lado externo das câmaras e, após 24 horas, aparar o excesso de tela com um estilete, de maneira circular, contornando as janelas. A cola deve ser do tipo selante de resina sintética, não siliconada, não acética. Após a secagem da cola, as câmaras devem permanecer mergulhadas em água por 48 horas. 